Prepared in cooperation with the KANSAS DEPARTMENT OF HEALTH AND ENVIRONMENT

\title{
Estimates of Median Flows for Streams on the 1999 Kansas Surface Water Register
}

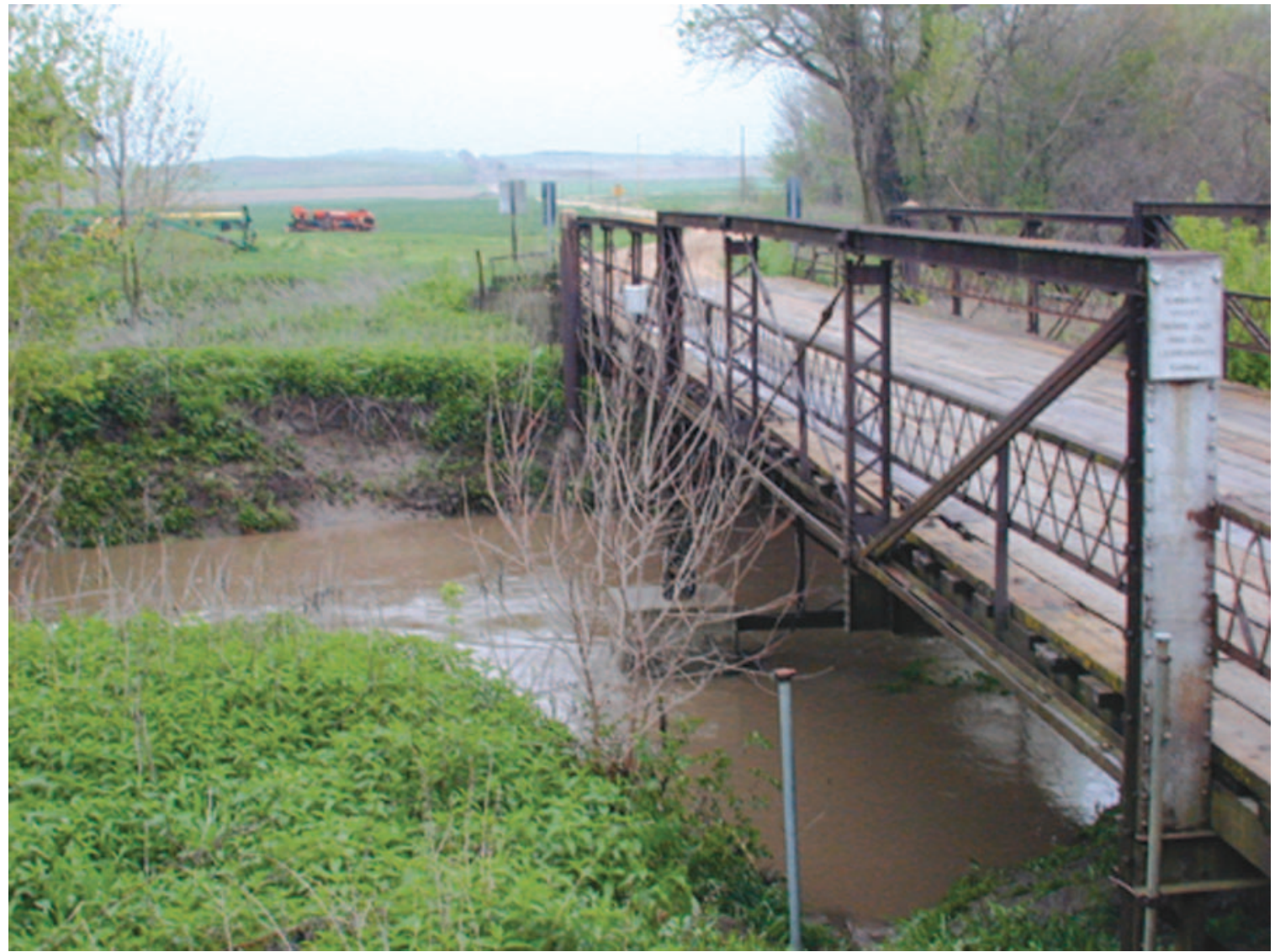

Scientific Investigations Report 2004-5032 
Cover photograph—Gypsum Creek near Gypsum (USGS station 06870300), April 2003. Photograph by Mark Lysaught, USGS, Lawrence, Kansas. 


\section{Estimates of Median Flows for Streams on the 1999 Kansas Surface Water Register}

By Charles A. Perry, David M. Wolock, and Joshua C. Artman

Prepared in cooperation with the

KANSAS DEPARTMENT OF HEALTH AND ENVIRONMENT

Scientific Investigations Report 2004-5032

U.S. Department of the Interior

U.S. Geological Survey 


\title{
U.S. Department of the Interior Gale A. Norton, Secretary
}

\author{
U.S. Geological Survey \\ Charles G. Groat, Director
}

\section{U.S. Geological Survey, Reston, Virginia: 2004}

\author{
For sale by U.S. Geological Survey, Information Services \\ Box 25286, Denver Federal Center \\ Denver, CO 80225 \\ For more information about the USGS and its products: \\ Telephone: 1-888-ASK-USGS \\ World Wide Web: http://www.usgs.gov/
}

Any use of trade, product, or firm names in this publication is for descriptive purposes only and does not imply endorsement by the U.S. Government.

Although this report is in the public domain, permission must be secured from the individual copyright owners to reproduce any copyrighted materials contained within this report.

Suggested citation:

Perry, C.A.,Wolock, D.M., and Artman, J.C., 2004, Estimates of median flows for streams on the 1999 Kansas Surface Water Register: U.S. Geological Survey Scientific Information Report 2004-5032, 219 p. 


\section{Contents}

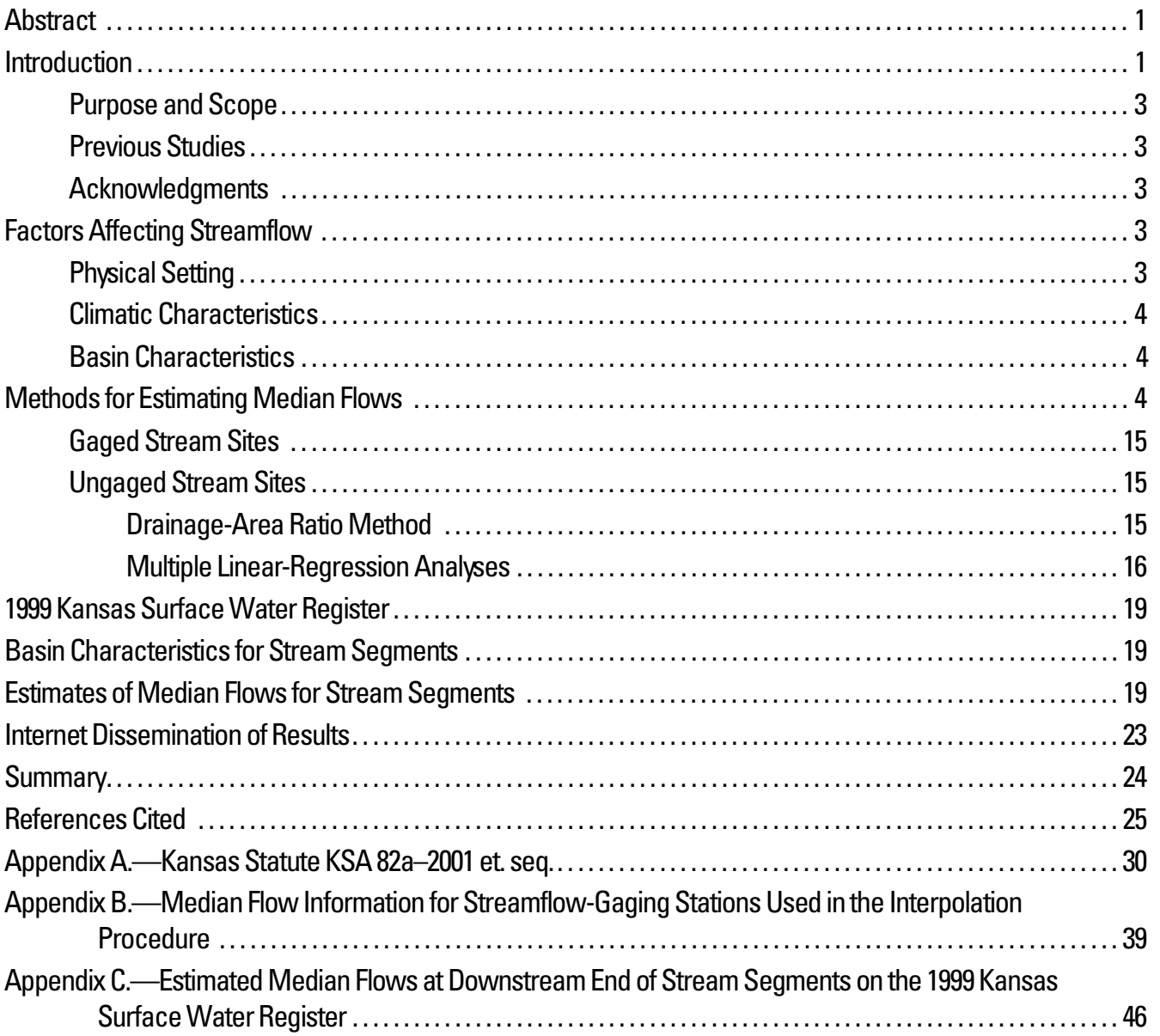

\section{Figures}

1-5. Map showing:

1. Location of U.S. Geological Survey streamflow-gaging stations in Kansas and parts of surrounding States with 10 or more years of record that were used to estimate median flows.2

2. Land-surface elevation in Kansas and parts of surrounding States....................5

3. Average land-surface slope in Kansas and parts of surrounding States.................6

4. Areas of equal average soil permeability in Kansas and parts of surrounding States .........7

5. Mean annual precipitation in Kansas and parts of surrounding States . .................8

6. Graphs showing comparison of observed and regression-estimated median flows for $(A)$ mostrecent 10 years of record (KSA) and (B) all-available hydrology (AAH) using Tobit analysis ...... 17

7. Map showing median flow values for stream segments in central Kansas estimated from regression equations and observed streamflow-gaging-station data for the most-recent 10 years of

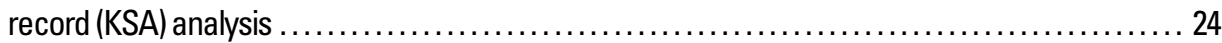

8. Map showing estimated median flow values for stream segments in central Kansas using interpolation procedures outlined in table 3 and observed streamflow-gaging-station data for the mostrecent 10 years of record (KSA) analysis 
9-113. Maps showing location of U.S. Geological Survey streamflow-gaging stations and stream segments on the 1999 Kansas Surface Water Register for:

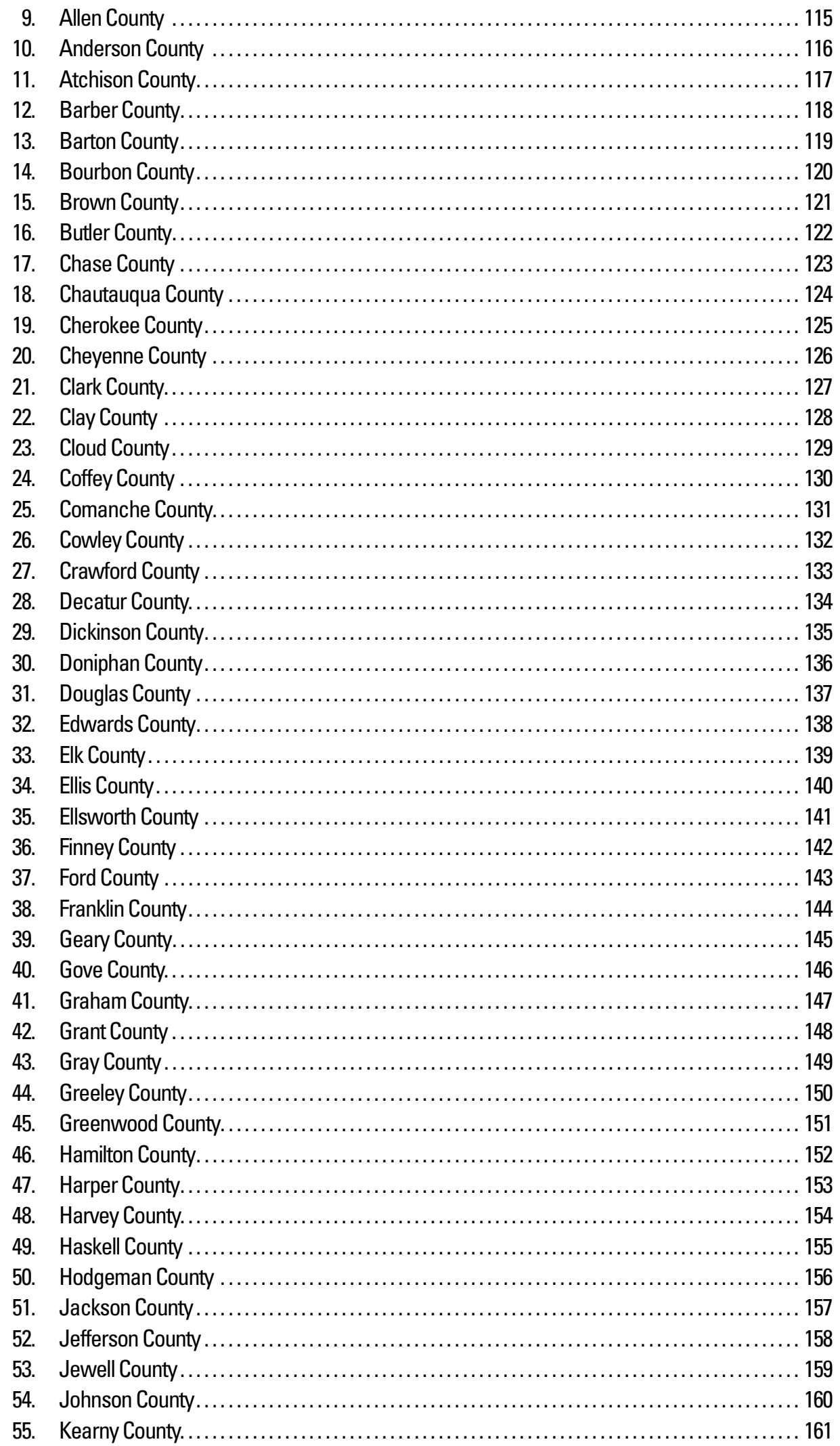




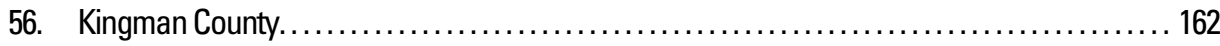

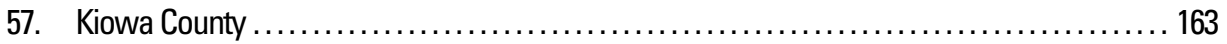

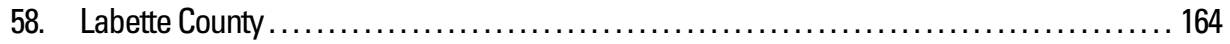

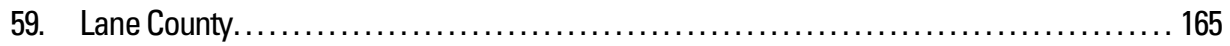

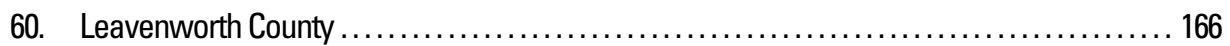

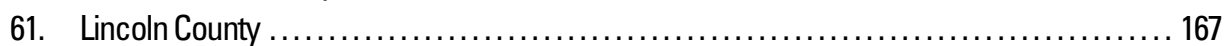

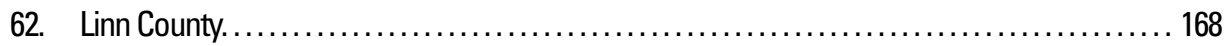

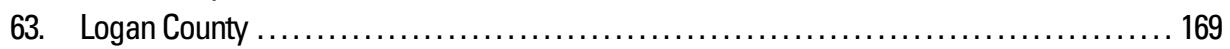

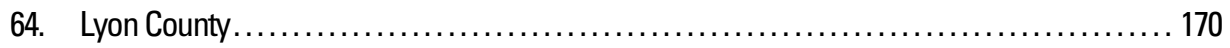

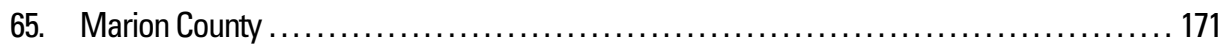

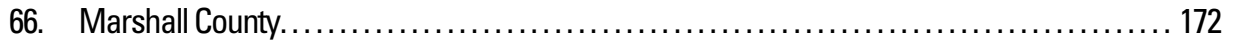

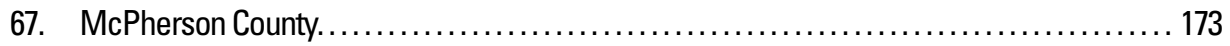

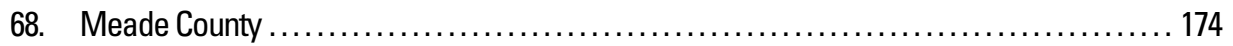

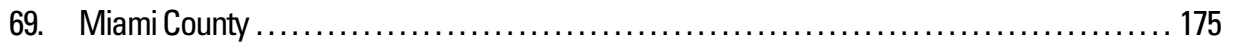

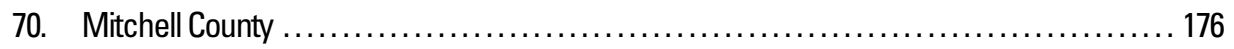

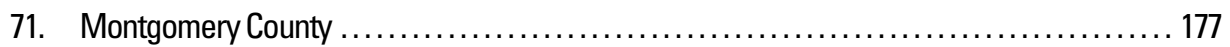

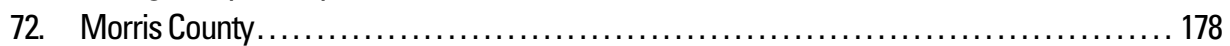

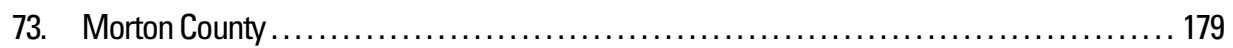

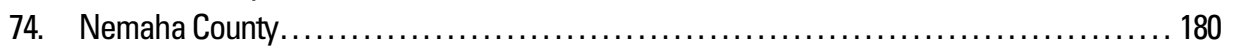

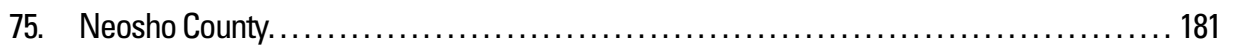

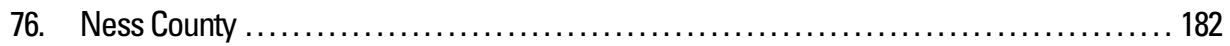

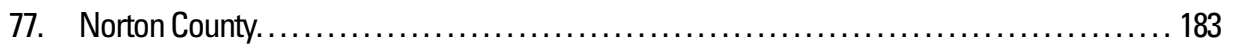

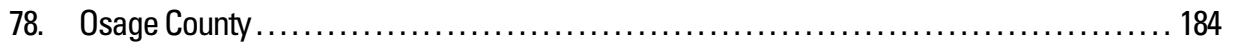

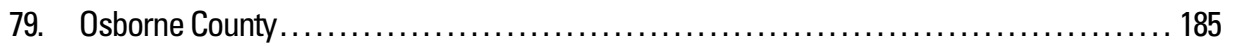

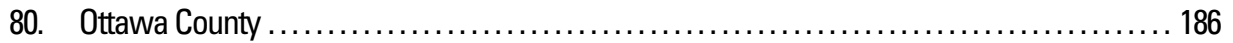

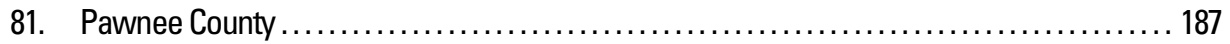

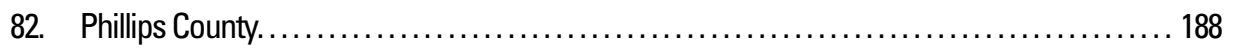

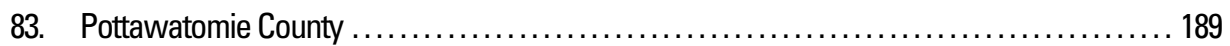

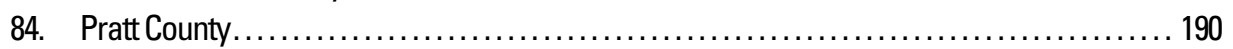

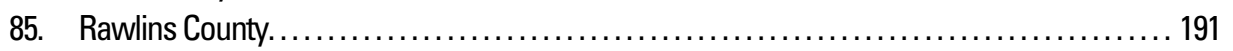

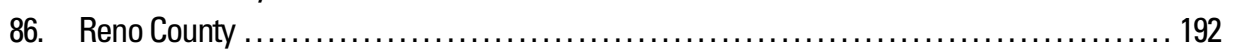

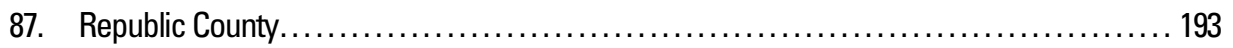

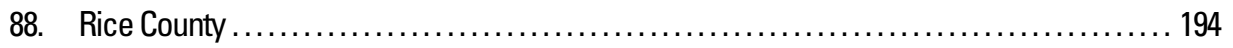

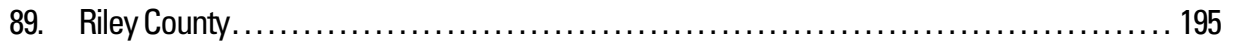

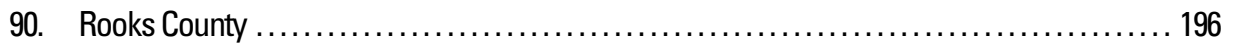

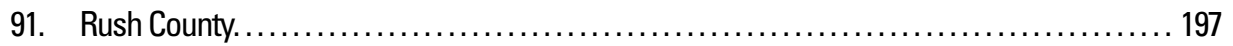

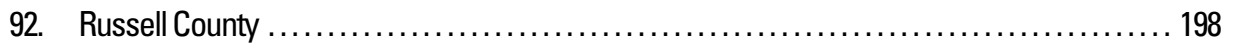

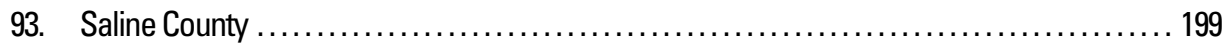

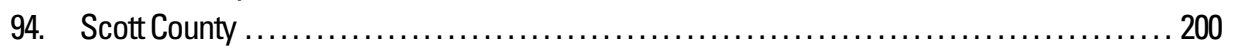

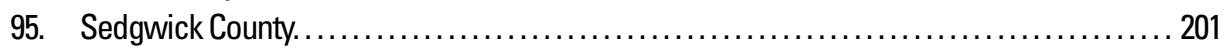

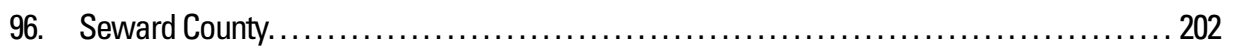

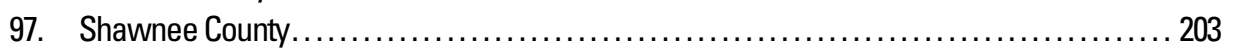

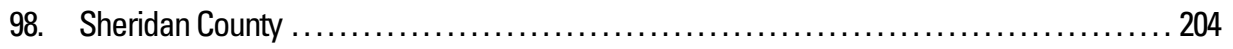

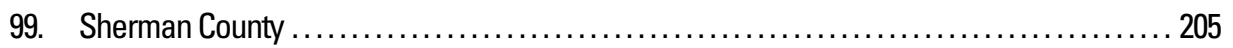

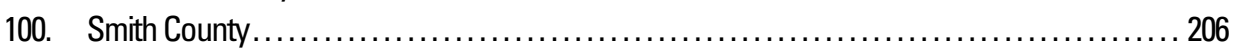

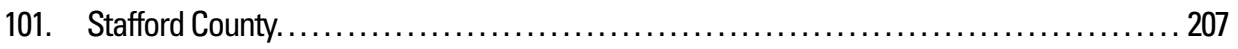

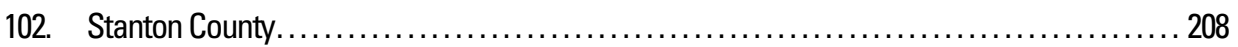

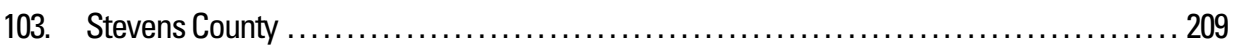

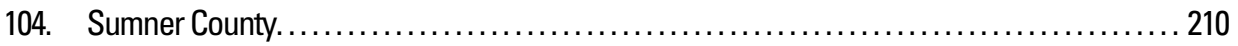




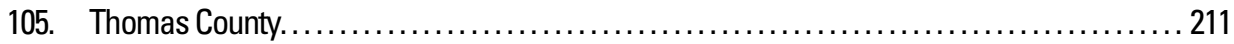

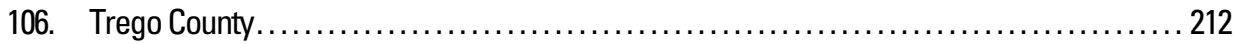

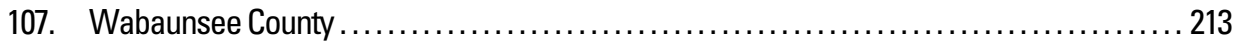

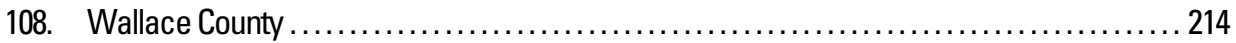

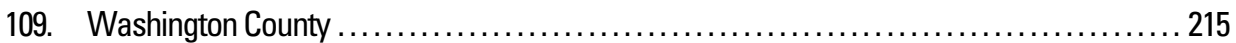

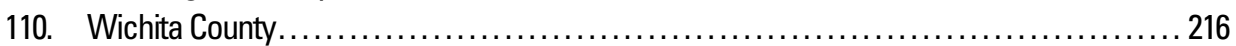

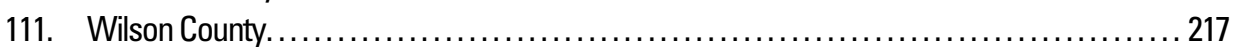

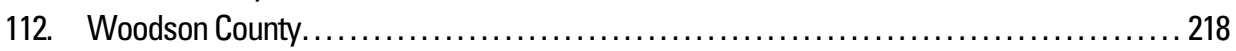

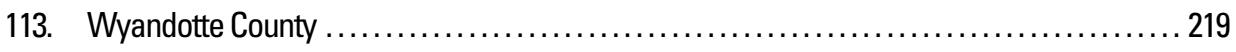

\section{Tables}

1. Streamflow-gaging stations and climatic and basin characteristics used in regression analyses of uncontrolled stream segments identified on the 1999 Kansas Surface Water Register ..9

2. Regression equations used to estimate median flows for uncontrolled stream segments on the 1999 Kansas Surface Water Register ....................................... 18

3. Summary of interpolation procedures used to estimate median flow information for stream segments on the 1999 Kansas Surface Water Register (KSWR) . ...................... 20

4. Streamflow-gaging stations and drainage areas used to interpolate median flows for controlled stream segments on the 1999 Kansas Surface Water Register.

5. Estimated median flows with 95-percent confidence intervals computed at streamflow-gaging stations used in the interpolation procedure for most-recent 10 years of record (KSA) and allavailable hydrology (AAH) analyses . ...

6. Stream segments on the 1999 Kansas Surface Water Register, CUSEGA numbers, stream names, and estimated median flows at downstream end of CUSEGA segments using the mostrecent 10 years of record (KSA) and all-available hydrology (AAH) analyses . ................ 47

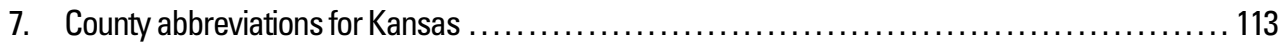




\section{Conversion Factors, Abbreviations, Datums, and Definitions}

\begin{tabular}{lcl}
\hline Multiply & By & To obtain \\
\hline cubic foot per second $\left(\mathrm{ft}^{3} / \mathrm{s}\right)$ & 0.02832 & cubic meter per second $\left(\mathrm{m}^{3} / \mathrm{s}\right)$ \\
foot $(\mathrm{ft})$ & 0.3048 & meter $(\mathrm{m})$ \\
foot per mile $(\mathrm{ft} / \mathrm{mi})$ & 0.1894 & meter per kilometer $(\mathrm{m} / \mathrm{km})$ \\
inch (in.) & 2.54 & centimeter $(\mathrm{cm})$ \\
inch per hour $(\mathrm{in} / \mathrm{h})$ & 25.40 & millimeter per hour $(\mathrm{mm} / \mathrm{h})$ \\
meter per kilometer $(\mathrm{m} / \mathrm{km})$ & 5.280 & foot per mile $(\mathrm{ft} / \mathrm{mi})$ \\
meter $(\mathrm{m})$ & 3.281 & foot $(\mathrm{ft})$ \\
mile $(\mathrm{mi})$ & 1.609 & kilometer $(\mathrm{km})$ \\
square mile $\left(\mathrm{mi}^{2}\right)$ & 2.590 & square kilometer $\left(\mathrm{km}^{2}\right)$ \\
\hline
\end{tabular}

\section{Datums}

Horizontal coordinate information is referenced to the North American Datum of 1983 (NAD 83).

Vertical coordinate information is referenced to the North American Vertical Datum of 1988 (NAVD 88).

\section{Definitions}

classified stream A stream listed on the Kansas Surface Water Register that is regulated by the Kansas Department of Health and Environment.

climatic year The 12-month period January 1 through December 31.

controlled stream segment A stream segment affected by releases from large reservoirs.

unclassified stream A stream not listed on the Kansas Surface Water Register that is not regulated by the Kansas Department of Health and Environment.

uncontrolled stream segment A stream segment not affected by releases from large reservoirs.

water year The 12-month period 0ctober 1 through September 30. The water year is designated by the calendar year in which it ends. Thus, the year ending September 30, 2000, is called the "2000 water year." 


\title{
Estimates of Median Flows for Streams on the 1999 Kansas Surface Water Register
}

\author{
By Charles A. Perry, David M. Wolock, and Joshua C. Artman
}

Abstract

The Kansas State Legislature, by enacting Kansas Statute KSA 82a-2001 et. seq., mandated the criteria for determining which Kansas stream segments would be subject to classification by the State. One criterion for the selection as a classified stream segment is based on the statistic of median flow being equal to or greater than 1 cubic foot per second. As specified by KSA 82a-2001 et. seq., median flows were determined from U.S. Geological Survey streamflow-gaging-station data by using the most-recent 10 years of gaged data (KSA) for each streamflow-gaging station. Median flows also were determined by using gaged data from the entire period of record (allavailable hydrology, AAH).

Least-squares multiple regression techniques were used, along with Tobit analyses, to develop equations for estimating median flows for uncontrolled stream segments. The drainage area of the gaging stations on uncontrolled stream segments used in the regression analyses ranged from 2.06 to 12,004 square miles. A logarithmic transformation of the data was needed to develop the best linear relation for computing median flows. In the regression analyses, the significant climatic and basin characteristics, in order of importance, were drainage area, mean annual precipitation, mean basin permeability, and mean basin slope. Tobit analyses of KSA data yielded a model standard error of prediction of 0.285 logarithmic units, and the best equations using Tobit analyses of AAH data had a model standard error of prediction of 0.250 logarithmic units.

These regression equations and an interpolation procedure were used to compute median flows for the uncontrolled stream segments on the 1999 Kansas Surface Water Register. Measured median flows from gaging stations were incorporated into the regression-estimated median flows along the stream segments where available. The segments that were uncontrolled were interpolated using gaged data weighted according to the drainage area and the bias between the regression-estimated and gaged flow information. On controlled segments of Kansas streams, the median flow information was interpolated between gaging stations using only gaged data weighted by drainage area.

Of the 2,232 total stream segments on the Kansas Surface Water Register, 34.5 percent of the segments had an estimated median streamflow of less than 1 cubic foot per second when the KSA analysis was used. When the AAH analysis was used, 36.2 percent of the segments had an estimated median streamflow of less than 1 cubic foot per second.

This report supercedes U.S. Geological Survey WaterResources Investigations Report 02-4292.

\section{Introduction}

The expected amount and historical range of flow in Kansas streams are important considerations for the classification, evaluation, and regulation of water supplies, recreation, aquatic life habitat, and pollution control within the State. Kansas Statute KSA 82a-2001 et. seq. (see Appendix A) specifically mentions median streamflow as one criterion for classifying streams. Current water-quality regulations in Kansas apply numeric water-quality criteria to the 2,232 stream segments listed on the 1999 Kansas Surface Water Register (KSWR). The register is maintained by the Kansas Department of Health and Environment (KDHE) and is used to identify designated uses of stream segments. Numeric water-quality criteria for the stream segments are based on assigned designated uses.

KSA $82 a-2001$ et. seq. defines one criterion for a classified stream segment as having a median flow of $1 \mathrm{ft}^{3} / \mathrm{s}$ or greater. Other criteria include whether a stream segment contains a wastewater discharge, contains threatened or endangered species, or has a cost/benefit ratio less than 1 where median streamflows are $0 \mathrm{ft}^{3} / \mathrm{s}$. Median flow statistics are available for stream segments and are based on daily flow data collected by the U.S. Geological Survey (USGS) at 216 streamflow-gaging stations with 10 or more years of record located throughout Kansas and surrounding States (fig. 1). The current and historical streamflow information collected by the USGS provides a resource for estimating the expected amount and range of streamflow throughout the State. The measured streamflow record can be used to define statistics that summarize historical streamflow amounts at each stream gage. These statistics then can be related to the physical characteristics of the drainage basins that contribute to measured flow at the gage. Furthermore, a statistical model that is based on these relations can be used to estimate streamflow statistics for ungaged stream segments. Therefore, information on median flow characteristics is needed for streams in Kansas. 


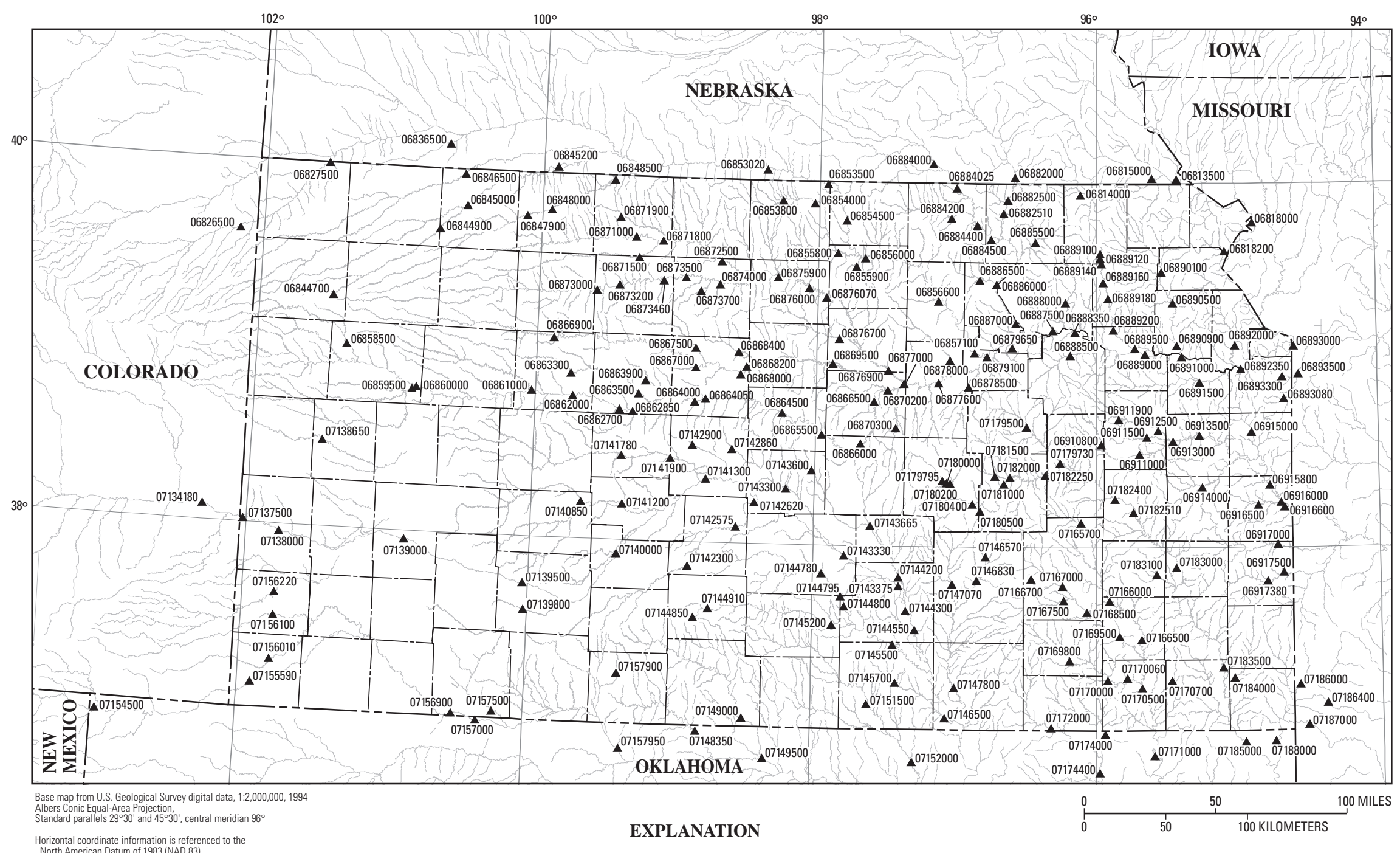

Figure 1. Location of U.S. Geological Survey streamflow-gaging stations in Kansas and parts of surrounding States with 10 or more years of record that were used to estimate median flows. 
To address this need, a study of median flows for gaged and ungaged Kansas streams was conducted by the USGS in cooperation with KDHE. Streamflow data used in this study were collected by the USGS (Putnam and others, 2001) through other cooperative studies with various government agencies.

\section{Purpose and Scope}

The purpose of this report is to document the methods and results of a study designed to estimate the median flow (50-percent flow duration) for the downstream end of each stream segment listed on the 1999 KSWR. Median flow for each stream segment was determined from gaged-location streamflow records or was estimated from statewide regression models. This report documents development of regression models to estimate median flow from climatic and basin characteristics. The report describes application of the drainage-area ratio method and the regression models to estimate the median flows for KSWR stream segments, the interpolation of estimates for ungaged segments, and the Internet dissemination of results and a geographic-information-system (GIS) database.

Two different statistical analysis were performed on uncontrolled flows measured at 149 gaging stations. According to language in KSA 82a-2001 et. seq., only the most-recent 10 years of streamflow data for each gaging station were to be used for statistical analysis. This analysis was termed the KSA analysis. The entire period of record also was used for analysis of median flows, and this analysis was termed the all-available hydrology (AAH) analysis.

The information contained in this report can be used by State agencies and others to help in the effective management of Kansas surface-water resources. Optimal reservoir operations, legally distributed in-stream withdrawals, and waterquality concerns are issues directly linked to median streamflows. The methods described herein can be applied nationwide using USGS streamflow data that are available throughout the United States.

\section{Previous Studies}

Previous low-flow and flow-duration studies for Kansas include an investigation by Furness (1959) who developed a method for estimating flow-duration curves for ungaged sites that was based on regionalized flow-duration data from 122 continuous-record, streamflow-gaging stations with drainage areas of between 100 and 3,000 $\mathrm{mi}^{2}$ for the period 1921-56. Maps were developed showing a variety of statewide low and mean streamflow maps. Furness (1959) also noted that the lowflow parts of the flow-duration curves could be verified or improved by relating base-flow measurements at the ungaged site to base-flow measurements at a nearby, index streamflowgaging station.

Jordan (1983) updated the maps developed by Furness by including additional streamflow-gaging stations and data for the period 1957-76. Jordan's study included a map that depicted the areas of Kansas where the median streamflow for a 500- $\mathrm{mi}^{2}$ basin was greater than $0.1 \mathrm{ft}^{3} / \mathrm{s}$.

Two studies by Studley $(2000,2001)$ evaluated the application of the Furness method to ungaged stream sites in Kansas using nearby streamflow-gaging stations as index stations. The results of these two recent studies indicated that the Furness method continues to be a useful tool for estimating flow-duration curves for ungaged sites and that the method could be used for sites with drainage areas less than $100 \mathrm{mi}^{2}$.

Many studies have been conducted to evaluate low flow from regression equations that relate low flow to basin characteristics. In a recent USGS study (Ries and Friesz, 2000), basin characteristics were determined from digital map data, and flow statistics were computed for individual stream segments using GIS techniques. Ries and Friesz (2000) used the drainage-area ratio method to compute streamflow characteristics for stream segments in Massachusetts that had between 0.5 and 1.5 times the drainage area of streamflow-gaging stations on the same stream. Many States have used regression analysis to regionalize low-flow frequency statistics including New Hampshire, Rhode Island, and Vermont (Johnson, 1970); New York (Ku and others, 1975); Maine (Parker, 1977); Massachusetts (Male and Ogawa, 1982; Vogel and Kroll, 1990; Risley, 1994; Ries and Friesz, 2000); Montana (Parrett and Hull, 1985); Indiana (Arihood and Glatfelter, 1991); and central New England (Wandle and Randall, 1994).

\section{Acknowledgments}

The authors would like to thank Aldo "Skip" Vecchia, Timothy Cohn, and Gregory Schwarz of the USGS who helped with the Tobit analyses and with the review of the statistical methods used in this report. The authors also would like to acknowledge the efforts of Michael Butler from KDHE who provided the initial stream coverage and reviewed much of the data presented.

\section{Factors Affecting Streamflow}

\section{Physical Setting}

Physiographically, Kansas is located almost entirely within the Interior Plains as described by Schoewe (1949). A description of the hydrologic characteristics of the physiographic provinces within the Interior Plains is beyond the scope of this report, but the fact that there are significant variations denotes the complex nature of and difficulty in attempting to define flow characteristics across Kansas.

The topography of the western two-thirds of the State is typical of the High Plains region (Rasmussen and Perry, 2000) and is characterized by flat or gently sloping surfaces with little relief. The topography of the eastern one-third of the State is more variable, with alternating hills and lowlands. Land-surface 


\section{Estimates of Median Flows for Streams on the 1999 Kansas Surface Water Register}

elevations within the State range from about $700 \mathrm{ft}$ above the North American Vertical Datum of 1988 (NAVD 88) at the Kansas-Oklahoma State line in southeast Kansas to about 4,135 ft above the NAVD 88 at a point near the KansasColorado State line in western Kansas - a vertical difference of about 3,435 ft (fig. 2). The average land-surface slope for Kansas (fig. 3) using 30-m grid elevation data is about 1.9 degrees.

Other physical characteristics affecting the flow characteristics of watersheds are the types of soils and land-use and treatment practices within the basin. For example, with all other factors being equal the low-flow potential from watersheds with soils of low permeability (fig. 4) is less than that from watersheds where highly permeable soils tend to allow greater infiltration and a greater ground-water contribution to base flow of the stream (Thomas, 1966). The western two-thirds of the State typically has soils of moderate to high permeability, whereas the eastern one-third has soils of lower permeability. Landtreatment practices, such as contour farming and construction of water-retention structures, can increase the amount of infiltration of runoff to ground water, which ultimately can return to stream channels as base flow. However, land-treatment practices are difficult to assess and apply to the various types of basins statewide.

\section{Climatic Characteristics}

The climate of Kansas is affected by the movement of various air masses of tropical and continental origin over the open, inland plains, and seasonal precipitation extremes are common. About 75 percent of the mean annual precipitation falls from April through September. Precipitation during early spring and late fall occurs in association with frontal air masses that produce low-intensity rainfall of regional coverage. During the summer months, the weather is dominated by warm, moist air from the Gulf of Mexico or by hot, dry air from the Southwest. Summer precipitation generally occurs as high-intensity thunderstorms (Paulson and others, 1991).

Watersheds in Kansas exhibit a wide range of climatic characteristics that affect streamflow. Generally, precipitation varies in an east-west direction, with little north-south variation. The general climate of the western part of Kansas is semiarid with hot, dry summer months and cold, windy winter months. The eastern part of the State tends to be more humid, with sultry summer months and cold, damp winter months. Mean annual precipitation, the major climatic factor affecting streamflow in the State, varies from about 16 in. in extreme western Kansas to about 42 in. in southeastern Kansas (Daly and others, 1997) (fig. 5). Mean annual precipitation at 149 streamflow-gaging stations used in the regression analyses for uncontrolled stream segments on the KSWR is given in table 1.

\section{Basin Characteristics}

Basin characteristics used in the analyses were selected on the basis of their theoretical relation to differences in flow magnitudes of streams, results of previous studies in similar hydrologic environments, and on the ability to measure them. The basin characteristics considered in this report included contributing drainage area, in square miles; mean basin elevation, in feet above NAVD 88; mean basin permeability, in inches; mean basin slope, in degrees; a Base Flow Index (Wahl and Wahl, 1995); mean annual runoff for hydrologic basins in the United States, in cubic feet per second (Gebert and others, 1987); and runoff from a water-balance model (Wolock and McCabe, 1999), in cubic feet per second, using the mean annual precipitation grid for the United States developed by Daly and others (1994). The mean annual runoff reflects the difference between precipitation and evapotranspiration. Selected basin characteristics for the 149 streamflow-gaging stations used in the regression analyses for uncontrolled stream segments are provided in table 1 .

All basin characteristics were measured from digital-map data using automated GIS procedures. The automated procedure was created using the AML programming language of the ARC/INFO GIS software (Environmental Systems Research Institute, Inc., 1991). The automated procedure determines the drainage-basin boundary at the gaging station or for the downstream end of a stream segment and creates a digital data layer of the basin boundary, then overlays the boundary on the other digital data layers to determine the other basin characteristics for the station or segment. The grid values then are averaged for the area within the drainage basin. Basin slope was determined from the 30-m elevation grid using the GIS command SLOPE (Burrough, 1986). The slope in degrees is essentially an average of the slope between the center grid cell and its eight surrounding cells.

\section{Methods for Estimating Median Flows}

Climatic and basin characteristics were used in the analyses of median flows at gaged and ungaged sites on controlled and uncontrolled streams. For this study, ARC/INFO GIS software was used to estimate climatic and basin characteristics. Many spatial data sets were available for this task, including: (1) 30-year (1961-90) mean annual precipitation data (Daly and others, 1997), (2) 30-m gridded elevation data (U.S. Geological Survey, 1998) for determining drainage area, mean basin slope, and mean basin elevation, and (3) STATSGO soil-permeability data (U.S. Department of Agriculture, 1994).

The flow information was derived from 216 gaging stations in Kansas and the surrounding States with at least 10 years of streamflow record. Streamflow at 149 of the stations on uncontrolled stream segments were included in the regression analyses. The flows of uncontrolled stream segments are unaffected by storage and release from large upstream reservoirs. One hundred thirty-one streamflow-gaging stations in Kansas and 18 in surrounding States ( 3 in Missouri, 5 in Nebraska, and 10 in Oklahoma) measured uncontrolled flow. All available records through water year (October through September) 2000 were used to compute the streamflow statistics for these gaging 


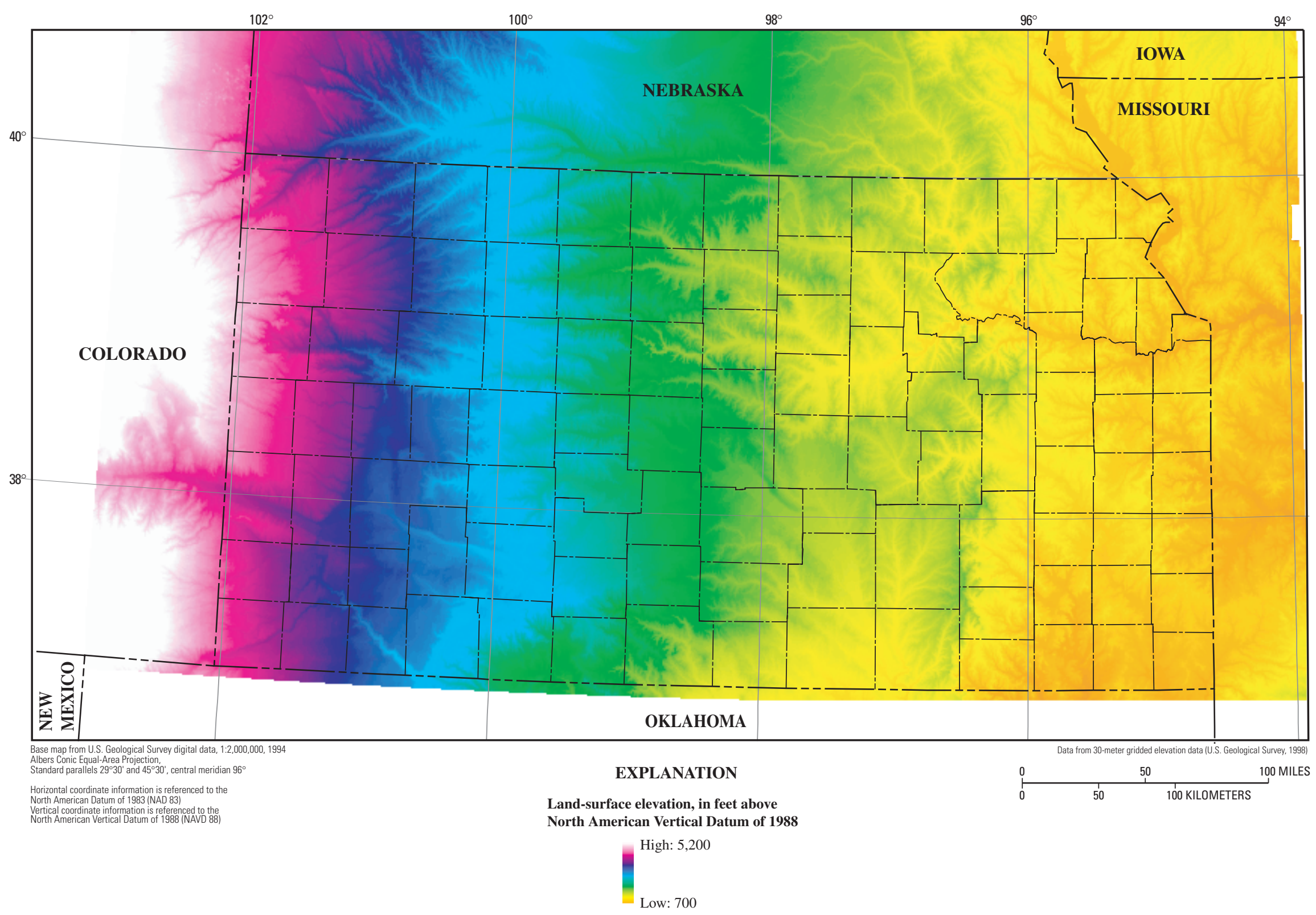

Figure 2. Land-surface elevation in Kansas and parts of surrounding States. 


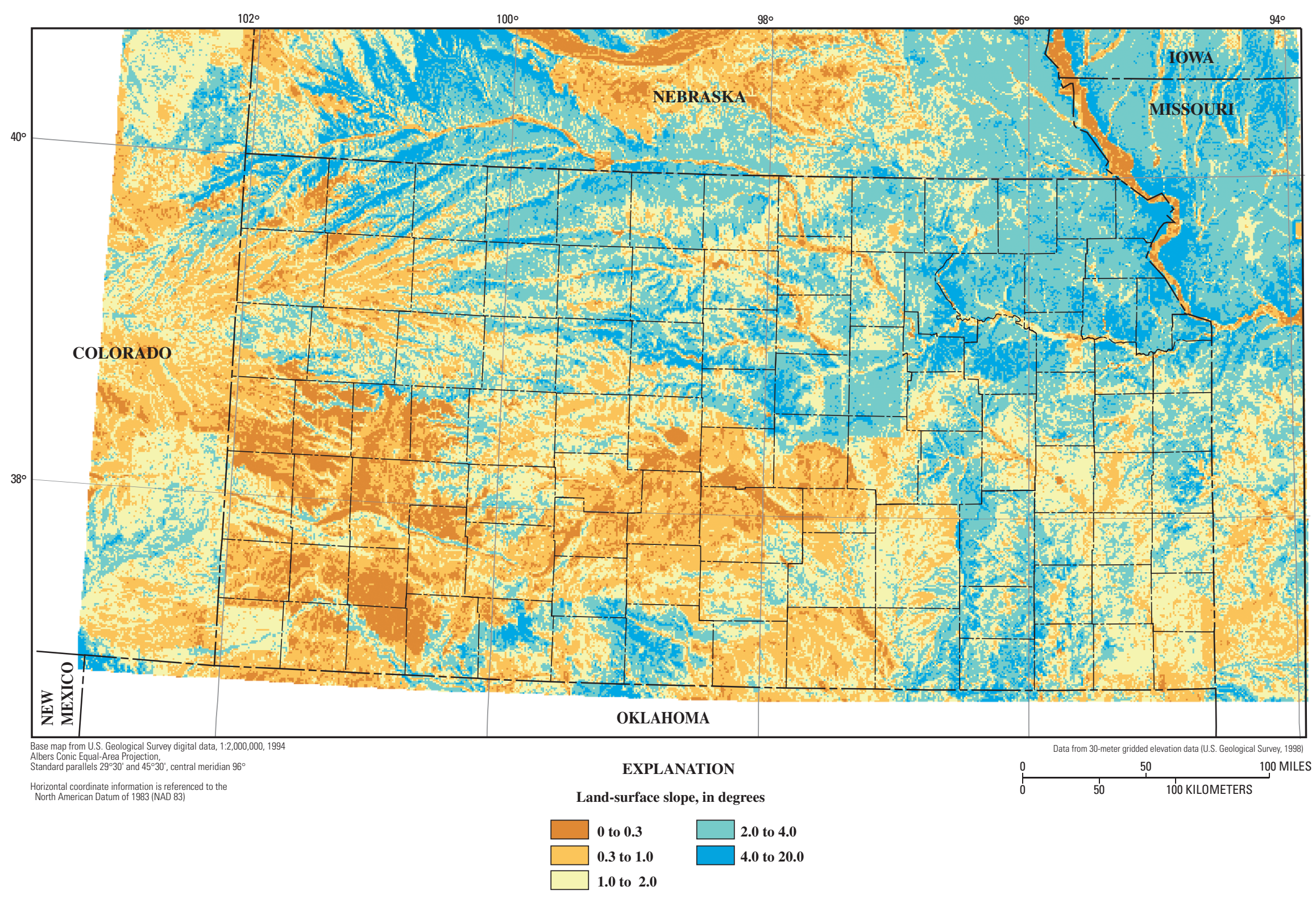

Figure 3. Average land-surface slope in Kansas and parts of surrounding States. 


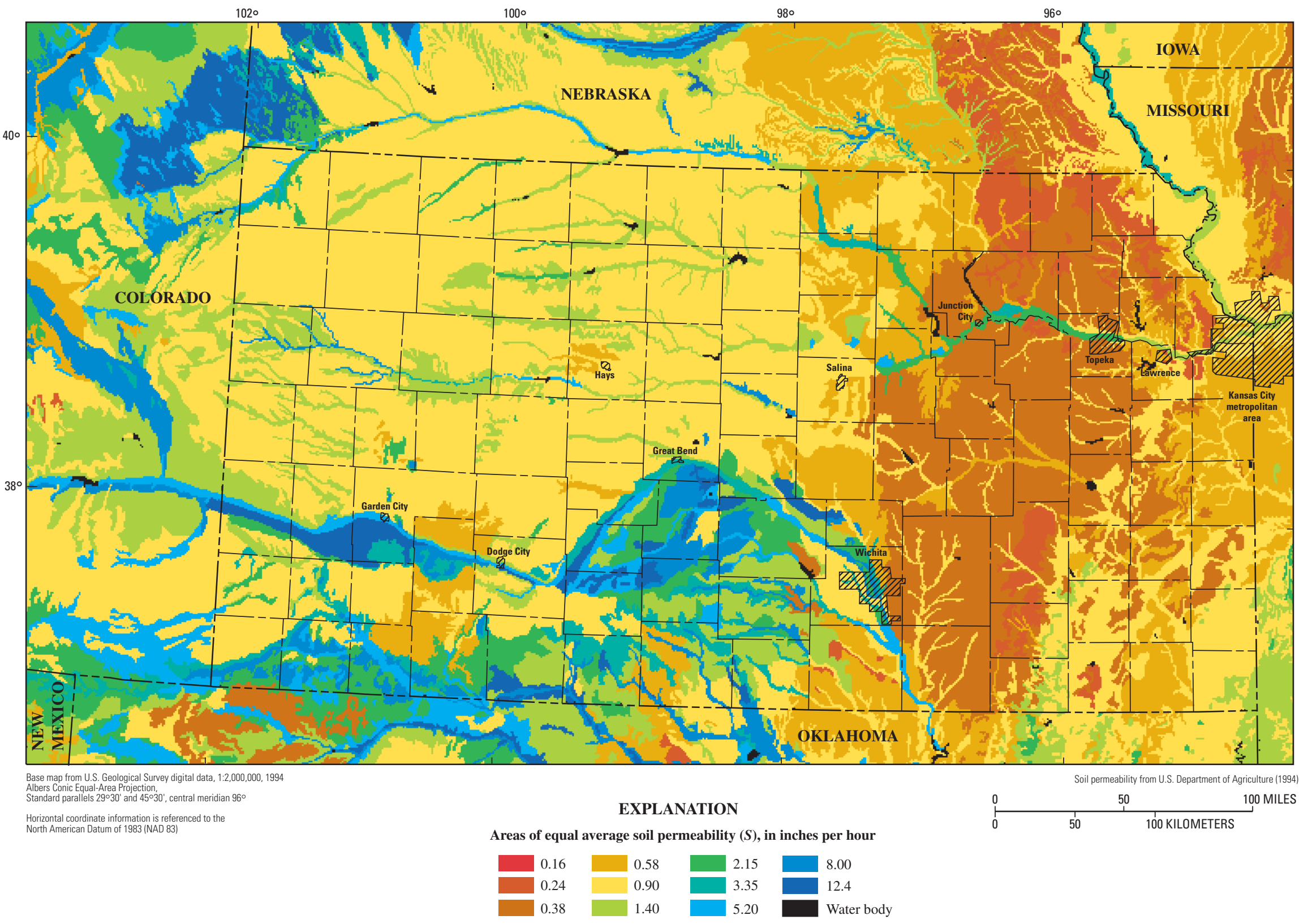

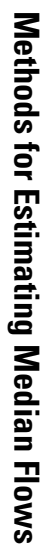

Figure 4. Areas of equal average soil permeability in Kansas and parts of surrounding States. 


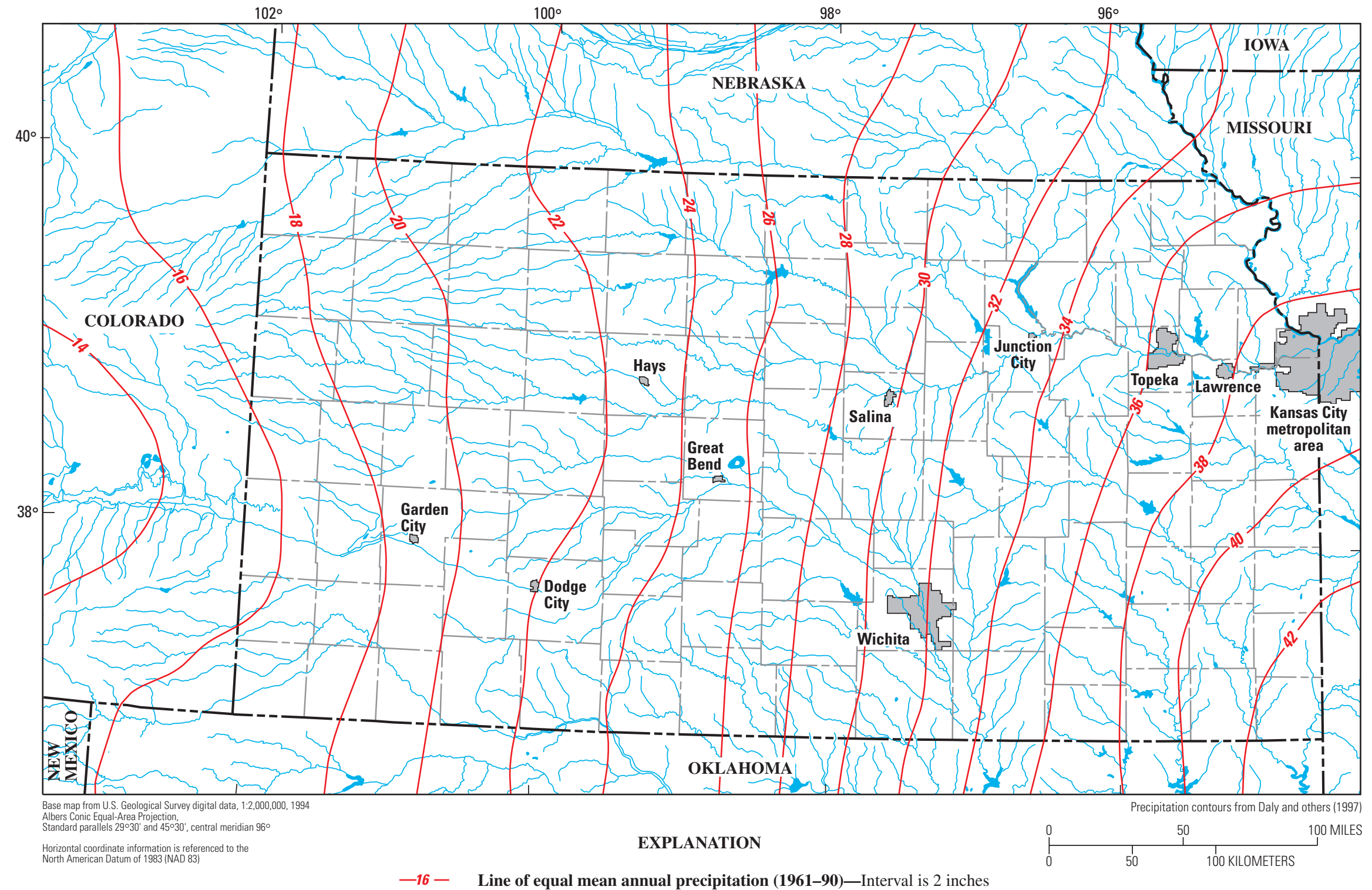

Figure 5. Mean annual precipitation in Kansas and parts of surrounding States (Daly and others, 1997). 
Table 1. Streamflow-gaging stations and climatic and basin characteristics used in regression analyses of uncontrolled stream segments identified on the 1999 Kansas Surface Water Register ${ }^{1}$.

$\left[\mathrm{ft}^{3} / \mathrm{s}\right.$, cubic feet per second; $\mathrm{mi}^{2}$, square miles; in/h, inches per hour]

\begin{tabular}{|c|c|c|c|c|c|c|c|c|c|c|}
\hline \multirow[b]{2}{*}{$\begin{array}{l}\text { Station } \\
\text { number } \\
\text { (fig. 1) }\end{array}$} & \multirow[b]{2}{*}{ Station name } & \multirow[b]{2}{*}{$\begin{array}{l}\text { Period of } \\
\text { record } \\
\text { (water } \\
\text { years) }\end{array}$} & \multirow[b]{2}{*}{$\begin{array}{l}\text { Years } \\
\text { of } \\
\text { record }\end{array}$} & \multicolumn{3}{|c|}{ Streamflow } & \multirow[b]{2}{*}{$\begin{array}{c}\text { Drainage } \\
\text { area } \\
\left(\mathrm{mi}^{2}\right)\end{array}$} & \multirow[b]{2}{*}{$\begin{array}{c}\text { Mean annual } \\
\text { precipitation, } \\
1961-90^{2} \\
\text { (inches) }\end{array}$} & \multirow[b]{2}{*}{$\begin{array}{l}\text { Mean basin } \\
\text { permeability } \\
\quad(\mathrm{in} / \mathrm{h})\end{array}$} & \multirow[b]{2}{*}{$\begin{array}{c}\text { Mean } \\
\text { basin } \\
\text { slope }^{4} \\
\text { (degrees) }\end{array}$} \\
\hline & & & & $\begin{array}{l}\text { Mean } \\
\left(\mathrm{ft}^{3} / \mathrm{s}\right)\end{array}$ & $\begin{array}{l}\text { Median for } \\
\text { period or } \\
\text { record } \\
\left(\mathrm{ft}^{3} / \mathrm{s}\right)\end{array}$ & $\begin{array}{l}\text { Median for } \\
\text { most-recent } \\
10 \text { years } \\
\left(\mathrm{ft}^{3} / \mathrm{s}\right)\end{array}$ & & & & \\
\hline 06814000 & Turkey Creek near Seneca, KS & $1950-2000$ & 51 & 129 & 22 & 30 & 276 & 32.35 & 0.467 & 3.1 \\
\hline 06815000 & Big Nemaha River at Falls City, NE & $1944-2000$ & 56 & 631 & 159 & 213 & 1,339 & 32.55 & .510 & 2.8 \\
\hline 06818200 & Doniphan Creek at Doniphan, KS & $1961-70$ & 10 & 3.0 & .87 & .87 & 4.15 & 36.71 & 1.08 & 4.8 \\
\hline 06836500 & Driftwood Creek near McCook, NE & 1977-86 & 10 & 9.5 & 4.8 & 5.0 & 361 & 20.94 & 1.30 & 2.9 \\
\hline 06844700 & South Fork Sappa Creek near Brewster, KS & $1968-87$ & 20 & .23 & 0 & 0 & 71.3 & 18.40 & 1.30 & .83 \\
\hline 06844900 & South Fork Sappa Creek near Achilles, KS & $1960-2000$ & 41 & 3.4 & 0 & .28 & 412 & 19.20 & 1.30 & 1.4 \\
\hline 06845000 & Sappa Creek near Oberlin, KS & $1930-2000$ & 71 & 16 & .70 & 1.9 & 1,086 & 19.82 & 1.32 & 1.5 \\
\hline 06845200 & Sappa Creek near Beaver City, NE & $1938-72$ & 35 & 38 & 5.0 & 4.5 & 1,500 & 20.57 & 1.36 & 1.9 \\
\hline 06847900 & Prairie Dog Creek above Keith Sebelius Lake, KS & $1963-2000$ & 38 & 9.0 & 2.1 & 6.1 & 590 & 20.65 & 1.36 & 1.7 \\
\hline 06848000 & Prairie Dog Creek at Norton, KS & $1945-63$ & 19 & 39 & 7.5 & 5.0 & 684 & 20.96 & 1.36 & 1.9 \\
\hline 06848500 & Prairie Dog Creek near Woodruff, KS & $1930-63$ & 34 & 57 & 10 & 5.0 & 1,007 & 21.56 & 1.37 & 2.1 \\
\hline 06853800 & White Rock Creek near Burr Oak, KS & $1958-2000$ & 43 & 29 & 6.0 & 12 & 227 & 26.49 & 1.30 & 2.5 \\
\hline 06854000 & White Rock Creek at Lovewell, KS & $1947-56$ & 10 & 68 & 5.7 & 5.7 & 354 & 27.07 & 1.31 & 2.6 \\
\hline 06855800 & Buffalo Creek near Jamestown, KS & $1960-89$ & 30 & 72 & 11 & 18 & 330 & 27.94 & 1.10 & 1.9 \\
\hline 06855900 & Wolf Creek near Concordia, KS & $1963-81$ & 19 & 11 & 1.0 & 1.6 & 56 & 28.76 & 1.01 & 2.5 \\
\hline 06858500 & North Fork Smoky Hill River near McAllaster, KS & $1948-84$ & 27 & 3.7 & 0 & 0 & 752 & 17.12 & 1.53 & 1.3 \\
\hline 06859500 & Ladder Creek below Chalk Creek near Scott City, KS & $1952-79$ & 28 & 8.0 & 1.9 & 1.3 & 1,432 & 17.65 & 1.40 & 1.0 \\
\hline 06860000 & Smoky Hill River at Elkader, KS & $1940-2000$ & 61 & 24 & 1.5 & .57 & 3,555 & 17.67 & 1.53 & 1.3 \\
\hline 06861000 & Smoky Hill River near Arnold, KS & $1951-2000$ & 50 & 44 & 2.3 & 5.3 & 5,220 & 18.44 & 1.52 & 1.4 \\
\hline 06863300 & Big Creek near Ogallah, KS & $1956-68$ & 13 & 22 & 2.9 & 3.0 & 297 & 21.43 & 1.28 & 1.1 \\
\hline 06863500 & Big Creek near Hays, KS & $1947-2000$ & 54 & 33 & 7.9 & 19 & 594 & 21.80 & 1.18 & 1.4 \\
\hline 06863900 & North Fork Big Creek near Victoria, KS & $1963-86$ & 24 & 3.1 & 0 & 0 & 90.3 & 22.61 & 1.20 & 1.7 \\
\hline 06864000 & Smoky Hill River near Russell, KS & $1940-49$ & 10 & 184 & 40 & 40 & 6,965 & 19.48 & 1.46 & 1.4 \\
\hline 06866000 & Smoky Hill River near Lindsborg, KS & $1906-47$ & 42 & 244 & 57 & 86 & 8,110 & 20.60 & 1.46 & 1.5 \\
\hline 06866500 & Smoky Hill River near Mentor, KS & $1925-47$ & 23 & 329 & 116 & 197 & 8,358 & 20.84 & 1.45 & 1.6 \\
\hline
\end{tabular}


Table 1. Streamflow-gaging stations and climatic and basin characteristics used in regression analyses of uncontrolled stream segments identified on the 1999 Kansas Surface Water Register ${ }^{1}$.-Continued

$\left[\mathrm{ft}^{3} / \mathrm{s}\right.$, cubic feet per second; $\mathrm{mi}^{2}$, square miles; in/h, inches per hour]

\begin{tabular}{|c|c|c|c|c|c|c|c|c|c|c|}
\hline \multirow[b]{2}{*}{$\begin{array}{l}\text { Station } \\
\text { number } \\
\text { (fig. 1) }\end{array}$} & \multirow[b]{2}{*}{ Station name } & \multirow[b]{2}{*}{$\begin{array}{l}\text { Period of } \\
\text { record } \\
\text { (water } \\
\text { years) }\end{array}$} & \multirow[b]{2}{*}{$\begin{array}{l}\text { Years } \\
\text { of } \\
\text { record }\end{array}$} & \multicolumn{3}{|c|}{ Streamflow } & \multirow[b]{2}{*}{$\begin{array}{c}\text { Drainage } \\
\text { area } \\
\left(\mathrm{mi}^{2}\right)\end{array}$} & \multirow[b]{2}{*}{$\begin{array}{c}\text { Mean annual } \\
\text { precipitation, } \\
1961-90^{2} \\
\text { (inches) }\end{array}$} & \multirow[b]{2}{*}{$\begin{array}{l}\text { Mean basin } \\
\text { permeability } \\
\quad(\text { in/h) }\end{array}$} & \multirow[b]{2}{*}{$\begin{array}{c}\text { Mean } \\
\text { basin } \\
\text { slope }^{4} \\
\text { (degrees) }\end{array}$} \\
\hline & & & & $\begin{array}{l}\text { Mean } \\
\left(\mathrm{ft}^{3} / \mathrm{s}\right)\end{array}$ & $\begin{array}{l}\text { Median for } \\
\text { period or } \\
\text { record } \\
\left(\mathrm{ft}^{3} / \mathrm{s}\right)\end{array}$ & $\begin{array}{c}\text { Median for } \\
\text { most-recent } \\
10 \text { years } \\
\left(\mathrm{ft}^{3} / \mathrm{s}\right)\end{array}$ & & & & \\
\hline 06866900 & Saline River near Wakeeney, KS & $1956-2000$ & 45 & 21 & 2.6 & 7.4 & 696 & 20.60 & 1.37 & 1.5 \\
\hline 06867000 & Saline River near Russell, KS & 1946-2000 & 55 & 98 & 31 & 64 & 1,502 & 21.68 & 1.39 & 2.2 \\
\hline 06868000 & Saline River near Wilson, KS & $1930-63$ & 34 & 166 & 46 & 66 & 1,900 & 22.36 & 1.36 & 2.4 \\
\hline 06868400 & Wolf Creek near Lucas, KS & $1960-71$ & 12 & 16 & 2.2 & 1.8 & 163 & 25.02 & 1.20 & 2.6 \\
\hline 06869500 & Saline River at Tescott, KS & $1920-63$ & 44 & 247 & 70 & 111 & 2,820 & 23.69 & 1.31 & 2.5 \\
\hline 06870300 & Gypsum Creek near Gypsum, KS & $1955-2000$ & 46 & 26 & 7.0 & 9.0 & 120 & 30.88 & .882 & 2.9 \\
\hline 06871000 & North Fork Solomon River at Glade, KS & $1953-2000$ & 48 & 28 & 8.4 & 26 & 849 & 21.31 & 1.34 & 2.5 \\
\hline 06871500 & Bow Creek near Stockton, KS & $1952-2000$ & 49 & 14 & 5.6 & 9.5 & 341 & 21.57 & 1.45 & 1.8 \\
\hline 06871800 & North Fork Solomon River at Kirwin, KS & $1920-54$ & 35 & 87 & 31 & 27 & 1,367 & 21.47 & 1.38 & 2.3 \\
\hline 06871900 & Deer Creek near Phillipsburg, KS & $1967-81$ & 15 & 4.0 & .69 & .63 & 65 & 23.00 & 1.37 & 3.0 \\
\hline 06873000 & South Fork Solomon River above Webster Reservoir, KS & 1946-2000 & 55 & 54 & 14 & 34 & 1,040 & 20.87 & 1.46 & 2.1 \\
\hline 06873500 & South Fork Solomon River at Alton, KS & $1920-57$ & 38 & 104 & 30 & 18 & 1,720 & 21.64 & 1.41 & 2.1 \\
\hline 06873700 & Kill Creek near Bloomington, KS & $1964-81$ & 18 & 2.1 & 0 & 0 & 49.4 & 24.57 & 1.25 & 2.6 \\
\hline 06876000 & Solomon River at Beloit, KS & $1930-54$ & 25 & 457 & 93 & 98 & 5,530 & 23.06 & 1.33 & 2.2 \\
\hline 06876700 & Salt Creek near Ada, KS & $1960-2000$ & 41 & 70 & 12 & 19 & 384 & 26.98 & 1.11 & 2.6 \\
\hline 06877000 & Smoky Hill River at Solomon, KS & 1919-34 & 16 & 931 & 404 & 420 & 8,830 & 22.1 & 1.39 & 1.9 \\
\hline 06878000 & Chapman Creek near Chapman, KS & $1955-2000$ & 46 & 93 & 24 & 37 & 300 & 30.89 & 1.02 & 2.2 \\
\hline 06878500 & Lyon Creek near Woodbine, KS & $1955-74$ & 20 & 108 & 33 & 32 & 230 & 34.13 & .533 & 2.4 \\
\hline 06879650 & Kings Creek near Manhattan, KS & $1980-2000$ & 20 & 2.6 & .19 & .04 & 4.09 & 33.00 & .458 & 5.9 \\
\hline 06882000 & Big Blue River near Barnestown, NE & $1933-2000$ & 78 & 867 & 280 & 401 & 4,447 & 28.54 & .820 & 1.3 \\
\hline 06882500 & Big Blue River near Hull, KS & $1931-40$ & 10 & 470 & 217 & 169 & 4,685 & 28.66 & .810 & 1.4 \\
\hline 06882510 & Big Blue River at Marysville, KS & $1985-2000$ & 16 & 1,190 & 467 & 469 & 4,777 & 28.67 & .809 & 1.4 \\
\hline 06884000 & Little Blue River near Fairbury, NE & $1911-2000$ & 90 & 383 & 160 & 169 & 2,350 & 27.34 & 1.43 & 1.4 \\
\hline 06884025 & Little Blue River at Hollenberg, KS & 1975-2000 & 26 & 535 & 211 & 220 & 2,752 & 27.64 & 1.37 & 1.6 \\
\hline 06884200 & Mill Creek at Washington, KS & $1960-2000$ & 41 & 108 & 19 & 26 & 344 & 30.62 & .908 & 2.4 \\
\hline 06884400 & Little Blue River near Barnes, KS & $1959-2000$ & 42 & 704 & 268 & 304 & 3,324 & 28.23 & 1.28 & 1.7 \\
\hline
\end{tabular}


Table 1. Streamflow-gaging stations and climatic and basin characteristics used in regression analyses of uncontrolled stream segments identified on the 1999 Kansas Surface Water Register ${ }^{1}$.-Continued

$\left[\mathrm{ft}^{3} / \mathrm{s}\right.$, cubic feet per second; $\mathrm{mi}^{2}$, square miles; in/h, inches per hour]

\begin{tabular}{|c|c|c|c|c|c|c|c|c|c|c|}
\hline \multirow[b]{2}{*}{$\begin{array}{l}\text { Station } \\
\text { number } \\
\text { (fig. 1) }\end{array}$} & \multirow[b]{2}{*}{ Station name } & \multirow[b]{2}{*}{$\begin{array}{l}\text { Period of } \\
\text { record } \\
\text { (water } \\
\text { years) }\end{array}$} & \multirow[b]{2}{*}{$\begin{array}{l}\text { Years } \\
\text { of } \\
\text { record }\end{array}$} & \multicolumn{3}{|c|}{ Streamflow } & \multirow[b]{2}{*}{$\begin{array}{c}\text { Drainage } \\
\text { area } \\
\left(\mathrm{mi}^{2}\right)\end{array}$} & \multirow[b]{2}{*}{$\begin{array}{c}\text { Mean annual } \\
\text { precipitation, } \\
1961-90^{2} \\
\text { (inches) }\end{array}$} & \multirow[b]{2}{*}{$\begin{array}{l}\text { Mean basin } \\
\text { permeability } \\
\quad(\text { in } / \mathrm{h})\end{array}$} & \multirow[b]{2}{*}{$\begin{array}{c}\text { Mean } \\
\text { basin } \\
\text { slope }^{4} \\
\text { (degrees) }\end{array}$} \\
\hline & & & & $\begin{array}{l}\text { Mean } \\
\left(\mathrm{ft}^{3} / \mathrm{s}\right)\end{array}$ & $\begin{array}{l}\text { Median for } \\
\text { period or } \\
\text { record } \\
\left(\mathrm{ft}^{3} / \mathrm{s}\right)\end{array}$ & $\begin{array}{c}\text { Median for } \\
\text { most-recent } \\
10 \text { years } \\
\left(\mathrm{ft}^{3} / \mathrm{s}\right)\end{array}$ & & & & \\
\hline$\overline{06884500}$ & Little Blue River at Waterville, KS & $1923-57$ & 35 & 619 & 200 & 243 & 3,509 & 28.23 & 1.28 & 1.7 \\
\hline 06885500 & Black Vermillion River near Frankfort, KS & $1954-2000$ & 47 & 174 & 29 & 43 & 410 & 33.31 & .359 & 2.4 \\
\hline 06886000 & Big Blue River at Randolph, KS & $1919-60$ & 42 & 1,690 & 600 & 730 & 9,100 & 28.94 & .946 & 1.7 \\
\hline 06886500 & Fancy Creek at Winkler, KS & $1955-71$ & 17 & 47 & 11 & 13 & 174 & 30.98 & .731 & 2.5 \\
\hline 06888000 & Vermillion Creek near Wamego, KS & $1937-71$ & 35 & 87 & 17 & 27 & 243 & 34.94 & .427 & 3.4 \\
\hline 06888500 & Mill Creek near Paxico, KS & $1955-2000$ & 46 & 194 & 56 & 59 & 316 & 34.67 & .505 & 4.2 \\
\hline 06889100 & Soldier Creek near Goff, KS & $1965-86$ & 22 & 1.4 & .08 & .09 & 2.06 & 35.54 & .318 & 2.6 \\
\hline 06889120 & Soldier Creek near Bancroft, KS & $1965-87$ & 23 & 6.9 & .55 & .88 & 10.5 & 35.16 & .344 & 2.6 \\
\hline 06889140 & Soldier Creek near Soldier, KS & $1965-98$ & 34 & 11 & 1.2 & 1.5 & 16.9 & 35.16 & .359 & 2.7 \\
\hline 06889160 & Soldier Creek near Circleville, KS & $1965-2000$ & 36 & 32 & 4.6 & 5.6 & 49.3 & 35.82 & .381 & 2.8 \\
\hline 06889180 & Soldier Creek near St. Clere, KS & $1965-80$ & 16 & 51 & 10 & 12 & 80 & 35.53 & .434 & 3.0 \\
\hline 06889200 & Soldier Creek near Delia, KS & $1959-2000$ & 42 & 99 & 21 & 22 & 157 & 35.63 & .476 & 3.2 \\
\hline 06889500 & Soldier Creek near Topeka, KS & $1930-2000$ & 71 & 158 & 30 & 43 & 290 & 35.73 & .557 & 3.3 \\
\hline 06890100 & Delaware River near Muscotah, KS & $1970-2000$ & 31 & 280 & 51 & 56 & 431 & 35.97 & .398 & 3.1 \\
\hline 06890500 & Delaware River at Valley Falls, KS & $1923-67$ & 45 & 388 & 65 & 101 & 922 & 36.28 & .432 & 3.1 \\
\hline 06891500 & Wakarusa River near Lawrence, KS & $1930-76$ & 47 & 195 & 23 & 64 & 425 & 36.61 & 617 & 2.6 \\
\hline 06892000 & Stranger Creek near Tonganoxie, KS & 1930-2000 & 71 & 247 & 40 & 52 & 406 & 37.89 & .503 & 3.2 \\
\hline 06893080 & Blue River near Stanley, KS & $1975-2000$ & 26 & 36 & 5 & 5.6 & 46 & 39.35 & 609 & 2.1 \\
\hline 06910800 & Marais des Cygnes River near Reading, KS & 1970-2000 & 31 & 113 & 15 & 13 & 177 & 35.80 & .399 & 2.2 \\
\hline 06911000 & Marais des Cygnes River at Melvern, KS & $1940-64$ & 25 & 196 & 23 & 33 & 351 & 36.61 & .421 & 2.2 \\
\hline 06911500 & Salt Creek near Lyndon, KS & 1940-99 & 60 & 66 & 5.1 & 6.4 & 111 & 36.60 & .461 & 2.1 \\
\hline 06911900 & Dragoon Creek near Burlingame, KS & $1961-2000$ & 40 & 68 & 8.0 & 7.5 & 114 & 36.07 & .443 & 2.7 \\
\hline 06912500 & Hundred and Ten Mile Creek near Quenemo, KS & $1940-62$ & 23 & 181 & 17 & 7.4 & 322 & 36.21 & .465 & 2.3 \\
\hline 06913000 & Marais des Cygnes River near Pomona, KS & $1923-62$ & 40 & 303 & 26 & 25 & 1,040 & 36.54 & .478 & 2.2 \\
\hline 06913500 & Marais des Cygnes River near Ottawa, KS & $1903-62$ & 60 & 627 & 70 & 168 & 1,250 & 36.70 & .520 & 2.2 \\
\hline 06914000 & Pottawatomie Creek near Garnett, KS & $1940-2000$ & 61 & 235 & 21 & 20 & 334 & 38.31 & .545 & 1.3 \\
\hline
\end{tabular}


Table 1. Streamflow-gaging stations and climatic and basin characteristics used in regression analyses of uncontrolled stream segments identified on the 1999 Kansas Surface Water Register ${ }^{1}$.-Continued

$\left[\mathrm{ft}^{3} / \mathrm{s}\right.$, cubic feet per second; $\mathrm{mi}^{2}$, square miles; in/h, inches per hour]

\begin{tabular}{|c|c|c|c|c|c|c|c|c|c|c|}
\hline \multirow[b]{2}{*}{$\begin{array}{l}\text { Station } \\
\text { number } \\
\text { (fig. 1) }\end{array}$} & \multirow[b]{2}{*}{ Station name } & \multirow[b]{2}{*}{$\begin{array}{l}\text { Period of } \\
\text { record } \\
\text { (water } \\
\text { years) }\end{array}$} & \multirow[b]{2}{*}{$\begin{array}{l}\text { Years } \\
\text { of } \\
\text { record }\end{array}$} & \multicolumn{3}{|c|}{ Streamflow } & \multirow[b]{2}{*}{$\begin{array}{c}\text { Drainage } \\
\text { area } \\
\left(\mathrm{mi}^{2}\right)\end{array}$} & \multirow[b]{2}{*}{$\begin{array}{c}\text { Mean annual } \\
\text { precipitation, } \\
1961-90^{2} \\
\text { (inches) }\end{array}$} & \multirow[b]{2}{*}{$\begin{array}{l}\text { Mean basin } \\
\text { permeability } \\
\quad(\text { in/h) }\end{array}$} & \multirow[b]{2}{*}{$\begin{array}{c}\text { Mean } \\
\text { basin } \\
\text { slope }^{4} \\
\text { (degrees) }\end{array}$} \\
\hline & & & & $\begin{array}{l}\text { Mean } \\
\left(\mathrm{ft}^{3} / \mathrm{s}\right)\end{array}$ & $\begin{array}{l}\text { Median for } \\
\text { period or } \\
\text { record } \\
\left(\mathrm{ft}^{3} / \mathrm{s}\right)\end{array}$ & $\begin{array}{c}\text { Median for } \\
\text { most-recent } \\
10 \text { years } \\
\left(\mathrm{ft}^{3} / \mathrm{s}\right)\end{array}$ & & & & \\
\hline 06915000 & Big Bull Creek near Hillsdale, KS & $1959-80$ & 22 & 104 & 14 & 21 & 147 & 39.25 & 0.660 & 2.1 \\
\hline 06916000 & Marais des Cygnes River at Trading Post, KS & $1929-58$ & 30 & 1,690 & 209 & 202 & 2,880 & 38.14 & .595 & 2.0 \\
\hline 06916500 & Big Sugar Creek at Farlinville, KS & $1930-70$ & 41 & 127 & 11 & 18 & 198 & 40.18 & 657 & 2.2 \\
\hline 06917000 & Little Osage River at Fulton, KS & $1950-2000$ & 51 & 238 & 32 & 44 & 295 & 40.67 & .728 & 2.0 \\
\hline 06917380 & Marmaton River near Marmaton, KS & $1972-2000$ & 29 & 302 & 43 & 42 & 292 & 41.34 & .829 & 1.9 \\
\hline 06917500 & Marmaton River at Fort Scott, KS & $1922-71$ & 50 & 288 & 31 & 30 & 408 & 41.47 & .827 & 1.9 \\
\hline 07138650 & White Woman Creek near Leoti, KS & $1967-85$ & 19 & 1.0 & 0 & 0 & 758 & 15.74 & 1.20 & .57 \\
\hline 07139800 & Mulberry Creek near Dodge City, KS & $1969-90$ & 22 & .64 & 0 & 0 & 217 & 21.70 & 1.23 & .83 \\
\hline 07140850 & Pawnee River near Burdett, KS & $1982-2000$ & 19 & 11 & 0 & 1.5 & 1,252 & 20.49 & 1.11 & 1.1 \\
\hline 07141200 & Pawnee River at Rozel, KS & $1925-2000$ & 76 & 63 & 3.7 & 4.2 & 2,148 & 20.98 & 1.12 & 1.1 \\
\hline 07141780 & Walnut Creek at Nekoma, KS & $1970-2000$ & 31 & 25 & 1.0 & 13 & 1,192 & 21.02 & 1.17 & 1.1 \\
\hline 07141900 & Walnut Creek at Albert, KS & 1959-2000 & 42 & 49 & 2.3 & 25 & 1,410 & 21.40 & 1.18 & 1.2 \\
\hline 07142300 & Rattlesnake Creek near Macksville, KS & $1960-2000$ & 41 & 26 & 15 & 13 & 784 & 24.14 & 5.57 & .82 \\
\hline 07142575 & Rattlesnake Creek near Zenith, KS & $1974-2000$ & 27 & 50 & 29 & 29 & 1,047 & 24.41 & 5.90 & .68 \\
\hline 07142620 & Rattlesnake Creek near Raymond, KS & $1961-98$ & 38 & 49 & 24 & 8.05 & 1,167 & 24.41 & 5.90 & .68 \\
\hline 07142860 & Cow Creek near Claflin, KS & $1967-81$ & 15 & 7.0 & .13 & .15 & 43 & 25.85 & 1.04 & 1.3 \\
\hline 07142900 & Blood Creek near Boyd, KS & $1963-80$ & 18 & 7.1 & .48 & .79 & 61 & 24.45 & 1.07 & 1.5 \\
\hline 07143300 & Cow Creek near Lyons, KS & 1939-2000 & 62 & 80 & 12 & 13 & 728 & 26.15 & 1.30 & .87 \\
\hline 07143600 & Little Arkansas River near Little River, KS & $1960-70$ & 11 & 9.5 & .80 & .6 & 71 & 27.67 & .856 & 1.3 \\
\hline 07143665 & Little Arkansas River at Alta Mills, KS & $1974-2000$ & 27 & 229 & 22 & 22 & 736 & 29.49 & 2.07 & .759 \\
\hline 07144200 & Little Arkansas River at Valley Center, KS & $1923-2000$ & 78 & 312 & 60 & 73 & 1,327 & 30.34 & 2.02 & .754 \\
\hline 07144780 & North Fork Ninnescah River above Cheney Reservoir, KS & 1966-2000 & 35 & 147 & 76 & 79 & 787 & 26.87 & 5.48 & .69 \\
\hline 07144800 & North Fork Ninnescah River near Cheney, KS & $1951-64$ & 14 & 160 & 85 & 84 & 930 & 27.47 & 4.96 & .83 \\
\hline 07144850 & South Fork South Fork Ninnescah River near Pratt, KS & $1962-80$ & 19 & 2.6 & 0 & 0 & 23.1 & 25.58 & 2.02 & .92 \\
\hline 07145200 & South Fork Ninnescah River near Murdock, KS & $1951-2000$ & 50 & 209 & 135 & 136 & 650 & 27.25 & 3.08 & 1.3 \\
\hline 07145500 & Ninnescah River near Peck, KS & 1939-63 & 25 & 550 & 272 & 248 & 2,129 & 28.06 & 3.78 & 1.1 \\
\hline
\end{tabular}


Table 1. Streamflow-gaging stations and climatic and basin characteristics used in regression analyses of uncontrolled stream segments identified on the 1999 Kansas Surface Water Register ${ }^{1}$.-Continued

[ft $\mathrm{ft}^{3} / \mathrm{s}$, cubic feet per second; $\mathrm{mi}^{2}$, square miles; in/h, inches per hour]

\begin{tabular}{|c|c|c|c|c|c|c|c|c|c|c|}
\hline \multirow[b]{2}{*}{$\begin{array}{l}\text { Station } \\
\text { number } \\
\text { (fig. 1) }\end{array}$} & \multirow[b]{2}{*}{ Station name } & \multirow[b]{2}{*}{$\begin{array}{l}\text { Period of } \\
\text { record } \\
\text { (water } \\
\text { years) }\end{array}$} & \multirow[b]{2}{*}{$\begin{array}{l}\text { Years } \\
\text { of } \\
\text { record }\end{array}$} & \multicolumn{3}{|c|}{ Streamflow } & \multirow[b]{2}{*}{$\begin{array}{c}\text { Drainage } \\
\text { area } \\
\left(\mathrm{mi}^{2}\right)\end{array}$} & \multirow[b]{2}{*}{$\begin{array}{c}\text { Mean annual } \\
\text { precipitation, } \\
1961-90^{2} \\
\text { (inches) }\end{array}$} & \multirow[b]{2}{*}{$\begin{array}{l}\text { Mean basin } \\
\text { permeability } \\
\quad(\text { in } / \mathrm{h})\end{array}$} & \multirow[b]{2}{*}{$\begin{array}{c}\text { Mean } \\
\text { basin } \\
\text { slope }^{4} \\
\text { (degrees) }\end{array}$} \\
\hline & & & & $\begin{array}{l}\text { Mean } \\
\left(\mathrm{ft}^{3} / \mathrm{s}\right)\end{array}$ & $\begin{array}{l}\text { Median for } \\
\text { period or } \\
\text { record } \\
\left(\mathrm{ft}^{3} / \mathrm{s}\right)\end{array}$ & $\begin{array}{c}\text { Median for } \\
\text { most-recent } \\
10 \text { years } \\
\left(\mathrm{ft}^{3} / \mathrm{s}\right)\end{array}$ & & & & \\
\hline 07145700 & Slate Creek at Wellington, KS & $1970-2000$ & 31 & 73 & 8.0 & 8.8 & 154 & 30.73 & 0.876 & 0.81 \\
\hline 07146570 & Cole Creek near DeGraff, KS & 1962-79 & 18 & 17 & 1.8 & 1.7 & 30 & 33.68 & .448 & 1.1 \\
\hline 07147070 & Whitewater River at Towanda, KS & $1962-2000$ & 39 & 206 & 36 & 39 & 426 & 33.05 & .468 & 1.2 \\
\hline 07147800 & Walnut River at Winfield, KS & $1922-80$ & 58 & 793 & 152 & 186 & 1,880 & 34.31 & .488 & 1.4 \\
\hline 07148350 & Salt Fork Arkansas near Winchester, OK & $1960-93$ & 24 & 96 & 34 & 58 & 856 & 24.58 & 2.81 & 2.6 \\
\hline 07149000 & Medicine Lodge River near Kiowa, KS & 1939-2000 & 62 & 154 & 85 & 109 & 903 & 25.47 & 2.56 & 2.7 \\
\hline 07149500 & Salt Fork Arkansas River near Cherokee, OK & $1941-50$ & 10 & 393 & 125 & 125 & 2,439 & 25.44 & 2.80 & 2.5 \\
\hline 07151500 & Chikaskia River near Corbin, KS & 1951-2000 & 50 & 250 & 94 & 106 & 794 & 28.69 & 2.65 & 1.1 \\
\hline 07152000 & Chikaskia River near Blackwell, OK & 1937-2000 & 64 & 585 & 144 & 221 & 1,859 & 32.94 & .800 & .95 \\
\hline 07154500 & Cimarron River near Kenton, OK & $1951-2000$ & 50 & 17 & .91 & .33 & 1,106 & 16.29 & 2.07 & 1.0 \\
\hline 07155590 & Cimarron River near Elkhart, KS & 1972-2000 & 29 & 11 & 0 & 0 & 3,410 & 16.33 & 3.04 & 1.8 \\
\hline 07156010 & North Fork Cimarron River at Richfield, KS & $1972-85$ & 14 & 5.6 & 0 & 0 & 492 & 16.12 & 3.27 & .97 \\
\hline 07156100 & Sand Arroyo Creek near Johnson, KS & $1972-85$ & 14 & .25 & 0 & 0 & 751 & 15.90 & 3.12 & .93 \\
\hline 07156220 & Bear Creek near Johnson, KS & 1967-98 & 32 & 3.4 & 0 & 0 & 1,093 & 15.85 & 1.27 & 1.2 \\
\hline 07156900 & Cimarron River near Forgan, OK & 1966-2000 & 35 & 58 & 45 & 38 & 8,536 & 16.85 & 3.16 & 1.1 \\
\hline 07157000 & Cimarron River near Mocane, OK & $1943-65$ & 13 & 100 & 60 & 60 & 8,670 & 17.07 & 3.32 & 1.2 \\
\hline 07157500 & Crooked Creek near Englewood, KS & 1943-2000 & 58 & 31 & 12 & 8.7 & 1,157 & 20.51 & 1.67 & .72 \\
\hline 07157900 & Cavalry Creek at Coldwater, KS & $1967-81$ & 15 & 3.4 & 1.5 & 1.6 & 39 & 24.81 & 2.73 & 1.1 \\
\hline 07157950 & Cimarron River near Buffalo, OK & 1961-94 & 34 & 128 & 56 & 47 & 12,004 & 19.53 & 3.19 & 1.3 \\
\hline 07165700 & Verdigris River near Madison, KS & $1956-76$ & 21 & 123 & 28 & 33 & 181 & 36.14 & .486 & 2.8 \\
\hline 07166000 & Verdigris River near Coyville, KS & $1940-59$ & 20 & 465 & 45 & 22 & 747 & 36.75 & .541 & 2.4 \\
\hline 07166500 & Verdigris River near Altoona, KS & $1940-59$ & 20 & 691 & 71 & 35 & 1,138 & 37.51 & .671 & 2.4 \\
\hline 07167000 & Fall River near Eureka, KS & $1947-76$ & 30 & 190 & 40 & 57 & 307 & 35.32 & .515 & 3.1 \\
\hline 07167500 & Otter Creek at Climax, KS & 1947-2000 & 54 & 82 & 10 & 10 & 129 & 36.19 & .461 & 2.8 \\
\hline 07168500 & Fall River near Fall River, KS & $1905-48$ & 44 & 331 & 53 & 44 & 585 & 35.84 & .518 & 2.8 \\
\hline 07169500 & Fall River at Fredonia, KS & $1939-48$ & 10 & 506 & 75 & 75 & 827 & 36.26 & .616 & 2.7 \\
\hline
\end{tabular}


Table 1. Streamflow-gaging stations and climatic and basin characteristics used in regression analyses of uncontrolled stream segments identified on the 1999 Kansas Surface Water Register ${ }^{1}$.-Continued

[ft $\mathrm{ft}^{3} / \mathrm{s}$, cubic feet per second; $\mathrm{mi}^{2}$, square miles; in/h, inches per hour]

\begin{tabular}{|c|c|c|c|c|c|c|c|c|c|c|}
\hline \multirow[b]{2}{*}{$\begin{array}{l}\text { Station } \\
\text { number } \\
\text { (fig. 1) }\end{array}$} & \multirow[b]{2}{*}{ Station name } & \multirow[b]{2}{*}{$\begin{array}{l}\text { Period of } \\
\text { record } \\
\text { (water } \\
\text { years) }\end{array}$} & \multirow[b]{2}{*}{$\begin{array}{l}\text { Years } \\
\text { of } \\
\text { record }\end{array}$} & \multicolumn{3}{|c|}{ Streamflow } & \multirow[b]{2}{*}{$\begin{array}{c}\text { Drainage } \\
\text { area } \\
\left(\mathrm{mi}^{2}\right)\end{array}$} & \multirow[b]{2}{*}{$\begin{array}{c}\text { Mean annual } \\
\text { precipitation, } \\
1961-90^{2} \\
\text { (inches) }\end{array}$} & \multirow[b]{2}{*}{$\begin{array}{l}\text { Mean basin } \\
\text { permeability } \\
\quad(\mathrm{in} / \mathrm{h})\end{array}$} & \multirow[b]{2}{*}{$\begin{array}{c}\text { Mean } \\
\text { basin } \\
\text { slope }^{4} \\
\text { (degrees) }\end{array}$} \\
\hline & & & & $\begin{array}{l}\text { Mean } \\
\left(\mathrm{ft}^{3} / \mathrm{s}\right)\end{array}$ & $\begin{array}{l}\text { Median for } \\
\text { period or } \\
\text { record } \\
\left(\mathrm{ft}^{3} / \mathrm{s}\right)\end{array}$ & $\begin{array}{c}\text { Median for } \\
\text { most-recent } \\
10 \text { years } \\
\left(\mathrm{ft}^{3} / \mathrm{s}\right)\end{array}$ & & & & \\
\hline 07169800 & Elk River at Elk Falls, KS & $1967-2000$ & 33 & 154 & 22 & 19 & 220 & 36.46 & 0.447 & 2.5 \\
\hline 07170000 & Elk River near Elk City, KS & 1939-69 & 31 & 308 & 26 & 44 & 575 & 37.41 & .740 & 2.6 \\
\hline 07170700 & Big Hill Creek near Cherryvale, KS & 1958-2000 & 43 & 27 & 1.3 & .69 & 37 & 41.31 & .834 & 2.3 \\
\hline 07172000 & Caney River near Elgin, KS & 1940-2000 & 61 & 273 & 40 & 65 & 445 & 35.53 & .556 & 3.2 \\
\hline 07174000 & Little Caney River near Copan, OK & $1944-58$ & 15 & 237 & 9.5 & 7.4 & 424 & 37.51 & 1.01 & 2.9 \\
\hline 07174400 & Caney River above Coon Creek near Bartlesville, OK & $1986-2000$ & 15 & 1,290 & 173 & 99 & 1,392 & 36.75 & .970 & 3.1 \\
\hline 07179500 & Neosho River at Council Grove, KS & $1939-63$ & 25 & 123 & 16 & 17 & 250 & 33.77 & .433 & 1.8 \\
\hline 07180000 & Cottonwood River near Marion, KS & $1939-68$ & 30 & 112 & 18 & 21 & 329 & 32.37 & .662 & 1.5 \\
\hline 07180500 & Cedar Creek near Cedar Point, KS & 1939-2000 & 62 & 58 & 16 & 18 & 110 & 33.33 & .518 & 1.6 \\
\hline 07181000 & Cottonwood River at Elmdale, KS & $1923-32$ & 10 & 357 & 88 & 88 & 1,045 & 32.92 & .566 & 1.6 \\
\hline 07181500 & Middle Creek near Elmdale, KS & $1939-50$ & 12 & 45 & 7 & 10 & 92 & 34.05 & .456 & 2.2 \\
\hline 07182000 & Cottonwood River at Cottonwood Falls, KS & $1933-67$ & 35 & 511 & 108 & 185 & 1,740 & 33.09 & .545 & 1.9 \\
\hline 07182400 & Neosho River at Strawn, KS & 1949-62 & 14 & 1,390 & 285 & 227 & 2,933 & 34.11 & .508 & 1.9 \\
\hline 07183100 & Owl Creek near Piqua, KS & $1960-70$ & 11 & 122 & 4 & 3.6 & 177 & 40.36 & .609 & 1.7 \\
\hline 07183500 & Neosho River near Parsons, KS & $1922-63$ & 42 & 2,450 & 472 & 494 & 4,905 & 36.39 & .579 & 1.7 \\
\hline 07184000 & Lightning Creek near McCune, KS & 1939-2000 & 62 & 169 & 12 & 15 & 197 & 42.25 & 1.02 & 1.2 \\
\hline 07186000 & Spring River at Waco, MO & $1925-2000$ & 76 & 947 & 301 & 405 & 1,164 & 43.38 & 1.41 & 1.2 \\
\hline 07186400 & Center Creek near Carterville, MO & $1963-91$ & 29 & 204 & 97 & 134 & 232 & 42.92 & 1.46 & 1.6 \\
\hline 07187000 & Shoal Creek above Joplin, MO & 1942-2000 & 59 & 427 & 237 & 290 & 427 & 43.21 & 1.48 & 2.7 \\
\hline 07188000 & Spring River near Quapaw, OK & 1940-2000 & 61 & 2,200 & 850 & 1,050 & 2,510 & 43.18 & 1.43 & 1.4 \\
\hline
\end{tabular}

${ }^{1}$ The Kansas Surface Water Register is maintained by the Kansas Department of Health and Environment (Topeka).

${ }^{2}$ Mean annual precipitation for each gaging station from Daly and others (1997).

${ }^{3}$ Mean basin permeability for each gaging station from U.S. Department of Agriculture (1994).

${ }^{4}$ Mean basin slope for each gaging station from U.S. Geological Survey (1998). 
stations. Names and descriptions of the streamflow-gaging stations used in measuring flow at uncontrolled sites are listed in table 1.

Three gaging stations in Kansas that measured uncontrolled flow and had at least 10 years of record were not included in the regression analyses. One station, Indian Creek at Overland Park (station 06893300), was not used because it is affected by extensive urbanization. Two other stations, Beaver Creek at Cedar Bluffs (station 06846500) and Paradise Creek near Paradise (station 06867500), were not used because streamflow statistics were not consistent with statistics for other nearby stations. These two gaging stations were located on stream reaches that were losing surface flow to ground water (losing streams).

\section{Gaged Stream Sites}

The USGS has established standard methods for estimating flow duration (Searcy, 1959) for streamflow-gaging stations. The computer software programs IOWDM, ANNIE, and SWSTAT were used to format input data, manage and display data, and complete the flow-duration statistical analyses (Lumb and others, 1990; Flynn and others, 1995). These programs are available on the World Wide Web at

http://water.usgs.gov/software/surface_water.html

Daily mean flows for all complete water years of record were used to determine flow-duration statistics for continuousrecord, streamflow-gaging stations. The water year begins on October 1 and ends on September 30 of the following year. Daily mean flows for USGS streamflow-gaging stations in Kansas are available on the World Wide Web at http://waterdata.usgs.gov/ks/nwis/

A flow-duration curve is a graphical representation of the percentage of time streamflows for a given time step (usually daily) are equaled or exceeded over a specified period (usually the complete period of record) at a stream site. Flow-duration curves usually are constructed by first ranking all of the daily mean discharges for the period of record at a gaging station from largest to smallest, next computing the probability for each value of being equaled or exceeded, then plotting the discharges against their associated exceedance probabilities (Loaiciga, 1989, p. 82). The daily mean discharges are not fit to an assumed distribution. Flow-duration analysis can be done by use of the USGS software described previously or by use of commercially available statistical software.

Flow-duration statistics are points along a flow-duration curve. For example, the 99-percent duration streamflow is equaled or exceeded 99 percent of the time, whereas the 50-percent duration streamflow is equaled or exceeded 50 percent of the time. Strictly interpreted, flow-duration statistics reflect only the period for which they are calculated; however, when the period of record used to compute the statistics is sufficiently long, the statistics often are used as an indicator of probable future conditions (Searcy, 1959). Median-flow statistics in this report were determined using a computer software program developed by the USGS (Xiaodong Jian, written commun., 2003). The software program is on file at the USGS office in Lawrence, Kansas.

\section{Ungaged Stream Sites}

Estimates of streamflow statistics often are needed for sites on streams where no data are available. The two methods most commonly used to estimate statistics for ungaged sites are the drainage-area ratio method and multiple linear-regression analysis. The drainage-area ratio method is most appropriate for use when the ungaged site is near a streamflow-gaging station on the same stream. Multiple linear-regression analysis is used to obtain estimates for most other ungaged sites.

\section{Drainage-Area Ratio Method}

The drainage-area ratio method assumes that the streamflow at an ungaged site for the same stream is the same per unit area or at least responds in the same fashion as that at a nearby, hydrologically similar streamflow-gaging station used as an index. Drainage areas for the ungaged site and the index station are determined from topographic maps, digital elevation maps (DEMs), or by other GIS methods. Streamflow statistics are computed for the index station, then the statistics are divided by the drainage area to determine streamflows per unit area at the index station. These values are multiplied by the drainage area at the ungaged site to obtain estimated statistics for the site. This method is most commonly applied when the index gaging station is on the same stream as the ungaged site because the accuracy of the method depends on the proximity of the two sites and on similarities in drainage area and on other climatic and basin characteristics of the respective drainage basins.

Several researchers have provided guidelines as to how large the difference in drainage areas can be before use of multiple linear-regression analysis is preferred over use of the drainage-area ratio method. Guidelines have been provided for estimating peak-flow statistics, and usually the preferred guideline has been that the drainage area for the ungaged site should be within 0.5 and 1.5 times the drainage area of the index station (Choquette, 1988, p. 41; Koltun and Roberts, 1990, p. 6; Lumia, 1991, p. 34; Bisese, 1995, p. 13). One report (Koltun and Schwartz, 1986, p. 32) selected a range of 0.85 to 1.15 times the drainage area of the index station for estimating low flows at ungaged sites in Ohio. None of these researchers provided any scientific basis for use of these guidelines (R.E. Thompson, Jr., U.S. Geological Survey, written commun., 1999).

In this report, the median flows at uncontrolled, ungaged sites are estimated by interpolation procedures using weighted drainage-area ratio from gaged sites and multiple-linear regression estimates with Tobit analysis at ungaged sites (discussed in a following section, "Estimates of Median Flows for Stream Segments"). Median flows at controlled ungaged sites were determined by the drainage-ratio method. No limit was placed 
on the ratios between the drainage area of the index station and the drainage area of the ungaged stream segment.

\section{Multiple Linear-Regression Analyses}

Multiple linear-regression analysis (regression analysis) has been used by the USGS and other researchers throughout the United States and elsewhere to develop equations for estimating streamflow statistics at ungaged sites. In regression analysis, a streamflow statistic (the dependent variable) for a group of gaging stations is related statistically to the climatic or basin characteristics of the drainage basins for the stations (the independent variables). This results in an equation that can be used to estimate the statistic for sites where no streamflow data are available.

Equations can be developed by use of several different regression analysis algorithms. The various algorithms use different methods to minimize the differences between the values of the dependent variable for the stations used in the analysis (the observed values) and the corresponding values provided by the resulting regression equation (the estimated or fitted values). Choice of one algorithm over another depends on the characteristics of the data used in the analysis and on the underlying assumptions for use of the algorithm. The multiple linearregression equation takes the general form:

$$
Y_{i}=b_{0}+b_{1} X_{1}+b_{2} X_{2}+\ldots+b_{n} X_{n}+\varepsilon_{i}
$$

where $Y_{i}$ is the value of the dependent variable for site $i, X_{1}$ to $X_{n}$ are the $n$ independent variables, $b_{0}$ to $b_{n}$ are the $n+1$ regression-model coefficients, and $\varepsilon_{i}$ is the error (difference between the observed and estimated values of the dependent variable) for site $i$. Assumptions for use of regression analysis are (1) equation 1 adequately describes the relation between the dependent and the independent variables, (2) the variance of the $\varepsilon_{i}$ is constant and independent of the values of $X_{n}$, (3) the $\varepsilon_{i}$ are normally distributed for a Tobit analysis, and (4) the $\varepsilon_{i}$ are independent of each other (Inman and Conover, 1983, p. 367). Tobit analysis is discussed in the following paragraph. Regression analysis results must be evaluated to assure that these assumptions are met. Streamflow and basin characteristics used in hydrologic regression usually are log normally distributed; therefore, transformation of the variables to logarithms is usually necessary to satisfy regression assumption 3 . Transformation results in a model of the form:

$\log Y_{i}=b_{0}+b_{1} \log X_{1}+b_{2} \log X_{2}+\ldots+b_{n} \log X_{n}+\varepsilon_{i \cdot}$ (2)

The algebraically equivalent form when logarithms-base 10 $\left(\log _{10}\right)$ are used in the transformations, and the equation retransformed to original units is:

$$
\begin{aligned}
Y_{i} & =10^{b_{o}}\left(X_{1}^{b_{1}}\right)\left(X_{2}^{b_{2}}\right) \ldots\left(X_{n}^{b_{n}}\right) 10^{\varepsilon_{i}}, \text { or } \\
Y_{i} & =10^{\left[b_{o}+b_{1} \log X_{1}+b_{2} \log X_{2}+\ldots b_{n} \log X_{n}+\varepsilon_{i}\right]} .
\end{aligned}
$$

To include zero values in a logarithmic transformation regression, the Tobit analysis was used. Tobit analysis is a widely accepted method for estimating a regression-like model when there are adjusted data (Tobin, 1958; Judge and others, 1985; Cohn, 1988). Adjusted data are data that are either censored or have had a discrete value delta $(\delta)$ added to them. Censored data are values below a threshold and are raised to the censoring value (for example, all values below 0.7 are raised to 0.7). Discrete values of delta $(\delta)$ are added to all data before transformation and then subtracted from the final regression model value. By applying these techniques, zero values of data can be transformed logarithmically. The Tobit analysis uses a maximum likelihood estimator (Cohn, 1988). The Survival Regression Procedure in the S-Plus 2000 software package (MathSoft, 1999) was used in this study to fit the Tobit regression model.

Least-squares multiple regression with a Tobit analysis was conducted on both the KSA and AAH data sets, and the resulting plots of observed and regression-estimated values of median flow from the KSA and AAH data sets are shown in figures $6 A$ and $6 B$. The graphs show the observed median flow plotted with the regression-estimated median flow. All observed and regression-estimated median flows have the delta value added. The $\mathrm{Chi}^{2}$ is a measure of the fit of the Tobit model. The delta value is varied until the $\mathrm{Chi}^{2}$ is maximized. The contributing-drainage area $(C D A)$ was divided by 1,000 , the 30 year mean precipitation $(P R E C)$ was divided by 28 , and the mean basin slope ( $S L O P E$ ) was divided by 2 before the log transformation was made so that the log values were balanced between greater than and less than zero. This removed the multi-colinearity problems that occur when using squared values (A.V. Vecchia, USGS, written commun., 2002). The addition of the squares of log drainage area and log mean annual precipitation to the regression equation improved both KSA and AAH models substantially. The equations for regressionestimated median flow and uncertainty measures for KSA and AAH methods are listed in table 2. Only the 149 gages on uncontrolled streams with at least 10 years of record were used in the regression analyses. The drainage area of these gages ranged from 2.06 to $12,004 \mathrm{mi}^{2}$.

$\mathrm{KSA}$ and AAH analyses provided regression estimates that were different. The KSA analysis used the most-recent 10 years of data. For many of the stations in this report this period was 1990 to 2000 . However, more than 50 percent of the stations had their last data recorded before 1990 and more than 40 percent before 1980. Climate variability becomes a factor when 10 years of record from an earlier period is compared with a later period. Application of the KSA 82a-2001 criterion to use the most-recent 10 years of streamflow data may mean that a new analysis would be required every few years, and the resulting equation always would reflect short-term (less than 10 years) climate variability.

The AAH analysis used all-available streamflow-data records that were from 10 to 90 years in length. Use of the entire period of record, which averaged 35 years for the 149 stations, incorporated all of the knowledge about streamflow at a 
A. Tobit model for $\log _{10}(\mathrm{KSA}$ median flow + delta $)$
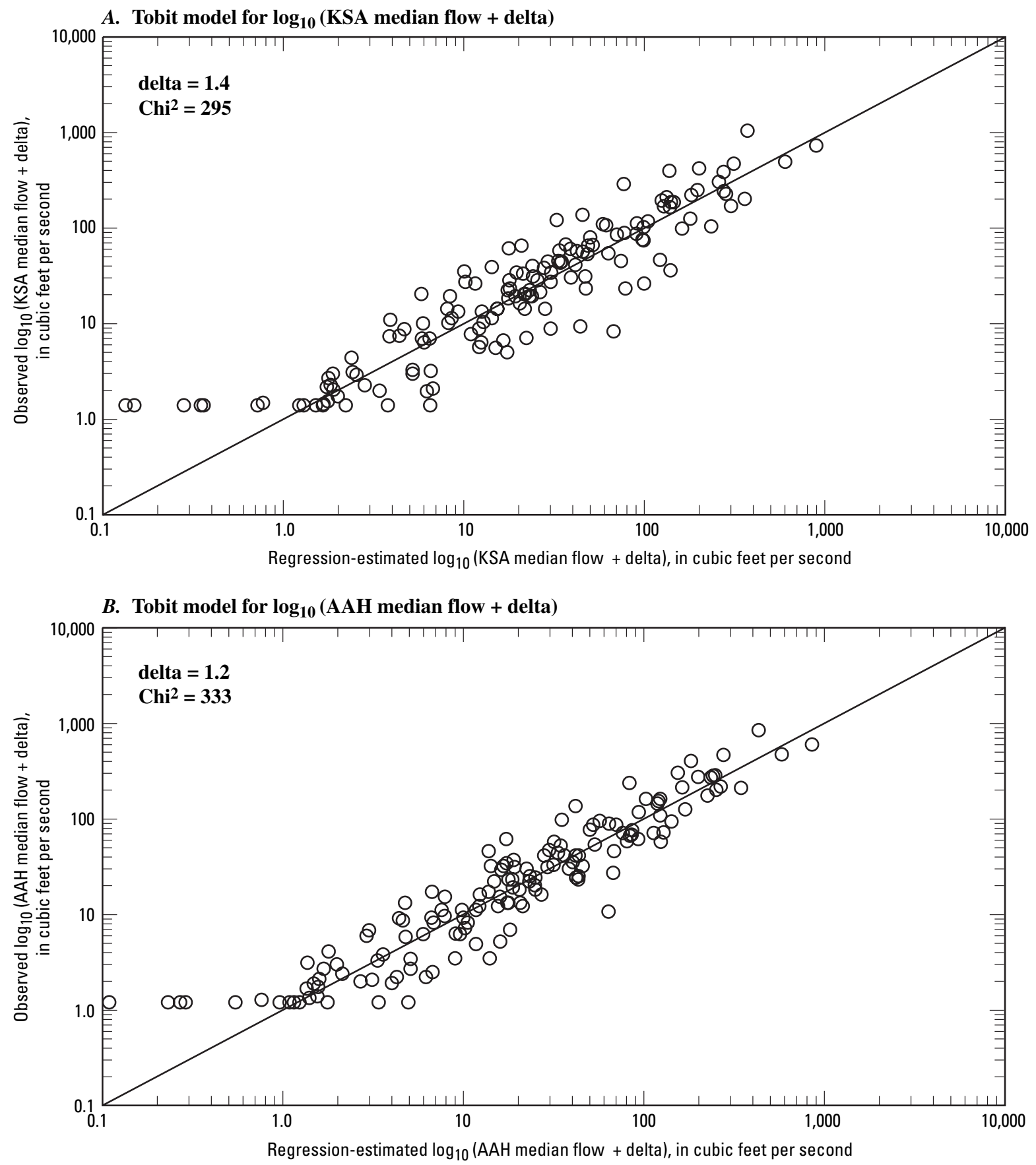

Figure 6. Comparison of observed and regression-estimated median flows for $(A)$ most-recent 10 years of record $(\mathrm{KSA})$ and $(B)$ all-available hydrology (AAH) using Tobit analysis.

particular site. The climate of Kansas has gone through periods of wet and dry conditions, some of which have lasted longer than 10 years. The AAH analysis with its longer period of record incorporates long-term climate variability.

Although both sets of median flow data (KSA and AAH) have some nonoverlapping time periods, the analyses are still valid statistically. The different time periods cover different streamflow regimes ranging from wet to dry. Had the most- recent 10 years been interpreted as the period 1991 to 2000 , the analysis would have been biased toward trends or cyclicity in the climate during that period. By using the different time periods of streamflow data for AAH analysis, this bias is removed. The increased number of sampled days of flow in the AAH data set makes it more robust than the KSA data set, which has a reduced number of sampled days. 
[KSA, Kansas Statute KSA 82a-2001 analysis; AAH, all-available hydrology analysis; $\mathrm{Chi}^{2}$, chi square statistical distribution; $C D A$, contributing-drainage area, in square miles; $P R E C$, precipitation, in inches; PERM, soil permeability, in inches per hour; SLOPE, land-surface slope, in degrees; $\quad \log d a=\log _{10}\left(\frac{C D A}{1000}\right) ; \log p r e c=\log _{10}\left(\frac{P R E C}{28}\right) ; \log$ perm $\left.=\log _{10} P E R M ; \log _{s} \operatorname{lope}=\log _{10}\left(\frac{S L O P E}{2}\right) \quad\right]$

\begin{tabular}{|c|c|c|c|c|}
\hline Flow value & Equation & $\mathrm{Chi}^{2}$ & $\begin{array}{l}\text { Standard } \\
\quad \text { error } \\
\text { (log units) }\end{array}$ & $\begin{array}{l}\text { Degrees } \\
\text { of } \\
\text { freedom }\end{array}$ \\
\hline $\begin{array}{l}\text { Median KSA } \\
\text { (most-recent } \\
10 \text { years of record) }\end{array}$ & $\mathrm{Q}_{\mathrm{KSA}}=\left[10^{\left[1.774+1.088 \log d a+4.867 \log p r e c+0.498 \log p e r m+0.513 \log s \operatorname{lope}+0.124(\log d a)^{2}-\left(16.154(\log \text { prec })^{2}\right)\right]}\right]-1.4$ & 295 & 0.285 & 143 \\
\hline $\begin{array}{l}\text { Median AAH } \\
\text { (entire period of } \\
\text { record) }\end{array}$ & $\mathrm{Q}_{\mathrm{AAH}}=\left[10^{\left[1.685+1.124 \log d a+5.283 \log \text { prec }+0.638 \log \text { perm }+0.517 \log \text { slope }+0.152(\log \mathrm{da})^{2}+\left(-15.38(\log \text { prec })^{2}\right)\right]}\right]-1.2$ & 333 & .250 & 143 \\
\hline
\end{tabular}

${ }^{1}$ The 1999 Kansas Surface Water Register is maintained by the Kansas Department of Health and Environment (Topeka). 


\section{Kansas Surface Water Register}

In 1994, the Kansas Department of Health and Environment (KDHE) adopted the Reach File Version 2 (RF2) streamsegment coverage within the State of Kansas as the basic coverage for stream classification. RF2 was completed in the late 1980s by the U.S. Environmental Protection Agency (USEPA) by using the Feature File of the USGS Geographic Names Information System (GNIS) to add one new level of reach segments to the Reach File Version 1 (RF1) coverage. The source of RF1 (completed in 1982) was the USGS's 1:250,000-scale hydrography that was photographically reduced to a scale of 1:500,000 by the National Oceanic and Atmospheric Association (NOAA).

In addition to the RF2 segments, other segments have been added by KDHE to the KSWR primarily for the protection of aquatic life and other water-quality issues. The original RF2 coverage has almost 30,000 subsegments in Kansas. By combining subsegments, the number of total segments for which median flows were determined in this report was reduced to 2,232 , which equals the number of segments listed in the 1999 KSWR. This number is about 900 more segments than the RF1 coverage. The KSWR of June 1, 1999, is a public document and can be obtained from the World Wide Web (http://www.kdhe.state.ks.us/pdf/befs/register99.pdf).

In addition to the 2,232 classified segments, there are segments that are unregulated that include lakes, tribal streams, and irrigation ditches. These segments were included in this report to complete the stream drainage pattern for the State. Each segment on the KSWR is identified by a unique CUSEGA number (Appendix C, table 6, at the end of this report). CUSEGA stands for catalog unit segment number alpha.

Because many of the stream basins in Kansas extend into the surrounding States, the data used for developing the KSWR, which is based on the more detailed RF2, were joined with the national RF1 coverage that is available for Colorado, Missouri, Nebraska, and Oklahoma. This process was done in a GIS procedure by clipping the Kansas extent of the original RF1 stream coverage and replacing it with the more detailed version of the RF2 stream coverage. The two coverages were joined at the State boundaries for continuity. The line topology was reconfigured so that spatial relations between connecting stream segments (from and to nodes) were updated. Then the updated stream coverage was rechecked to correct any remaining digitizing errors including cycles, overshoots, and undershoots (that is, an arc that does not extend far enough to intersect another arc). Finally, the topology was checked for consistency (that is, all segments point downstream). All GIS analyses were performed using the Environmental Systems Research Institute (ESRI) ArcGIS and ArcInfo workstation.

A GIS database was used to manage and display the basin characteristics and estimated median flows for stream segments on the KSWR. The relational database design facilitates identification and analysis of data unique to individual stream segments.

\section{Basin Characteristics for Stream Segments}

Drainage basins for each stream segment on the KSWR were determined in the GIS by converting the vector streamsegment coverage into a raster-grid network with a raster size of 492 by $492 \mathrm{ft}$ ( 150 by $150 \mathrm{~m}$ ). Euclidean allocation was performed on the rasterized stream network to calculate for each cell the identity of the closest source or stream cell using the Euclidean distance. Euclidean distance is defined as the shortest length between two points in two-dimensional space. GIS Euclidean allocation zones may not coincide with actual topographic basin divides; therefore, basin contributing-drainage areas obtained by GIS methods used herein may differ from those obtained using conventional topographic planimetering methods.

Mean values for climatic and basin characteristics were calculated for stream-segment drainage basins using zonal statistics on basin-characteristic grids with Euclidean allocation zones. Zonal statistics were recorded in an attribute table and included the area and mean of the values of all cells in the basincharacteristic grids that belong to the same Euclidean zone. The climatic and basin characteristics computed included contributing-drainage area, mean annual precipitation, mean basin elevation, mean basin permeability, mean basin slope, a Base Flow Index (BFI), and mean annual runoff (Gebert and others, 1987) and water-balance model runoff (Wolock and McCabe, 1999) flow values. Output zonal statistics tables were relationally joined back to the original vector streams coverage so that each reach had an estimated value for each climatic and basin characteristic.

\section{Estimates of Median Flows for Stream Segments}

Different procedures were used to estimate median flow for each stream segment on the KSWR depending on whether the segment was controlled or uncontrolled and whether there was a streamflow-gaging station located either upstream or downstream from the segment. These interpolation procedures use the previously defined drainage-area ratio method and multiple linear-regression equations with Tobit analysis and are summarized in table 3 . The interpolation procedures outlined in table 3 for an ungaged segment between two gaged segments selects the upstream gage segment (if there is more than one) that has the largest drainage area. These procedures were applied to flow statistics developed for KSA and AAH analyses for each stream segment on the KSWR. Median-flow computations for controlled streamflow-gaging stations, used in the interpolation of the KSA and AAH analyses, are listed in table 4. Median-flow computations for the uncontrolled streamflow-gaging stations, used in the interpolation of the KSA and AAH analyses, are listed in table 5 (Appendix B). The AAH median flow at gages representing controlled stream segments 
Table 3. Summary of interpolation procedures used to estimate median flow information for stream segments on the 1999 Kansas Surface Water Register (KSWR).

$[Q$, median flow; $D A$, drainage area; $B$, bias equals measured gaging station $Q$ minus regression equation $Q$; Subscripts: $r$, regression-equation estimate of median flow; $s$, segment (ungaged); $b$, with bias added; $u$, upstream gaging station; $d$, downstream gaging station; $g$, at streamflow gage]

\begin{tabular}{|c|c|c|c|}
\hline $\begin{array}{l}\text { Case } \\
\text { number }\end{array}$ & Case & Controlled segment interpolation procedure & Uncontrolled segment interpolation procedure \\
\hline 1 & No gage on stream. & Never occurs. & Use regression estimate (no adjustment). \\
\hline 2 & $\begin{array}{l}\text { Gage on that segment near }{ }^{1} \text { downstream end of } \\
\text { segment. }\end{array}$ & Use gaged value. & Use gaged value. \\
\hline 3 & $\begin{array}{l}\text { Gage on stream only upstream or downstream from } \\
\text { that segment. }\end{array}$ & $\begin{array}{l}\text { Estimate flow from gage data using ratio of gage drain- } \\
\text { age area to downstream end of KSWR segment drainage } \\
\text { area. Ignore regression equations. }\end{array}$ & $\begin{array}{l}\text { Use regression estimate adjusted by weighting the bias } \\
\text { between the gaged value and the estimated value at the gaged } \\
\text { site by the ratio of the gaged drainage area to the downstream } \\
\text { end of the KSWR segment drainage area. }\end{array}$ \\
\hline \multirow[b]{2}{*}{4} & \multirow[b]{2}{*}{$\begin{array}{l}\text { Gage on stream both upstream and } \\
\text { downstream from that segment. }\end{array}$} & $\begin{aligned} Q_{s} & =\frac{Q_{u}}{D A_{u}} * D A_{s} \text { or } \\
Q_{s} & =\frac{Q_{d}}{D A_{d}} * D A_{s}\end{aligned}$ & $\begin{array}{c}B_{s}=\frac{B_{u}}{D A_{u}} * D A_{s} * \frac{D A_{u}}{D A_{s}} \text { or } B_{s}=\frac{B_{d}}{D A_{d}} * D A_{s} * \frac{D A_{s}}{D A_{d}} \\
Q_{s b}=Q_{s r}+B_{s}\end{array}$ \\
\hline & & $\begin{array}{l}\text { Estimate the flow from upstream and downstream gage } \\
\text { data using weighted average ratios of gage drainage } \\
\text { areas to downstream end of KSWR segment drainage } \\
\text { area. Ignore regression equations. }\end{array}$ & $\begin{array}{l}\text { Use regression estimate adjusted by a weighted average bias } \\
\text { between the two gages. } \\
\qquad B_{s}=\frac{B_{u}\left(D A_{d}-D A_{s}\right)+B_{a}\left(D A_{s}-D A_{u}\right)}{D A_{d}-D A_{u}}\end{array}$ \\
\hline
\end{tabular}

${ }^{1}$ Near is defined as location on the stream segment that is downstream from any natural hydrologic break, such as a tributary stream. 
Table 4. Streamflow-gaging stations and drainage areas used to interpolate median flows for controlled stream segments on the 1999 Kansas Surface Water Register'.

$\left[\mathrm{mi}^{2}\right.$, square miles; $\mathrm{ft}^{3} / \mathrm{s}$, cubic feet per second; KSA, Kansas Statute KSA 82a-2001 analysis; AAH, all-available hydrology analysis]

\begin{tabular}{|c|c|c|c|c|c|}
\hline \multirow{2}{*}{$\begin{array}{l}\text { Station number } \\
\text { (fig. 1) }\end{array}$} & \multirow{2}{*}{ Station name } & \multirow{2}{*}{$\begin{array}{l}\text { Period of } \\
\text { record } \\
\text { (water } \\
\text { years) }\end{array}$} & \multirow{2}{*}{$\begin{array}{c}\text { Drainage } \\
\text { area } \\
\left(\mathrm{mi}^{2}\right)\end{array}$} & \multicolumn{2}{|c|}{$\begin{array}{l}\text { Median flow } \\
\left(\mathrm{ft}^{3} / \mathrm{s}\right)\end{array}$} \\
\hline & & & & KSA & AAH \\
\hline 06813500 & Missouri River at Rulo, NE & $1961-2000$ & 418,859 & 46,200 & 40,800 \\
\hline 06818000 & Missouri River at St. Joseph, MO & $1961-2000$ & 420,300 & 49,000 & 43,300 \\
\hline 06826500 & South Fork Republican River near Hale, CO & $1961-86$ & 1,825 & 6.0 & 6.2 \\
\hline 06827500 & South Fork Republican River near Benkelman, NE & $1961-2000$ & 2,740 & 16 & 16 \\
\hline 06848000 & Prairie Dog Creek at Norton, KS & $1965-2000$ & 684 & .47 & .10 \\
\hline 06848500 & Prairie Dog Creek near Woodruff, KS & $1965-2000$ & 1,007 & 7.4 & 2.0 \\
\hline 06853020 & Republican River at Guide Rock, NE & $1985-2000$ & 22,100 & 116 & 111 \\
\hline 06853500 & Republican River near Hardy, NE & $1961-2000$ & 22,401 & 164 & 167 \\
\hline 06854000 & White Rock Creek at Lovewell, KS & $1961-2000$ & 345 & .15 & .20 \\
\hline 06854500 & Republican River at Scandia, KS & $1961-72$ & 23,560 & 250 & 244 \\
\hline 06856000 & Republican River at Concordia, KS & $1961-2000$ & 23,560 & 269 & 284 \\
\hline 06856600 & Republican River at Clay Center, KS & $1961-2000$ & 24,542 & 407 & 396 \\
\hline 06857100 & Republican River below Milford Dam, KS & $1968-2000$ & 24,890 & 276 & 357 \\
\hline 06862000 & Smoky Hill River at Cedar Buff Dam, KS & $1961-90$ & 5,530 & 0 & .28 \\
\hline 06862700 & Smoky Hill River near Schoenchen, KS & $1965-2000$ & 5,750 & 6.3 & 11 \\
\hline 06862850 & Smoky Hill River below Schoenchen, KS & $1982-2000$ & 5,810 & 7.7 & 1.8 \\
\hline 06864000 & Smoky Hill River near Russell, KS & $1965-74$ & 6,965 & 35 & 35 \\
\hline 06864050 & Smoky Hill River near Bunker Hill, KS & $1961-2000$ & 7,075 & 63 & 34 \\
\hline 06864500 & Smoky Hill River at Ellsworth, KS & $1961-2000$ & 7,580 & 94 & 65 \\
\hline 06865500 & Smoky Hill River near Langley, KS & $1961-2000$ & 7,857 & 121 & 78 \\
\hline 06866500 & Smoky Hill River near Mentor, KS & $1961-2000$ & 8,358 & 197 & 135 \\
\hline 06868200 & Saline River at Wilson Dam, KS & $1965-2000$ & 1,917 & 21 & 16 \\
\hline 06869500 & Saline River at Tescott, KS & $1965-2000$ & 2,820 & 105 & 45 \\
\hline 06870200 & Smoky Hill River at New Cambria, KS & $1963-2000$ & 11,730 & 400 & 224 \\
\hline 06871800 & North Fork Solomon River at Kirwin, KS & $1961-2000$ & 1,367 & .04 & .03 \\
\hline 06872500 & North Fork Solomon River at Portis, KS & $1961-2000$ & 2,315 & 80 & 34 \\
\hline 06873200 & South Fork Solomon River below Webster Reservoir, KS & $1961-2000$ & 1,150 & .68 & 0 \\
\hline 06873460 & South Fork Solomon River at Woodston, KS & $1979-2000$ & 1,502 & 21 & 6.5 \\
\hline 06874000 & South Fork Solomon River at Osborne, KS & $1961-2000$ & 2,012 & 56 & 21 \\
\hline 06875900 & Solomon River near Glen Elder, KS & $1968-2000$ & 5,340 & 149 & 54 \\
\hline 06876070 & Solomon River near Simpson, KS & $1991-2000$ & 5,538 & 187 & 187 \\
\hline 06876900 & Solomon River at Niles, KS & $1968-2000$ & 6,770 & 320 & 174 \\
\hline 06877600 & Smoky Hill River at Enterprise, KS & $1961-2000$ & 19,260 & 1,000 & 595 \\
\hline 06879100 & Kansas River at Fort Riley, KS & $1968-2000$ & 44,870 & 1,680 & 1,350 \\
\hline 06887000 & Big Blue River near Manhattan, KS & $1963-2000$ & 9,640 & 1,170 & 974 \\
\hline 06887500 & Kansas River at Wamego, KS & $1963-2000$ & 55,280 & 3,470 & 2,720 \\
\hline 06888350 & Kansas River near Belvue, KS & $1983-2000$ & 55,870 & 3,640 & 3,480 \\
\hline 06889000 & Kansas River at Topeka, KS & $1963-2000$ & 56,720 & 3,820 & 3,020 \\
\hline 06890900 & Delaware River below Perry Dam, KS & $1970-2000$ & 1,117 & 103 & 100 \\
\hline 06891000 & Kansas River at Lecompton, KS & $1963-2000$ & 58,460 & 4,480 & 3,580 \\
\hline
\end{tabular}




\section{Estimates of Median Flows for Streams on the 1999 Kansas Surface Water Register}

Table 4. Streamflow-gaging stations and drainage areas used to interpolate median flows for controlled stream segments on the 1999 Kansas Surface Water Register ${ }^{1}$.-Continued

$\left[\mathrm{mi}^{2}\right.$, square miles; $\mathrm{ft}^{3} / \mathrm{s}$, cubic feet per second; KSA, Kansas Statute KSA 82a-2001 analysis; AAH, all-available hydrology analysis]

\begin{tabular}{|c|c|c|c|c|c|}
\hline \multirow{2}{*}{$\begin{array}{l}\text { Station number } \\
\text { (fig. 1) }\end{array}$} & \multirow{2}{*}{ Station name } & \multirow{2}{*}{$\begin{array}{l}\text { Period of } \\
\text { record } \\
\text { (water } \\
\text { years) }\end{array}$} & \multirow{2}{*}{$\begin{array}{c}\text { Drainage } \\
\text { area } \\
\left(\mathrm{mi}^{2}\right)\end{array}$} & \multicolumn{2}{|c|}{$\begin{array}{c}\text { Median flow } \\
\left(\mathrm{ft}^{3} / \mathrm{s}\right)\end{array}$} \\
\hline & & & & KSA & AAH \\
\hline 06891500 & Wakarusa River near Lawrence, KS & $1978-2000$ & 425 & 24 & 29 \\
\hline 06892350 & Kansas River at De Soto, KS & $1963-2000$ & 59,756 & 4,860 & 4,000 \\
\hline 06893000 & Missouri River at Kansas City, MO & 1961-2000 & 485,200 & 57,800 & 50,200 \\
\hline 06911000 & Marais des Cygnes River at Melvern, KS & $1965-74$ & 351 & 33 & 33 \\
\hline 06912500 & Hundred and Ten Mile Creek near Quenemo, KS & $1965-2000$ & 322 & 20 & 22 \\
\hline 06913000 & Marais des Cygnes River near Pomona, KS & 1974-2000 & 1,040 & 102 & 106 \\
\hline 06913500 & Marais des Cygnes River near Ottawa, KS & 1974-2000 & 1,250 & 143 & 146 \\
\hline 06915000 & Big Bull Creek near Hillsdale, KS & $1981-2000$ & 147 & 21 & 20 \\
\hline 06915800 & Marais des Cygnes River at La Cygne, KS & $1985-2000$ & 2,669 & 463 & 525 \\
\hline 06916600 & Marais des Cygnes River near Kansas-Missouri State line, KS & 1974-2000 & 3,230 & 562 & 578 \\
\hline 07134180 & Arkansas River near Granada, CO & $1981-2000$ & 23,707 & 112 & 106 \\
\hline 07137500 & Arkansas River near Coolidge, KS & $1961-2000$ & 25,410 & 206 & 129 \\
\hline 07138000 & Arkansas River at Syracuse, KS & 1961-2000 & 25,763 & 209 & 133 \\
\hline 07139000 & Arkansas River at Garden City, KS & 1980-2000 & 27,071 & 55 & 32 \\
\hline 07139500 & Arkansas River at Dodge City, KS & $1961-2000$ & 30,600 & 0 & 8.7 \\
\hline 07140000 & Arkansas River near Kinsley, KS & 1961-2000 & 33,066 & 3.7 & 32 \\
\hline 07141300 & Arkansas River at Great Bend, KS & 1961-2000 & 34,356 & 68 & 41 \\
\hline 07143330 & Arkansas River near Hutchinson, KS & 1961-2000 & 38,910 & 345 & 275 \\
\hline 07143375 & Arkansas River near Maize, KS & 1988-2000 & 39,110 & 362 & 303 \\
\hline 07144300 & Arkansas River at Wichita, KS & $1961-2000$ & 40,490 & 520 & 433 \\
\hline 07144550 & Arkansas River at Derby, KS & 1969-2000 & 40,830 & 659 & 541 \\
\hline 07144795 & North Fork Ninnescah River at Cheney Dam, KS & 1965-2000 & 901 & 58 & .48 \\
\hline 07145500 & Ninnescah River near Peck, KS & $1965-2000$ & 2,129 & 218 & 212 \\
\hline 07146500 & Arkansas River at Arkansas City, KS & $1961-2000$ & 43,713 & 1,170 & 1,030 \\
\hline 07146830 & Walnut River at Highway 54 east of El Dorado, KS & 1982-98 & 350 & 20 & 24 \\
\hline 07147800 & Walnut River at Winfield, KS & 1982-2000 & 1,880 & 228 & 262 \\
\hline 07166000 & Verdigris River near Coyville, KS & 1961-98 & 747 & 32 & 74 \\
\hline 07166500 & Verdigris River near Altoona, KS & 1961-2000 & 1,138 & 120 & 138 \\
\hline 07168500 & Fall River near Fall River, KS & $1961-89$ & 585 & 44 & 53 \\
\hline 07169500 & Fall River at Fredonia, KS & 1961-2000 & 827 & 109 & 92 \\
\hline 07170060 & Elk River below Elk City Lake, KS & 1966-2000 & 634 & 28 & 21 \\
\hline 07170500 & Verdigris River at Independence, KS & 1961-2000 & 2,892 & 455 & 401 \\
\hline 07170700 & Big Hill Creek near Cherryvale, KS & 1982-2000 & 37.0 & .69 & .88 \\
\hline 07171000 & Verdigris River near Lenopah, OK & 1961-2000 & 3,639 & 644 & 570 \\
\hline 07179500 & Neosho River at Council Grove, KS & $1965-2000$ & 250 & 15 & 13 \\
\hline 07179730 & Neosho River near Americus, KS & 1965-2000 & 622 & 67 & 70 \\
\hline 07179795 & North Cottonwood River below Marion Lake, KS & 1969-2000 & 200 & 8.6 & 7.6 \\
\hline 07180200 & Cottonwood River at Marion, KS & 1985-99 & 502 & 28 & 32 \\
\hline 07180400 & Cottonwood River near Florence, KS & 1969-2000 & 754 & 87 & 88 \\
\hline 07182250 & Cottonwood River near Plymouth, KS & $1969-2000$ & 1,740 & 266 & 298 \\
\hline
\end{tabular}


Table 4. Streamflow-gaging stations and drainage areas used to interpolate median flows for controlled stream segments on the 1999 Kansas Surface Water Register ${ }^{1}$.—Continued

$\left[\mathrm{mi}^{2}\right.$, square miles; $\mathrm{ft}^{3} / \mathrm{s}$, cubic feet per second; KSA, Kansas Statute KSA 82a-2001 analysis; AAH, all-available hydrology analysis]

\begin{tabular}{|c|c|c|c|c|c|}
\hline \multirow{2}{*}{$\begin{array}{l}\text { Station number } \\
\text { (fig. 1) }\end{array}$} & \multirow{2}{*}{ Station name } & \multirow{2}{*}{$\begin{array}{l}\text { Period of } \\
\text { record } \\
\text { (water } \\
\text { years) }\end{array}$} & \multirow{2}{*}{$\begin{array}{c}\text { Drainage } \\
\text { area } \\
\left(\mathrm{mi}^{2}\right)\end{array}$} & \multicolumn{2}{|c|}{$\begin{array}{c}\text { Median flow } \\
\left(\mathrm{ft}^{3} / \mathrm{s}\right)\end{array}$} \\
\hline & & & & KSA & AAH \\
\hline 07182510 & Neosho River at Burlington, KS & $1964-2000$ & 3,042 & 434 & 397 \\
\hline 07183000 & Neosho River near Iola, KS & $1964-2000$ & 3,818 & 619 & 581 \\
\hline 07185000 & Neosho River near Commerce, OK & 1964-2000 & 5,876 & 1,310 & 1,140 \\
\hline
\end{tabular}

${ }^{1}$ The Kansas Surface Water Register is maintained by the Kansas Department of Health and Environment (Topeka).

(those with large reservoirs upstream) was computed from the controlled period of record only. These records had to be at least 10 years in length during the period 1960 to 2000. Use of the 1960 to 2000 time period maintains a degree of consistency for comparison and interpolation of median flows between gaging stations on controlled segments.

Figure 7 shows part of a stream network and some stream gages in central Kansas. The numbers next to the stream gages are the most-recent 10-year median flow values for those gages. Regression equations for the most-recent 10-year median flow were developed in the section on "Multiple Linear-

Regression Analyses." The numbers next to the stream segments are the median flow values estimated from those regression equations. A comparison of the stream-segment median flow values with the stream-gage median values shows substantial "local" differences between the stream-segment and streamgage values. Figure 8 shows the effect of using the local stream-gage median flow values to develop estimated median streamflow values by KSA analysis for the stream segments as outlined in table 3 and used in this report rather than only using the regression-estimated values. The local differences in estimated median flow values noted in figure 7 (regression estimates) are not as large in figure 8 (estimates derived in this report) because of the use of local stream-gage data. As a result, the interpolation procedure used in this report to develop median flow estimates appears to develop more accurate estimates than those that result from using only the regression equations.

The median flow information from streamflow-gaging stations and the regression equations from the KSA and the AAH analyses were used with the described interpolation procedures to generate a table of median flow values for the downstream end of stream segments on the KSWR. The estimated median flow values for the KSA analysis and the AAH analysis are listed with their respective CUSEGA segment number in table 6 in Appendix C. In addition, county maps are provided in figures 9-113 in the back of this report. These figures show the location of USGS streamflow-gaging stations used in the interpolation procedure and KSWR stream segments and numbers.

Of the 2,232 stream segments on the Kansas Surface Water Register, 34.5 percent of the segments had an estimated median flow of less than $1 \mathrm{ft}^{3} / \mathrm{s}$ when the most-recent 10 years of data
(KSA analysis) were used. When all-available data (AAH analysis) were used, which resulted in a regression equation with a lower level of uncertainty when compared to the KSA analysis, 36.2 percent of the stream segments had an estimated median flow of less than $1 \mathrm{ft}^{3} / \mathrm{s}$.

The uncertainty of the estimated median streamflows varies depending on the analysis used to determine the estimate for that segment. The greatest uncertainties exist for streams where no stream-gage information was available and only the regression estimates were used. For these segments, the uncertainty of the median flow estimate is the model standard error of prediction of the regression estimate, which for the KSA analysis was $0.285 \log$ units. This means that there is a 95-percent probability that the actual median flow for an estimate of $1 \mathrm{ft}^{3} / \mathrm{s}$ is between 0.28 and $3.6 \mathrm{ft}^{3} / \mathrm{s}$ (72 to 260 percent). For the AAH analysis, the model standard error of prediction was $0.250 \mathrm{log}$ units (table 2), which translates into a 95-percent probability that the actual median flow for an estimate of $1 \mathrm{ft}^{3} / \mathrm{s}$ is between 0.33 and $3.04 \mathrm{ft}^{3} / \mathrm{s}$ (67 to 204 percent). The least uncertainty exists for stream segments with gages near the downstream end of those segments. For these stream segments the uncertainty is a fraction of the uncertainty of the gaging-station flow measurement and the rating process due to the central tendency of the median statistic. The average uncertainty for those segments with gages varies from 7.3 percent for the KSA data to 4.3 percent for the AAH data. The 95-percent confidence intervals for the gaged data used in the interpolation are listed in table 5 in Appendix B. Reporting estimated median values in table 6 to two or three significant figures was done to conform with the intent of KSA 82a-2001 et. seq. and does not denote the level of accuracy of the estimates.

\section{Internet Dissemination of Results}

This report and its associated figures, tables, appendixes, and the GIS database are available and can be downloaded from the World Wide Web (http://ks.water.usgs.gov/streamstats). This Web page is maintained by the USGS and has links to the GIS database described in this report to display the information on median flow by county for the State of Kansas. Estimated 


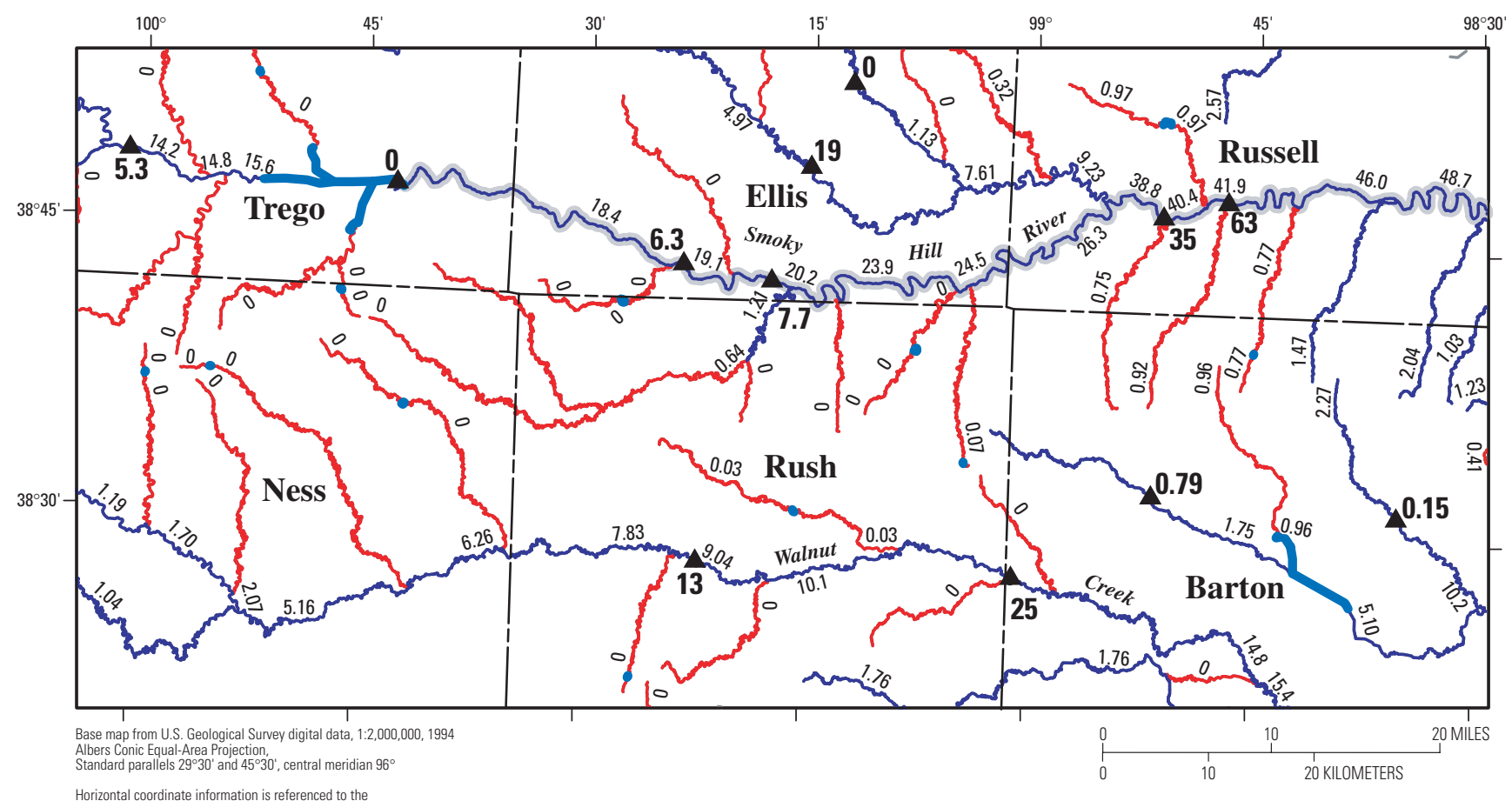
Horizontal coordinate information is referenced to the
North American Datum of 1983 (NAD 83)

EXPLANATION

Estimated median flow, in cubic feet per second

0.03 Less than 1.0

5.16 Greater than or equal to 1.0
26.3 Controlled stream segment

Hydro (lake) segment-No median flow computed

25 Streamflow-gaging station-Number is estimated median flow for most-recent 10 years, in cubic feet per second

Note: Numbers next to the stream segments are median flow values estimated from regression equations.

Figure 7. Median flow values for stream segments in central Kansas estimated from regression equations and observed streamflow-gaging-station data for the most-recent 10 years of record (KSA) analysis.

median flows from the KSA and AAH analyses are available for stream segments on the 1999 KSWR. The county-map format includes county boundaries, State and Federal highways, and the stream segments for spatial reference. The estimated median flow values using the KSA and AAH analyses, indexed with their respective segment identifier number, are displayed as a pop-up window as the cursor is placed over a stream segment.

\section{Summary}

The Kansas State Legislature, by enacting Kansas Statute 82a-2001 et. seq. (KSA), has mandated the selection of Kansas streams for water-quality classification by the State. One criterion for selecting stream segments for classification is whether stream segments listed on the 1999 Kansas Surface Water Register (KSWR) have a median flow equal to or greater than $1 \mathrm{ft}^{3} / \mathrm{s}$. Therefore, information on median flow characteristics is needed for streams in Kansas. Daily streamflow information available for 216 gaging stations within Kansas and in adjacent
States were used by the USGS in cooperation with KDHE to compute these statistics at gaged sites and to estimate these statistics at ungaged sites.

Least-squares multiple-regression techniques, along with Tobit analyses, were used to develop equations for estimating median flow (dependent variable) for ungaged, uncontrolled stream segments. Median flows were determined from streamflow-gaging station data using the most-recent 10 years of gaged data as defined by KSA analysis, and from the entire period of record, which is defined in this report as the allavailable hydrology (AAH) analysis. Independent variables in the regression equations were the climatic and basin characteristics for streams flowing through Kansas. In the development of the regression equations, the significant climatic and basin characteristics, in order of importance, were drainage area, mean annual precipitation, mean basin permeability, and mean basin slope. Only the 149 gages on uncontrolled streams with at least 10 years of streamflow record were used in the regression analyses. The drainage area of these gages ranged from 2.06 to $12,004 \mathrm{mi}^{2}$.

A logarithmic transformation of the basin characteristics was needed to develop a linear relation for computing median 


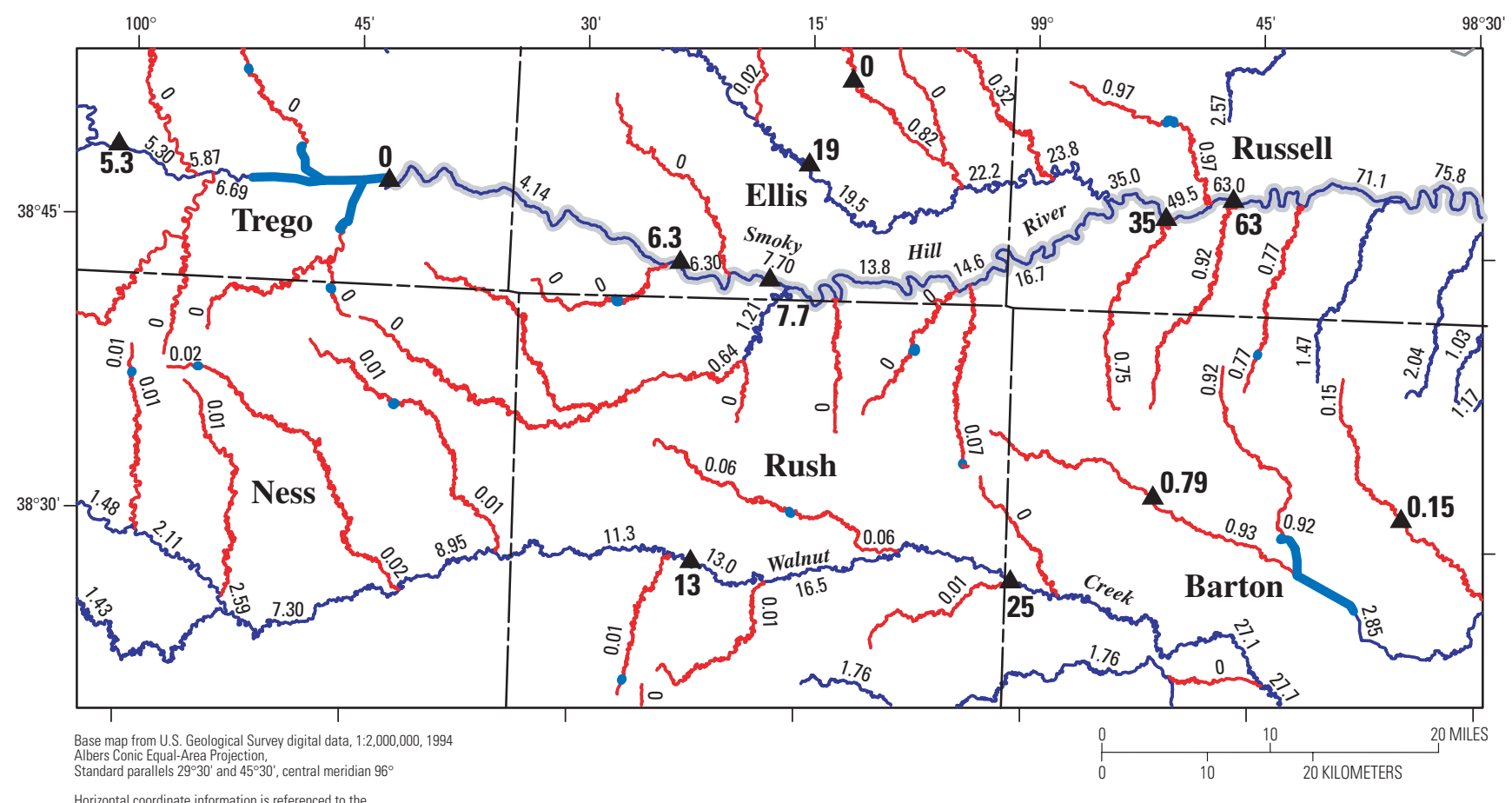

Horizontal coordinate information is referenced to the
North American Datum of 1983 (NAD 83)

EXPLANATION

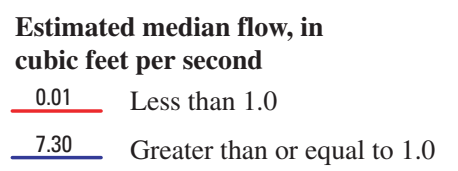

16.7 Controlled stream segment
Hydro (lake) segment-No median flow computed

25 Streamflow-gaging station-Number is estimated median flow for most-recent 10 years, in cubic feet per second

Note: Numbers next to the stream segments are median flow values estimated using procedures in table 3 .

Figure 8. Estimated median flow values for stream segments in central Kansas using interpolation procedures outlined in table 3 and observed streamflow-gaging-station data for the most-recent 10 years of record (KSA) analysis.

flows. Because there were numerous zero values for median gaging-station flows, Tobit analysis was used to include those zero values in the regression. The resulting regression equations and an interpolation procedure were used to estimate median flows for the uncontrolled stream segments on the 1999 KSWR.

Streamflow-gaging-station data were used to improve the quality of the estimates along the streams that had gages. Median flows for the segments that were uncontrolled were interpolated using gaged data weighted according to the drainage area and the bias between the regression estimate and gaged flow information. On controlled reaches of Kansas streams, the median flow information was interpolated between gaging stations by using only gaged data weighted by drainage area.

Of the 2,232 stream segments on the Kansas Surface Water Register, 34.5 percent of the segments had an estimated median flow of less than $1 \mathrm{ft}^{3} / \mathrm{s}$ when the most-recent 10 years of data (KSA analysis) were used. When all-available data (AAH analysis) were used, which resulted in a regression equation with less uncertainty when compared to KSA analysis, 36.2 percent of the stream segments had an estimated median flow of less than $1 \mathrm{ft}^{3} / \mathrm{s}$.
This report supercedes U.S. Geological Survey WaterResources Investigations Report 02-4282.

\section{References Cited}

Arihood, L.D., and Glatfelter, D.R., 1991, Method for estimating low-flow characteristics of ungaged streams in Indiana: U.S. Geological Survey Water-Supply Paper 2372, 18 p.

Bisese, J.A., 1995, Methods for estimating the magnitude and frequency of peak discharges of rural, unregulated stream in Virginia: U.S. Geological Survey Water-Resources Investigations Report 94-4148, 70 p., 1 pl.

Burrough, P.A., 1986, Principles of geographical information systems for land resources assessment: New York, Oxford University Press, $50 \mathrm{p}$.

Choquette, A.F., 1988, Regionalization of peak discharges for streams in Kentucky: U.S. Geological Survey WaterResources Investigations Report 88-4209, 105 p., 1 pl. 
Cohn, T.A., 1988, Adjusted maximum likelihood estimation of the moments of lognormal population of type 1 censored samples: U.S. Geological Survey Open-File Report 88-350, $34 \mathrm{p}$.

Daly, C., Neilson, R.P., and Phillips, D.L., 1994, A statisticaltopographic model for mapping climatological precipitation over mountainous terrain: Journal of Applied Meteorology, v. 33, no. 2, p. 140-158.

Daly, C., Taylor, C.H., and Gibson, W.P., 1997, The PRISM approach to mapping precipitation and temperature, in Reprints of 10th Conference on Applied Climatology, Reno, Nevada: American Meteorological Society, p. 10-12.

Environmental Systems Research Institute, Inc., 1991, Understanding GIS - the ARC/INFO method: Redlands, California, various pagination.

Flynn, K.M., Hummel, P.R., Lumb, A.M., and Kittle, J.L., Jr., 1995, User's manual for ANNIE, version 2, a computer program for interactive hydrologic data management: U.S. Geological Survey Water-Resources Investigations Report 95-4085, 211 p.

Furness, L.W., 1959, Kansas streamflow characteristicspart 1, Flow duration: Kansas Water Resources Board Technical Report No. 1, 213 p.

Gebert, W.A., Graczyk, D.J., and Krug, W.R., 1987, Average annual runoff in the United States, 1951-80: U.S. Geological Survey Hydrologic Investigations Atlas HA-710, scale 1:7,500,000, 1 sheet.

Inman, R.L., and Conover, W.J., 1983, A modern approach to statistics: New York, John Wiley, 497 p.

Johnson, C.G., 1970, A proposed streamflow data program for central New England: Boston, Massachusetts, U.S. Geological Survey open-file report, $38 \mathrm{p}$.

Jordan, P.R., 1983, Kansas streamflow characteristics - magnitude and frequency of low flows of unregulated streams in Kansas, and estimation of flow-duration curves for ungaged sites: Kansas Water Office Technical Report No. 17, 55 p.

Judge, G.G., Griffiths, W.E., Hill, R.C., Lutkepohl, H., and Lee, T.C., 1985, Qualitative and limited dependent variable models, chapter 18, in The theory and practice of econometrics: New York, Wiley, 1019 p.

Koltun, G.F., and Roberts, J.W., 1990, Techniques for estimating flood-peak discharges of rural, unregulated stream in Ohio: U.S. Geological Survey Water- Resources Investigations Report 89-4126, 68 p., 1 pl.

Koltun, G.F., and Schwartz, R.R., 1986, Multiple-regression equations for estimating low flows at ungaged stream sites in Ohio: U.S. Geological Survey Water-Resources Investigations Report 86-4354, 39 p., 6 pls.

Ku, H.F., Randall, A.D., and MacNish, R.D., 1975, Streamflow in the New York part of the Susquehanna River Basin: New York State Department of Environmental Conservation Bulletin $71,130 \mathrm{p}$.

Loaiciga, H.A., 1989, Variability of empirical flow quantiles: Journal of Hydraulic Engineering, American Society of Civil Engineers, v. 115 , no. 1, p. 82-100.
Lumb, A.M., Kittle, J.L., Jr., and Flynn, K.M., 1990, Users manual for ANNIE, a computer program for interactivelhydrologic analyses and data management: U.S. Geological Survey Water-Resources Investigations Report 89-4080, $236 \mathrm{p}$.

Lumia, Richard, 1991, Regionalization of flood discharges for rural, unregulated streams in New York, excluding Long Island: U.S. Geological Survey Water-Resources Investigations Report 90-4197, 119 p., 2 pls.

Male, J.W., and Ogawa, Hisashi, 1982, Low flow of Massachusetts streams: Amherst, Massachusetts, University of Massachusetts, Water Resources Research Center Publication 125, $152 \mathrm{p}$.

MathSoft, 1999, S-PLUS 2000 guide to statistics: Seattle, Washington, volumes I, II, and III, various pagination.

Parker, G.W., 1977, Methods for determining selected flow characteristics for streams in Maine: U.S. Geological Survey Open-File Report 78-871, 31 p.

Parrett, Charles, and Hull, J.A., 1985, Streamflow characteristics of mountain streams in western Montana: U.S. Geological Survey Water-Supply Paper 2260, 58 p.

Paulson, R.W., Chase, E.B., Roberts, R.S., and Moody, D.W., compilers, 1991, National water summary 198889-hydrologic events and floods and droughts: U.S. Geological Survey Water-Supply Paper 2375, 591 p.

Putnam, J.E., Lacock, D.L., Schneider, D.R., and Carlson, M.D., 2001, Water resources data, Kansas, water year 2000: U.S. Geological Survey Water-Data Report KS-00-1, 505 p.

Rasmussen, P.P., and Perry, C.A., 2000, Estimation of peak streamflows for unregulated rural streams in Kansas: U.S. Geological Survey Water-Resources Investigations Report 00-4079, 33 p.

Ries, K.G., and Friesz, P.I., 2000, Methods for estimating lowflow statistics for Massachusetts streams: U.S. Geological Survey Water-Resources Investigations Report 00-4135, $81 \mathrm{p}$.

Risley, J.C., 1994, Estimating the magnitude and frequency of low flows of streams in Massachusetts: U.S. Geological Survey Water-Resources Investigations Report 94-4100, $29 \mathrm{p}$.

Schoewe, W.H., 1949, The geography of Kansas-part 2, Physical geography: Transactions of the Kansas Academy of Science, v. 52, no. 3, p. 261-333.

Searcy, J.K., 1959, Flow-duration curves, manual of hydrology_part 2. Low-flow techniques: U.S. Geological Survey Water-Supply Paper 1542-A, p. 1-33.

Studley, S.E., 2000, Estimated flow-duration curves for selected ungaged sites in the Cimarron and Lower Arkansas River Basins in Kansas: U.S. Geological Survey WaterResources Investigations Report 00-4113, 43 p.

Studley, S.E., 2001, Estimated flow-duration curves for selected ungaged sites in Kansas: U.S. Geological Survey Water-Resources Investigations Report 01-4142, 90 p. 
Thomas, M.P., 1966, Effect of glacial geology upon the time distribution of streamflow in eastern and southern Connecticut, in Geological Survey Research 1966: U.S. Geological Survey Professional Paper 0550-B, p. B209-B212.

Tobin, J., 1958, Estimation of relationships for limited dependent variables: Eonometrica, v. 26, p. 24-36.

U.S. Department of Agriculture, 1994, State soil geographic (STATSGO) data base: Soil Conservation Miscellaneous Publication 1462, $37 \mathrm{p}$.

U.S. Geological Survey, 1998, National elevation data base: Sioux Falls, South Dakota, National Mapping Division EROS Data Center, accessed June 6, 1998, at URL http://edcwww2.cr.usgs.gov/ned/ned.html
Vogel, R.M., and Kroll, C.N., 1990, Generalized low-flow frequency relationships for ungaged sites in Massachusetts: Water Resources Bulletin, v. 26, no. 2, p. 241-253.

Wahl, K.L., and Wahl, T. L., 1995, Determining the flow of Comal Springs at New Braunfels, Texas, in Texas Water '95: American Society of Civil Engineers, August 16-17, 1995, San Antonio, Texas, p. 77-86.

Wandle, S.W., Jr., and Randall, A.D., 1994, Effects of surficial geology, lakes and swamps, and annual water availability on low flows of streams in central New England, and their use in low-flow estimation: U.S. Geological Survey WaterResources Investigations Report 93-4092, 57 p.

Wolock, D.M., and McCabe, G.J., 1999, Explaining spatial variability in mean annual runoff in the conterminous United States: Journal of Climate Research, v. 11, p. 149-159. 
28 Estimates of Median Flows for Streams on the 1999 Kansas Surface Water Register 
Appendixes 


\section{Appendix A. - Kansas Statute KSA 82a-2001 et. seq.}




\section{Dowloaded November 12, 2002 from the World Wide Web at URL: http://www.kslegislature.org/cgi-bin/statutes/index.cgi \\ Kansas Statute No. 82a-2001 \\ Chapter 82a.--WATERS AND WATERCOURSES Article 20.--CLASSIFIED STREAM SEGMENTS}

82a-2001. Classified stream segments defined; other definitions. As used in this act:

(a) (1) "Classified stream segments" shall include all stream segments that are waters of the state as defined in subsection (a) of K.S.A. 65-161, and amendments thereto, and waters described in subsection (d) of K.S.A. 65-171d, and amendments thereto, that:

(A) Are indicated on the federal environmental protection agency's reach file 1 (RF1) (1982) and have the most recent 10-year median flow of equal to or in excess of 1 cubic foot per second based on data collected and evaluated by the United States geological survey or in the absence of stream segment flow data, calculations of flow conducted by extrapolation methods provided by the United States Geological Survey;

(B) have the most recent 10-year median flow of equal to or in excess of 1 cubic foot per second based on data collected and evaluated by the United States geological survey or in the absence of stream segment flow data, calculations of flow conducted by extrapolation methods provided by the United States geological survey;

(C) are actually inhabited by threatened or endangered aquatic species listed in rules and regulations promulgated by the Kansas department of wildlife and parks or the United States fish and wildlife service;

(D) (i) scientific studies conducted by the department show that pooling of water during periods of zero flow provides important refuges for aquatic life and permits biological recolonization of intermittently flowing segments; and

(ii) a cost/benefit analysis conducted by the department and taking into account the economic and social impact of classifying the stream segment indicates that the benefits of classifying the stream segment outweigh the costs of classifying the stream segment, as consistent with the federal clean water act and federal regulations; or

(E) are at the point of discharge on the stream segment and downstream from such point where the department has issued a national pollutant discharge elimination system permit other than a permit for a confined feeding facility, as defined in K.S.A. 65-171d, and amendments thereto.

(2) Classified stream segments other than those described in subsection (a)(1)(E) shall not include ephemeral streams; grass, vegetative or other waterways; culverts; or ditches.

(3) Any definition of classified stream or "classified stream segment" in rules and regulations or law that is inconsistent with this definition is hereby declared null and void.

(b) "Department" means the department of health and environment. 
(c) "Designated uses of classified stream segments" shall be defined as follows:

(1) "Agricultural water supply use" means the use of a classified stream segment for agricultural purposes, including the following:

(A) "Irrigation" means the withdrawal of water from a classified stream segment for application onto land; or

(B) "livestock watering" means the provision of water from a classified stream segment to livestock for consumption.

(2) "Aquatic life support use" means the use of a classified stream segment for the maintenance of the ecological integrity of streams, lakes and wetlands, including the sustained growth and propagation of native aquatic life; naturalized, important, recreational aquatic life; and indigenous or migratory semi aquatic or terrestrial wildlife directly or indirectly dependent on surface water for survival. Categories of aquatic life support use include:

(A) "Special aquatic life use waters" means classified stream segments that contain combinations of habitat types and indigenous biota not found commonly in the state, or classified stream segments that contain representative populations of threatened or endangered species, that are listed in rules and regulations promulgated by the Kansas department of wildlife and parks or the United States fish and wildlife service.

(B) "Expected aquatic life use waters" means classified stream segments containing habitat types and indigenous biota commonly found or expected in the state.

(C) "Restricted aquatic life use waters" means classified stream segments containing indigenous biota limited in abundance or diversity by the physical quality or availability of habitat, due to natural deficiencies or artificial modifications, compared to more suitable habitats in adjacent waters.

(3) "Domestic water supply" means the use of a classified stream segment, after appropriate treatment, for the production of potable water.

(4) "Food procurement use" means the use of a classified stream segment for the obtaining of edible forms of aquatic or semi aquatic life for human consumption.

(5) "Groundwater recharge use" means the use of a classified stream segment for the replenishing of fresh or usable groundwater resources. This use may involve the infiltration and percolation of surface water through sediments and soils or the direct injection of surface water into underground aquifers.

(6) "Industrial water supply use" means the use of a classified stream segment for nonpotable purposes by industry, including withdrawals for cooling or process water.

(7) (A) "Recreational use" means:

(i) Primary contact recreational use is use of a classified stream segment for recreation during the period from April 1 through October 31 of each year, provided such classified stream segment (a) by law or written permission of the landowner is open to and accessible by the public and (b) is capable of supporting 
the recreational activities of swimming, skin diving, water-skiing, wind surfing, boating or mussel harvesting where the body is intended to be immersed in surface water to the extent that some inadvertent ingestion of water is probable;

(ii) Secondary contact recreational use:

(a) is use of a classified stream segment for recreation, provided such classified stream segment (1) by law or by written permission of the landowner is open to and accessible by the public and (2) is capable of supporting the recreational activities of wading or fishing where the body is not intended to be immersed and where ingestion of surface water is not probable; or

(b) is use of a classified stream segment for recreation, provided such classified stream segment (1) is not open to and accessible by the public under Kansas law and (2) is capable of supporting the recreational activities of swimming, skin diving, water-skiing, wind surfing, boating, mussel harvesting, wading or fishing.

(B) If opposite sides of a classified stream segment would have different designated recreational uses due to differences in public access, the designated use of the entire classified stream segment may be the higher attainable use, notwithstanding that such designation does not grant the public access to both sides of such segment.

(C) Recreational use designations shall not apply to stream segments where the natural, ephemeral, intermittent or low flow conditions or water levels prevent recreational activities.

(d) "Ephemeral stream" means streams that flow only in response to precipitation and whose channel is at all times above the water table.

(e) "Secretary" means the secretary of health and environment.

History: L. 2001, ch. 100, § 1; Sept. 1

\section{Kansas Statute No. 82a-2002 \\ Chapter 82a.--WATERS AND WATERCOURSES \\ Article 20.--CLASSIFIED STREAM SEGMENTS}

82a-2002. Establishment of classified stream segments; use of such. Notwithstanding any other provisions of law and in addition to the powers of the secretary pursuant to K.S.A. 65-171d, and amendments thereto, the secretary shall establish classified stream segments in Kansas and, following such classification, designate use of such classified stream segments pursuant to K.S.A. 2001 Supp. 82a-2003 and 82a-2004, and amendments thereto.

History: L. 2001, ch. 100, § 2; Sept. 1. 


\section{Kansas Statute No. 82a-2003 Chapter 82a.--WATERS AND WATERCOURSES Article 20.--CLASSIFIED STREAM SEGMENTS}

82a-2003. Determination of which stream segments are listed as classified stream segments; duration of determination. (a) Prior to December 31, 2002, the department shall review all stream segments listed on the 1999 Kansas surface water register and determine whether such stream segments meet the definitions of classified stream segments pursuant to paragraph (a)(1)(A) or (a)(1)(B) of K.S.A. 2001 Supp. 82a-2001, and amendments thereto. The department shall begin the review with stream segments listed on the 1999 Kansas surface water register west of the 98th longitude line and consider stream flow data or methodologies of extrapolating flow from the United States geological survey.

(b) Prior to December 31, 2005, the department shall review all stream segments listed on the 1999 Kansas surface water register which do not meet the definitions of classified stream segments pursuant to paragraph (a)(1)(A) or (a)(1)(B) of K.S.A. 2001 Supp. 82a-2001, and amendments thereto, and determine whether such stream segments meet the definitions of classified stream segments pursuant to paragraph (a)(1)(C), (a)(1)(D) or (a)(1)(E) of K.S.A. 2001 Supp. 82a-2001, and amendments thereto. The department shall establish a procedure, adopted in rules and regulations, requiring that all of the reviews and findings have been met pursuant to paragraph (a)(1)(D) of K.S.A. 2001 Supp. 82a-2001, and amendments thereto.

(c) All current stream classifications shall remain in effect until December 31, 2005, or as deleted or changed through the procedures set forth above.

History: L. 2001, ch. 100, § 3; Sept. 1.

\section{Kansas Statute No. 82a-2004 Chapter 82a.--WATERS AND WATERCOURSES Article 20.--CLASSIFIED STREAM SEGMENTS}

82a-2004. Listing of all currently classified stream segments; minimum action for unclassified stream segments; information available to public; duration of designation. (a) Prior to October 15, 2001, the department shall make publicly available a listing of all currently classified stream segments for which: (1) Designated use attainability analyses for recreational use have been completed; (2) recreational use has been determined not attainable; or (3) designated use attainability analyses for recreational use have not been completed. For such classified stream segments for which designated use attainability analyses for recreational use have not been completed, the department, at a minimum, shall complete a designated use attainability analysis for recreational use according to the following schedule:

(A) An aggregate of at least $25 \%$ of such classified stream segments shall have a designated use attainability analyses for recreational use completed prior to October 31, 2002.

(B) An aggregate of at least 50\% of such classified stream segments shall have a designated use attainability analyses for recreational use completed prior to October 31, 2003.

(C) An aggregate of at least $75 \%$ of such classified stream segments shall have a designated use attainability analyses for recreational use completed prior to October 31, 2004. 
(D) All of such classified stream segments shall have designated use attainability analyses for recreational use completed prior to October 31, 2005.

(b) Prior to October 15, 2002, the department shall make publicly available a listing of all currently classified stream segments for which: (1) Designated use attainability analyses for use other than recreational use have been completed; (2) use other than recreational use has been determined not attainable; or (3) designated use attainability analyses for use other than recreational use have not been completed. For such classified stream segments for which designated use attainability analyses for use other than recreational use have not been completed, the department, at a minimum, shall complete a designated use attainability analysis for use other than recreational use according to a schedule adopted before June 1, 2004 , by rules and regulations of the secretary.

(c) Barring flooding or acts of God, which would prevent the department from completing designated use attainability analyses, the schedules provided for pursuant to subsections (a) and (b) shall be accelerated to allow for completion of designated use attainability analyses for all designated uses on or before December 31, 2007.

(d) All current designated uses of classified stream segments listed on the Kansas surface water register 1999 shall remain in effect until December 31, 2007, or until deleted or changed through the procedures set forth above.

History: L. 2001, ch. 100, § 4; Sept. 1.

\section{Kansas Statute No. 82a-2005 Chapter 82a.--WATERS AND WATERCOURSES Article 20.--CLASSIFIED STREAM SEGMENTS}

82a-2005. Publication of attainability analysis protocols; review of use attainability analysis; updating of Kansas surface water register. (a) Prior to December 1, 2001, the secretary shall publish as guidance designated use attainability analysis protocols for the revision and adoption of designated uses of classified stream segments to protect the public health or welfare and to enhance the quality of classified stream segments. The secretary shall take into consideration the uses and values of such waters for public water supplies, propagation of fish and wildlife, navigation and recreational, agricultural, industrial and other purposes.

(b) The designated use attainability analysis protocols shall include, if applicable for the respective designated use, procedures for:

(1) Review of physical, chemical, biological and economic and social factors affecting attainment of a use or uses;

(2) review of naturally-occurring pollutant concentrations and conditions affecting attainment of a use or uses;

(3) review of natural, ephemeral, intermittent or low flow conditions or water levels affecting attainment of a use or uses; 
(4) review of human conditions that prevent attainment of a use or uses, including state laws, and that cannot be remedied or that would cause more damage or an inproportionate cost to remedy than to leave in place;

(5) review of hydrologic modifications such as dams and diversions affecting attainment of a use or uses;

(6) review of physical conditions related to natural features such as lack of proper substrate, cover, flow, depth, pools, riffles and other stream morphology affecting attainment of a use or uses;

(7) identification and description of cost-effective and reasonable best management practices for nonpoint source pollutant control where such control would be needed to attain a use or uses; and

(8) qualified persons outside the department to conduct designated use attainability analyses.

(c) A use or uses shall not be designated unless it is demonstrated that such use or uses are actually existing and attainable, or unless it is demonstrated that the adverse social and economic impacts of designating a use or uses that are not actually existing are outweighed by the social and economic benefits resulting from the attainment of such use or uses.

(d) Within 60 days after receipt of submission of a use attainability analysis, the department shall review and provide a written determination of whether the documentation submitted is complete.

(e) Within 60 days after receipt of submission of a complete use attainability analysis, the department shall review and provide a written determination of whether revision of the designated use will be proposed as a rule and regulation. Any person aggrieved by such determination may make written request, within 30 days after receipt of such determination, for a meeting with the secretary or the secretary's designee to discuss the determination and exchange information.

(f) All proposed revisions to the surface water register shall be proposed for adoption in accordance with the rules and regulations filing act (K.S.A. 77-415, and amendments thereto).

(g) Following the promulgation of a revision of the surface water register as a rule and regulation pursuant to subsections (d) and (e), any person aggrieved by such promulgation, within 15 days after publication of the rule and regulation, may request a hearing by filing an application for an order under the Kansas administrative procedure act. Any action of the secretary in a proceeding pursuant to this subsection is subject to review in accordance with the act for judicial review and civil enforcement of agency actions.

(h) The Kansas surface water register shall be updated and published annually.

History: L. 2001, ch. 100, § 5; Sept. 1. 


\section{Kansas Statute No. 82a-2006 \\ Chapter 82a.--WATERS AND WATERCOURSES \\ Article 20.--CLASSIFIED STREAM SEGMENTS}

82a-2006. Reports to the governor and legislature. (a) Annually, on or before the first day of the legislative session, the secretary shall prepare and submit a report to the governor and the chairperson, vicechairperson and ranking minority member of the standing committees of the house of representatives and the senate on environment and natural resources regarding the status of completing the classification of streams as required in K.S.A. 2001 Supp. 82a-2003, and amendments thereto, and designated use attainability analyses as required in K.S.A. 2001 Supp. 82a-2004, and amendments thereto.

(b) On or before February 15, 2003, the secretary shall report to the governor and the chairperson, vice-chairperson and ranking minority member of the standing committees of the house of representatives and the senate on environment and natural resources regarding the status of new methodologies of measuring stream flow, in particular that under development by the United States geological survey.

History: L. 2001, ch. 100, § 6; Sept. 1.

\section{Kansas Statute No. 82a-2007 \\ Chapter 82a.--WATERS AND WATERCOURSES \\ Article 20.--CLASSIFIED STREAM SEGMENTS}

82a-2007. Additional employee authorized for state conservation commission. Subject to appropriations, there shall be an additional employee at the state conservation commission to work on total maximum daily load compliance and to coordinate with the department and other appropriate federal and state agencies to further implement voluntary incentive based conservation programs to protect water quality.

History: L. 2001, ch. 100, § 7; Sept. 1.

\section{Kansas Statute No. 82a-2008 Chapter 82a.--WATERS AND WATERCOURSES Article 20.--CLASSIFIED STREAM SEGMENTS}

82a-2008. Limitations on secretary's actions. Nothing in this act shall be construed to:

(1) Require the secretary to designate the use of any classified stream as secondary contact recreational use pursuant to subsection (c)(7)(A)(ii)(b) of K.S.A. 2001 Supp. 82a-2001, and amendments thereto; or

(2) authorize public access to private property unless such public access is otherwise authorized by law or by written permission of the landowner.

History: L. 2001, ch. 100, § 8; Sept. 1. 


\section{Kansas Statute No. 82a-2009 Chapter 82a.--WATERS AND WATERCOURSES Article 20.--CLASSIFIED STREAM SEGMENTS}

82a-2009. Severability of act. If any provisions of this act or its application to any person or circumstances is held invalid, the invalidity does not affect other provisions or applications of the act that can be given effect without the invalid provisions or application. To this end the provisions of this act are severable.

History: L. 2001, ch. 100, § 9; Sept. 1. 


\section{Appendix B. - Median Flow Information for Streamflow-Gaging Stations Used in the Interpolation Procedure}


Table 5. Estimated median flows with 95-percent confidence intervals computed at streamflow-gaging stations used in the interpolation procedure for most-recent 10 years of record (KSA) and all-available hydrology (AAH) analyses.

[KSA, most-recent 10 years of record; AAH, all-available hydrology; $\mathrm{ft}^{3} / \mathrm{s}$, cubic feet per second]

\begin{tabular}{|c|c|c|c|c|c|c|}
\hline \multirow{2}{*}{$\begin{array}{l}\text { Station } \\
\text { number } \\
\text { (fig. 1) }\end{array}$} & \multicolumn{3}{|c|}{ KSA analysis } & \multicolumn{3}{|c|}{ AAH analysis } \\
\hline & $\begin{array}{l}\text { Median flow } \\
\qquad\left(\mathrm{ft}^{3} / \mathrm{s}\right)\end{array}$ & $\begin{array}{c}\text { 95-percent confidence } \\
\text { interval } \\
\left(\mathrm{ft}^{3} / \mathrm{s}\right)\end{array}$ & $\begin{array}{l}\text { Period of record } \\
\text { (water years) }\end{array}$ & $\begin{array}{l}\text { Median } \\
\text { flow } \\
\left(\mathrm{ft}^{3} / \mathrm{s}\right)\end{array}$ & $\begin{array}{c}\text { 95-percent confidence } \\
\text { interval } \\
\left(\mathrm{ft}^{3} / \mathrm{s}\right)\end{array}$ & $\begin{array}{l}\text { Period of record } \\
\text { (water years) }\end{array}$ \\
\hline 06813500 & 46,200 & $45,300-47,200$ & $1991-2000$ & 40,800 & $40,600-41,100$ & $1961-2000$ \\
\hline 06814000 & 30 & $28-32$ & $1991-2000$ & 22 & $21-23$ & $1950-2000$ \\
\hline 06815000 & 213 & $202-224$ & $1991-2000$ & 159 & $155-162$ & $1946-2000$ \\
\hline 06818000 & 49,000 & $48,000-50,100$ & $1991-2000$ & 43,300 & $43,000-43,600$ & $1961-2000$ \\
\hline 06826500 & 6 & $5.9-6.1$ & $1977-86$ & 6.2 & $6.2-6.4$ & $1961-86$ \\
\hline 06827500 & 16 & $15-17$ & $1991-2000$ & 16 & $15-16$ & $1961-2000$ \\
\hline 06836500 & 5 & $4.9-5.0$ & $1991-2000$ & 4.8 & $4.7-4.8$ & $1947-2000$ \\
\hline 06844700 & 0 & $0-0$ & $1977-86$ & 0 & $0-0$ & $1968-87$ \\
\hline 06844900 & .28 & $0.26-0.29$ & $1991-2000$ & 0 & $0-0$ & $1960-2000$ \\
\hline 06845000 & .39 & $0.34-0.47$ & $1968-2000$ & .7 & $0.6-0.78$ & $1930-2000$ \\
\hline 06845200 & 4.5 & $4.3-4.7$ & $1963-72$ & 5 & $4.8-5.2$ & $1938-72$ \\
\hline 06846500 & .01 & $0-0.04$ & $1991-2000$ & .02 & $0-0.04$ & $1947-2000$ \\
\hline 06847900 & 6.1 & $5.8-6.3$ & $1991-2000$ & 2.1 & $2-2.2$ & $1963-2000$ \\
\hline 06848000 & .47 & $0.46-0.48$ & $1991-2000$ & .1 & $0.1-0.11$ & $1965-2000$ \\
\hline 06848500 & 7.4 & $7.0-7.8$ & $1991-2000$ & 2 & $1.9-2.1$ & $1965-2000$ \\
\hline 06853020 & 116 & $112-120$ & $1991-2000$ & 111 & $109-114$ & $1985-2000$ \\
\hline 06853500 & 164 & $159-169$ & $1991-2000$ & 167 & $165-170$ & $1961-2000$ \\
\hline 06853800 & 12 & $11-13$ & $1991-2000$ & 6 & $5.9-6.2$ & $1958-2000$ \\
\hline 06854000 & .15 & $0.14-0.16$ & $1991-2000$ & .2 & $0.2-0.2$ & $1961-2000$ \\
\hline 06854500 & 250 & $241-260$ & $1963-72$ & 244 & $238-252$ & $1961-72$ \\
\hline 06855800 & 18 & $17-19$ & $1980-89$ & 11 & $11-12$ & $1960-89$ \\
\hline 06855900 & 1.6 & $1.4-1.7$ & $1972-81$ & 1 & $0.91-1.1$ & $1963-81$ \\
\hline 06856000 & 269 & $258-279$ & $1991-2000$ & 284 & $280-289$ & $1961-2000$ \\
\hline 06856600 & 407 & $393-421$ & $1991-2000$ & 396 & $390-400$ & $1961-2000$ \\
\hline 06857100 & 276 & $250-295$ & $1991-2000$ & 357 & $340-368$ & $1968-2000$ \\
\hline 06858500 & 0 & $0-0$ & $1975-84$ & 0 & $0-0$ & $1948-84$ \\
\hline 06859500 & 1.3 & $1.3-1.4$ & $1970-79$ & 1.9 & $1.8-2.0$ & $1952-79$ \\
\hline 06860000 & .57 & $0.54-0.63$ & $1991-2000$ & 1.5 & $1.4-1.5$ & $1940-2000$ \\
\hline 06861000 & 5.3 & $4.5-6.0$ & $1991-2000$ & 2.3 & $2.2-2.5$ & $1951-2000$ \\
\hline 06862000 & 0 & $0-0$ & $1981-90$ & .28 & $0.26-0.3$ & $1961-90$ \\
\hline 06862700 & 6.3 & $5.6-7.2$ & $1991-2000$ & 11 & $11-12$ & $1965-2000$ \\
\hline 06862850 & 7.7 & $7.2-8.2$ & $1991-2000$ & 1.8 & $1.5-2.0$ & $1982-2000$ \\
\hline 06863300 & 3 & $3.0-3.1$ & $1959-68$ & 2.9 & $2.8-3.0$ & $1956-68$ \\
\hline 06863500 & 19 & $19-20$ & $1991-2000$ & 7.9 & $7.7-8.0$ & $1947-2000$ \\
\hline 06863900 & 0 & $0-0$ & $1977-86$ & 0 & $0-0$ & $1963-86$ \\
\hline 06864000 & 35 & $34-36$ & $1965-74$ & 35 & $34-36$ & $1965-74$ \\
\hline
\end{tabular}


Table 5. Estimated median flows with 95-percent confidence intervals computed at streamflow-gaging stations used in the interpolation procedure for most-recent 10 years of record (KSA) and all-available hydrology (AAH) analyses. - Continued

[KSA, most-recent 10 years of record; AAH, all-available hydrology; $\mathrm{ft}^{3} / \mathrm{s}$, cubic feet per second]

\begin{tabular}{|c|c|c|c|c|c|c|}
\hline \multirow{2}{*}{$\begin{array}{l}\text { Station } \\
\text { number } \\
\text { (fig. 1) }\end{array}$} & \multicolumn{3}{|c|}{ KSA analysis } & \multicolumn{3}{|c|}{$\mathrm{AAH}$ analysis } \\
\hline & $\begin{array}{l}\text { Median flow } \\
\left(\mathrm{ft}^{3} / \mathrm{s}\right)\end{array}$ & $\begin{array}{c}\text { 95-percent confidence } \\
\text { interval } \\
\left(\mathrm{ft}^{3} / \mathrm{s}\right)\end{array}$ & $\begin{array}{l}\text { Period of record } \\
\text { (water years) }\end{array}$ & $\begin{array}{l}\text { Median } \\
\text { flow } \\
\left(\mathrm{ft}^{3} / \mathrm{s}\right)\end{array}$ & $\begin{array}{c}\text { 95-percent confidence } \\
\text { interval } \\
\left(\mathrm{ft}^{3} / \mathrm{s}\right)\end{array}$ & $\begin{array}{l}\text { Period of record } \\
\text { (water years) }\end{array}$ \\
\hline 06864050 & 63 & $61-66$ & $1991-2000$ & 34 & $34-35$ & $1961-2000$ \\
\hline 06864500 & 94 & $90-98$ & $1991-2000$ & 65 & $63-66$ & $1961-2000$ \\
\hline 06865500 & 121 & $109-134$ & $1991-2000$ & 78 & $76-79$ & $1961-2000$ \\
\hline 06866500 & 197 & $188-205$ & $1991-2000$ & 135 & $132-138$ & $1961-2000$ \\
\hline 06866900 & 7.4 & $7.0-7.9$ & $1991-2000$ & 2.6 & $2.3-2.9$ & $1956-2000$ \\
\hline 06867000 & 64 & $62-66$ & $1991-2000$ & 31 & $30-32$ & $1946-2000$ \\
\hline 06867500 & .03 & $0.03-0.04$ & $1965-74$ & .13 & $0.10-0.20$ & $1947-74$ \\
\hline 06868200 & 21 & $20-21$ & $1991-2000$ & 16 & $16-17$ & $1965-2000$ \\
\hline 06868400 & 1.8 & $1.7-1.9$ & $1962-71$ & 2.2 & $2.2-2.4$ & $1960-71$ \\
\hline 06869500 & 105 & $97-113$ & $1991-2000$ & 45 & $44-47$ & $1965-2000$ \\
\hline 06870200 & 400 & $386-415$ & $1991-2000$ & 224 & $220-229$ & $1963-2000$ \\
\hline 06870300 & 9 & $8.6-9.3$ & $1962-71$ & 7 & $6.6-7.4$ & $1955-71$ \\
\hline 06871000 & 26 & $25-27$ & $1991-2000$ & 8.4 & $8.0-8.8$ & $1953-2000$ \\
\hline 06871500 & 9.5 & $9.4-9.7$ & $1991-2000$ & 5.6 & $5.5-5.7$ & $1952-2000$ \\
\hline 06871800 & .04 & $0.04-0.04$ & $1991-2000$ & .03 & $0.03-0.03$ & $1961-2000$ \\
\hline 06871900 & .63 & $0.56-0.70$ & $1972-81$ & .69 & $0.63-0.72$ & $1967-81$ \\
\hline 06872500 & 80 & $79-82$ & $1991-2000$ & 34 & $33-35$ & $1961-2000$ \\
\hline 06873000 & 34 & $32-35$ & $1991-2000$ & 14 & $13-14$ & $1946-2000$ \\
\hline 06873200 & .68 & $0.56-0.74$ & $1991-2000$ & 0 & $0-0.01$ & $1961-2000$ \\
\hline 06873460 & 21 & $20-22$ & $1991-2000$ & 6.5 & $6.0-7.0$ & $1979-2000$ \\
\hline 06873700 & 0 & $0-0$ & $1972-81$ & 0 & $0-0$ & $1964-81$ \\
\hline 06874000 & 56 & $54-58$ & $1991-2000$ & 21 & $20-21$ & $1961-2000$ \\
\hline 06875900 & 149 & $140-169$ & $1991-2000$ & 54 & $53-56$ & $1968-2000$ \\
\hline 06876070 & 187 & $175-200$ & $1991-2000$ & 187 & $175-200$ & $1991-2000$ \\
\hline 06876700 & 19 & $18-20$ & $1991-2000$ & 12 & $12-12$ & $1960-2000$ \\
\hline 06876900 & 320 & $309-338$ & $1991-99$ & 174 & $169-178$ & $1968-2000$ \\
\hline 06877600 & 1,000 & $967-1,040$ & $1991-2000$ & 595 & $582-611$ & $1961-2000$ \\
\hline 06878000 & 37 & $36-39$ & $1991-2000$ & 24 & $24-24$ & $1955-2000$ \\
\hline 06878500 & 32 & $31-33$ & $1965-74$ & 33 & $32-34$ & $1955-74$ \\
\hline 06879100 & 1,680 & $1,600-1,780$ & $1991-2000$ & 1,350 & $1,310-1,390$ & $1968-2000$ \\
\hline 06882000 & 401 & $393-415$ & $1991-2000$ & 280 & $276-283$ & $1933-2000$ \\
\hline 06882500 & 169 & $164-175$ & $1931-40$ & 217 & $210-222$ & $1920-40$ \\
\hline 06882510 & 469 & $452-484$ & $1991-2000$ & 467 & $456-476$ & $1985-2000$ \\
\hline 06884000 & 169 & $165-171$ & $1991-2000$ & 160 & $159-160$ & $1911-2000$ \\
\hline 06884025 & 220 & $213-226$ & $1991-2000$ & 211 & $208-216$ & $1975-2000$ \\
\hline 06884200 & 26 & $25-28$ & $1991-2000$ & 19 & $19-20$ & $1960-2000$ \\
\hline
\end{tabular}


Estimates of Median Flows for Streams on the 1999 Kansas Surface Water Register

Table 5. Estimated median flows with 95-percent confidence intervals computed at streamflow-gaging stations used in the interpolation procedure for most-recent 10 years of record (KSA) and all-available hydrology (AAH) analyses. - Continued

[KSA, most-recent 10 years of record; AAH, all-available hydrology; $\mathrm{ft}^{3} / \mathrm{s}$, cubic feet per second]

\begin{tabular}{|c|c|c|c|c|c|c|}
\hline \multirow{2}{*}{$\begin{array}{l}\text { Station } \\
\text { number } \\
\text { (fig. 1) }\end{array}$} & \multicolumn{3}{|c|}{$\mathrm{KSA}$ analysis } & \multicolumn{3}{|c|}{$\mathrm{AAH}$ analysis } \\
\hline & $\begin{array}{l}\text { Median flow } \\
\left(\mathrm{ft}^{3} / \mathrm{s}\right)\end{array}$ & $\begin{array}{c}\text { 95-percent confidence } \\
\text { interval } \\
\left(\mathrm{ft}^{3} / \mathrm{s}\right)\end{array}$ & $\begin{array}{l}\text { Period of record } \\
\text { (water years) }\end{array}$ & $\begin{array}{l}\text { Median } \\
\text { flow } \\
\left(\mathrm{ft}^{3} / \mathrm{s}\right)\end{array}$ & $\begin{array}{c}\text { 95-percent confidence } \\
\text { interval } \\
\left(\mathrm{ft}^{3} / \mathrm{s}\right)\end{array}$ & $\begin{array}{l}\text { Period of record } \\
\text { (water years) }\end{array}$ \\
\hline 06884400 & 304 & $297-316$ & $1991-2000$ & 268 & $263-272$ & $1959-2000$ \\
\hline 06885500 & 43 & $40-45$ & $1991-2000$ & 29 & $28-29$ & $1954-2000$ \\
\hline 06886000 & 730 & $700-751$ & $1951-60$ & 600 & $590-610$ & $1919-60$ \\
\hline 06886500 & 13 & $13-14$ & $1962-71$ & 11 & $11-12$ & $1955-71$ \\
\hline 06887000 & 1,170 & $1,140-1,280$ & $1991-2000$ & 974 & $959-994$ & $1963-2000$ \\
\hline 06887500 & 3,470 & $3,390-3,570$ & $1991-2000$ & 2,720 & $2,660-2,780$ & $1963-2000$ \\
\hline 06888000 & 27 & $26-28$ & $1962-71$ & 17 & $16-18$ & $1937-71$ \\
\hline 06888350 & 3,640 & $3,500-3,800$ & $1991-2000$ & 3,480 & $3,390-3,620$ & $1983-2000$ \\
\hline 06888500 & 59 & $55-63$ & $1991-2000$ & 56 & $54-58$ & $1955-2000$ \\
\hline 06889000 & 3,820 & $3,690-3,980$ & $1991-2000$ & 3,020 & $2,960-3090$ & $1963-2000$ \\
\hline 06889100 & .09 & $0.08-0.09$ & $1977-86$ & .08 & $0.07-0.08$ & $1965-86$ \\
\hline 06889120 & .88 & $0.82-0.92$ & $1978-87$ & .55 & $0.53-0.59$ & $1965-87$ \\
\hline 06889140 & 1.5 & $1.4-1.5$ & $1989-98$ & 1.2 & $1.2-1.3$ & $1965-98$ \\
\hline 06889160 & 5.6 & $5.3-5.8$ & $1991-2000$ & 4.6 & $4.5-4.7$ & $1965-2000$ \\
\hline 06889180 & 12 & $11-12$ & $1971-80$ & 10 & $10-11$ & $1965-80$ \\
\hline 06889200 & 22 & $21-23$ & $1991-2000$ & 21 & $20-22$ & $1959-2000$ \\
\hline 06889500 & 43 & $40-47$ & $1991-2000$ & 30 & $29-31$ & $1930-2000$ \\
\hline 06890100 & 56 & $53-60$ & $1991-2000$ & 51 & $50-53$ & $1970-2000$ \\
\hline 06890500 & 101 & $95-106$ & $1958-67$ & 65 & $62-66$ & $1923-67$ \\
\hline 06890900 & 103 & $100-115$ & $1991-2000$ & 100 & $100-103$ & $1970-2000$ \\
\hline 06891000 & 4,480 & $4,220-4,760$ & $1991-2000$ & 3,580 & $3,500-3,650$ & $1963-2000$ \\
\hline 06891500 & 24 & $23-25$ & $1991-2000$ & 29 & $27-30$ & $1978-2000$ \\
\hline 06892000 & 52 & $47-57$ & $1991-2000$ & 40 & $38-40$ & $1930-2000$ \\
\hline 06892350 & 4,860 & $4,630-5,170$ & $1991-2000$ & 4,000 & $3,890-4,080$ & $1963-2000$ \\
\hline 06893000 & 57,800 & $56,800-58,900$ & $1991-2000$ & 50,200 & $49,600-50,700$ & $1961-2000$ \\
\hline 06893080 & 5.6 & $5-6.2$ & $1991-2000$ & 5 & $4.7-5.4$ & $1975-2000$ \\
\hline 06893300 & 18 & $18-19$ & $1991-2000$ & 13 & $13-13$ & $1964-2000$ \\
\hline 06893500 & 64 & $61-67$ & $1991-2000$ & 46 & $44-46$ & $1940-2000$ \\
\hline 06910800 & 13 & $11-14$ & $1991-2000$ & 15 & $14-16$ & $1970-2000$ \\
\hline 06911000 & 33 & $30-36$ & $1965-74$ & 33 & $30-36$ & $1965-74$ \\
\hline 06911500 & 7.7 & $6.8-8.4$ & $1981-99$ & 5.1 & $5.0-5.4$ & $1940-99$ \\
\hline 06911900 & 7.5 & $6.8-8.3$ & $1991-2000$ & 8 & $7.6-8.5$ & $1961-2000$ \\
\hline 06912500 & 20 & $20-21$ & $1991-2000$ & 22 & $22-22$ & $1965-2000$ \\
\hline 06913000 & 102 & $94-117$ & $1991-2000$ & 106 & $99-113$ & $1974-2000$ \\
\hline 06913500 & 143 & $134-157$ & $1991-2000$ & 146 & $138-155$ & $1974-2000$ \\
\hline 06914000 & 20 & $19-23$ & $1991-2000$ & 21 & $20-22$ & $1940-2000$ \\
\hline
\end{tabular}


Table 5. Estimated median flows with 95-percent confidence intervals computed at streamflow-gaging stations used in the interpolation procedure for most-recent 10 years of record (KSA) and all-available hydrology (AAH) analyses. - Continued

[KSA, most-recent 10 years of record; AAH, all-available hydrology; $\mathrm{ft}^{3} / \mathrm{s}$, cubic feet per second]

\begin{tabular}{|c|c|c|c|c|c|c|}
\hline \multirow[b]{2}{*}{$\begin{array}{l}\text { Station } \\
\text { number } \\
\text { (fig. 1) }\end{array}$} & \multicolumn{3}{|c|}{ KSA analysis } & \multicolumn{3}{|c|}{$\mathrm{AAH}$ analysis } \\
\hline & $\begin{array}{l}\text { Median flow } \\
\left(\mathrm{ft}^{3} / \mathrm{s}\right)\end{array}$ & $\begin{array}{c}\text { 95-percent confidence } \\
\text { interval } \\
\left(\mathrm{ft}^{3} / \mathrm{s}\right)\end{array}$ & $\begin{array}{l}\text { Period of record } \\
\text { (water years) }\end{array}$ & $\begin{array}{l}\text { Median } \\
\text { flow } \\
\left(\mathrm{ft}^{3} / \mathrm{s}\right)\end{array}$ & $\begin{array}{c}\text { 95-percent confidence } \\
\text { interval } \\
\left(\mathrm{ft}^{3} / \mathrm{s}\right)\end{array}$ & $\begin{array}{l}\text { Period of record } \\
\text { (water years) }\end{array}$ \\
\hline 06915000 & 21 & $21-22$ & $1990-99$ & 20 & $19-21$ & $1982-2000$ \\
\hline 06915800 & 463 & $415-506$ & $1991-2000$ & 526 & $495-569$ & $1985-2000$ \\
\hline 06916500 & 18 & $16-20$ & $1961-70$ & 11 & $10-12$ & $1930-70$ \\
\hline 06916600 & 562 & $495-616$ & $1991-2000$ & 578 & $545-612$ & $1974-2000$ \\
\hline 06917000 & 44 & $41-47$ & $1991-2000$ & 32 & $30-33$ & $1950-2000$ \\
\hline 06917380 & 42 & $38-45$ & $1991-2000$ & 43 & $41-45$ & $1972-2000$ \\
\hline 06917500 & 30 & $27-32$ & $1962-71$ & 31 & $30-32$ & $1922-71$ \\
\hline 07134180 & 112 & $108-115$ & $1991-2000$ & 106 & $104-108$ & $1981-2000$ \\
\hline 07137500 & 206 & $201-210$ & $1991-2000$ & 129 & $127-132$ & $1961-2000$ \\
\hline 07138000 & 209 & $203-217$ & $1991-2000$ & 133 & $130-135$ & $1961-2000$ \\
\hline 07138650 & 0 & $0-0$ & $1976-85$ & 0 & $0-0$ & $1967-85$ \\
\hline 07139000 & 55 & $37-68$ & $1991-2000$ & 32 & $28-35$ & $1961-2000$ \\
\hline 07139500 & 0 & $0-0$ & $1991-2000$ & 8.7 & $7.2-10$ & $1961-2000$ \\
\hline 07139800 & 0 & $0-0$ & $1981-90$ & 0 & $0-0$ & $1969-90$ \\
\hline 07140000 & 3.7 & $3.2-4.8$ & $1991-2000$ & 32 & $30-34$ & $1961-2000$ \\
\hline 07140850 & 1.5 & $1.3-1.7$ & $1991-2000$ & 0 & $0-0$ & $1982-2000$ \\
\hline 07141200 & 4.2 & $3.3-4.7$ & $1991-2000$ & 3.7 & $3.4-4.0$ & $1925-2000$ \\
\hline 07141300 & 68 & $57-81$ & $1991-2000$ & 41 & $39-44$ & $1961-2000$ \\
\hline 07141780 & 13 & $13-14$ & $1991-2000$ & 1 & $0.87-1.2$ & $1970-2000$ \\
\hline 07141900 & 25 & $24-26$ & $1991-2000$ & 2.3 & $2.1-2.6$ & $1959-2000$ \\
\hline 07142300 & 13 & $12-14$ & $1991-2000$ & 15 & $15-16$ & $1960-2000$ \\
\hline 07142575 & 29 & $27-30$ & $1991-2000$ & 29 & $28-29$ & $1974-2000$ \\
\hline 07142620 & 8.05 & $7.3-9.0$ & $1989-98$ & 24 & $23-25$ & $1961-1998$ \\
\hline 07142860 & .15 & $0.12-0.18$ & $1972-81$ & .13 & $0.12-0.15$ & $1967-81$ \\
\hline 07142900 & .79 & $0.75-0.81$ & $1971-80$ & .48 & $0.46-0.50$ & $1963-1980$ \\
\hline 07143300 & 13 & $12-14$ & $1991-2000$ & 12 & $12-12$ & $1939-2000$ \\
\hline 07143330 & 345 & $336-354$ & $1991-2000$ & 275 & $270-280$ & $1961-2000$ \\
\hline 07143375 & 362 & $350-378$ & $1991-2000$ & 303 & $292-315$ & $1988-2000$ \\
\hline 07143600 & .6 & $0.55-0.62$ & $1962-71$ & .80 & $0.70-0.80$ & $1960-70$ \\
\hline 07143665 & 22 & $21-23$ & $1991-2000$ & 22 & $22-23$ & $1974-2000$ \\
\hline 07144200 & 73 & $70-77$ & $1991-2000$ & 60 & $59-60$ & $1923-2000$ \\
\hline 07144300 & 520 & $505-537$ & $1991-2000$ & 433 & $423-442$ & $1961-2000$ \\
\hline 07144550 & 659 & $633-678$ & $1991-2000$ & 541 & $530-550$ & $1969-2000$ \\
\hline 07144780 & 79 & $76-80$ & $1991-2000$ & 76 & $75-77$ & $1966-2000$ \\
\hline 07144795 & .58 & $0.55-0.60$ & $1991-2000$ & .48 & $0.47-0.49$ & $1965-2000$ \\
\hline 07144850 & 0 & $0-0$ & $1971-80$ & 0 & $0-0$ & $1962-80$ \\
\hline
\end{tabular}


Estimates of Median Flows for Streams on the 1999 Kansas Surface Water Register

Table 5. Estimated median flows with 95-percent confidence intervals computed at streamflow-gaging stations used in the interpolation procedure for most-recent 10 years of record (KSA) and all-available hydrology (AAH) analyses. - Continued

[KSA, most-recent 10 years of record; AAH, all-available hydrology; $\mathrm{ft}^{3} / \mathrm{s}$, cubic feet per second]

\begin{tabular}{|c|c|c|c|c|c|c|}
\hline \multirow{2}{*}{$\begin{array}{l}\text { Station } \\
\text { number } \\
\text { (fig. 1) }\end{array}$} & \multicolumn{3}{|c|}{ KSA analysis } & \multicolumn{3}{|c|}{ AAH analysis } \\
\hline & $\begin{array}{c}\text { Median flow } \\
\left(\mathrm{ft}^{3} / \mathrm{s}\right)\end{array}$ & $\begin{array}{c}\text { 95-percent confidence } \\
\text { interval } \\
\left(\mathrm{ft}^{3} / \mathrm{s}\right)\end{array}$ & $\begin{array}{l}\text { Period of record } \\
\text { (water years) }\end{array}$ & $\begin{array}{l}\text { Median } \\
\text { flow } \\
\left(\mathrm{ft}^{3} / \mathrm{s}\right)\end{array}$ & $\begin{array}{c}\text { 95-percent confidence } \\
\text { interval } \\
\left(\mathrm{ft}^{3} / \mathrm{s}\right)\end{array}$ & $\begin{array}{l}\text { Period of record } \\
\text { (water years) }\end{array}$ \\
\hline 07144910 & 12 & $11-12$ & $1991-2000$ & 11 & $11-11$ & $1981-2000$ \\
\hline 07145200 & 136 & $134-140$ & $1991-2000$ & 135 & $134-136$ & $1951-2000$ \\
\hline 07145500 & 218 & $206-227$ & $1991-2000$ & 212 & $207-218$ & $1965-2000$ \\
\hline 07145700 & 8.8 & $8.3-9.5$ & $1991-2000$ & 8.0 & $7.8-8.3$ & $1970-2000$ \\
\hline 07146500 & 1,170 & $1,130-1,220$ & $1991-2000$ & 1,030 & $1,010-1,050$ & $1961-2000$ \\
\hline 07146570 & 1.7 & $1.5-1.8$ & $1970-79$ & 1.8 & $1.7-1.9$ & $1962-79$ \\
\hline 07146830 & 20 & $19-21$ & $1989-98$ & 24 & $23-25$ & $1982-98$ \\
\hline 07147070 & 39 & $37-41$ & $1991-2000$ & 36 & $35-37$ & $1962-2000$ \\
\hline 07147800 & 228 & $213-248$ & $1991-2000$ & 262 & $247-280$ & $1982-2000$ \\
\hline 07148350 & 58 & $55-60$ & $1984-93$ & 34 & $33-35$ & $1960-93$ \\
\hline 07149000 & 109 & $106-111$ & $1991-2000$ & 85 & $85-86$ & $1939-2000$ \\
\hline 07149500 & 125 & $120-130$ & $1941-50$ & 125 & $120-130$ & $1941-50$ \\
\hline 07151500 & 106 & $103-111$ & $1991-2000$ & 94 & $92-95$ & $1951-2000$ \\
\hline 07152000 & 221 & $208-235$ & $1991-2000$ & 144 & $141-146$ & $1937-2000$ \\
\hline 07154500 & .33 & $0.29-0.38$ & $1991-2000$ & .91 & $0.90-0.97$ & $1951-2000$ \\
\hline 07155590 & 0 & $0-0$ & $1991-2000$ & 0 & $0-0$ & $1972-2000$ \\
\hline 07156010 & 0 & $0-0$ & $1976-85$ & 0 & $0-0$ & $1972-85$ \\
\hline 07156100 & 0 & $0-0$ & $1976-85$ & 0 & $0-0$ & $1972-85$ \\
\hline 07156220 & 0 & $0-0$ & $1989-98$ & 0 & $0-0$ & $1967-98$ \\
\hline 07156900 & 38 & $37-38$ & $1991-2000$ & 45 & $45-45$ & $1966-2000$ \\
\hline 07157000 & 60 & $60-60$ & $1956-65$ & 60 & $60-63$ & $1943-65$ \\
\hline 07157500 & 8.7 & $8.6-8.9$ & $1991-2000$ & 12 & $12-12$ & $1943-2000$ \\
\hline 07157900 & 1.6 & $1.6-1.7$ & $1972-81$ & 1.5 & $1.5-1.5$ & $1967-81$ \\
\hline 07157950 & 47 & $43 \quad 50$ & $1985-94$ & 56 & $54-58$ & $1961-94$ \\
\hline 07165700 & 33 & $31-35$ & $1967-76$ & 28 & $27-30$ & $1956-76$ \\
\hline 07166000 & 32 & $27-38$ & $1989-98$ & 74 & $68-80$ & $1961-98$ \\
\hline 07166500 & 120 & $107-135$ & $1991-2000$ & 138 & $130-145$ & $1961-2000$ \\
\hline 07167000 & 57 & $52-61$ & $1967-76$ & 40 & $38-41$ & $1947-76$ \\
\hline 07167500 & 10 & $9.3-11$ & $1991-2000$ & 10 & $9.4-10$ & $1947-2000$ \\
\hline 07168500 & 44 & $31-58$ & $1980-89$ & 53 & $49-56$ & $1961-89$ \\
\hline 07169500 & 109 & $96-120$ & $1991-2000$ & 92 & $88-98$ & $1961-2000$ \\
\hline 07169800 & 19 & $18-21$ & $1991-2000$ & 22 & $21-23$ & $1968-2000$ \\
\hline 07170060 & 28 & $24-35$ & $1991-2000$ & 21 & $19-22$ & $1966-2000$ \\
\hline 07170500 & 455 & $407-490$ & $1991-99$ & 401 & $380-427$ & $1961-2000$ \\
\hline 07170700 & .69 & $0.57-0.80$ & $1991-2000$ & .88 & $0.76-1.1$ & $1982-2000$ \\
\hline 07171000 & 644 & $582-696$ & $1991-2000$ & 570 & $539-598$ & $1961-2000$ \\
\hline
\end{tabular}


Table 5. Estimated median flows with 95-percent confidence intervals computed at streamflow-gaging stations used in the interpolation procedure for most-recent 10 years of record (KSA) and all-available hydrology (AAH) analyses. - Continued

[KSA, most-recent 10 years of record; AAH, all-available hydrology; $\mathrm{ft}^{3} / \mathrm{s}$, cubic feet per second]

\begin{tabular}{|c|c|c|c|c|c|c|}
\hline \multirow{2}{*}{$\begin{array}{l}\text { Station } \\
\text { number } \\
\text { (fig. 1) }\end{array}$} & \multicolumn{3}{|c|}{ KSA analysis } & \multicolumn{3}{|c|}{$\mathrm{AAH}$ analysis } \\
\hline & $\begin{array}{c}\text { Median flow } \\
\left(\mathrm{ft}^{3} / \mathrm{s}\right)\end{array}$ & $\begin{array}{c}\text { 95-percent confidence } \\
\text { interval } \\
\left(\mathrm{ft}^{3} / \mathrm{s}\right)\end{array}$ & $\begin{array}{l}\text { Period of record } \\
\text { (water years) }\end{array}$ & $\begin{array}{c}\text { Median } \\
\text { flow } \\
\left(\mathrm{ft}^{3} / \mathrm{s}\right)\end{array}$ & $\begin{array}{c}\text { 95-percent confidence } \\
\text { interval } \\
\left(\mathrm{ft}^{3} / \mathrm{s}\right)\end{array}$ & $\begin{array}{l}\text { Period of record } \\
\text { (water years) }\end{array}$ \\
\hline 07172000 & 65 & $61-71$ & $1991-2000$ & 40 & $39-42$ & $1940-2000$ \\
\hline 07174000 & 7.4 & $6.6-8.5$ & $1949-58$ & 9.5 & $8.9-10$ & $1944-58$ \\
\hline 07174400 & 99 & $85-115$ & $1991-2000$ & 173 & $150-200$ & $1986-2000$ \\
\hline 07179500 & 15 & $14-17$ & $1991-2000$ & 13 & $13-14$ & $1965-2000$ \\
\hline 07179730 & 67 & $61-73$ & $1991-2000$ & 70 & $67-73$ & $1965-2000$ \\
\hline 07179795 & 8.6 & $8.2-8.9$ & $1991-2000$ & 7.6 & $7.5-7.8$ & $1969-2000$ \\
\hline 07180200 & 28 & $26-30$ & $1990-99$ & 32 & $31-34$ & $1985-99$ \\
\hline 07180400 & 87 & $84-91$ & $1991-2000$ & 88 & $86-90$ & $1969-2000$ \\
\hline 07180500 & 18 & $17-19$ & $1991-2000$ & 16 & $16-17$ & $1939-2000$ \\
\hline 07181500 & 10 & $9.5-10$ & $1941-50$ & 7.0 & $6.6-8.0$ & $1939-50$ \\
\hline 07182250 & 266 & $252-282$ & $1991-2000$ & 298 & $288-309$ & $1969-2000$ \\
\hline 07182510 & 434 & $378-461$ & $1991-2000$ & 397 & $381-419$ & $1964-2000$ \\
\hline 07183000 & 619 & $557-672$ & $1991-2000$ & 581 & $554-605$ & $1964-2000$ \\
\hline 07183100 & 3.6 & $3.2-4.0$ & $1961-70$ & 4.0 & $3.7-4.4$ & $1960-70$ \\
\hline 07183500 & 950 & $862-1,040$ & $1991-2000$ & 852 & $804-892$ & $1964-2000$ \\
\hline 07184000 & 15 & $14-17$ & $1991-2000$ & 12 & $11-12$ & $1939-2000$ \\
\hline 07185000 & 1,310 & $1,180-1,440$ & $1991-2000$ & 1,140 & $1,100-1,180$ & $1961-2000$ \\
\hline 07186000 & 405 & $388-423$ & $1991-2000$ & 301 & $294-306$ & $1925-2000$ \\
\hline 07186400 & 134 & $129-139$ & $1982-91$ & 97 & $94-100$ & $1963-91$ \\
\hline 07187000 & 290 & $282-300$ & $1991-2000$ & 237 & $234-241$ & $1942-2000$ \\
\hline 07188000 & 1,050 & $1,010-1,110$ & $1991-2000$ & 850 & $832-868$ & $1940-2000$ \\
\hline
\end{tabular}


Appendix C. - Estimated Median Flows at Downstream End of Stream Segments on the 1999 Kansas Surface Water Register 
Table 6. Stream segments on the 1999 Kansas Surface Water Register, CUSEGA numbers, stream names, and estimated median flows at downstream end of CUSEGA segments using the most-recent 10 years of record (KSA) and all-available hydrology (AAH) analyses.

[Estimated median flows are rounded to two or three significant figures. Reporting estimated median values to three signficant figures (median greater than or equal to $1 \mathrm{ft}^{3} / \mathrm{s}$ ) or two significant figures (median less than $1 \mathrm{ft}^{3} / \mathrm{s}$ ) was done to conform with the intent of KSA $82 \mathrm{a}-2001 \mathrm{et}$. seq. $\mathrm{ft}^{3} / \mathrm{s}$, cubic feet per second; KSA, Kansas Statute 82a-2001 analysis; AAH, all-available hydrology analysis]

\begin{tabular}{|c|c|c|c|c|c|}
\hline \multirow{2}{*}{$\begin{array}{c}\text { Stream } \\
\text { segment } \\
\text { number } \\
\text { (figs. 9-113) }\end{array}$} & \multirow[b]{2}{*}{ CUSEGA number } & \multirow{2}{*}{$\begin{array}{c}\text { County location } \\
\text { (abbreviation explained } \\
\text { in table 7) }\end{array}$} & \multirow[b]{2}{*}{ Stream name } & \multicolumn{2}{|c|}{ Estimated median flows $\left(\mathrm{ft}^{3} / \mathrm{s}\right)$} \\
\hline & & & & KSA analysis & $\mathrm{AAH}$ analysis \\
\hline 1 & 102400051 & $\overline{\mathrm{DP}}$ & Missouri River & 48,000 & 42,400 \\
\hline 2 & 1024000519 & DP & Missouri River & 47,600 & 42,000 \\
\hline 3 & 102400052 & DP & Missouri River & 47,800 & 42,200 \\
\hline 4 & 1024000521 & DP & Missouri River & 47,600 & 42,000 \\
\hline 5 & 10240005240 & BR & Unnamed tributary, Brown 1 & 3.91 & 3.86 \\
\hline 6 & 10240005339 & DP & Mission Creek & 3.55 & 3.90 \\
\hline 7 & 1024000551 & DP & Cedar Creek & 7.52 & 7.45 \\
\hline 8 & 1024000552 & DP & Mill Creek & 3.81 & 4.12 \\
\hline 9 & 1024000553 & $\mathrm{BR}, \mathrm{DP}$ & Wolf River & 41.3 & 37.6 \\
\hline 10 & 1024000554 & $\mathrm{BR}$ & Wolf River & 17.4 & 15.6 \\
\hline 11 & 1024000555 & BR & Unnamed tributary, Brown 2 & 3.71 & 3.84 \\
\hline 12 & 1024000556 & BR & Wolf River & 14.6 & 13.0 \\
\hline 13 & 1024000557 & $\mathrm{AT}, \mathrm{BR}$ & South Fork Wolf River & 5.57 & 5.06 \\
\hline 14 & 1024000565 & $\mathrm{BR}, \mathrm{DP}$ & Spring Creek & 2.17 & 2.51 \\
\hline 15 & 1024000566 & BR & North Fork Wolf River & 2.02 & 2.12 \\
\hline 16 & 1024000567 & BR & Middle Fork Wolf River & 4.12 & 3.82 \\
\hline 17 & 1024000568 & DP & Haling Creek & 4.01 & 3.99 \\
\hline 18 & 1024000569 & DP & Rittenhouse Branch & 2.26 & 2.64 \\
\hline 19 & 1024000570 & DP & Cold Ryan Branch & 3.28 & 3.52 \\
\hline 20 & 1024000571 & DP & Coon Creek & 4.55 & 4.88 \\
\hline 21 & 1024000572 & DP & Striker Branch & 2.02 & 2.48 \\
\hline 22 & 1024000573 & DP & Mosquito Creek & 6.75 & 7.09 \\
\hline 23 & 1024000712 & NM & Wolf Creek & 2.95 & 2.20 \\
\hline 24 & 1024000713 & MS, NM & Wolf Creek & .85 & .65 \\
\hline 25 & 10240007132 & MS, NM & Clear Creek & 2.49 & 1.86 \\
\hline 26 & 1024000714 & MS, NM & Manley Creek & .91 & .70 \\
\hline 27 & 1024000715 & NM & South Fork Big Nemaha River & 23.7 & 18.2 \\
\hline 28 & 1024000716 & NM & South Fork Big Nemaha River & 18.1 & 13.8 \\
\hline 29 & 10240007166 & NM & Harris Creek & 3.11 & 2.42 \\
\hline 30 & 1024000718 & NM & Deer Creek & 3.27 & 2.46 \\
\hline 31 & 1024000720 & NM & Rock Creek & 1.05 & .81 \\
\hline 32 & 10240007212 & NM & Unnamed tributary, Nemaha 2 & .95 & .85 \\
\hline
\end{tabular}


Table 6. Stream segments on the 1999 Kansas Surface Water Register, CUSEGA numbers, stream names, and estimated median flows at downstream end of CUSEGA segments using the most-recent 10 years of record (KSA) and all-available hydrology (AAH) analyses. - Continued

[Estimated median flows are rounded to two or three significant figures. Reporting estimated median values to three signficant figures (median greater than or equal to $1 \mathrm{ft}^{3} / \mathrm{s}$ ) or two significant figures (median less than $1 \mathrm{ft}^{3} / \mathrm{s}$ ) was done to conform with the intent of KSA $82 \mathrm{a}-2001 \mathrm{et}$. seq. $\mathrm{ft}^{3} / \mathrm{s}$, cubic feet per second; KSA, Kansas Statute 82a-2001 analysis; AAH, all-available hydrology analysis]

\begin{tabular}{|c|c|c|c|c|c|}
\hline \multirow{2}{*}{$\begin{array}{c}\text { Stream } \\
\text { segment } \\
\text { number } \\
\text { (figs. 9-113) }\end{array}$} & \multirow[b]{2}{*}{ CUSEGA number } & \multirow{2}{*}{$\begin{array}{c}\text { County location } \\
\text { (abbreviation explained } \\
\text { in table 7) }\end{array}$} & \multirow[b]{2}{*}{ Stream name } & \multicolumn{2}{|c|}{ Estimated median flows $\left(\mathrm{ft}^{3} / \mathrm{s}\right)$} \\
\hline & & & & KSA analysis & AAH analysis \\
\hline 33 & 1024000723 & NM & Wildcat Creek & 1.90 & 1.35 \\
\hline 34 & 1024000724 & NM & Burger Creek & .63 & .60 \\
\hline 35 & 1024000725 & NM & Wolf Pen Creek & .83 & .60 \\
\hline 36 & 1024000726 & NM & Honey Creek & 0 & 0 \\
\hline 37 & 1024000727 & NM & Rattlesnake Creek & .81 & .82 \\
\hline 38 & 1024000728 & NM & Fisher Creek & .68 & .48 \\
\hline 39 & 1024000729 & NM & Tennessee Creek & 3.23 & 2.58 \\
\hline 40 & 102400073 & NM & South Fork Big Nemaha River & 98.4 & 74.7 \\
\hline 41 & 1024000730 & NM & Illinois Creek & 1.52 & 1.26 \\
\hline 42 & 102400074 & NM & Turkey Creek & 33.7 & 24.8 \\
\hline 43 & 102400075 & NM & Turkey Creek & 20.3 & 15.0 \\
\hline 44 & 10240008308 & $\mathrm{BR}$ & Terrapin Creek & 2.52 & 1.91 \\
\hline 45 & 1024000838 & BR, NM & Pony Creek & 5.44 & 4.48 \\
\hline 46 & 1024000839 & BR & Walnut Creek & 10.5 & 8.66 \\
\hline 47 & 1024000840 & BR & Roys Creek & 7.95 & 7.43 \\
\hline 48 & 1024000841 & BR & Pedee Creek & 1.51 & 1.47 \\
\hline 49 & 1024000842 & $\mathrm{BR}$ & Noharts Creek & 2.55 & 2.65 \\
\hline 50 & 102400111 & WY, LV & Missouri River & 49,500 & 43,700 \\
\hline 51 & 1024001111 & AT & Missouri River & 49,100 & 43,300 \\
\hline 52 & 1024001113 & $\mathrm{AT}, \mathrm{DP}$ & Missouri River & 49,000 & 43,300 \\
\hline 53 & 10240011142 & WY & Sorter Creek & 2.23 & 2.81 \\
\hline 54 & 1024001115 & DP & Missouri River & 49,000 & 43,300 \\
\hline 55 & 10240011157 & LV & Seven Mile Creek & 5.77 & 5.95 \\
\hline 56 & 10240011161 & LV & Nine Mile Creek & 2.59 & 2.92 \\
\hline 57 & 10240011175 & LV & Corral Creek & .92 & 1.65 \\
\hline 58 & 10240011176 & LV & Quarry Creek & 1.23 & 1.96 \\
\hline 59 & 1024001119 & DP & Missouri River & 49,000 & 43,300 \\
\hline 60 & 102400112 & LV & Missouri River & 49,100 & 43,400 \\
\hline 61 & 1024001120 & AT, DP & Independence Creek & 27.6 & 25.5 \\
\hline 62 & 1024001121 & $\mathrm{DP}$ & Rock Creek & 6.65 & 6.74 \\
\hline 63 & 1024001122 & AT, BR, DP & Independence Creek & 17.2 & 16.1 \\
\hline 64 & 1024001123 & AT & Walnut Creek & 5.09 & 5.21 \\
\hline 65 & 10240011235 & AT & Whiskey Creek & 1.62 & 2.08 \\
\hline
\end{tabular}


Table 6. Stream segments on the 1999 Kansas Surface Water Register, CUSEGA numbers, stream names, and estimated median flows at downstream end of CUSEGA segments using the most-recent 10 years of record (KSA) and all-available hydrology (AAH) analyses. - Continued

[Estimated median flows are rounded to two or three significant figures. Reporting estimated median values to three signficant figures (median greater than or equal to $1 \mathrm{ft}^{3} / \mathrm{s}$ ) or two significant figures (median less than $1 \mathrm{ft}^{3} / \mathrm{s}$ ) was done to conform with the intent of KSA $82 \mathrm{a}-2001 \mathrm{et}$. seq. $\mathrm{ft}^{3} / \mathrm{s}$, cubic feet per second; KSA, Kansas Statute 82a-2001 analysis; AAH, all-available hydrology analysis]

\begin{tabular}{|c|c|c|c|c|c|}
\hline \multirow{2}{*}{$\begin{array}{c}\text { Stream } \\
\text { segment } \\
\text { number } \\
\text { (figs. 9-113) }\end{array}$} & \multirow[b]{2}{*}{ CUSEGA number } & \multirow{2}{*}{$\begin{array}{c}\text { County location } \\
\text { (abbreviation explained } \\
\text { in table 7) }\end{array}$} & \multirow[b]{2}{*}{ Stream name } & \multicolumn{2}{|c|}{ Estimated median flows $\left(\mathrm{ft}^{3} / \mathrm{s}\right)$} \\
\hline & & & & KSA analysis & AAH analysis \\
\hline 66 & 1024001125 & $\overline{\mathrm{DP}}$ & Walnut Creek & 4.56 & 4.83 \\
\hline 67 & 1024001126 & DP & Brush Creek & 5.85 & 6.03 \\
\hline 68 & 1024001127 & DP & Peters Creek & 9.44 & 9.37 \\
\hline 69 & 1024001128 & DP & Smith Creek & 4.82 & 5.20 \\
\hline 70 & 1024001129 & DP & North Branch Independence Creek & 5.38 & 5.45 \\
\hline 71 & 1024001130 & DP & Jordan Creek & 4.46 & 4.64 \\
\hline 72 & 1024001131 & AT & White Clay Creek & 3.26 & 3.42 \\
\hline 73 & 1024001132 & AT & Deer Creek & 5.66 & 5.46 \\
\hline 74 & 1024001133 & AT & Owl Creek & 4.55 & 4.72 \\
\hline 75 & 1024001134 & LV & Salt Creek & 6.76 & 6.65 \\
\hline 76 & 1024001135 & LV & Fivemile Creek & 3.16 & 3.59 \\
\hline 77 & 1024001136 & LV & Threemile Creek & 2.36 & 2.92 \\
\hline 78 & 1024001137 & LV, WY & Island Creek & 4.89 & 5.22 \\
\hline 79 & 1024001138 & WY & Jersey Creek & 1.92 & 2.47 \\
\hline 80 & 102400114 & LV & Missouri River & 49,100 & 43,400 \\
\hline 81 & 102400115 & AT & Missouri River & 49,100 & 43,400 \\
\hline 82 & 102400117 & AT & Missouri River & 49,100 & 43,400 \\
\hline 83 & 102400119 & AT & Missouri River & 49,100 & 43,300 \\
\hline 84 & 102400119031 & AT & White Clay Creek & 3.47 & 3.61 \\
\hline 85 & 102400119099 & WY & Missouri River & 57,800 & 50,200 \\
\hline 86 & 102400119235 & AT & Whiskey Creek & 1.69 & 2.16 \\
\hline 87 & 102500011 & $\mathrm{CN}$ & Arikaree River & .69 & .67 \\
\hline 88 & 102500032 & $\mathrm{CN}$ & South Fork Republican River & 16.0 & 16.0 \\
\hline 89 & 102500033 & $\mathrm{CN}$ & Hackberry Creek & 0 & 0 \\
\hline 90 & 102500034 & $\mathrm{CN}$ & South Fork Republican River & 14.0 & 14.1 \\
\hline 91 & 102500035 & $\mathrm{CN}$ & Cherry Creek & 0 & 0 \\
\hline 92 & 102500036 & $\mathrm{CN}$ & South Fork Republican River & 11.4 & 11.5 \\
\hline 93 & 1025000360 & $\mathrm{CN}$ & Drury Creek & 0 & 0 \\
\hline 94 & 1025000361 & $\mathrm{CN}$ & Big Timber Creek & 0 & 0 \\
\hline 95 & 1025000366 & $\mathrm{CN}$ & Delay Creek & 0 & 0 \\
\hline 96 & 1025000367 & $\mathrm{CN}$ & Spring Creek & 0 & 0 \\
\hline 97 & 1025000368 & $\mathrm{CN}$ & Sand Creek & 0 & 0 \\
\hline 98 & 1025000369 & $\mathrm{CN}$ & Valley Creek & 0 & 0 \\
\hline 99 & 102500037 & $\mathrm{CN}$ & South Fork Republican River & 10.9 & 11.0 \\
\hline 100 & 1025000370 & $\mathrm{CN}$ & Bluff Creek & 0 & 0 \\
\hline
\end{tabular}


Table 6. Stream segments on the 1999 Kansas Surface Water Register, CUSEGA numbers, stream names, and estimated median flows at downstream end of CUSEGA segments using the most-recent 10 years of record (KSA) and all-available hydrology (AAH) analyses. - Continued

[Estimated median flows are rounded to two or three significant figures. Reporting estimated median values to three signficant figures (median greater than or equal to $1 \mathrm{ft}^{3} / \mathrm{s}$ ) or two significant figures (median less than $1 \mathrm{ft}^{3} / \mathrm{s}$ ) was done to conform with the intent of KSA $82 \mathrm{a}-2001 \mathrm{et}$. seq. $\mathrm{ft}^{3} / \mathrm{s}$, cubic feet per second; KSA, Kansas Statute 82a-2001 analysis; AAH, all-available hydrology analysis]

\begin{tabular}{|c|c|c|c|c|c|}
\hline \multirow{2}{*}{$\begin{array}{l}\text { Stream } \\
\text { segment } \\
\text { number } \\
\text { (figs. 9-113) }\end{array}$} & \multirow[b]{2}{*}{ CUSEGA number } & \multirow{2}{*}{$\begin{array}{c}\text { County location } \\
\text { (abbreviation explained } \\
\text { in table 7) }\end{array}$} & \multirow[b]{2}{*}{ Stream name } & \multicolumn{2}{|c|}{ Estimated median flows $\left(\mathrm{ft}^{3} / \mathrm{s}\right)$} \\
\hline & & & & KSA analysis & AAH analysis \\
\hline 101 & 1025000371 & $\mathrm{CN}$ & Battle Creek & 0 & 0 \\
\hline 102 & 1025000372 & $\mathrm{CN}$ & Crosby Creek & 0 & 0 \\
\hline 103 & 102500038 & $\mathrm{CN}$ & Cowpe Creek & 0 & 0 \\
\hline 104 & 102500039 & $\mathrm{CN}$ & South Fork Republican River & 9.12 & 9.25 \\
\hline 105 & 1025000450 & $\mathrm{CN}$ & Unnamed tributary, Cheyenne 1 & 0 & 0 \\
\hline 106 & 1025000459 & RA & Driftwood Creek & .40 & .38 \\
\hline 107 & 102500101 & $\mathrm{DC}, \mathrm{RA}$ & Middle Fork Sappa Creek & .47 & .34 \\
\hline 108 & 102500102 & RA & North Fork Sappa Creek & 0 & 0 \\
\hline 109 & 102500103 & RA, TH, SH & Middle Fork Sappa Creek & 0 & 0 \\
\hline 110 & 102500104 & DC, RA, TH & South Fork Sappa Creek & .35 & 0 \\
\hline 111 & 102500105 & $\mathrm{SH}, \mathrm{TH}$ & Unnamed tributary, Sherman 2 & .01 & 0 \\
\hline 112 & 102500106 & $\mathrm{SH}, \mathrm{TH}$ & South Fork Sappa Creek & .02 & 0 \\
\hline 113 & 1025001110 & NT & Rock Branch & 0 & 0 \\
\hline 114 & 1025001111 & NT & Walnut Creek & 0 & 0 \\
\hline 115 & 1025001112 & NT & Squaw Branch & 0 & 0 \\
\hline 116 & 1025001113 & NT & Boy Creek & 0 & 0 \\
\hline 117 & 1025001115 & DC & Cotton Creek & 0 & 0 \\
\hline 118 & 1025001116 & NT & Dutch Creek & 0 & 0 \\
\hline 119 & 1025001117 & NT & Jones Creek & 0 & 0 \\
\hline 120 & 1025001118 & NT & Maple Creek & 0 & 0 \\
\hline 121 & 1025001119 & NT & Sheep Creek & 0 & 0 \\
\hline 122 & 102500113 & NT & Sappa Creek & 12.8 & 11.3 \\
\hline 123 & 102500114 & $\mathrm{DC}, \mathrm{NT}$ & Sappa Creek & 5.88 & 5.40 \\
\hline 124 & 102500115 & $\mathrm{DC}, \mathrm{NT}$ & Long Branch & .01 & .01 \\
\hline 125 & 102500117 & NT & Deer Creek & 0 & 0 \\
\hline 126 & 102500118 & NT & Dry Creek & 0 & 0 \\
\hline 127 & 102500119 & DC & Spring Branch & 0 & 0 \\
\hline 128 & 102500121 & $\mathrm{CN}, \mathrm{RA}, \mathrm{SH}$ & Beaver Creek & 0 & 0 \\
\hline 129 & 1025001210 & $\mathrm{SH}$ & Unnamed tributary, Sherman 1 & 0 & 0 \\
\hline 130 & 1025001211 & $\mathrm{SH}$ & South Beaver Creek & 0 & 0 \\
\hline 131 & 102500122 & $\mathrm{SH}$ & Middle Beaver Creek & 0 & 0 \\
\hline 132 & 102500123 & SH & North Fork Beaver Creek & 0 & 0 \\
\hline 133 & 102500128 & SH & Middle Beaver Creek & 0 & 0 \\
\hline
\end{tabular}


Table 6. Stream segments on the 1999 Kansas Surface Water Register, CUSEGA numbers, stream names, and estimated median flows at downstream end of CUSEGA segments using the most-recent 10 years of record (KSA) and all-available hydrology (AAH) analyses. - Continued

[Estimated median flows are rounded to two or three significant figures. Reporting estimated median values to three signficant figures (median greater than or equal to $1 \mathrm{ft}^{3} / \mathrm{s}$ ) or two significant figures (median less than $1 \mathrm{ft}^{3} / \mathrm{s}$ ) was done to conform with the intent of KSA $82 \mathrm{a}-2001 \mathrm{et}$. seq. $\mathrm{ft}^{3} / \mathrm{s}$, cubic feet per second; KSA, Kansas Statute 82a-2001 analysis; AAH, all-available hydrology analysis]

\begin{tabular}{|c|c|c|c|c|c|}
\hline \multirow{2}{*}{$\begin{array}{c}\text { Stream } \\
\text { segment } \\
\text { number } \\
\text { (figs. 9-113) }\end{array}$} & \multirow[b]{2}{*}{ CUSEGA number } & \multirow{2}{*}{$\begin{array}{c}\text { County location } \\
\text { (abbreviation explained } \\
\text { in table 7) }\end{array}$} & \multirow[b]{2}{*}{ Stream name } & \multicolumn{2}{|c|}{ Estimated median flows $\left(\mathrm{ft}^{3} / \mathrm{s}\right)$} \\
\hline & & & & KSA analysis & AAH analysis \\
\hline 134 & 102500129 & $\mathrm{SH}$ & South Beaver Creek & 0 & 0 \\
\hline 135 & 102500131 & RA & Little Beaver Creek & 0 & 0 \\
\hline 136 & 102500132 & RA & North Beaver Creek & 0 & 0 \\
\hline 137 & 102500133 & $\mathrm{CN}, \mathrm{RA}$ & Little Beaver Creek & 0 & 0 \\
\hline 138 & 102500134 & $\mathrm{CN}, \mathrm{SH}$ & Little Beaver Creek & 0 & 0 \\
\hline 139 & 102500137 & $\mathrm{CN}, \mathrm{SH}$ & Sand Creek & 0 & 0 \\
\hline 140 & 102500142 & $\mathrm{DC}, \mathrm{RA}$ & Beaver Creek & .01 & .03 \\
\hline 141 & 1025001510 & DC & Prairie Dog Creek & 2.23 & .44 \\
\hline 142 & 1025001511 & $\mathrm{DC}, \mathrm{SD}, \mathrm{TH}$ & North Fork Prairie Dog Creek & .07 & 0 \\
\hline 143 & 1025001512 & $\mathrm{DC}, \mathrm{SD}, \mathrm{TH}$ & Prairie Dog Creek & .37 & 0 \\
\hline 144 & 1025001513 & PL & Walnut Creek & 0 & 0 \\
\hline 145 & 1025001514 & $\mathrm{DC}, \mathrm{NT}$ & Plum Creek & .01 & 0 \\
\hline 146 & 1025001515 & NT & Spring Creek & 0 & 0 \\
\hline 147 & 1025001516 & NT & Robinson Creek & 0 & 0 \\
\hline 148 & 1025001517 & NT & North Fork Prairie Dog Creek & 0 & 0 \\
\hline 149 & 1025001518 & NT & Horse Creek & 0 & 0 \\
\hline 150 & 1025001519 & NT & Fancy Creek & 0 & 0 \\
\hline 151 & 102500152 & NT, PL & Prairie Dog Creek & 13.0 & 7.57 \\
\hline 152 & 1025001520 & NT & Sand Creek & 0 & 0 \\
\hline 153 & 1025001521 & NT & Buffalo Creek & 0 & 0 \\
\hline 154 & 1025001522 & PL & Jack Creek & 0 & 0 \\
\hline 155 & 1025001523 & PL & Dry Creek & 0 & 0 \\
\hline 156 & 1025001524 & PL & Battle Creek & 0 & 0 \\
\hline 157 & 1025001525 & NT & Walnut Creek & 0 & 0 \\
\hline 158 & 1025001526 & NT & Wildcat Creek & 0 & 0 \\
\hline 159 & 102500153 & NT, PL & Elk Creek & 0 & 0 \\
\hline 160 & 102500154 & NT & Prairie Dog Creek & 4.12 & 1.10 \\
\hline 161 & 102500158 & $\mathrm{DC}, \mathrm{NT}$ & Prairie Dog Creek & 6.10 & 2.10 \\
\hline 162 & 102500159 & DC & Big Timber Creek & .06 & 0 \\
\hline 163 & 102500161 & $\mathrm{RP}$ & Republican River & 250 & 244 \\
\hline 164 & 102500161301 & JW & Big Timber Creek & 1.53 & 1.34 \\
\hline 165 & 102500162 & JW, RP & Republican River & 172 & 174 \\
\hline 166 & 1025001639 & PL & Rebecca Creek & 0 & 0 \\
\hline 167 & 1025001640 & SM & Walnut Creek & .31 & .22 \\
\hline 168 & 1025001641 & JW, RP & White Rock Creek & .64 & .68 \\
\hline
\end{tabular}


Table 6. Stream segments on the 1999 Kansas Surface Water Register, CUSEGA numbers, stream names, and estimated median flows at downstream end of CUSEGA segments using the most-recent 10 years of record (KSA) and all-available hydrology (AAH) analyses. - Continued

[Estimated median flows are rounded to two or three significant figures. Reporting estimated median values to three signficant figures (median greater than or equal to $1 \mathrm{ft}^{3} / \mathrm{s}$ ) or two significant figures (median less than $1 \mathrm{ft}^{3} / \mathrm{s}$ ) was done to conform with the intent of KSA $82 \mathrm{a}-2001 \mathrm{et}$. seq. $\mathrm{ft}^{3} / \mathrm{s}$, cubic feet per second; KSA, Kansas Statute 82a-2001 analysis; AAH, all-available hydrology analysis]

\begin{tabular}{|c|c|c|c|c|c|}
\hline \multirow{2}{*}{$\begin{array}{c}\text { Stream } \\
\text { segment } \\
\text { number } \\
\text { (figs. 9-113) }\end{array}$} & \multirow[b]{2}{*}{ CUSEGA number } & \multirow{2}{*}{$\begin{array}{c}\text { County location } \\
\text { (abbreviation explained } \\
\text { in table 7) }\end{array}$} & \multirow[b]{2}{*}{ Stream name } & \multicolumn{2}{|c|}{ Estimated median flows $\left(\mathrm{ft}^{3} / \mathrm{s}\right)$} \\
\hline & & & & KSA analysis & AAH analysis \\
\hline 169 & 1025001645 & JW & White Rock Creek & 16.7 & 9.87 \\
\hline 170 & 1025001646 & JW & Walnut Creek & .67 & .57 \\
\hline 171 & 1025001647 & JW & White Rock Creek & 9.57 & 5.13 \\
\hline 172 & 1025001648 & JW & Burr Oak Creek & 1.87 & 1.44 \\
\hline 173 & 1025001649 & JW, SM & White Rock Creek & 7.02 & 4.02 \\
\hline 174 & 1025001650 & SM & White Rock Creek & .54 & .37 \\
\hline 175 & 1025001651 & SM & Cora Creek & .66 & .41 \\
\hline 176 & 1025001652 & PL & Crow Creek & 0 & 0 \\
\hline 177 & 1025001653 & SM & Lost Creek & 0 & 0 \\
\hline 178 & 1025001654 & SM & Unnamed tributary, Smith 2 & 0 & 0 \\
\hline 179 & 1025001656 & SM & Unnamed tributary, Smith 4 & 0 & 0 \\
\hline 180 & 1025001657 & SM & Unnamed tributary, Smith 3 & 0 & 0 \\
\hline 181 & 1025001659 & SM & Buffalo Creek & 0 & 0 \\
\hline 182 & 1025001660 & JW, SM & North Branch White Rock Creek & .74 & .55 \\
\hline 183 & 1025001661 & SM & Louisa Creek & 0 & 0 \\
\hline 184 & 1025001662 & SM & Unnamed tributary, Smith 1 & 0 & 0 \\
\hline 185 & 1025001663 & SM & Cedar Creek & 0 & 0 \\
\hline 186 & 1025001664 & JW & Unnamed tributary, Jewell 1 & 0 & 0 \\
\hline 187 & 1025001665 & JW & Ash Creek & .55 & .44 \\
\hline 188 & 1025001666 & JW & Antelope Creek & 0 & 0 \\
\hline 189 & 1025001667 & JW & Wolf Creek & 0 & 0 \\
\hline 190 & 1025001668 & JW & Long Branch & .08 & 0 \\
\hline 191 & 1025001669 & JW & Unnamed tributary, Jewell 2 & 0 & 0 \\
\hline 192 & 1025001670 & JW & Unnamed tributary, Jewell 3 & 0 & 0 \\
\hline 193 & 1025001671 & JW & Spring Creek & .26 & .14 \\
\hline 194 & 1025001672 & JW & Korb Creek & .09 & .02 \\
\hline 195 & 1025001673 & JW & Norway Creek & 0 & 0 \\
\hline 196 & 1025001674 & JW & Taylor Creek & .69 & .63 \\
\hline 197 & 1025001675 & JW & Oak Creek & 0 & 0 \\
\hline 198 & 1025001676 & JW, RP & Bean Creek & .69 & .61 \\
\hline 199 & 1025001677 & JW & Crosby Creek & .09 & .04 \\
\hline 200 & 1025001678 & JW, RP & Spring Creek & .25 & .25 \\
\hline 201 & 1025001679 & $\mathrm{RP}$ & Otter Creek & 1.08 & .84 \\
\hline
\end{tabular}


Table 6. Stream segments on the 1999 Kansas Surface Water Register, CUSEGA numbers, stream names, and estimated median flows at downstream end of CUSEGA segments using the most-recent 10 years of record (KSA) and all-available hydrology (AAH) analyses.-Continued

[Estimated median flows are rounded to two or three significant figures. Reporting estimated median values to three signficant figures (median greater than or equal to $1 \mathrm{ft}^{3} / \mathrm{s}$ ) or two significant figures (median less than $1 \mathrm{ft}^{3} / \mathrm{s}$ ) was done to conform with the intent of KSA $82 \mathrm{a}-2001 \mathrm{et}$. seq. $\mathrm{ft}^{3} / \mathrm{s}$, cubic feet per second; KSA, Kansas Statute 82a-2001 analysis; AAH, all-available hydrology analysis]

\begin{tabular}{|c|c|c|c|c|c|}
\hline \multirow{2}{*}{$\begin{array}{c}\text { Stream } \\
\text { segment } \\
\text { number } \\
\text { (figs. 9-113) }\end{array}$} & \multirow[b]{2}{*}{ CUSEGA number } & \multirow{2}{*}{$\begin{array}{c}\text { County location } \\
\text { (abbreviation explained } \\
\text { in table 7) }\end{array}$} & \multirow[b]{2}{*}{ Stream name } & \multicolumn{2}{|c|}{ Estimated median flows $\left(\mathrm{ft}^{3} / \mathrm{s}\right)$} \\
\hline & & & & KSA analysis & AAH analysis \\
\hline 202 & 1025001680 & $\mathrm{RP}$ & Dry Creek & 1.90 & 1.68 \\
\hline 203 & 1025001686 & $\mathrm{RP}$ & Unnamed tributary, Republic 1 & .07 & .03 \\
\hline 204 & 102500171 & $\mathrm{GE}$ & Republican River & 278 & 358 \\
\hline 205 & 1025001710 & CY, WS & Peats Creek & 7.94 & 6.47 \\
\hline 206 & 1025001711 & $\mathrm{CY}$ & Republican River & 357 & 356 \\
\hline 207 & 1025001712 & CY, WS & Parsons Creek & 7.10 & 5.74 \\
\hline 208 & 1025001713 & CY, CD & Republican River & 343 & 344 \\
\hline 209 & 102500171354 & $\mathrm{CY}$ & Spring Creek & 2.40 & 1.96 \\
\hline 210 & 102500171369 & $\mathrm{CY}$ & Dry Creek & 1.79 & 1.72 \\
\hline 211 & 1025001714 & $\mathrm{CD}$ & Elk Creek & 6.81 & 5.64 \\
\hline 212 & 102500171477 & $\mathrm{GE}$ & Rush Creek & .57 & .51 \\
\hline 213 & 1025001715 & $\mathrm{CD}, \mathrm{RP}$ & Elk Creek & 3.47 & 2.87 \\
\hline 214 & 1025001716 & $\mathrm{CD}, \mathrm{RP}$ & West Fork Elk Creek & 1.91 & 1.61 \\
\hline 215 & 1025001717 & $\mathrm{CD}$ & Republican River & 323 & 328 \\
\hline 216 & 1025001718 & $\mathrm{CD}$ & Republican River & 312 & 319 \\
\hline 217 & 1025001719 & $\mathrm{CD}$ & Salt Creek & 14.8 & 12.2 \\
\hline 218 & 1025001720 & $\mathrm{RP}, \mathrm{CD}$ & Salt Creek & 9.34 & 7.65 \\
\hline 219 & 1025001721 & $\mathrm{RP}$ & East Creek & 4.04 & 3.41 \\
\hline 220 & 1025001722 & $\mathrm{RP}$ & Salt Creek & 5.30 & 4.34 \\
\hline 221 & 1025001723 & $\mathrm{RP}$ & Salt Creek & 2.26 & 1.87 \\
\hline 222 & 1025001724 & RP & Riley Creek & 1.82 & 1.50 \\
\hline 223 & 1025001725 & $\mathrm{CD}, \mathrm{RP}$ & West Salt Creek & 4.33 & 3.47 \\
\hline 224 & 1025001726 & $\mathrm{CD}$ & Republican River & 281 & 294 \\
\hline 225 & 1025001728 & $\mathrm{CD}, \mathrm{RP}$ & Republican River & 254 & 251 \\
\hline 226 & 1025001729 & CD & Buffalo Creek & 21.6 & 14.0 \\
\hline 227 & 1025001730 & $\mathrm{CD}$ & Salt Creek & 7.32 & 5.23 \\
\hline 228 & 1025001734 & JW, RP & Salt Creek & 6.57 & 4.71 \\
\hline 229 & 1025001735 & JW & Marsh Creek & 4.01 & 2.99 \\
\hline 230 & 1025001736 & JW & West Marsh Creek & 1.77 & 1.34 \\
\hline 231 & 1025001737 & $\mathrm{CD}, \mathrm{JW}$ & Buffalo Creek & 8.04 & 5.76 \\
\hline 232 & 1025001738 & $\mathrm{CD}$ & Wolf Creek & 1.60 & 1.00 \\
\hline 233 & 1025001739 & $\mathrm{CD}$ & Elm Creek & 5.19 & 4.24 \\
\hline 234 & 1025001740 & $\mathrm{CY}, \mathrm{CD}$ & Mulberry Creek & 5.02 & 4.09 \\
\hline 235 & 10250017413 & $\mathrm{CY}, \mathrm{CD}$ & Five Creek & 7.14 & 5.86 \\
\hline 236 & 1025001742 & JW & East March Creek & 2.01 & 1.58 \\
\hline
\end{tabular}


Table 6. Stream segments on the 1999 Kansas Surface Water Register, CUSEGA numbers, stream names, and estimated median flows at downstream end of CUSEGA segments using the most-recent 10 years of record (KSA) and all-available hydrology (AAH) analyses. - Continued

[Estimated median flows are rounded to two or three significant figures. Reporting estimated median values to three signficant figures (median greater than or equal to $1 \mathrm{ft}^{3} / \mathrm{s}$ ) or two significant figures (median less than $1 \mathrm{ft}^{3} / \mathrm{s}$ ) was done to conform with the intent of KSA $82 \mathrm{a}-2001 \mathrm{et}$. seq. $\mathrm{ft}^{3} / \mathrm{s}$, cubic feet per second; KSA, Kansas Statute 82a-2001 analysis; AAH, all-available hydrology analysis]

\begin{tabular}{|c|c|c|c|c|c|}
\hline \multirow{2}{*}{$\begin{array}{c}\text { Stream } \\
\text { segment } \\
\text { number } \\
\text { (figs. 9-113) }\end{array}$} & \multirow[b]{2}{*}{ CUSEGA number } & \multirow{2}{*}{$\begin{array}{c}\text { County location } \\
\text { (abbreviation explained } \\
\text { in table 7) }\end{array}$} & \multirow[b]{2}{*}{ Stream name } & \multicolumn{2}{|c|}{ Estimated median flows $\left(\mathrm{ft}^{3} / \mathrm{s}\right)$} \\
\hline & & & & KSA analysis & $\mathrm{AAH}$ analysis \\
\hline 237 & 1025001743 & JW & Dry Creek & 0.06 & 0.05 \\
\hline 238 & 1025001744 & JW & Spring Creek & .65 & .51 \\
\hline 239 & 1025001745 & $\mathrm{RP}$ & Beaver Creek & .96 & .67 \\
\hline 240 & 1025001747 & $\mathrm{RP}$ & Coal Creek & 1.16 & 1.11 \\
\hline 241 & 1025001748 & $\mathrm{RP}$ & Oak Creek & .29 & .23 \\
\hline 242 & 1025001749 & $\mathrm{CD}, \mathrm{RP}$ & Hay Creek & 1.41 & 1.30 \\
\hline 243 & 1025001750 & $\mathrm{CD}, \mathrm{RP}$ & Cool Creek & .69 & .74 \\
\hline 244 & 1025001751 & $\mathrm{RP}$ & Turkey Creek & .26 & .32 \\
\hline 245 & 1025001752 & $\mathrm{CD}, \mathrm{RP}$ & Upton Creek & 1.08 & .93 \\
\hline 246 & 1025001753 & WS & Spring Creek & 1.19 & 1.03 \\
\hline 247 & 1025001754 & $\mathrm{CD}$ & Whites Creek & 2.23 & 1.74 \\
\hline 248 & 1025001755 & $\mathrm{CD}$ & Cheyenne Creek & 1.55 & 1.15 \\
\hline 249 & 1025001756 & $\mathrm{CD}$ & West Branch Wolf Creek & .62 & .44 \\
\hline 250 & 1025001757 & $\mathrm{CD}$ & Lost Creek & 1.23 & 1.20 \\
\hline 251 & 1025001758 & $\mathrm{CD}$ & Oak Creek & 2.48 & 2.16 \\
\hline 252 & 1025001759 & $\mathrm{CD}$ & West Branch Elm Creek & .64 & .56 \\
\hline 253 & 102500176 & CY, RL & Timber Creek & 4.23 & 3.28 \\
\hline 254 & 1025001760 & $\mathrm{CD}$ & Plum Creek & .74 & .66 \\
\hline 255 & 1025001761 & $\mathrm{CD}$ & Beaver Creek & .92 & .81 \\
\hline 256 & 1025001762 & $\mathrm{CD}$ & East Branch Elm Creek & 1.46 & 1.19 \\
\hline 257 & 1025001763 & $\mathrm{CY}$ & Mud Creek & .48 & .43 \\
\hline 258 & 1025001764 & CY & Finney Creek & 1.47 & 1.29 \\
\hline 259 & 1025001765 & $\mathrm{CY}$ & Lincoln Creek & 3.09 & 2.58 \\
\hline 260 & 1025001766 & CY & Otter Creek & 4.54 & 3.70 \\
\hline 261 & 1025001767 & GE & Fourmile Creek & 1.54 & 1.41 \\
\hline 262 & 1025001768 & JW & East Buffalo Creek & 1.30 & 1.08 \\
\hline 263 & 102500177 & CY & Republican River & 348 & 378 \\
\hline 264 & 102500178 & CY & Republican River & 354 & 380 \\
\hline 265 & 102500179 & CY & Republican River & 372 & 367 \\
\hline 266 & 102500179354 & CY & Huntress Creek & 4.82 & 4.10 \\
\hline 267 & 102600011 & LG & Smoky Hill River & 0 & 0 \\
\hline 268 & 1026000110 & WA & Smoky Hill River & 0 & 0 \\
\hline 269 & 1026000117 & WA & Eagletail Creek & 0 & 0 \\
\hline
\end{tabular}


Table 6. Stream segments on the 1999 Kansas Surface Water Register, CUSEGA numbers, stream names, and estimated median flows at downstream end of CUSEGA segments using the most-recent 10 years of record (KSA) and all-available hydrology (AAH) analyses.-Continued

[Estimated median flows are rounded to two or three significant figures. Reporting estimated median values to three signficant figures (median greater than or equal to $1 \mathrm{ft}^{3} / \mathrm{s}$ ) or two significant figures (median less than $1 \mathrm{ft}^{3} / \mathrm{s}$ ) was done to conform with the intent of KSA $82 \mathrm{a}-2001 \mathrm{et}$. seq. $\mathrm{ft}^{3} / \mathrm{s}$, cubic feet per second; KSA, Kansas Statute 82a-2001 analysis; AAH, all-available hydrology analysis]

\begin{tabular}{|c|c|c|c|c|c|}
\hline \multirow{2}{*}{$\begin{array}{c}\text { Stream } \\
\text { segment } \\
\text { number } \\
\text { (figs. 9-113) }\end{array}$} & \multirow[b]{2}{*}{ CUSEGA number } & \multirow{2}{*}{$\begin{array}{c}\text { County location } \\
\text { (abbreviation explained } \\
\text { in table 7) }\end{array}$} & \multirow[b]{2}{*}{ Stream name } & \multicolumn{2}{|c|}{ Estimated median flows $\left(\mathrm{ft}^{3} / \mathrm{s}\right)$} \\
\hline & & & & KSA analysis & AAH analysis \\
\hline 270 & 1026000118 & WA & South Fork Lake Creek & 0 & 0 \\
\hline 271 & 1026000119 & WA & Rose Creek & 0 & 0 \\
\hline 272 & 102600012 & LG, WA, SH & Lake Creek & 0 & 0 \\
\hline 273 & 1026000120 & WA & Coon Creek & 0 & 0 \\
\hline 274 & 1026000121 & WA & Pond Creek & 0 & 0 \\
\hline 275 & 102600013 & LG, WA & Smoky Hill River & 0 & 0 \\
\hline 276 & 10260001309 & LG, WA & Depperschmidt Draw & 0 & 0 \\
\hline 277 & 10260001311 & WA & Capper Draw & 0 & 0 \\
\hline 278 & 102600014 & WA & Smoky Hill River & 0 & 0 \\
\hline 279 & 102600015 & WA & Goose Creek & 0 & 0 \\
\hline 280 & 102600016 & WA & Smoky Hill River & 0 & 0 \\
\hline 281 & 102600017 & WA & Willow Creek & 0 & 0 \\
\hline 282 & 102600018 & WA & Smoky Hill River & 0 & 0 \\
\hline 283 & 102600019 & WA & Unnamed tributary, Wallace 3 & 0 & 0 \\
\hline 284 & 102600021 & LG & North Fork Smoky Hill River & 0 & 0 \\
\hline 285 & 1026000215 & $\mathrm{SH}, \mathrm{WA}$ & Turtle Creek & 0 & 0 \\
\hline 286 & 102600022 & LG, SH & Sand Creek & 0 & 0 \\
\hline 287 & 102600023 & LG, SH, WA & North Fork Smoky Hill River & 0 & 0 \\
\hline 288 & 102600024 & $\mathrm{SH}$ & Sandy Creek & 0 & 0 \\
\hline 289 & 102600025 & SH & North Fork Smoky Hill River & 0 & 0 \\
\hline 290 & 102600026 & SH & North Fork Smoky Hill River & 0 & 0 \\
\hline 291 & 1026000310 & TR & Smoky Hill River & 5.87 & 2.80 \\
\hline 292 & 1026000311 & TR & Downer Creek & 0 & 0 \\
\hline 293 & 1026000312 & TR & Smoky Hill River & 5.30 & 2.30 \\
\hline 294 & 1026000313 & TR & Smoky Hill River & 3.28 & 1.98 \\
\hline 295 & 1026000314 & GO, TR & Smoky Hill River & 2.85 & 1.81 \\
\hline 296 & 1026000315 & GO & Indian Creek & 0 & 0 \\
\hline 297 & 1026000316 & $\mathrm{GO}$ & Smoky Hill River & 2.09 & 1.55 \\
\hline 298 & 1026000317 & GO & Smoky Hill River & 1.88 & 1.46 \\
\hline 299 & 1026000318 & GO, LG & Plum Creek & 0 & 0 \\
\hline 300 & 1026000319 & GO & Smoky Hill River & 1.24 & 1.44 \\
\hline 301 & 1026000320 & GO & Smoky Hill River & .80 & 1.49 \\
\hline 302 & 1026000321 & GO, LG & Smoky Hill River & .57 & 1.50 \\
\hline 303 & 1026000322 & LG & Smoky Hill River & 0 & .35 \\
\hline 304 & 1026000323 & LG & Six Mile Creek & 0 & 0 \\
\hline
\end{tabular}


Table 6. Stream segments on the 1999 Kansas Surface Water Register, CUSEGA numbers, stream names, and estimated median flows at downstream end of CUSEGA segments using the most-recent 10 years of record (KSA) and all-available hydrology (AAH) analyses. - Continued

[Estimated median flows are rounded to two or three significant figures. Reporting estimated median values to three signficant figures (median greater than or equal to $1 \mathrm{ft}^{3} / \mathrm{s}$ ) or two significant figures (median less than $1 \mathrm{ft}^{3} / \mathrm{s}$ ) was done to conform with the intent of KSA $82 \mathrm{a}-2001 \mathrm{et}$. seq. $\mathrm{ft}^{3} / \mathrm{s}$, cubic feet per second; KSA, Kansas Statute 82a-2001 analysis; AAH, all-available hydrology analysis]

\begin{tabular}{|c|c|c|c|c|c|}
\hline \multirow{2}{*}{$\begin{array}{c}\text { Stream } \\
\text { segment } \\
\text { number } \\
\text { (figs. 9-113) }\end{array}$} & \multirow[b]{2}{*}{ CUSEGA number } & \multirow{2}{*}{$\begin{array}{c}\text { County location } \\
\text { (abbreviation explained } \\
\text { in table 7) }\end{array}$} & \multirow[b]{2}{*}{ Stream name } & \multicolumn{2}{|c|}{ Estimated median flows $\left(\mathrm{ft}^{3} / \mathrm{s}\right)$} \\
\hline & & & & KSA analysis & AAH analysis \\
\hline 305 & 1026000324 & LG & Smoky Hill River & 0 & 0.07 \\
\hline 306 & 1026000325 & $\mathrm{GO}, \mathrm{LG}, \mathrm{SC}$ & Hell Creek & 0 & 0 \\
\hline 307 & 1026000326 & GO, LE, SC & Salt Creek & 0 & 0 \\
\hline 308 & 1026000327 & GO, LE & Unnamed tributary, Gove 2 & 0 & 0 \\
\hline 309 & 1026000328 & NS, TR & Wild Horse Creek & 0 & 0 \\
\hline 310 & 1026000329 & NS, TR & Sand Creek & 0 & 0 \\
\hline 311 & 1026000331 & NS, TR & Page Creek & 0 & 0 \\
\hline 312 & 1026000333 & LG & West Spring Creek & 0 & 0 \\
\hline 313 & 1026000334 & TR & Gibson Creek & 0 & 0 \\
\hline 314 & 1026000335 & $\mathrm{LE}$ & East Salt Creek & 0 & 0 \\
\hline 315 & 1026000336 & GO, LE & Cheyenne Creek & 0 & 0 \\
\hline 316 & 1026000337 & GO, NS & Sand Creek & 0 & 0 \\
\hline 317 & 1026000338 & GO, NS & Big Windy Creek & 0 & 0 \\
\hline 318 & 1026000339 & $\mathrm{TR}$ & East Branch Downer Creek & 0 & 0 \\
\hline 319 & 1026000340 & NS, TR & East Branch Sand Creek & 0 & 0 \\
\hline 320 & 1026000341 & NS, TR & Goat Canyon Creek & 0 & 0 \\
\hline 321 & 102600037 & $\mathrm{TR}$ & Indian Creek & 0 & 0 \\
\hline 322 & 102600039 & TR & Smoky Hill River & 6.69 & 3.52 \\
\hline 323 & 102600041 & LG & Ladder Creek & 1.30 & 1.90 \\
\hline 324 & 1026000410 & WA & Ladder Creek & .01 & .01 \\
\hline 325 & 1026000411 & WA & Unnamed tributary, Wallace 1 & 0 & 0 \\
\hline 326 & 1026000412 & GL & South Ladder Creek & .04 & .07 \\
\hline 327 & 1026000413 & GL, WA & Middle Ladder Creek & 0 & 0 \\
\hline 328 & 1026000414 & GL & South Ladder Creek & .02 & .04 \\
\hline 329 & 1026000415 & GL, WH & Unnamed tributary, Greeley 1 & .01 & .01 \\
\hline 330 & 1026000417 & WA & Unnamed tributary, Wallace 2 & 0 & 0 \\
\hline 331 & 102600042 & LG, WA & Twin Butte Creek & .01 & .03 \\
\hline 332 & 102600043 & LG & Ladder Creek & .59 & 1.22 \\
\hline 333 & 102600044 & LG, WA & Chalk Creek & .01 & .03 \\
\hline 334 & 102600045 & LG, SC, WH & Ladder Creek & .42 & .88 \\
\hline 335 & 102600046 & WH & Unnamed tributary, Witchita 1 & 0 & 0 \\
\hline 336 & 102600047 & WH & Ladder Creek & .23 & .48 \\
\hline 337 & 102600048 & GL, WH & Ladder Creek & .13 & .26 \\
\hline
\end{tabular}


Table 6. Stream segments on the 1999 Kansas Surface Water Register, CUSEGA numbers, stream names, and estimated median flows at downstream end of CUSEGA segments using the most-recent 10 years of record (KSA) and all-available hydrology (AAH) analyses.-Continued

[Estimated median flows are rounded to two or three significant figures. Reporting estimated median values to three signficant figures (median greater than or equal to $1 \mathrm{ft}^{3} / \mathrm{s}$ ) or two significant figures (median less than $1 \mathrm{ft}^{3} / \mathrm{s}$ ) was done to conform with the intent of KSA $82 \mathrm{a}-2001 \mathrm{et}$. seq. $\mathrm{ft}^{3} / \mathrm{s}$, cubic feet per second; KSA, Kansas Statute 82a-2001 analysis; AAH, all-available hydrology analysis]

\begin{tabular}{|c|c|c|c|c|c|}
\hline \multirow{2}{*}{$\begin{array}{c}\text { Stream } \\
\text { segment } \\
\text { number } \\
\text { (figs. 9-113) }\end{array}$} & \multirow[b]{2}{*}{ CUSEGA number } & \multirow{2}{*}{$\begin{array}{c}\text { County location } \\
\text { (abbreviation explained } \\
\text { in table 7) }\end{array}$} & \multirow[b]{2}{*}{ Stream name } & \multicolumn{2}{|c|}{ Estimated median flows $\left(\mathrm{ft}^{3} / \mathrm{s}\right)$} \\
\hline & & & & KSA analysis & AAH analysis \\
\hline 338 & 102600049 & GL, WA & Ladder Creek & 0.02 & 0.04 \\
\hline 339 & 102600051 & GO, TR & Hackberry Creek & 1.55 & .97 \\
\hline 340 & 102600052 & GO & Spring Creek & 0 & 0 \\
\hline 341 & 102600053 & $\mathrm{GO}$ & Hackberry Creek & .78 & .41 \\
\hline 342 & 102600054 & $\mathrm{GO}$ & Middle Branch Hackberry Creek & 0 & 0 \\
\hline 343 & 102600055 & GO, LG & North Branch Hackberry Creek & 0 & 0 \\
\hline 344 & 102600056 & GO, LG & Middle Branch Hackberry Creek & 0 & 0 \\
\hline 345 & 102600057 & GO, LG & South Branch Hackberry Creek & 0 & 0 \\
\hline 346 & 102600058 & GO & West Spring Creek & 0 & 0 \\
\hline 347 & 1026000610 & RS & Smoky Hill River & 75.9 & 46.9 \\
\hline 348 & 1026000611 & RS & Smoky Hill River & 71.1 & 42.1 \\
\hline 349 & 102600061190 & EW & Ash Creek & 1.09 & .92 \\
\hline 350 & 1026000612 & RS & Smoky Hill River & 63.0 & 34.0 \\
\hline 351 & 1026000613 & RS & Fossel Creek & .77 & .51 \\
\hline 352 & 1026000614 & RS & Smoky Hill River & 49.5 & 34.5 \\
\hline 353 & 1026000615 & RS & Smoky Hill River & 35.0 & 35.0 \\
\hline 354 & 1026000616 & EL, RS & Smoky Hill River & 16.7 & 12.7 \\
\hline 355 & 1026000617 & EL & Smoky Hill River & 14.6 & 10.2 \\
\hline 356 & 1026000618 & EL & Smoky Hill River & 13.8 & 9.25 \\
\hline 357 & 1026000619 & EL & Smoky Hill River & 7.70 & 1.80 \\
\hline 358 & 1026000620 & EL & Unnamed tributary, Ellis 1 & 0 & 0 \\
\hline 359 & 1026000621 & EL & Smoky Hill River & 6.30 & 11.0 \\
\hline 360 & 1026000622 & EL, TR & Smoky Hill River & 4.14 & 7.32 \\
\hline 361 & 1026000623 & EL, RH & Unnamed tributary, Ellis 2 & 0 & 0 \\
\hline 362 & 1026000624 & EL, RH & Big Timber Creek & 1.01 & .61 \\
\hline 363 & 1026000625 & RH & Big Timber Creek & .44 & .17 \\
\hline 364 & 1026000626 & NS, RH, TR & Timber Creek & 0 & 0 \\
\hline 365 & 1026000627 & NS, RH & Big Timber Creek & 0 & 0 \\
\hline 366 & 1026000628 & RH & Unnamed tributary, Rush 1 & 0 & 0 \\
\hline 367 & 1026000629 & EL, RH & Buck Creek & 0 & 0 \\
\hline 368 & 1026000630 & EL, RH & Eagle Creek & 0 & 0 \\
\hline 369 & 1026000631 & $\mathrm{BT}, \mathrm{RS}$ & Landon Creek & .55 & .32 \\
\hline 370 & 1026000632 & BT, RS & Sellens Creek & .72 & .47 \\
\hline 371 & 1026000633 & $\mathrm{BT}, \mathrm{RS}$ & Beaver Creek & 1.27 & .94 \\
\hline 372 & 1026000634 & BT, RS & Coal Creek & 1.84 & 1.40 \\
\hline
\end{tabular}


Table 6. Stream segments on the 1999 Kansas Surface Water Register, CUSEGA numbers, stream names, and estimated median flows at downstream end of CUSEGA segments using the most-recent 10 years of record (KSA) and all-available hydrology (AAH) analyses.-Continued

[Estimated median flows are rounded to two or three significant figures. Reporting estimated median values to three signficant figures (median greater than or equal to $1 \mathrm{ft}^{3} / \mathrm{s}$ ) or two significant figures (median less than $1 \mathrm{ft}^{3} / \mathrm{s}$ ) was done to conform with the intent of KSA $82 \mathrm{a}-2001$ et. seq. $\mathrm{ft}^{3} / \mathrm{s}$, cubic feet per second; KSA, Kansas Statute 82a-2001 analysis; AAH, all-available hydrology analysis]

\begin{tabular}{|c|c|c|c|c|c|}
\hline \multirow{2}{*}{$\begin{array}{c}\text { Stream } \\
\text { segment } \\
\text { number } \\
\text { (figs. 9-113) }\end{array}$} & \multirow[b]{2}{*}{ CUSEGA number } & \multirow{2}{*}{$\begin{array}{c}\text { County location } \\
\text { (abbreviation explained } \\
\text { in table 7) }\end{array}$} & \multirow[b]{2}{*}{ Stream name } & \multicolumn{2}{|c|}{ Estimated median flows $\left(\mathrm{ft}^{3} / \mathrm{s}\right)$} \\
\hline & & & & KSA analysis & $\mathrm{AAH}$ analysis \\
\hline 373 & 1026000635 & BT, EW, RS & Blood Creek & 0.83 & 0.64 \\
\hline 374 & 1026000636 & BT, EW & Wolf Creek & 1.10 & .89 \\
\hline 375 & 1026000637 & EW & Thompson Creek & 2.30 & 1.86 \\
\hline 376 & 1026000638 & EW, LC & Cow Creek & 1.16 & 1.07 \\
\hline 377 & 1026000639 & BT, RS & Goose Creek & .57 & .37 \\
\hline 378 & 1026000640 & $\mathrm{EW}, \mathrm{RS}$ & Wilson Creek & 1.90 & 1.61 \\
\hline 379 & 1026000641 & EW, RS & Spring Creek & 0 & 0 \\
\hline 380 & 1026000642 & EW & Clear Creek & 2.99 & 2.56 \\
\hline 381 & 1026000643 & $\mathrm{EL}, \mathrm{RH}$ & Shelter Creek & 0 & 0 \\
\hline 382 & 1026000644 & EW & Loss Creek & 1.28 & 1.04 \\
\hline 383 & 1026000645 & EW & Oxide Creek & 1.46 & 1.24 \\
\hline 384 & 1026000646 & EW & Turkey Creek & 1.40 & 1.16 \\
\hline 385 & 1026000647 & EW & Mud Creek & .16 & .19 \\
\hline 386 & 1026000648 & EW & Skunk Creek & .17 & .19 \\
\hline 387 & 102600065 & EW & Smoky Hill River & 111 & 73.0 \\
\hline 388 & 102600066 & EW, LC & Buffalo Creek & 2.94 & 2.68 \\
\hline 389 & 102600067 & EW & Smoky Hill River & 88.5 & 59.5 \\
\hline 390 & 102600068 & EW & Smoky Hill River & 85.3 & 56.3 \\
\hline 391 & 102600069 & EW, RS & Smoky Hill River & 81.4 & 52.4 \\
\hline 392 & 102600071 & RS & Big Creek & 23.8 & 11.7 \\
\hline 393 & 102600072 & EL, RS & Walker Creek & .12 & 0 \\
\hline 394 & 102600073 & EL, RS & Big Creek & 22.2 & 10.4 \\
\hline 395 & 102600074 & EL & North Fork Big Creek & .82 & .56 \\
\hline 396 & 102600075 & EL, TR & Big Creek & 19.5 & 8.29 \\
\hline 397 & 102600076 & TR & Ogallah Creek & .25 & .08 \\
\hline 398 & 102600077 & GO, TR & Big Creek & 4.99 & 3.52 \\
\hline 399 & 102600078 & EL & Chetolah Creek & .02 & .01 \\
\hline 400 & 102600079 & EL & Mud Creek & 0 & 0 \\
\hline 401 & 102600081 & GE & Smoky Hill River & 1,020 & 618 \\
\hline 402 & 1026000810 & DK, SA & Smoky Hill River & 964 & 573 \\
\hline 403 & 1026000811 & SA & Smoky Hill River & 423 & 238 \\
\hline 404 & 1026000812 & SA & Smoky Hill River & 400 & 224 \\
\hline 405 & 1026000813 & SA & Smoky Hill River & 198 & 136 \\
\hline
\end{tabular}


Table 6. Stream segments on the 1999 Kansas Surface Water Register, CUSEGA numbers, stream names, and estimated median flows at downstream end of CUSEGA segments using the most-recent 10 years of record (KSA) and all-available hydrology (AAH) analyses.-Continued

[Estimated median flows are rounded to two or three significant figures. Reporting estimated median values to three signficant figures (median greater than or equal to $1 \mathrm{ft}^{3} / \mathrm{s}$ ) or two significant figures (median less than $1 \mathrm{ft}^{3} / \mathrm{s}$ ) was done to conform with the intent of KSA $82 \mathrm{a}-2001 \mathrm{et}$. seq. $\mathrm{ft}^{3} / \mathrm{s}$, cubic feet per second; KSA, Kansas Statute 82a-2001 analysis; AAH, all-available hydrology analysis]

\begin{tabular}{|c|c|c|c|c|c|}
\hline \multirow{2}{*}{$\begin{array}{c}\text { Stream } \\
\text { segment } \\
\text { number } \\
\text { (figs. 9-113) }\end{array}$} & \multirow[b]{2}{*}{ CUSEGA number } & \multirow{2}{*}{$\begin{array}{c}\text { County location } \\
\text { (abbreviation explained } \\
\text { in table 7) }\end{array}$} & \multirow[b]{2}{*}{ Stream name } & \multicolumn{2}{|c|}{ Estimated median flows $\left(\mathrm{ft}^{3} / \mathrm{s}\right)$} \\
\hline & & & & KSA analysis & $\mathrm{AAH}$ analysis \\
\hline 406 & 1026000814 & MP, SA & Smoky Hill River & 162 & 108 \\
\hline 407 & 1026000815 & EW, MP & Smoky Hill River & 134 & 87.9 \\
\hline 408 & 1026000816 & $\mathrm{MP}, \mathrm{RC}$ & Sharps Creek & 5.79 & 4.66 \\
\hline 409 & 1026000817 & MP, SA & Kentucky Creek & 3.98 & 3.36 \\
\hline 410 & 1026000818 & SA & Gypsum Creek & 24.6 & 19.7 \\
\hline 411 & 1026000819 & MP, SA & Stag Creek & 2.28 & 2.05 \\
\hline 412 & 102600082 & DK, GE & Smoky Hill River & 1,010 & 608 \\
\hline 413 & 1026000820 & MP, SA & Gypsum Creek & 9.00 & 7.00 \\
\hline 414 & 1026000821 & MP & Gypsum Creek & 5.26 & 4.29 \\
\hline 415 & 1026000822 & MP & Gypsum Creek & 3.94 & 3.25 \\
\hline 416 & 1026000823 & MP & Battle Creek & 1.35 & 1.23 \\
\hline 417 & 1026000824 & MP & South Gypsum Creek & 2.79 & 2.41 \\
\hline 418 & 1026000825 & DK & Holland Creek & 10.2 & 8.24 \\
\hline 419 & 1026000826 & DK, MN & West Holland Creek & 3.49 & 2.89 \\
\hline 420 & 1026000827 & $\mathrm{DK}, \mathrm{MN}$ & East Holland Creek & 2.32 & 2.00 \\
\hline 421 & 1026000828 & DK & Turkey Creek & 15.8 & 12.4 \\
\hline 422 & 1026000829 & DK & West Branch Turkey Creek & 3.39 & 2.67 \\
\hline 423 & 102600083 & CY, DK & Chapman Creek & 37.0 & 24.0 \\
\hline 424 & 1026000830 & $\mathrm{DK}, \mathrm{MN}$ & Turkey Creek & 9.55 & 7.38 \\
\hline 425 & 1026000831 & $\mathrm{DK}, \mathrm{GE}$ & Lyon Creek & 34.1 & 34.6 \\
\hline 426 & 1026000832 & DK & Unnamed tributary, Dickinson 2 & .51 & .47 \\
\hline 427 & 1026000834 & DK & West Branch Lyon Creek & 17.0 & 16.2 \\
\hline 428 & 1026000835 & DK & Carry Creek & 7.83 & 6.82 \\
\hline 429 & 1026000836 & MP, SA & Dry Creek & 7.54 & 6.04 \\
\hline 430 & 102600084 & $\mathrm{CD}, \mathrm{CY}, \mathrm{OT}$ & Chapman Creek & 8.11 & 6.31 \\
\hline 431 & 1026000840 & $\mathrm{CY}, \mathrm{DK}$ & Basket Creek & 1.51 & 1.24 \\
\hline 432 & 1026000841 & DK & Lone Tree Creek & 3.82 & 3.39 \\
\hline 433 & 1026000842 & GE & Otter Creek & .98 & .78 \\
\hline 434 & 1026000843 & SA & East Dry Creek & 1.73 & 1.50 \\
\hline 435 & 1026000844 & SA & West Branch Gypsum Creek & 3.14 & 2.69 \\
\hline 436 & 1026000845 & SA & Spring Creek & 2.88 & 2.47 \\
\hline 437 & 1026000846 & EW & Sand Creek & 2.62 & 2.66 \\
\hline 438 & 1026000847 & EW & Wiley Creek & 1.09 & 1.07 \\
\hline 439 & 1026000848 & DK, MN, SA & Hobbs Creek & 3.09 & 2.58 \\
\hline 440 & 1026000849 & DK, SA & McAllister Creek & 1.36 & 1.07 \\
\hline
\end{tabular}


Table 6. Stream segments on the 1999 Kansas Surface Water Register, CUSEGA numbers, stream names, and estimated median flows at downstream end of CUSEGA segments using the most-recent 10 years of record (KSA) and all-available hydrology (AAH) analyses. - Continued

[Estimated median flows are rounded to two or three significant figures. Reporting estimated median values to three signficant figures (median greater than or equal to $1 \mathrm{ft}^{3} / \mathrm{s}$ ) or two significant figures (median less than $1 \mathrm{ft}^{3} / \mathrm{s}$ ) was done to conform with the intent of KSA 82a-2001 et. seq. $\mathrm{ft}^{3} / \mathrm{s}$, cubic feet per second; KSA, Kansas Statute 82a-2001 analysis; AAH, all-available hydrology analysis]

\begin{tabular}{|c|c|c|c|c|c|}
\hline \multirow{2}{*}{$\begin{array}{l}\text { Stream } \\
\text { segment } \\
\text { number } \\
\text { (figs. 9-113) }\end{array}$} & \multirow[b]{2}{*}{ CUSEGA number } & \multirow{2}{*}{$\begin{array}{c}\text { County location } \\
\text { (abbreviation explained } \\
\text { in table 7) }\end{array}$} & \multirow[b]{2}{*}{ Stream name } & \multicolumn{2}{|c|}{ Estimated median flows $\left(\mathrm{ft}^{3} / \mathrm{s}\right)$} \\
\hline & & & & KSA analysis & AAH analysis \\
\hline 441 & 102600085 & CY, OT & West Chapman Creek & 5.25 & 4.16 \\
\hline 442 & 1026000850 & $\mathrm{DK}, \mathrm{MN}$ & East Turkey Creek & 3.02 & 2.34 \\
\hline 443 & 1026000851 & DK, MR & Lime Creek & 2.71 & 2.39 \\
\hline 444 & 10260008515 & DK & Unnamed tributary, Dickinson 3 & 0 & 0 \\
\hline 445 & 1026000852 & MP & Paint Creek & 1.42 & 1.22 \\
\hline 446 & 1026000854 & MP & West Kentucky Creek & .90 & .86 \\
\hline 447 & 10260008540 & $\mathrm{DK}, \mathrm{MN}$ & Lyon Creek & 5.94 & 5.14 \\
\hline 448 & 10260008542 & DK & Unnamed tributary, Dickinson 5 & 0 & 0 \\
\hline 449 & 1026000856 & MP, SA & Pewee Creek & 1.18 & 1.18 \\
\hline 450 & 1026000857 & MP & North Gypsum Creek & 1.57 & 1.39 \\
\hline 451 & 1026000858 & $\mathrm{DK}, \mathrm{MN}$ & Middle Branch Turkey Creek & 1.07 & .86 \\
\hline 452 & 102600086 & DK & Smoky Hill River & 1,000 & 597 \\
\hline 453 & 10260008618 & DK & Unnamed tributary, Dickinson 4 & 0 & 0 \\
\hline 454 & 10260008638 & DK, GE, MR & Unnamed tributary, Dickinson 1 & .95 & .86 \\
\hline 455 & 102600088 & DK & Mud Creek & 13.5 & 11.6 \\
\hline 456 & 102600089 & DK & Smoky Hill River & 972 & 578 \\
\hline 457 & 1026000910 & EL, RO & East Spring Creek & .06 & .02 \\
\hline 458 & 102600091061 & GO, TR & Unnamed tributary, Gove 1 & 0 & 0 \\
\hline 459 & 1026000911 & EL & Saline River & 36.2 & 16.1 \\
\hline 460 & 1026000912 & $\mathrm{EL}, \mathrm{RO}, \mathrm{TR}$ & Saline River & 28.5 & 12.3 \\
\hline 461 & 1026000913 & GH, TR & Unnamed tributary, Graham 1 & .07 & .03 \\
\hline 462 & 1026000914 & TR & Saline River & 16.6 & 6.77 \\
\hline 463 & 1026000915 & $\mathrm{GH}, \mathrm{SD}, \mathrm{TR}$ & North Fork Saline River & .14 & .01 \\
\hline 464 & 1026000916 & $\mathrm{GH}, \mathrm{SD}, \mathrm{TR}$ & Saline River & 4.42 & 1.39 \\
\hline 465 & 1026000917 & $\mathrm{SD}, \mathrm{TH}$ & North Fork Saline River & .06 & 0 \\
\hline 466 & 1026000918 & $\mathrm{SD}, \mathrm{TH}$ & South Fork Saline River & .22 & .02 \\
\hline 467 & 1026000919 & EL, TR & Trego Creek & .17 & .04 \\
\hline 468 & 1026000920 & EL, RS & Salt Creek & 1.05 & .69 \\
\hline 469 & 1026000921 & SD & Spring Brook Creek & .02 & 0 \\
\hline 470 & 1026000922 & GO, GH, TR & Plum Creek & .01 & 0 \\
\hline 471 & 1026000923 & TR & Coyote Creek & .02 & 0 \\
\hline 472 & 1026000924 & TR & Trego Creek & .04 & .02 \\
\hline 473 & 1026000925 & GH, TR & Happy Creek & .04 & .01 \\
\hline
\end{tabular}


Table 6. Stream segments on the 1999 Kansas Surface Water Register, CUSEGA numbers, stream names, and estimated median flows at downstream end of CUSEGA segments using the most-recent 10 years of record (KSA) and all-available hydrology (AAH) analyses.-Continued

[Estimated median flows are rounded to two or three significant figures. Reporting estimated median values to three signficant figures (median greater than or equal to $1 \mathrm{ft}^{3} / \mathrm{s}$ ) or two significant figures (median less than $1 \mathrm{ft}^{3} / \mathrm{s}$ ) was done to conform with the intent of KSA $82 \mathrm{a}-2001$ et. seq. $\mathrm{ft}^{3} / \mathrm{s}$, cubic feet per second; KSA, Kansas Statute 82a-2001 analysis; AAH, all-available hydrology analysis]

\begin{tabular}{|c|c|c|c|c|c|}
\hline \multirow{2}{*}{$\begin{array}{c}\text { Stream } \\
\text { segment } \\
\text { number } \\
\text { (figs. 9-113) }\end{array}$} & \multirow[b]{2}{*}{ CUSEGA number } & \multirow{2}{*}{$\begin{array}{c}\text { County location } \\
\text { (abbreviation explained } \\
\text { in table 7) }\end{array}$} & \multirow[b]{2}{*}{ Stream name } & \multicolumn{2}{|c|}{ Estimated median flows $\left(\mathrm{ft}^{3} / \mathrm{s}\right)$} \\
\hline & & & & KSA analysis & AAH analysis \\
\hline 474 & 1026000926 & GH, TR & Chalk Creek & 0.01 & 0 \\
\hline 475 & 1026000927 & EL, RO & Wild Horse Creek & .03 & .01 \\
\hline 476 & 1026000928 & EL, RO & Tomcat Creek & .02 & .01 \\
\hline 477 & 1026000929 & EL & Sweetwater Creek & .12 & .01 \\
\hline 478 & 1026000930 & RS & Cedar Creek & 2.37 & 1.81 \\
\hline 479 & 102600094 & RS & Saline River & 76.9 & 41.7 \\
\hline 480 & 102600095 & RS & Paradise Creek & 1.03 & .91 \\
\hline 481 & 102600096 & OB, RS, RO & Eagle Creek & .72 & .49 \\
\hline 482 & 102600097 & $\mathrm{OB}, \mathrm{RO}, \mathrm{RS}$ & Paradise Creek & .69 & .49 \\
\hline 483 & 102600098 & $\mathrm{RS}$ & Saline River & 64.0 & 31.0 \\
\hline 484 & 102600099 & EL, RS & Saline River & 57.1 & 27.1 \\
\hline 485 & 102600101 & SA & Saline River & 121 & 54.5 \\
\hline 486 & 1026001010 & LC, RS & Wolf Creek & 7.04 & 6.34 \\
\hline 487 & 1026001011 & $\mathrm{OB}, \mathrm{RS}$ & East Fork Wolf Creek & 1.89 & 1.40 \\
\hline 488 & 1026001012 & OB, RS & West Fork Wolf Creek & 1.80 & 2.20 \\
\hline 489 & 1026001013 & LC, RS & Saline River & 21.0 & 16.0 \\
\hline 490 & 1026001014 & LC & Bullfoot Creek & 5.67 & 4.53 \\
\hline 491 & 1026001015 & LC & Bullfoot Creek & 2.24 & 1.82 \\
\hline 492 & 1026001016 & EW, LC & Spring Creek & 2.45 & 2.00 \\
\hline 493 & 1026001017 & EW, LC & Elkhorn Creek & 6.28 & 5.06 \\
\hline 494 & 1026001018 & LC, OT & Table Rock Creek & 3.37 & 2.78 \\
\hline 495 & 1026001019 & SA & Mulberry Creek & 26.8 & 21.9 \\
\hline 496 & 102600102 & OT, SA & Saline River & 109 & 47.7 \\
\hline 497 & 1026001020 & SA & Mulberry Creek & 24.8 & 20.2 \\
\hline 498 & 1026001021 & SA & Mulberry Creek & 11.7 & 9.51 \\
\hline 499 & 1026001022 & EW, LC, SA & Mulberry Creek & 6.87 & 5.60 \\
\hline 500 & 1026001023 & SA & Eff Creek & 3.23 & 2.69 \\
\hline 501 & 1026001024 & SA & Spring Creek & 12.2 & 9.86 \\
\hline 502 & 1026001025 & EW, SA & West Spring Creek & 4.87 & 4.02 \\
\hline 503 & 1026001026 & SA & Spring Creek & 4.87 & 3.98 \\
\hline 504 & 1026001027 & SA & Spring Creek & 2.01 & 1.70 \\
\hline 505 & 1026001028 & SA & Ralston Creek & 2.69 & 2.27 \\
\hline 506 & 1026001029 & SA & Dry Creek & .92 & .77 \\
\hline
\end{tabular}


Table 6. Stream segments on the 1999 Kansas Surface Water Register, CUSEGA numbers, stream names, and estimated median flows at downstream end of CUSEGA segments using the most-recent 10 years of record (KSA) and all-available hydrology (AAH) analyses. - Continued

[Estimated median flows are rounded to two or three significant figures. Reporting estimated median values to three signficant figures (median greater than or equal to $1 \mathrm{ft}^{3} / \mathrm{s}$ ) or two significant figures (median less than $1 \mathrm{ft}^{3} / \mathrm{s}$ ) was done to conform with the intent of KSA $82 \mathrm{a}-2001 \mathrm{et}$. seq. $\mathrm{ft}^{3} / \mathrm{s}$, cubic feet per second; KSA, Kansas Statute 82a-2001 analysis; AAH, all-available hydrology analysis]

\begin{tabular}{|c|c|c|c|c|c|}
\hline \multirow{2}{*}{$\begin{array}{l}\text { Stream } \\
\text { segment } \\
\text { number } \\
\text { (figs. 9-113) }\end{array}$} & \multirow[b]{2}{*}{ CUSEGA number } & \multirow{2}{*}{$\begin{array}{c}\text { County location } \\
\text { (abbreviation explained } \\
\text { in table 7) }\end{array}$} & \multirow[b]{2}{*}{ Stream name } & \multicolumn{2}{|c|}{ Estimated median flows $\left(\mathrm{ft}^{3} / \mathrm{s}\right)$} \\
\hline & & & & KSA analysis & AAH analysis \\
\hline 507 & 102600103 & $\mathrm{LC}, \mathrm{OT}$ & Saline River & 105 & 45.2 \\
\hline 508 & 1026001030 & $\mathrm{OB}, \mathrm{RS}$ & Fourmile Creek & .32 & .22 \\
\hline 509 & 1026001031 & $\mathrm{OB}, \mathrm{RS}$ & Coon Creek & .02 & 0 \\
\hline 510 & 1026001032 & LC & Trail Creek & .73 & .54 \\
\hline 511 & 1026001033 & $\mathrm{LC}, \mathrm{RS}$ & Blue Stem Creek & .95 & .72 \\
\hline 512 & 1026001034 & LC & Lost Creek & .51 & .46 \\
\hline 513 & 1026001035 & $\mathrm{LC}$ & Yauger Creek & .95 & .81 \\
\hline 514 & 1026001036 & $\mathrm{LC}$ & Twelve mile Creek & .94 & .83 \\
\hline 515 & 1026001037 & $\mathrm{LC}$ & West Twin Creek & 1.82 & 1.47 \\
\hline 516 & 1026001038 & EW, LC & West Elkhorn Creek & 2.06 & 1.69 \\
\hline 517 & 1026001039 & LC & Owl Creek & 1.75 & 1.46 \\
\hline 518 & 102600104 & $\mathrm{LC}$ & Saline River & 86.5 & 38.6 \\
\hline 519 & 1026001040 & EW, LC & Table Rock Creek & 1.59 & 1.37 \\
\hline 520 & 1026001041 & SA & Shaw Creek & .91 & .82 \\
\hline 521 & 102600105 & $\mathrm{LC}$ & Saline River & 77.5 & 35.5 \\
\hline 522 & 102600106 & $\mathrm{LC}$ & Spillman Creek & 7.28 & 5.64 \\
\hline 523 & 102600107 & $\mathrm{LC}, \mathrm{MC}$ & Bacon Creek & 1.14 & .83 \\
\hline 524 & 102600108 & $\mathrm{LC}, \mathrm{MC}, \mathrm{OB}$ & North Branch Spillman Creek & 2.58 & 1.94 \\
\hline 525 & 102600109 & $\mathrm{LC}$ & Saline River & 56.5 & 28.3 \\
\hline 526 & 1026001110 & NT & Otter Creek & .04 & 0 \\
\hline 527 & 1026001111 & NT & North Fork Solomon River & 9.16 & 2.70 \\
\hline 528 & 1026001112 & $\mathrm{DC}, \mathrm{NT}$ & Elk Creek & .09 & 0 \\
\hline 529 & 1026001113 & DC, NT, SD, TH & North Fork Solomon River & 3.69 & .78 \\
\hline 530 & 1026001115 & GH, PL, RO, NT, SD & Bow Creek & 9.50 & 5.60 \\
\hline 531 & 1026001116 & SD & Bow Creek & .06 & .01 \\
\hline 532 & 1026001117 & $\mathrm{SD}, \mathrm{TH}$ & South Bow Creek & .36 & .08 \\
\hline 533 & 1026001119 & $\mathrm{GH}, \mathrm{NT}$ & Spring Creek & .01 & 0 \\
\hline 534 & 1026001120 & GH, NT & Lost Creek & .01 & 0 \\
\hline 535 & 1026001121 & NT & Scull Creek & .01 & 0 \\
\hline 536 & 1026001122 & PL & Wolf Creek & .01 & 0 \\
\hline 537 & 1026001123 & PL & Beaver Creek & .01 & 0 \\
\hline 538 & 1026001124 & PL & Ash Creek & .01 & 0 \\
\hline 539 & 1026001125 & NT & East Elk Creek & .04 & 0 \\
\hline 540 & 1026001126 & NT & Sand Creek & 0 & 0 \\
\hline
\end{tabular}


Table 6. Stream segments on the 1999 Kansas Surface Water Register, CUSEGA numbers, stream names, and estimated median flows at downstream end of CUSEGA segments using the most-recent 10 years of record (KSA) and all-available hydrology (AAH) analyses.-Continued

[Estimated median flows are rounded to two or three significant figures. Reporting estimated median values to three signficant figures (median greater than or equal to $1 \mathrm{ft}^{3} / \mathrm{s}$ ) or two significant figures (median less than $1 \mathrm{ft}^{3} / \mathrm{s}$ ) was done to conform with the intent of $\mathrm{KSA} 82 \mathrm{a}-2001$ et. seq. $\mathrm{ft}^{3} / \mathrm{s}$, cubic feet per second; KSA, Kansas Statute 82a-2001 analysis; AAH, all-available hydrology analysis]

\begin{tabular}{|c|c|c|c|c|c|}
\hline \multirow{2}{*}{$\begin{array}{c}\text { Stream } \\
\text { segment } \\
\text { number } \\
\text { (figs. 9-113) }\end{array}$} & \multirow[b]{2}{*}{ CUSEGA number } & \multirow{2}{*}{$\begin{array}{c}\text { County location } \\
\text { (abbreviation explained } \\
\text { in table 7) }\end{array}$} & \multirow[b]{2}{*}{ Stream name } & \multicolumn{2}{|c|}{ Estimated median flows $\left(\mathrm{ft}^{3} / \mathrm{s}\right)$} \\
\hline & & & & KSA analysis & AAH analysis \\
\hline 541 & 1026001127 & NT & Game Creek & 0 & 0 \\
\hline 542 & 1026001128 & NT, PL & Cactus Creek & .01 & 0 \\
\hline 543 & 102600115 & PL & North Fork Solomon River & 26.0 & 8.40 \\
\hline 544 & 102600116 & NT, PL & Crooked Creek & .03 & 0 \\
\hline 545 & 102600117 & NT, PL & North Fork Solomon River & 16.8 & 5.27 \\
\hline 546 & 102600118 & NT & Big Timber Creek & .01 & 0 \\
\hline 547 & 102600119 & NT & North Fork Solomon River & 12.1 & 3.71 \\
\hline 548 & 1026001210 & SM & Beaver Creek & 4.47 & 3.37 \\
\hline 549 & 1026001211 & SM & East Branch Beaver Creek & .72 & .48 \\
\hline 550 & 1026001212 & SM & Beaver Creek & 2.36 & 1.73 \\
\hline 551 & 1026001213 & SM & Middle Beaver Creek & 1.02 & .72 \\
\hline 552 & 1026001214 & SM & West Beaver Creek & .44 & .26 \\
\hline 553 & 1026001215 & SM & North Fork Solomon River & 66.8 & 28.4 \\
\hline 554 & 1026001216 & SM & Cedar Creek & 4.08 & 3.02 \\
\hline 555 & 1026001217 & SM & East Cedar Creek & .39 & .20 \\
\hline 556 & 1026001218 & SM & Cedar Creek & 2.54 & 1.84 \\
\hline 557 & 1026001219 & PL, SM & Middle Cedar Creek & .83 & .54 \\
\hline 558 & 102600122 & $\mathrm{MC}$ & Oak Creek & 8.69 & 6.79 \\
\hline 559 & 1026001220 & PL, SM & West Cedar Creek & .57 & .33 \\
\hline 560 & 1026001221 & SM & North Fork Solomon River & 59.9 & 25.4 \\
\hline 561 & 1026001222 & PL, SM & North Fork Solomon River & 56.6 & 24.0 \\
\hline 562 & 1026001223 & PL & Deer Creek & 6.41 & 5.16 \\
\hline 563 & 1026001224 & PL & Plum Creek & .30 & .13 \\
\hline 564 & 1026001225 & PL & Deer Creek & 4.92 & 3.99 \\
\hline 565 & 1026001226 & PL & Big Creek & .03 & 0 \\
\hline 566 & 1026001227 & PL & Deer Creek & 3.74 & 3.08 \\
\hline 567 & 1026001228 & PL & Spring Creek & 2.68 & 2.26 \\
\hline 568 & 1026001229 & PL & Deer Creek & 2.68 & 2.26 \\
\hline 569 & 102600123 & JW, MC & Little Oak Creek & 1.22 & .92 \\
\hline 570 & 1026001230 & PL & Plotner Creek & 0 & 0 \\
\hline 571 & 1026001231 & NT, PL & Deer Creek & 1.64 & 1.46 \\
\hline 572 & 1026001233 & PL, RO, SM & Medicine Creek & .22 & .07 \\
\hline 573 & 1026001234 & PL & Boughton Creek & 0 & 0 \\
\hline 574 & 1026001237 & SM & East Middle Cedar Creek & 0 & 0 \\
\hline
\end{tabular}


Table 6. Stream segments on the 1999 Kansas Surface Water Register, CUSEGA numbers, stream names, and estimated median flows at downstream end of CUSEGA segments using the most-recent 10 years of record (KSA) and all-available hydrology (AAH) analyses. - Continued

[Estimated median flows are rounded to two or three significant figures. Reporting estimated median values to three signficant figures (median greater than or equal to $1 \mathrm{ft}^{3} / \mathrm{s}$ ) or two significant figures (median less than $1 \mathrm{ft}^{3} / \mathrm{s}$ ) was done to conform with the intent of KSA $82 \mathrm{a}-2001$ et. seq. $\mathrm{ft}^{3} / \mathrm{s}$, cubic feet per second; KSA, Kansas Statute 82a-2001 analysis; AAH, all-available hydrology analysis]

\begin{tabular}{|c|c|c|c|c|c|}
\hline \multirow{2}{*}{$\begin{array}{c}\text { Stream } \\
\text { segment } \\
\text { number } \\
\text { (figs. 9-113) }\end{array}$} & \multirow[b]{2}{*}{ CUSEGA number } & \multirow{2}{*}{$\begin{array}{c}\text { County location } \\
\text { (abbreviation explained } \\
\text { in table 7) }\end{array}$} & \multirow[b]{2}{*}{ Stream name } & \multicolumn{2}{|c|}{ Estimated median flows $\left(\mathrm{ft}^{3} / \mathrm{s}\right)$} \\
\hline & & & & KSA analysis & $\mathrm{AAH}$ analysis \\
\hline 575 & 1026001238 & PL & Starvation Creek & 0.03 & 0.06 \\
\hline 576 & 1026001239 & SM & West Oak Creek & .42 & .27 \\
\hline 577 & 102600124 & JW, OB, SM, MC & Oak Creek & 6.47 & 5.03 \\
\hline 578 & 1026001240 & SM & East Oak Creek & 1.16 & .89 \\
\hline 579 & 1026001241 & $\mathrm{OB}, \mathrm{SM}$ & Glen Rock Creek & 0 & 0 \\
\hline 580 & 1026001242 & SM & Dry Creek & 0 & 0 \\
\hline 581 & 1026001243 & SM & Buck Creek & 0 & 0 \\
\hline 582 & 1026001244 & $\mathrm{OB}, \mathrm{SM}$ & Lawrence Creek & .66 & .42 \\
\hline 583 & 1026001245 & $\mathrm{OB}, \mathrm{SM}$ & Lindley Creek & 0 & 0 \\
\hline 584 & 102600125 & $\mathrm{MC}, \mathrm{OB}$ & North Fork Solomon River & 87.9 & 36.3 \\
\hline 585 & 102600126 & OB, SM & Twelvemile Creek & .95 & .66 \\
\hline 586 & 102600127 & $\mathrm{OB}, \mathrm{SM}$ & North Fork Solomon River & 8.0 & 34.0 \\
\hline 587 & 102600128 & SM & Spring Creek & .77 & .51 \\
\hline 588 & 102600129 & SM & North Fork Solomon River & 73.1 & 31.1 \\
\hline 589 & 1026001310 & $\mathrm{GH}$ & South Fork Solomon River & 12.3 & 4.78 \\
\hline 590 & 1026001311 & $\mathrm{GH}$ & Sand Creek & .02 & .01 \\
\hline 591 & 1026001312 & GH & South Fork Solomon River & 1.7 & 4.09 \\
\hline 592 & 1026001313 & $\mathrm{GH}, \mathrm{SD}$ & Antelope Creek & .02 & .01 \\
\hline 593 & 1026001314 & $\mathrm{GH}, \mathrm{SD}$ & South Fork Solomon River & 7.17 & 2.54 \\
\hline 594 & 1026001315 & $\mathrm{SD}, \mathrm{TH}$ & Sand Creek & .38 & .11 \\
\hline 595 & 1026001316 & $\mathrm{SD}, \mathrm{SH}, \mathrm{TH}$ & South Fork Solomon River & 1.95 & .59 \\
\hline 596 & 1026001317 & $\mathrm{GH}$ & Brush Creek & .33 & .09 \\
\hline 597 & 1026001318 & GH & Wildhorse Creek & .04 & .01 \\
\hline 598 & 1026001319 & SD & Foster Creek & 0 & 0 \\
\hline 599 & 1026001320 & SD & Storer Creek & 0 & 0 \\
\hline 600 & 1026001321 & GH & Youngs Creek & .01 & 0 \\
\hline 601 & 1026001322 & $\mathrm{GH}$ & Rock Creek & .01 & 0 \\
\hline 602 & 1026001323 & SD & South Martin Creek & .02 & .01 \\
\hline 603 & 1026001324 & GH & Jackson Branch & .03 & .01 \\
\hline 604 & 1026001325 & RO & Slate Creek & 0 & 0 \\
\hline 605 & 1026001326 & GH & Skunk Creek & .01 & 0 \\
\hline 606 & 1026001327 & GH & Sand Creek & .08 & .02 \\
\hline 607 & 102600134 & $\mathrm{GH}, \mathrm{RO}$ & South Fork Solomon River & 35.4 & 15.1 \\
\hline
\end{tabular}


Table 6. Stream segments on the 1999 Kansas Surface Water Register, CUSEGA numbers, stream names, and estimated median flows at downstream end of CUSEGA segments using the most-recent 10 years of record (KSA) and all-available hydrology (AAH) analyses. - Continued

[Estimated median flows are rounded to two or three significant figures. Reporting estimated median values to three signficant figures (median greater than or equal to $1 \mathrm{ft}^{3} / \mathrm{s}$ ) or two significant figures (median less than $1 \mathrm{ft}^{3} / \mathrm{s}$ ) was done to conform with the intent of KSA 82a-2001 et. seq. $\mathrm{ft}^{3} / \mathrm{s}$, cubic feet per second; KSA, Kansas Statute 82a-2001 analysis; AAH, all-available hydrology analysis]

\begin{tabular}{|c|c|c|c|c|c|}
\hline \multirow{2}{*}{$\begin{array}{c}\text { Stream } \\
\text { segment } \\
\text { number } \\
\text { (figs. 9-113) }\end{array}$} & \multirow[b]{2}{*}{ CUSEGA number } & \multirow{2}{*}{$\begin{array}{c}\text { County location } \\
\text { (abbreviation explained } \\
\text { in table 7) }\end{array}$} & \multirow[b]{2}{*}{ Stream name } & \multicolumn{2}{|c|}{ Estimated median flows $\left(\mathrm{ft}^{3} / \mathrm{s}\right)$} \\
\hline & & & & KSA analysis & AAH analysis \\
\hline 608 & 102600135 & $\overline{\mathrm{GH}}$ & Spring Creek & 0.19 & 0.05 \\
\hline 609 & 102600136 & GH & South Fork Solomon River & 27.8 & 11.4 \\
\hline 610 & 102600137 & GH & South Fork Solomon River & 21.8 & 8.83 \\
\hline 611 & 102600138 & GH & Coon Creek & .06 & .02 \\
\hline 612 & 10260013817 & RO & Spring Creek & 0 & 0 \\
\hline 613 & 102600139 & GH & South Fork Solomon River & 17.6 & 7.03 \\
\hline 614 & 102600141 & $\mathrm{MC}, \mathrm{OB}$ & South Fork Solomon River & 61.7 & 23.0 \\
\hline 615 & 1026001410 & RO & South Fork Solomon River & 2.79 & .67 \\
\hline 616 & 1026001413 & RO & Lost Creek & 0 & 0 \\
\hline 617 & 1026001414 & RO & Boxelder Creek & 0 & 0 \\
\hline 618 & 1026001415 & RO & Elm Creek & 0 & 0 \\
\hline 619 & 1026001416 & RO & Medicine Creek & .77 & .49 \\
\hline 620 & 1026001417 & OB, RO & Medicine Creek & .63 & .39 \\
\hline 621 & 1026001418 & OB & Kill Creek & 1.48 & 1.14 \\
\hline 622 & 1026001419 & OB & Covert Creek & 2.18 & 1.62 \\
\hline 623 & 102600142 & OB & South Fork Solomon River & 59.3 & 22.2 \\
\hline 624 & 1026001420 & OB & Twin Creek & 3.20 & 2.41 \\
\hline 625 & 1026001421 & $\mathrm{MC}, \mathrm{OB}$ & Carr Creek & 2.26 & 1.71 \\
\hline 626 & 1026001422 & RO & Ash Creek & 0 & 0 \\
\hline 627 & 1026001423 & RO & Cocklebur Creek & 0 & 0 \\
\hline 628 & 1026001424 & RO & Robbers Roost Creek & 0 & 0 \\
\hline 629 & 1026001425 & RO & Jim Creek & 0 & 0 \\
\hline 630 & 1026001426 & OB, RO & Lucky Creek & 0 & 0 \\
\hline 631 & 1026001427 & $\mathrm{OB}$ & Crooked Creek & 0 & 0 \\
\hline 632 & 1026001428 & $\mathrm{OB}$ & East Kill Creek & .37 & .22 \\
\hline 633 & 1026001429 & $\mathrm{OB}$ & East Twin Creek & .57 & .39 \\
\hline 634 & 102600143 & OB & South Fork Solomon River & 56.0 & 21.0 \\
\hline 635 & 10260014363 & RO & Dibble Creek & 0 & 0 \\
\hline 636 & 10260014395 & RO & Sand Creek & 0 & 0 \\
\hline 637 & 102600144 & OB & South Fork Solomon River & 45.6 & 16.7 \\
\hline 638 & 102600145 & $\mathrm{OB}$ & South Fork Solomon River & 36.1 & 12.7 \\
\hline 639 & 102600146 & OB, RO & South Fork Solomon River & 30.5 & 10.4 \\
\hline 640 & 102600147 & RO & South Fork Solomon River & 16.3 & 4.98 \\
\hline 641 & 10260014798 & RO & South Fork Solomon River & .68 & 0 \\
\hline 642 & 102600148 & RO & South Fork Solomon River & 11.8 & 3.56 \\
\hline
\end{tabular}


Table 6. Stream segments on the 1999 Kansas Surface Water Register, CUSEGA numbers, stream names, and estimated median flows at downstream end of CUSEGA segments using the most-recent 10 years of record (KSA) and all-available hydrology (AAH) analyses. - Continued

[Estimated median flows are rounded to two or three significant figures. Reporting estimated median values to three signficant figures (median greater than or equal to $1 \mathrm{ft}^{3} / \mathrm{s}$ ) or two significant figures (median less than $1 \mathrm{ft}^{3} / \mathrm{s}$ ) was done to conform with the intent of KSA $82 \mathrm{a}-2001$ et. seq. $\mathrm{ft}^{3} / \mathrm{s}$, cubic feet per second; KSA, Kansas Statute 82a-2001 analysis; AAH, all-available hydrology analysis]

\begin{tabular}{|c|c|c|c|c|c|}
\hline \multirow{2}{*}{$\begin{array}{c}\text { Stream } \\
\text { segment } \\
\text { number } \\
\text { (figs. 9-113) }\end{array}$} & \multirow[b]{2}{*}{ CUSEGA number } & \multirow{2}{*}{$\begin{array}{c}\text { County location } \\
\text { (abbreviation explained } \\
\text { in table 7) }\end{array}$} & \multirow[b]{2}{*}{ Stream name } & \multicolumn{2}{|c|}{ Estimated median flows $\left(\mathrm{ft}^{3} / \mathrm{s}\right)$} \\
\hline & & & & KSA analysis & AAH analysis \\
\hline 643 & 102600149 & $\mathrm{RO}$ & South Fork Solomon River & 7.90 & 2.31 \\
\hline 644 & 102600151 & OT, SA & Solomon River & 321 & 174 \\
\hline 645 & 1026001510 & $\mathrm{CD}, \mathrm{OT}$ & Pipe Creek & 4.40 & 3.56 \\
\hline 646 & 1026001511 & $\mathrm{CD}, \mathrm{OT}$ & West Pipe Creek & 2.63 & 2.05 \\
\hline 647 & 1026001512 & $\mathrm{CD}, \mathrm{MC}, \mathrm{OT}$ & Solomon River & 210 & 185 \\
\hline 648 & 1026001513 & JW, MC & Plum Creek & 2.67 & 2.04 \\
\hline 649 & 1026001514 & MC & Solomon River & 169 & 125 \\
\hline 650 & 1026001515 & JW, MC & Brown Creek & 2.25 & 1.75 \\
\hline 651 & 1026001516 & $\mathrm{MC}$ & Solomon River & 154 & 70.8 \\
\hline 652 & 1026001518 & JW, MC & Limestone Creek & 8.55 & 6.76 \\
\hline 653 & 1026001519 & JW & Limestone Creek & 3.08 & 2.46 \\
\hline 654 & 102600152 & OT & Coal Creek & 8.62 & 7.35 \\
\hline 655 & 1026001520 & JW & Limestone Creek & 3.59 & 2.82 \\
\hline 656 & 1026001521 & JW & Middle Limestone Creek & .83 & .65 \\
\hline 657 & 1026001522 & JW & West Limestone Creek & 2.05 & 1.61 \\
\hline 658 & 1026001523 & $\mathrm{MC}$ & Solomon River & 144 & 52.6 \\
\hline 659 & 1026001524 & JW, MC & Granite Creek & .21 & .11 \\
\hline 660 & 1026001526 & $\mathrm{MC}$ & Walnut Creek & .50 & .33 \\
\hline 661 & 1026001527 & OT & Salt Creek & 21.9 & 14.3 \\
\hline 662 & 1026001528 & $\mathrm{MC}, \mathrm{OT}$ & Cow Creek & 2.07 & 1.62 \\
\hline 663 & 1026001529 & $\mathrm{LC}, \mathrm{OT}$ & Salt Creek & 15.3 & 9.98 \\
\hline 664 & 102600153 & OT & Solomon River & 303 & 176 \\
\hline 665 & 1026001530 & $\mathrm{LC}, \mathrm{MC}$ & Salt Creek & 5.98 & 4.22 \\
\hline 666 & 1026001531 & LC & Rattlesnake Creek & 3.99 & 2.96 \\
\hline 667 & 1026001532 & $\mathrm{LC}$ & Rattlesnake Creek & 1.59 & 1.19 \\
\hline 668 & 1026001533 & $\mathrm{LC}$ & Battle Creek & 1.90 & 1.45 \\
\hline 669 & 1026001534 & $\mathrm{MC}$ & Solomon River tributary & 0 & 0 \\
\hline 670 & 1026001535 & JW, MC & Disappointment Creek & 0 & 0 \\
\hline 671 & 1026001536 & JW, MC & Mulberry Creek & .37 & .25 \\
\hline 672 & 1026001537 & $\mathrm{MC}$ & Plum Creek tributary & .83 & .62 \\
\hline 673 & 1026001538 & $\mathrm{MC}$ & Mill Creek & 0 & 0 \\
\hline 674 & 1026001539 & $\mathrm{MC}$ & Turkey Creek & 0 & 0 \\
\hline 675 & 102600154 & OT & Sand Creek & 4.34 & 3.80 \\
\hline
\end{tabular}


Table 6. Stream segments on the 1999 Kansas Surface Water Register, CUSEGA numbers, stream names, and estimated median flows at downstream end of CUSEGA segments using the most-recent 10 years of record (KSA) and all-available hydrology (AAH) analyses.-Continued

[Estimated median flows are rounded to two or three significant figures. Reporting estimated median values to three signficant figures (median greater than or equal to $1 \mathrm{ft}^{3} / \mathrm{s}$ ) or two significant figures (median less than $1 \mathrm{ft}^{3} / \mathrm{s}$ ) was done to conform with the intent of KSA $82 \mathrm{a}-2001$ et. seq. $\mathrm{ft}^{3} / \mathrm{s}$, cubic feet per second; KSA, Kansas Statute 82a-2001 analysis; AAH, all-available hydrology analysis]

\begin{tabular}{|c|c|c|c|c|c|}
\hline \multirow{2}{*}{$\begin{array}{c}\text { Stream } \\
\text { segment } \\
\text { number } \\
\text { (figs. 9-113) }\end{array}$} & \multirow[b]{2}{*}{ CUSEGA number } & \multirow{2}{*}{$\begin{array}{c}\text { County location } \\
\text { (abbreviation explained } \\
\text { in table 7) }\end{array}$} & \multirow[b]{2}{*}{ Stream name } & \multicolumn{2}{|c|}{ Estimated median flows $\left(\mathrm{ft}^{3} / \mathrm{s}\right)$} \\
\hline & & & & KSA analysis & AAH analysis \\
\hline 676 & 1026001540 & $\mathrm{MC}$ & Unnamed tributary, Mitchell 1 & 0 & 0 \\
\hline 677 & 1026001541 & $\mathrm{MC}$ & Leban Creek & .41 & .26 \\
\hline 678 & 1026001542 & $\mathrm{MC}$ & Unnamed tributary, Mitchell 2 & 0 & 0 \\
\hline 679 & 1026001543 & $\mathrm{MC}$ & Antelope Creek & 0 & 0 \\
\hline 680 & 1026001544 & $\mathrm{MC}$ & Rock Creek & .57 & .40 \\
\hline 681 & 1026001545 & $\mathrm{MC}$ & Fifth Creek & .75 & .55 \\
\hline 682 & 1026001546 & MC & Unnamed tributary, Mitchell 3 & .65 & .49 \\
\hline 683 & 1026001547 & $\mathrm{LC}$ & West Elkhorn Creek & 1.47 & 1.21 \\
\hline 684 & 1026001548 & $\mathrm{CD}$ & Cris Creek & 1.61 & 1.28 \\
\hline 685 & 1026001549 & $\mathrm{CD}, \mathrm{OT}$ & Mortimer Creek & .87 & .67 \\
\hline 686 & 102600155 & OT & Solomon River & 293 & 177 \\
\hline 687 & 1026001550 & $\mathrm{CD}, \mathrm{OT}$ & Eacker Creek & 1.44 & 1.12 \\
\hline 688 & 1026001551 & $\mathrm{CD}, \mathrm{MC}$ & Second Creek & .85 & .69 \\
\hline 689 & 1026001552 & OT & Solomon River tributary & .04 & 0 \\
\hline 690 & 1026001553 & LC, OT & Spring Creek & 2.64 & 2.20 \\
\hline 691 & 1026001554 & $\mathrm{LC}, \mathrm{MC}$ & Second Creek & .88 & .67 \\
\hline 692 & 1026001555 & OT & Salt Creek tributary & .84 & .71 \\
\hline 693 & 1026001556 & OT & Lost Creek & 1.30 & 1.03 \\
\hline 694 & 1026001557 & OT & Battle Creek & 1.31 & 1.12 \\
\hline 695 & 1026001558 & OT & Antelope Creek & .83 & .74 \\
\hline 696 & 1026001559 & JW & Elm Creek & 1.32 & 1.08 \\
\hline 697 & 102600156 & OT & Solomon River & 232 & 183 \\
\hline 698 & 102600157 & OT & Lindsey Creek & 2.53 & 1.98 \\
\hline 699 & 102600158 & OT & Solomon River & 226 & 183 \\
\hline 700 & 102600159 & OT & Pipe Creek & 8.11 & 6.37 \\
\hline 701 & 102701011 & PT, RL & Kansas River & 1,780 & 1,420 \\
\hline 702 & 1027010110 & GE & Humbolt Creek & 6.15 & 4.89 \\
\hline 703 & 1027010111 & GE, RL & McDowell Creek & 10.4 & 8.34 \\
\hline 704 & 1027010112 & RL & Silver Creek & .79 & .69 \\
\hline 705 & 1027010113 & RL & Little Arkansas Creek & 1.39 & 1.11 \\
\hline 706 & 1027010114 & RL & Kitten Creek & 1.23 & 1.12 \\
\hline 707 & 1027010115 & RL & Threemile Creek & 2.87 & 2.52 \\
\hline 708 & 1027010116 & RL & Little Kitten Creek & .62 & .65 \\
\hline 709 & 1027010117 & GE, RL & Swede Creek & 2.15 & 1.80 \\
\hline 710 & 1027010118 & GE, MR & Davis Creek & 2.61 & 2.07 \\
\hline
\end{tabular}


Table 6. Stream segments on the 1999 Kansas Surface Water Register, CUSEGA numbers, stream names, and estimated median flows at downstream end of CUSEGA segments using the most-recent 10 years of record (KSA) and all-available hydrology (AAH) analyses. - Continued

[Estimated median flows are rounded to two or three significant figures. Reporting estimated median values to three signficant figures (median greater than or equal to $1 \mathrm{ft}^{3} / \mathrm{s}$ ) or two significant figures (median less than $1 \mathrm{ft}^{3} / \mathrm{s}$ ) was done to conform with the intent of KSA $82 \mathrm{a}-2001$ et. seq. $\mathrm{ft}^{3} / \mathrm{s}$, cubic feet per second; KSA, Kansas Statute 82a-2001 analysis; AAH, all-available hydrology analysis]

\begin{tabular}{|c|c|c|c|c|c|}
\hline \multirow{2}{*}{$\begin{array}{c}\text { Stream } \\
\text { segment } \\
\text { number } \\
\text { (figs. 9-113) }\end{array}$} & \multirow[b]{2}{*}{ CUSEGA number } & \multirow{2}{*}{$\begin{array}{c}\text { County location } \\
\text { (abbreviation explained } \\
\text { in table 7) }\end{array}$} & \multirow[b]{2}{*}{ Stream name } & \multicolumn{2}{|c|}{ Estimated median flows $\left(\mathrm{ft}^{3} / \mathrm{s}\right)$} \\
\hline & & & & KSA analysis & $\mathrm{AAH}$ analysis \\
\hline 711 & 1027010119 & GE & Dry Creek & 2.93 & 2.34 \\
\hline 712 & 102701012 & RL & Wildcat Creek & 11.0 & 8.87 \\
\hline 713 & 1027010120 & MR & Mulberry Creek & .71 & .58 \\
\hline 714 & 1027010121 & MR & Ralls Creek & .87 & .68 \\
\hline 715 & 102701013 & RL & Kansas River & 1,760 & 1,410 \\
\hline 716 & 102701014 & RL & Kansas River & 1,740 & 1,390 \\
\hline 717 & 102701015 & RL & Sevenmile Creek & 5.13 & 4.40 \\
\hline 718 & 102701016 & RL & Kansas River & 1,740 & 1,390 \\
\hline 719 & 102701017 & GE, RL & Kansas River & 1,680 & 1,350 \\
\hline 720 & 102701018 & GE, RL & Clarks Creek & 23.6 & 18.7 \\
\hline 721 & 102701019 & GE, MR & Clarks Creek & 16.4 & 12.9 \\
\hline 722 & 102701021 & $\mathrm{DG}, \mathrm{JF}, \mathrm{SN}$ & Kansas River & 4,030 & 3,200 \\
\hline 723 & 1027010210 & $\mathrm{SN}$ & Kansas River & 3,820 & 3,020 \\
\hline 724 & 10270102100 & $\mathrm{SN}, \mathrm{WB}$ & Vassar Creek & 1.40 & 1.22 \\
\hline 725 & 10270102101 & SN, WB & Post Creek & 1.48 & 1.33 \\
\hline 726 & 10270102102 & $\mathrm{SN}$ & Blacksmith Creek & 1.56 & 1.39 \\
\hline 727 & 10270102103 & $\mathrm{JF}$ & Elm Creek & 2.10 & 2.08 \\
\hline 728 & 10270102104 & $\mathrm{JF}, \mathrm{SN}$ & Whetstone Creek & 1.81 & 1.84 \\
\hline 729 & 10270102105 & DG, JF, SN & Spring Creek & 3.92 & 3.88 \\
\hline 730 & 10270102106 & $\mathrm{SN}$ & South Branch Shunganunga Creek & .81 & .69 \\
\hline 731 & 10270102107 & SN & Tecumseh Creek & .89 & .94 \\
\hline 732 & 1027010211 & SN, WB & Kansas River & 3,790 & 3,090 \\
\hline 733 & 1027010212 & JA, PT, SN & Cross Creek & 19.7 & 16.3 \\
\hline 734 & 102701021223 & PT, WB & Riley Creek & 3.79 & 3.54 \\
\hline 735 & 102701021229 & PT & Deep Creek & 2.44 & 2.34 \\
\hline 736 & 1027010213 & SN, WB & Kansas River & 3,740 & 3,210 \\
\hline 737 & 102701021365 & SN & Indian Creek & 1.98 & 1.79 \\
\hline 738 & 102701021367 & $\mathrm{SN}$ & Unnamed tributary, Shawnee 2 & 0 & 0 \\
\hline 739 & 102701021389 & SN & Unnamed tributary, Shawnee 1 & .27 & .49 \\
\hline 740 & 1027010214 & PT, SN, WB & Kansas River & 3,650 & 3,440 \\
\hline 741 & 1027010215 & PT & Vermillion Creek & 65.7 & 50.5 \\
\hline 742 & 1027010216 & PT & Vermillion Creek & 34.7 & 23.3 \\
\hline 743 & 1027010217 & PT & Vermillion Creek & 27.7 & 17.6 \\
\hline
\end{tabular}


Table 6. Stream segments on the 1999 Kansas Surface Water Register, CUSEGA numbers, stream names, and estimated median flows at downstream end of CUSEGA segments using the most-recent 10 years of record (KSA) and all-available hydrology (AAH) analyses. - Continued

[Estimated median flows are rounded to two or three significant figures. Reporting estimated median values to three signficant figures (median greater than or equal to $1 \mathrm{ft}^{3} / \mathrm{s}$ ) or two significant figures (median less than $1 \mathrm{ft}^{3} / \mathrm{s}$ ) was done to conform with the intent of KSA 82a-2001 et. seq. $\mathrm{ft}^{3} / \mathrm{s}$, cubic feet per second; KSA, Kansas Statute 82a-2001 analysis; AAH, all-available hydrology analysis]

\begin{tabular}{|c|c|c|c|c|c|}
\hline \multirow{2}{*}{$\begin{array}{c}\text { Stream } \\
\text { segment } \\
\text { number } \\
\text { (figs. 9-113) }\end{array}$} & \multirow[b]{2}{*}{ CUSEGA number } & \multirow{2}{*}{$\begin{array}{c}\text { County location } \\
\text { (abbreviation explained } \\
\text { in table 7) }\end{array}$} & \multirow[b]{2}{*}{ Stream name } & \multicolumn{2}{|c|}{ Estimated median flows $\left(\mathrm{ft}^{3} / \mathrm{s}\right)$} \\
\hline & & & & KSA analysis & AAH analysis \\
\hline 744 & 1027010218 & $\mathrm{NM}, \mathrm{PT}$ & Vermillion Creek & 10.5 & 7.49 \\
\hline 745 & 1027010219 & NM, PT & French Creek & 5.71 & 4.24 \\
\hline 746 & 102701022 & JA, SN, JF & Muddy Creek & 11.2 & 9.67 \\
\hline 747 & 1027010220 & PT & Indian Creek & 3.38 & 2.77 \\
\hline 748 & 1027010221 & PT & Rock Creek & 27.7 & 23.6 \\
\hline 749 & 1027010222 & PT & East Fork Rock Creek & 8.33 & 6.49 \\
\hline 750 & 1027010223 & PT & Pleasant Hill Run & 8.03 & 6.54 \\
\hline 751 & 1027010224 & PT, WB & Kansas River & 3,470 & 2,720 \\
\hline 752 & 1027010225 & PT, RL, WB & Kansas River & 3,450 & 2,700 \\
\hline 753 & 1027010226 & GE, RL, WB & Deep Creek & 9.55 & 7.79 \\
\hline 754 & 1027010227 & WB & Mill Creek & 69.5 & 64.8 \\
\hline 755 & 1027010228 & WB & West Branch Mill Creek & 18.9 & 16.7 \\
\hline 756 & 1027010229 & GE, MR, WB & West Branch Mill Creek & 8.18 & 7.01 \\
\hline 757 & 102701023 & $\mathrm{JF}, \mathrm{SN}$ & Kansas River & 3,990 & 3,160 \\
\hline 758 & 1027010230 & WB & Illinois Creek & 4.77 & 4.00 \\
\hline 759 & 1027010231 & WB & East Branch Mill Creek & 14.9 & 12.9 \\
\hline 760 & 1027010232 & WB & South Branch Mill Creek & 5.09 & 4.36 \\
\hline 761 & 1027010233 & WB & East Branch Mill Creek & 8.20 & 7.02 \\
\hline 762 & 1027010234 & SN & Mission Creek & 12.7 & 10.5 \\
\hline 763 & 1027010235 & SN, WB & Ross Creek & .50 & .55 \\
\hline 764 & 1027010236 & $\mathrm{SN}, \mathrm{WB}$ & Mission Creek & 8.18 & 6.84 \\
\hline 765 & 1027010237 & WB & Mission Creek & 5.39 & 4.56 \\
\hline 766 & 1027010238 & WB & South Branch Mission Creek & 1.92 & 1.77 \\
\hline 767 & 1027010239 & SN & Shunganunga Creek & 6.13 & 5.13 \\
\hline 768 & 10270102394 & SN & Stinson Creek & .32 & .44 \\
\hline 769 & 102701024 & $\mathrm{JF}, \mathrm{SN}$ & Kansas River & 3,950 & 3,130 \\
\hline 770 & 1027010240 & SN & Shunganunga Creek & 3.71 & 3.08 \\
\hline 771 & 1027010241 & SN & Deer Creek & .91 & .87 \\
\hline 772 & 1027010242 & NM & Mulberry Creek & .51 & .44 \\
\hline 773 & 1027010243 & PT & Hise Creek & 2.63 & 2.18 \\
\hline 774 & 1027010244 & MS, PT & Mud Creek & .22 & .21 \\
\hline 775 & 1027010245 & PT & Cow Creek & .79 & .77 \\
\hline 776 & 1027010246 & NM, PT & Coal Creek & 2.70 & 2.13 \\
\hline 777 & 1027010247 & MS, NM & Gilson Creek & .33 & .28 \\
\hline 778 & 1027010248 & PT & Spring Creek & 1.35 & 1.14 \\
\hline
\end{tabular}




\section{Estimates of Median Flows for Streams on the 1999 Kansas Surface Water Register}

Table 6. Stream segments on the 1999 Kansas Surface Water Register, CUSEGA numbers, stream names, and estimated median flows at downstream end of CUSEGA segments using the most-recent 10 years of record (KSA) and all-available hydrology (AAH) analyses.-Continued

[Estimated median flows are rounded to two or three significant figures. Reporting estimated median values to three signficant figures (median greater than or equal to $1 \mathrm{ft}^{3} / \mathrm{s}$ ) or two significant figures (median less than $1 \mathrm{ft}^{3} / \mathrm{s}$ ) was done to conform with the intent of KSA 82a-2001 et. seq. $\mathrm{ft}^{3} / \mathrm{s}$, cubic feet per second; KSA, Kansas Statute 82a-2001 analysis; AAH, all-available hydrology analysis]

\begin{tabular}{|c|c|c|c|c|c|}
\hline \multirow{2}{*}{$\begin{array}{l}\text { Stream } \\
\text { segment } \\
\text { number } \\
\text { (figs. 9-113) }\end{array}$} & \multirow[b]{2}{*}{ CUSEGA number } & \multirow{2}{*}{$\begin{array}{c}\text { County location } \\
\text { (abbreviation explained } \\
\text { in table 7) }\end{array}$} & \multirow[b]{2}{*}{ Stream name } & \multicolumn{2}{|c|}{ Estimated median flows $\left(\mathrm{ft}^{3} / \mathrm{s}\right)$} \\
\hline & & & & KSA analysis & AAH analysis \\
\hline 779 & 1027010249 & JA, NM, PT & Wolf Creek & 1.01 & 0.84 \\
\hline 780 & 102701025 & SN & Soldier Creek & 49.6 & 35.7 \\
\hline 781 & 1027010250 & PT & Wilson Creek & 2.42 & 1.91 \\
\hline 782 & 1027010251 & PT & Darnells Creek & .84 & .73 \\
\hline 783 & 1027010252 & PT & Jim Creek & 3.23 & 2.66 \\
\hline 784 & 1027010253 & PT & Adams Creek & 2.43 & 1.94 \\
\hline 785 & 1027010254 & PT & Spring Creek & .50 & .50 \\
\hline 786 & 1027010255 & PT & Bartlett Creek & 2.53 & 2.09 \\
\hline 787 & 1027010256 & PT & Mud Creek & 2.80 & 2.18 \\
\hline 788 & 1027010257 & PT & Brush Creek & 2.22 & 1.76 \\
\hline 789 & 1027010258 & PT & Elm Slough & 5.96 & 7.06 \\
\hline 790 & 1027010259 & PT & Pomeroy Creek & .50 & .55 \\
\hline 791 & 102701026 & SN & Little Soldier Creek & 8.54 & 6.78 \\
\hline 792 & 1027010260 & PT & Lost Creek & 4.55 & 4.19 \\
\hline 793 & 1027010261 & JA, PT & Little Cross Creek & 2.09 & 1.75 \\
\hline 794 & 1027010262 & JA & Illinois Creek & .41 & .44 \\
\hline 795 & 1027010263 & $\mathrm{PT}, \mathrm{SN}$ & Bourbonais Creek & 4.35 & 4.32 \\
\hline 796 & 1027010264 & PT & Blackjack Creek & 4.06 & 5.22 \\
\hline 797 & 1027010265 & PT & Sand Creek & 4.41 & 5.05 \\
\hline 798 & 1027010266 & RL, WB & Emmons Creek & 1.09 & .97 \\
\hline 799 & 1027010267 & PT, WB, RL & Antelope Creek & 3.63 & 3.46 \\
\hline 800 & 1027010268 & WB & Wells Creek & 2.17 & 1.94 \\
\hline 801 & 1027010269 & PT & Doyle Creek & 6.21 & 5.81 \\
\hline 802 & 10270102693 & WB & Unnamed tributary, Wabaunsee 1 & 2.41 & 2.12 \\
\hline 803 & 102701027 & JA, SN & Little Soldier Creek & 6.62 & 5.28 \\
\hline 804 & 1027010271 & PT, WB & Turkey Creek & 3.19 & 2.89 \\
\hline 805 & 1027010272 & RL & East Branch Deep Creek & 1.71 & 1.53 \\
\hline 806 & 1027010273 & RL, WB & Hendricks Creek & 2.26 & 2.02 \\
\hline 807 & 1027010274 & WB & Pretty Creek & 1.07 & 1.03 \\
\hline 808 & 1027010275 & WB & Paw Paw Creek & 1.22 & 1.15 \\
\hline 809 & 1027010276 & WB & Spring Creek & .33 & .43 \\
\hline 810 & 1027010277 & WB & Mulberry Creek & 1.00 & .83 \\
\hline 811 & 1027010278 & WB & Dog Creek & 1.73 & 1.61 \\
\hline
\end{tabular}


Table 6. Stream segments on the 1999 Kansas Surface Water Register, CUSEGA numbers, stream names, and estimated median flows at downstream end of CUSEGA segments using the most-recent 10 years of record (KSA) and all-available hydrology (AAH) analyses. - Continued

[Estimated median flows are rounded to two or three significant figures. Reporting estimated median values to three signficant figures (median greater than or equal to $1 \mathrm{ft}^{3} / \mathrm{s}$ ) or two significant figures (median less than $1 \mathrm{ft}^{3} / \mathrm{s}$ ) was done to conform with the intent of KSA $82 \mathrm{a}-2001$ et. seq. $\mathrm{ft}^{3} / \mathrm{s}$, cubic feet per second; KSA, Kansas Statute 82a-2001 analysis; AAH, all-available hydrology analysis]

\begin{tabular}{|c|c|c|c|c|c|}
\hline \multirow{2}{*}{$\begin{array}{c}\text { Stream } \\
\text { segment } \\
\text { number } \\
\text { (figs. 9-113) }\end{array}$} & \multirow[b]{2}{*}{ CUSEGA number } & \multirow{2}{*}{$\begin{array}{c}\text { County location } \\
\text { (abbreviation explained } \\
\text { in table 7) }\end{array}$} & \multirow[b]{2}{*}{ Stream name } & \multicolumn{2}{|c|}{ Estimated median flows $\left(\mathrm{ft}^{3} / \mathrm{s}\right)$} \\
\hline & & & & KSA analysis & AAH analysis \\
\hline 812 & 1027010279 & WB & Dry Creek & 1.18 & 1.06 \\
\hline 813 & 102701028 & JA, SN & Unnamed tributary, Jackson 2 & .58 & .65 \\
\hline 814 & 1027010280 & $\mathrm{RL}, \mathrm{WB}$ & Loire Creek & 3.14 & 2.70 \\
\hline 815 & 1027010281 & WB & Nehring Creek & 2.80 & 2.51 \\
\hline 816 & 1027010282 & WB & Kuenzli Creek & 4.07 & 3.51 \\
\hline 817 & 1027010283 & WB & North Branch Mission Creek & 1.38 & 1.32 \\
\hline 818 & 1027010284 & WB & Johnson Creek & 1.16 & 1.12 \\
\hline 819 & 1027010285 & WB & Snokomo Creek & 3.15 & 2.75 \\
\hline 820 & 1027010287 & JA & James Creek & 1.84 & 1.67 \\
\hline 821 & 1027010288 & JA & Salt Creek & .84 & .79 \\
\hline 822 & 1027010289 & JA & Sullivan Creek & .89 & .86 \\
\hline 823 & 102701029 & JA, SN & Soldier Creek & 27.2 & 23.2 \\
\hline 824 & 1027010290 & JA & Big Elm Creek & .45 & .52 \\
\hline 825 & 102701029009 & JA, NM & Soldier Creek & 5.60 & 4.60 \\
\hline 826 & 1027010291 & JA, SN & Walnut Creek & 2.03 & 1.79 \\
\hline 827 & 1027010292 & JA & Dutch Creek & 1.40 & 1.31 \\
\hline 828 & 1027010293 & JA & West Fork Muddy Creek & 2.70 & 2.40 \\
\hline 829 & 1027010294 & JA, SN & Coryell Creek & .56 & .57 \\
\hline 830 & 1027010295 & JA, SN & Snake Creek & 1.55 & 1.62 \\
\hline 831 & 1027010296 & $\mathrm{SN}$ & Messhoss Creek & 1.52 & 1.46 \\
\hline 832 & 1027010297 & JA, SN & Halfday Creek & 3.75 & 3.29 \\
\hline 833 & 1027010298 & SN & Elm Creek & .60 & .67 \\
\hline 834 & 1027010299 & $\mathrm{JF}, \mathrm{SN}$ & Little Muddy Creek & 1.25 & 1.30 \\
\hline 835 & 102701031 & DG, JF & Delaware River & 91.9 & 73.5 \\
\hline 836 & 1027010312 & $\mathrm{JF}$ & Delaware River & 101 & 70.8 \\
\hline 837 & 1027010313 & AT, JF & Delaware River & 88.4 & 60.2 \\
\hline 838 & 1027010314 & $\mathrm{AT}$ & Delaware River & 67.7 & 54.4 \\
\hline 839 & 1027010315 & AT & Delaware River & 56.0 & 51.0 \\
\hline 840 & 1027010316 & AT & Little Grasshopper Creek & 4.81 & 3.95 \\
\hline 841 & 1027010317 & AT & Delaware River & 44.2 & 39.5 \\
\hline 842 & 1027010318 & AT & Grasshopper Creek & 10.1 & 8.30 \\
\hline 843 & 1027010319 & $\mathrm{AT}, \mathrm{BR}$ & Clear Creek & 1.87 & 1.50 \\
\hline 844 & 1027010320 & AT, BR & Grasshopper Creek & 6.77 & 5.54 \\
\hline 845 & 1027010321 & AT, JA & Delaware River & 30.8 & 26.8 \\
\hline 846 & 1027010322 & $\mathrm{BR}, \mathrm{JA}$ & Delaware River & 15.6 & 13.2 \\
\hline
\end{tabular}




\section{Estimates of Median Flows for Streams on the 1999 Kansas Surface Water Register}

Table 6. Stream segments on the 1999 Kansas Surface Water Register, CUSEGA numbers, stream names, and estimated median flows at downstream end of CUSEGA segments using the most-recent 10 years of record (KSA) and all-available hydrology (AAH) analyses. - Continued

[Estimated median flows are rounded to two or three significant figures. Reporting estimated median values to three signficant figures (median greater than or equal to $1 \mathrm{ft}^{3} / \mathrm{s}$ ) or two significant figures (median less than $1 \mathrm{ft}^{3} / \mathrm{s}$ ) was done to conform with the intent of KSA $82 \mathrm{a}-2001$ et. seq. $\mathrm{ft}^{3} / \mathrm{s}$, cubic feet per second; KSA, Kansas Statute 82a-2001 analysis; AAH, all-available hydrology analysis]

\begin{tabular}{|c|c|c|c|c|c|}
\hline \multirow{2}{*}{$\begin{array}{c}\text { Stream } \\
\text { segment } \\
\text { number } \\
\text { (figs. 9-113) }\end{array}$} & \multirow[b]{2}{*}{ CUSEGA number } & \multirow{2}{*}{$\begin{array}{c}\text { County location } \\
\text { (abbreviation explained } \\
\text { in table 7) }\end{array}$} & \multirow[b]{2}{*}{ Stream name } & \multicolumn{2}{|c|}{ Estimated median flows $\left(\mathrm{ft}^{3} / \mathrm{s}\right)$} \\
\hline & & & & KSA analysis & $\mathrm{AAH}$ analysis \\
\hline 847 & 1027010323 & BR, NM & Delaware River & 4.44 & 3.60 \\
\hline 848 & 1027010324 & $\mathrm{BR}, \mathrm{NM}$ & Craig Creek & 6.72 & 5.49 \\
\hline 849 & 1027010325 & JA & Muddy Creek & 11.1 & 9.06 \\
\hline 850 & 1027010326 & BR, JA, NM & Muddy Creek & 4.12 & 3.33 \\
\hline 851 & 1027010327 & JA, NM & Wolfley Creek & 4.64 & 3.79 \\
\hline 852 & 1027010328 & AT, JA, NM & Straight Creek & 12.8 & 10.3 \\
\hline 853 & 1027010329 & AT, JA & Elk Creek & 13.8 & 10.9 \\
\hline 854 & 1027010330 & JA, NM & Elk Creek & 5.22 & 4.22 \\
\hline 855 & 1027010331 & JA & Unnamed tributary, Jackson 1 & .04 & .19 \\
\hline 856 & 1027010332 & $\mathrm{JF}$ & Cedar Creek & 1.4 & 8.61 \\
\hline 857 & 1027010334 & $\mathrm{JA}, \mathrm{JF}$ & Rock Creek & 6.65 & 5.71 \\
\hline 858 & 1027010336 & $\mathrm{BR}$ & Plum Creek & 1.29 & 1.11 \\
\hline 859 & 1027010337 & NM & Cedar Creek & .39 & .31 \\
\hline 860 & 1027010338 & BR & Squaw Creek & .16 & .16 \\
\hline 861 & 1027010339 & NM & Barnes Creek & 1.24 & 1.09 \\
\hline 862 & 1027010340 & $\mathrm{AT}, \mathrm{BR}$ & Mission Creek & .92 & .85 \\
\hline 863 & 1027010341 & $\mathrm{AT}, \mathrm{BR}$ & Otter Creek & 2.97 & 2.45 \\
\hline 864 & 1027010342 & JA, NM & Spring Creek & 6.80 & 5.51 \\
\hline 865 & 1027010343 & AT, JA & Negro Creek & 1.99 & 1.67 \\
\hline 866 & 1027010344 & AT & Brush Creek & 0 & 0 \\
\hline 867 & 1027010345 & JA & Banner Creek & 2.89 & 2.42 \\
\hline 868 & 1027010346 & $\mathrm{JA}, \mathrm{JF}$ & North Cedar Creek & 2.99 & 2.61 \\
\hline 869 & 1027010347 & JA & Bills Creek & 1.89 & 1.61 \\
\hline 870 & 1027010348 & AT, JA & Nebo Creek & 1.26 & 1.12 \\
\hline 871 & 1027010349 & AT, JF & Catamount Creek & 1.20 & 1.19 \\
\hline 872 & 1027010350 & AT, JF & Coal Creek & 3.88 & 3.17 \\
\hline 873 & 1027010351 & $\mathrm{JF}$ & Walnut Creek & 2.72 & 2.38 \\
\hline 874 & 1027010352 & $\mathrm{JF}$ & Tick Creek & 1.97 & 1.84 \\
\hline 875 & 1027010353 & $\mathrm{JF}$ & Rock Creek & 2.06 & 2.05 \\
\hline 876 & 1027010354 & $\mathrm{JF}$ & Brush Creek & .92 & .96 \\
\hline 877 & 1027010355 & $\mathrm{JF}$ & Honey Creek & 1.40 & 1.37 \\
\hline 878 & 1027010356 & $\mathrm{JF}$ & Claywell Creek & 1.25 & 1.28 \\
\hline 879 & 1027010357 & $\mathrm{JF}$ & Little Wild Horse Creek & 3.97 & 4.05 \\
\hline
\end{tabular}


Table 6. Stream segments on the 1999 Kansas Surface Water Register, CUSEGA numbers, stream names, and estimated median flows at downstream end of CUSEGA segments using the most-recent 10 years of record (KSA) and all-available hydrology (AAH) analyses. - Continued

[Estimated median flows are rounded to two or three significant figures. Reporting estimated median values to three signficant figures (median greater than or equal to $1 \mathrm{ft}^{3} / \mathrm{s}$ ) or two significant figures (median less than $1 \mathrm{ft}^{3} / \mathrm{s}$ ) was done to conform with the intent of KSA 82a-2001 et. seq. $\mathrm{ft}^{3} / \mathrm{s}$, cubic feet per second; KSA, Kansas Statute 82a-2001 analysis; AAH, all-available hydrology analysis]

\begin{tabular}{|c|c|c|c|c|c|}
\hline \multirow{2}{*}{$\begin{array}{c}\text { Stream } \\
\text { segment } \\
\text { number } \\
\text { (figs. 9-113) }\end{array}$} & \multirow[b]{2}{*}{ CUSEGA number } & \multirow{2}{*}{$\begin{array}{c}\text { County location } \\
\text { (abbreviation explained } \\
\text { in table 7) }\end{array}$} & \multirow[b]{2}{*}{ Stream name } & \multicolumn{2}{|c|}{ Estimated median flows $\left(\mathrm{ft}^{3} / \mathrm{s}\right)$} \\
\hline & & & & KSA analysis & AAH analysis \\
\hline 880 & 10270103602 & JA, NM & Mosquito Creek & 2.07 & 1.79 \\
\hline 881 & 102701037 & $\mathrm{JF}$ & Slough Creek & 6.99 & 6.39 \\
\hline 882 & 102701038 & $\mathrm{JF}$ & Burr Oak Creek & .95 & 1.13 \\
\hline 883 & 10270103805 & $\mathrm{JF}$ & Little Slough Creek & 3.91 & 3.79 \\
\hline 884 & 102701039 & $\mathrm{JF}$ & Slough Creek & 3.84 & 3.51 \\
\hline 885 & 102701039032 & $\mathrm{JA}, \mathrm{JF}$ & South Cedar Creek & 5.14 & 4.35 \\
\hline 886 & 102701041 & WY & Kansas River & 4,910 & 4,040 \\
\hline 887 & 1027010410 & $\mathrm{AT}$ & Crooked Creek & 6.71 & 5.36 \\
\hline 888 & 102701041011 & AT, JF & Mooney Creek & .60 & .61 \\
\hline 889 & 1027010411 & AT & Unnamed tributary, Atchison 1 & 1.33 & 1.14 \\
\hline 890 & 102701041154 & WY & Piper Creek & 1.79 & 2.07 \\
\hline 891 & 102701041164 & WY & West Mission Creek & 1.57 & 1.93 \\
\hline 892 & 102701041175 & WY & Brenner Heights Creek & 2.09 & 2.64 \\
\hline 893 & 102701041178 & WY & Mattoon Creek & .97 & 1.73 \\
\hline 894 & 1027010412 & AT, JF & Crooked Creek & 3.09 & 2.51 \\
\hline 895 & 1027010413 & $\mathrm{JF}, \mathrm{LV}$ & Scatter Creek & 5.65 & 5.10 \\
\hline 896 & 1027010414 & $\mathrm{JF}, \mathrm{LV}$ & Tonganoxie Creek & 4.59 & 4.22 \\
\hline 897 & 1027010415 & LV & Ninemile Creek & 11.0 & 10.1 \\
\hline 898 & 1027010416 & LV & Unnamed tributary, Leavenworth 1 & 1.65 & 1.80 \\
\hline 899 & 1027010417 & $\mathrm{JF}, \mathrm{LV}$ & Ninemile Creek & 3.76 & 3.75 \\
\hline 900 & 1027010418 & $\mathrm{JO}, \mathrm{LV}$ & Kansas River & 4,700 & 3,820 \\
\hline 901 & 1027010419 & DG, LV & Kansas River & 4,680 & 3,800 \\
\hline 902 & 102701042 & JO, LV, WY & Kansas River & 4,890 & 4,020 \\
\hline 903 & 1027010420 & DG, JF, LV & Mud Creek & 9.44 & 9.09 \\
\hline 904 & 1027010421 & DG, JF, LV & Kansas River & 4,510 & 3,610 \\
\hline 905 & 1027010422 & $\mathrm{JF}$ & Buck Creek & 4.34 & 4.51 \\
\hline 906 & 1027010423 & $\mathrm{DG}, \mathrm{JF}$ & Kansas River & 4,490 & 3,590 \\
\hline 907 & 1027010424 & DG & Wakarusa River & 30.1 & 34.0 \\
\hline 908 & 1027010425 & DG & Wakarusa River & 19.6 & 23.7 \\
\hline 909 & 102701043 & LV & Kansas River & 4,870 & 4,010 \\
\hline 910 & 1027010430 & $\mathrm{DG}, \mathrm{SN}$ & Wakarusa River & 23.8 & 19.9 \\
\hline 911 & 1027010431 & $\mathrm{SN}, \mathrm{WB}$ & Wakarusa River & 14.1 & 11.6 \\
\hline 912 & 1027010432 & OS, SN & Burys Creek & 2.29 & 2.02 \\
\hline 913 & 1027010435 & DG, OS & Rock Creek & 3.68 & 3.45 \\
\hline 914 & 1027010436 & DG & Washington Creek & 7.77 & 7.27 \\
\hline
\end{tabular}




\section{Estimates of Median Flows for Streams on the 1999 Kansas Surface Water Register}

Table 6. Stream segments on the 1999 Kansas Surface Water Register, CUSEGA numbers, stream names, and estimated median flows at downstream end of CUSEGA segments using the most-recent 10 years of record (KSA) and all-available hydrology (AAH) analyses. - Continued

[Estimated median flows are rounded to two or three significant figures. Reporting estimated median values to three signficant figures (median greater than or equal to $1 \mathrm{ft}^{3} / \mathrm{s}$ ) or two significant figures (median less than $1 \mathrm{ft}^{3} / \mathrm{s}$ ) was done to conform with the intent of KSA $82 \mathrm{a}-2001$ et. seq. $\mathrm{ft}^{3} / \mathrm{s}$, cubic feet per second; KSA, Kansas Statute 82a-2001 analysis; AAH, all-available hydrology analysis]

\begin{tabular}{|c|c|c|c|c|c|}
\hline \multirow{2}{*}{$\begin{array}{c}\text { Stream } \\
\text { segment } \\
\text { number } \\
\text { (figs. 9-113) }\end{array}$} & \multirow[b]{2}{*}{ CUSEGA number } & \multirow{2}{*}{$\begin{array}{c}\text { County location } \\
\text { (abbreviation explained } \\
\text { in table 7) }\end{array}$} & \multirow[b]{2}{*}{ Stream name } & \multicolumn{2}{|c|}{ Estimated median flows $\left(\mathrm{ft}^{3} / \mathrm{s}\right)$} \\
\hline & & & & KSA analysis & AAH analysis \\
\hline 915 & 1027010437 & JO, LV & Kill Creek & 7.08 & 6.53 \\
\hline 916 & 10270104373 & JO, WY & Barber Creek & 3.47 & 4.03 \\
\hline 917 & 10270104379 & WY & Tooley Creek & 1.35 & 2.14 \\
\hline 918 & 1027010438 & $\mathrm{JO}$ & Cedar Creek & 7.82 & 7.28 \\
\hline 919 & 10270104383 & $\mathrm{JO}$ & Clear Creek & 2.74 & 2.83 \\
\hline 920 & 1027010439 & JO, WY & Mill Creek & 11.7 & 11.0 \\
\hline 921 & 102701044 & LV & Kansas River & 4,860 & 4,000 \\
\hline 922 & 10270104406 & $\mathrm{JO}$ & Hays Creek & 1.90 & 2.41 \\
\hline 923 & 1027010441 & $\mathrm{AT}$ & Camp Creek & 3.23 & 2.96 \\
\hline 924 & 1027010442 & $\mathrm{JF}$ & Hulls Branch & .16 & .21 \\
\hline 925 & 1027010443 & JF & Howard Creek & 0 & 0 \\
\hline 926 & 10270104437 & $\mathrm{JO}$ & Hanson Creek & .03 & .17 \\
\hline 927 & 1027010444 & $\mathrm{JF}, \mathrm{LV}$ & Buttermilk Creek & .98 & 1.08 \\
\hline 928 & 1027010445 & $\mathrm{JF}, \mathrm{LV}$ & Dawson Creek & 1.33 & 1.45 \\
\hline 929 & 10270104452 & $\mathrm{JO}$ & Unnamed tributary, Johnson 1 & 1.48 & 1.57 \\
\hline 930 & 1027010446 & $\mathrm{JF}, \mathrm{LV}$ & West Brush Creek & 1.73 & 1.91 \\
\hline 931 & 1027010447 & $\mathrm{JF}$ & Prairie Creek & .94 & .97 \\
\hline 932 & 1027010448 & $\mathrm{JF}$ & Indian Creek & 1.13 & 1.28 \\
\hline 933 & 1027010449 & LV & Brush Creek & 1.99 & 2.14 \\
\hline 934 & 102701045 & LV & Stranger Creek & 69.9 & 56.4 \\
\hline 935 & 1027010450 & JF & Plum Creek & 1.31 & 1.54 \\
\hline 936 & 1027010451 & LV & Jarbalo Creek & 2.13 & 2.11 \\
\hline 937 & 1027010452 & $\mathrm{JF}, \mathrm{LV}$ & Fall Creek & 2.93 & 2.76 \\
\hline 938 & 1027010453 & LV, WY & Wolf Creek & 5.15 & 4.84 \\
\hline 939 & 1027010454 & LV & Hog Creek & .89 & .82 \\
\hline 940 & 1027010455 & WY & Muncie Creek & 4.18 & 4.57 \\
\hline 941 & 1027010456 & DG & Oakley Creek & 3.11 & 3.26 \\
\hline 942 & 1027010457 & $\mathrm{DG}, \mathrm{JF}$ & Stone House Creek & 4.50 & 4.70 \\
\hline 943 & 1027010458 & LV & Cow Creek & 1.58 & 1.67 \\
\hline 944 & 10270104583 & SN & Unnamed tributary, Shawnee 3 & 1.12 & 1.00 \\
\hline 945 & 10270104584 & $\mathrm{SN}$ & Unnamed tributary, Shawnee 4 & .44 & .46 \\
\hline 946 & 1027010459 & LV, WY & Little Kaw Creek & 2.12 & 2.03 \\
\hline 947 & 102701046 & LV & Stranger Creek & 59.3 & 46.7 \\
\hline
\end{tabular}


Table 6. Stream segments on the 1999 Kansas Surface Water Register, CUSEGA numbers, stream names, and estimated median flows at downstream end of CUSEGA segments using the most-recent 10 years of record (KSA) and all-available hydrology (AAH) analyses. - Continued

[Estimated median flows are rounded to two or three significant figures. Reporting estimated median values to three signficant figures (median greater than or equal to $1 \mathrm{ft}^{3} / \mathrm{s}$ ) or two significant figures (median less than $1 \mathrm{ft}^{3} / \mathrm{s}$ ) was done to conform with the intent of KSA 82a-2001 et. seq. $\mathrm{ft}^{3} / \mathrm{s}$, cubic feet per second; KSA, Kansas Statute 82a-2001 analysis; AAH, all-available hydrology analysis]

\begin{tabular}{|c|c|c|c|c|c|}
\hline \multirow{2}{*}{$\begin{array}{c}\text { Stream } \\
\text { segment } \\
\text { number } \\
\text { (figs. 9-113) }\end{array}$} & \multirow[b]{2}{*}{ CUSEGA number } & \multirow{2}{*}{$\begin{array}{c}\text { County location } \\
\text { (abbreviation explained } \\
\text { in table 7) }\end{array}$} & \multirow[b]{2}{*}{ Stream name } & \multicolumn{2}{|c|}{ Estimated median flows $\left(\mathrm{ft}^{3} / \mathrm{s}\right)$} \\
\hline & & & & KSA analysis & AAH analysis \\
\hline 948 & 1027010461 & WY & East Mission Creek & 3.59 & 3.82 \\
\hline 949 & 1027010462 & WY & Little Turkey Creek & 5.25 & 5.55 \\
\hline 950 & 1027010463 & OS, SN, WB & South Branch Wakarusa River & 3.45 & 2.94 \\
\hline 951 & 1027010464 & $\mathrm{SN}$ & Middle Branch Wakarusa River & 1.38 & 1.21 \\
\hline 952 & 1027010465 & $\mathrm{SN}$ & Sixmile Creek & 3.59 & 2.93 \\
\hline 953 & 1027010466 & OS, SN & Camp Creek & 3.31 & 2.93 \\
\hline 954 & 1027010467 & $\mathrm{SN}$ & Lynn Creek & 1.53 & 1.41 \\
\hline 955 & 1027010468 & DG, OS, SN & Elk Creek & 2.18 & 2.02 \\
\hline 956 & 1027010469 & DG & Baldwin Creek & 3.01 & 3.15 \\
\hline 957 & 102701047 & LV & Stranger Creek & 52.0 & 40.0 \\
\hline 958 & 1027010470 & DG & Yankee Tank Creek & 2.23 & 2.40 \\
\hline 959 & 10270104701 & $\mathrm{DG}, \mathrm{SN}$ & Deer Creek & 3.54 & 3.35 \\
\hline 960 & 1027010471 & DG & Little Wakarusa Creek & 2.88 & 2.78 \\
\hline 961 & 1027010472 & DG, JO, LV & Captain Creek & 5.04 & 4.76 \\
\hline 962 & 1027010473 & LV & Kent Creek & 1.58 & 1.77 \\
\hline 963 & 1027010474 & $\mathrm{JO}$ & Camp Creek & 1.77 & 1.87 \\
\hline 964 & 1027010475 & $\mathrm{JO}$ & Spoon Creek & 1.74 & 1.79 \\
\hline 965 & 1027010476 & $\mathrm{JO}$ & Little Cedar Creek & 1.61 & 1.75 \\
\hline 966 & 1027010477 & JO, WY & Turkey Creek & 6.46 & 6.63 \\
\hline 967 & 1027010478 & $\mathrm{JO}$ & Little Mill Creek & 3.45 & 3.66 \\
\hline 968 & 1027010479 & DG & Chicken Creek & 2.56 & 2.63 \\
\hline 969 & 102701048 & AT, LV & Stranger Creek & 29.9 & 23.6 \\
\hline 970 & 1027010480 & DG & Coal Creek & 5.79 & 5.76 \\
\hline 971 & 10270104830 & $\mathrm{JF}$ & West Stone House Creek & 1.27 & 1.63 \\
\hline 972 & 10270104881 & LV & Little Stranger Creek & 3.78 & 3.30 \\
\hline 973 & 10270104883 & LV & Little Sandy Creek & .50 & .53 \\
\hline 974 & 102701049 & AT & Stranger Creek & 10.6 & 8.44 \\
\hline 975 & 10270104902 & LV & Rock Creek & .67 & .75 \\
\hline 976 & 102701049057 & $\mathrm{JF}$ & East Stone House Creek & 1.34 & 1.69 \\
\hline 977 & 10270104959 & AT & Little Stranger Creek & 2.38 & 1.89 \\
\hline 978 & 102702051 & PT, RL & Big Blue River & 1,170 & 975 \\
\hline 979 & 1027020510 & MS & Black Vermillion River & 44.1 & 29.4 \\
\hline 980 & 1027020511 & MS & Black Vermillion River & 28.5 & 19.6 \\
\hline
\end{tabular}




\section{Estimates of Median Flows for Streams on the 1999 Kansas Surface Water Register}

Table 6. Stream segments on the 1999 Kansas Surface Water Register, CUSEGA numbers, stream names, and estimated median flows at downstream end of CUSEGA segments using the most-recent 10 years of record (KSA) and all-available hydrology (AAH) analyses.-Continued

[Estimated median flows are rounded to two or three significant figures. Reporting estimated median values to three signficant figures (median greater than or equal to $1 \mathrm{ft}^{3} / \mathrm{s}$ ) or two significant figures (median less than $1 \mathrm{ft}^{3} / \mathrm{s}$ ) was done to conform with the intent of KSA $82 \mathrm{a}-2001$ et. seq. $\mathrm{ft}^{3} / \mathrm{s}$, cubic feet per second; KSA, Kansas Statute 82a-2001 analysis; AAH, all-available hydrology analysis]

\begin{tabular}{|c|c|c|c|c|c|}
\hline \multirow{2}{*}{$\begin{array}{l}\text { Stream } \\
\text { segment } \\
\text { number } \\
\text { (figs. 9-113) }\end{array}$} & \multirow[b]{2}{*}{ CUSEGA number } & \multirow{2}{*}{$\begin{array}{c}\text { County location } \\
\text { (abbreviation explained } \\
\text { in table 7) }\end{array}$} & \multirow[b]{2}{*}{ Stream name } & \multicolumn{2}{|c|}{ Estimated median flows $\left(\mathrm{ft}^{3} / \mathrm{s}\right)$} \\
\hline & & & & KSA analysis & AAH analysis \\
\hline 981 & 1027020512 & MS, PT & Irish Creek & 3.98 & 2.95 \\
\hline 982 & 1027020513 & MS & Black Vermillion River & 18.6 & 13.0 \\
\hline 983 & 1027020514 & MS, NM & Black Vermillion River & 5.30 & 4.04 \\
\hline 984 & 1027020515 & MS, NM & North Fork Black Vermilliion River & 7.63 & 5.37 \\
\hline 985 & 1027020516 & MS & Robidoux Creek & 7.47 & 5.21 \\
\hline 986 & 1027020517 & MS & Big Blue River & 644 & 535 \\
\hline 987 & 1027020518 & MS & Big Blue River & 476 & 469 \\
\hline 988 & 1027020519 & MS & Spring Creek & 3.08 & 2.15 \\
\hline 989 & 102702052 & PT, RL & Big Blue River & 1,170 & 974 \\
\hline 990 & 1027020520 & MS & Big Blue River & 469 & 467 \\
\hline 991 & 1027020521 & MS & Big Blue River & 229 & 267 \\
\hline 992 & 1027020522 & MS & Mission Creek & 2.15 & 1.49 \\
\hline 993 & 1027020526 & MS, WS & Horseshoe Creek & 8.53 & 6.64 \\
\hline 994 & 1027020529 & CY, RL, WS & West Fancy Creek & 19.7 & 16.4 \\
\hline 995 & 1027020531 & $\mathrm{RL}$ & Mill Creek & 3.92 & 3.10 \\
\hline 996 & 1027020533 & MS & Raemer Creek & .96 & .74 \\
\hline 997 & 1027020534 & MS & Meadow Creek & 0 & 0 \\
\hline 998 & 1027020535 & MS & Little Indian Creek & .20 & .17 \\
\hline 999 & 1027020536 & MS & Deer Creek & 1.24 & .98 \\
\hline 1000 & 1027020537 & MS & Indian Creek & .83 & .67 \\
\hline 1001 & 1027020538 & MS & Scotch Creek & 0 & 0 \\
\hline 1002 & 1027020539 & MS & Lily Creek & 0 & 0 \\
\hline 1003 & 1027020540 & MS & Bommer Creek & 0 & 0 \\
\hline 1004 & 1027020541 & MS & North Elm Creek & .71 & .44 \\
\hline 1005 & 1027020542 & MS & Murdock Creek & 0 & 0 \\
\hline 1006 & 1027020543 & MS & Hop Creek & .76 & .61 \\
\hline 1007 & 1027020544 & MS & Dutch Creek & .34 & .32 \\
\hline 1008 & 1027020545 & MS & Schell Creek & 0 & 0 \\
\hline 1009 & 1027020546 & MS & Elm Creek & 1.39 & 1.05 \\
\hline 1010 & 1027020547 & MS & Perkins Creek & .30 & .15 \\
\hline 1011 & 1027020548 & MS & Little Timber Creek & 1.24 & .84 \\
\hline 1012 & 1027020549 & MS & Ackerman Creek & 2.04 & 1.42 \\
\hline 1013 & 1027020550 & $\mathrm{MS}, \mathrm{NM}$ & Weyer Creek & 1.34 & .97 \\
\hline
\end{tabular}


Table 6. Stream segments on the 1999 Kansas Surface Water Register, CUSEGA numbers, stream names, and estimated median flows at downstream end of CUSEGA segments using the most-recent 10 years of record (KSA) and all-available hydrology (AAH) analyses.-Continued

[Estimated median flows are rounded to two or three significant figures. Reporting estimated median values to three signficant figures (median greater than or equal to $1 \mathrm{ft}^{3} / \mathrm{s}$ ) or two significant figures (median less than $1 \mathrm{ft}^{3} / \mathrm{s}$ ) was done to conform with the intent of $\mathrm{KSA} 82 \mathrm{a}-2001$ et. seq. $\mathrm{ft}^{3} / \mathrm{s}$, cubic feet per second; KSA, Kansas Statute 82a-2001 analysis; AAH, all-available hydrology analysis]

\begin{tabular}{|c|c|c|c|c|c|}
\hline \multirow{2}{*}{$\begin{array}{c}\text { Stream segment } \\
\text { number } \\
\text { (figs. 9-113) }\end{array}$} & \multirow{2}{*}{ CUSEGA number } & \multirow{2}{*}{$\begin{array}{c}\text { County location } \\
\text { (abbreviation } \\
\text { explained in table 7) }\end{array}$} & \multirow{2}{*}{ Stream name } & \multicolumn{2}{|c|}{ Estimated median flows $\left(\mathrm{ft}^{3} / \mathrm{s}\right)$} \\
\hline & & & & KSA analysis & AAH analysis \\
\hline 1014 & 1027020551 & MS & Johnson Fork & 0.04 & 0 \\
\hline 1015 & 1027020552 & MS & Corndodger Creek & .60 & .40 \\
\hline 1016 & 1027020553 & MS & Dog Walk Creek & .01 & .01 \\
\hline 1017 & 1027020554 & MS & Game Fork & 2.83 & 2.35 \\
\hline 1018 & 1027020555 & MS & De Shazer Creek & 1.13 & .85 \\
\hline 1019 & 1027020556 & MS & Cedar Creek & .24 & .21 \\
\hline 1020 & 10270205566 & PT & Bucksnort Creek & .53 & .46 \\
\hline 1021 & 1027020557 & MS & Jim Creek & .49 & .36 \\
\hline 1022 & 10270205573 & PT & Bluff Creek & 3.14 & 2.44 \\
\hline 1023 & 1027020558 & MS & Kearney Branch & .93 & .69 \\
\hline 1024 & 1027020559 & CY, WS & Carter Creek & 1.02 & .92 \\
\hline 1025 & 1027020560 & CY, WS & Deadman Creek & 1.39 & 1.18 \\
\hline 1026 & 1027020561 & RL, WS & North Fork Fancy Creek & 2.87 & 2.37 \\
\hline 1027 & 1027020562 & RL, WS & North Otter Creek & 3.54 & 2.82 \\
\hline 1028 & 1027020563 & RL, WS & School Branch & 1.83 & 1.55 \\
\hline 1029 & 1027020564 & MS, RL & Timber Creek & 1.94 & 1.72 \\
\hline 1030 & 1027020565 & MS, PT, RL & Spring Creek & 8.31 & 6.37 \\
\hline 1031 & 1027020567 & $\mathrm{RL}$ & Otter Creek & 2.89 & 2.29 \\
\hline 1032 & 1027020568 & RL & Phiel Creek & 1.12 & 1.06 \\
\hline 1033 & 102702057 & MS, RL & Big Blue River & 721 & 592 \\
\hline 1034 & 102702058 & MS & Black Vermillion River & 50.2 & 32.8 \\
\hline 1035 & 102702059 & MS, PT & Clear Fork & 4.08 & 3.07 \\
\hline 1036 & 102702059029 & RL & Fancy Creek & 19.9 & 16.5 \\
\hline 1037 & 1027020641 & $\mathrm{RP}$ & Dry Creek & .01 & 0 \\
\hline 1038 & 102702071 & MS & Little Blue River & 324 & 284 \\
\hline 1039 & 1027020712 & RP & Rose Creek & 4.28 & 3.39 \\
\hline 1040 & 1027020713 & WS & Joy Creek & 3.33 & 2.84 \\
\hline 1041 & 1027020714 & WS & Mill Creek & 33.2 & 25.1 \\
\hline 1042 & 1027020715 & WS & Devils Creek & 5.08 & 4.42 \\
\hline 1043 & 1027020716 & WS & Mill Creek & 26.0 & 19.0 \\
\hline 1044 & 1027020717 & WS & Riddle Creek & 2.66 & 2.25 \\
\hline 1045 & 1027020718 & WS & Mill Creek & 19.4 & 14.5 \\
\hline 1046 & 1027020719 & WS & Salt Creek & 1.28 & 1.13 \\
\hline 1047 & 102702072 & MS, WS & Little Blue River & 310 & 272 \\
\hline 1048 & 1027020720 & WS & Mill Creek & 16.8 & 12.6 \\
\hline
\end{tabular}




\section{Estimates of Median Flows for Streams on the 1999 Kansas Surface Water Register}

Table 6. Stream segments on the 1999 Kansas Surface Water Register, CUSEGA numbers, stream names, and estimated median flows at downstream end of CUSEGA segments using the most-recent 10 years of record (KSA) and all-available hydrology (AAH) analyses.-Continued

[Estimated median flows are rounded to two or three significant figures. Reporting estimated median values to three signficant figures (median greater than or equal to $1 \mathrm{ft}^{3} / \mathrm{s}$ ) or two significant figures (median less than $1 \mathrm{ft}^{3} / \mathrm{s}$ ) was done to conform with the intent of KSA $82 \mathrm{a}-2001$ et. seq. $\mathrm{ft}^{3} / \mathrm{s}$, cubic feet per second; KSA, Kansas Statute 82a-2001 analysis; AAH, all-available hydrology analysis]

\begin{tabular}{|c|c|c|c|c|c|}
\hline \multirow{2}{*}{$\begin{array}{c}\text { Stream segment } \\
\text { number } \\
\text { (figs. 9-113) }\end{array}$} & \multirow{2}{*}{ CUSEGA number } & \multirow{2}{*}{$\begin{array}{c}\text { County location } \\
\text { (abbreviation } \\
\text { explained in table 7) }\end{array}$} & \multirow{2}{*}{ Stream name } & \multicolumn{2}{|c|}{ Estimated median flows $\left(\mathrm{ft}^{3} / \mathrm{s}\right)$} \\
\hline & & & & KSA analysis & AAH analysis \\
\hline 1049 & 1027020721 & WS & Bowman Creek & 2.36 & 1.95 \\
\hline 1050 & 1027020722 & RP, WS & Mill Creek & 11.1 & 8.45 \\
\hline 1051 & 1027020723 & MS, WS & Coon Creek & 8.41 & 6.72 \\
\hline 1052 & 1027020724 & $\mathrm{RP}$ & Humphrey Branch & 0 & 0 \\
\hline 1053 & 1027020725 & RP, WS & Cherry Creek & 1.81 & 1.44 \\
\hline 1054 & 1027020726 & WS & Myer Creek & 2.28 & 1.86 \\
\hline 1055 & 1027020727 & WS & Gray Branch & 1.00 & .86 \\
\hline 1056 & 1027020728 & WS & Silver Creek & 0 & 0 \\
\hline 1057 & 1027020729 & WS & Jones Creek & .37 & .40 \\
\hline 1058 & 102702073 & WS & Little Blue River & 226 & 215 \\
\hline 1059 & 1027020730 & WS & Spring Creek & 1.14 & 1.22 \\
\hline 1060 & 1027020731 & RP, WS & South Fork Mill Creek & 3.10 & 2.54 \\
\hline 1061 & 1027020732 & WS & Buffalo Creek & .78 & .86 \\
\hline 1062 & 1027020733 & WS & Melvin Creek & .61 & .74 \\
\hline 1063 & 1027020734 & WS & Iowa Creek & 2.44 & 2.23 \\
\hline 1064 & 1027020735 & WS & Camp Creek & 1.34 & 1.28 \\
\hline 1065 & 1027020736 & WS & Ash Creek & 1.80 & 1.51 \\
\hline 1066 & 1027020737 & WS & Malone Creek & 0 & 0 \\
\hline 1067 & 1027020738 & WS & Beaver Creek & 1.31 & 1.05 \\
\hline 1068 & 1027020739 & WS & Lane Branch & 1.34 & 1.23 \\
\hline 1069 & 102702074 & WS & Little Blue River & 220 & 211 \\
\hline 1070 & 1027020740 & WS & Cedar Creek & .91 & .76 \\
\hline 1071 & 1027020741 & MS & Walnut Creek & 1.93 & 1.51 \\
\hline 1072 & 1027020742 & WS & Bolling Creek & .57 & .51 \\
\hline 1073 & 1027020743 & WS & Mercer Creek & 0 & 0 \\
\hline 1074 & 1027020744 & WS & Camp Creek & 1.19 & .96 \\
\hline 1075 & 1027020745 & MS & Fawn Creek & 2.64 & 2.15 \\
\hline 1076 & 1027020749 & WS & School Creek & 225 & 215 \\
\hline 1077 & 102901011 & MI & Marais des Cygnes River & 223 & 241 \\
\hline 1078 & 1029010110 & FR & Marais des Cygnes River & 182 & 192 \\
\hline 1079 & 102901011072 & WB & Unnamed tributary, Wabaunsee 2 & .63 & .64 \\
\hline 1080 & 102901011083 & OS, WB & Soldier Creek & 2.12 & 1.93 \\
\hline 1081 & 1029010111 & DG, FR & Tauy Creek & 11.6 & 10.7 \\
\hline 1082 & 1029010112 & FR & Marais des Cygnes River & 151 & 156 \\
\hline 1083 & 1029010113 & DG, FR & Eightmile Creek & 8.10 & 7.50 \\
\hline
\end{tabular}


Table 6. Stream segments on the 1999 Kansas Surface Water Register, CUSEGA numbers, stream names, and estimated median flows at downstream end of CUSEGA segments using the most-recent 10 years of record (KSA) and all-available hydrology (AAH) analyses.-Continued

[Estimated median flows are rounded to two or three significant figures. Reporting estimated median values to three signficant figures (median greater than or equal to $1 \mathrm{ft}^{3} / \mathrm{s}$ ) or two significant figures (median less than $1 \mathrm{ft}^{3} / \mathrm{s}$ ) was done to conform with the intent of KSA $82 \mathrm{a}-2001$ et. seq. $\mathrm{ft}^{3} / \mathrm{s}$, cubic feet per second; KSA, Kansas Statute 82a-2001 analysis; AAH, all-available hydrology analysis]

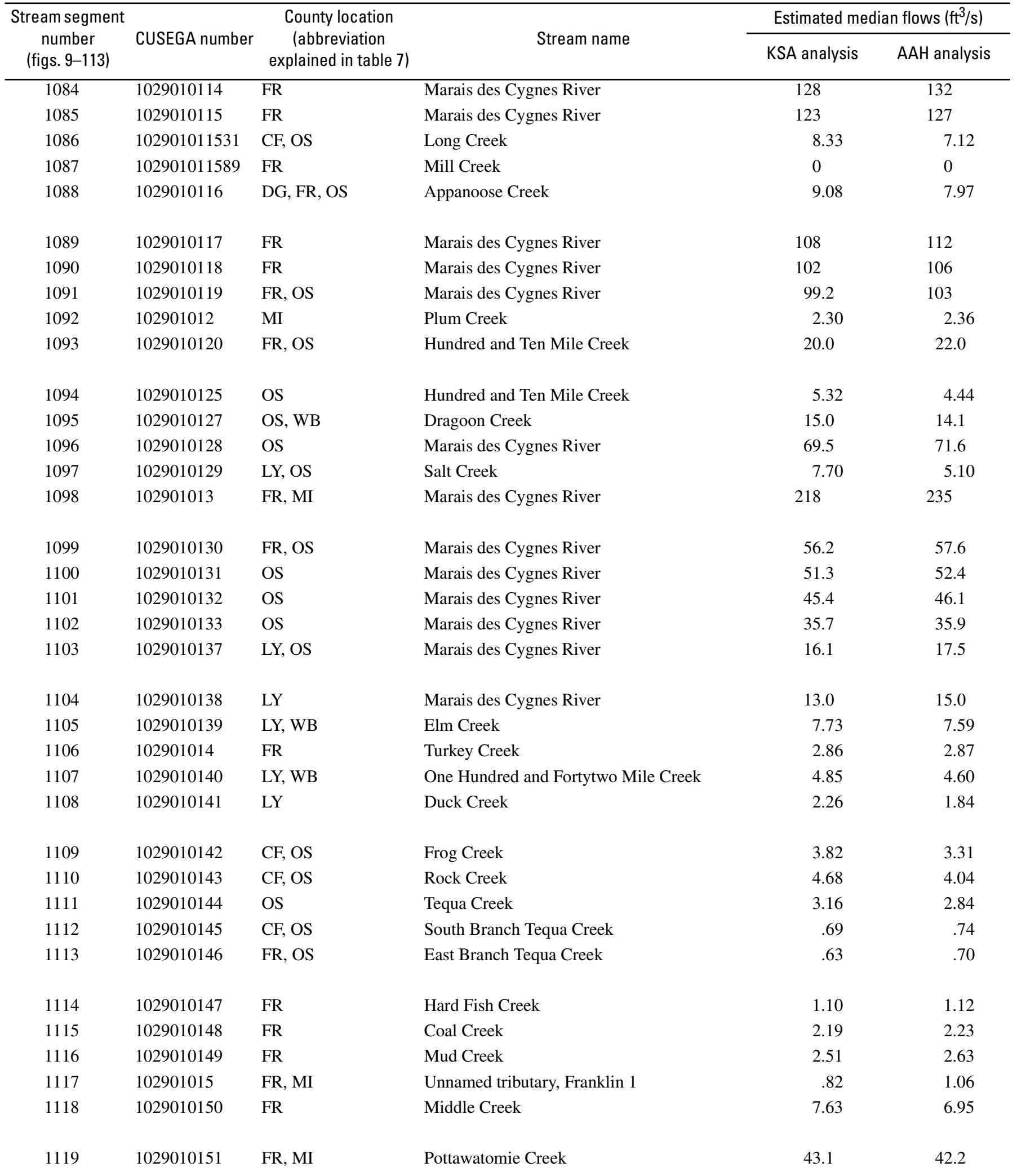


Table 6. Stream segments on the 1999 Kansas Surface Water Register, CUSEGA numbers, stream names, and estimated median flows at downstream end of CUSEGA segments using the most-recent 10 years of record (KSA) and all-available hydrology (AAH) analyses.-Continued

[Estimated median flows are rounded to two or three significant figures. Reporting estimated median values to three signficant figures (median greater than or equal to $1 \mathrm{ft}^{3} / \mathrm{s}$ ) or two significant figures (median less than $1 \mathrm{ft}^{3} / \mathrm{s}$ ) was done to conform with the intent of KSA $82 \mathrm{a}-2001$ et. seq. $\mathrm{ft}^{3} / \mathrm{s}$, cubic feet per second; KSA, Kansas Statute 82a-2001 analysis; AAH, all-available hydrology analysis]

\begin{tabular}{|c|c|c|c|c|c|}
\hline \multirow{2}{*}{$\begin{array}{c}\text { Stream segment } \\
\text { number } \\
\text { (figs. 9-113) }\end{array}$} & \multirow{2}{*}{ CUSEGA number } & \multirow{2}{*}{$\begin{array}{c}\text { County location } \\
\text { (abbreviation } \\
\text { explained in table 7) }\end{array}$} & \multirow{2}{*}{ Stream name } & \multicolumn{2}{|c|}{ Estimated median flows $\left(\mathrm{ft}^{3} / \mathrm{s}\right)$} \\
\hline & & & & KSA analysis & AAH analysis \\
\hline 1120 & 1029010152 & $\overline{F R}$ & Mosquito Creek & 2.08 & 2.12 \\
\hline 1121 & 1029010153 & FR & Pottawatomie Creek & 37.8 & 37.3 \\
\hline 1122 & 1029010154 & FR & Sac Branch & 2.13 & 2.10 \\
\hline 1123 & 1029010155 & AN, FR & Pottawatomie Creek & 34.6 & 34.4 \\
\hline 1124 & 1029010156 & AN & Pottawatomie Creek & 22.8 & 23.5 \\
\hline 1125 & 1029010157 & AN, FR & Dry Creek & 1.81 & 1.80 \\
\hline 1126 & 1029010158 & AN & Pottawatomie Creek & 20.0 & 21.0 \\
\hline 1127 & 1029010159 & AN & Pottawatomie Creek & 15.4 & 15.3 \\
\hline 1128 & 102901016 & FR, MI & Turkey Creek & 1.50 & 1.65 \\
\hline 1129 & 1029010160 & AN, FR & Sac Creek & 3.44 & 3.23 \\
\hline 1130 & 1029010161 & AN & Pottawatomie Creek & 12.2 & 11.8 \\
\hline 1131 & 1029010162 & $\mathrm{AN}, \mathrm{CF}, \mathrm{FR}$ & Iantha Creek & 2.53 & 2.41 \\
\hline 1132 & 1029010163 & AN & Pottawatomie Creek & 9.90 & 9.35 \\
\hline 1133 & 1029010164 & $\mathrm{AN}, \mathrm{CF}$ & Kenoma Creek & 2.16 & 1.94 \\
\hline 1134 & 1029010165 & $\mathrm{AN}, \mathrm{CF}$ & North Fork Pottawatomie Creek & 7.49 & 7.04 \\
\hline 1135 & 1029010166 & AN & Cedar Creek & 5.29 & 4.87 \\
\hline 1136 & 1029010167 & AN & South Fork Pottawatomie Creek & 10.2 & 9.24 \\
\hline 1137 & 1029010169 & WB & Locust Creek & .42 & .40 \\
\hline 1138 & 102901017 & FR & Marais des Cygnes River & 205 & 220 \\
\hline 1139 & 1029010170 & LY, WB & Chicken Creek & 1.65 & 1.45 \\
\hline 1140 & 1029010171 & LY & Hill Creek & 1.28 & 1.12 \\
\hline 1141 & 1029010172 & $\mathrm{AN}, \mathrm{CF}$ & Thomas Creek & 1.72 & 1.72 \\
\hline 1142 & 1029010173 & $\mathrm{CF}, \mathrm{OS}$ & Little Rock Creek & .29 & .37 \\
\hline 1143 & 1029010174 & $\mathrm{AN}, \mathrm{CF}$ & Cherry Creek & 1.25 & 1.47 \\
\hline 1144 & 1029010175 & AN & Bradshaw Creek & 1.25 & 1.20 \\
\hline 1145 & 1029010176 & OS & Jersey Creek & .81 & .77 \\
\hline 1146 & 1029010177 & OS & Smith Creek & 1.05 & .92 \\
\hline 1147 & 1029010178 & OS & Mud Creek & .24 & .26 \\
\hline 1148 & 1029010179 & OS & Plum Creek & .55 & .57 \\
\hline 1149 & 102901018 & FR, MI & Hickory Creek & 2.86 & 2.78 \\
\hline 1150 & 1029010180 & OS & Switzler Creek & 3.24 & 2.69 \\
\hline 1151 & 1029010181 & FR & Blue Creek & 1.11 & 1.39 \\
\hline 1152 & 1029010182 & FR & Sand Creek & 1.24 & 1.54 \\
\hline 1153 & 1029010183 & FR & Wilson Creek & .15 & .31 \\
\hline 1154 & 1029010184 & FR & Spring Creek & 1.55 & 1.74 \\
\hline
\end{tabular}


Table 6. Stream segments on the 1999 Kansas Surface Water Register, CUSEGA numbers, stream names, and estimated median flows at downstream end of CUSEGA segments using the most-recent 10 years of record (KSA) and all-available hydrology (AAH) analyses.-Continued

[Estimated median flows are rounded to two or three significant figures. Reporting estimated median values to three signficant figures (median greater than or equal to $1 \mathrm{ft}^{3} / \mathrm{s}$ ) or two significant figures (median less than $1 \mathrm{ft}^{3} / \mathrm{s}$ ) was done to conform with the intent of KSA $82 \mathrm{a}-2001$ et. seq. $\mathrm{ft}^{3} / \mathrm{s}$, cubic feet per second; KSA, Kansas Statute 82a-2001 analysis; AAH, all-available hydrology analysis]

\begin{tabular}{|c|c|c|c|c|c|}
\hline \multirow{2}{*}{$\begin{array}{c}\text { Stream segment } \\
\text { number } \\
\text { (figs. 9-113) }\end{array}$} & \multirow{2}{*}{ CUSEGA number } & \multirow{2}{*}{$\begin{array}{l}\text { County location } \\
\text { (abbreviation } \\
\text { explained in table 7) }\end{array}$} & \multirow{2}{*}{ Stream name } & \multicolumn{2}{|c|}{ Estimated median flows $\left(\mathrm{ft}^{3} / \mathrm{s}\right)$} \\
\hline & & & & KSA analysis & AAH analysis \\
\hline 1155 & 1029010185 & DG, FR & East Fork Tauy Creek & 4.61 & 4.43 \\
\hline 1156 & 1029010186 & WB & Batch Creek & 1.01 & .94 \\
\hline 1157 & 1029010187 & OS & Popcorn Creek & .91 & .82 \\
\hline 1158 & 1029010188 & DG, FR & West Fork Eightmile Creek & .93 & .98 \\
\hline 1159 & 1029010189 & DG, FR & East Appanoose Creek & 1.80 & 1.74 \\
\hline 1160 & 102901019 & FR & Marais des Cygnes River & 199 & 213 \\
\hline 1161 & 1029010190 & DG, FR & Walnut Creek & 3.67 & 3.38 \\
\hline 1162 & 102901019011 & FR & Ottawa Creek & 15.4 & 14.0 \\
\hline 1163 & 102901019054 & FR & North Fork Sac Branch & 1.68 & 1.69 \\
\hline 1164 & 1029010191 & LY, OS & Mud Creek & 1.29 & 1.16 \\
\hline 1165 & 1029010192 & OS & Mute Creek & 2.53 & 2.00 \\
\hline 1166 & 1029010193 & OS & Chicken Creek & 1.34 & 1.32 \\
\hline 1167 & 1029010194 & $\mathrm{CF}, \mathrm{OS}$ & Willow Creek & .98 & .97 \\
\hline 1168 & 1029010195 & OS & Dry Creek & 1.10 & 1.11 \\
\hline 1169 & 1029010196 & OS & Wolf Creek & .79 & .86 \\
\hline 1170 & 1029010197 & FR & Rock Creek & 1.41 & 1.31 \\
\hline 1171 & 1029010210 & MI & North Sugar Creek & 4.23 & 4.18 \\
\hline 1172 & 102901021029 & $\mathrm{LN}$ & Turkey Creek & 2.03 & 2.33 \\
\hline 1173 & 1029010211 & $\mathrm{LN}$ & Marais des Cygnes River & 480 & 534 \\
\hline 1174 & 1029010212 & LN, MI & Middle Creek & 11.1 & 10.4 \\
\hline 1175 & 102901021244 & $\mathrm{LN}$ & Mine Creek & 5.52 & 5.54 \\
\hline 1176 & 1029010213 & MI & Middle Creek & 4.35 & 4.25 \\
\hline 1177 & 1029010214 & MI & Walnut Creek & 1.23 & 1.48 \\
\hline 1178 & 1029010215 & $\mathrm{LN}$ & Marais des Cygnes River & 463 & 525 \\
\hline 1179 & 1029010216 & LN, MI & Marais des Cygnes River & 432 & 489 \\
\hline 1180 & 1029010218 & MI & South Wea Creek & 13.0 & 12.1 \\
\hline 1181 & 1029010219 & MI & South Wea Creek & 11.4 & 10.6 \\
\hline 1182 & 1029010220 & MI & South Wea Creek & 5.44 & 5.27 \\
\hline 1183 & 1029010221 & $\mathrm{JO}, \mathrm{MI}$ & North Wea Creek & 5.16 & 4.92 \\
\hline 1184 & 1029010222 & MI & Dorsey Creek & 1.31 & 1.54 \\
\hline 1185 & 1029010224 & MI & Bull Creek & 57.3 & 61.5 \\
\hline 1186 & 1029010225 & $\mathrm{JO}, \mathrm{MI}$ & Tenmile Creek & 5.80 & 5.48 \\
\hline 1187 & 1029010226 & $\mathrm{JO}$ & Bull Creek & 3.57 & 3.48 \\
\hline 1188 & 1029010227 & DG, FR, MI & Rock Creek & 2.16 & 2.16 \\
\hline 1189 & 1029010229 & MI & Marais des Cygnes River & 343 & 383 \\
\hline 1190 & 1029010230 & AN, LN, MI & Middle Creek & 11.7 & 10.9 \\
\hline
\end{tabular}


Table 6. Stream segments on the 1999 Kansas Surface Water Register, CUSEGA numbers, stream names, and estimated median flows at downstream end of CUSEGA segments using the most-recent 10 years of record (KSA) and all-available hydrology (AAH) analyses.-Continued

[Estimated median flows are rounded to two or three significant figures. Reporting estimated median values to three signficant figures (median greater than or equal to $1 \mathrm{ft}^{3} / \mathrm{s}$ ) or two significant figures (median less than $1 \mathrm{ft}^{3} / \mathrm{s}$ ) was done to conform with the intent of KSA $82 \mathrm{a}-2001$ et. seq. $\mathrm{ft}^{3} / \mathrm{s}$, cubic feet per second; KSA, Kansas Statute 82a-2001 analysis; AAH, all-available hydrology analysis]

\begin{tabular}{|c|c|c|c|c|c|}
\hline \multirow{2}{*}{$\begin{array}{c}\text { Stream segment } \\
\text { number } \\
\text { (figs. 9-113) }\end{array}$} & \multirow{2}{*}{ CUSEGA number } & \multirow{2}{*}{$\begin{array}{c}\text { County location } \\
\text { (abbreviation } \\
\text { explained in table 7) }\end{array}$} & \multirow{2}{*}{ Stream name } & \multicolumn{2}{|c|}{ Estimated median flows $\left(\mathrm{ft}^{3} / \mathrm{s}\right)$} \\
\hline & & & & KSA analysis & AAH analysis \\
\hline 1191 & 1029010231 & $\mathrm{LN}$ & Big Sugar Creek & 36.9 & 28.8 \\
\hline 1192 & 1029010232 & AN, LN & Big Sugar Creek & 26.4 & 18.9 \\
\hline 1193 & 1029010233 & LN & Little Sugar Creek & 10.3 & 9.84 \\
\hline 1194 & 1029010234 & LN & Walnut Creek & 1.37 & 1.66 \\
\hline 1195 & 1029010235 & MI & Mound Creek & 2.91 & 2.92 \\
\hline 1196 & 1029010236 & MI & Jordan Branch & .94 & 1.22 \\
\hline 1197 & 1029010237 & MI & Hushpuckney Creek & 2.29 & 2.45 \\
\hline 1198 & 1029010238 & LN & Davis Creek & 2.69 & 2.79 \\
\hline 1199 & 1029010239 & AN, LN & North Sugar Creek & 5.60 & 5.00 \\
\hline 1200 & 102901024 & $\mathrm{LN}$ & Marais des Cygnes River & 562 & 578 \\
\hline 1201 & 1029010240 & LN & Elm Creek & 3.80 & 3.85 \\
\hline 1202 & 1029010241 & $\mathrm{LN}$ & Richland Creek & 4.57 & 4.59 \\
\hline 1203 & 1029010242 & AN, LN & Sugar Creek & 5.56 & 4.65 \\
\hline 1204 & 1029010243 & $\mathrm{LN}$ & South Fork Little Sugar Creek & .76 & .96 \\
\hline 1205 & 1029010244 & $\mathrm{LN}$ & Buck Creek & 1.16 & 1.45 \\
\hline 1206 & 1029010245 & LN & Turkey Creek & 3.07 & 3.24 \\
\hline 1207 & 1029010246 & $\mathrm{LN}$ & Muddy Creek & 2.67 & 2.89 \\
\hline 1208 & 1029010247 & MI & Smith Branch & 1.19 & 1.41 \\
\hline 1209 & 1029010248 & MI & Elm Branch & .18 & .43 \\
\hline 1210 & 1029010249 & JO, MI & Sweetwater Creek & 1.18 & 1.36 \\
\hline 1211 & 102901025 & LN & Marais des Cygnes River & 496 & 543 \\
\hline 1212 & 1029010250 & JO, MI & Spring Creek & 3.20 & 3.18 \\
\hline 1213 & 1029010251 & JO & Little Bull Creek & 1.65 & 1.78 \\
\hline 1214 & 1029010252 & MI & Walnut Creek & 2.97 & 3.02 \\
\hline 1215 & 1029010253 & MI & Elm Branch & 1.90 & 2.10 \\
\hline 1216 & 1029010254 & MI & Jake Branch & 1.34 & 1.55 \\
\hline 1217 & 102901026 & $\mathrm{LN}$ & North Sugar Creek & 9.05 & 8.55 \\
\hline 1218 & 10290102754 & MI & Unnamed tributary, Miami 1 & .08 & .37 \\
\hline 1219 & 1029010299 & DG, JO & Martin Creek & 1.45 & 1.56 \\
\hline 1220 & 1029010310 & $\mathrm{BB}, \mathrm{LN}$ & Lost Creek & 3.25 & 3.25 \\
\hline 1221 & 1029010311 & $\mathrm{BB}, \mathrm{LN}$ & Elk Creek & 3.25 & 3.33 \\
\hline 1222 & 1029010312 & $\mathrm{BB}, \mathrm{LN}$ & Indian Creek & 3.10 & 3.31 \\
\hline 1223 & 1029010313 & $\mathrm{BB}, \mathrm{LN}$ & East Laberdie Creek & 1.75 & 1.99 \\
\hline 1224 & 10290103202 & $\mathrm{BB}, \mathrm{LN}$ & Irish Creek & 1.55 & 1.63 \\
\hline 1225 & 10290103220 & $\mathrm{AL}, \mathrm{AN}$ & North Fork Little Osage River & 2.25 & 2.28 \\
\hline
\end{tabular}


Table 6. Stream segments on the 1999 Kansas Surface Water Register, CUSEGA numbers, stream names, and estimated median flows at downstream end of CUSEGA segments using the most-recent 10 years of record (KSA) and all-available hydrology (AAH) analyses.-Continued

[Estimated median flows are rounded to two or three significant figures. Reporting estimated median values to three signficant figures (median greater than or equal to $1 \mathrm{ft}^{3} / \mathrm{s}$ ) or two significant figures (median less than $1 \mathrm{ft}^{3} / \mathrm{s}$ ) was done to conform with the intent of KSA $82 \mathrm{a}-2001$ et. seq. $\mathrm{ft}^{3} / \mathrm{s}$, cubic feet per second; KSA, Kansas Statute 82a-2001 analysis; AAH, all-available hydrology analysis]

\begin{tabular}{|c|c|c|c|c|c|}
\hline \multirow{2}{*}{$\begin{array}{c}\text { Stream segment } \\
\text { number } \\
\text { (figs. 9-113) }\end{array}$} & \multirow{2}{*}{ CUSEGA number } & \multirow{2}{*}{$\begin{array}{c}\text { County location } \\
\text { (abbreviation } \\
\text { explained in table 7) }\end{array}$} & \multirow{2}{*}{ Stream name } & \multicolumn{2}{|c|}{ Estimated median flows $\left(\mathrm{ft}^{3} / \mathrm{s}\right)$} \\
\hline & & & & KSA analysis & AAH analysis \\
\hline 1226 & 10290103249 & $\overline{\mathrm{AL}}$ & South Fork Little Osage River & 2.89 & 2.93 \\
\hline 1227 & 102901033 & $\mathrm{AL}, \mathrm{BB}$ & Little Osage River & 50.8 & 38.7 \\
\hline 1228 & 1029010336 & $\mathrm{AL}, \mathrm{AN}$ & Middle Fork Little Osage River & 3.27 & 3.25 \\
\hline 1229 & 102901035 & $\mathrm{AL}, \mathrm{BB}$ & Limestone Creek & 4.29 & 4.19 \\
\hline 1230 & 102901036 & $\mathrm{BB}$ & Reagan Branch & 1.94 & 2.44 \\
\hline 1231 & 102901037 & BB & Clever Creek & .59 & .82 \\
\hline 1232 & 102901038 & BB & Fish Creek & 1.63 & 1.88 \\
\hline 1233 & 102901039 & $\mathrm{BB}, \mathrm{LN}$ & Owl Creek & 1.07 & 1.35 \\
\hline 1234 & 1029010411 & $\mathrm{BB}$ & Marmaton River & 42.0 & 43.0 \\
\hline 1235 & 1029010412 & $\mathrm{AL}, \mathrm{BB}$ & Marmaton River & 20.2 & 20.2 \\
\hline 1236 & 1029010413 & BB & Paint Creek & 15.4 & 15.5 \\
\hline 1237 & 1029010414 & BB & Paint Creek & 7.94 & 7.83 \\
\hline 1238 & 1029010415 & BB & Elm Creek & .50 & .86 \\
\hline 1239 & 1029010417 & BB & Moores Branch Drywood Creek & 2.67 & 2.99 \\
\hline 1240 & 1029010419 & $\mathrm{BB}, \mathrm{CR}$ & West Fork Drywood Creek & 11.1 & 11.7 \\
\hline 1241 & 1029010430 & $\mathrm{AL}$ & Sweet Branch & .48 & .81 \\
\hline 1242 & 1029010431 & BB & Tennyson Creek & 3.08 & 3.52 \\
\hline 1243 & 10290104313 & $\mathrm{BB}, \mathrm{CR}$ & Pawnee Creek & 6.90 & 7.33 \\
\hline 1244 & 1029010432 & $\mathrm{BB}$ & Walnut Creek & .88 & 1.14 \\
\hline 1245 & 10290104323 & CR & West Fork Drywood Creek & 4.79 & 5.46 \\
\hline 1246 & 10290104324 & $\mathrm{BB}, \mathrm{CR}$ & Cox Creek & 7.09 & 8.10 \\
\hline 1247 & 1029010433 & BB & Turkey Creek & 3.09 & 3.45 \\
\hline 1248 & 1029010434 & BB & Little Mill Creek & 1.56 & 1.83 \\
\hline 1249 & 1029010435 & BB & Wolverine Creek & 1.76 & 2.04 \\
\hline 1250 & 1029010436 & BB & Shiloh Creek & 1.75 & 2.15 \\
\hline 1251 & 1029010437 & $\mathrm{AL}, \mathrm{BB}$ & Wolfpen Creek & 1.91 & 2.27 \\
\hline 1252 & 1029010438 & $\mathrm{BB}$ & Hinton Creek & 2.34 & 2.69 \\
\hline 1253 & 1029010439 & BB & Bunion Creek & .72 & .94 \\
\hline 1254 & 1029010440 & BB & Robinson Branch & .09 & .35 \\
\hline 1255 & 1029010441 & BB & Cedar Creek & 1.05 & 1.30 \\
\hline 1256 & 1029010442 & BB & Lath Branch & 1.35 & 1.83 \\
\hline 1257 & 1029010444 & BB & Prong Creek & .03 & .34 \\
\hline 1258 & 1029010445 & BB & Owl Creek & .45 & .67 \\
\hline 1259 & 1029010446 & BB & Buck Run & 2.16 & 2.49 \\
\hline 1260 & 1029010447 & BB & Walnut Creek & 2.23 & 2.65 \\
\hline 1261 & 102901045 & $\mathrm{BB}$ & Marmaton River & 32.3 & 33.3 \\
\hline
\end{tabular}


Table 6. Stream segments on the 1999 Kansas Surface Water Register, CUSEGA numbers, stream names, and estimated median flows at downstream end of CUSEGA segments using the most-recent 10 years of record (KSA) and all-available hydrology (AAH) analyses.-Continued

[Estimated median flows are rounded to two or three significant figures. Reporting estimated median values to three signficant figures (median greater than or equal to $1 \mathrm{ft}^{3} / \mathrm{s}$ ) or two significant figures (median less than $1 \mathrm{ft}^{3} / \mathrm{s}$ ) was done to conform with the intent of KSA $82 \mathrm{a}-2001$ et. seq. $\mathrm{ft}^{3} / \mathrm{s}$, cubic feet per second; KSA, Kansas Statute 82a-2001 analysis; AAH, all-available hydrology analysis]

\begin{tabular}{|c|c|c|c|c|c|}
\hline \multirow{2}{*}{$\begin{array}{c}\text { Stream segment } \\
\text { number } \\
\text { (figs. 9-113) }\end{array}$} & \multirow{2}{*}{ CUSEGA number } & \multirow{2}{*}{$\begin{array}{c}\text { County location } \\
\text { (abbreviation } \\
\text { explained in table 7) }\end{array}$} & \multirow{2}{*}{ Stream name } & \multicolumn{2}{|c|}{ Estimated median flows $\left(\mathrm{ft}^{3} / \mathrm{s}\right)$} \\
\hline & & & & KSA analysis & $\mathrm{AAH}$ analysis \\
\hline 1262 & 102901046 & $\overline{B B}$ & Mill Creek & 6.76 & 6.84 \\
\hline 1263 & 102901047 & BB & Marmaton River & 30.0 & 31.0 \\
\hline 1264 & 102901048 & $\mathrm{BB}$ & Marmaton River & 40.5 & 41.5 \\
\hline 1265 & 102901049019 & $\mathrm{CR}$ & Bone Creek & 3.84 & 4.36 \\
\hline 1266 & 1029010848 & MI & Pony Creek & .58 & .84 \\
\hline 1267 & 103001011102 & $\mathrm{JO}$ & Wolf Creek & 2.75 & 2.66 \\
\hline 1268 & 1030010132 & $\mathrm{JO}$ & Indian Creek & 21.1 & 15.8 \\
\hline 1269 & 1030010133 & $\mathrm{JO}$ & Blue River & 41.7 & 31.8 \\
\hline 1270 & 1030010153 & $\mathrm{JO}$ & Tomahawk Creek & 3.00 & 2.99 \\
\hline 1271 & 1030010154 & $\mathrm{JO}$ & Brush Creek & 2.21 & 2.56 \\
\hline 1272 & 1030010155 & $\mathrm{JO}$ & Dyke Branch & .39 & .78 \\
\hline 1273 & 1030010156 & $\mathrm{JO}$ & Camp Branch & 6.62 & 5.65 \\
\hline 1274 & 1030010157 & $\mathrm{JO}$ & Coffee Creek & 1.92 & 1.95 \\
\hline 1275 & 1030010158 & $\mathrm{JO}$ & Negro Creek & 1.91 & 1.92 \\
\hline 1276 & 110300011 & FI, KE & Arkansas River & 55.0 & 32.0 \\
\hline 1277 & 1103000110 & GL, HM, KE, WH & James Draw & 0 & 0 \\
\hline 1278 & 1103000111 & KE & Mattox Draw & 0 & 0 \\
\hline 1279 & 1103000113 & KE & Sand Creek & 0 & 0 \\
\hline 1280 & 1103000114 & KE & Sand Creek & 0 & 0 \\
\hline 1281 & 1103000118 & $\mathrm{KE}$ & Unnamed tributary, Kearny 1 & 0 & 0 \\
\hline 1282 & 110300013 & $\mathrm{HM}, \mathrm{KE}$ & Arkansas River & 91.3 & 55.8 \\
\hline 1283 & 110300014 & $\mathrm{HM}$ & Shirley Creek & 0 & 0 \\
\hline 1284 & 110300015 & HM & Arkansas River & 209 & 133 \\
\hline 1285 & 110300016 & HM & East Bridge Creek & 0 & 0 \\
\hline 1286 & 110300017 & HM & Arkansas River & 208 & 132 \\
\hline 1287 & 110300018 & HM & West Bridge Creek & 0 & 0 \\
\hline 1288 & 110300019 & HM & Arkansas River & 206 & 129 \\
\hline 1289 & 110300021 & $\mathrm{SC}$ & Whitewoman Creek & 0 & 0 \\
\hline 1290 & 110300022 & GL, WH, SC & Whitewoman Creek & 0 & 0 \\
\hline 1291 & 110300023 & $\mathrm{SC}, \mathrm{WH}$ & Sand Creek & 0 & 0 \\
\hline 1292 & 110300031 & FI, GY, FO & Arkansas River & 0 & 8.70 \\
\hline 1293 & 110300041 & BT, RC & Arkansas River & 185 & 140 \\
\hline 1294 & 1103000410 & $\mathrm{ED}, \mathrm{FO}, \mathrm{PN}$ & Arkansas River & 3.70 & 32.0 \\
\hline 1295 & 1103000411 & FO & Arkansas River & .46 & 11.6 \\
\hline 1296 & 1103000412 & $\mathrm{FO}, \mathrm{GY}$ & Mulberry Creek & 2.15 & 1.70 \\
\hline
\end{tabular}


Table 6. Stream segments on the 1999 Kansas Surface Water Register, CUSEGA numbers, stream names, and estimated median flows at downstream end of CUSEGA segments using the most-recent 10 years of record (KSA) and all-available hydrology (AAH) analyses.-Continued

[Estimated median flows are rounded to two or three significant figures. Reporting estimated median values to three signficant figures (median greater than or equal to $1 \mathrm{ft}^{3} / \mathrm{s}$ ) or two significant figures (median less than $1 \mathrm{ft}^{3} / \mathrm{s}$ ) was done to conform with the intent of KSA $82 \mathrm{a}-2001$ et. seq. $\mathrm{ft}^{3} / \mathrm{s}$, cubic feet per second; KSA, Kansas Statute 82a-2001 analysis; AAH, all-available hydrology analysis]

\begin{tabular}{|c|c|c|c|c|c|}
\hline \multirow{2}{*}{$\begin{array}{c}\text { Stream segment } \\
\text { number } \\
\text { (figs. 9-113) }\end{array}$} & \multirow{2}{*}{ CUSEGA number } & \multirow{2}{*}{$\begin{array}{c}\text { County location } \\
\text { (abbreviation } \\
\text { explained in table 7) }\end{array}$} & \multirow{2}{*}{ Stream name } & \multicolumn{2}{|c|}{ Estimated median flows $\left(\mathrm{ft}^{3} / \mathrm{s}\right)$} \\
\hline & & & & KSA analysis & AAH analysis \\
\hline 1297 & 1103000413 & PN & Pickerel Creek & 1.81 & 1.64 \\
\hline 1298 & 1103000414 & FO & Cow Creek & 0 & 0 \\
\hline 1299 & 1103000415 & $\mathrm{FO}, \mathrm{HG}$ & White Woman Creek & 0 & 0 \\
\hline 1300 & 110300042 & BT & Arkansas River & 46.8 & 55.3 \\
\hline 1301 & 110300043 & PN & Ash Creek & 1.10 & .82 \\
\hline 1302 & 110300044 & BT, PN & Arkansas River & 60.4 & 39.9 \\
\hline 1303 & 110300045 & PN & Arkansas River & 57.0 & 39.5 \\
\hline 1304 & 110300046 & PN & Arkansas River & 12.5 & 33.2 \\
\hline 1305 & 110300047 & $\mathrm{ED}, \mathrm{PN}$ & Coon Creek & 4.80 & 3.85 \\
\hline 1306 & 110300048 & $\mathrm{ED}, \mathrm{HG}, \mathrm{FO}$ & Little Coon Creek & .79 & .48 \\
\hline 1307 & 110300049 & $\mathrm{ED}, \mathrm{FO}$ & Coon Creek & 1.45 & 1.15 \\
\hline 1308 & 110300049013 & BT, PN, RH & Dry Walnut Creek & 1.56 & 1.11 \\
\hline 1309 & 110300051 & PN & Pawnee River & 8.27 & 7.05 \\
\hline 1310 & 1103000510 & HG & Cottonwood Creek & 0 & 0 \\
\hline 1311 & 1103000511 & HG, NS & Sand Creek & 0 & 0 \\
\hline 1312 & 1103000512 & $\mathrm{PN}, \mathrm{RH}$ & Cocklebur Creek & 0 & 0 \\
\hline 1313 & 110300052 & $\mathrm{PN}$ & Pawnee River & 5.53 & 4.79 \\
\hline 1314 & 110300053 & $\mathrm{HG}, \mathrm{NS}, \mathrm{PN}$ & Pawnee River & 1.50 & 0 \\
\hline 1315 & 110300054 & HG, NS, LE & Hackberry Creek & 0 & 0 \\
\hline 1316 & 110300055 & FI, GY, HG & Pawnee River & 0 & 0 \\
\hline 1317 & 110300056 & $\mathrm{HG}, \mathrm{PN}$ & Sawmill Creek & .75 & .41 \\
\hline 1318 & 110300057 & $\mathrm{HG}, \mathrm{NS}$ & Plum Creek & 0 & 0 \\
\hline 1319 & 110300058 & FI, HG & Cottonwood Creek & 0 & 0 \\
\hline 1320 & 110300059 & FI, GY, HG & Sand Creek & 0 & 0 \\
\hline 1321 & 110300061 & $\mathrm{HG}, \mathrm{PN}$ & Buckner Creek & 4.06 & 2.94 \\
\hline 1322 & 110300062 & GY, HG & Buckner Creek & 1.15 & .65 \\
\hline 1323 & 110300063 & $\mathrm{FO}, \mathrm{HG}$ & Saw Log Creek & 1.85 & 1.25 \\
\hline 1324 & 110300064 & GY, FO, HG & Saw Log Creek & 0 & 0 \\
\hline 1325 & 110300065 & FO & Elm Creek & 0 & 0 \\
\hline 1326 & 110300066 & FO, GY, HG & South Fork Buckner Creek & 0 & 0 \\
\hline 1327 & 110300067 & HG & Spring Creek & 0 & 0 \\
\hline 1328 & 110300068 & FO & Duck Creek & 0 & 0 \\
\hline 1329 & 110300069 & HG & Rock Creek & 0 & 0 \\
\hline 1330 & 110300071 & NS & North Fork Walnut Creek & 2.42 & .48 \\
\hline 1331 & 1103000710 & LE, NS & South Fork Walnut Creek & 1.25 & 0 \\
\hline 1332 & 1103000711 & LE, NS & Wild Horse Creek & 0 & 0 \\
\hline
\end{tabular}


Table 6. Stream segments on the 1999 Kansas Surface Water Register, CUSEGA numbers, stream names, and estimated median flows at downstream end of CUSEGA segments using the most-recent 10 years of record (KSA) and all-available hydrology (AAH) analyses.-Continued

[Estimated median flows are rounded to two or three significant figures. Reporting estimated median values to three signficant figures (median greater than or equal to $1 \mathrm{ft}^{3} / \mathrm{s}$ ) or two significant figures (median less than $1 \mathrm{ft}^{3} / \mathrm{s}$ ) was done to conform with the intent of KSA $82 \mathrm{a}-2001$ et. seq. $\mathrm{ft}^{3} / \mathrm{s}$, cubic feet per second; KSA, Kansas Statute 82a-2001 analysis; AAH, all-available hydrology analysis]

\begin{tabular}{|c|c|c|c|c|c|}
\hline \multirow{2}{*}{$\begin{array}{c}\text { Stream segment } \\
\text { number } \\
\text { (figs. 9-113) }\end{array}$} & \multirow{2}{*}{ CUSEGA number } & \multirow{2}{*}{$\begin{array}{c}\text { County location } \\
\text { (abbreviation } \\
\text { explained in table 7) }\end{array}$} & \multirow{2}{*}{ Stream name } & \multicolumn{2}{|c|}{ Estimated median flows $\left(\mathrm{ft}^{3} / \mathrm{s}\right)$} \\
\hline & & & & KSA analysis & AAH analysis \\
\hline 1333 & 1103000712 & LE, NS & Darr Creek & 0.01 & 0 \\
\hline 1334 & 110300072 & NS & Long Branch Walnut Creek & .01 & 0 \\
\hline 1335 & 110300073 & NS & North Fork Walnut Creek & 1.93 & .35 \\
\hline 1336 & 110300074 & NS & Wild Horse Creek & .01 & 0 \\
\hline 1337 & 110300075 & NS & North Fork Walnut Creek & 1.29 & .15 \\
\hline 1338 & 110300076 & LE, NS & North Fork Walnut Creek & .02 & 0 \\
\hline 1339 & 110300077 & LE, NS & Middle Fork Walnut Creek & .11 & 0 \\
\hline 1340 & 110300078 & LE & North Fork of Middle Fork Walnut Creek & .01 & 0 \\
\hline 1341 & 110300079 & LE & Middle Fork Walnut Creek & .03 & 0 \\
\hline 1342 & 110300081 & BT & Walnut Creek & 27.7 & 4.51 \\
\hline 1343 & 1103000810 & NS & Walnut Creek & 7.20 & .57 \\
\hline 1344 & 1103000811 & RH & Sandy Creek & .01 & 0 \\
\hline 1345 & 1103000812 & RH & Otter Creek & .01 & 0 \\
\hline 1346 & 1103000813 & BT & Dry Walnut Creek & 0 & 0 \\
\hline 1347 & 1103000814 & BT, RH & Dry Creek & .01 & 0 \\
\hline 1348 & 1103000815 & BT, RH & Boot Creek & 0 & 0 \\
\hline 1349 & 110300082 & $\mathrm{BT}, \mathrm{RH}$ & Walnut Creek & 27.1 & 4.02 \\
\hline 1350 & 110300083 & RH & Sand Creek & .03 & 0 \\
\hline 1351 & 110300084 & RH & Walnut Creek & 16.5 & 1.37 \\
\hline 1352 & 110300085 & RH & Walnut Creek & 13.0 & 1.00 \\
\hline 1353 & 110300086 & NS, RH & Walnut Creek & 11.2 & .79 \\
\hline 1354 & 110300087 & NS, RH & Alexander Dry Creek & .01 & 0 \\
\hline 1355 & 110300088 & NS & Walnut Creek & 8.88 & .62 \\
\hline 1356 & 110300089 & NS & Bazine Creek & .02 & 0 \\
\hline 1357 & 110300091 & $\mathrm{RC}, \mathrm{SF}$ & Rattlesnake Creek & 8.05 & 24.0 \\
\hline 1358 & 110300092 & ED, SF, PN & Wildhorse Creek & 4.01 & 3.70 \\
\hline 1359 & 110300093 & $\mathrm{ED}, \mathrm{KW}, \mathrm{SF}$ & Rattlesnake Creek & 16.9 & 18.4 \\
\hline 1360 & 110300094 & $\mathrm{CA}, \mathrm{FO}, \mathrm{KW}$ & Rattlesnake Creek & 8.49 & 8.40 \\
\hline 1361 & 110300095 & $\mathrm{KW}$ & East Fork Rattlesnake Creek & 1.13 & 1.12 \\
\hline 1362 & 110300096 & $\mathrm{PN}, \mathrm{SF}$ & Little Wild Horse Creek & 0 & 0 \\
\hline 1363 & 110300097 & $\mathrm{SF}$ & Spring Creek & 0 & 0 \\
\hline 1364 & 110300098 & SF & Bear Creek & 0 & 0 \\
\hline 1365 & 110300099 & KW & South Branch Rattlesnake Creek & 1.70 & 1.72 \\
\hline 1366 & 110300101 & RN, SG & Arkansas River & 362 & 303 \\
\hline 1367 & 110300103 & $\mathrm{RN}$ & Arkansas River & 287 & 226 \\
\hline
\end{tabular}


Table 6. Stream segments on the 1999 Kansas Surface Water Register, CUSEGA numbers, stream names, and estimated median flows at downstream end of CUSEGA segments using the most-recent 10 years of record (KSA) and all-available hydrology (AAH) analyses.-Continued

[Estimated median flows are rounded to two or three significant figures. Reporting estimated median values to three signficant figures (median greater than or equal to $1 \mathrm{ft}^{3} / \mathrm{s}$ ) or two significant figures (median less than $1 \mathrm{ft}^{3} / \mathrm{s}$ ) was done to conform with the intent of KSA $82 \mathrm{a}-2001$ et. seq. $\mathrm{ft}^{3} / \mathrm{s}$, cubic feet per second; KSA, Kansas Statute 82a-2001 analysis; AAH, all-available hydrology analysis]

\begin{tabular}{|c|c|c|c|c|c|}
\hline \multirow{2}{*}{$\begin{array}{c}\text { Stream segment } \\
\text { number } \\
\text { (figs. 9-113) }\end{array}$} & \multirow{2}{*}{ CUSEGA number } & \multirow{2}{*}{$\begin{array}{c}\text { County location } \\
\text { (abbreviation } \\
\text { explained in table 7) }\end{array}$} & \multirow{2}{*}{ Stream name } & \multicolumn{2}{|c|}{ Estimated median flows $\left(\mathrm{ft}^{3} / \mathrm{s}\right)$} \\
\hline & & & & KSA analysis & AAH analysis \\
\hline 1368 & 110300104 & $\mathrm{RN}, \mathrm{RC}$ & Arkansas River & 279 & 219 \\
\hline 1369 & 110300105 & $\mathrm{RC}$ & Arkansas River & 264 & 207 \\
\hline 1370 & 110300106 & $\mathrm{RN}, \mathrm{RC}, \mathrm{SF}$ & Peace Creek & 6.67 & 6.59 \\
\hline 1371 & 110300107 & $\mathrm{RN}$ & Salt Creek & 5.66 & 5.41 \\
\hline 1372 & 110300108 & $\mathrm{RN}, \mathrm{SG}$ & Gar Creek & 3.44 & 2.90 \\
\hline 1373 & 110300109011 & $\mathrm{RN}, \mathrm{SG}$ & Big Slough & 4.59 & 4.11 \\
\hline 1374 & 110300109035 & RN, SG & South Fork Big Slough & 1.05 & 1.04 \\
\hline 1375 & 110300111 & $\mathrm{RN}, \mathrm{RC}$ & Cow Creek & 25.4 & 23.5 \\
\hline 1376 & 1103001113 & BT & Deception Creek & .72 & .50 \\
\hline 1377 & 1103001115 & $\mathrm{BT}, \mathrm{RH}$ & Blood Creek & .93 & .62 \\
\hline 1378 & 1103001116 & BT, EW, RC & Calf Creek & .18 & .06 \\
\hline 1379 & 1103001117 & EW, RC & Lost Creek & .13 & .04 \\
\hline 1380 & 110300111755 & $\mathrm{RN}$ & Cow Creek & 1.29 & 1.48 \\
\hline 1381 & 1103001118 & $\mathrm{RC}$ & Owl Creek & 0 & 0 \\
\hline 1382 & 1103001119 & $\mathrm{RC}$ & Jarvis Creek & .09 & .04 \\
\hline 1383 & 110300112 & $\mathrm{EW}, \mathrm{RC}$ & Little Cow Creek & 1.03 & .76 \\
\hline 1384 & 1103001120 & $\mathrm{RC}$ & Spring Creek & 1.16 & 1.09 \\
\hline 1385 & 1103001121 & $\mathrm{RC}$ & Salt Creek & 0 & 0 \\
\hline 1386 & 1103001122 & $\mathrm{RC}$ & Dry Creek & .67 & .73 \\
\hline 1387 & 110300113 & $\mathrm{RC}$ & Cow Creek & 11.4 & 10.5 \\
\hline 1388 & 110300114 & BT, EW, RC & Plum Creek & .97 & .68 \\
\hline 1389 & 110300115 & $\mathrm{BT}, \mathrm{RC}$ & Cow Creek & 6.26 & 5.63 \\
\hline 1390 & 110300116 & BT & Cow Creek & .15 & .13 \\
\hline 1391 & 110300117 & BT & Little Cheyenne Creek & 2.85 & 2.44 \\
\hline 1392 & 110300121 & SG & Little Arkansas River & 80.4 & 67.1 \\
\hline 1393 & 1103001210 & HV & Little Arkansas River & 27.7 & 25.7 \\
\hline 1394 & 1103001211 & HV, MP & Turkey Creek & 4.27 & 2.97 \\
\hline 1395 & 1103001212 & MP & Turkey Creek & 2.30 & 1.72 \\
\hline 1396 & 1103001213 & $\mathrm{MP}$ & Dry Turkey Creek & 2.10 & 1.50 \\
\hline 1397 & 1103001214 & EW, RC, HV, RN MP & Little Arkansas River & 18.8 & 19.4 \\
\hline 1398 & 1103001215 & $\mathrm{HV}, \mathrm{RN}$ & Kisiwa Creek & 9.51 & 9.17 \\
\hline 1399 & 1103001216 & $\mathrm{HV}$ & Mud Creek & 0 & 0 \\
\hline 1400 & 110300121693 & SG & Chisholm Creek & 2.24 & 1.90 \\
\hline 1401 & 1103001217 & HV, SG & Gooseberry Creek & .33 & .36 \\
\hline 1402 & 1103001218 & HV & West Fork Jester Creek & 0 & .01 \\
\hline 1403 & 1103001219 & $\mathrm{EW}, \mathrm{RC}$ & Horse Creek & .80 & .68 \\
\hline
\end{tabular}


Table 6. Stream segments on the 1999 Kansas Surface Water Register, CUSEGA numbers, stream names, and estimated median flows at downstream end of CUSEGA segments using the most-recent 10 years of record (KSA) and all-available hydrology (AAH) analyses.-Continued

[Estimated median flows are rounded to two or three significant figures. Reporting estimated median values to three signficant figures (median greater than or equal to $1 \mathrm{ft}^{3} / \mathrm{s}$ ) or two significant figures (median less than $1 \mathrm{ft}^{3} / \mathrm{s}$ ) was done to conform with the intent of KSA $82 \mathrm{a}-2001$ et. seq. $\mathrm{ft}^{3} / \mathrm{s}$, cubic feet per second; KSA, Kansas Statute 82a-2001 analysis; AAH, all-available hydrology analysis]

\begin{tabular}{|c|c|c|c|c|c|}
\hline \multirow{2}{*}{$\begin{array}{c}\text { Stream segment } \\
\text { number } \\
\text { (figs. 9-113) }\end{array}$} & \multirow{2}{*}{ CUSEGA number } & \multirow{2}{*}{$\begin{array}{c}\text { County location } \\
\text { (abbreviation } \\
\text { explained in table 7) }\end{array}$} & \multirow{2}{*}{ Stream name } & \multicolumn{2}{|c|}{ Estimated median flows $\left(\mathrm{ft}^{3} / \mathrm{s}\right)$} \\
\hline & & & & KSA analysis & $\mathrm{AAH}$ analysis \\
\hline 1404 & 110300122 & HV, SG & Jester Creek & 4.74 & 4.12 \\
\hline 1405 & 1103001220 & MP & Lone Tree Creek & 2.00 & 1.47 \\
\hline 1406 & 1103001221 & $\mathrm{RC}$ & Salt Creek & .03 & 0 \\
\hline 1407 & 1103001222 & $\mathrm{RC}$ & Dry Creek & 0 & 0 \\
\hline 1408 & 1103001223 & $\mathrm{MP}, \mathrm{RC}$ & Sand Creek & 4.47 & 4.90 \\
\hline 1409 & 1103001224 & MP & Bull Creek & .43 & .26 \\
\hline 1410 & 1103001225 & MP & Running Turkey Creek & 1.00 & .74 \\
\hline 1411 & 1103001226 & HV & Beaver Creek & .05 & 0 \\
\hline 1412 & 110300123 & HV, SG & Little Arkansas River & 63.4 & 52.3 \\
\hline 1413 & 11030012368 & HV, MP & Black Kettle Creek & 2.27 & 1.80 \\
\hline 1414 & 110300124 & $\mathrm{HV}, \mathrm{MN}$ & Sand Creek & 4.22 & 3.26 \\
\hline 1415 & 110300125 & HV & Little Arkansas River & 52.4 & 44.1 \\
\hline 1416 & 110300126 & $\mathrm{HV}$ & Emma Creek & 6.95 & 5.58 \\
\hline 1417 & 110300127 & HV, MN, MP & Middle Emma Creek & 2.11 & 1.66 \\
\hline 1418 & 110300128 & HV, MP & West Emma Creek & 3.55 & 2.94 \\
\hline 1419 & 11030012817 & SG & Middle Fork Chisholm Creek & .99 & .82 \\
\hline 1420 & 110300129 & $\mathrm{HV}$ & Little Arkansas River & 40.1 & 35.8 \\
\hline 1421 & 110300131 & $\mathrm{CL}, \mathrm{SU}$ & Arkansas River & 1,170 & 1,030 \\
\hline 1422 & 1103001310 & SG, SU & Cowskin Creek & 5.33 & 5.12 \\
\hline 1423 & 1103001311 & SG & Big Slough & 3.26 & 3.53 \\
\hline 1424 & 1103001312 & SG & Cowskin Creek & 11.1 & 9.71 \\
\hline 1425 & 1103001313 & SG & Cowskin Creek & 8.75 & 7.74 \\
\hline 1426 & 1103001314 & SG & Cowskin Creek & 3.46 & 3.11 \\
\hline 1427 & 1103001315 & SG & Dry Creek & 2.88 & 2.69 \\
\hline 1428 & 1103001316 & SG & Dry Creek & 1.88 & 1.69 \\
\hline 1429 & 1103001317 & SU & Slate Creek & 17.4 & 15.1 \\
\hline 1430 & 1103001318 & SU & Arkansas River & 718 & 598 \\
\hline 1431 & 1103001319 & $\mathrm{CL}, \mathrm{SU}$ & Spring Creek & .43 & .52 \\
\hline 1432 & 110300132 & $\mathrm{CL}, \mathrm{SU}$ & Arkansas River & 1,100 & 964 \\
\hline 1433 & 1103001320 & $\mathrm{CL}, \mathrm{SU}$ & Negro Creek & .31 & .38 \\
\hline 1434 & 1103001321 & $\mathrm{CL}$ & Spring Creek & 1.65 & 1.84 \\
\hline 1435 & 1103001322 & $\mathrm{CL}, \mathrm{SU}$ & Salt Creek & 1.13 & 1.02 \\
\hline 1436 & 1103001323 & SU & Lost Creek & 0 & 0 \\
\hline 1437 & 1103001324 & SU & Hargis Creek & .61 & .54 \\
\hline 1438 & 1103001325 & SU & Antelope Creek & .58 & .50 \\
\hline
\end{tabular}


Table 6. Stream segments on the 1999 Kansas Surface Water Register, CUSEGA numbers, stream names, and estimated median flows at downstream end of CUSEGA segments using the most-recent 10 years of record (KSA) and all-available hydrology (AAH) analyses.-Continued

[Estimated median flows are rounded to two or three significant figures. Reporting estimated median values to three signficant figures (median greater than or equal to $1 \mathrm{ft}^{3} / \mathrm{s}$ ) or two significant figures (median less than $1 \mathrm{ft}^{3} / \mathrm{s}$ ) was done to conform with the intent of KSA $82 \mathrm{a}-2001$ et. seq. $\mathrm{ft}^{3} / \mathrm{s}$, cubic feet per second; KSA, Kansas Statute 82a-2001 analysis; AAH, all-available hydrology analysis]

\begin{tabular}{|c|c|c|c|c|c|}
\hline \multirow{2}{*}{$\begin{array}{c}\text { Stream segment } \\
\text { number } \\
\text { (figs. 9-113) }\end{array}$} & \multirow{2}{*}{ CUSEGA number } & \multirow{2}{*}{$\begin{array}{l}\text { County location } \\
\text { (abbreviation } \\
\text { explained in table 7) }\end{array}$} & \multirow{2}{*}{ Stream name } & \multicolumn{2}{|c|}{ Estimated median flows $\left(\mathrm{ft}^{3} / \mathrm{s}\right)$} \\
\hline & & & & KSA analysis & AAH analysis \\
\hline 1439 & 1103001326 & SU & Oak Creek & 0.39 & 0.34 \\
\hline 1440 & 1103001327 & SU & Spring Creek & .28 & .23 \\
\hline 1441 & 1103001328 & SG, SU & Bitter Creek & .06 & 0 \\
\hline 1442 & 1103001329 & SU & Beaver Creek & 0 & 0 \\
\hline 1443 & 110300133 & SG, SU & Arkansas River & 673 & 554 \\
\hline 1444 & 1103001331 & SU & Badger Creek & .51 & .43 \\
\hline 1445 & 1103001332 & SU & Winser Creek & .66 & .55 \\
\hline 1446 & 1103001333 & $\mathrm{CL}$ & Beaver Creek & .75 & .82 \\
\hline 1447 & 1103001334 & $\mathrm{CL}, \mathrm{SU}$ & Spring Creek & 1.90 & 1.97 \\
\hline 1448 & 1103001337 & SG & Spring Creek & 1.87 & 1.63 \\
\hline 1449 & 110300134 & SG & Chisholm Creek & 5.41 & 4.80 \\
\hline 1450 & 110300135 & SG & Gypsum Creek & 1.72 & 1.44 \\
\hline 1451 & 11030013531 & SG, SU & Dog Creek & 1.62 & 1.59 \\
\hline 1452 & 110300136 & SG & Chisholm Creek & 3.25 & 3.14 \\
\hline 1453 & 110300137 & SG & East Fork Chisholm Creek & .78 & .71 \\
\hline 1454 & 110300138 & SG & Chisholm Creek & 0 & 0 \\
\hline 1455 & 110300139 & SG & Arkansas River & 520 & 433 \\
\hline 1456 & 110300139001 & SG & Wichita-Valley Center Floodway & .74 & .50 \\
\hline 1457 & 110300139010 & SG & Wichita-Valley Center Floodway & 17.5 & 16.0 \\
\hline 1458 & 110300139011 & SG & Wichita-Valley Center Floodway & 5.89 & 6.10 \\
\hline 1459 & 110300141 & $\mathrm{RN}, \mathrm{SG}$ & North Fork Ninnescah River & 14.4 & 13.9 \\
\hline 1460 & 1103001410 & $\mathrm{KM}, \mathrm{RN}$ & Goose Creek & 2.63 & 2.39 \\
\hline 1461 & 1103001411 & RN & Crow Creek & 2.50 & 2.23 \\
\hline 1462 & 1103001412 & $\mathrm{RN}$ & Red Rock Creek & 3.49 & 3.22 \\
\hline 1463 & 1103001413 & RN, SG & Rock Creek & 1.08 & .94 \\
\hline 1464 & 1103001414 & $\mathrm{RN}, \mathrm{SG}$ & Spring Creek & 1.86 & 1.70 \\
\hline 1465 & 11030014289 & $\mathrm{RN}$ & Unnamed tributary, Reno 2 & 1.64 & 1.94 \\
\hline 1466 & 11030014411 & $\mathrm{KM}, \mathrm{SG}$ & Unnamed tributary, Kingman 12 & .71 & .87 \\
\hline 1467 & 110300145 & $\mathrm{RN}$ & North Fork Ninnescah River & 84.4 & 81.3 \\
\hline 1468 & 110300146 & $\mathrm{RN}, \mathrm{SF}$ & North Fork Ninnescah River & 25.6 & 25.0 \\
\hline 1469 & 110300147 & KM, PR, RN & Silver Creek & 20.2 & 19.1 \\
\hline 1470 & 110300148 & SF & Dooleyville Creek & .19 & .22 \\
\hline 1471 & 110300149 & $\mathrm{RN}$ & Wolf Creek & 2.04 & 2.27 \\
\hline 1472 & 110300151 & $\mathrm{KM}, \mathrm{SG}$ & South Fork Ninnescah River & 159 & 157 \\
\hline 1473 & 1103001510 & KM & Mead Creek & .10 & 0 \\
\hline 1474 & 1103001511 & KM & Pat Creek & .20 & .10 \\
\hline
\end{tabular}


Table 6. Stream segments on the 1999 Kansas Surface Water Register, CUSEGA numbers, stream names, and estimated median flows at downstream end of CUSEGA segments using the most-recent 10 years of record (KSA) and all-available hydrology (AAH) analyses.-Continued

[Estimated median flows are rounded to two or three significant figures. Reporting estimated median values to three signficant figures (median greater than or equal to $1 \mathrm{ft}^{3} / \mathrm{s}$ ) or two significant figures (median less than $1 \mathrm{ft}^{3} / \mathrm{s}$ ) was done to conform with the intent of KSA $82 \mathrm{a}-2001$ et. seq. $\mathrm{ft}^{3} / \mathrm{s}$, cubic feet per second; KSA, Kansas Statute 82a-2001 analysis; AAH, all-available hydrology analysis]

\begin{tabular}{|c|c|c|c|c|c|}
\hline \multirow{2}{*}{$\begin{array}{c}\text { Stream segment } \\
\text { number } \\
\text { (figs. 9-113) }\end{array}$} & \multirow{2}{*}{ CUSEGA number } & \multirow{2}{*}{$\begin{array}{c}\text { County location } \\
\text { (abbreviation } \\
\text { explained in table 7) }\end{array}$} & \multirow{2}{*}{ Stream name } & \multicolumn{2}{|c|}{ Estimated median flows $\left(\mathrm{ft}^{3} / \mathrm{s}\right)$} \\
\hline & & & & KSA analysis & $\mathrm{AAH}$ analysis \\
\hline 1475 & 1103001512 & KM & Petyt Creek & 0.96 & 1.05 \\
\hline 1476 & 1103001513 & KM & Negro Creek & .43 & .50 \\
\hline 1477 & 1103001514 & KM & Hunter Creek & 1.97 & 2.03 \\
\hline 1478 & 1103001515 & KM & Nester Creek & 2.39 & 2.39 \\
\hline 1479 & 1103001516 & KM & Wild Run Creek & .83 & 1.01 \\
\hline 1480 & 1103001517 & $\mathrm{KM}$ & Coon Creek & 1.26 & 1.26 \\
\hline 1481 & 1103001518 & KM & Sand Creek & 2.04 & 2.14 \\
\hline 1482 & 1103001519 & $\mathrm{KM}, \mathrm{SG}$ & Mod Creek & .07 & .08 \\
\hline 1483 & 110300152 & $\mathrm{KM}, \mathrm{RN}$ & Smoots Creek & 14.9 & 14.1 \\
\hline 1484 & 11030015249 & KM & Unnamed tributary, Kingman 10 & .01 & 0 \\
\hline 1485 & 11030015253 & $\mathrm{KM}$ & Unnamed tributary, Kingman 6 & .24 & 0 \\
\hline 1486 & 11030015259 & KM & Unnamed tributary, Kingman 5 & .40 & .20 \\
\hline 1487 & 11030015261 & KM & Unnamed tributary, Kingman 4 & .06 & 0 \\
\hline 1488 & 11030015270 & KM & Unnamed tributary, Kingman 3 & .39 & .05 \\
\hline 1489 & 11030015271 & KM & Unnamed tributary, Kingman 2 & .36 & .20 \\
\hline 1490 & 110300153 & KM & South Fork Ninnescah River & 136 & 135 \\
\hline 1491 & 11030015307 & PR & Natrona Creek & 3.35 & 3.27 \\
\hline 1492 & 110300154 & KM, PR & South Fork Ninnescah River & 48.3 & 47.3 \\
\hline 1493 & 11030015417 & KM & Unnamed tributary, Kingman 1 & 0 & 0 \\
\hline 1494 & 110300155 & $\mathrm{PR}$ & West Branch of South Fork Ninnescah River & 6.55 & 6.30 \\
\hline 1495 & 11030015514 & $\mathrm{KM}$ & Unnamed tributary, Kingman 8 & .92 & 1.16 \\
\hline 1496 & 11030015518 & KM & Unnamed tributary, Kingman 7 & 0 & 0 \\
\hline 1497 & 11030015520 & KM & Unnamed tributary, Kingman 9 & 0 & 0 \\
\hline 1498 & 11030015579 & KM & Unnamed tributary, Kingman 11 & 2.05 & 2.64 \\
\hline 1499 & 110300156 & PR & South Fork Ninnescah River & 1.05 & .95 \\
\hline 1500 & 110300157 & $\mathrm{KM}, \mathrm{PR}$ & Painter Creek & 3.76 & 3.48 \\
\hline 1501 & 110300158 & $\mathrm{KM}, \mathrm{RN}$ & Spring Creek & 2.98 & 2.77 \\
\hline 1502 & 110300159 & PR & Coon Creek & .10 & .05 \\
\hline 1503 & 110300161 & SU & Ninnescah River & 221 & 215 \\
\hline 1504 & 1103001610 & SU & Elm Creek & 0 & .01 \\
\hline 1505 & 1103001611 & SU & Garvey Creek & 0 & 0 \\
\hline 1506 & 1103001612 & SG, SU & Silver Creek & 0 & 0 \\
\hline 1507 & 1103001613 & SG, SU & Turtle Creek & 0 & 0 \\
\hline 1508 & 1103001614 & $\mathrm{KM}, \mathrm{SG}$ & Sand Creek & 3.50 & 3.07 \\
\hline 1509 & 11030016148 & SG & Afton Creek & .97 & .94 \\
\hline
\end{tabular}


Table 6. Stream segments on the 1999 Kansas Surface Water Register, CUSEGA numbers, stream names, and estimated median flows at downstream end of CUSEGA segments using the most-recent 10 years of record (KSA) and all-available hydrology (AAH) analyses.-Continued

[Estimated median flows are rounded to two or three significant figures. Reporting estimated median values to three signficant figures (median greater than or equal to $1 \mathrm{ft}^{3} / \mathrm{s}$ ) or two significant figures (median less than $1 \mathrm{ft}^{3} / \mathrm{s}$ ) was done to conform with the intent of KSA $82 \mathrm{a}-2001$ et. seq. $\mathrm{ft}^{3} / \mathrm{s}$, cubic feet per second; KSA, Kansas Statute 82a-2001 analysis; AAH, all-available hydrology analysis]

\begin{tabular}{|c|c|c|c|c|c|}
\hline \multirow{2}{*}{$\begin{array}{c}\text { Stream } \\
\text { segment } \\
\text { number } \\
\text { (figs. 9-113) }\end{array}$} & \multirow[b]{2}{*}{ CUSEGA number } & \multirow{2}{*}{$\begin{array}{c}\text { County location } \\
\text { (abbreviation explained } \\
\text { in (table 7) }\end{array}$} & \multirow[b]{2}{*}{ Stream name } & \multicolumn{2}{|c|}{ Estimated median flows $\left(\mathrm{ft}^{3} / \mathrm{s}\right)$} \\
\hline & & & & KSA analysis & AAH analysis \\
\hline 1510 & 1103001615 & SG & Spring Creek & 1.44 & 1.38 \\
\hline 1511 & 1103001616 & SG & Dry Creek & .43 & .47 \\
\hline 1512 & 11030016161 & SG & Clear Creek & 0 & 0 \\
\hline 1513 & 110300162 & $\mathrm{SG}, \mathrm{SU}$ & Spring Creek & 3.39 & 2.98 \\
\hline 1514 & 110300163 & $\mathrm{SG}, \mathrm{SU}$ & Ninnescah River & 218 & 212 \\
\hline 1515 & 110300164 & SG & Clearwater Creek & 4.88 & 4.19 \\
\hline 1516 & 1103001659 & SG & Polecat Creek & .90 & .87 \\
\hline 1517 & 110300167 & SG & Clearwater Creek & 2.61 & 2.28 \\
\hline 1518 & 110300168 & SG & Ninnescah River & 193 & 191 \\
\hline 1519 & 1103001710 & BU & Satchel Creek & 2.10 & 1.67 \\
\hline 1520 & 1103001712 & BU & Durechen Creek & 2.00 & 1.54 \\
\hline 1521 & 1103001714 & BU & Walnut River & 2.19 & 1.63 \\
\hline 1522 & 1103001715 & BU & Cole Creek & 2.39 & 2.33 \\
\hline 1523 & 1103001716 & BU & West Branch Walnut River & 3.54 & 2.87 \\
\hline 1524 & 1103001717 & $\mathrm{BU}$ & Whitewater River & 45.0 & 40.9 \\
\hline 1525 & 1103001718 & BU & Whitewater River & 41.9 & 38.4 \\
\hline 1526 & 1103001719 & $\mathrm{BU}$ & Whitewater River & 15.6 & 13.5 \\
\hline 1527 & 110300172 & BU & Walnut River & 34.0 & 37.8 \\
\hline 1528 & 1103001720 & BU & Fourmile Creek & 1.18 & .89 \\
\hline 1529 & 1103001721 & $\mathrm{BU}$ & Whitewater River & 9.15 & 7.70 \\
\hline 1530 & 11030017213 & BU & Bird Creek & 2.15 & 1.71 \\
\hline 1531 & 1103001722 & BU, MN & East Branch Whitewater River & 1.28 & .97 \\
\hline 1532 & 1103001723 & BU, MN & Whitewater River & 3.27 & 2.59 \\
\hline 1533 & 1103001724 & $\mathrm{BU}$ & West Branch Whitewater River & 13.7 & 11.7 \\
\hline 1534 & 1103001725 & $\mathrm{BU}, \mathrm{HV}$ & West Branch Whitewater River & 5.51 & 4.52 \\
\hline 1535 & 1103001726 & BU, SG, HV & Wildcat Creek & 2.25 & 1.82 \\
\hline 1536 & 1103001727 & BU, SG & Dry Creek & 2.48 & 1.91 \\
\hline 1537 & 1103001728 & $\mathrm{HV}$ & West Wildcat Creek & .06 & .06 \\
\hline 1538 & 1103001729 & $\mathrm{HV}, \mathrm{SG}$ & Sand Creek & 0 & .01 \\
\hline 1539 & 110300173 & $\mathrm{BU}$ & Walnut River & 18.3 & 19.9 \\
\hline 1540 & 1103001730 & $\mathrm{HV}$ & Gypsum Creek & .30 & .23 \\
\hline 1541 & 1103001731 & HV & East Branch Whitewater Creek & .48 & .34 \\
\hline 1542 & 1103001732 & BU & Dry Creek & .82 & .61 \\
\hline
\end{tabular}


Table 6. Stream segments on the 1999 Kansas Surface Water Register, CUSEGA numbers, stream names, and estimated median flows at downstream end of CUSEGA segments using the most-recent 10 years of record (KSA) and all-available hydrology (AAH) analyses.-Continued

[Estimated median flows are rounded to two or three significant figures. Reporting estimated median values to three signficant figures (median greater than or equal to $1 \mathrm{ft}^{3} / \mathrm{s}$ ) or two significant figures (median less than $1 \mathrm{ft}^{3} / \mathrm{s}$ ) was done to conform with the intent of KSA $82 \mathrm{a}-2001$ et. seq. $\mathrm{ft}^{3} / \mathrm{s}$, cubic feet per second; KSA, Kansas Statute 82a-2001 analysis; AAH, all-available hydrology analysis]

\begin{tabular}{|c|c|c|c|c|c|}
\hline \multirow{2}{*}{$\begin{array}{c}\text { Stream } \\
\text { segment } \\
\text { number } \\
\text { (figs. 9-113) }\end{array}$} & \multirow[b]{2}{*}{ CUSEGA number } & \multirow{2}{*}{$\begin{array}{c}\text { County location } \\
\text { (abbreviation explained } \\
\text { in (table 7) }\end{array}$} & \multirow[b]{2}{*}{ Stream name } & \multicolumn{2}{|c|}{ Estimated median flows $\left(\mathrm{ft}^{3} / \mathrm{s}\right)$} \\
\hline & & & & KSA analysis & AAH analysis \\
\hline 1543 & 1103001733 & $\mathrm{BU}, \mathrm{MN}$ & Henry Creek & 0.96 & 0.71 \\
\hline 1544 & 1103001734 & BU, SG & Whitewater Creek & .82 & .62 \\
\hline 1545 & 1103001735 & BU, SG & Prairie Creek & .73 & .56 \\
\hline 1546 & 1103001736 & $\mathrm{BU}$ & Badger Creek & .42 & .34 \\
\hline 1547 & 1103001737 & BU & Rock Creek & 1.27 & .98 \\
\hline 1548 & 1103001739 & BU & Gilmore Branch & 0 & 0 \\
\hline 1549 & 1103001740 & BU & Sutton Creek & .36 & .32 \\
\hline 1550 & 1103001741 & BU & Constant Creek & .35 & .30 \\
\hline 1551 & 1103001742 & BU & Lower Branch & 2.36 & 1.90 \\
\hline 1552 & 1103001743 & BU & Elm Creek & .58 & .50 \\
\hline 1553 & 1103001744 & $\mathrm{HV}$ & Walnut Creek & .01 & .01 \\
\hline 1554 & 1103001745 & BU & School Branch & .09 & .02 \\
\hline 1555 & 110300178 & BU & Bemis Creek & 3.20 & 2.53 \\
\hline 1556 & 110300181 & $\mathrm{CL}$ & Walnut River & 241 & 276 \\
\hline 1557 & 1103001810 & $\mathrm{BU}, \mathrm{CL}$ & Walnut River & 155 & 177 \\
\hline 1558 & 1103001811 & BU & Little Walnut River & 20.3 & 16.7 \\
\hline 1559 & 1103001812 & BU & Hickory Creek & 7.80 & 6.39 \\
\hline 1560 & 1103001813 & BU & Little Walnut River & 11.0 & 8.95 \\
\hline 1561 & 1103001814 & BU & Walnut River & 119 & 136 \\
\hline 1562 & 1103001815 & BU & Walnut River & 109 & 124 \\
\hline 1563 & 1103001816 & BU, SG & Fourmile Creek & 3.69 & 2.92 \\
\hline 1564 & 1103001817 & BU, CL, SG & Polecat Creek & 1.89 & 1.42 \\
\hline 1565 & 1103001818 & $\mathrm{CL}$ & Black Crook Creek & 1.34 & 1.14 \\
\hline 1566 & 1103001819 & $\mathrm{CL}$ & Cedar Creek & 1.27 & 1.03 \\
\hline 1567 & 110300182 & $\mathrm{CL}$ & Timber Creek & 10.7 & 8.55 \\
\hline 1568 & 1103001820 & $\mathrm{CL}$ & Lower Dutch Creek & 0 & 0 \\
\hline 1569 & 1103001821 & BU & Chigger Creek & 0 & .02 \\
\hline 1570 & 1103001822 & BU & Swisher Branch & 0 & 0 \\
\hline 1571 & 1103001823 & $\mathrm{CL}$ & Durham Creek & 0 & 0 \\
\hline 1572 & 1103001824 & CL & Stalter Branch & 0 & 0 \\
\hline 1573 & 1103001825 & $\mathrm{CL}$ & Richland Creek & .36 & .29 \\
\hline 1574 & 1103001826 & CL & Foos Creek & .44 & .40 \\
\hline 1575 & 1103001827 & $\mathrm{CL}$ & Little Dutch Creek & .46 & .38 \\
\hline 1576 & 1103001828 & CL & Stewart Creek & .54 & .38 \\
\hline 1577 & 1103001829 & $\mathrm{CL}$ & Sanford Creek & 0 & 0 \\
\hline
\end{tabular}


Table 6. Stream segments on the 1999 Kansas Surface Water Register, CUSEGA numbers, stream names, and estimated median flows at downstream end of CUSEGA segments using the most-recent 10 years of record (KSA) and all-available hydrology (AAH) analyses.-Continued

[Estimated median flows are rounded to two or three significant figures. Reporting estimated median values to three signficant figures (median greater than or equal to $1 \mathrm{ft}^{3} / \mathrm{s}$ ) or two significant figures (median less than $1 \mathrm{ft}^{3} / \mathrm{s}$ ) was done to conform with the intent of KSA 82a-2001 et. seq. $\mathrm{ft}^{3} / \mathrm{s}$, cubic feet per second; KSA, Kansas Statute 82a-2001 analysis; AAH, all-available hydrology analysis]

\begin{tabular}{|c|c|c|c|c|c|}
\hline \multirow{2}{*}{$\begin{array}{c}\text { Stream } \\
\text { segment } \\
\text { number } \\
\text { (figs. 9-113) }\end{array}$} & \multirow[b]{2}{*}{ CUSEGA number } & \multirow{2}{*}{$\begin{array}{c}\text { County location } \\
\text { (abbreviation explained } \\
\text { in (table 7) }\end{array}$} & \multirow[b]{2}{*}{ Stream name } & \multicolumn{2}{|c|}{ Estimated median flows $\left(\mathrm{ft}^{3} / \mathrm{s}\right)$} \\
\hline & & & & KSA analysis & AAH analysis \\
\hline 1578 & 110300183 & $\mathrm{BU}, \mathrm{CL}$ & Timber Creek & 4.32 & 3.51 \\
\hline 1579 & 1103001830 & $\mathrm{BU}, \mathrm{CL}, \mathrm{SG}$ & Eightmile Creek & 2.86 & 2.30 \\
\hline 1580 & 1103001831 & $\mathrm{CL}$ & Crooked Creek & .20 & .25 \\
\hline 1581 & 1103001832 & SG & Spring Branch & 0 & 0 \\
\hline 1582 & 1103001833 & $\mathrm{BU}$ & Honey Creek & .69 & .59 \\
\hline 1583 & 1103001834 & $\mathrm{BU}, \mathrm{GW}$ & South Branch Little Walnut River & 3.17 & 2.60 \\
\hline 1584 & 1103001835 & BU & North Branch Rock Creek & 1.47 & 1.23 \\
\hline 1585 & 1103001836 & $\mathrm{BU}$ & Plum Creek & .92 & .84 \\
\hline 1586 & 1103001837 & $\mathrm{CL}$ & Posey Creek & .99 & .91 \\
\hline 1587 & 110300184 & $\mathrm{BU}, \mathrm{CL}$ & Dutch Creek & 3.21 & 2.54 \\
\hline 1588 & 110300185 & $\mathrm{CL}$ & Walnut River & 206 & 236 \\
\hline 1589 & 110300186 & $\mathrm{BU}, \mathrm{CL}$ & Rock Creek & 9.18 & 7.37 \\
\hline 1590 & 110300187 & $\mathrm{CL}$ & Walnut River & 175 & 201 \\
\hline 1591 & 110300188 & $\mathrm{CL}$ & Walnut River & 169 & 194 \\
\hline 1592 & 110300189 & $\mathrm{BU}, \mathrm{CL}$ & Muddy Creek & 3.33 & 2.74 \\
\hline 1593 & 110300189012 & $\mathrm{BU}$ & North Branch Hickory Creek & 1.80 & 1.54 \\
\hline 1594 & 110400021 & GT, SV, MT & Cimarron River & 3.19 & 3.80 \\
\hline 1595 & 110400031 & GT & North Fork Cimarron River & 5.94 & 7.48 \\
\hline 1596 & 110400032 & GT, MT, ST, SV & North Fork Cimarron River & 1.23 & 1.54 \\
\hline 1597 & 110400033 & MT & Unnamed tributary, Morton 1 & .02 & .02 \\
\hline 1598 & 110400034 & MT & North Fork Cimarron River & 0 & 0 \\
\hline 1599 & 110400041 & GT, ST & Sand Arroyo Creek & .47 & .59 \\
\hline 1600 & 110400051 & GT, KE, ST & Bear Creek & 0 & 0 \\
\hline 1601 & 1104000510 & ST & Buffalo Creek & 0 & 0 \\
\hline 1602 & 1104000511 & ST & Bear Creek & 0 & 0 \\
\hline 1603 & 110400052 & GT, HM, ST & Wolf Creek & 0 & 0 \\
\hline 1604 & 110400055 & $\mathrm{HM}$ & Dry Creek & 0 & 0 \\
\hline 1605 & 110400056 & HM & North Bear Creek & 0 & 0 \\
\hline 1606 & 110400057 & $\mathrm{HM}, \mathrm{ST}$ & Little Bear Creek & 0 & 0 \\
\hline 1607 & 110400058 & ST & Beaty Creek & 0 & 0 \\
\hline 1608 & 110400059 & ST & Bear Creek & 0 & 0 \\
\hline 1609 & 110400061 & ME & Cimarron River & 45.8 & 51.0 \\
\hline 1610 & 110400062 & GT, HS, SW, ME & Cimarron River & 35.8 & 42.5 \\
\hline
\end{tabular}


Table 6. Stream segments on the 1999 Kansas Surface Water Register, CUSEGA numbers, stream names, and estimated median flows at downstream end of CUSEGA segments using the most-recent 10 years of record (KSA) and all-available hydrology (AAH) analyses.-Continued

[Estimated median flows are rounded to two or three significant figures. Reporting estimated median values to three signficant figures (median greater than or equal to $1 \mathrm{ft}^{3} / \mathrm{s}$ ) or two significant figures (median less than $1 \mathrm{ft}^{3} / \mathrm{s}$ ) was done to conform with the intent of KSA $82 \mathrm{a}-2001$ et. seq. $\mathrm{ft}^{3} / \mathrm{s}$, cubic feet per second; KSA, Kansas Statute 82a-2001 analysis; AAH, all-available hydrology analysis]

\begin{tabular}{|c|c|c|c|c|c|}
\hline \multirow{2}{*}{$\begin{array}{c}\text { Stream } \\
\text { segment } \\
\text { number } \\
\text { (figs. 9-113) }\end{array}$} & \multirow[b]{2}{*}{ CUSEGA number } & \multirow{2}{*}{$\begin{array}{c}\text { County location } \\
\text { (abbreviation explained } \\
\text { in (table 7) }\end{array}$} & \multirow[b]{2}{*}{ Stream name } & \multicolumn{2}{|c|}{ Estimated median flows $\left(\mathrm{ft}^{3} / \mathrm{s}\right)$} \\
\hline & & & & KSA analysis & AAH analysis \\
\hline 1611 & 110400071 & $\mathrm{ME}$ & Crooked Creek & 8.70 & 12.0 \\
\hline 1612 & 110400071180 & ME & Unnamed tributary, Meade 1 & 0 & 0 \\
\hline 1613 & 110400071247 & ME & Stumpie Arroyo & .02 & 0 \\
\hline 1614 & 110400071253 & ME & Unnamed tributary, Meade 2 & 0 & 0 \\
\hline 1615 & 110400071259 & ME & Unnamed tributary, Meade 3 & 0 & .02 \\
\hline 1616 & 110400072 & FO, ME, GY, HS & Crooked Creek & 2.96 & 4.26 \\
\hline 1617 & 110400073 & ME & Spring Creek & .05 & .05 \\
\hline 1618 & 110400074 & $\mathrm{ME}$ & Crooked Creek tributary & 0 & 0 \\
\hline 1619 & 110400081 & $\mathrm{CM}$ & Cimarron River & 101 & 109 \\
\hline 1620 & 1104000810 & $\mathrm{CA}, \mathrm{ME}$ & Ballard Creek & 1.71 & 1.75 \\
\hline 1621 & 1104000811 & $\mathrm{CA}$ & Cimarron River & 76.4 & 79.9 \\
\hline 1622 & 110400081173 & CM, KW & Wiggins Creek & 0 & 0 \\
\hline 1623 & 110400081180 & $\mathrm{CA}, \mathrm{CM}, \mathrm{KW}$ & West Kiowa Creek & 4.38 & 3.68 \\
\hline 1624 & 110400081182 & $\mathrm{CM}, \mathrm{KW}$ & Middle Kiowa Creek & .95 & .81 \\
\hline 1625 & 1104000812 & $\mathrm{CM}, \mathrm{KW}$ & Kiowa Creek & 7.89 & 6.80 \\
\hline 1626 & 1104000813 & $\mathrm{CA}, \mathrm{CM}, \mathrm{FO}$ & Bluff Creek & 5.74 & 4.62 \\
\hline 1627 & 1104000814 & $\mathrm{CA}$ & Indian Creek & 0 & 0 \\
\hline 1628 & 1104000815 & $\mathrm{CA}, \mathrm{ME}$ & Twomile Creek & 0 & 0 \\
\hline 1629 & 1104000816 & $\mathrm{CA}$ & Antelope Creek & 0 & 0 \\
\hline 1630 & 1104000817 & $\mathrm{CA}$ & Stink Creek & 0 & 0 \\
\hline 1631 & 1104000818 & $\mathrm{CA}$ & Bear Creek & 1.57 & 1.31 \\
\hline 1632 & 1104000819 & $\mathrm{CA}, \mathrm{CM}$ & Trout Creek & .91 & .97 \\
\hline 1633 & 110400082 & $\mathrm{CM}$ & Bluff Creek & 23.3 & 21.2 \\
\hline 1634 & 1104000820 & $\mathrm{CA}$ & Day Creek & 1.19 & .94 \\
\hline 1635 & 1104000821 & $\mathrm{CA}$ & Snake Creek & 2.06 & 1.93 \\
\hline 1636 & 1104000825 & $\mathrm{CA}, \mathrm{ME}$ & Gyp Creek & .12 & .06 \\
\hline 1637 & 110400083 & $\mathrm{CM}, \mathrm{KW}$ & Cavalry Creek & 14.6 & 13.4 \\
\hline 1638 & 110400085 & $\mathrm{CA}, \mathrm{CM}$ & Cimarron River & 88.3 & 94.3 \\
\hline 1639 & 110400086 & $\mathrm{CA}$ & Big Sandy Creek & 13.0 & 11.7 \\
\hline 1640 & 11040008652 & $\mathrm{CA}$ & Little Sandy Creek & 1.19 & .92 \\
\hline 1641 & 110400087 & $\mathrm{CA}$ & Big Sandy Creek & 6.78 & 5.97 \\
\hline 1642 & 110400088 & CA & Keiger Creek & .38 & .35 \\
\hline 1643 & 110400089 & $\mathrm{CA}, \mathrm{ME}$ & Big Sandy Creek & 5.34 & 4.68 \\
\hline 1644 & 1105000124 & $\mathrm{CM}$ & Unnamed tributary, Comanche 3 & .89 & .96 \\
\hline 1645 & 1105000139 & $\mathrm{CM}$ & Unnamed tributary, Comanche 2 & 0 & 0 \\
\hline
\end{tabular}


Table 6. Stream segments on the 1999 Kansas Surface Water Register, CUSEGA numbers, stream names, and estimated median flows at downstream end of CUSEGA segments using the most-recent 10 years of record (KSA) and all-available hydrology (AAH) analyses.-Continued

[Estimated median flows are rounded to two or three significant figures. Reporting estimated median values to three signficant figures (median greater than or equal to $1 \mathrm{ft}^{3} / \mathrm{s}$ ) or two significant figures (median less than $1 \mathrm{ft}^{3} / \mathrm{s}$ ) was done to conform with the intent of KSA 82a-2001 et. seq. $\mathrm{ft}^{3} / \mathrm{s}$, cubic feet per second; KSA, Kansas Statute 82a-2001 analysis; AAH, all-available hydrology analysis]

\begin{tabular}{|c|c|c|c|c|c|}
\hline \multirow{2}{*}{$\begin{array}{c}\text { Stream } \\
\text { segment } \\
\text { number } \\
\text { (figs. 9-113) }\end{array}$} & \multirow[b]{2}{*}{ CUSEGA number } & \multirow{2}{*}{$\begin{array}{c}\text { County location } \\
\text { (abbreviation explained } \\
\text { in (table 7) }\end{array}$} & \multirow[b]{2}{*}{ Stream name } & \multicolumn{2}{|c|}{ Estimated median flows $\left(\mathrm{ft}^{3} / \mathrm{s}\right)$} \\
\hline & & & & KSA analysis & AAH analysis \\
\hline 1646 & 1106000111 & $\overline{C L}$ & Little Beaver Creek & 2.37 & 2.13 \\
\hline 1647 & 1106000114 & $\mathrm{CL}$ & Arkansas River & 1,240 & 1,090 \\
\hline 1648 & 1106000115 & $\mathrm{CL}$ & Grouse Creek & 40.2 & 33.2 \\
\hline 1649 & 1106000116 & $\mathrm{BU}, \mathrm{CL}$ & Grouse Creek & 28.4 & 23.3 \\
\hline 1650 & 1106000117 & $\mathrm{CL}$ & Silver Creek & 7.87 & 6.32 \\
\hline 1651 & 1106000118 & $\mathrm{CL}$ & Arkansas River & 1,230 & 1,080 \\
\hline 1652 & 1106000119 & $\mathrm{CL}, \mathrm{SU}$ & Chilocco Creek & .65 & .62 \\
\hline 1653 & 1106000120 & CL & Otter Creek & 1.42 & 1.32 \\
\hline 1654 & 1106000121 & $\mathrm{CL}$ & Spring Creek & .83 & .82 \\
\hline 1655 & 1106000122 & $\mathrm{CL}$ & Shellrock Creek & .54 & .62 \\
\hline 1656 & 1106000124 & $\mathrm{CL}$ & Myers Creek & .03 & .26 \\
\hline 1657 & 1106000125 & $\mathrm{CL}$ & Snake Creek & .79 & .66 \\
\hline 1658 & 1106000126 & $\mathrm{CL}$ & Pebble Creek & .59 & .50 \\
\hline 1659 & 1106000127 & $\mathrm{CL}$ & Turkey Creek & .63 & .61 \\
\hline 1660 & 1106000128 & $\mathrm{CL}$ & Bullington Creek & 1.14 & 1.03 \\
\hline 1661 & 1106000129 & $\mathrm{CL}$ & Crabb Creek & 3.81 & 3.15 \\
\hline 1662 & 1106000130 & CL & Blue Branch & .63 & .60 \\
\hline 1663 & 1106000131 & $\mathrm{CL}$ & School Creek & .67 & .66 \\
\hline 1664 & 1106000132 & $\mathrm{CL}$ & Cedar Creek & 3.36 & 2.84 \\
\hline 1665 & 1106000133 & CL & Plum Creek & 0 & .02 \\
\hline 1666 & 1106000134 & $\mathrm{CL}$ & Goose Creek & 1.13 & 1.04 \\
\hline 1667 & 1106000135 & $\mathrm{BU}, \mathrm{CL}$ & Franklin Creek & .58 & .55 \\
\hline 1668 & 1106000136 & $\mathrm{BU}, \mathrm{CL}, \mathrm{EK}$ & Wagoner Creek & .54 & .57 \\
\hline 1669 & 1106000137 & CL, EK & Riley Creek & .15 & .27 \\
\hline 1670 & 1106000138 & CL & Ferguson Creek & .66 & .68 \\
\hline 1671 & 1106000139 & $\mathrm{CL}$ & Gardners Branch & 1.18 & 1.08 \\
\hline 1672 & 110600019 & CL & Beaver Creek & 2.75 & 2.37 \\
\hline 1673 & 1106000210 & $\mathrm{CM}$ & Salt Fork Arkansas River & 23.6 & 18.3 \\
\hline 1674 & 1106000211 & $\mathrm{CM}$ & Salt Fork Arkansas River & 17.9 & 14.2 \\
\hline 1675 & 1106000212 & $\mathrm{CM}$ & Wildcat Creek & .35 & .15 \\
\hline 1676 & 1106000213 & $\mathrm{CM}$ & Salt Fork Arkansas River & 14.9 & 12.0 \\
\hline 1677 & 1106000214 & $\mathrm{CM}$ & Nescatunga Creek & 4.28 & 3.96 \\
\hline 1678 & 1106000215 & $\mathrm{CM}$ & Salt Fork Arkansas River & 5.45 & 4.37 \\
\hline
\end{tabular}


Table 6. Stream segments on the 1999 Kansas Surface Water Register, CUSEGA numbers, stream names, and estimated median flows at downstream end of CUSEGA segments using the most-recent 10 years of record (KSA) and all-available hydrology (AAH) analyses.-Continued

[Estimated median flows are rounded to two or three significant figures. Reporting estimated median values to three signficant figures (median greater than or equal to $1 \mathrm{ft}^{3} / \mathrm{s}$ ) or two significant figures (median less than $1 \mathrm{ft}^{3} / \mathrm{s}$ ) was done to conform with the intent of KSA $82 \mathrm{a}-2001$ et. seq. $\mathrm{ft}^{3} / \mathrm{s}$, cubic feet per second; KSA, Kansas Statute 82a-2001 analysis; AAH, all-available hydrology analysis]

\begin{tabular}{|c|c|c|c|c|c|}
\hline \multirow{2}{*}{$\begin{array}{l}\text { Stream } \\
\text { segment } \\
\text { number } \\
\text { (figs. 9-113) }\end{array}$} & \multirow[b]{2}{*}{ CUSEGA number } & \multirow{2}{*}{$\begin{array}{c}\text { County location } \\
\text { (abbreviation explained } \\
\text { in (table 7) }\end{array}$} & \multirow[b]{2}{*}{ Stream name } & \multicolumn{2}{|c|}{ Estimated median flows $\left(\mathrm{ft}^{3} / \mathrm{s}\right)$} \\
\hline & & & & KSA analysis & AAH analysis \\
\hline 1679 & 1106000216 & $\mathrm{CM}$ & Red Creek & 2.24 & 1.78 \\
\hline 1680 & 1106000217 & BA & Yellowstone Creek & 1.90 & 1.39 \\
\hline 1681 & 1106000220 & BA & Ash Creek & .02 & .01 \\
\hline 1682 & 1106000221 & $\mathrm{BA}, \mathrm{CM}$ & Inman Creek & 1.01 & .91 \\
\hline 1683 & 1106000222 & BA & Deadman Creek & .48 & .38 \\
\hline 1684 & 1106000223 & BA & Hackberry Creek & .96 & .66 \\
\hline 1685 & 1106000224 & $\mathrm{CM}, \mathrm{KW}$ & Spring Creek & .62 & .45 \\
\hline 1686 & 1106000227 & $\mathrm{CM}$ & East Branch Nescatunga Creek & .10 & 0 \\
\hline 1687 & 1106000228 & $\mathrm{BA}, \mathrm{CM}$ & Cave Creek & .18 & .09 \\
\hline 1688 & 1106000229 & $\mathrm{CM}$ & Dog Creek & .01 & 0 \\
\hline 1689 & 1106000230 & $\mathrm{CM}$ & Cottonwood Creek & .20 & .15 \\
\hline 1690 & 1106000231 & $\mathrm{CM}$ & Mustang Creek & .21 & .17 \\
\hline 1691 & 110600024 & BA & Salt Fork Arkansas River & 79.6 & 57.8 \\
\hline 1692 & 110600025 & BA & Big Sandy Creek & 3.41 & 2.69 \\
\hline 1693 & 11060002503 & $\mathrm{CM}$ & Unnamed tributary, Comanche 1 & 1.15 & 1.18 \\
\hline 1694 & 110600026 & BA & Salt Fork Arkansas River & 66.7 & 49.0 \\
\hline 1695 & 110600027 & $\mathrm{BA}, \mathrm{CM}, \mathrm{KW}$ & Mule Creek & 13.7 & 10.8 \\
\hline 1696 & 110600028 & $\mathrm{BA}, \mathrm{CM}$ & Salt Fork Arkansas River & 29.2 & 22.4 \\
\hline 1697 & 110600029 & $\mathrm{CM}$ & Indian Creek & 1.74 & 1.52 \\
\hline 1698 & 1106000310 & $\mathrm{BA}, \mathrm{PR}$ & East Branch South Elm Creek & .39 & .39 \\
\hline 1699 & 1106000311 & $\mathrm{BA}, \mathrm{PR}$ & Crooked Creek & .42 & .30 \\
\hline 1700 & 1106000312 & BA, PR & Amber Creek & 1.24 & 1.36 \\
\hline 1701 & 1106000313 & BA & Bear Creek & 1.72 & 1.48 \\
\hline 1702 & 1106000314 & BA, PR & Mulberry Creek & .68 & .70 \\
\hline 1703 & 1106000315 & BA & Puckett Creek & .01 & .01 \\
\hline 1704 & 1106000316 & BA & Cottonwood Creek & .02 & 0 \\
\hline 1705 & 1106000317 & BA & Sand Creek & .44 & .44 \\
\hline 1706 & 1106000318 & BA & Bitter Creek & .06 & 0 \\
\hline 1707 & 1106000319 & BA & Little Bear Creek & .95 & .77 \\
\hline 1708 & 110600032 & BA & Medicine Lodge River & 109 & 85.0 \\
\hline 1709 & 1106000320 & BA & Cedar Creek & 2.39 & 1.98 \\
\hline 1710 & 1106000321 & BA & Dry Creek & .72 & .56 \\
\hline 1711 & 1106000322 & BA & Antelope Creek & .01 & 0 \\
\hline 1712 & 1106000323 & BA & Wilson Slough & .16 & .10 \\
\hline 1713 & 1106000324 & KW & North Branch Medicine Lodge River & .09 & 0 \\
\hline
\end{tabular}


Table 6. Stream segments on the 1999 Kansas Surface Water Register, CUSEGA numbers, stream names, and estimated median flows at downstream end of CUSEGA segments using the most-recent 10 years of record (KSA) and all-available hydrology (AAH) analyses.-Continued

[Estimated median flows are rounded to two or three significant figures. Reporting estimated median values to three signficant figures (median greater than or equal to $1 \mathrm{ft}^{3} / \mathrm{s}$ ) or two significant figures (median less than $1 \mathrm{ft}^{3} / \mathrm{s}$ ) was done to conform with the intent of KSA 82a-2001 et. seq. $\mathrm{ft}^{3} / \mathrm{s}$, cubic feet per second; KSA, Kansas Statute 82a-2001 analysis; AAH, all-available hydrology analysis]

\begin{tabular}{|c|c|c|c|c|c|}
\hline \multirow{2}{*}{$\begin{array}{c}\text { Stream } \\
\text { segment } \\
\text { number } \\
\text { (figs. 9-113) }\end{array}$} & \multirow[b]{2}{*}{ CUSEGA number } & \multirow{2}{*}{$\begin{array}{c}\text { County location } \\
\text { (abbreviation explained } \\
\text { in (table 7) }\end{array}$} & \multirow[b]{2}{*}{ Stream name } & \multicolumn{2}{|c|}{ Estimated median flows $\left(\mathrm{ft}^{3} / \mathrm{s}\right)$} \\
\hline & & & & KSA analysis & AAH analysis \\
\hline 1714 & 1106000325 & KW & Otter Creek & 0.31 & 0.09 \\
\hline 1715 & 1106000326 & KW & Thompson Creek & 2.60 & 2.17 \\
\hline 1716 & 1106000327 & $\mathrm{KW}$ & Soldier Creek & 3.61 & 3.27 \\
\hline 1717 & 1106000328 & BA & Stink Creek & 0 & 0 \\
\hline 1718 & 110600033 & BA & Elm Creek & 12.8 & 11.1 \\
\hline 1719 & 11060003370 & BA & Unnamed tributary, Barber 1 & 1.10 & 1.04 \\
\hline 1720 & 110600034 & BA, PR & North Elm Creek & 1.32 & 1.25 \\
\hline 1721 & 11060003415 & BA & Unnamed tributary, Barber 2 & .01 & 0 \\
\hline 1722 & 11060003452 & BA & Unnamed tributary, Barber 3 & 0 & 0 \\
\hline 1723 & 110600035 & BA & South Elm Creek & 3.17 & 2.72 \\
\hline 1724 & 11060003559 & KW & Unnamed tributary, Kiowa 1 & .01 & 0 \\
\hline 1725 & 110600036 & BA & Medicine Lodge River & 55.4 & 43.3 \\
\hline 1726 & 110600037 & BA, PR & Turkey Creek & 2.35 & 2.03 \\
\hline 1727 & 110600038 & $\mathrm{BA}, \mathrm{KW}$ & Medicine Lodge River & 18.7 & 14.9 \\
\hline 1728 & 110600039 & BA & Little Mule Creek & 5.19 & 4.15 \\
\hline 1729 & 110600039005 & BA, PR & West Branch South Elm Creek & .77 & .69 \\
\hline 1730 & 11060003905 & BA & Driftwood Creek & .45 & .32 \\
\hline 1731 & 1106000418 & HP & Pond Creek & .02 & .02 \\
\hline 1732 & 1106000424 & HP & Crooked Creek & 0 & 0 \\
\hline 1733 & 1106000425 & HP & Unnamed tributary, Harper 1 & 0 & 0 \\
\hline 1734 & 1106000437 & HP & Sandy Creek & 12.7 & 12.2 \\
\hline 1735 & 1106000439 & BA, HP & Little Sandy Creek & 12.6 & 12.4 \\
\hline 1736 & 1106000440 & BA, HP & Salty Creek & 3.01 & 2.46 \\
\hline 1737 & 1106000465 & BA & East Branch Little Sandy Creek & 2.74 & 2.73 \\
\hline 1738 & 1106000466 & BA, HP & Spring Creek & .67 & .83 \\
\hline 1739 & 1106000467 & BA, HP & West Sandy Creek & 2.91 & 3.19 \\
\hline 1740 & 1106000468 & HP & Camp Creek & .94 & .95 \\
\hline 1741 & 1106000469 & HP & Rush Creek & 0 & 0 \\
\hline 1742 & 1106000470 & HP & Plum Creek & .40 & .40 \\
\hline 1743 & 1106000471 & HP & Cooper Creek & 1.30 & 1.13 \\
\hline 1744 & 110600049039 & BA & West Branch Little Sandy Creek & 2.55 & 2.42 \\
\hline 1745 & 1106000510 & KM, PR & Chikaskia River & 1.6 & 9.85 \\
\hline 1746 & 1106000511 & $\mathrm{BA}, \mathrm{KM}, \mathrm{PR}$ & Sand Creek & 11.8 & 10.5 \\
\hline
\end{tabular}


Table 6. Stream segments on the 1999 Kansas Surface Water Register, CUSEGA numbers, stream names, and estimated median flows at downstream end of CUSEGA segments using the most-recent 10 years of record (KSA) and all-available hydrology (AAH) analyses.-Continued

[Estimated median flows are rounded to two or three significant figures. Reporting estimated median values to three signficant figures (median greater than or equal to $1 \mathrm{ft}^{3} / \mathrm{s}$ ) or two significant figures (median less than $1 \mathrm{ft}^{3} / \mathrm{s}$ ) was done to conform with the intent of KSA $82 \mathrm{a}-2001$ et. seq. $\mathrm{ft}^{3} / \mathrm{s}$, cubic feet per second; KSA, Kansas Statute 82a-2001 analysis; AAH, all-available hydrology analysis]

\begin{tabular}{|c|c|c|c|c|c|}
\hline \multirow{2}{*}{$\begin{array}{c}\text { Stream } \\
\text { segment } \\
\text { number } \\
\text { (figs. 9-113) }\end{array}$} & \multirow[b]{2}{*}{ CUSEGA number } & \multirow{2}{*}{$\begin{array}{c}\text { County location } \\
\text { (abbreviation explained } \\
\text { in (table 7) }\end{array}$} & \multirow[b]{2}{*}{ Stream name } & \multicolumn{2}{|c|}{ Estimated median flows $\left(\mathrm{ft}^{3} / \mathrm{s}\right)$} \\
\hline & & & & KSA analysis & AAH analysis \\
\hline 1747 & 1106000512 & $\mathrm{HP}, \mathrm{KM}, \mathrm{SU}$ & East Sand Creek & 6.66 & 6.04 \\
\hline 1748 & 1106000514 & HP, SU & Fall Creek & 4.58 & 3.56 \\
\hline 1749 & 1106000515 & $\mathrm{HP}, \mathrm{SU}$ & Bluff Creek & 26.4 & 23.1 \\
\hline 1750 & 1106000516 & SU & East Bitter Creek & 0.10 & 0.20 \\
\hline 1751 & 1106000517 & SU & Dry Creek & 0 & 0 \\
\hline 1752 & 1106000518 & SU & Spring Creek & .38 & .33 \\
\hline 1753 & 1106000519 & SU & East Shoo Fly Creek & 0 & 0 \\
\hline 1754 & 1106000520 & SU & Meridian Creek & 2.17 & 1.80 \\
\hline 1755 & 1106000521 & HP & Spring Branch & .31 & .22 \\
\hline 1756 & 1106000522 & HP & Baehr Creek & 1.33 & 1.15 \\
\hline 1757 & 1106000523 & $\mathrm{HP}$ & Rock Creek & 1.90 & 1.65 \\
\hline 1758 & 1106000524 & HP & Wildcat Creek & 1.10 & 1.01 \\
\hline 1759 & 1106000525 & SU & Spring Creek & .57 & .53 \\
\hline 1760 & 1106000526 & SU & Rodgers Branch & 0 & 0 \\
\hline 1761 & 1106000527 & SU & East Branch Fall Creek & .53 & .39 \\
\hline 1762 & 1106000528 & SU & Beaver Creek & .64 & .51 \\
\hline 1763 & 1106000529 & SU & Silver Creek & 1.63 & 1.47 \\
\hline 1764 & 1106000530 & HP, KM & Sandy Creek & 2.00 & 1.86 \\
\hline 1765 & 1106000531 & HP, KM & Spring Creek & 3.13 & 2.85 \\
\hline 1766 & 1106000532 & KM & Duck Creek & 1.10 & 1.45 \\
\hline 1767 & 1106000534 & $\mathrm{KM}$ & Big Spring Creek & 2.14 & 2.40 \\
\hline 1768 & 1106000535 & SU & Shore Creek & .52 & .45 \\
\hline 1769 & 1106000536 & $\mathrm{BA}, \mathrm{PR}$ & Chicken Creek & .65 & .70 \\
\hline 1770 & 1106000537 & KM, PR & North Fork Chikaskia River & 1.57 & 1.64 \\
\hline 1771 & 1106000538 & KM & Goose Creek & .38 & .48 \\
\hline 1772 & 1106000539 & KM & Skunk Creek & .80 & .93 \\
\hline 1773 & 110600054 & SU & Bitter Creek & 29.8 & 19.7 \\
\hline 1774 & 1106000540 & KM & Allen Creek & 1.05 & 1.17 \\
\hline 1775 & 1106000541 & $\mathrm{KM}$ & Wild Horse Creek & 1.83 & 1.93 \\
\hline 1776 & 1106000542 & KM & Copper Creek & .39 & 0 \\
\hline 1777 & 1106000543 & KM & Red Creek & 2.53 & 2.53 \\
\hline 1778 & 1106000544 & $\mathrm{KM}$ & Rose Bud Creek & .36 & .30 \\
\hline 1779 & 1106000545 & HP & Rush Creek & 2.68 & 2.52 \\
\hline 1780 & 1106000546 & $\mathrm{HP}$ & Beaver Creek & .97 & .83 \\
\hline 1781 & 1106000547 & HP & Spring Creek & 1.97 & 1.75 \\
\hline
\end{tabular}


Table 6. Stream segments on the 1999 Kansas Surface Water Register, CUSEGA numbers, stream names, and estimated median flows at downstream end of CUSEGA segments using the most-recent 10 years of record (KSA) and all-available hydrology (AAH) analyses.-Continued

[Estimated median flows are rounded to two or three significant figures. Reporting estimated median values to three signficant figures (median greater than or equal to $1 \mathrm{ft}^{3} / \mathrm{s}$ ) or two significant figures (median less than $1 \mathrm{ft}^{3} / \mathrm{s}$ ) was done to conform with the intent of KSA 82a-2001 et. seq. $\mathrm{ft}^{3} / \mathrm{s}$, cubic feet per second; KSA, Kansas Statute 82a-2001 analysis; AAH, all-available hydrology analysis]

\begin{tabular}{|c|c|c|c|c|c|}
\hline \multirow{2}{*}{$\begin{array}{c}\text { Stream } \\
\text { segment } \\
\text { number } \\
\text { (figs. 9-113) }\end{array}$} & \multirow[b]{2}{*}{ CUSEGA number } & \multirow{2}{*}{$\begin{array}{c}\text { County location } \\
\text { (abbreviation explained } \\
\text { in (table 7) }\end{array}$} & \multirow[b]{2}{*}{ Stream name } & \multicolumn{2}{|c|}{ Estimated median flows $\left(\mathrm{ft}^{3} / \mathrm{s}\right)$} \\
\hline & & & & KSA analysis & AAH analysis \\
\hline 1782 & 1106000548 & KM & Blue Stem Creek & 0.01 & 0 \\
\hline 1783 & 1106000549 & KM & Kemp Creek & .38 & .20 \\
\hline 1784 & 11060005512 & SU & Prairie Creek & 2.98 & 2.52 \\
\hline 1785 & 11060005516 & SU & East Prairie Creek & 2.80 & 2.36 \\
\hline 1786 & 11060005527 & SU & West Prairie Creek & 1.42 & 1.26 \\
\hline 1787 & 11060005529 & SU & Long Creek & 0 & 0 \\
\hline 1788 & 110600056 & SU & Shoo Fly Creek & 6.10 & 4.91 \\
\hline 1789 & 110600058 & SU & Chikaskia River & 117 & 104 \\
\hline 1790 & 110600059 & $\mathrm{HP}, \mathrm{KM}, \mathrm{SU}$ & Chikaskia River & 67.3 & 60.5 \\
\hline 1791 & 110600059006 & SU & West Shoo Fly Creek & .76 & .60 \\
\hline 1792 & 110701011 & WL & Verdigris River & 296 & 276 \\
\hline 1793 & 1107010111 & GW & Verdigris River & 64.7 & 55.8 \\
\hline 1794 & 1107010112 & GW & Verdigris River & 46.0 & 39.4 \\
\hline 1795 & 1107010113 & GW, LY & North Branch Verdigris River & 17.6 & 14.8 \\
\hline 1796 & 1107010114 & GW, LY & Rock Creek & 1.75 & 1.56 \\
\hline 1797 & 1107010115 & CS, LY, GW & North Branch Verdigris River & 11.7 & 9.77 \\
\hline 1798 & 1107010116 & GW & South Branch Verdigris River & 4.39 & 3.81 \\
\hline 1799 & 1107010117 & GW & West Creek & 10.4 & 8.51 \\
\hline 1800 & 1107010119 & GW & Walnut Creek & 16.5 & 13.7 \\
\hline 1801 & 110701012 & WL, WO & Buffalo Creek & 16.8 & 16.2 \\
\hline 1802 & 1107010120 & GW & Homer Creek & 4.34 & 3.48 \\
\hline 1803 & 1107010121 & GW & Bachelor Creek & 5.17 & 4.09 \\
\hline 1804 & 1107010122 & $\mathrm{NO}, \mathrm{WL}$ & Chetopa Creek & 6.10 & 5.83 \\
\hline 1805 & 1107010123 & GW & Onion Creek & .28 & .25 \\
\hline 1806 & 1107010124 & GW & Bernard Creek & 0 & 0 \\
\hline 1807 & 1107010125 & GW & Slate Creek & 2.71 & 2.19 \\
\hline 1808 & 1107010126 & GW & Greenhall Creek & 2.59 & 2.47 \\
\hline 1809 & 1107010127 & GW, WO & Dry Creek & 4.23 & 4.23 \\
\hline 1810 & 1107010128 & GW & Fancy Creek & 2.47 & 2.53 \\
\hline 1811 & 1107010129 & GW & Kuntz Branch & 2.26 & 2.11 \\
\hline 1812 & 110701013 & WL & Verdigris River & 62.8 & 93.3 \\
\hline 1813 & 1107010130 & GW, WO & Miller Creek & 2.29 & 2.30 \\
\hline 1814 & 1107010131 & GW, WO & Brazil Creek & 3.31 & 3.42 \\
\hline
\end{tabular}


Table 6. Stream segments on the 1999 Kansas Surface Water Register, CUSEGA numbers, stream names, and estimated median flows at downstream end of CUSEGA segments using the most-recent 10 years of record (KSA) and all-available hydrology (AAH) analyses.-Continued

[Estimated median flows are rounded to two or three significant figures. Reporting estimated median values to three signficant figures (median greater than or equal to $1 \mathrm{ft}^{3} / \mathrm{s}$ ) or two significant figures (median less than $1 \mathrm{ft}^{3} / \mathrm{s}$ ) was done to conform with the intent of KSA $82 \mathrm{a}-2001 \mathrm{et}$. seq. $\mathrm{ft}^{3} / \mathrm{s}$, cubic feet per second; KSA, Kansas Statute 82a-2001 analysis; AAH, all-available hydrology analysis]

\begin{tabular}{|c|c|c|c|c|c|}
\hline \multirow{2}{*}{$\begin{array}{l}\text { Stream } \\
\text { segment } \\
\text { number } \\
\text { (figs. 9-113) }\end{array}$} & \multirow[b]{2}{*}{ CUSEGA number } & \multirow{2}{*}{$\begin{array}{c}\text { County location } \\
\text { (abbreviation explained } \\
\text { in (table 7) }\end{array}$} & \multirow[b]{2}{*}{ Stream name } & \multicolumn{2}{|c|}{ Estimated median flows $\left(\mathrm{ft}^{3} / \mathrm{s}\right)$} \\
\hline & & & & KSA analysis & AAH analysis \\
\hline 1815 & 1107010132 & WO & Cedar Creek & 1.71 & 1.97 \\
\hline 1816 & 1107010133 & WL, WO & Little Sandy Creek & 3.04 & 3.32 \\
\hline 1817 & 1107010134 & WL, WO & West Buffalo Creek & 6.66 & 6.79 \\
\hline 1818 & 1107010135 & GW, WL & Ross Branch & 5.51 & 5.42 \\
\hline 1819 & 1107010136 & WL & Snake Creek & 2.61 & 2.62 \\
\hline 1820 & 1107010137 & WL & Elder Branch & 4.14 & 4.35 \\
\hline 1821 & 1107010138 & WL & Crooked Creek & 3.50 & 3.78 \\
\hline 1822 & 1107010139 & WL & Big Cedar Creek & 4.05 & 4.02 \\
\hline 1823 & 110701014 & WL, WO & Sandy Creek & 12.1 & 12.0 \\
\hline 1824 & 1107010140 & CS, LY & Shaw Creek & 1.38 & 1.26 \\
\hline 1825 & 1107010141 & CS, LY & Wolf Creek & 1.48 & 1.33 \\
\hline 1826 & 1107010142 & GW, LY & Kelly Branch & .41 & .45 \\
\hline 1827 & 1107010143 & LY & Moon Branch & .85 & .77 \\
\hline 1828 & 1107010144 & GW, LY & Tate Branch Creek & 1.59 & 1.43 \\
\hline 1829 & 1107010145 & GW & Long Creek & 1.46 & 1.39 \\
\hline 1830 & 1107010146 & GW & Van Horn Creek & .93 & .83 \\
\hline 1831 & 1107010147 & GW & Holderman Creek & .75 & .66 \\
\hline 1832 & 11070101471 & NO, WL & Little Chetopa Creek & 2.25 & 2.57 \\
\hline 1833 & 110701015 & WL, WO & Verdigris River & 45.8 & 80.1 \\
\hline 1834 & 110701019017 & GW & Willow Creek & 3.23 & 2.57 \\
\hline 1835 & 110701021 & WL & Fall River & 120 & 102 \\
\hline 1836 & 1107010211 & GW & West Branch Fall River & 13.7 & 10.5 \\
\hline 1837 & 1107010212 & GW & Spring Creek & 11.5 & 8.99 \\
\hline 1838 & 1107010213 & BU, GW & Otter Creek & 12.9 & 12.3 \\
\hline 1839 & 1107010214 & EK, GW & Salt Creek & 6.14 & 5.25 \\
\hline 1840 & 1107010215 & EK, WL & Indian Creek & 7.49 & 6.93 \\
\hline 1841 & 1107010217 & EK, WL & East Rainbow Creek & 3.60 & 3.55 \\
\hline 1842 & 1107010218 & BU, GW & Battle Creek & .25 & .31 \\
\hline 1843 & 1107010219 & BU, GW & Ivanpah Creek & 2.98 & 2.53 \\
\hline 1844 & 110701022 & EK, GW, WL & Fall River & 75.3 & 70.5 \\
\hline 1845 & 1107010220 & GW & Otis Creek & 1.68 & 1.45 \\
\hline 1846 & 1107010221 & GW & Oleson Creek & 1.35 & 1.20 \\
\hline 1847 & 1107010223 & GW & Watson Branch & 1.67 & 1.53 \\
\hline 1848 & 1107010224 & GW & Burnt Creek & 2.51 & 2.12 \\
\hline 1849 & 1107010225 & GW & Coon Creek & 1.21 & 1.18 \\
\hline
\end{tabular}


Table 6. Stream segments on the 1999 Kansas Surface Water Register, CUSEGA numbers, stream names, and estimated median flows at downstream end of CUSEGA segments using the most-recent 10 years of record (KSA) and all-available hydrology (AAH) analyses.-Continued

[Estimated median flows are rounded to two or three significant figures. Reporting estimated median values to three signficant figures (median greater than or equal to $1 \mathrm{ft}^{3} / \mathrm{s}$ ) or two significant figures (median less than $1 \mathrm{ft}^{3} / \mathrm{s}$ ) was done to conform with the intent of KSA 82a-2001 et. seq. $\mathrm{ft}^{3} / \mathrm{s}$, cubic feet per second; KSA, Kansas Statute 82a-2001 analysis; AAH, all-available hydrology analysis]

\begin{tabular}{|c|c|c|c|c|c|}
\hline \multirow{2}{*}{$\begin{array}{c}\text { Stream } \\
\text { segment } \\
\text { number } \\
\text { (figs. 9-113) }\end{array}$} & \multirow[b]{2}{*}{ CUSEGA number } & \multirow{2}{*}{$\begin{array}{l}\text { County location } \\
\text { (abbreviation explained } \\
\text { in (table 7) }\end{array}$} & \multirow[b]{2}{*}{ Stream name } & \multicolumn{2}{|c|}{ Estimated median flows $\left(\mathrm{ft}^{3} / \mathrm{s}\right)$} \\
\hline & & & & KSA analysis & AAH analysis \\
\hline 1850 & 1107010226 & GW & Honey Creek & 1.21 & 1.01 \\
\hline 1851 & 1107010227 & GW & Kitty Creek & .23 & .31 \\
\hline 1852 & 1107010228 & GW & South Branch Otter Creek & 3.15 & 2.87 \\
\hline 1853 & 1107010229 & GW & Tadpole Creek & .46 & .44 \\
\hline 1854 & 110701023 & GW & Fall River & 53.1 & 56.3 \\
\hline 1855 & 1107010230 & GW & Plum Creek & .07 & .09 \\
\hline 1856 & 1107010231 & GW & Snake Creek & .37 & .36 \\
\hline 1857 & 1107010232 & GW & Crain Creek & 4.10 & 4.24 \\
\hline 1858 & 1107010233 & EK, GW, WL & Silver Creek & 5.47 & 6.00 \\
\hline 1859 & 1107010234 & EK & Little Indian Creek & 2.09 & 2.40 \\
\hline 1860 & 1107010235 & EK, GW & Little Salt Creek & 1.52 & 1.59 \\
\hline 1861 & 1107010236 & EK, WL & Coon Creek & 3.00 & 3.19 \\
\hline 1862 & 1107010237 & $\mathrm{WL}$ & Clear Creek & 3.16 & 3.36 \\
\hline 1863 & 1107010238 & WL & Salt Creek & 2.20 & 2.16 \\
\hline 1864 & 11070102635 & GW & East Branch Fall River & 8.93 & 6.93 \\
\hline 1865 & 110701027 & GW & Fall River & 73.5 & 54.0 \\
\hline 1866 & 110701028 & GW & Fall River & 57.6 & 40.5 \\
\hline 1867 & 110701029 & GW & Fall River & 29.6 & 21.5 \\
\hline 1868 & 11070102989 & GW & Swing Creek & 1.59 & 1.40 \\
\hline 1869 & 1107010321 & LB & Big Creek & .20 & .54 \\
\hline 1870 & 1107010325 & LB & Snow Creek & 3.67 & 3.85 \\
\hline 1871 & 1107010327 & MG & Verdigris River & 564 & 498 \\
\hline 1872 & 1107010328 & LB, MG & Pumpkin Creek & 13.5 & 13.4 \\
\hline 1873 & 1107010329 & MG & Verdigris River & 528 & 466 \\
\hline 1874 & 1107010330 & MG & Big Hill Creek & 13.0 & 11.8 \\
\hline 1875 & 1107010331 & LB, MG & Potatoe Creek & 1.86 & 2.21 \\
\hline 1876 & 1107010332 & LB, MG, NO & Big Hill Creek & 9.04 & 8.27 \\
\hline 1877 & 1107010333 & MG & Verdigris River & 493 & 435 \\
\hline 1878 & 1107010334 & MG, NO, WL & Drum Creek & 9.35 & 9.20 \\
\hline 1879 & 1107010335 & MG & Verdigris River & 465 & 410 \\
\hline 1880 & 1107010336 & MG, WL & Verdigris River & 455 & 401 \\
\hline 1881 & 1107010337 & $\mathrm{NO}, \mathrm{WL}$ & Dry Creek & 4.65 & 4.97 \\
\hline 1882 & 1107010338 & WL & Verdigris River & 296 & 276 \\
\hline
\end{tabular}


Table 6. Stream segments on the 1999 Kansas Surface Water Register, CUSEGA numbers, stream names, and estimated median flows at downstream end of CUSEGA segments using the most-recent 10 years of record (KSA) and all-available hydrology (AAH) analyses.-Continued

[Estimated median flows are rounded to two or three significant figures. Reporting estimated median values to three signficant figures (median greater than or equal to $1 \mathrm{ft}^{3} / \mathrm{s}$ ) or two significant figures (median less than $1 \mathrm{ft}^{3} / \mathrm{s}$ ) was done to conform with the intent of KSA $82 \mathrm{a}-2001$ et. seq. $\mathrm{ft}^{3} / \mathrm{s}$, cubic feet per second; KSA, Kansas Statute 82a-2001 analysis; AAH, all-available hydrology analysis]

\begin{tabular}{|c|c|c|c|c|c|}
\hline \multirow{2}{*}{$\begin{array}{c}\text { Stream } \\
\text { segment } \\
\text { number } \\
\text { (figs. 9-113) }\end{array}$} & \multirow[b]{2}{*}{ CUSEGA number } & \multirow{2}{*}{$\begin{array}{c}\text { County location } \\
\text { (abbreviation explained } \\
\text { in (table 7) }\end{array}$} & \multirow[b]{2}{*}{ Stream name } & \multicolumn{2}{|c|}{ Estimated median flows $\left(\mathrm{ft}^{3} / \mathrm{s}\right)$} \\
\hline & & & & KSA analysis & AAH analysis \\
\hline 1883 & 1107010339 & MG & Onion Creek & 17.3 & 16.7 \\
\hline 1884 & 1107010349 & LB & Richland Creek & 2.89 & 3.18 \\
\hline 1885 & 1107010350 & $\mathrm{LB}, \mathrm{MG}$ & Claymore Creek & .84 & 1.12 \\
\hline 1886 & 1107010351 & LB & Deer Creek & 2.38 & 2.63 \\
\hline 1887 & 1107010352 & MG & Sycamore Creek & 1.54 & 1.83 \\
\hline 1888 & 1107010353 & MG & Biscuit Creek & .80 & 1.27 \\
\hline 1889 & 1107010354 & MG & Bluff Run & 2.04 & 2.56 \\
\hline 1890 & 1107010355 & MG & Spring Creek & .66 & .83 \\
\hline 1891 & 1107010356 & MG & Fawn Creek & 2.35 & 2.57 \\
\hline 1892 & 1107010357 & MG & Deadman Creek & 3.89 & 4.35 \\
\hline 1893 & 1107010358 & MG & Rock Creek & 3.87 & 3.86 \\
\hline 1894 & 1107010359 & LB & Mud Creek & 1.84 & 2.37 \\
\hline 1895 & 1107010360 & LB & Wildcat Creek & 2.24 & 2.82 \\
\hline 1896 & 1107010361 & $\mathrm{LB}, \mathrm{NO}$ & Rock Creek & 1.52 & 1.97 \\
\hline 1897 & 1107010362 & MG & Prior Creek & 2.23 & 2.82 \\
\hline 1898 & 1107010363 & MG & Choteau Creek & 3.24 & 3.67 \\
\hline 1899 & 110701041 & MG & Elk River & 42.4 & 33.8 \\
\hline 1900 & 1107010410 & EK & Elk River & 15.7 & 17.2 \\
\hline 1901 & 1107010411 & EK, GW & Pawpaw Creek & 3.92 & 3.61 \\
\hline 1902 & 1107010412 & $\mathrm{EK}$ & Elk River & 11.4 & 11.3 \\
\hline 1903 & 1107010413 & EK, GW & Rock Creek & 2.62 & 2.37 \\
\hline 1904 & 1107010414 & BU, EK & Elk River & 8.65 & 8.03 \\
\hline 1905 & 1107010415 & EK & Mound Branch Elk River & 2.23 & 2.02 \\
\hline 1906 & 1107010416 & EK & Wildcat Creek & 3.12 & 2.66 \\
\hline 1907 & 1107010417 & $\mathrm{CQ}, \mathrm{EK}, \mathrm{MG}$ & Salt Creek & 12.5 & 12.2 \\
\hline 1908 & 1107010418 & MG & Chetopa Creek & .47 & .55 \\
\hline 1909 & 1107010419 & MG & Card Creek & 3.15 & 3.53 \\
\hline 1910 & 110701042 & MG & Elk River & 60.1 & 60.1 \\
\hline 1911 & 1107010420 & CQ & Coffey Branch & 3.14 & 3.63 \\
\hline 1912 & 1107010421 & MG & Racket Creek & 3.43 & 3.71 \\
\hline 1913 & 1107010422 & MG, WL & Sycamore Creek & 5.77 & 5.89 \\
\hline 1914 & 1107010423 & MG, WL & Elm Branch & 1.49 & 1.71 \\
\hline 1915 & 1107010424 & MG & Little Duck Creek & 1.89 & 2.22 \\
\hline 1916 & 1107010425 & $\mathrm{EK}, \mathrm{MG}, \mathrm{WL}$ & Bachelor Creek & 3.71 & 3.97 \\
\hline 1917 & 1107010426 & EK & Bloody Run & 2.15 & 2.61 \\
\hline
\end{tabular}


Table 6. Stream segments on the 1999 Kansas Surface Water Register, CUSEGA numbers, stream names, and estimated median flows at downstream end of CUSEGA segments using the most-recent 10 years of record (KSA) and all-available hydrology (AAH) analyses.-Continued

[Estimated median flows are rounded to two or three significant figures. Reporting estimated median values to three signficant figures (median greater than or equal to $1 \mathrm{ft}^{3} / \mathrm{s}$ ) or two significant figures (median less than $1 \mathrm{ft}^{3} / \mathrm{s}$ ) was done to conform with the intent of KSA 82a-2001 et. seq. $\mathrm{ft}^{3} / \mathrm{s}$, cubic feet per second; KSA, Kansas Statute 82a-2001 analysis; AAH, all-available hydrology analysis]

\begin{tabular}{|c|c|c|c|c|c|}
\hline \multirow{2}{*}{$\begin{array}{c}\text { Stream } \\
\text { segment } \\
\text { number } \\
\text { (figs. 9-113) }\end{array}$} & \multirow[b]{2}{*}{ CUSEGA number } & \multirow{2}{*}{$\begin{array}{c}\text { County location } \\
\text { (abbreviation explained } \\
\text { in (table 7) }\end{array}$} & \multirow[b]{2}{*}{ Stream name } & \multicolumn{2}{|c|}{ Estimated median flows $\left(\mathrm{ft}^{3} / \mathrm{s}\right)$} \\
\hline & & & & KSA analysis & AAH analysis \\
\hline 1918 & 1107010427 & EK & Pan Creek & 1.48 & 1.85 \\
\hline 1919 & 1107010428 & EK & Hickory Creek & 4.02 & 4.28 \\
\hline 1920 & 1107010429 & CQ, EK & North Salt Creek & 2.23 & 2.59 \\
\hline 1921 & 110701043 & MG, WL & Duck Creek & 8.36 & 7.99 \\
\hline 1922 & 1107010430 & EK & Clear Creek & 2.57 & 2.68 \\
\hline 1923 & 1107010431 & EK & Skull Creek & 0 & 0 \\
\hline 1924 & 1107010432 & EK & Clear Creek & 1.15 & 1.08 \\
\hline 1925 & 1107010433 & EK & Bull Creek & .38 & .45 \\
\hline 1926 & 1107010434 & EK & Snake Creek & 1.08 & .95 \\
\hline 1927 & 1107010435 & EK & East Hitchen Creek & .75 & .97 \\
\hline 1928 & 1107010436 & EK & East Painterhood Creek & 2.84 & 3.00 \\
\hline 1929 & 1107010437 & EK & Little Hitchen Creek & 2.97 & 3.39 \\
\hline 1930 & 1107010438 & EK & South Branch Elk River & 1.41 & 1.36 \\
\hline 1931 & 1107010439 & EK & Rowe Branch Elk River & 1.29 & 1.22 \\
\hline 1932 & 110701044 & EK, MG & Elk River & 51.5 & 52.0 \\
\hline 1933 & 110701045 & EK & Painterhood Creek & 7.51 & 7.29 \\
\hline 1934 & 110701046 & EK & Elk River & 34.1 & 35.6 \\
\hline 1935 & 110701047 & EK & Hitchen Creek & 8.30 & 7.79 \\
\hline 1936 & 110701048 & EK & Elk River & 26.2 & 28.3 \\
\hline 1937 & 110701049 & EK & Elk River & 19.0 & 22.0 \\
\hline 1938 & 1107010610 & CQ & Little Caney Creek & 49.1 & 46.6 \\
\hline 1939 & 1107010611 & CQ, EK & North Caney Creek & 19.8 & 19.3 \\
\hline 1940 & 1107010612 & CQ, EK & Middle Caney Creek & 27.3 & 25.2 \\
\hline 1941 & 1107010619 & CQ & Caney River & 66.2 & 41.5 \\
\hline 1942 & 1107010620 & CQ, EK & Caney River & 17.6 & 12.6 \\
\hline 1943 & 1107010621 & $\mathrm{CQ}, \mathrm{CL}$ & Otter Creek & 6.51 & 5.20 \\
\hline 1944 & 1107010628 & $\mathrm{CQ}, \mathrm{CL}$ & Rock Creek & 8.76 & 7.03 \\
\hline 1945 & 1107010629 & CQ & Dry Creek & 2.49 & 2.28 \\
\hline 1946 & 1107010630 & CQ, CL & Cedar Creek & 5.11 & 4.15 \\
\hline 1947 & 1107010631 & CQ & Sycamore Creek & 4.87 & 4.35 \\
\hline 1948 & 1107010632 & CQ & Cedar Creek & 7.54 & 7.72 \\
\hline 1949 & 1107010633 & CQ & Otter Creek & 5.04 & 5.37 \\
\hline 1950 & 1107010634 & CQ & Lake Creek & 7.81 & 7.79 \\
\hline
\end{tabular}


Table 6. Stream segments on the 1999 Kansas Surface Water Register, CUSEGA numbers, stream names, and estimated median flows at downstream end of CUSEGA segments using the most-recent 10 years of record (KSA) and all-available hydrology (AAH) analyses.-Continued

[Estimated median flows are rounded to two or three significant figures. Reporting estimated median values to three signficant figures (median greater than or equal to $1 \mathrm{ft}^{3} / \mathrm{s}$ ) or two significant figures (median less than $1 \mathrm{ft}^{3} / \mathrm{s}$ ) was done to conform with the intent of KSA $82 \mathrm{a}-2001$ et. seq. $\mathrm{ft}^{3} / \mathrm{s}$, cubic feet per second; KSA, Kansas Statute 82a-2001 analysis; AAH, all-available hydrology analysis]

\begin{tabular}{|c|c|c|c|c|c|}
\hline \multirow{2}{*}{$\begin{array}{c}\text { Stream } \\
\text { segment } \\
\text { number } \\
\text { (figs. 9-113) }\end{array}$} & \multirow[b]{2}{*}{ CUSEGA number } & \multirow{2}{*}{$\begin{array}{c}\text { County location } \\
\text { (abbreviation explained } \\
\text { in (table 7) }\end{array}$} & \multirow[b]{2}{*}{ Stream name } & \multicolumn{2}{|c|}{ Estimated median flows $\left(\mathrm{ft}^{3} / \mathrm{s}\right)$} \\
\hline & & & & KSA analysis & AAH analysis \\
\hline 1951 & 1107010635 & CQ & Wolf Creek & 4.75 & 5.11 \\
\hline 1952 & 1107010636 & CQ & Coon Creek & 4.66 & 4.98 \\
\hline 1953 & 1107010637 & MG & North Fork Cotton Creek & 0 & 0 \\
\hline 1954 & 1107010638 & MG & Cotton Creek & 1.44 & 1.65 \\
\hline 1955 & 1107010639 & MG & Illinois Creek & 4.00 & 4.35 \\
\hline 1956 & 1107010640 & MG & Cheyenne Creek & 5.69 & 5.62 \\
\hline 1957 & 1107010641 & $\mathrm{CQ}, \mathrm{CL}$ & Union Creek & 2.31 & 2.03 \\
\hline 1958 & 1107010642 & $\mathrm{CQ}$ & Squaw Creek & .90 & .88 \\
\hline 1959 & 1107010643 & CQ & Pool Creek & 3.34 & 3.11 \\
\hline 1960 & 1107010644 & CQ & Spring Creek & 3.01 & 2.70 \\
\hline 1961 & 1107010645 & CQ & Turkey Creek & 2.21 & 2.47 \\
\hline 1962 & 1107010646 & CQ & Fly Creek & 4.97 & 5.46 \\
\hline 1963 & 1107010647 & $\mathrm{CQ}$ & Bachelor Creek & 3.70 & 3.98 \\
\hline 1964 & 1107010648 & CQ & California Creek & 4.28 & 4.71 \\
\hline 1965 & 1107010649 & CL & Jim Creek & 1.19 & 1.10 \\
\hline 1966 & 1107010650 & $\mathrm{CQ}, \mathrm{EK}$ & Wolf Creek & 1.38 & 1.22 \\
\hline 1967 & 11070106509 & MG & Hafer Run & 2.41 & 2.72 \\
\hline 1968 & 1107010651 & EK & Corum Creek & .65 & .55 \\
\hline 1969 & 1107010652 & EK & East Fork Caney River & 1.65 & 1.49 \\
\hline 1970 & 1107010653 & CL, EK, CQ & Spring Creek & 2.29 & 2.04 \\
\hline 1971 & 1107010674 & CQ & Possum Trot Creek & 2.70 & 2.66 \\
\hline 1972 & 110701068 & $\mathrm{CQ}, \mathrm{MG}$ & Little Caney Creek & 79.1 & 76.8 \\
\hline 1973 & 110701069 & $\mathrm{CQ}, \mathrm{MG}$ & Bee Creek & 14.6 & 14.1 \\
\hline 1974 & 110702011 & $\mathrm{CF}$ & Neosho River & 429 & 394 \\
\hline 1975 & 1107020110 & MR & Neosho River & 37.6 & 37.7 \\
\hline 1976 & 1107020111 & MR & Neosho River & 15.0 & 13.0 \\
\hline 1977 & 1107020118 & MR, WB & Munkers Creek & 4.50 & 3.53 \\
\hline 1978 & 110702012 & LY & Neosho River & 94.9 & 94.9 \\
\hline 1979 & 1107020121 & MR & Lanos Creek & 2.00 & 1.55 \\
\hline 1980 & 1107020123 & MR & Neosho River & 8.13 & 6.26 \\
\hline 1981 & 1107020124 & MR & Four Mile Creek & 4.95 & 3.89 \\
\hline 1982 & 1107020125 & CF, LY & Eagle Creek & 7.41 & 6.14 \\
\hline 1983 & 1107020126 & $\mathrm{CF}, \mathrm{LY}$ & Neosho River & 412 & 384 \\
\hline
\end{tabular}


Table 6. Stream segments on the 1999 Kansas Surface Water Register, CUSEGA numbers, stream names, and estimated median flows at downstream end of CUSEGA segments using the most-recent 10 years of record (KSA) and all-available hydrology (AAH) analyses.-Continued

[Estimated median flows are rounded to two or three significant figures. Reporting estimated median values to three signficant figures (median greater than or equal to $1 \mathrm{ft}^{3} / \mathrm{s}$ ) or two significant figures (median less than $1 \mathrm{ft}^{3} / \mathrm{s}$ ) was done to conform with the intent of KSA 82a-2001 et. seq. $\mathrm{ft}^{3} / \mathrm{s}$, cubic feet per second; KSA, Kansas Statute 82a-2001 analysis; AAH, all-available hydrology analysis]

\begin{tabular}{|c|c|c|c|c|c|}
\hline \multirow{2}{*}{$\begin{array}{c}\text { Stream } \\
\text { segment } \\
\text { number } \\
\text { (figs. 9-113) }\end{array}$} & \multirow[b]{2}{*}{ CUSEGA number } & \multirow{2}{*}{$\begin{array}{c}\text { County location } \\
\text { (abbreviation explained } \\
\text { in (table 7) }\end{array}$} & \multirow[b]{2}{*}{ Stream name } & \multicolumn{2}{|c|}{ Estimated median flows $\left(\mathrm{ft}^{3} / \mathrm{s}\right)$} \\
\hline & & & & KSA analysis & AAH analysis \\
\hline 1984 & 1107020127 & MR & Parkers Creek & 0.28 & 0.20 \\
\hline 1985 & 1107020128 & MR & West Fork Neosho River & .14 & .06 \\
\hline 1986 & 1107020129 & MR & Haun Creek & .59 & .44 \\
\hline 1987 & 110702013 & LY & Allen Creek & 6.64 & 5.29 \\
\hline 1988 & 1107020130 & MR & Lairds Creek & 1.43 & 1.10 \\
\hline 1989 & 1107020131 & MR, WB & East Branch Munkers Creek & .60 & .49 \\
\hline 1990 & 1107020132 & MR & Middle Branch Munkers Creek & 1.42 & 1.13 \\
\hline 1991 & 1107020133 & WB & Horse Creek & .81 & .69 \\
\hline 1992 & 1107020134 & WB & East Branch Rock Creek & .89 & .77 \\
\hline 1993 & 1107020135 & MR & Crooked Creek & .60 & .50 \\
\hline 1994 & 1107020136 & MR & Elm Creek & 2.78 & 2.16 \\
\hline 1995 & 1107020137 & MR & Big John Creek & 3.14 & 2.54 \\
\hline 1996 & 1107020138 & LY & Wrights Creek & 1.98 & 1.64 \\
\hline 1997 & 1107020139 & MR & East Creek & .36 & .33 \\
\hline 1998 & 110702014 & LY & Dows Creek & 2.29 & 1.83 \\
\hline 1999 & 1107020140 & MR & Spring Creek & .29 & .30 \\
\hline 2000 & 1107020141 & MR & Wolf Creek & .49 & .48 \\
\hline 2001 & 1107020142 & MR & Walker Branch & .84 & .80 \\
\hline 2002 & 1107020143 & CS, MR, LY & Kahola Creek & 2.72 & 2.27 \\
\hline 2003 & 1107020144 & LY & Stillman Creek & 0 & 0 \\
\hline 2004 & 1107020145 & LY & Badger Creek & 2.12 & 1.78 \\
\hline 2005 & 1107020146 & LY & Taylor Creek & .02 & .08 \\
\hline 2006 & 1107020147 & LY & South Eagle Creek & .65 & .61 \\
\hline 2007 & 1107020148 & LY & Fourmile Creek & 2.26 & 1.93 \\
\hline 2008 & 1107020149 & LY & Plumb Creek & .32 & .33 \\
\hline 2009 & 110702015 & LY & Allen Creek & 3.30 & 2.65 \\
\hline 2010 & 1107020150 & LY & Plum Creek & 2.16 & 1.89 \\
\hline 2011 & 1107020151 & $\mathrm{CF}$ & Lebo Creek & 2.62 & 2.25 \\
\hline 2012 & 110702016 & LY, MR & Neosho River & 68.6 & 71.4 \\
\hline 2013 & 110702017 & MR & Rock Creek & 11.1 & 8.90 \\
\hline 2014 & 110702018 & LY, MR, WB & Bluff Creek & 3.28 & 2.70 \\
\hline 2015 & 110702019 & LY, MR, WB & Rock Creek & 7.04 & 5.63 \\
\hline 2016 & 110702019023 & MR & Level Creek & 0 & 0 \\
\hline
\end{tabular}


Table 6. Stream segments on the 1999 Kansas Surface Water Register, CUSEGA numbers, stream names, and estimated median flows at downstream end of CUSEGA segments using the most-recent 10 years of record (KSA) and all-available hydrology (AAH) analyses.-Continued

[Estimated median flows are rounded to two or three significant figures. Reporting estimated median values to three signficant figures (median greater than or equal to $1 \mathrm{ft}^{3} / \mathrm{s}$ ) or two significant figures (median less than $1 \mathrm{ft}^{3} / \mathrm{s}$ ) was done to conform with the intent of KSA 82a-2001 et. seq. $\mathrm{ft}^{3} / \mathrm{s}$, cubic feet per second; KSA, Kansas Statute 82a-2001 analysis; AAH, all-available hydrology analysis]

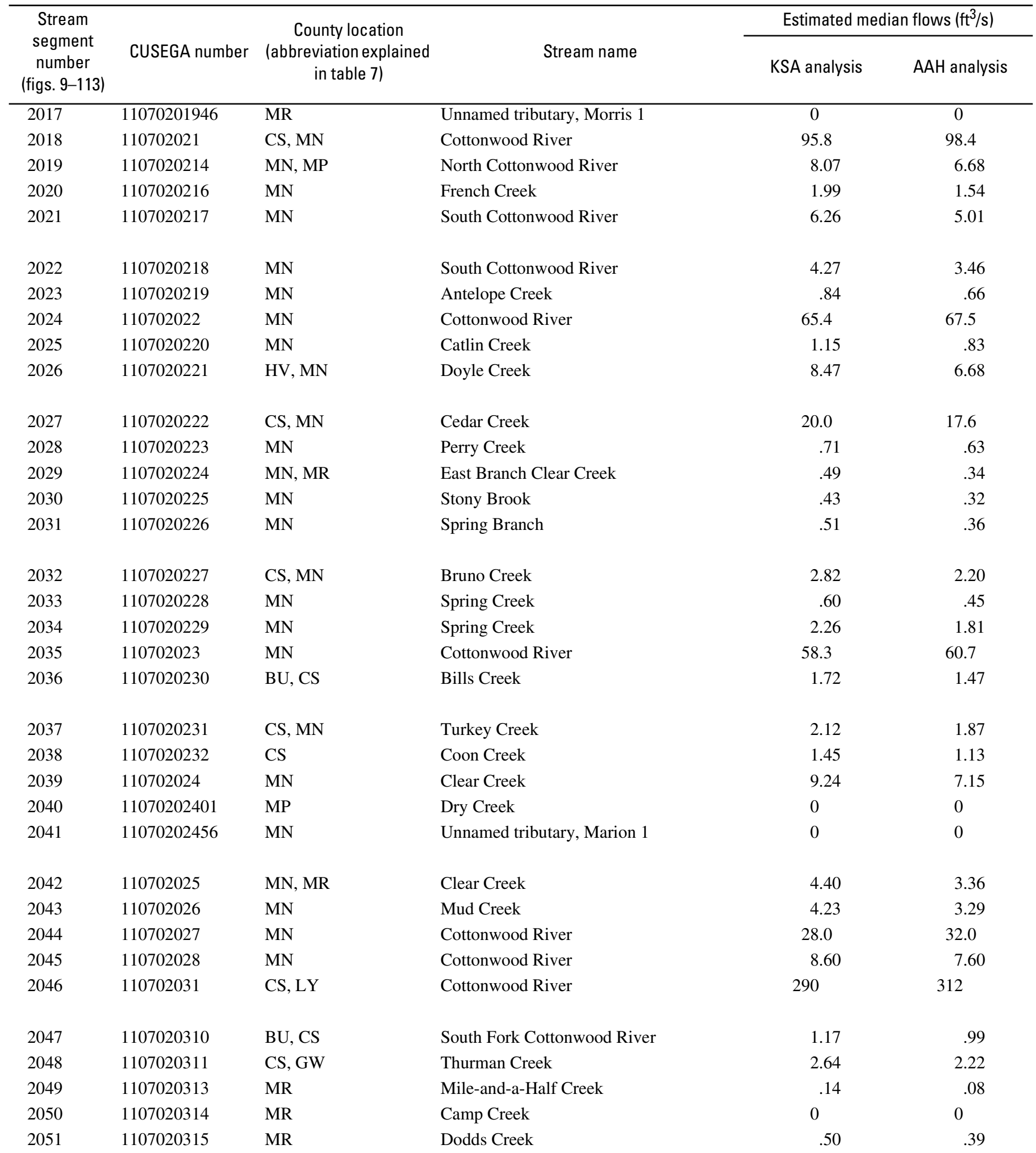


Table 6. Stream segments on the 1999 Kansas Surface Water Register, CUSEGA numbers, stream names, and estimated median flows at downstream end of CUSEGA segments using the most-recent 10 years of record (KSA) and all-available hydrology (AAH) analyses.-Continued

[Estimated median flows are rounded to two or three significant figures. Reporting estimated median values to three signficant figures (median greater than or equal to $1 \mathrm{ft}^{3} / \mathrm{s}$ ) or two significant figures (median less than $1 \mathrm{ft}^{3} / \mathrm{s}$ ) was done to conform with the intent of KSA $82 \mathrm{a}-2001 \mathrm{et}$. seq. $\mathrm{ft}^{3} / \mathrm{s}$, cubic feet per second; KSA, Kansas Statute 82a-2001 analysis; AAH, all-available hydrology analysis]

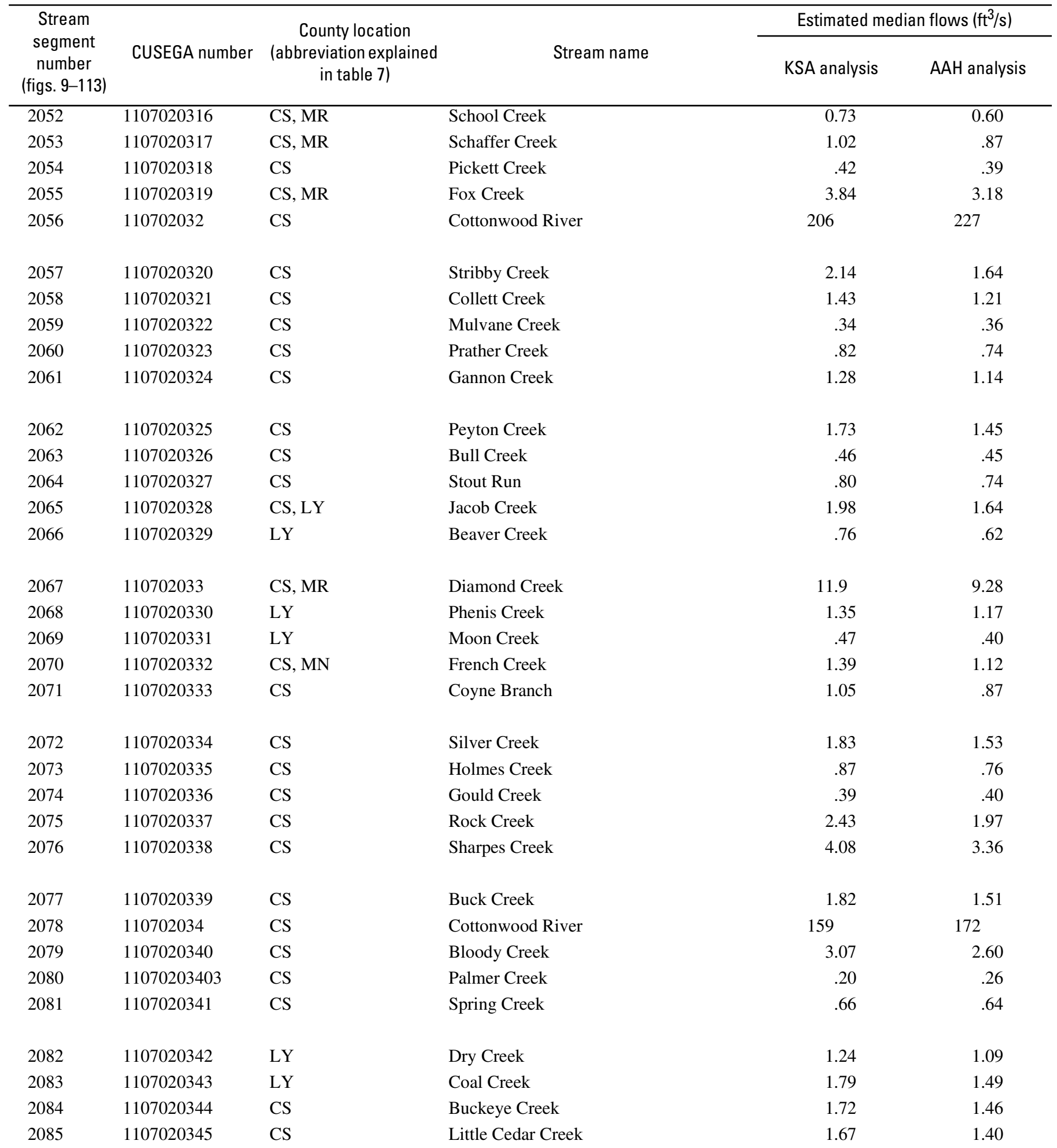


Table 6. Stream segments on the 1999 Kansas Surface Water Register, CUSEGA numbers, stream names, and estimated median flows at downstream end of CUSEGA segments using the most-recent 10 years of record (KSA) and all-available hydrology (AAH) analyses.-Continued

[Estimated median flows are rounded to two or three significant figures. Reporting estimated median values to three signficant figures (median greater than or equal to $1 \mathrm{ft}^{3} / \mathrm{s}$ ) or two significant figures (median less than $1 \mathrm{ft}^{3} / \mathrm{s}$ ) was done to conform with the intent of KSA $82 \mathrm{a}-2001$ et. seq. $\mathrm{ft}^{3} / \mathrm{s}$, cubic feet per second; KSA, Kansas Statute 82a-2001 analysis; AAH, all-available hydrology analysis]

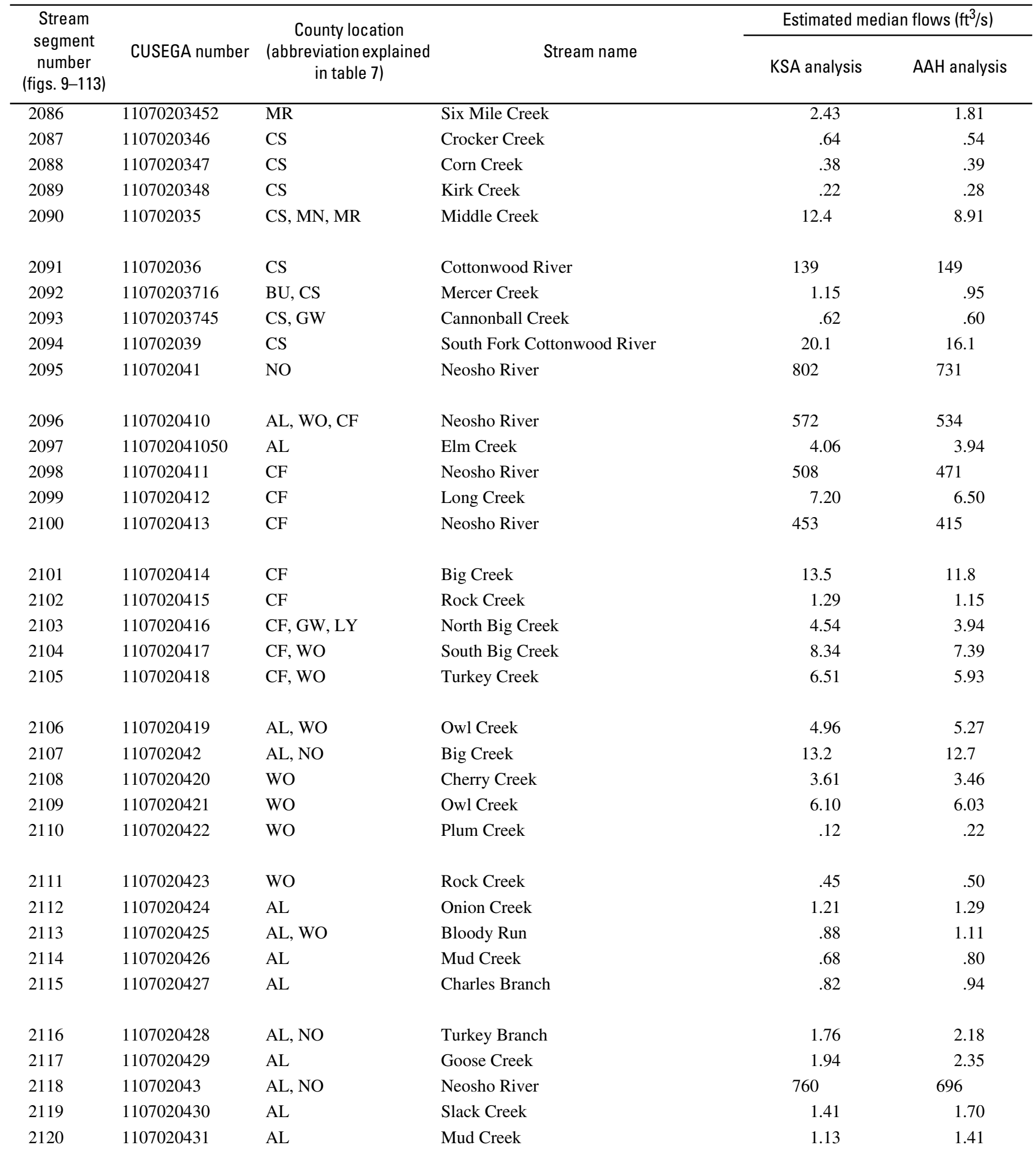


Table 6. Stream segments on the 1999 Kansas Surface Water Register, CUSEGA numbers, stream names, and estimated median flows at downstream end of CUSEGA segments using the most-recent 10 years of record (KSA) and all-available hydrology (AAH) analyses.-Continued

[Estimated median flows are rounded to two or three significant figures. Reporting estimated median values to three signficant figures (median greater than or equal to $1 \mathrm{ft}^{3} / \mathrm{s}$ ) or two significant figures (median less than $1 \mathrm{ft}^{3} / \mathrm{s}$ ) was done to conform with the intent of KSA $82 \mathrm{a}-2001 \mathrm{et}$. seq. $\mathrm{ft}^{3} / \mathrm{s}$, cubic feet per second; KSA, Kansas Statute 82a-2001 analysis; AAH, all-available hydrology analysis]

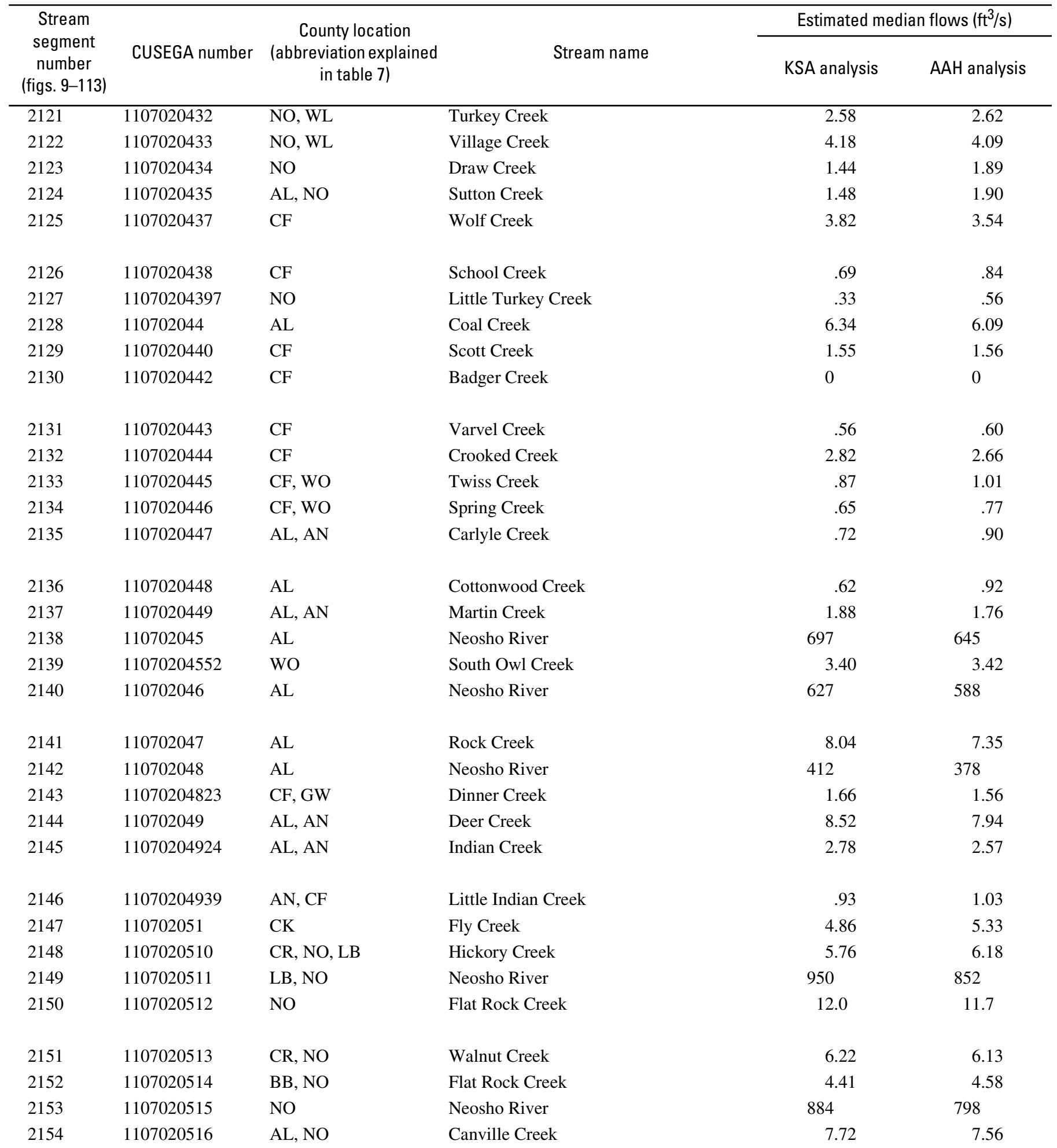




\section{Estimates of Median Flows for Streams on the 1999 Kansas Surface Water Register}

Table 6. Stream segments on the 1999 Kansas Surface Water Register, CUSEGA numbers, stream names, and estimated median flows at downstream end of CUSEGA segments using the most-recent 10 years of record (KSA) and all-available hydrology (AAH) analyses.-Continued

[Estimated median flows are rounded to two or three significant figures. Reporting estimated median values to three signficant figures (median greater than or equal to $1 \mathrm{ft}^{3} / \mathrm{s}$ ) or two significant figures (median less than $1 \mathrm{ft}^{3} / \mathrm{s}$ ) was done to conform with the intent of KSA $82 \mathrm{a}-2001$ et. seq. $\mathrm{ft}^{3} / \mathrm{s}$, cubic feet per second; KSA, Kansas Statute 82a-2001 analysis; AAH, all-available hydrology analysis]

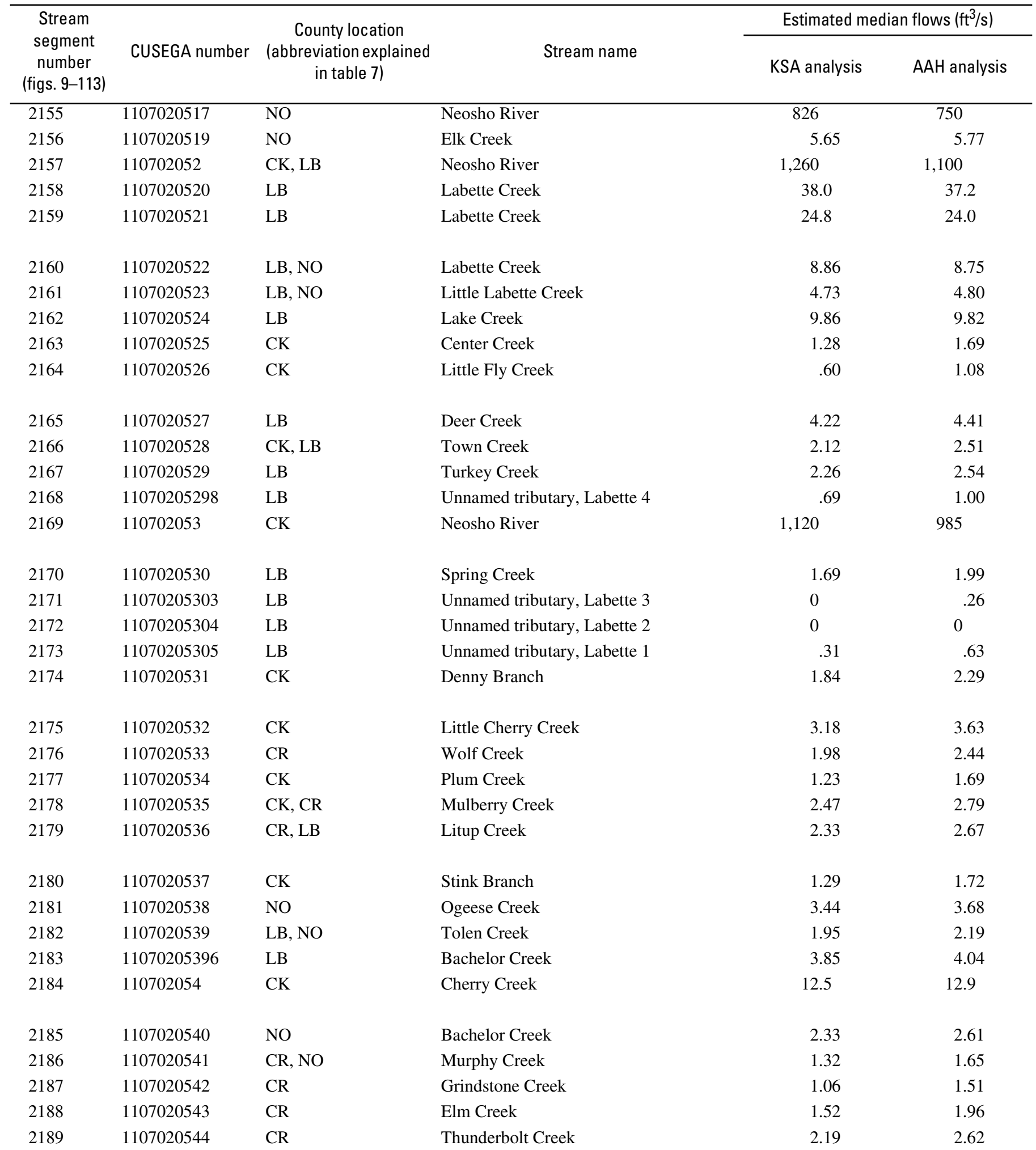


Table 6. Stream segments on the 1999 Kansas Surface Water Register, CUSEGA numbers, stream names, and estimated median flows at downstream end of CUSEGA segments using the most-recent 10 years of record (KSA) and all-available hydrology (AAH) analyses.-Continued

[Estimated median flows are rounded to two or three significant figures. Reporting estimated median values to three signficant figures (median greater than or equal to $1 \mathrm{ft}^{3} / \mathrm{s}$ ) or two significant figures (median less than $1 \mathrm{ft}^{3} / \mathrm{s}$ ) was done to conform with the intent of KSA $82 \mathrm{a}-2001 \mathrm{et}$. seq. $\mathrm{ft}^{3} / \mathrm{s}$, cubic feet per second; KSA, Kansas Statute 82a-2001 analysis; AAH, all-available hydrology analysis]

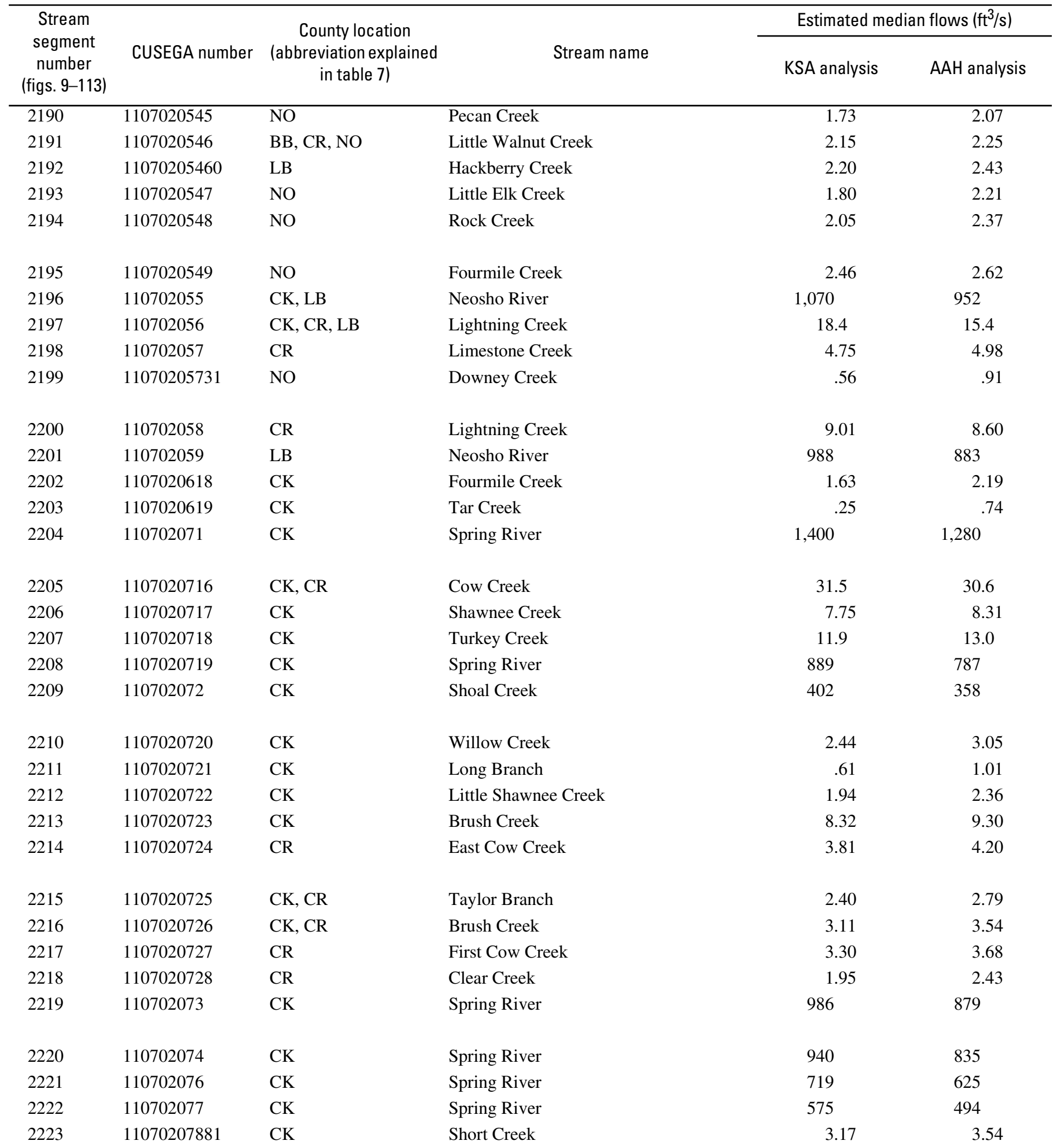


Table 6. Stream segments on the 1999 Kansas Surface Water Register, CUSEGA numbers, stream names, and estimated median flows at downstream end of CUSEGA segments using the most-recent 10 years of record (KSA) and all-available hydrology (AAH) analyses.-Continued

[Estimated median flows are rounded to two or three significant figures. Reporting estimated median values to three signficant figures (median greater than or equal to $1 \mathrm{ft}^{3} / \mathrm{s}$ ) or two significant figures (median less than $1 \mathrm{ft}^{3} / \mathrm{s}$ ) was done to conform with the intent of KSA $82 \mathrm{a}-2001$ et. seq. $\mathrm{ft}^{3} / \mathrm{s}$, cubic feet per second; KSA, Kansas Statute 82a-2001 analysis; AAH, all-available hydrology analysis]

\begin{tabular}{|c|c|c|c|c|c|}
\hline \multirow{2}{*}{$\begin{array}{c}\text { Stream } \\
\text { segment } \\
\text { number } \\
\text { (figs. 9-113) }\end{array}$} & \multirow[b]{2}{*}{ CUSEGA number } & \multirow{2}{*}{$\begin{array}{c}\text { County location } \\
\text { (abbreviation explained } \\
\text { in table 7) }\end{array}$} & \multirow[b]{2}{*}{ Stream name } & \multicolumn{2}{|c|}{ Estimated median flows $\left(\mathrm{ft}^{3} / \mathrm{s}\right)$} \\
\hline & & & & KSA analysis & AAH analysis \\
\hline 2224 & 1024000722 & NM, MS & Unnamed tributary, Nemaha 1 & 0.45 & 0.36 \\
\hline 2225 & 1025000464 & RA & Unnamed tributary, Rawlins 1 & 0 & 0 \\
\hline 2226 & 1029010867 & MI & Unnamed tributary, Miami 2 & .07 & .38 \\
\hline 2227 & 1106000417 & SU & Unnamed tributary, Sumner 1 & 0 & 0 \\
\hline 2228 & 1106000513 & SU & Bluff Creek & 32.9 & 28.50 \\
\hline 2229 & 11030014999 & RN & Unnamed tributary, Reno 1 (Cable Lake) & 0 & 0 \\
\hline 2230 & 11030013456 & SG & Wichita-Valley Center Floodway & 17.8 & 16.50 \\
\hline 2231 & 11070207886 & $\mathrm{CK}$ & Unnamed tributary, Cherokee 1 & .61 & 1.51 \\
\hline 2232 & 1105000122 & $\mathrm{CM}$ & Keno Creek & 0 & 0 \\
\hline
\end{tabular}


Table 7. County abbreviations for Kansas.

\begin{tabular}{|c|c|c|c|}
\hline $\begin{array}{l}\text { County abbreviation } \\
\text { used in table } 6\end{array}$ & County name & $\begin{array}{l}\text { County abbreviation } \\
\text { used in table } 6\end{array}$ & County name \\
\hline$\overline{\mathrm{AL}}$ & Allen & HS & Haskell \\
\hline $\mathrm{AN}$ & Anderson & $\mathrm{HV}$ & Harvey \\
\hline $\mathrm{AT}$ & Atchison & $\mathrm{JA}$ & Jackson \\
\hline BA & Barber & $\mathrm{JF}$ & Jefferson \\
\hline $\mathrm{BB}$ & Bourbon & $\mathrm{JO}$ & Johnson \\
\hline $\mathrm{BR}$ & Brown & JW & Jewell \\
\hline BT & Barton & $\mathrm{KE}$ & Kearny \\
\hline $\mathrm{BU}$ & Butler & KM & Kingman \\
\hline $\mathrm{CA}$ & Clark & KW & Kiowa \\
\hline $\mathrm{CD}$ & Cloud & LB & Labette \\
\hline $\mathrm{CF}$ & Coffey & $\mathrm{LC}$ & Lincoln \\
\hline CK & Cherokee & LE & Lane \\
\hline CL & Cowley & LG & Logan \\
\hline $\mathrm{CM}$ & Comanche & $\mathrm{LN}$ & Linn \\
\hline $\mathrm{CN}$ & Cheyenne & LV & Leavenworth \\
\hline CQ & Chautauqua & LY & Lyon \\
\hline $\mathrm{CR}$ & Crawford & $\mathrm{MC}$ & Mitchell \\
\hline $\mathrm{CS}$ & Chase & $\mathrm{ME}$ & Meade \\
\hline $\mathrm{CY}$ & Clay & MG & Montgomery \\
\hline $\mathrm{DC}$ & Decatur & MI & Miami \\
\hline DG & Douglas & $\mathrm{MN}$ & Marion \\
\hline DK & Dickinson & MP & McPherson \\
\hline DP & Doniphan & MR & Morris \\
\hline ED & Edwards & MS & Marshall \\
\hline EK & Elk & MT & Morton \\
\hline EL & Ellis & $\mathrm{NM}$ & Nemaha \\
\hline EW & Ellsworth & NO & Neosho \\
\hline FI & Finney & NS & Ness \\
\hline FO & Ford & NT & Norton \\
\hline FR & Franklin & OB & Osborne \\
\hline GE & Geary & OS & Osage \\
\hline $\mathrm{GH}$ & Graham & OT & Ottawa \\
\hline GL & Greeley & PL & Phillips \\
\hline GO & Gove & PN & Pawnee \\
\hline GT & Grant & PR & Pratt \\
\hline GW & Greenwood & PT & Pottawatomie \\
\hline GY & Gray & RA & Rawlins \\
\hline $\mathrm{HG}$ & Hodgeman & $\mathrm{RC}$ & Rice \\
\hline HM & Hamilton & $\mathrm{RH}$ & Rush \\
\hline $\mathrm{HP}$ & Harper & RL & Riley \\
\hline
\end{tabular}


Table 7. County abbreviations for Kansas.-Continued

\begin{tabular}{|c|c|}
\hline $\begin{array}{l}\text { County abbreviation } \\
\text { used in table } 6\end{array}$ & County name \\
\hline$\overline{\mathrm{RN}}$ & Reno \\
\hline RO & Rooks \\
\hline $\mathrm{RP}$ & Republic \\
\hline RS & Russell \\
\hline SA & Saline \\
\hline $\mathrm{SC}$ & Scott \\
\hline SD & Sheridan \\
\hline $\mathrm{SF}$ & Stafford \\
\hline SG & Sedgwick \\
\hline SH & Sherman \\
\hline SM & Smith \\
\hline $\mathrm{SN}$ & Shawnee \\
\hline ST & Stanton \\
\hline SU & Sumner \\
\hline SV & Stevens \\
\hline SW & Seward \\
\hline $\mathrm{TH}$ & Thomas \\
\hline TR & Trego \\
\hline WA & Wallace \\
\hline WB & Wabaunsee \\
\hline WH & Wichita \\
\hline WL & Wilson \\
\hline WO & Woodson \\
\hline WS & Washington \\
\hline WY & Wyandotte \\
\hline
\end{tabular}




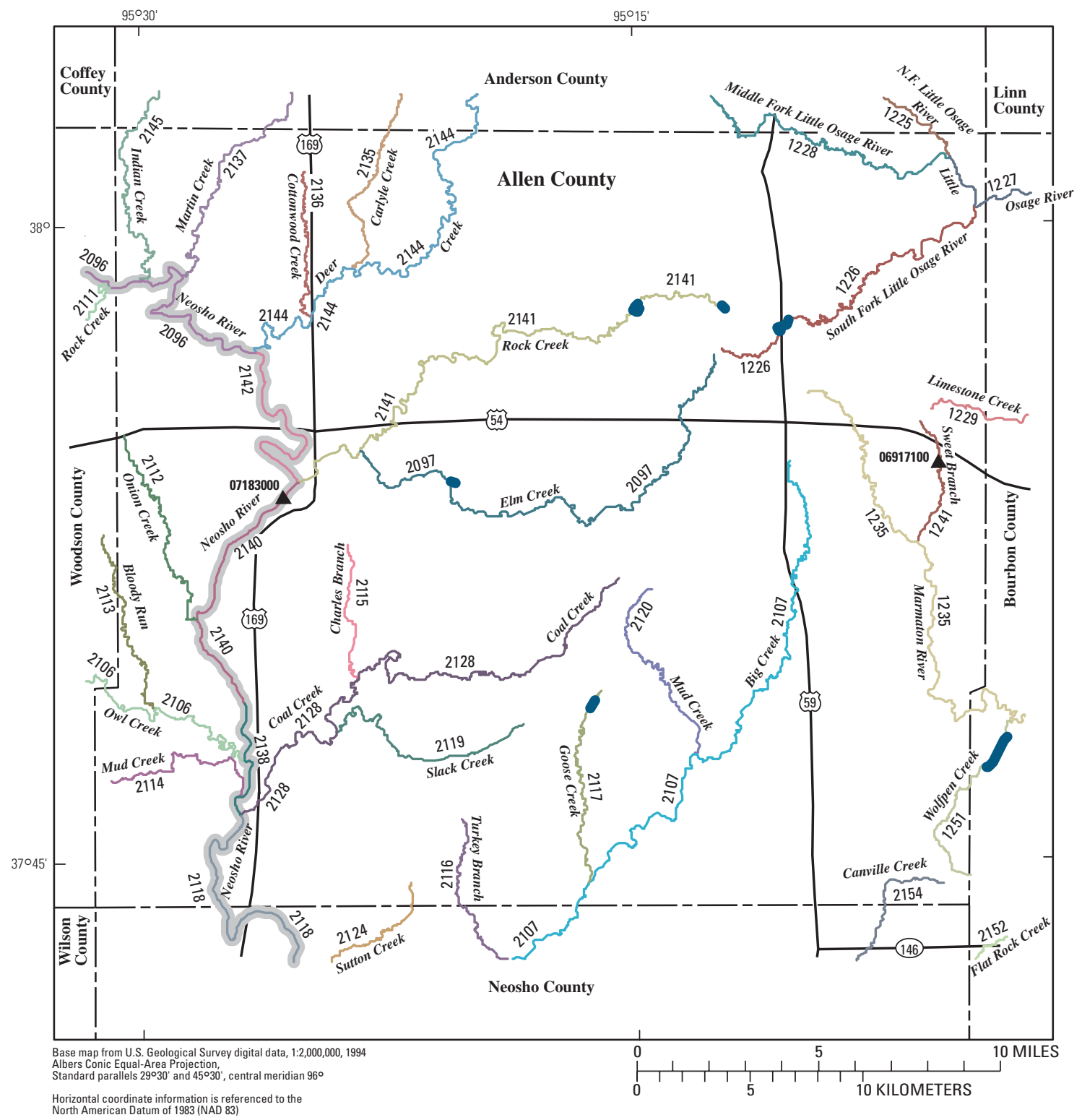

EXPLANATION
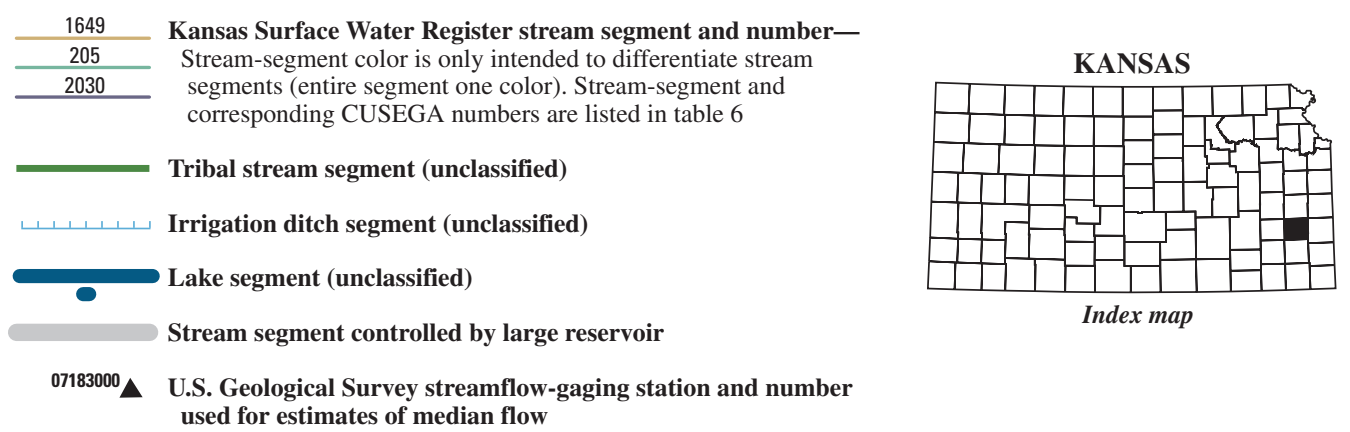

Figure 9. Location of U.S. Geological Survey streamflow-gaging stations and stream segments on the 1999 Kansas Surface Water Register for Allen County. 


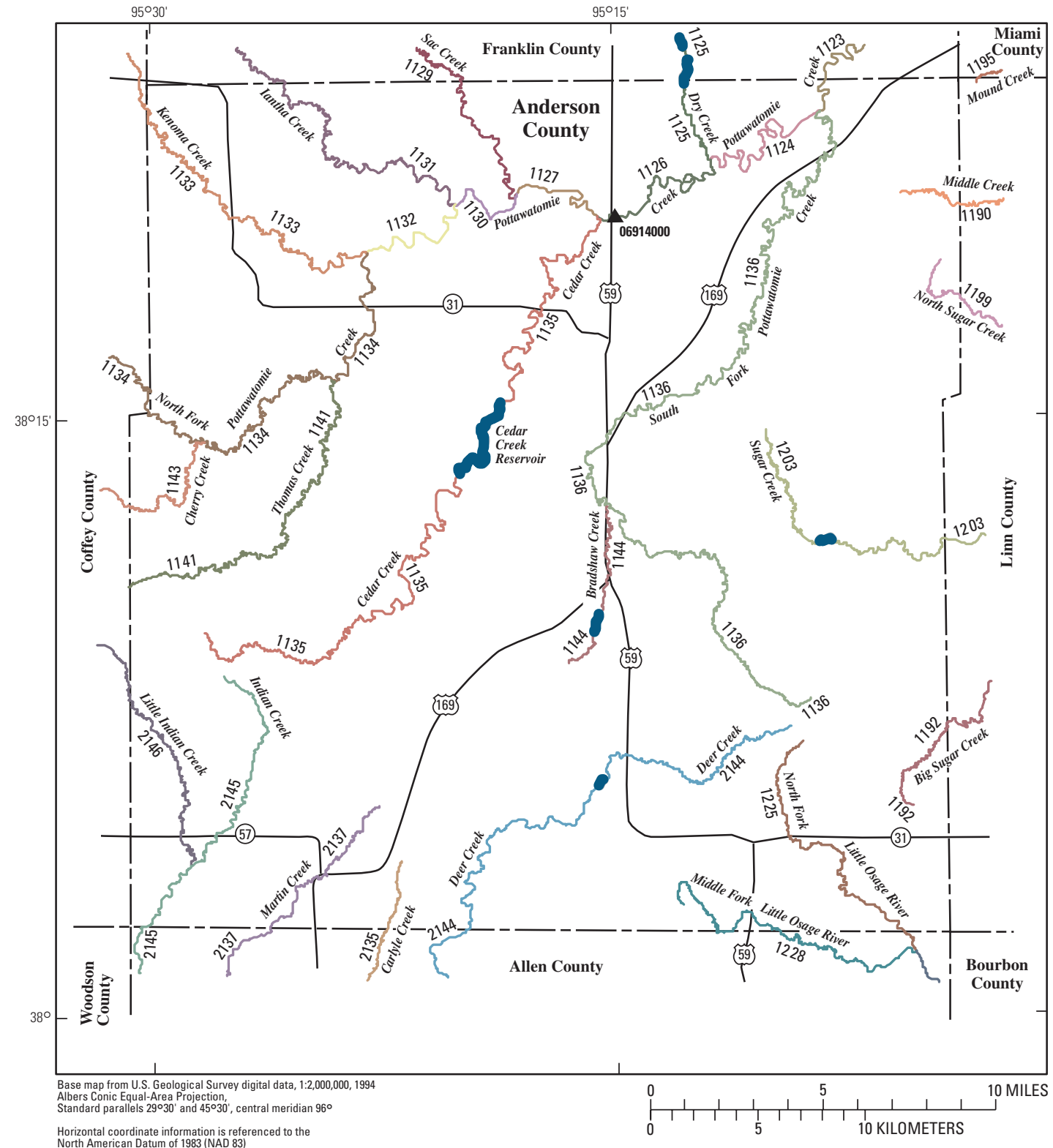

EXPLANATION
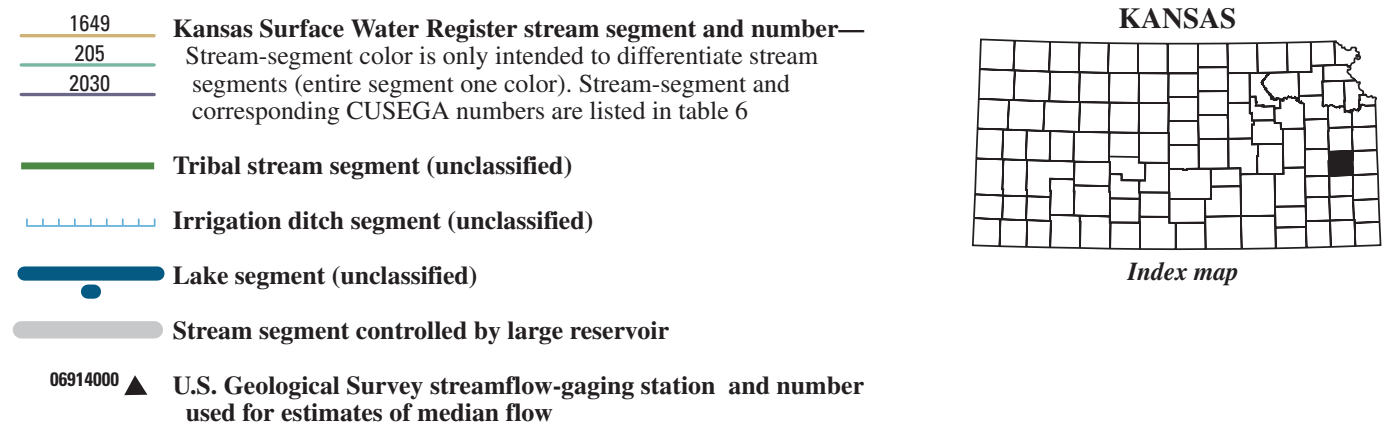

Index map used for estimates of median flow

Figure 10. Location of U.S. Geological Survey streamflow-gaging stations and stream segments on the 1999 Kansas Surface Water Register for Anderson County. 


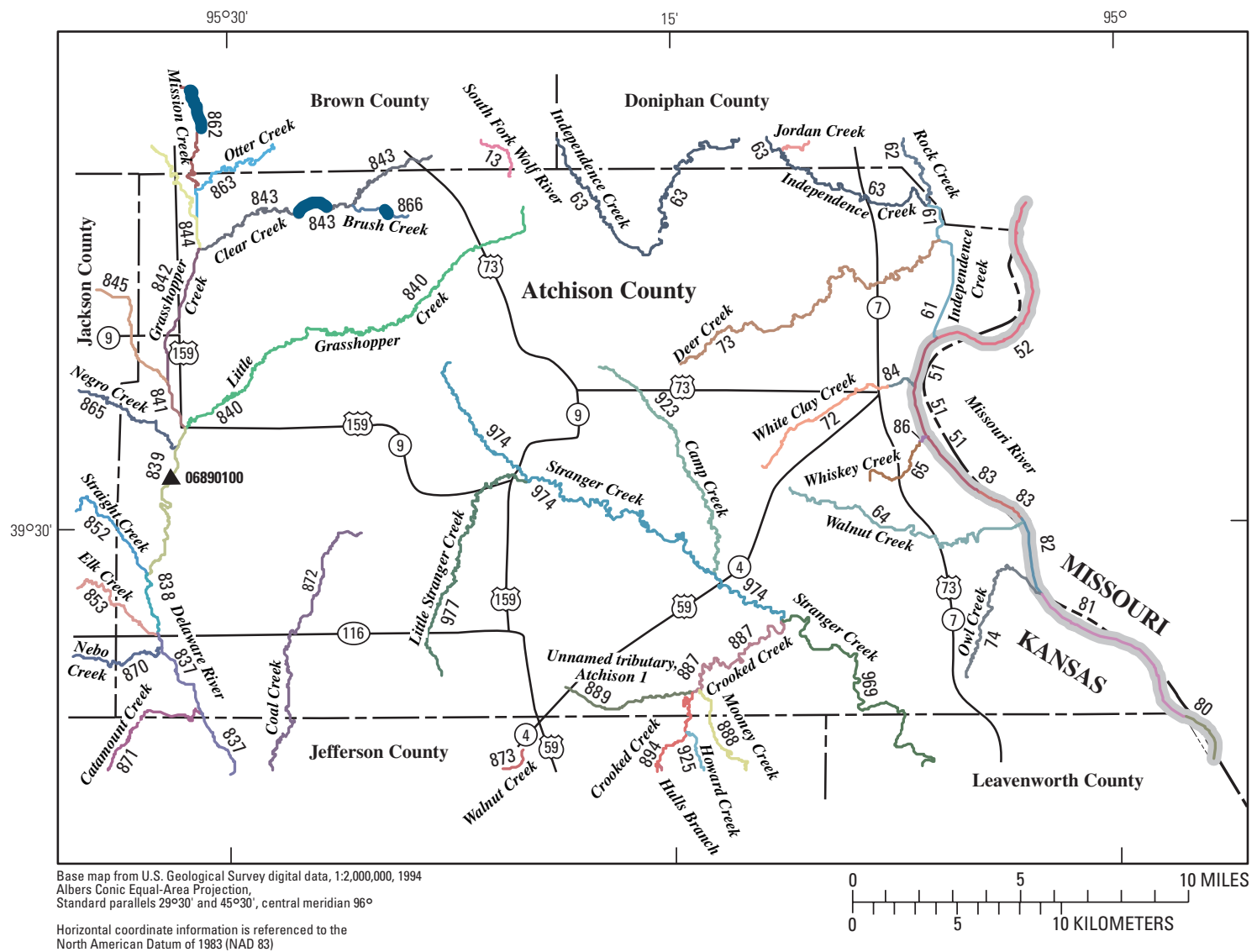

EXPLANATION

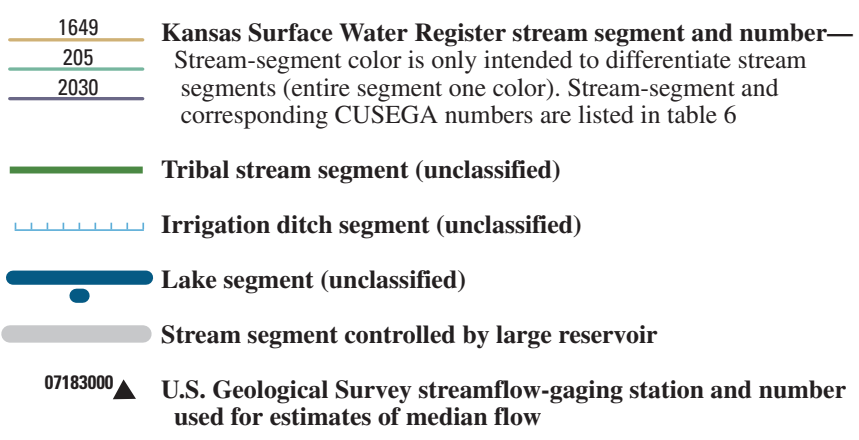

KANSAS

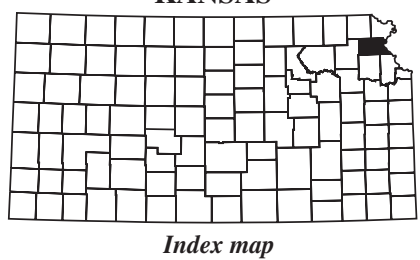

Figure 11. Location of U.S. Geological Survey streamflow-gaging stations and stream segments on the 1999 Kansas Surface Water Register for Atchison County. 


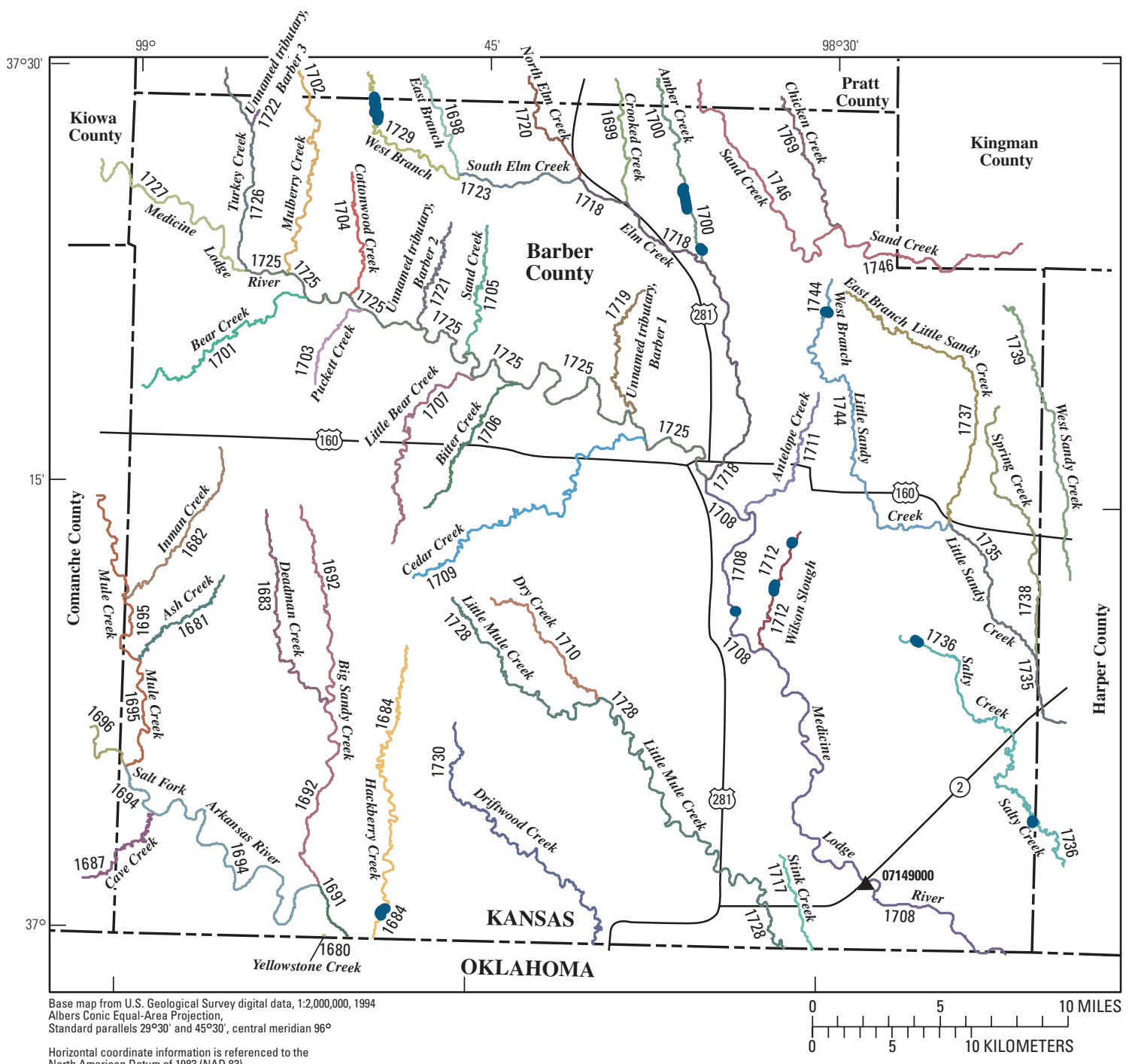

Horizontal coordinate information is referenced to the

\section{EXPLANATION}
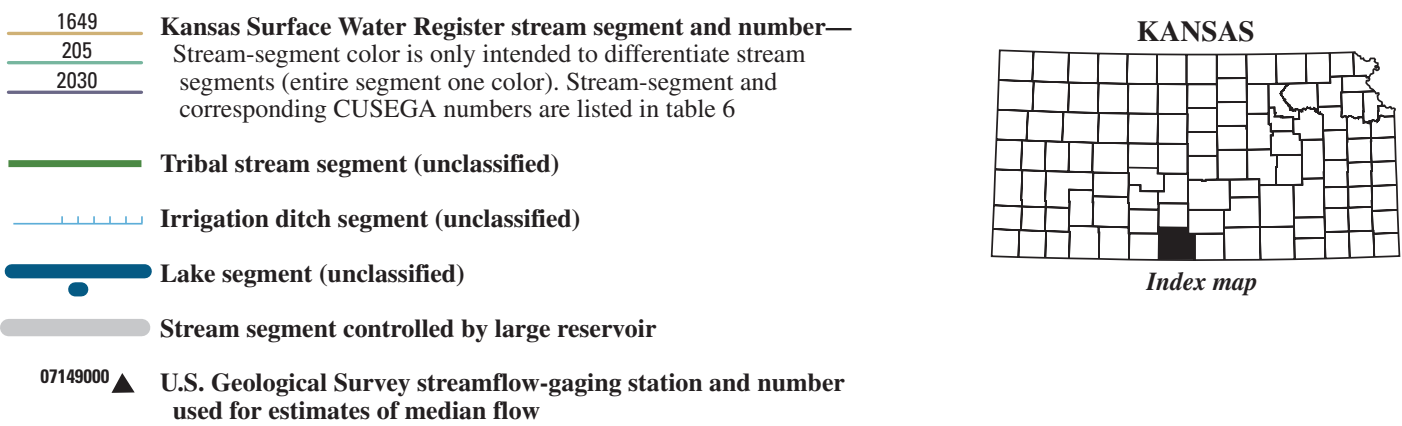

Figure 12. Location of U.S. Geological Survey streamflow-gaging stations and stream segments on the 1999 Kansas Surface Water Register for Barber County. 


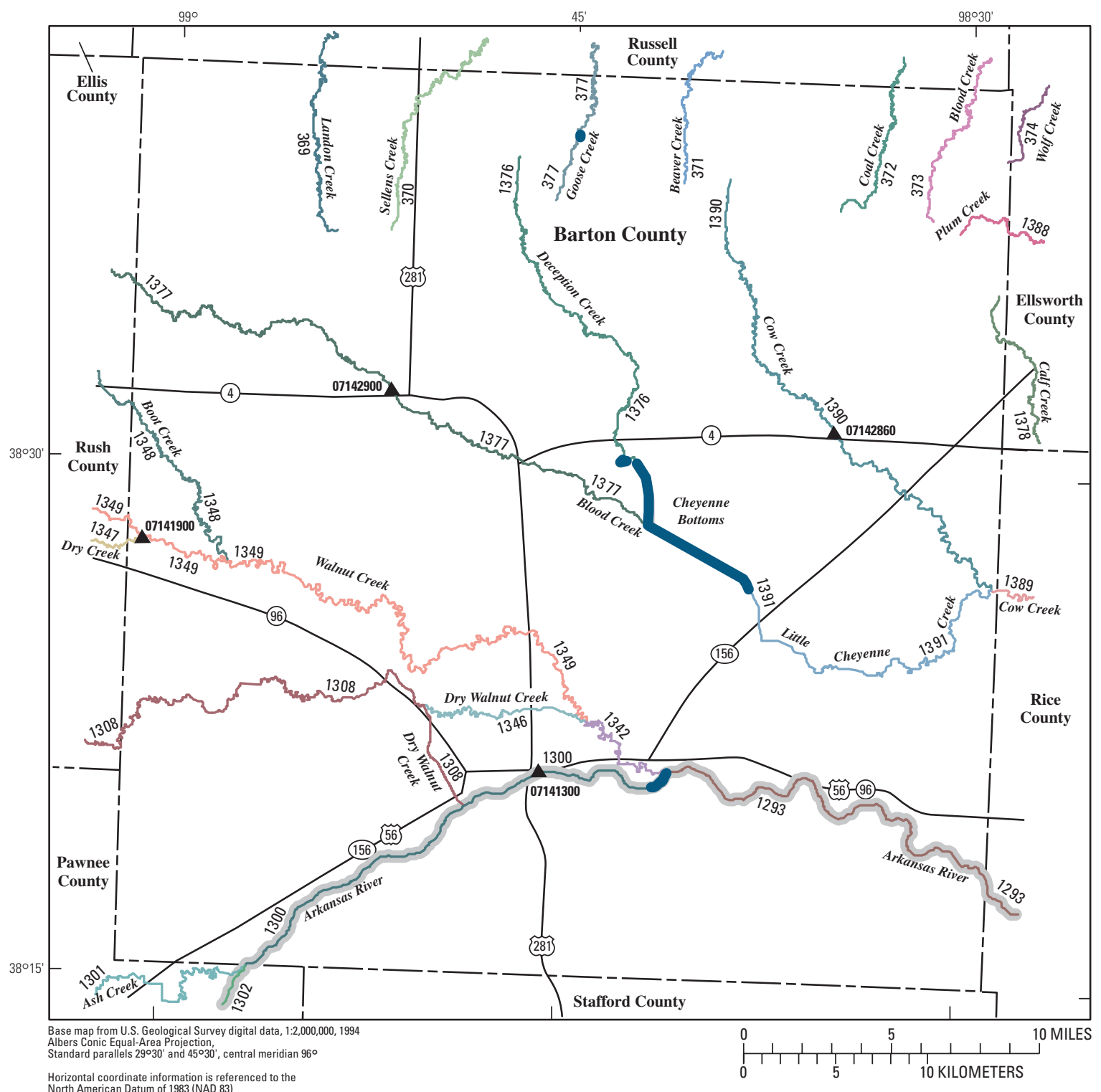

EXPLANATION

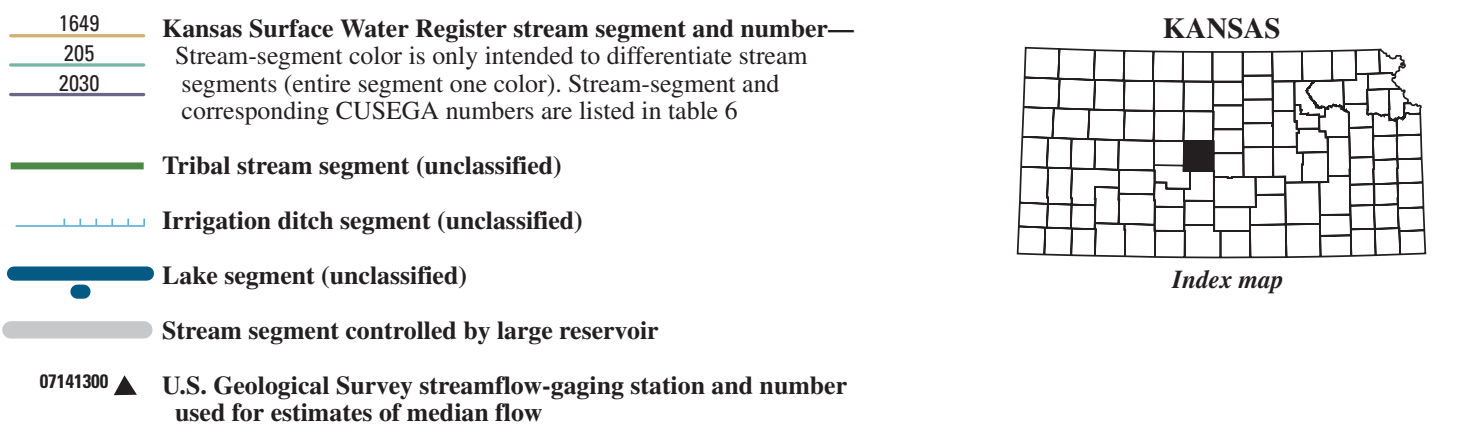

Figure 13. Location of U.S. Geological Survey streamflow-gaging stations and stream segments on the 1999 Kansas Surface Water Register for Barton County. 


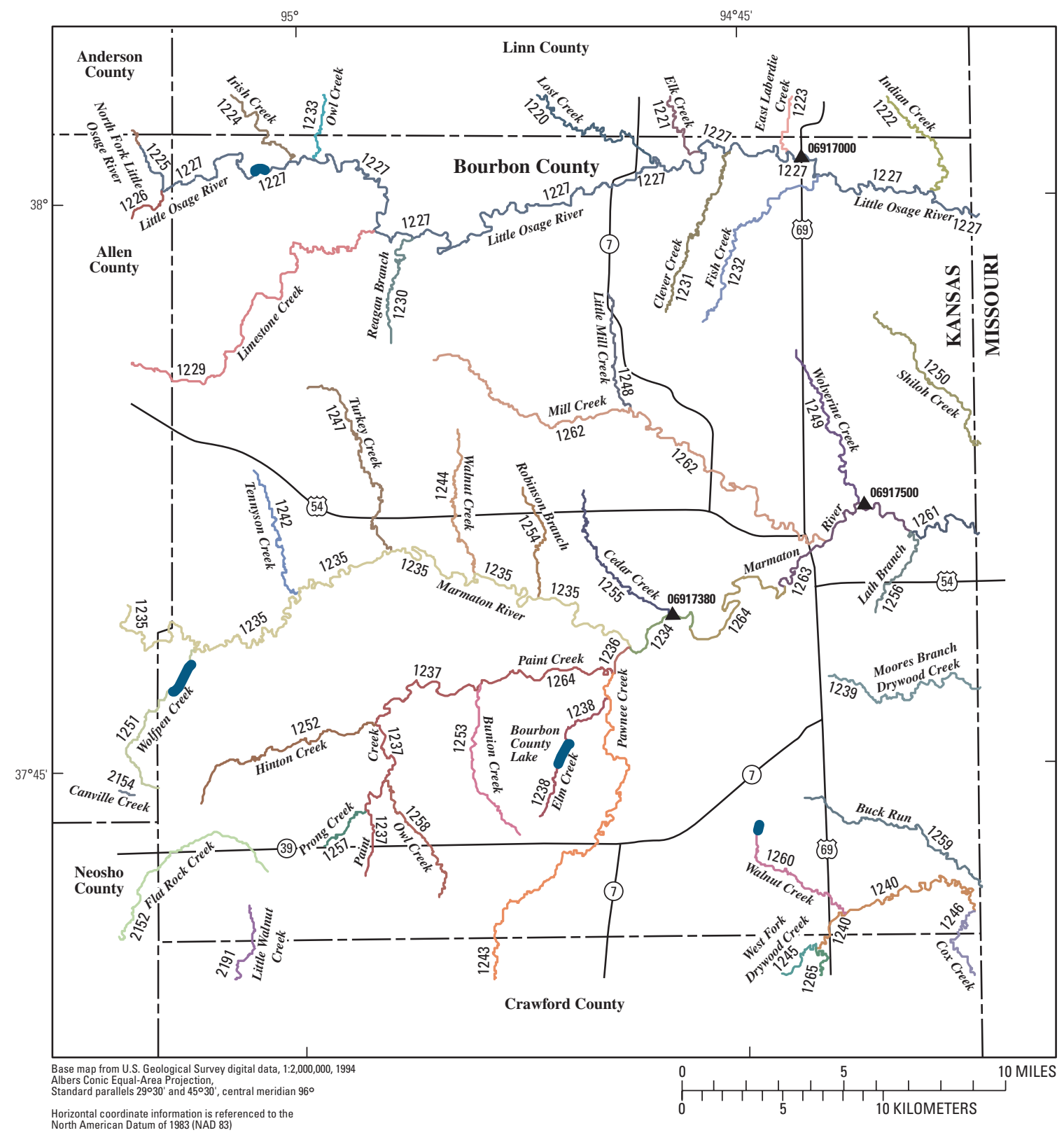

EXPLANATION
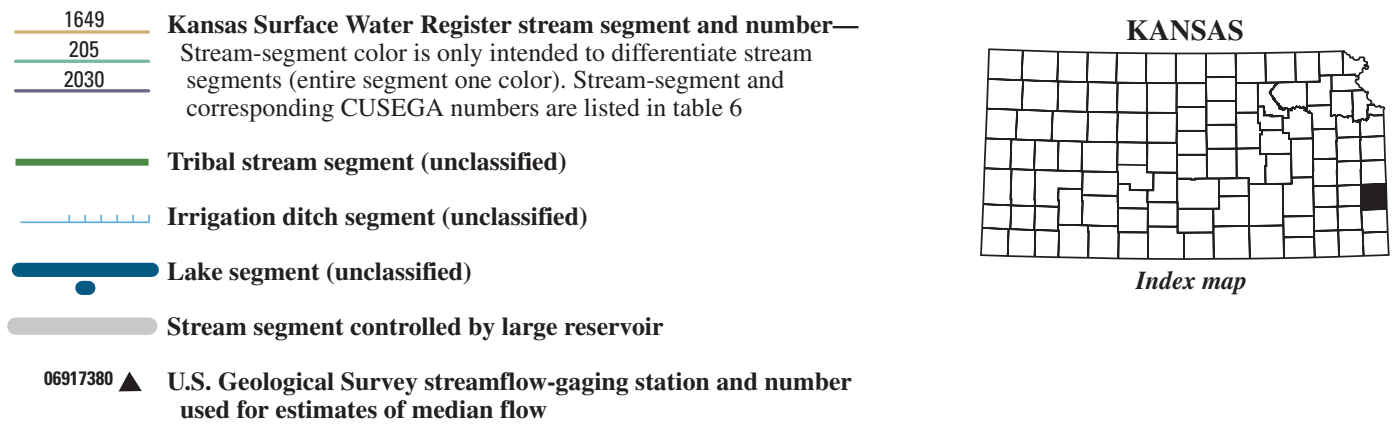

Index map used for estimates of median flow

Figure 14. Location of U.S. Geological Survey streamflow-gaging stations and stream segments on the 1999 Kansas Surface Water Register for Bourbon County. 


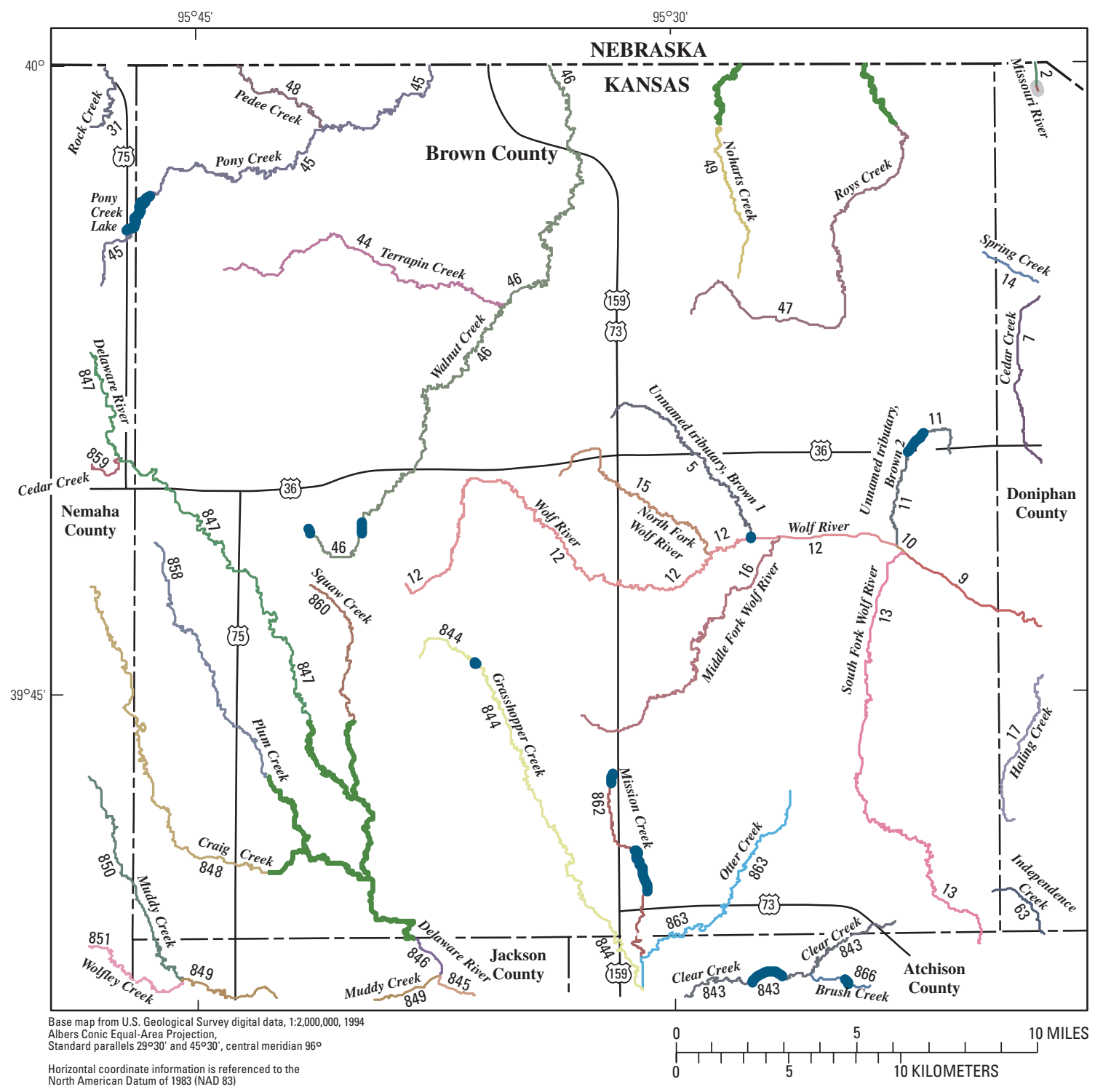

EXPLANATION
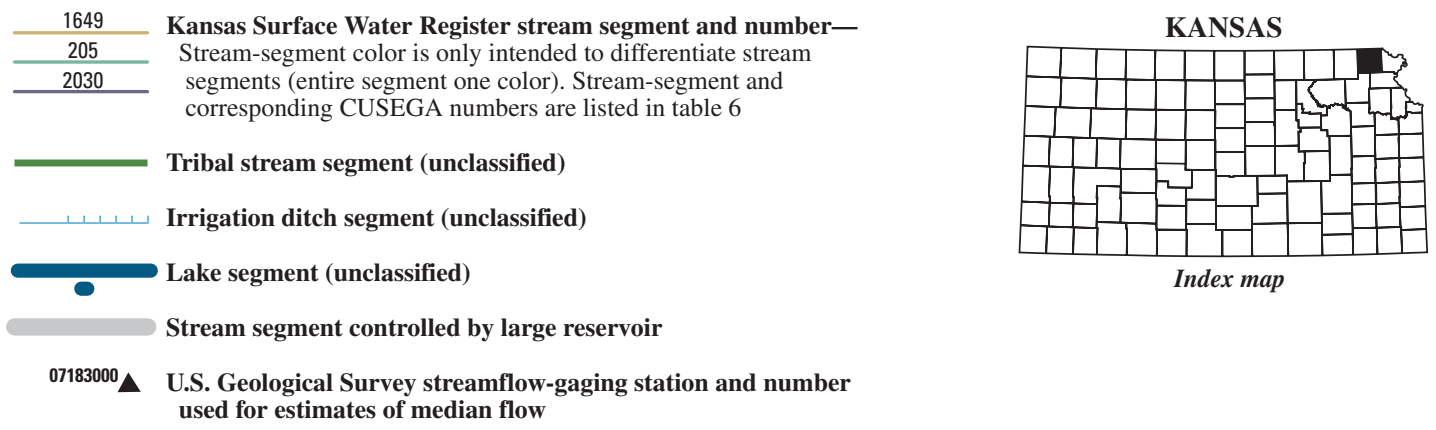

Index map

Figure 15. Location of U.S. Geological Survey streamflow-gaging stations and stream segments on the 1999 Kansas Surface Water Register for Brown County. 


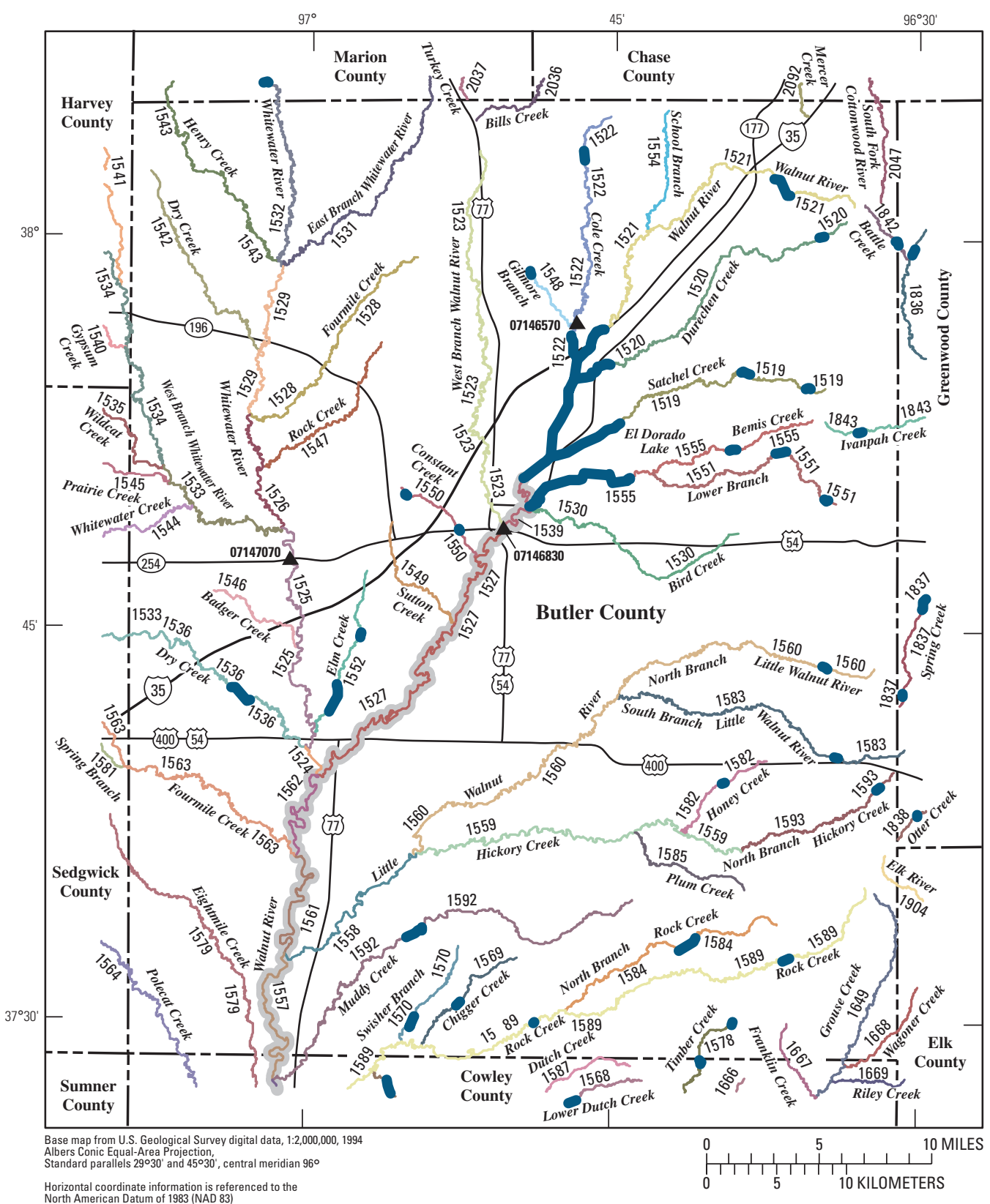

EXPLANATION

\begin{tabular}{|c|c|}
\hline 1649 & Kansas Surface Water Register stream segment and number- \\
\hline 205 & Stream-segment color is only intended to differentiate stream \\
\hline 2030 & segments (entire segment one color). Stream-segment and \\
\hline & corresponding CUSEGA numbers are listed in table 6 \\
\hline & Tribal stream segment (unclassified) \\
\hline $1,1,1,1$ & Irrigation ditch segment (unclassified) \\
\hline - & Lake segment (unclassified) \\
\hline & Stream segment controlled by large reservoir \\
\hline $07146830 \Delta$ & $\begin{array}{l}\text { U.S. Geological Survey streamflow-gaging station and number } \\
\text { used for estimates of median flow }\end{array}$ \\
\hline
\end{tabular}

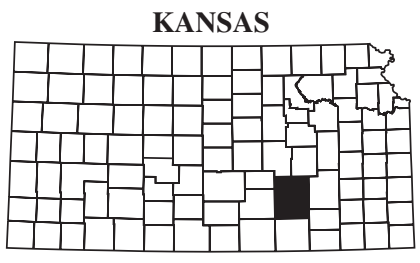

Index map

Figure 16. Location of U.S. Geological Survey streamflow-gaging stations and stream segments on the 1999 Kansas Surface Water Register for Butler County. 


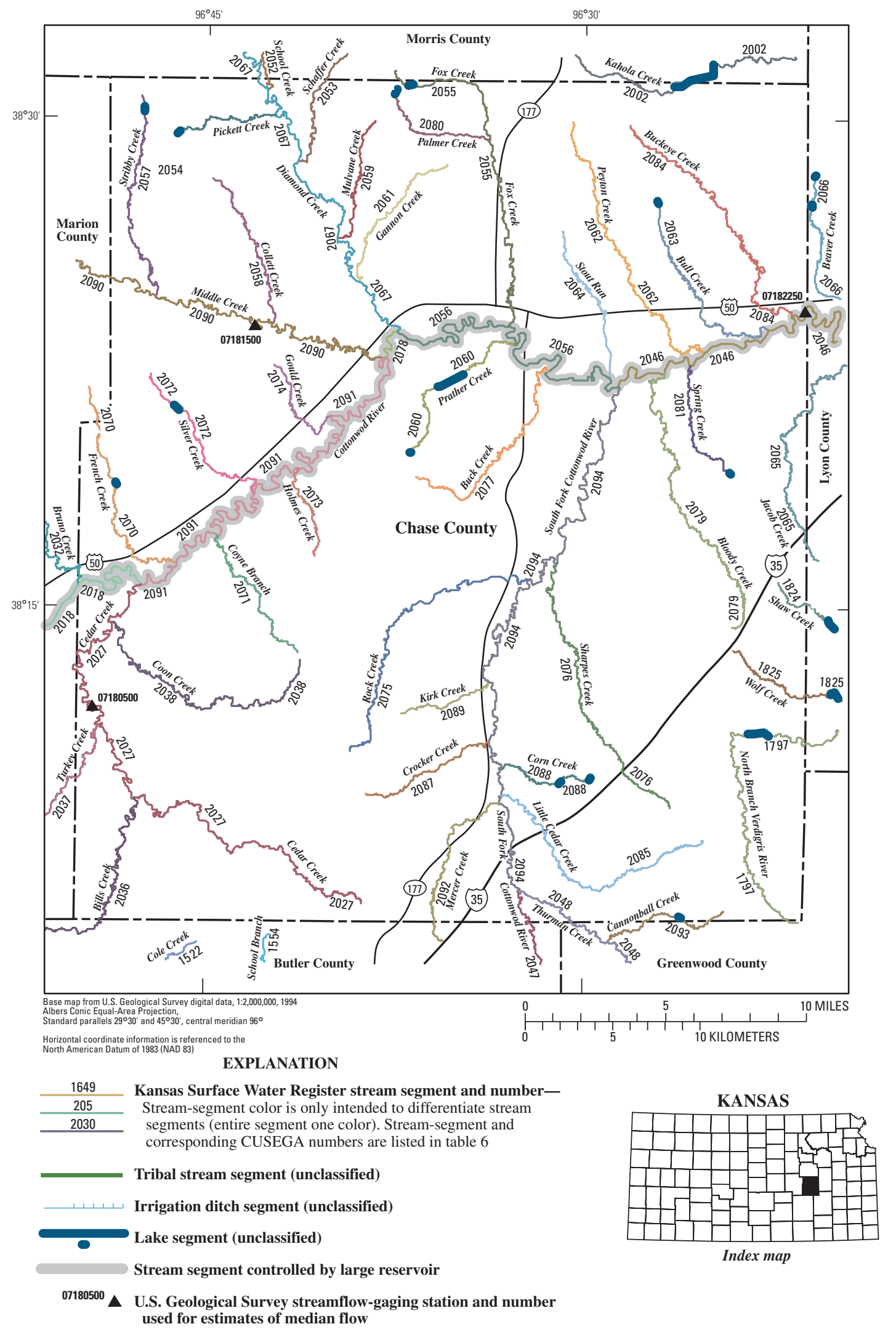

Figure 17. Location of U.S. Geological Survey streamflow-gaging stations and stream segments on the 1999 Kansas Surface Water Register for Chase County. 


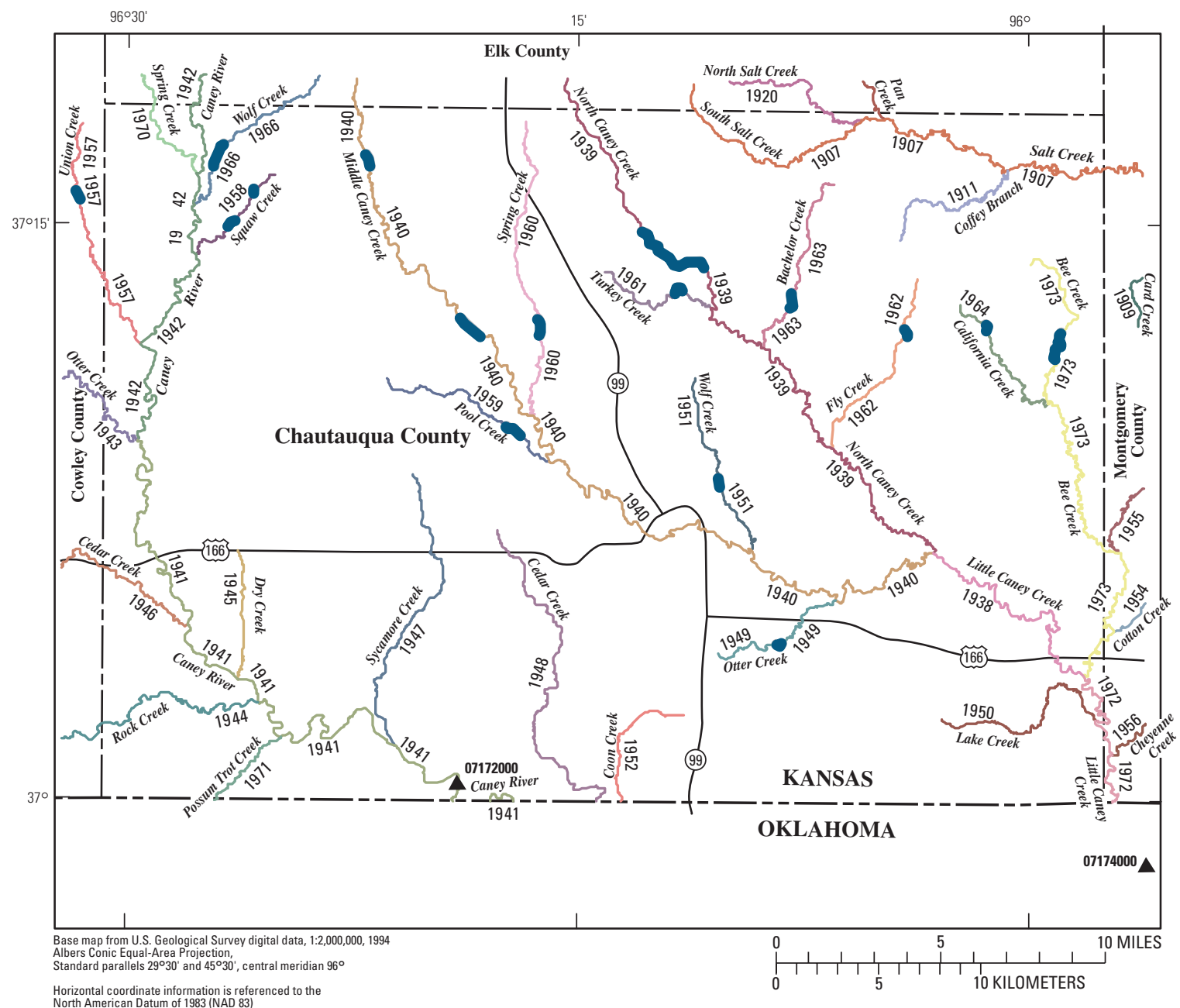

EXPLANATION

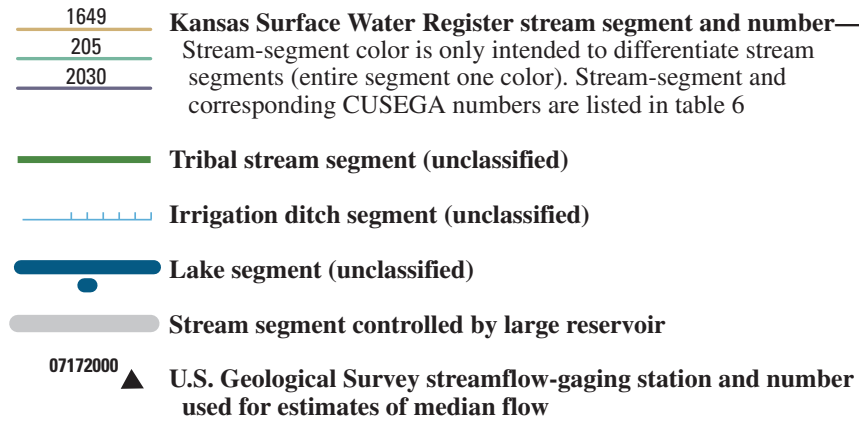

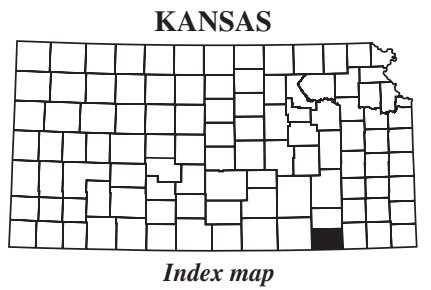

Figure 18. Location of U.S. Geological Survey streamflow-gaging stations and stream segments on the 1999 Kansas Surface Water Register for Chautauqua County. 


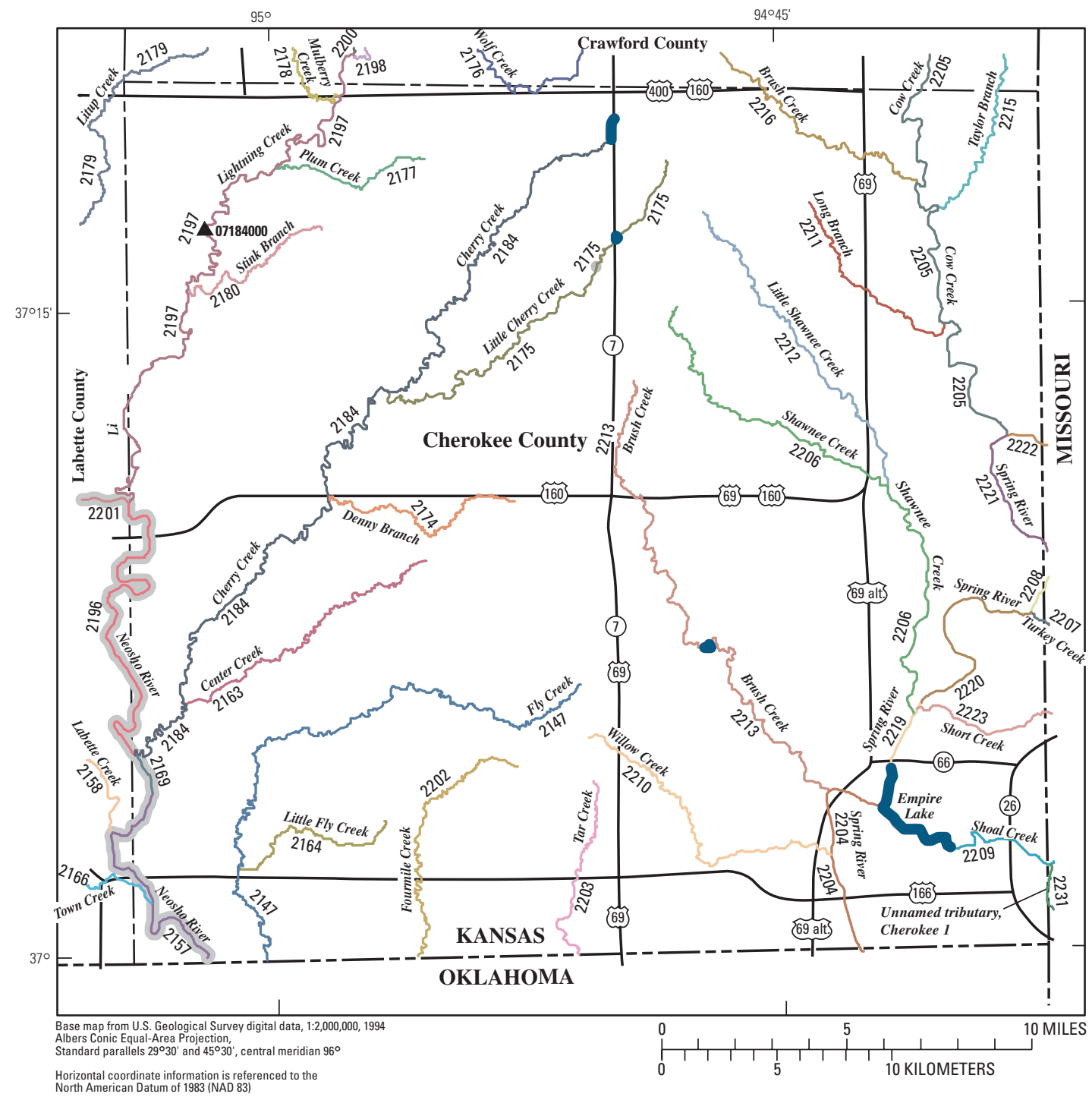

EXPLANATION
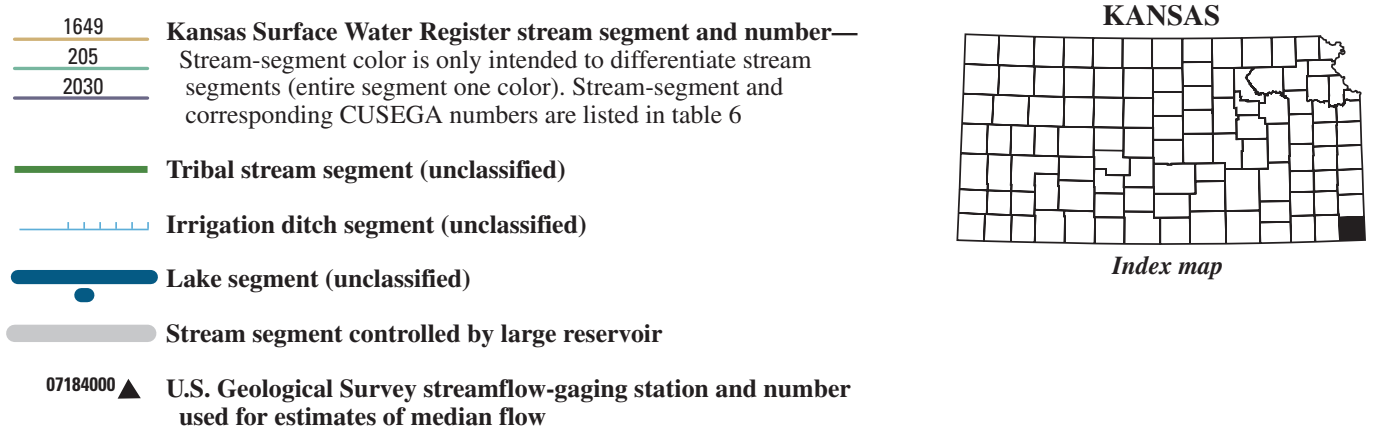

Index map used for estimates of median flow

Figure 19. Location of U.S. Geological Survey streamflow-gaging stations and stream segments on the 1999 Kansas Surface Water Register for Cherokee County. 


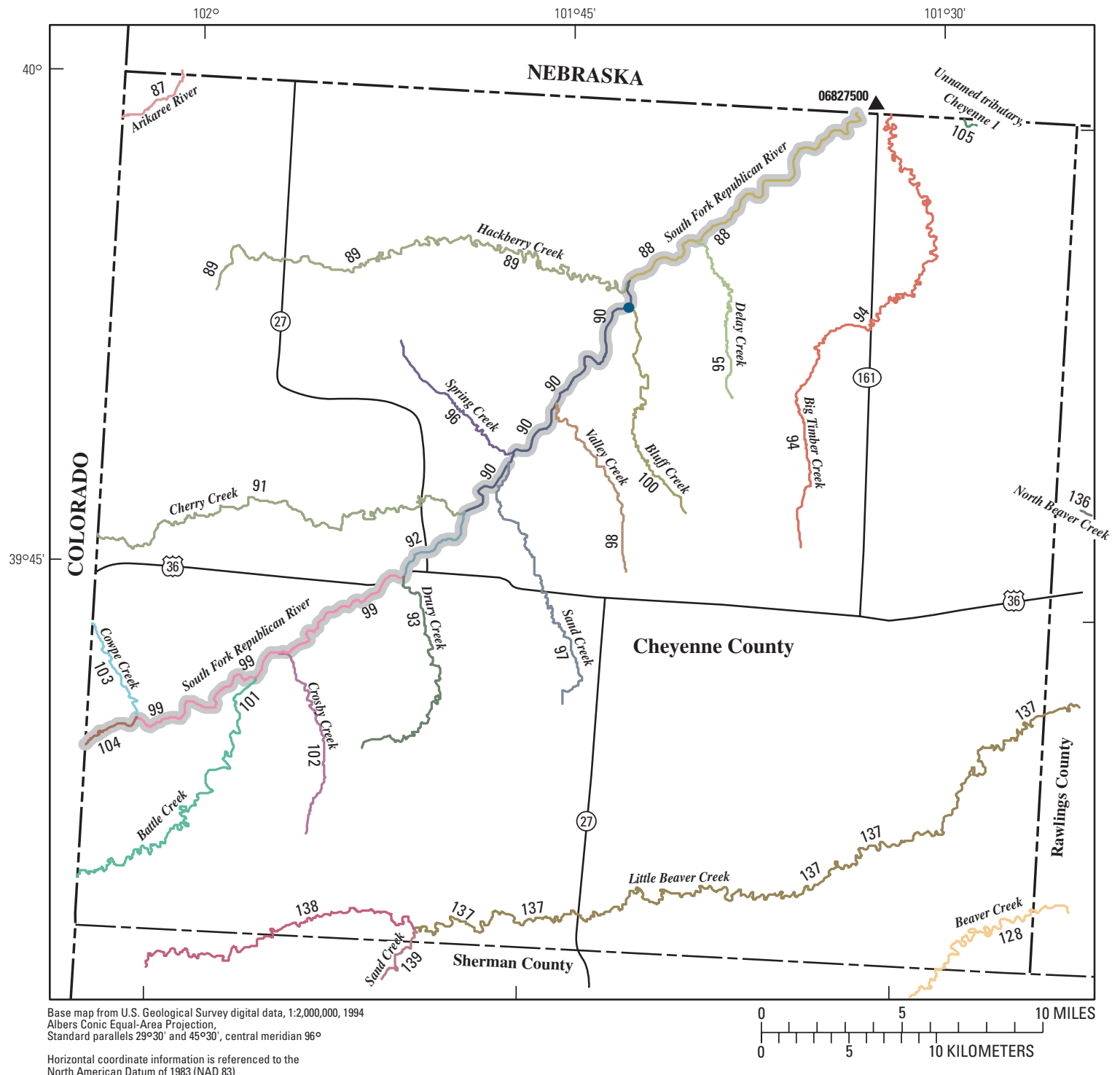

EXPLANATION

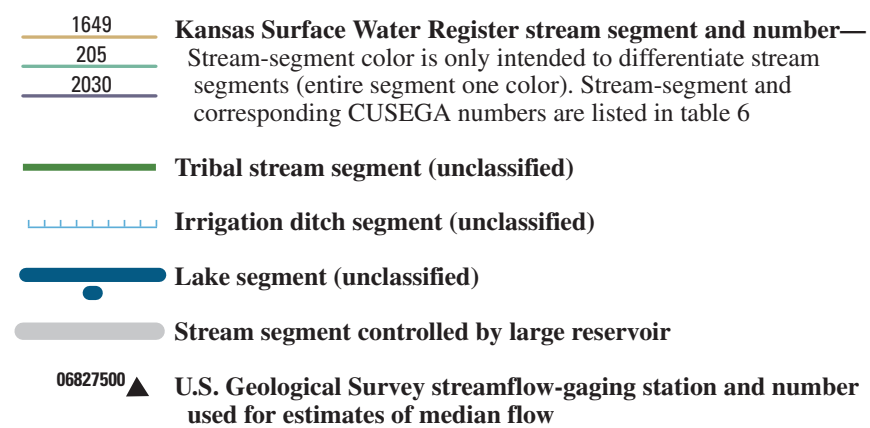

Figure 20. Location of U.S. Geological Survey streamflow-gaging stations and stream segments on the 1999 Kansas Surface Water Register for Cheyenne County. 

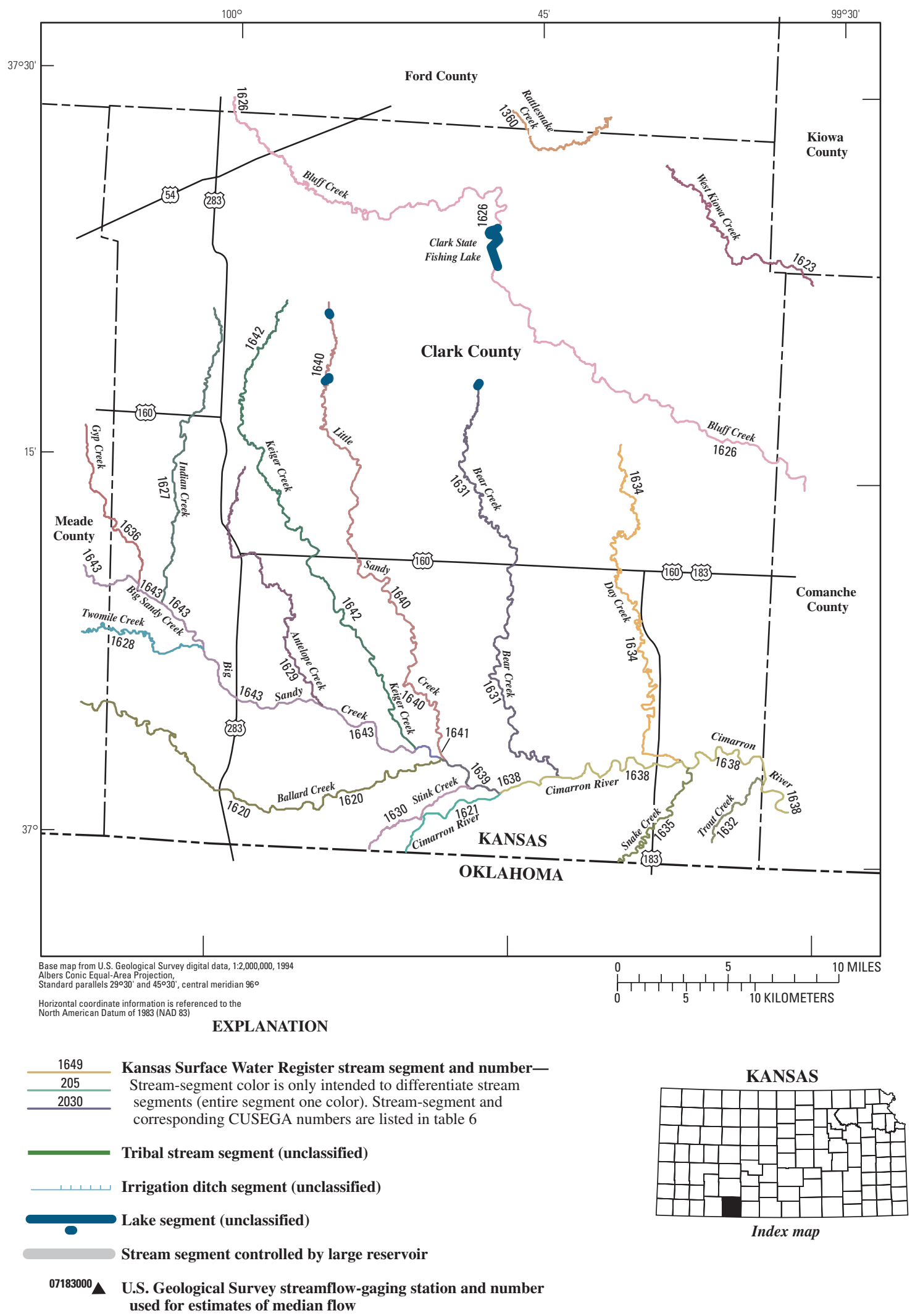

Figure 21. Location of U.S. Geological Survey streamflow-gaging stations and stream segments on the 1999 Kansas Surface Water Register for Clark County. 


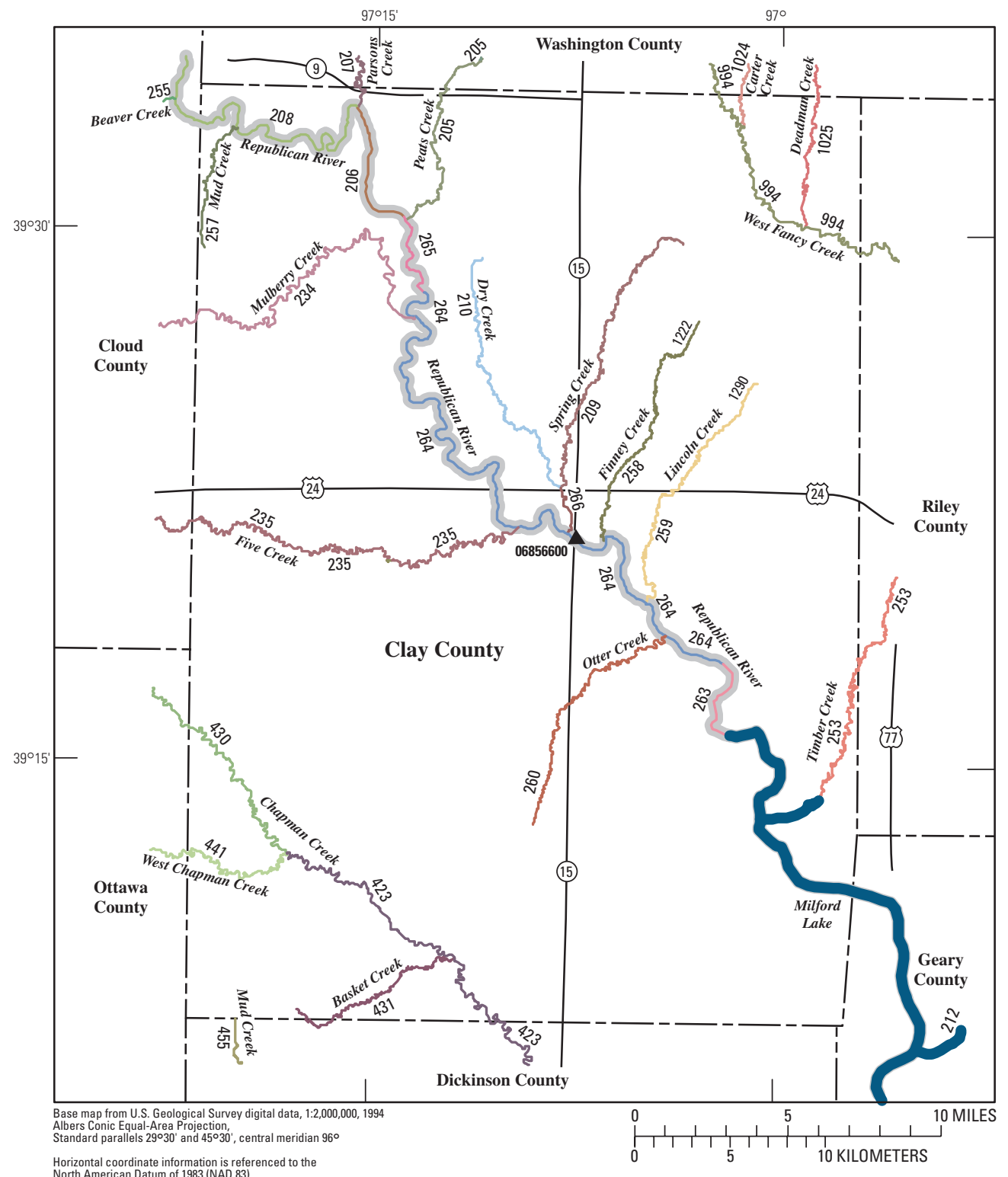

EXPLANATION
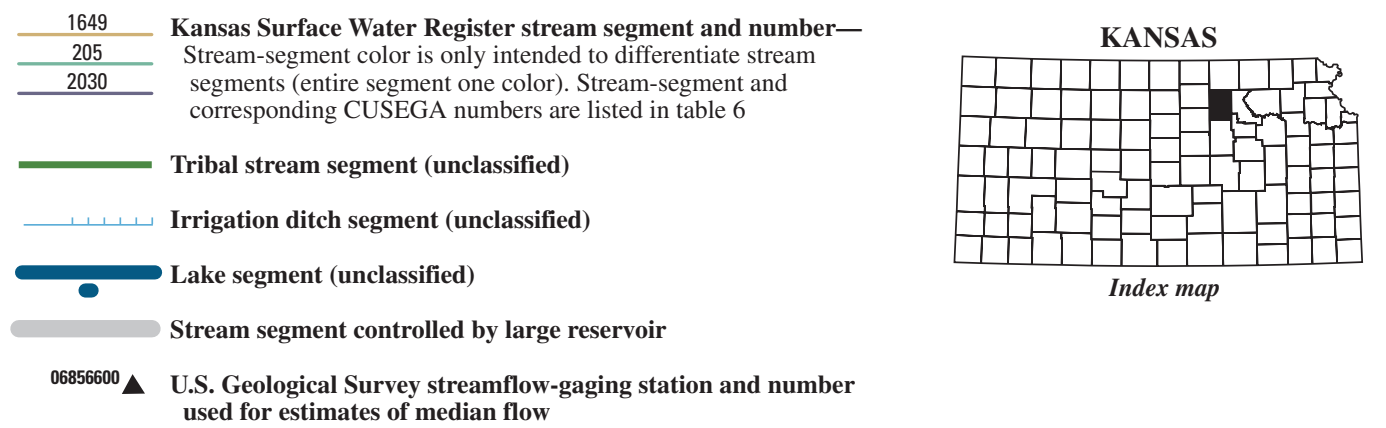

Figure 22. Location of U.S. Geological Survey streamflow-gaging stations and stream segments on the 1999 Kansas Surface Water Register for Clay County. 


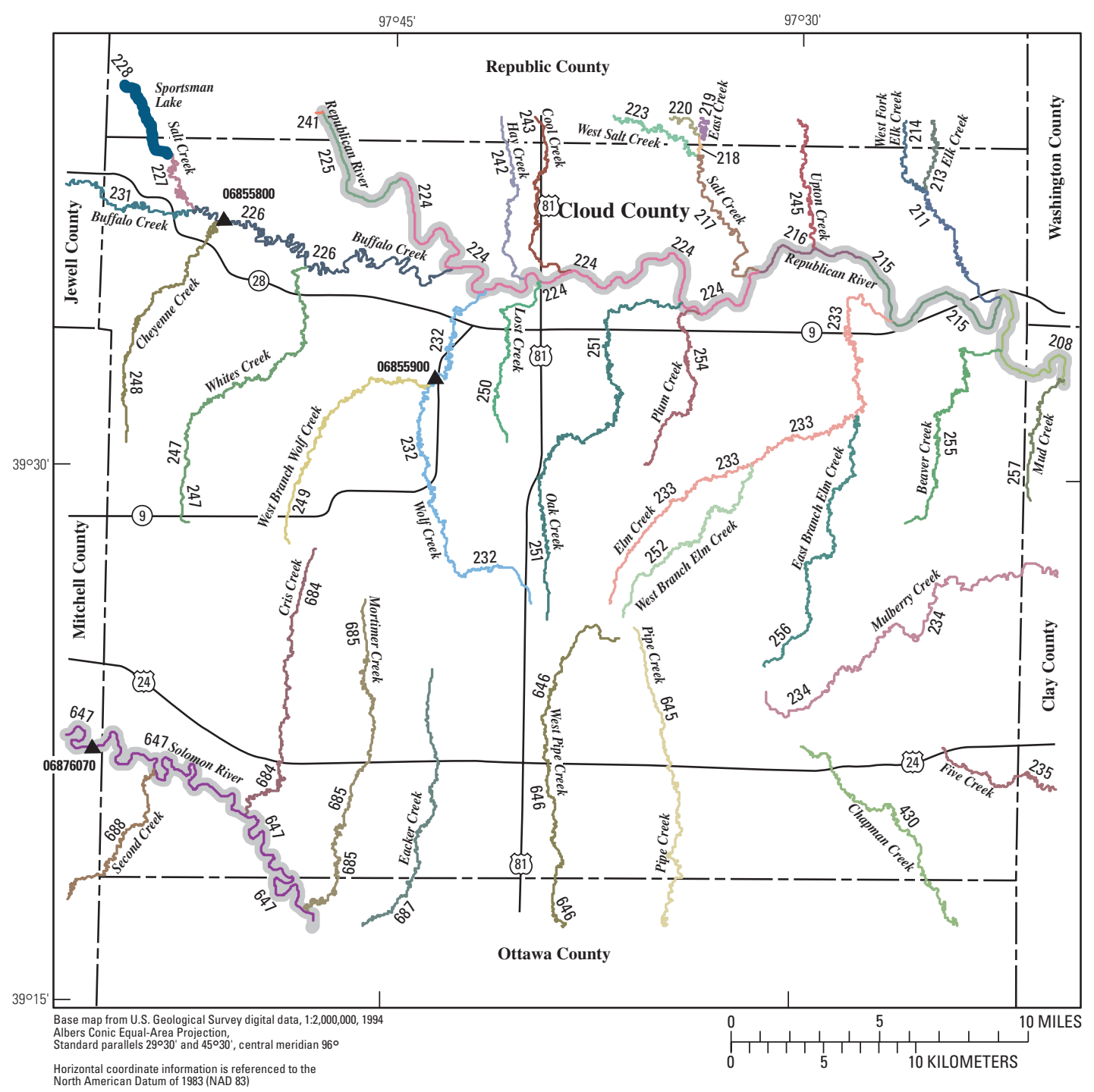

EXPLANATION
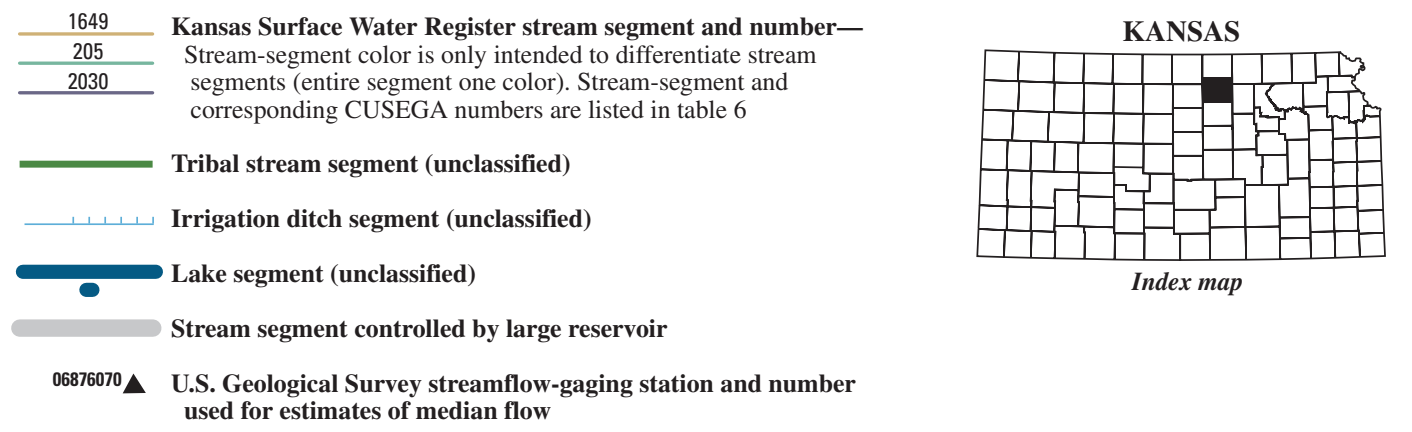

Figure 23. Location of U.S. Geological Survey streamflow-gaging stations and stream segments on the 1999 Kansas Surface Water Register for Cloud County. 


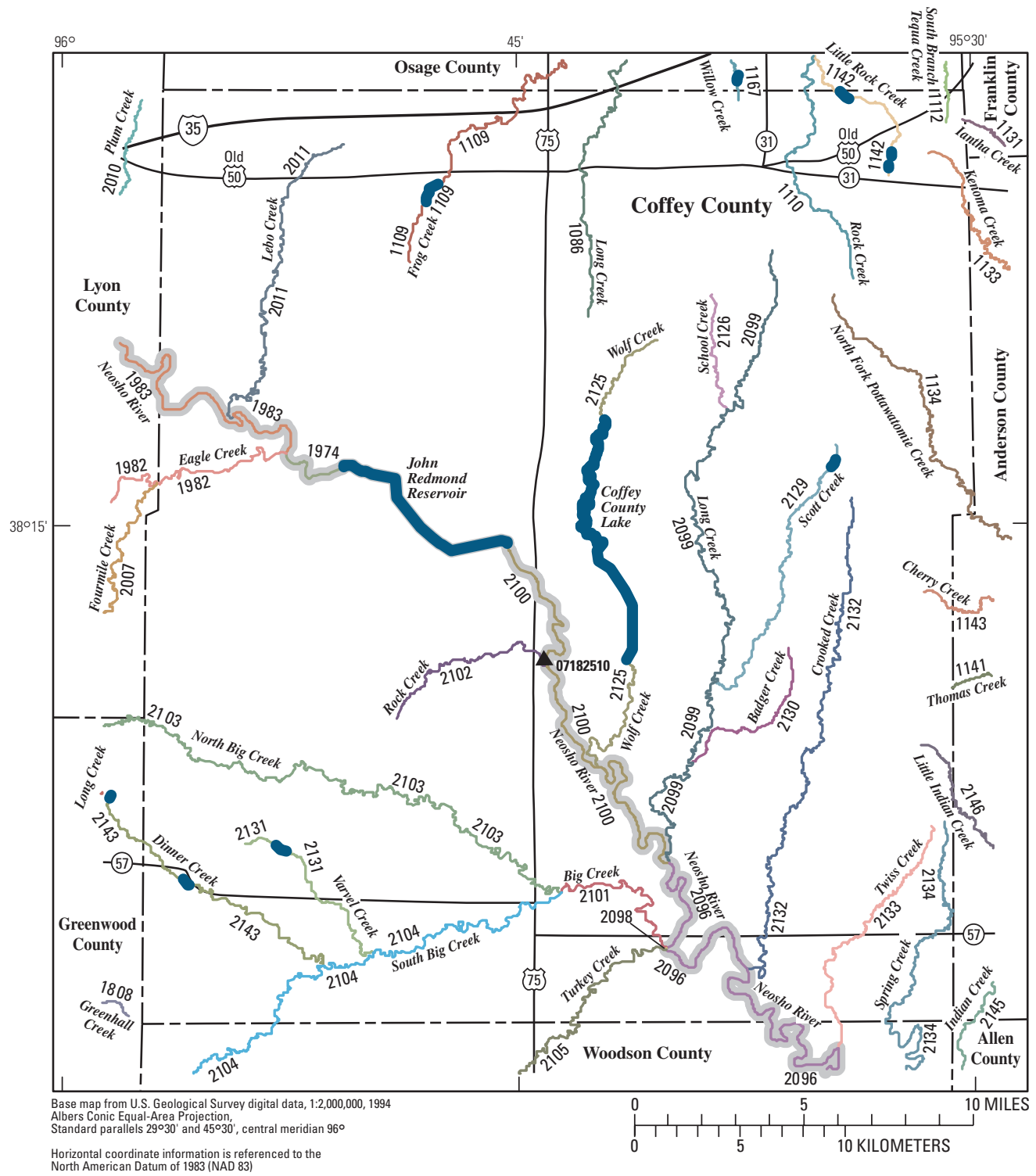

EXPLANATION

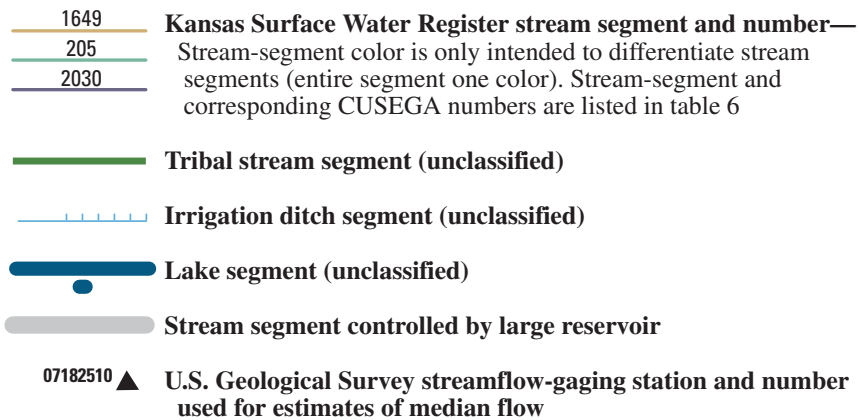

KANSAS

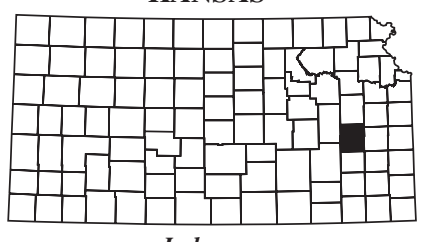

Index map used for estimates of median flow

Figure 24. Location of U.S. Geological Survey streamflow-gaging stations and stream segments on the 1999 Kansas Surface Water Register for Coffey County. 


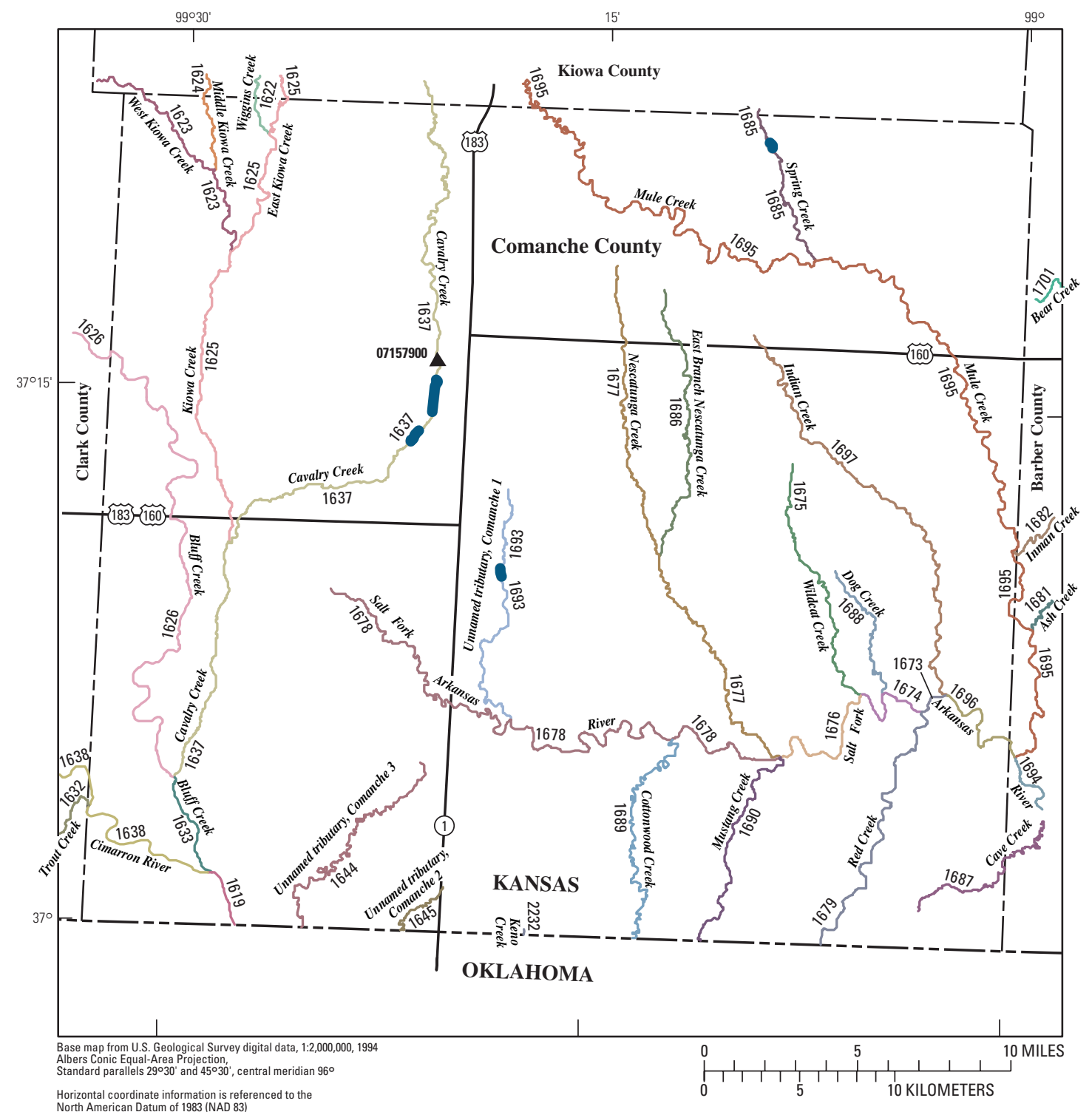

EXPLANATION
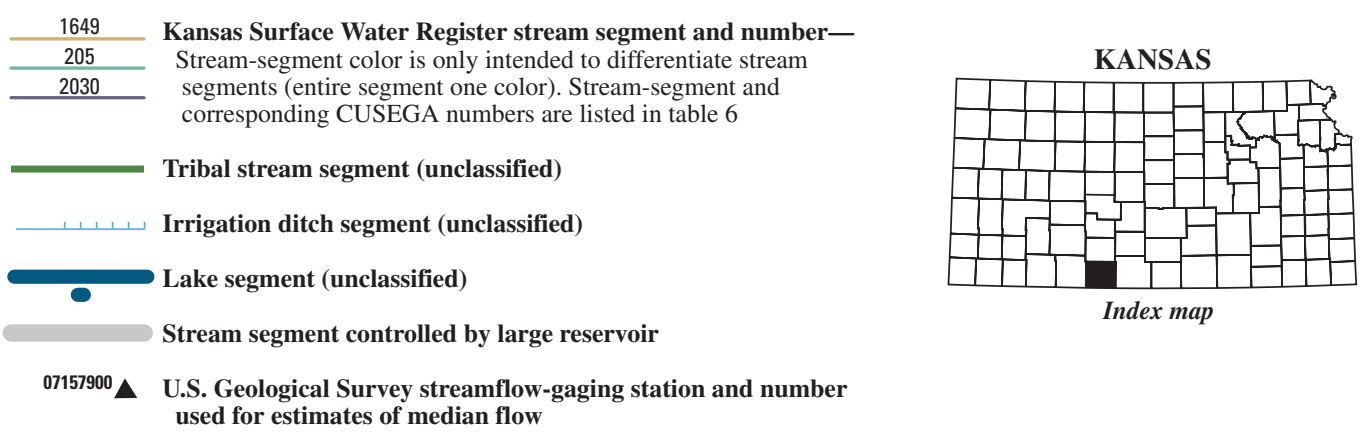

Figure 25. Location of U.S. Geological Survey streamflow-gaging stations and stream segments on the 1999 Kansas Surface Water Register for Comanche County. 


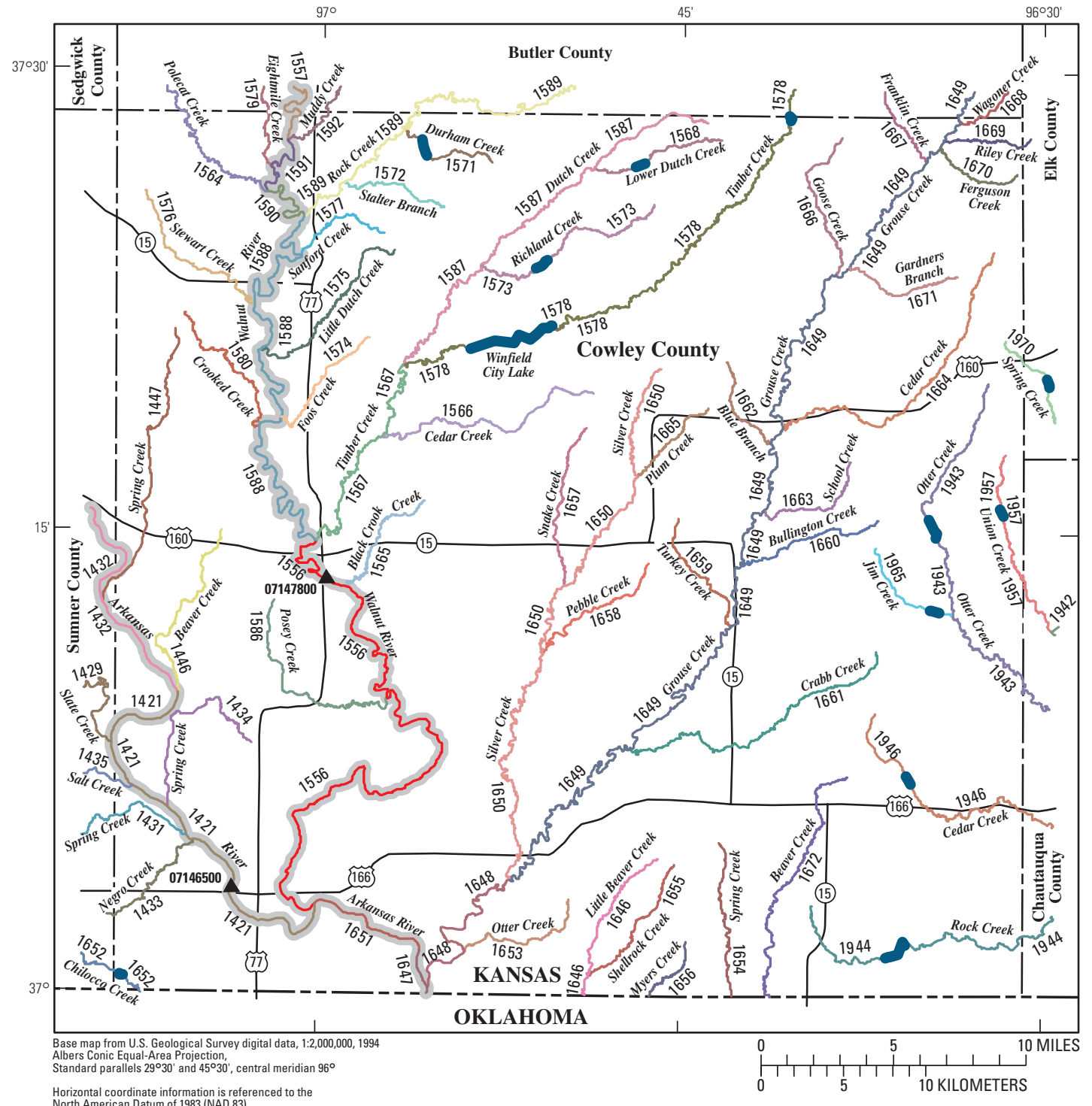

EXPLANATION

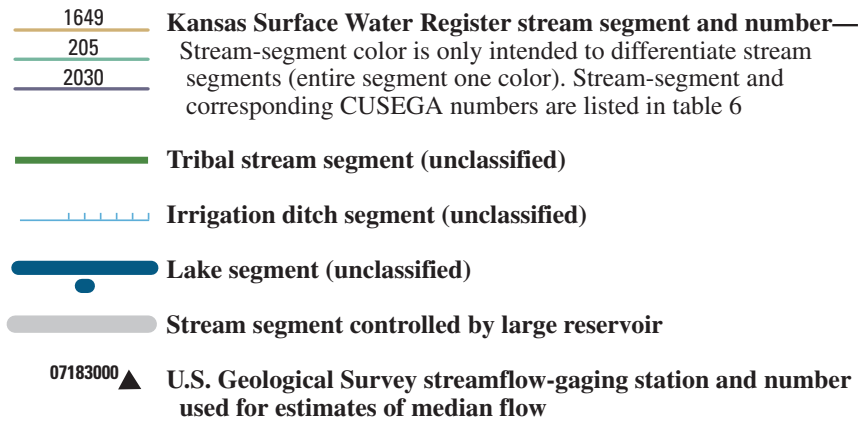

Figure 26. Location of U.S. Geological Survey streamflow-gaging stations and stream segments on the 1999 Kansas Surface Water Register for Cowley County. 


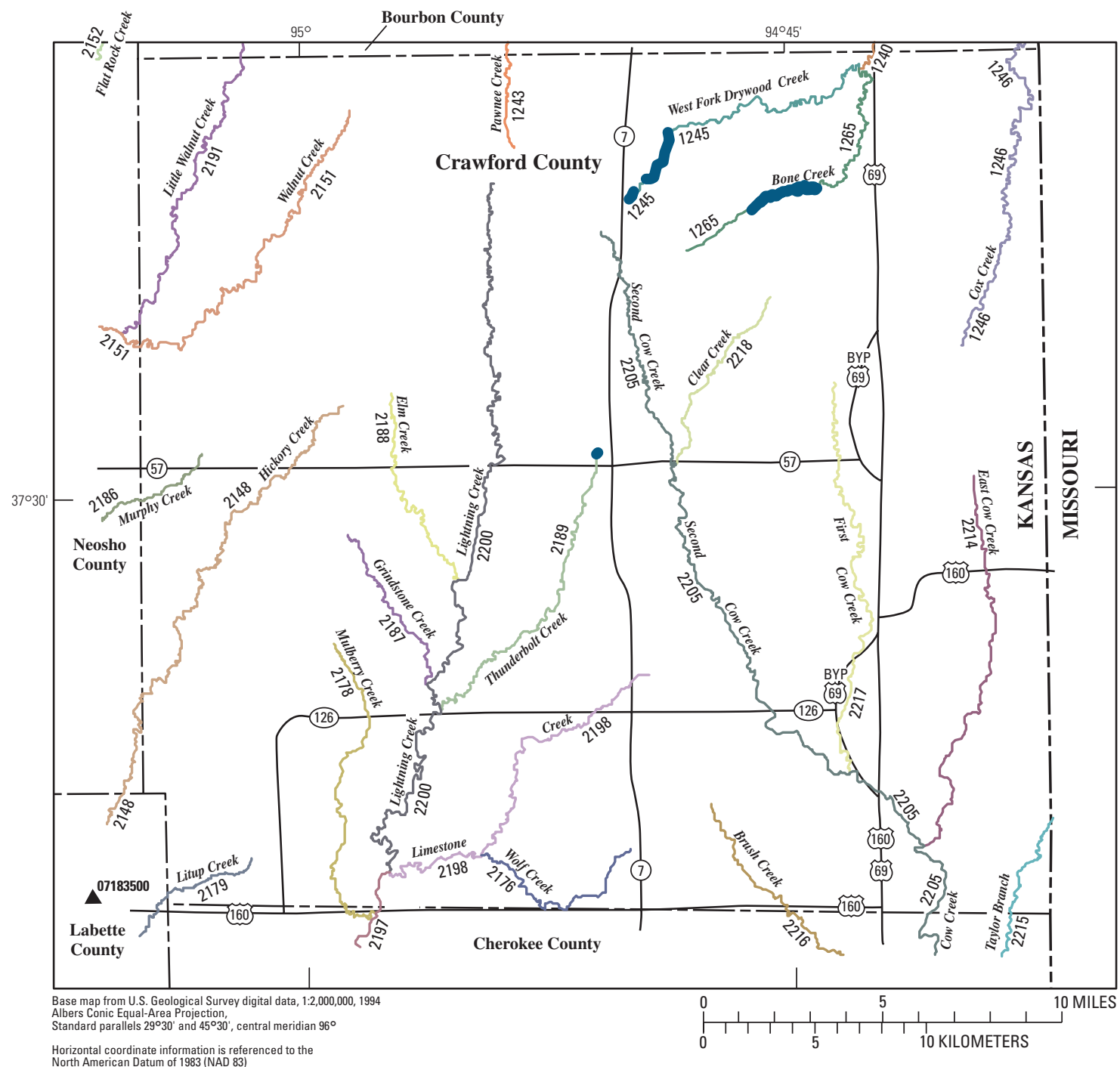

EXPLANATION
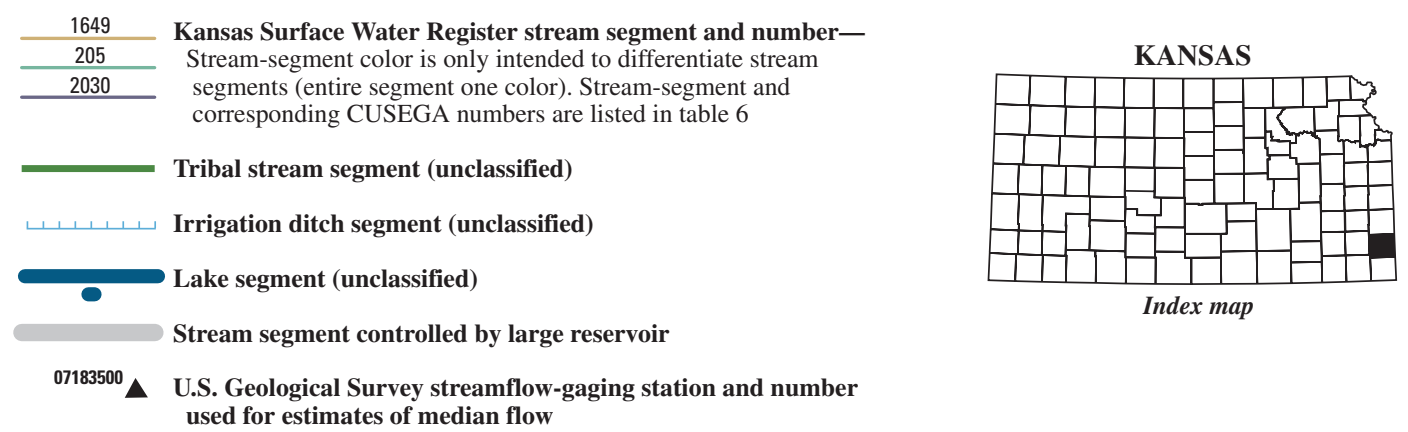

Figure 27. Location of U.S. Geological Survey streamflow-gaging stations and stream segments on the 1999 Kansas Surface Water Register for Crawford County. 


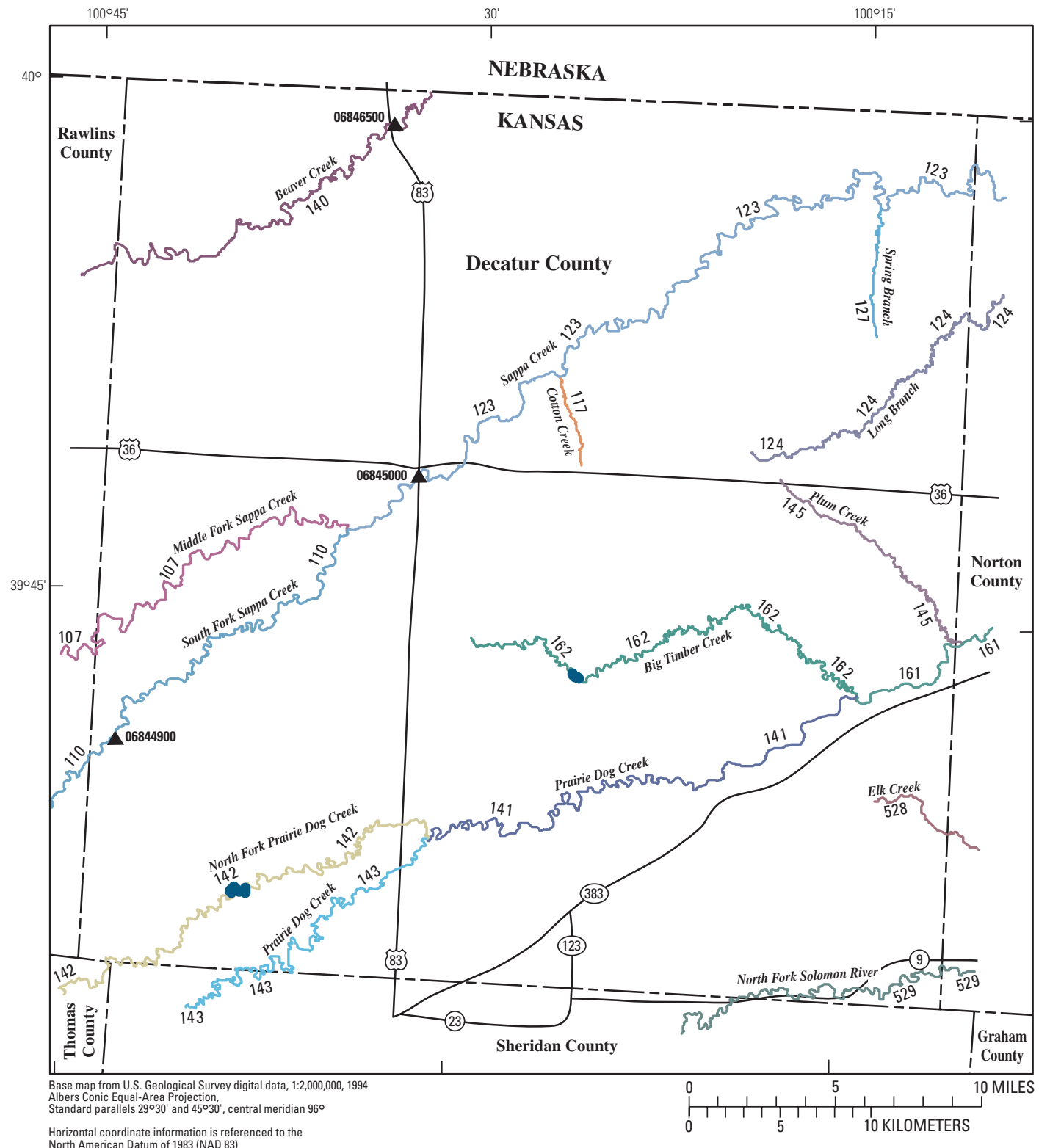

EXPLANATION

$\begin{array}{cc}\frac{1649}{205} & \begin{array}{c}\text { Kansas Surface Water Register stream segment and number- } \\ \text { Stream-segment color is only intended to differentiate stream } \\ \text { segments (entire segment one color). Stream-segment and } \\ \text { corresponding CUSEGA numbers are listed in table } 6\end{array} \\ \begin{array}{c}\text { Tribal stream segment (unclassified) } \\ \text { Irrigation ditch segment (unclassified) }\end{array} \\ \begin{array}{c}\text { Lake segment (unclassified) } \\ \text { Stream segment controlled by large reservoir }\end{array} \\ \begin{array}{c}\text { U.S. Geological Survey streamflow-gaging station and number } \\ \text { used for estimates of median flow }\end{array}\end{array}$

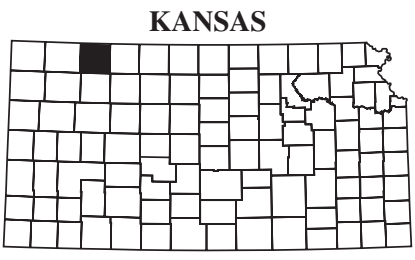

Index map

Figure 28. Location of U.S. Geological Survey streamflow-gaging stations and stream segments on the 1999 Kansas Surface Water Register for Decatur County. 


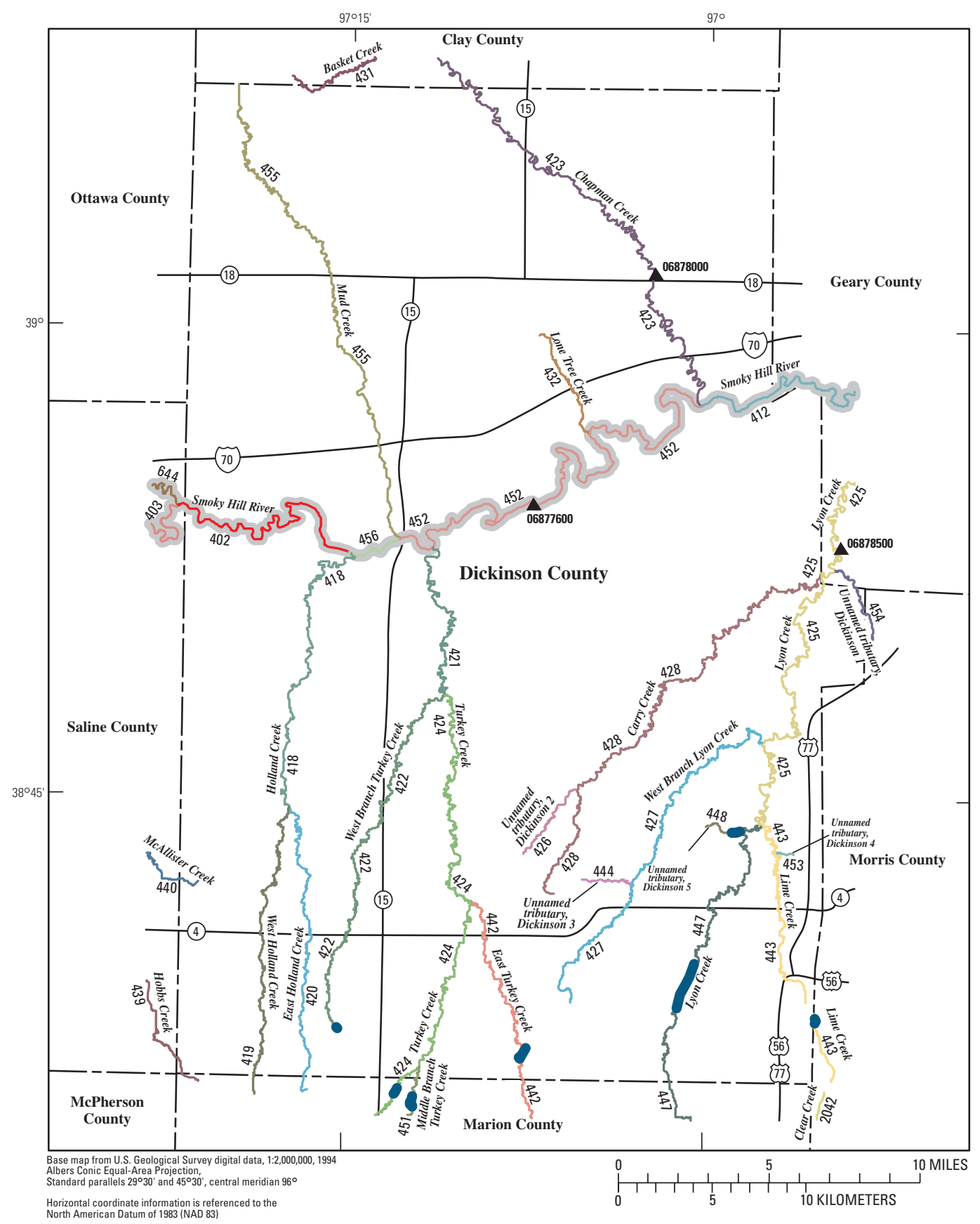

EXPLANATION

\begin{tabular}{|c|c|}
\hline 1649 & \multirow{3}{*}{$\begin{array}{l}\text { Kansas Surface Water Register stream segment and number- } \\
\text { Stream-segment color is only intended to differentiate stream } \\
\text { segments (entire segment one color). Stream-segment and } \\
\text { corresponding CUSEGA numbers are listed in table } 6\end{array}$} \\
\hline 205 & \\
\hline 2030 & \\
\hline & \\
\hline & Tribal stream segment (unclassified) \\
\hline & Irrigation ditch segment (unclassified) \\
\hline - & Lake segment (unclassified) \\
\hline & Stream segment controlled by large reservoir \\
\hline 06878500 & $\begin{array}{l}\text { U.S. Geological Survey streamflow-gaging station a } \\
\text { used for estimates of median flow }\end{array}$ \\
\hline
\end{tabular}

KANSAS

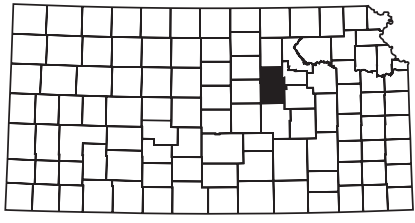

Index map

Figure 29. Location of U.S. Geological Survey streamflow-gaging stations and stream segments on the 1999 Kansas Surface Water Register for Dickinson County. 


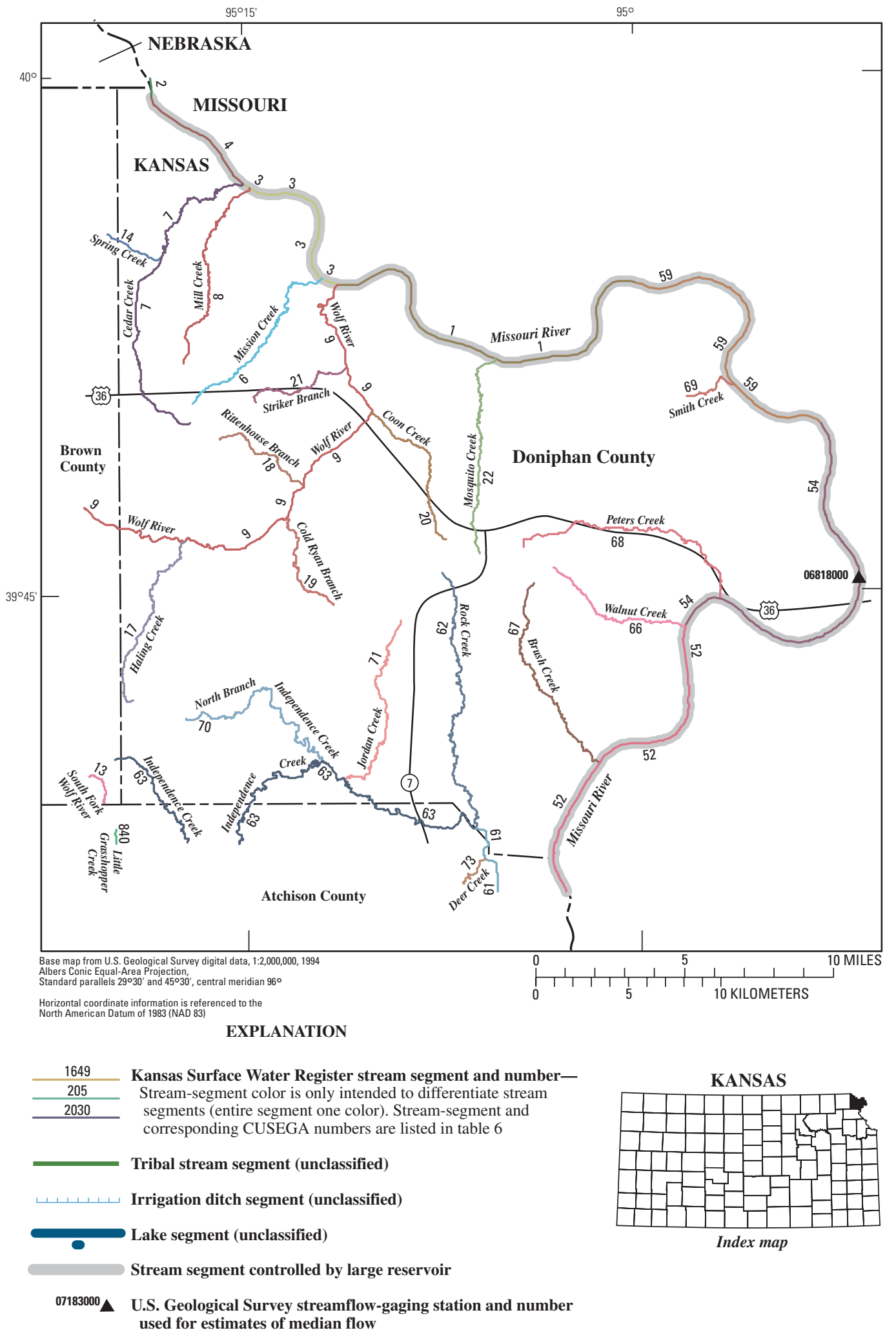

Figure 30. Location of U.S. Geological Survey streamflow-gaging stations and stream segments on the 1999 Kansas Surface Water Register for Doniphan County. 


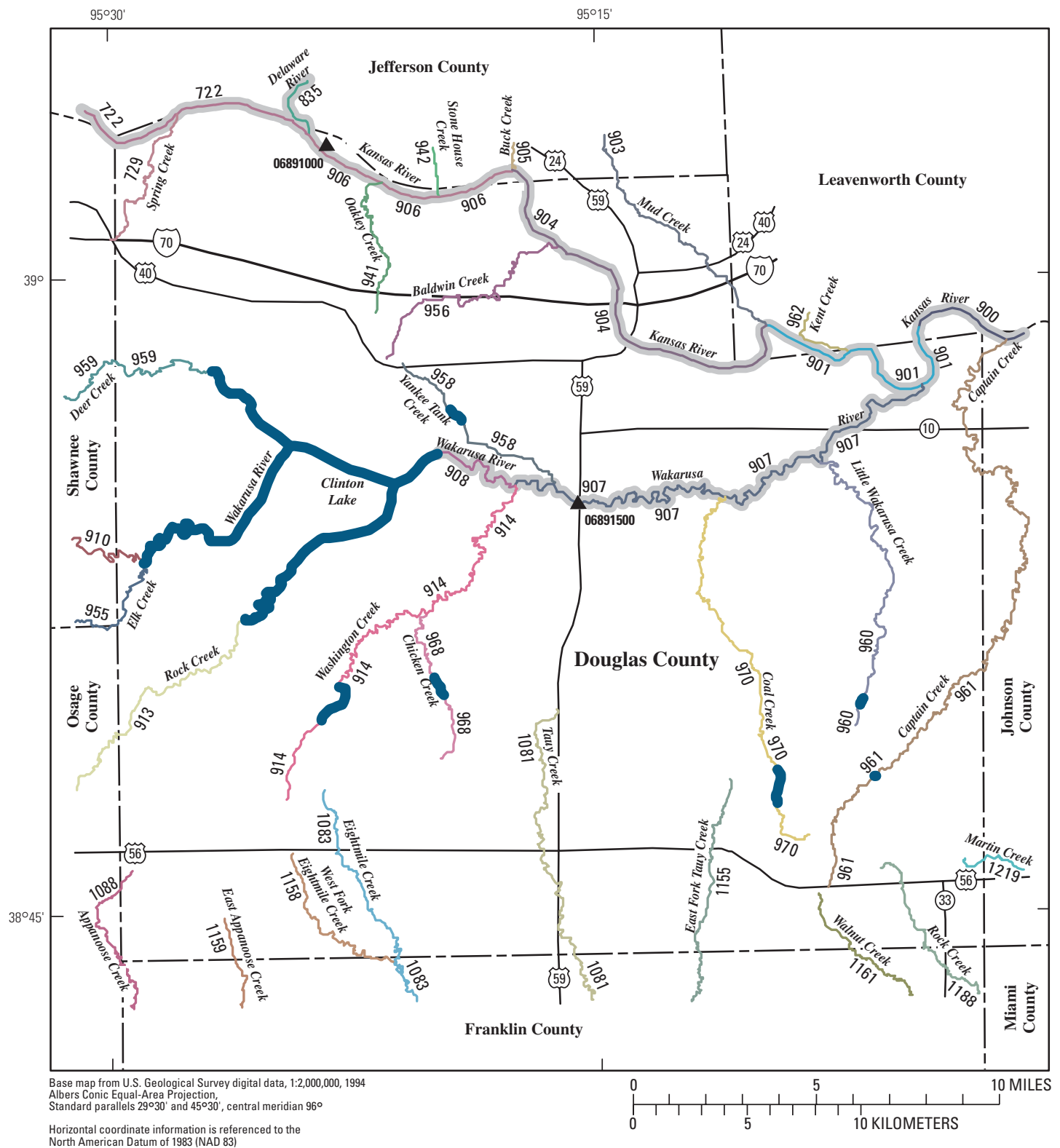

EXPLANATION
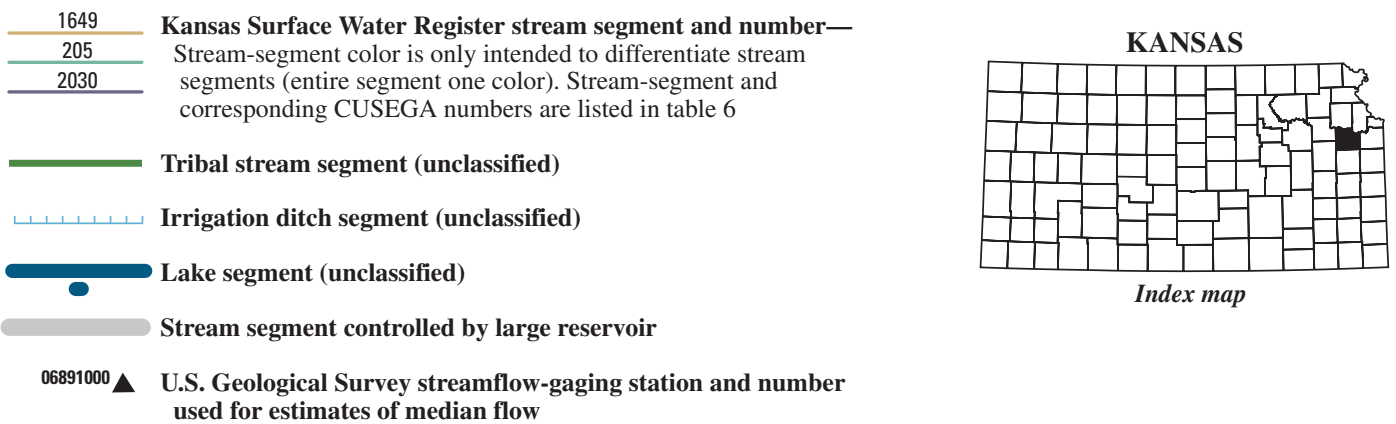

Index map

Figure 31. Location of U.S. Geological Survey streamflow-gaging stations and stream segments on the 1999 Kansas Surface Water Register for Douglas County. 


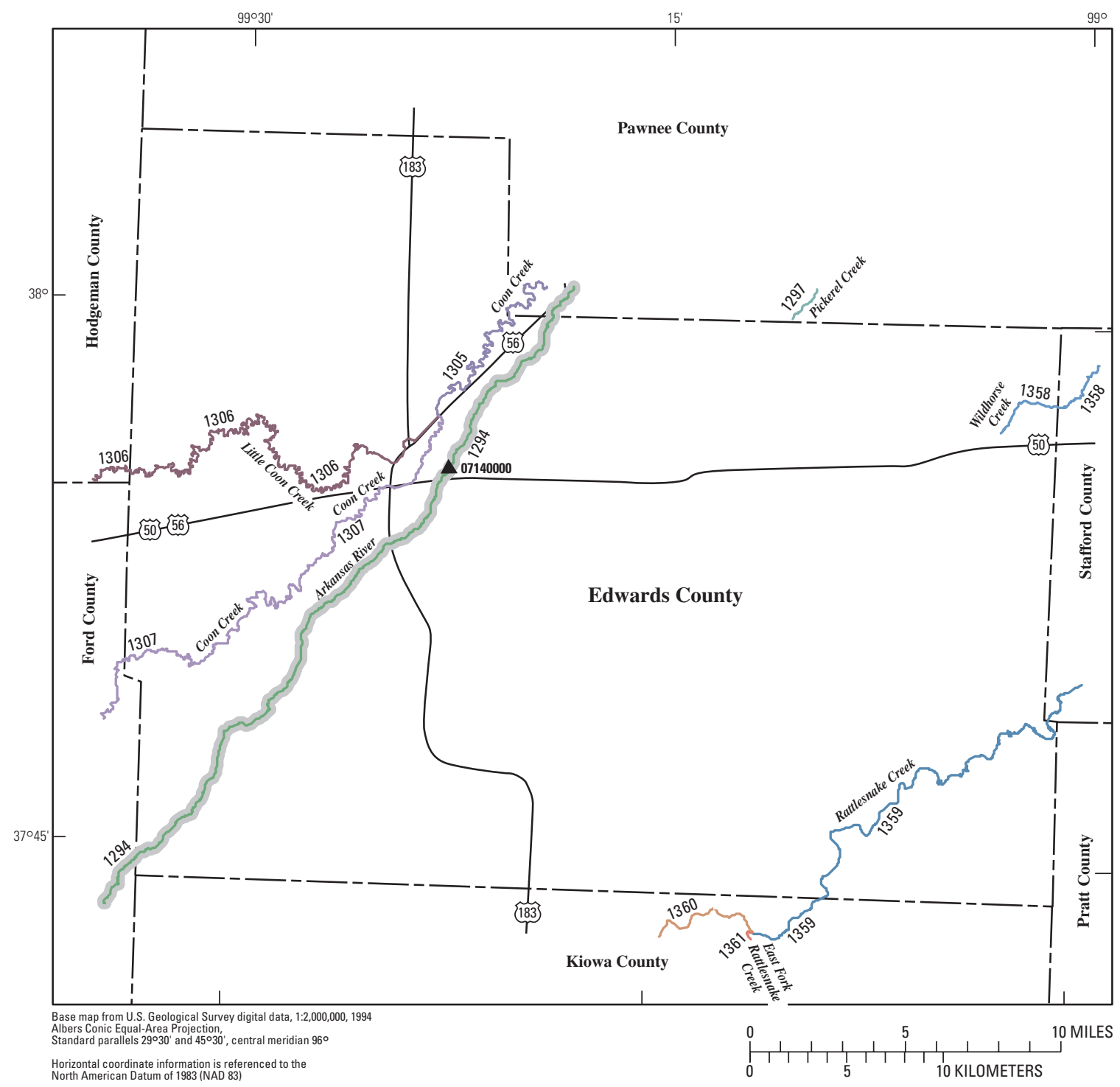

EXPLANATION
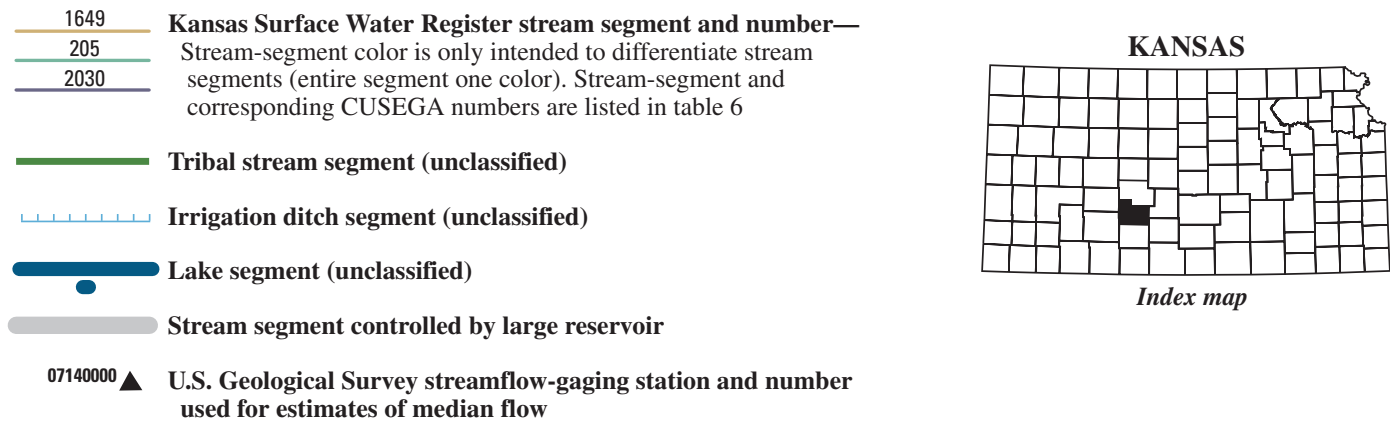

Index map used for estimates of median flow

Figure 32. Location of U.S. Geological Survey streamflow-gaging stations and stream segments on the 1999 Kansas Surface Water Register for Edwards County. 


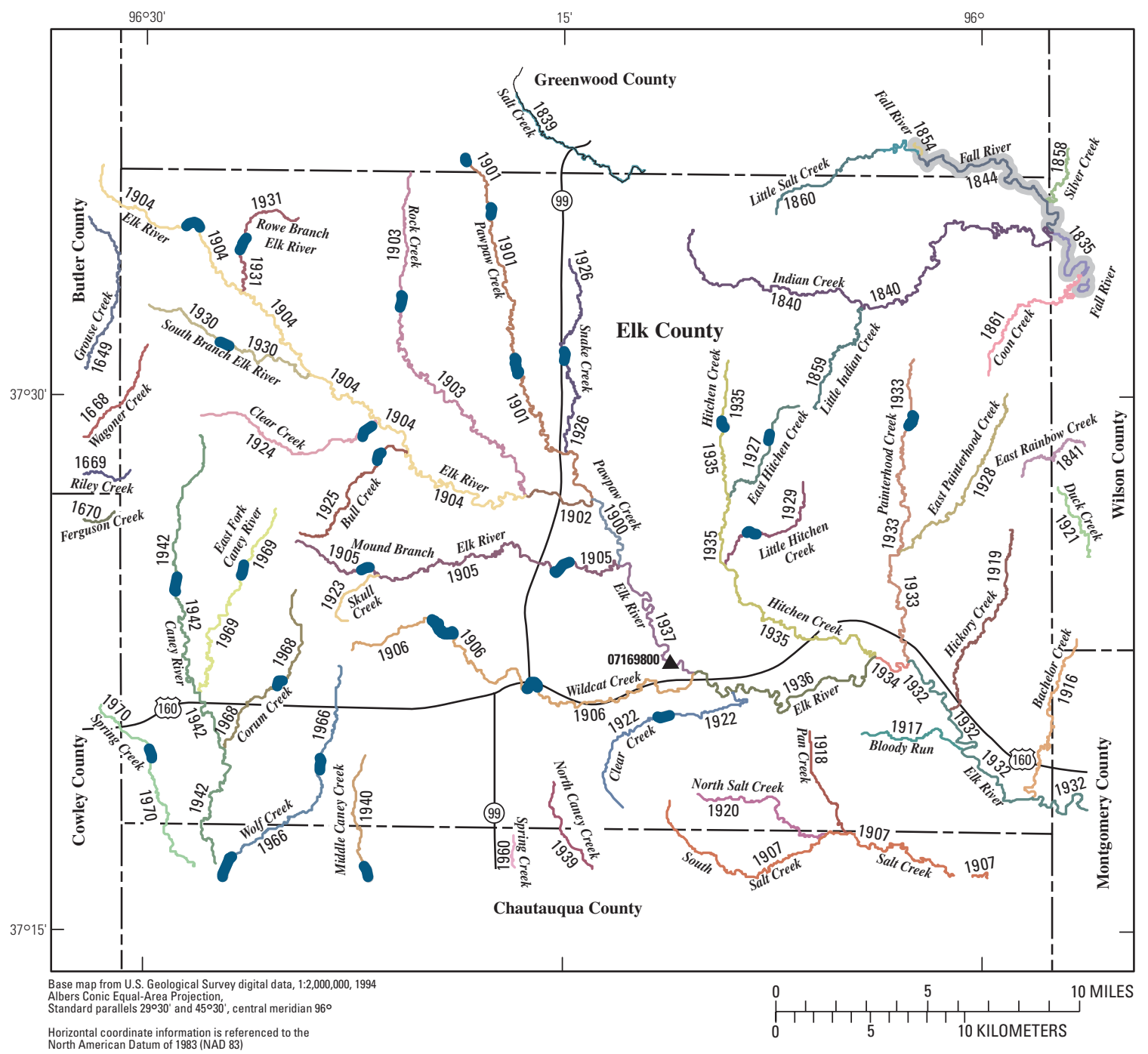

EXPLANATION

\begin{tabular}{|c|c|}
\hline 1649 & Kansas Surface Water Register stream segment and number- \\
\hline 205 & Stream-segment color is only intended to differentiate stream \\
\hline 2030 & segments (entire segment one color). Stream-segment and \\
\hline & corresponding CUSEGA numbers are listed in table 6 \\
\hline & Tribal stream segment (unclassified) \\
\hline $1,1,1,1,1$ & Irrigation ditch segment (unclassified) \\
\hline 0 & Lake segment (unclassified) \\
\hline & Stream segment controlled by large reservoir \\
\hline $07169800 \Delta$ & $\begin{array}{l}\text { U.S. Geological Survey streamflow-gaging station and number } \\
\text { used for estimates of median flow }\end{array}$ \\
\hline
\end{tabular}

KANSAS

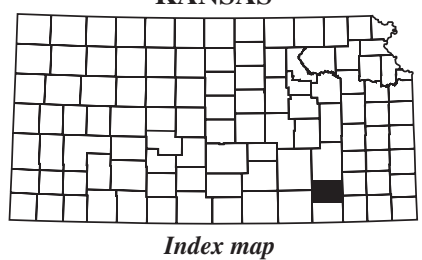

Index map

Figure 33. Location of U.S. Geological Survey streamflow-gaging stations and stream segments on the 1999 Kansas Surface Water Register for Elk County. 


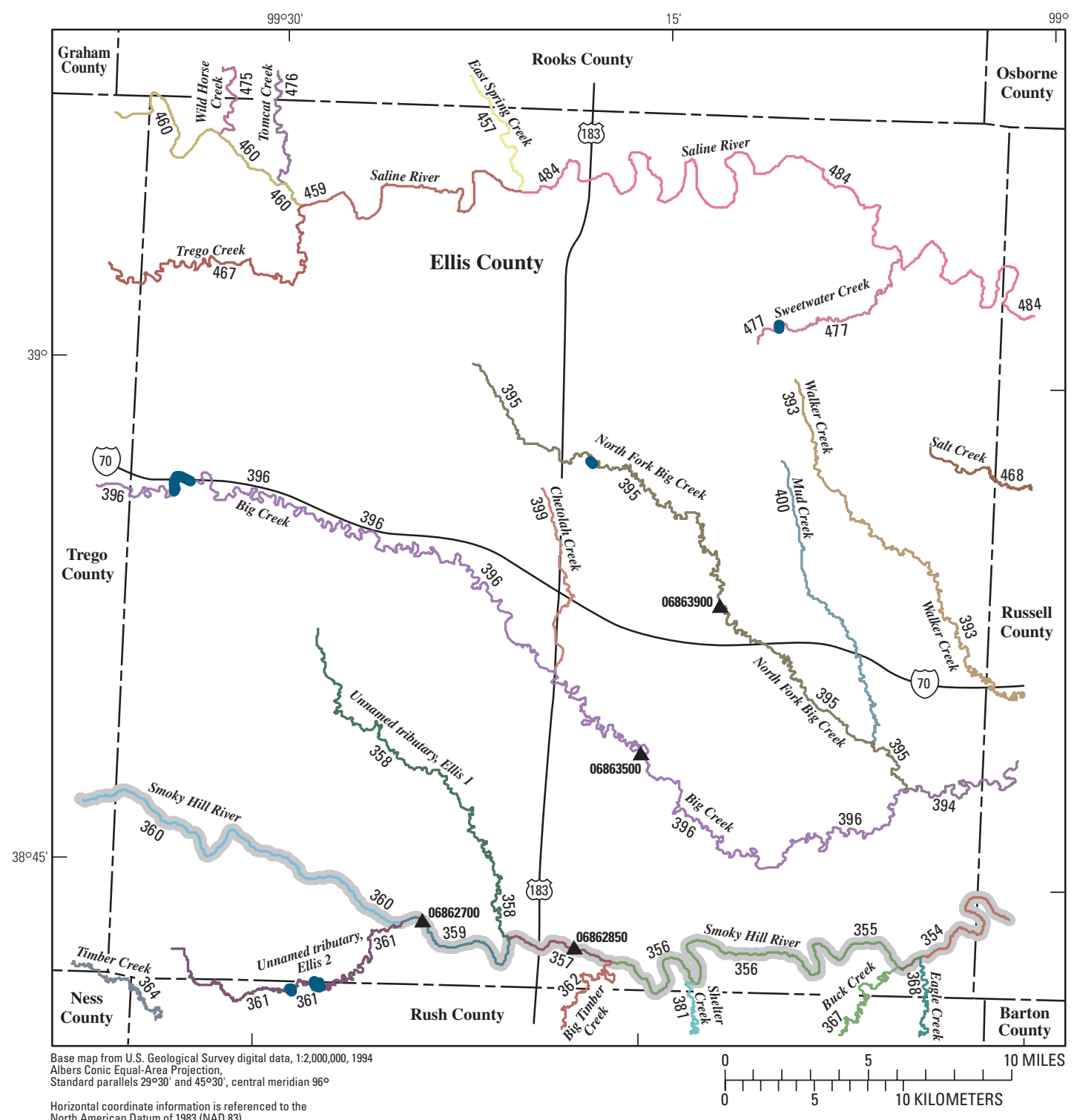

EXPLANATION
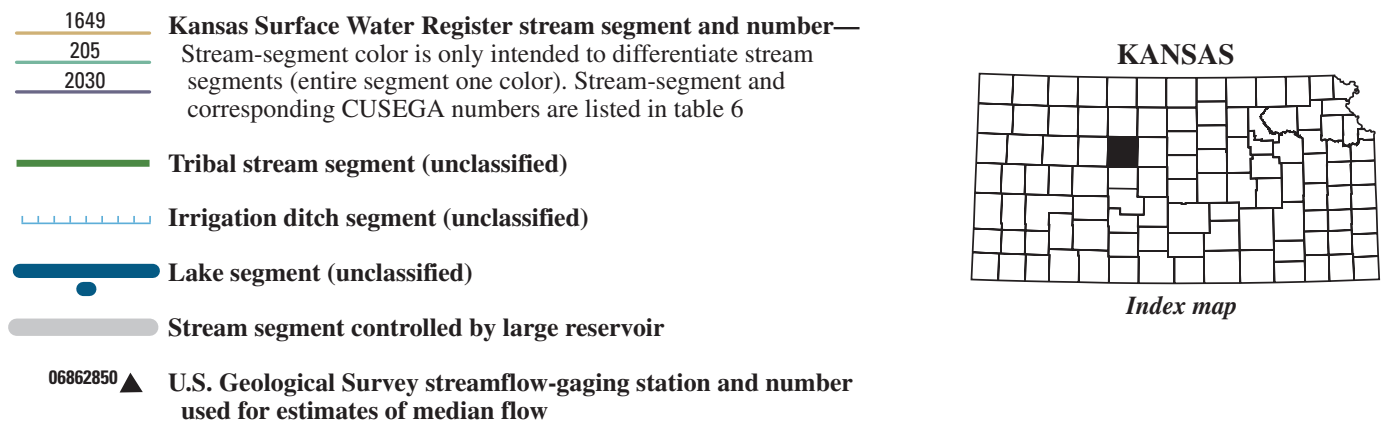

Figure 34. Location of U.S. Geological Survey streamflow-gaging stations and stream segments on the 1999 Kansas Surface Water Register for Ellis County. 


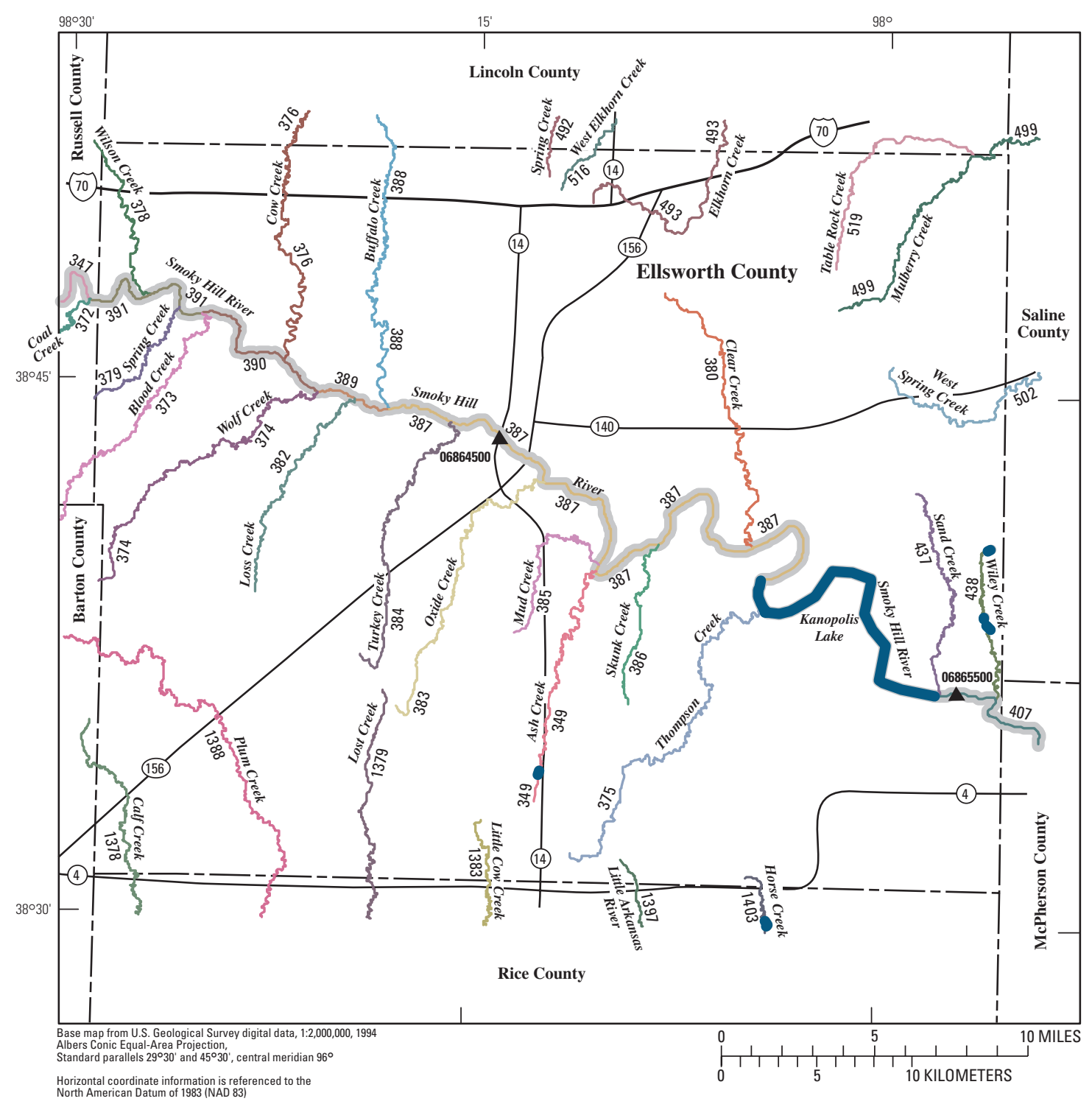

\section{EXPLANATION}
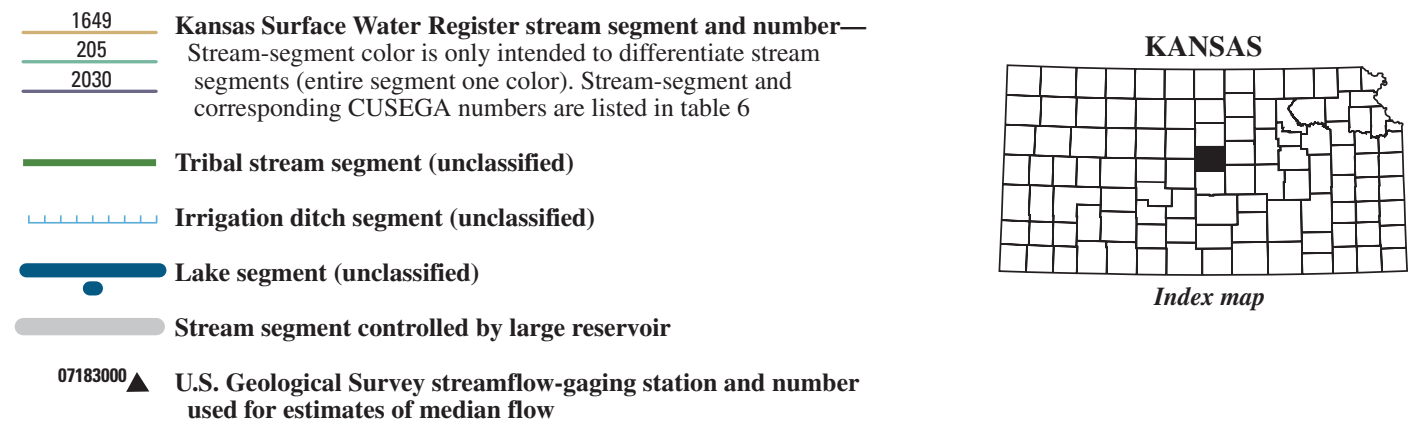

Figure 35. Location of U.S. Geological Survey streamflow-gaging stations and stream segments on the 1999 Kansas Surface Water Register for Ellsworth County. 


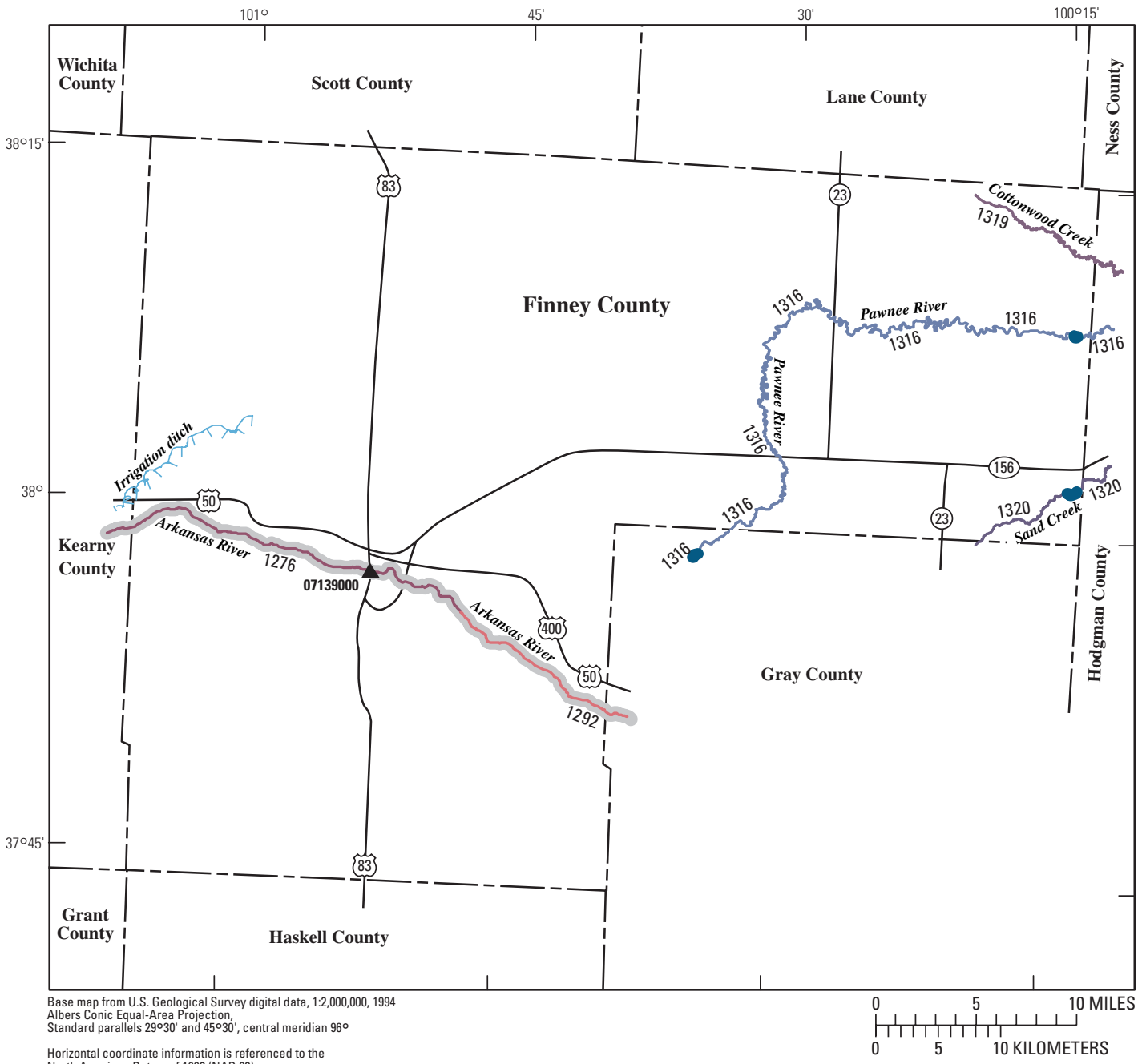

EXPLANATION

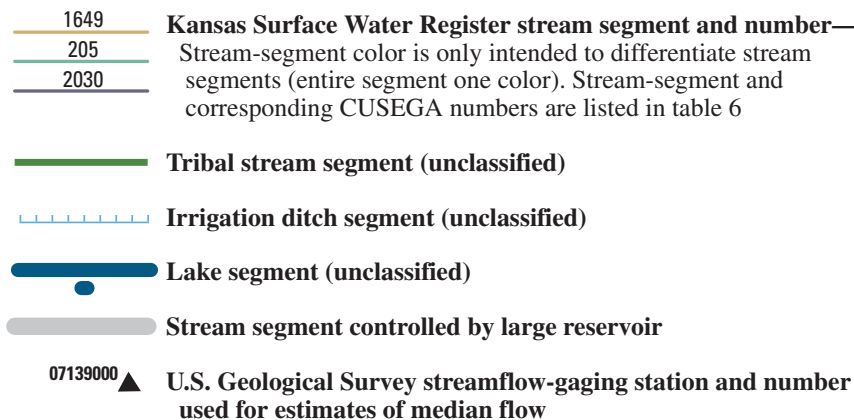

Figure 36. Location of U.S. Geological Survey streamflow-gaging stations and stream segments on the 1999 Kansas Surface Water Register for Finney County. 


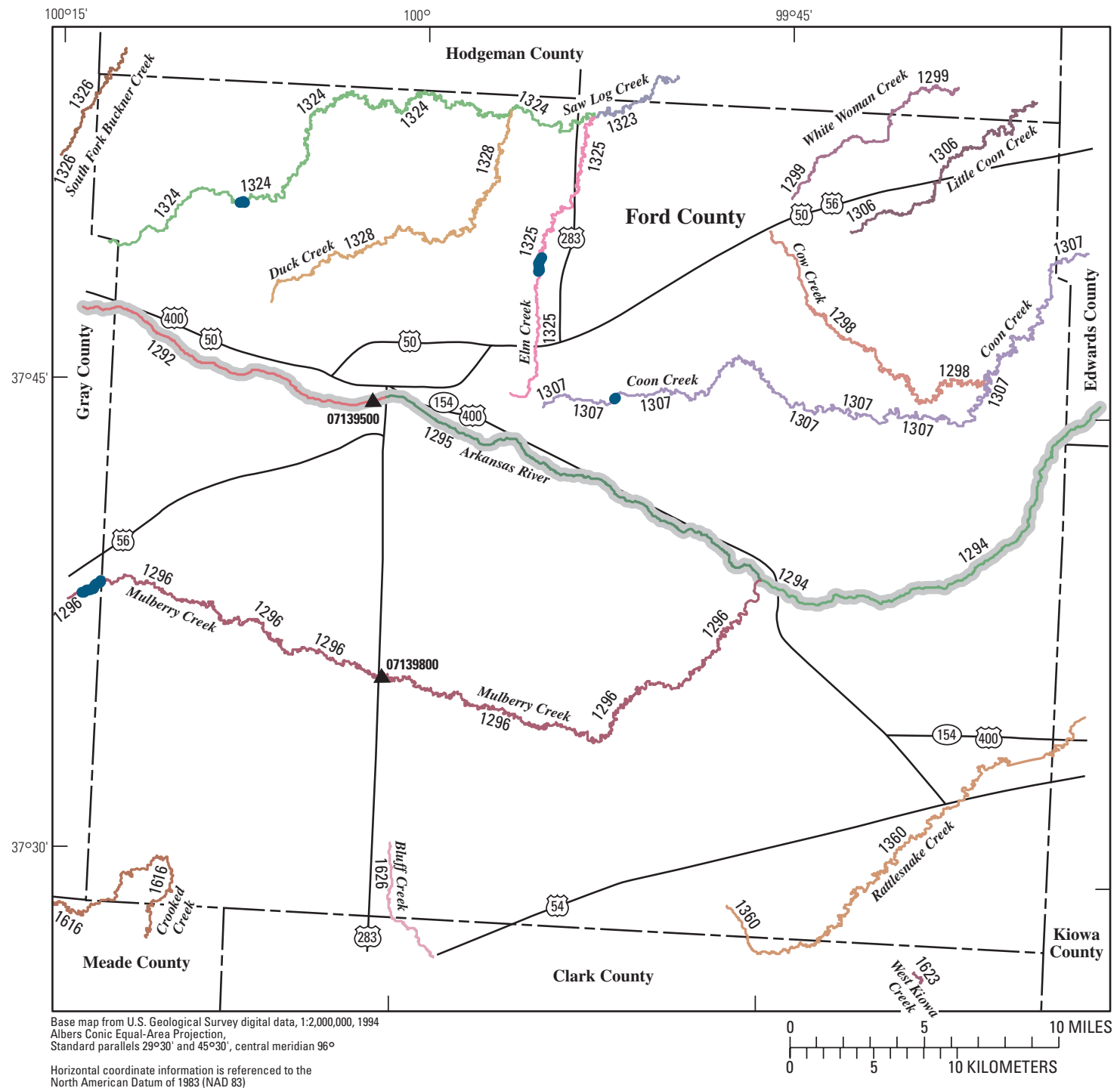

\section{EXPLANATION}

\begin{tabular}{cc}
1649 & $\begin{array}{c}\text { Kansas Surface Water Register stream segment and number- } \\
\text { Stream-segment color is only intended to differentiate stream } \\
\text { segments (entire segment one color). Stream-segment and } \\
\text { corresponding CUSEGA numbers are listed in table } 6\end{array}$ \\
\cline { 1 - 2 } 2030 & $\begin{array}{c}\text { Tribal stream segment (unclassified) } \\
\text { Irrigation ditch segment (unclassified) }\end{array}$ \\
0 & Lake segment (unclassified) \\
07183000 & $\begin{array}{c}\text { Stream segment controlled by large reservoir } \\
\text { U.S. Geological Survey streamflow-gaging station and number } \\
\text { used for estimates of median flow }\end{array}$
\end{tabular}

Figure 37. Location of U.S. Geological Survey streamflow-gaging stations and stream segments on the 1999 Kansas Surface Water Register for Ford County. 


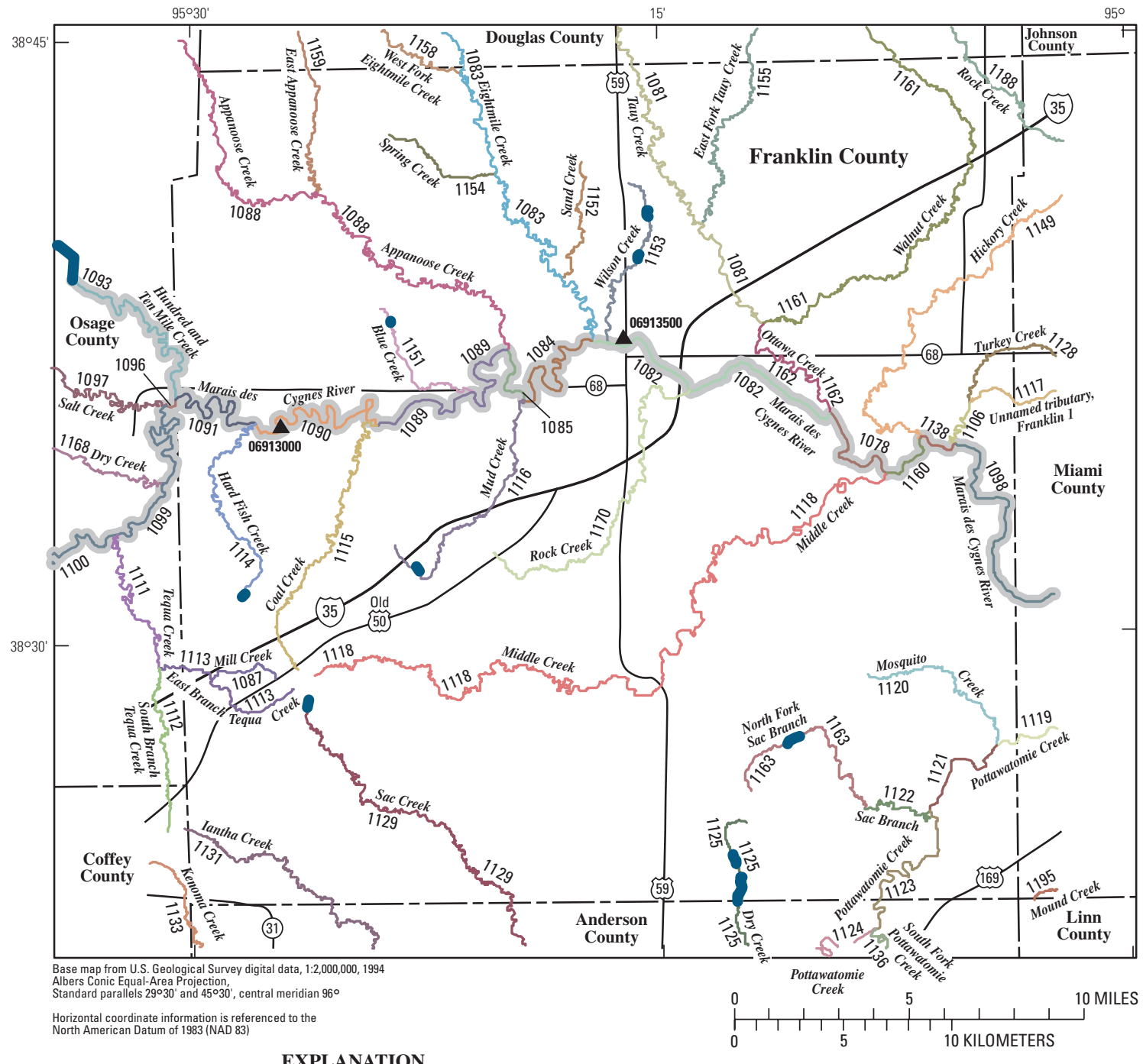

EXPLANATION
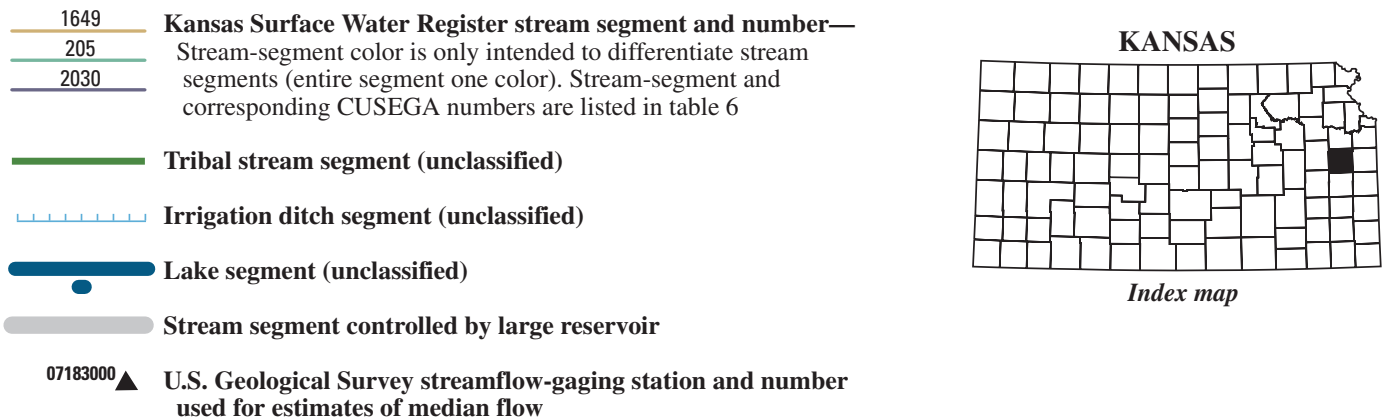
used for estimates of median flow

Figure 38. Location of U.S. Geological Survey streamflow-gaging stations and stream segments on the 1999 Kansas Surface Water Register for Franklin County. 


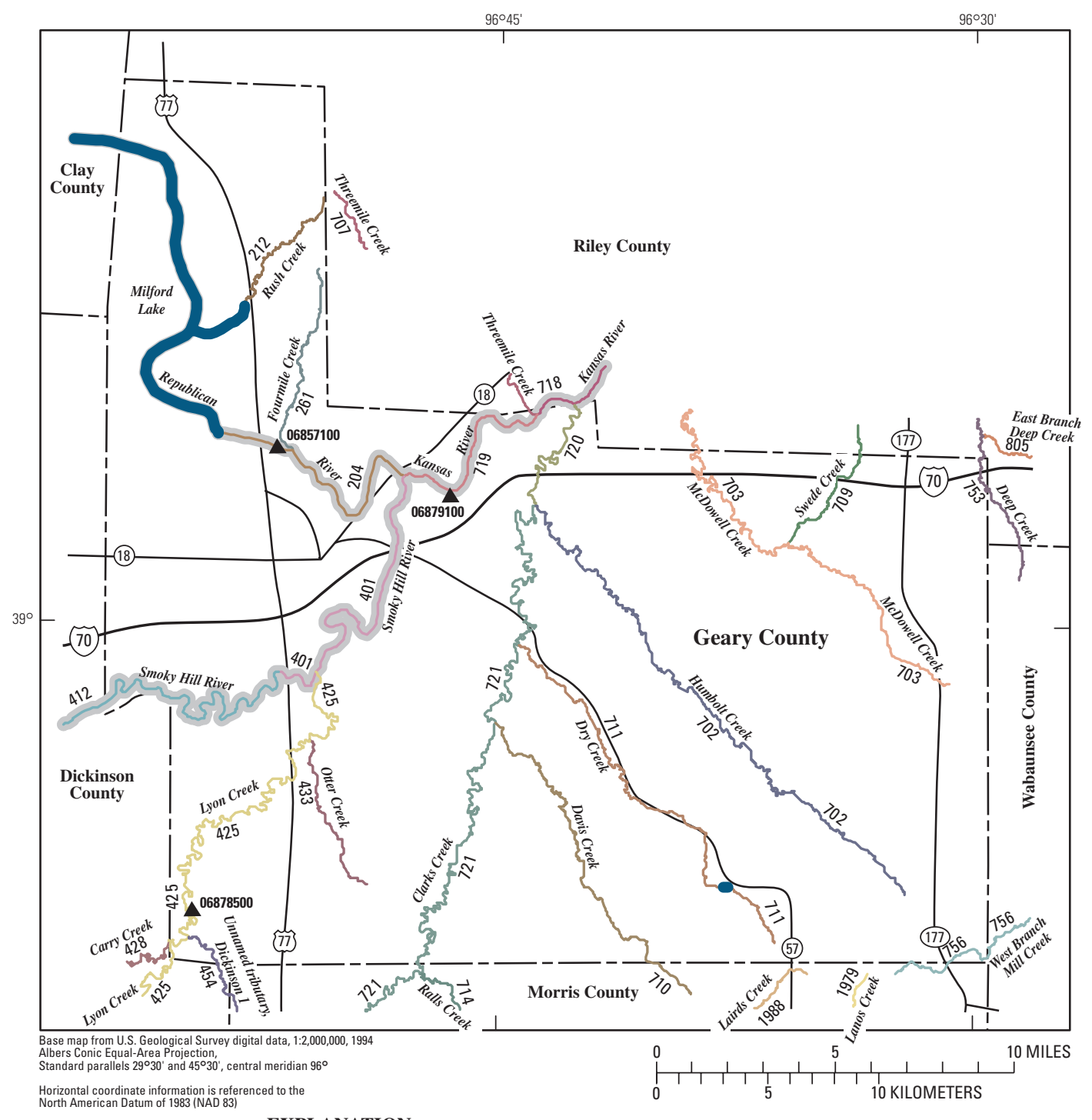

EXPLANATION
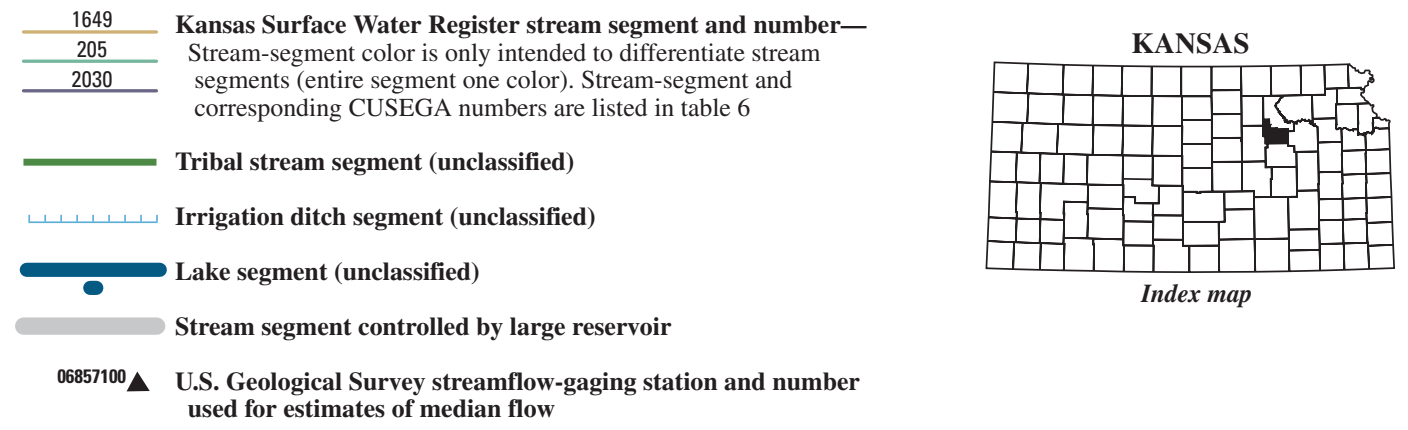

Figure 39. Location of U.S. Geological Survey streamflow-gaging stations and stream segments on the 1999 Kansas Surface Water Register for Geary County. 


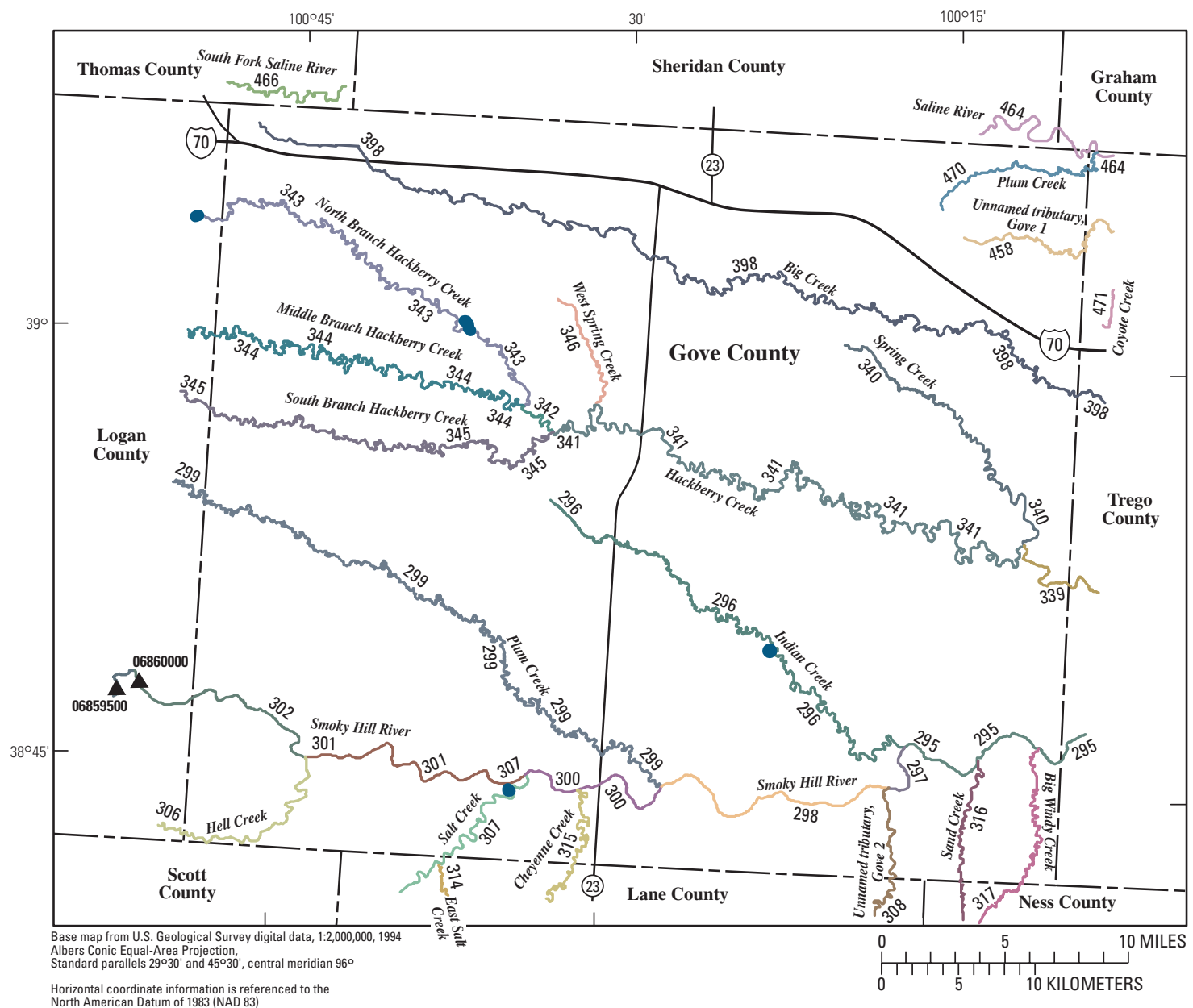

EXPLANATION

\begin{tabular}{|c|c|}
\hline 1649 & \multirow{4}{*}{$\begin{array}{l}\text { Kansas Surface Water Register stream segment and number- } \\
\text { Stream-segment color is only intended to differentiate stream } \\
\text { segments (entire segment one color). Stream-segment and } \\
\text { corresponding CUSEGA numbers are listed in table } 6\end{array}$} \\
\hline 205 & \\
\hline \multirow[t]{3}{*}{2030} & \\
\hline & \\
\hline & Tribal stream segment (unclassified) \\
\hline $1,1,1,1$, & Irrigation ditch segment (unclassified) \\
\hline \multirow[t]{2}{*}{0} & Lake segment (unclassified) \\
\hline & Stream segment controlled by large reservoir \\
\hline $06859500 \Delta$ & $\begin{array}{l}\text { U.S. Geological Survey streamflow-gaging station and number } \\
\text { used for estimates of median flow }\end{array}$ \\
\hline
\end{tabular}

Figure 40. Location of U.S. Geological Survey streamflow-gaging stations and stream segments on the 1999 Kansas Surface Water Register for Gove County. 


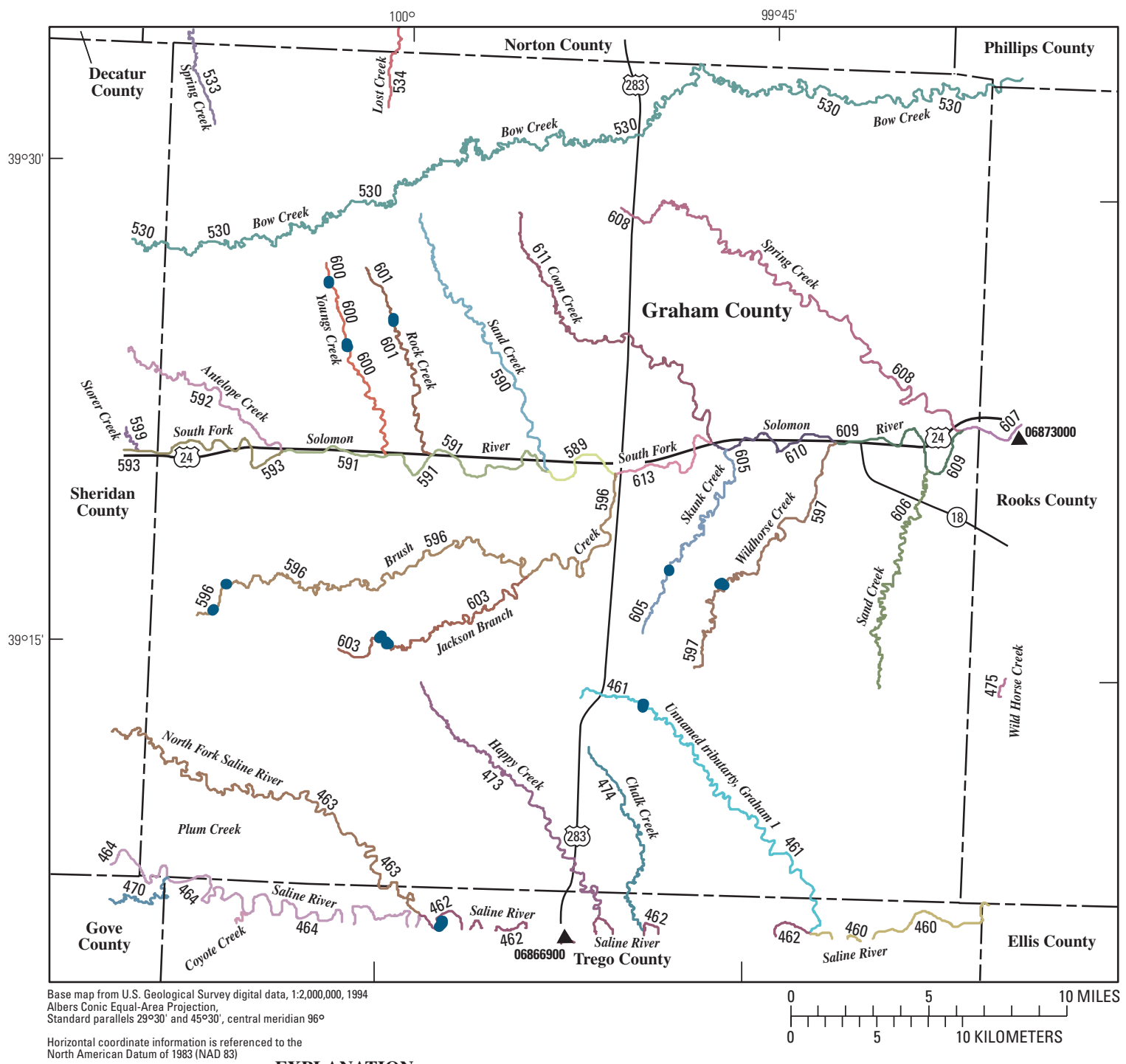

EXPLANATION
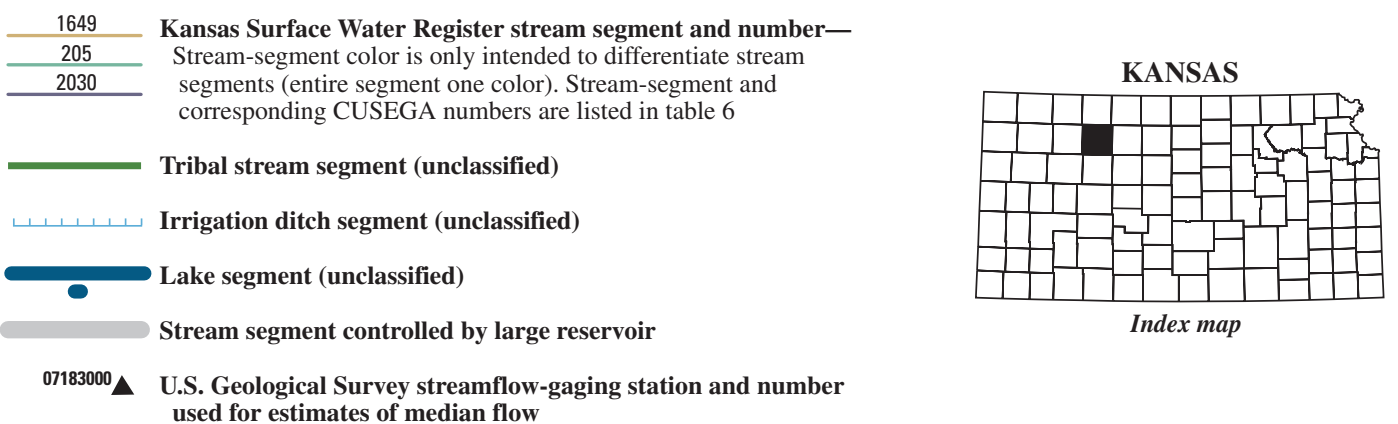

Figure 41. Location of U.S. Geological Survey streamflow-gaging stations and stream segments on the 1999 Kansas Surface Water Register for Graham County. 


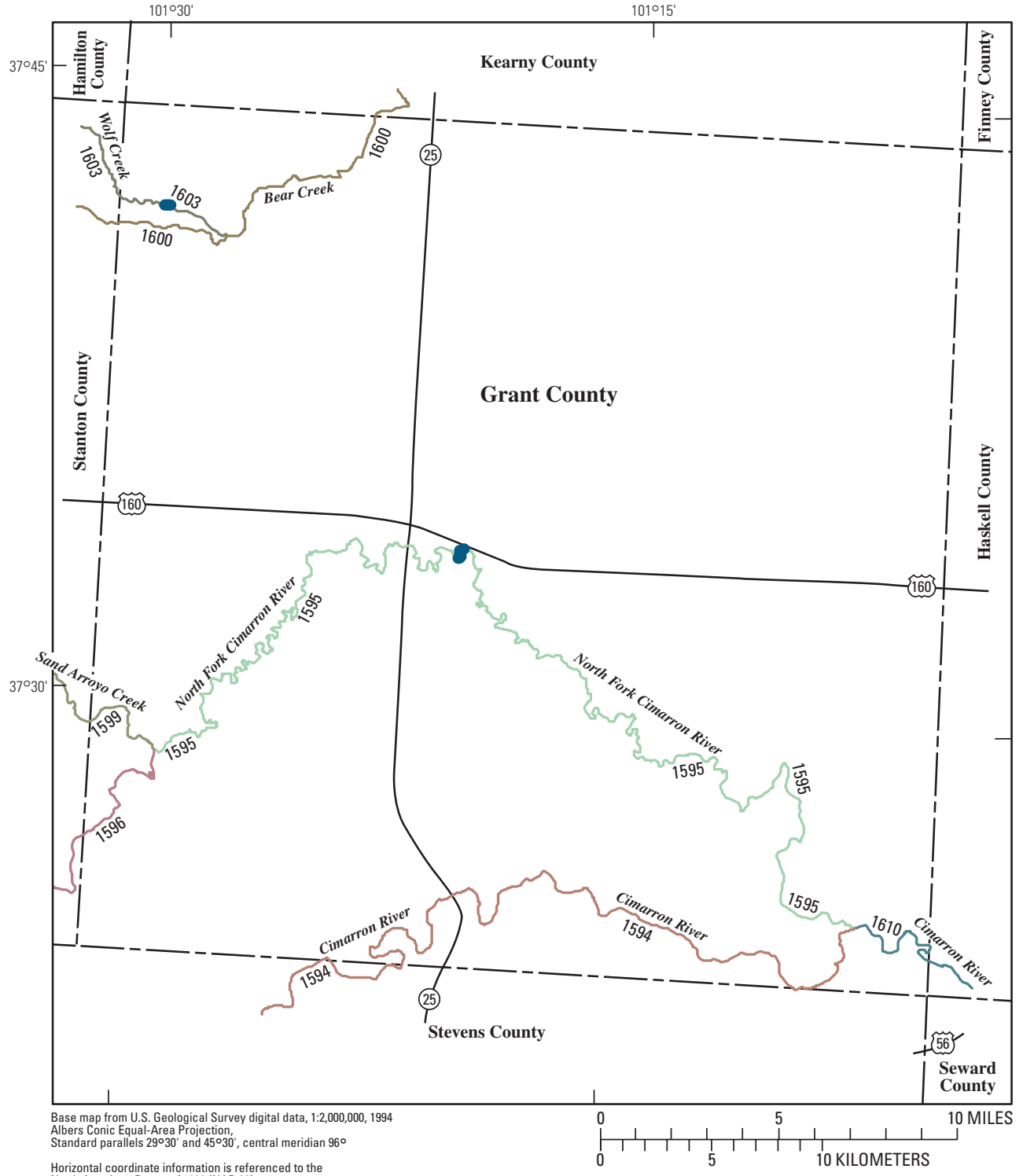

Horizontal coordinate information is referenced to the
North American Datum of 1983 (NAD 83)

\section{EXPLANATION}

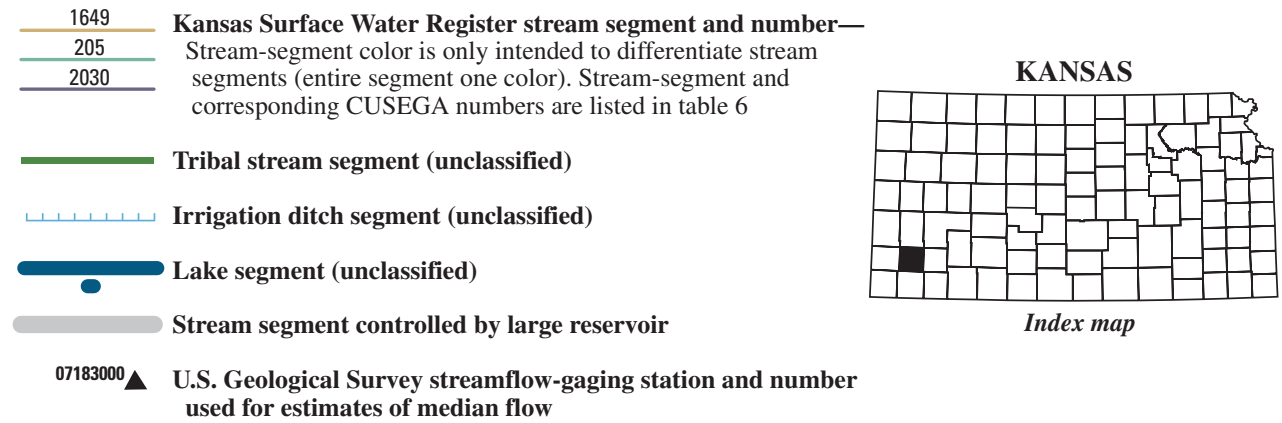

Figure 42. Location of U.S. Geological Survey streamflow-gaging stations and stream segments on the 1999 Kansas Surface Water Register for Grant County. 


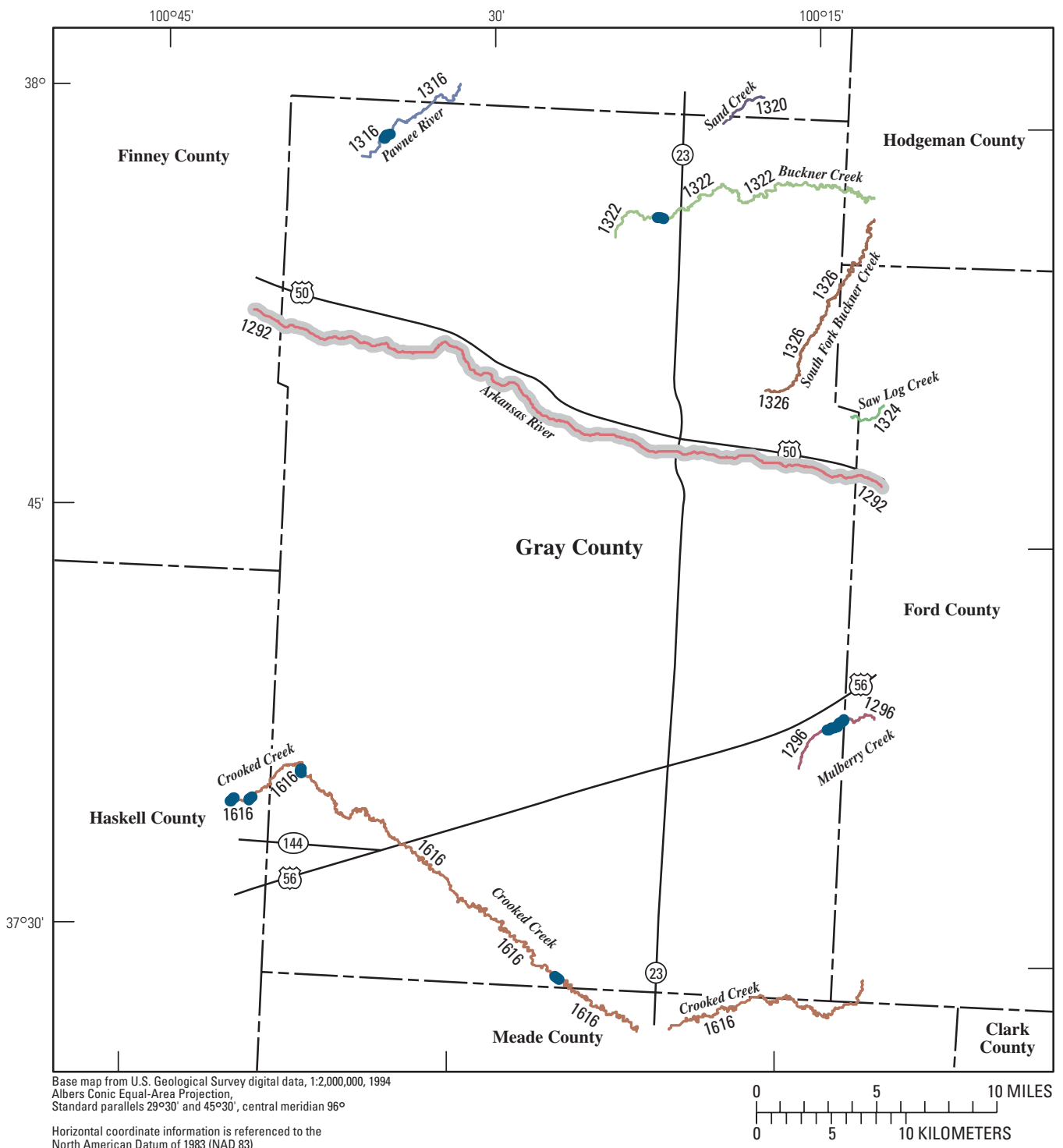

EXPLANATION

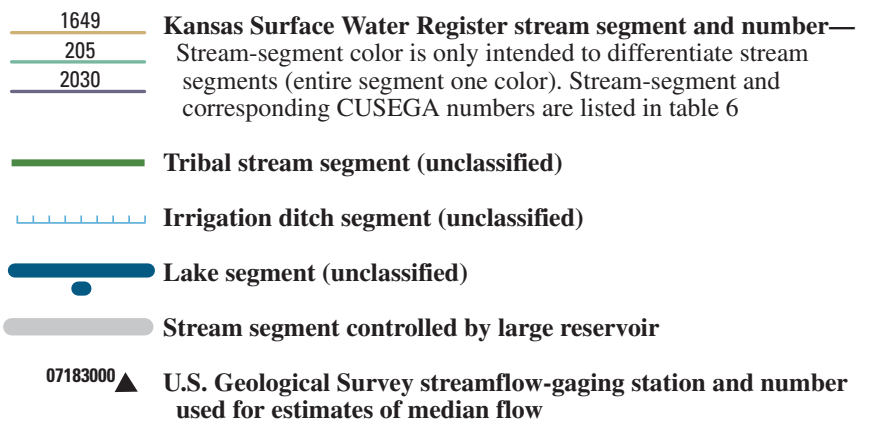

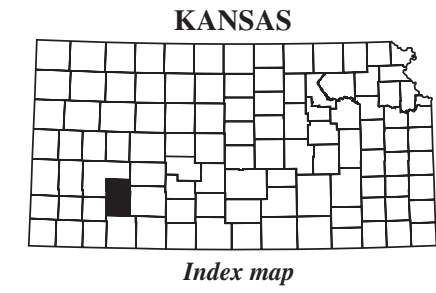

Figure 43. Location of U.S. Geological Survey streamflow-gaging stations and stream segments on the 1999 Kansas Surface Water Register for Gray County. 


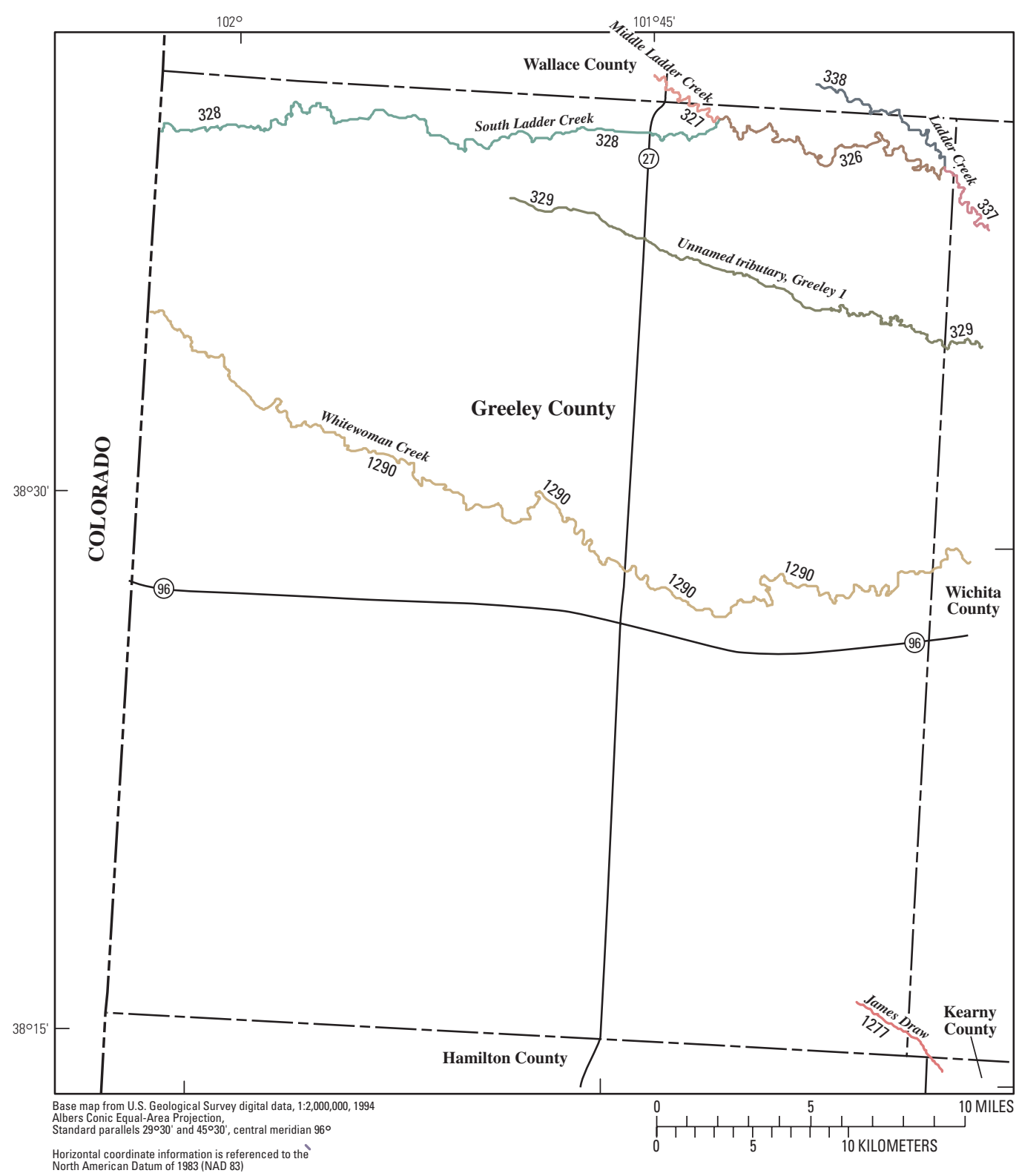

EXPLANATION

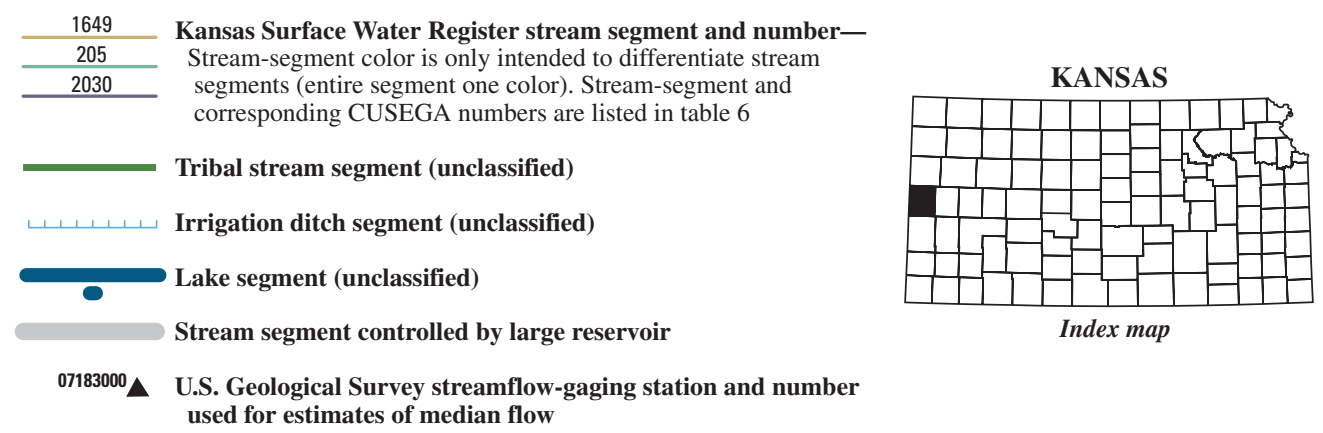

Figure 44. Location of U.S. Geological Survey streamflow-gaging stations and stream segments on the 1999 Kansas Surface Water Register for Greeley County. 


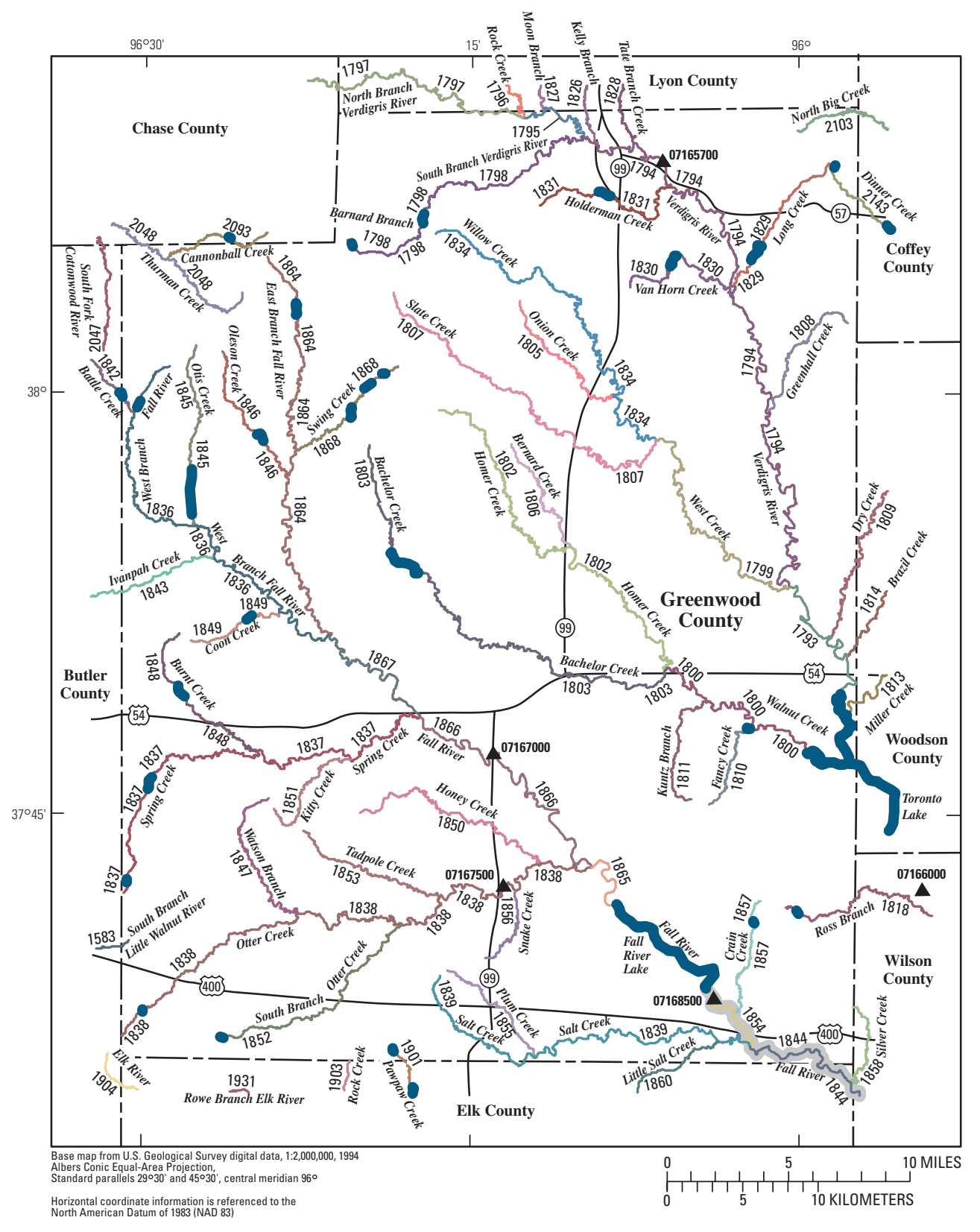

EXPLANATION
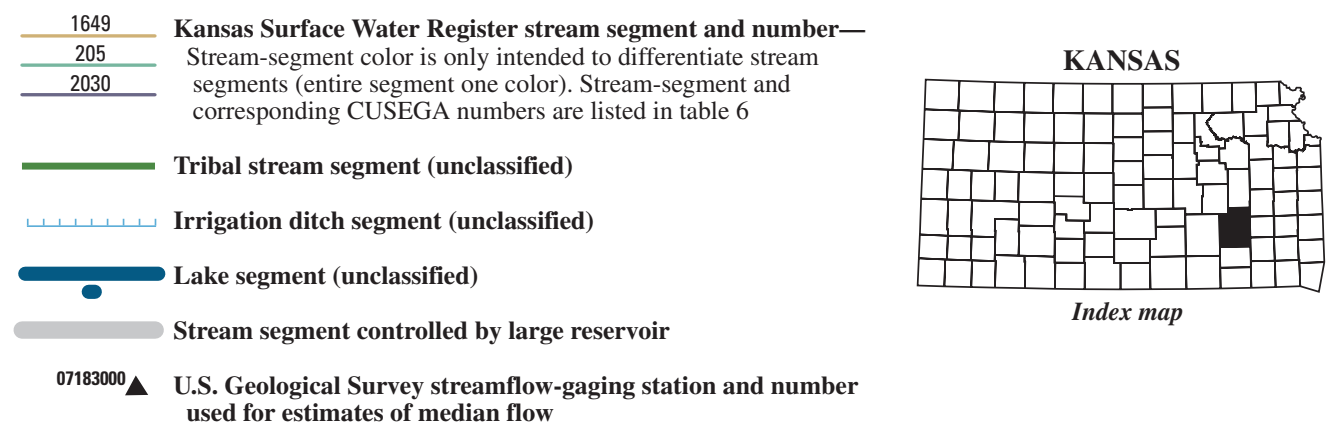

Figure 45. Location of U.S. Geological Survey streamflow-gaging stations and stream segments on the 1999 Kansas Surface Water Register for Greenwood County. 


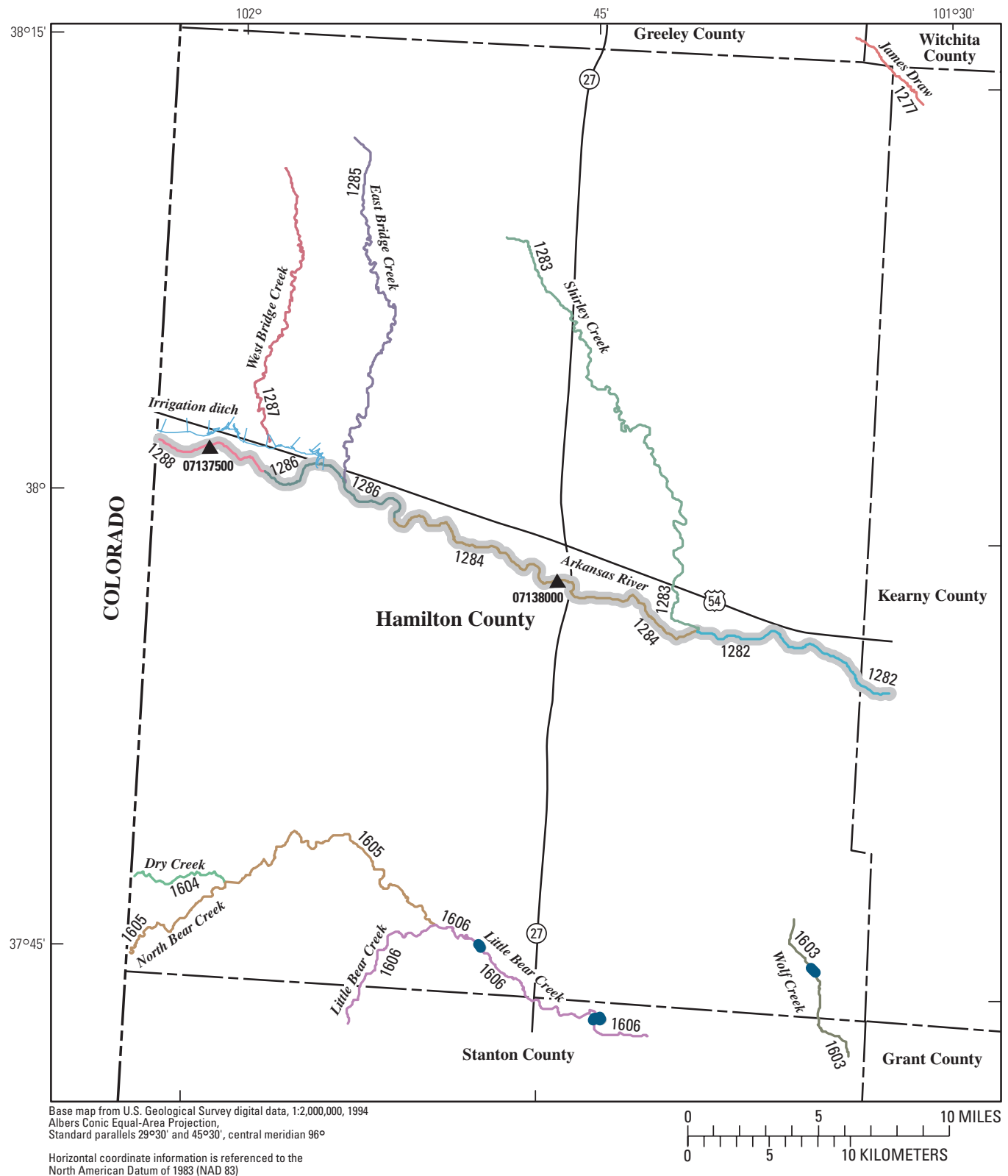

EXPLANATION

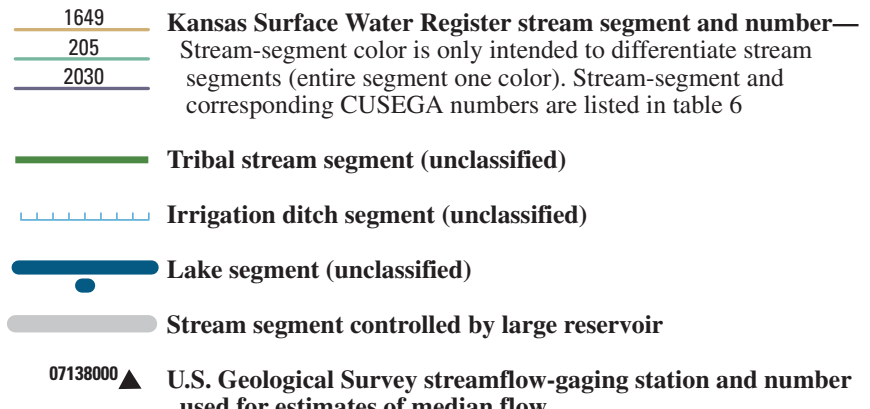

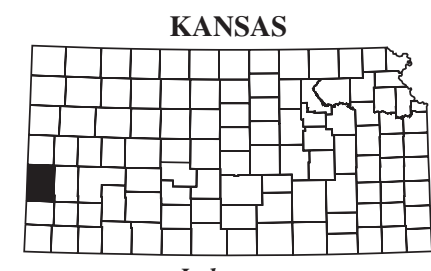

Index map used for estimates of median flow

Figure 46. Location of U.S. Geological Survey streamflow-gaging stations and stream segments on the 1999 Kansas Surface Water Register for Hamilton County. 


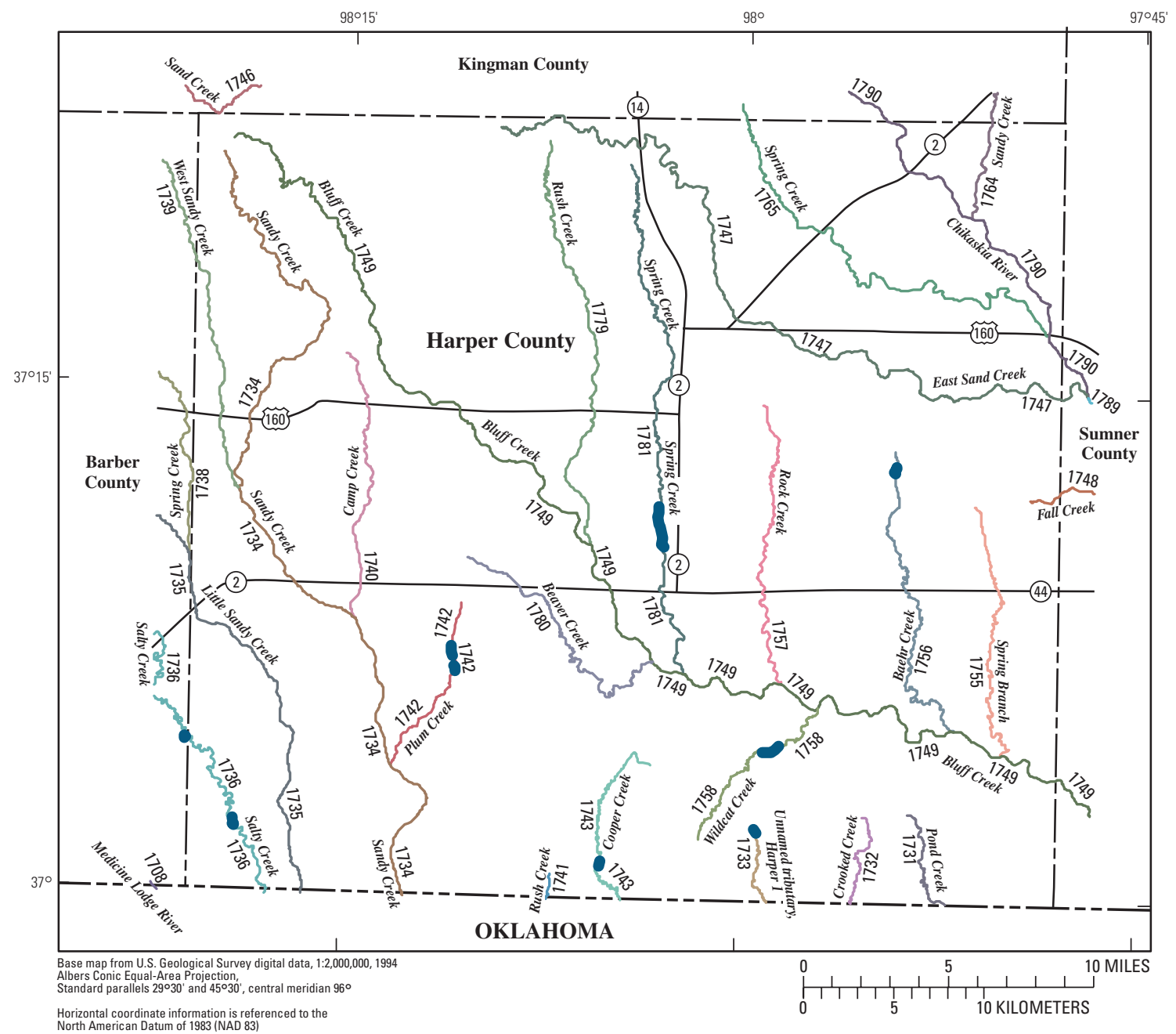

EXPLANATION

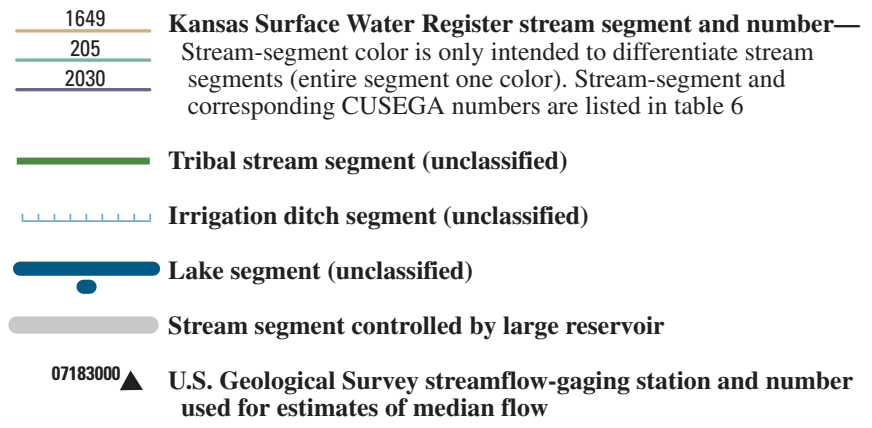

Figure 47. Location of U.S. Geological Survey streamflow-gaging stations and stream segments on the 1999 Kansas Surface Water Register for Harper County. 


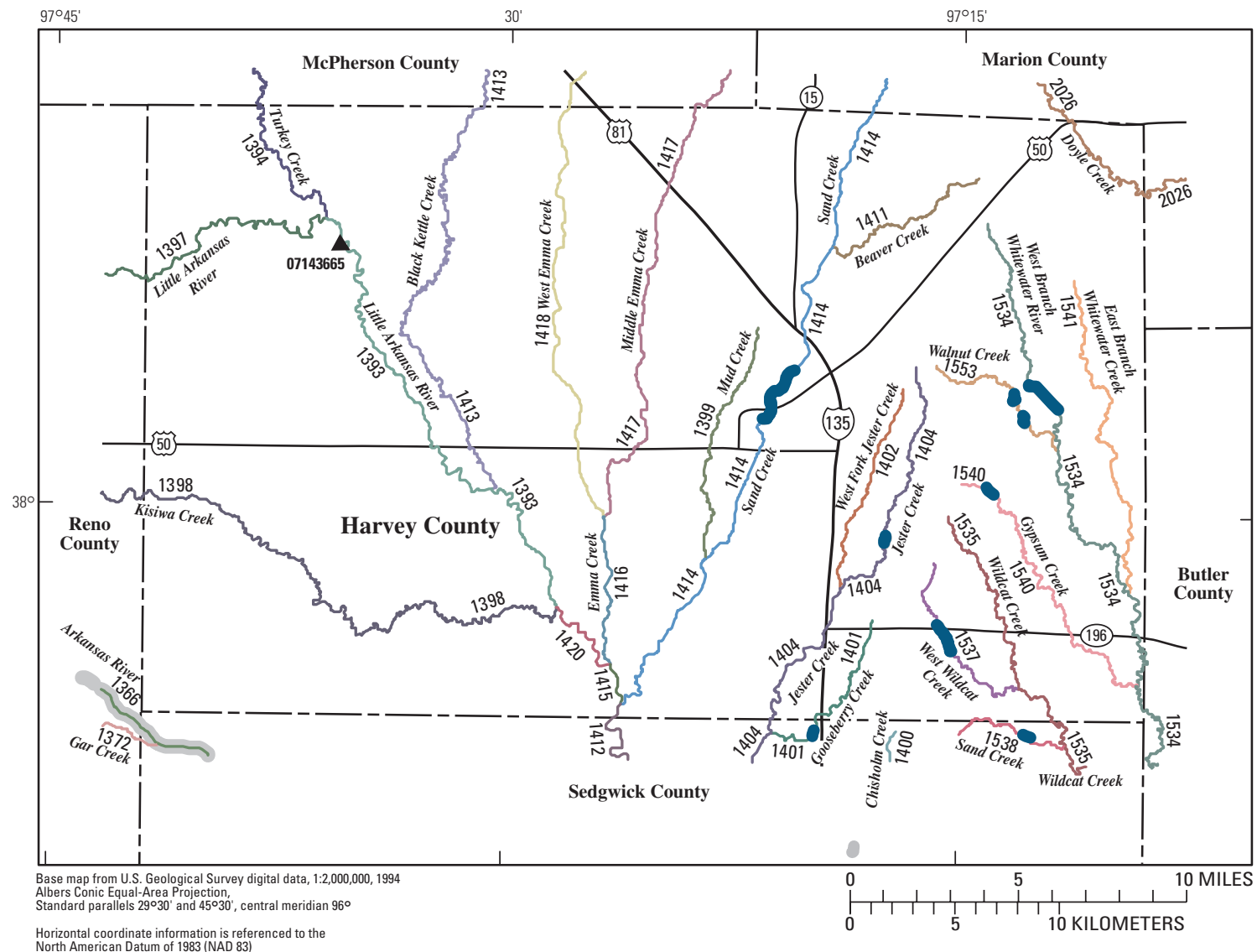

EXPLANATION

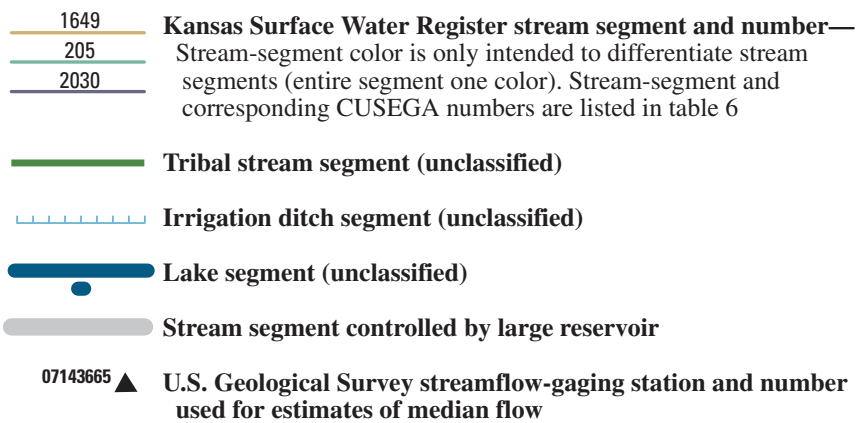

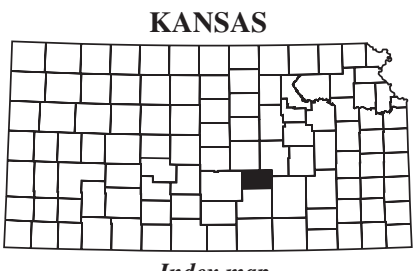

Index map

Figure 48. Location of U.S. Geological Survey streamflow-gaging stations and stream segments on the 1999 Kansas Surface Water Register for Harvey County. 


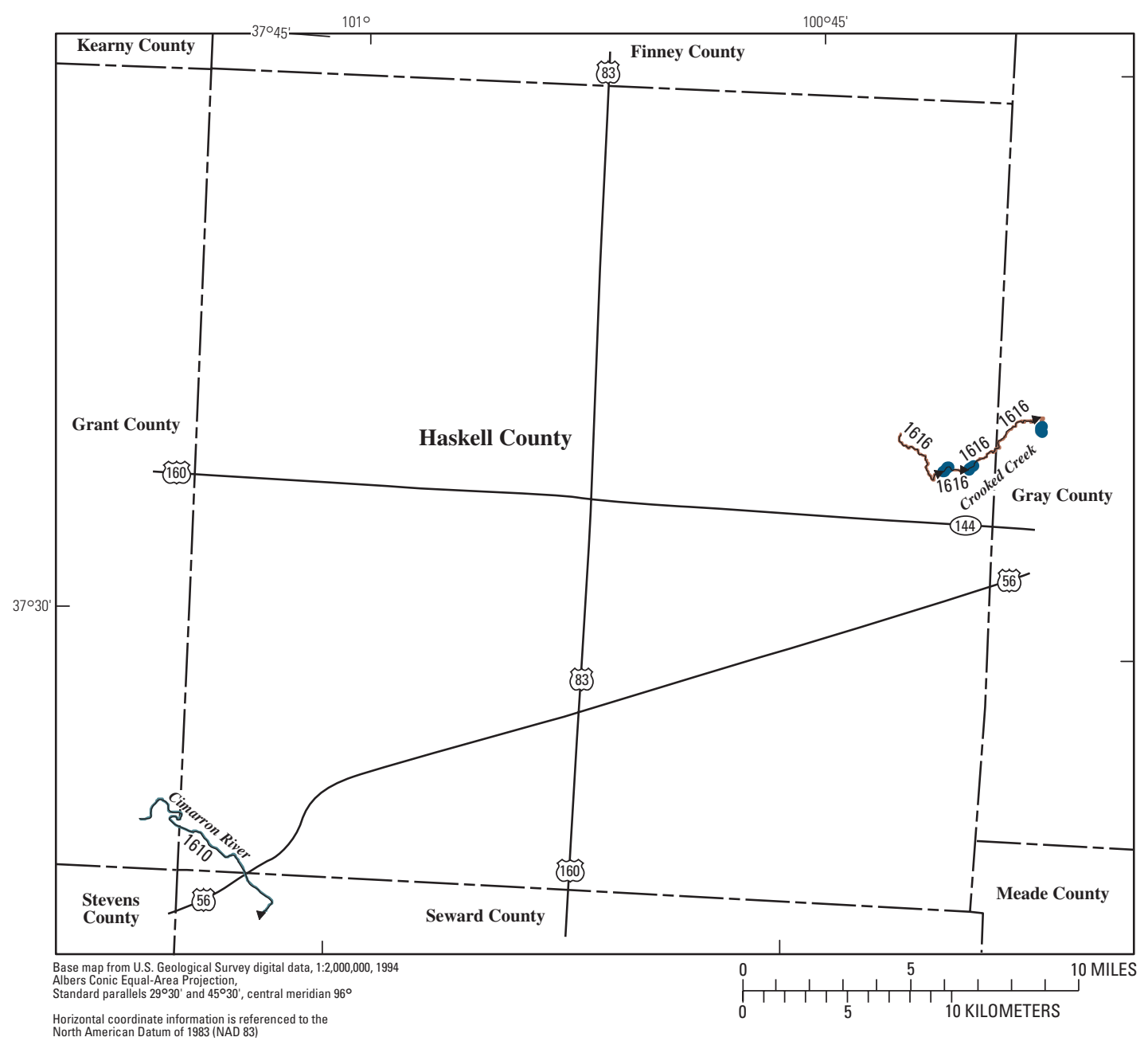

\section{EXPLANATION}
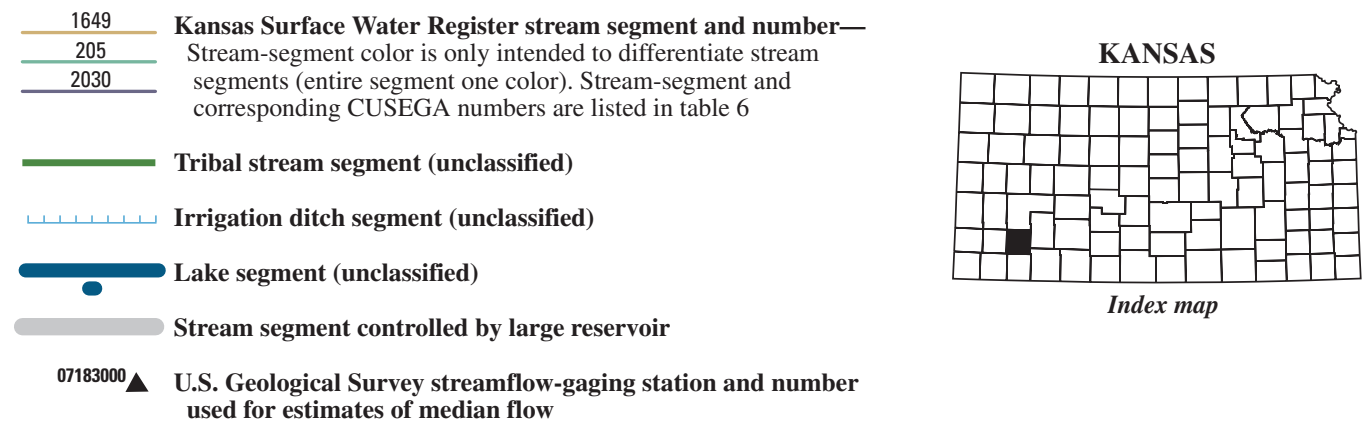

Figure 49. Location of U.S. Geological Survey streamflow-gaging stations and stream segments on the 1999 Kansas Surface Water Register for Haskell County. 


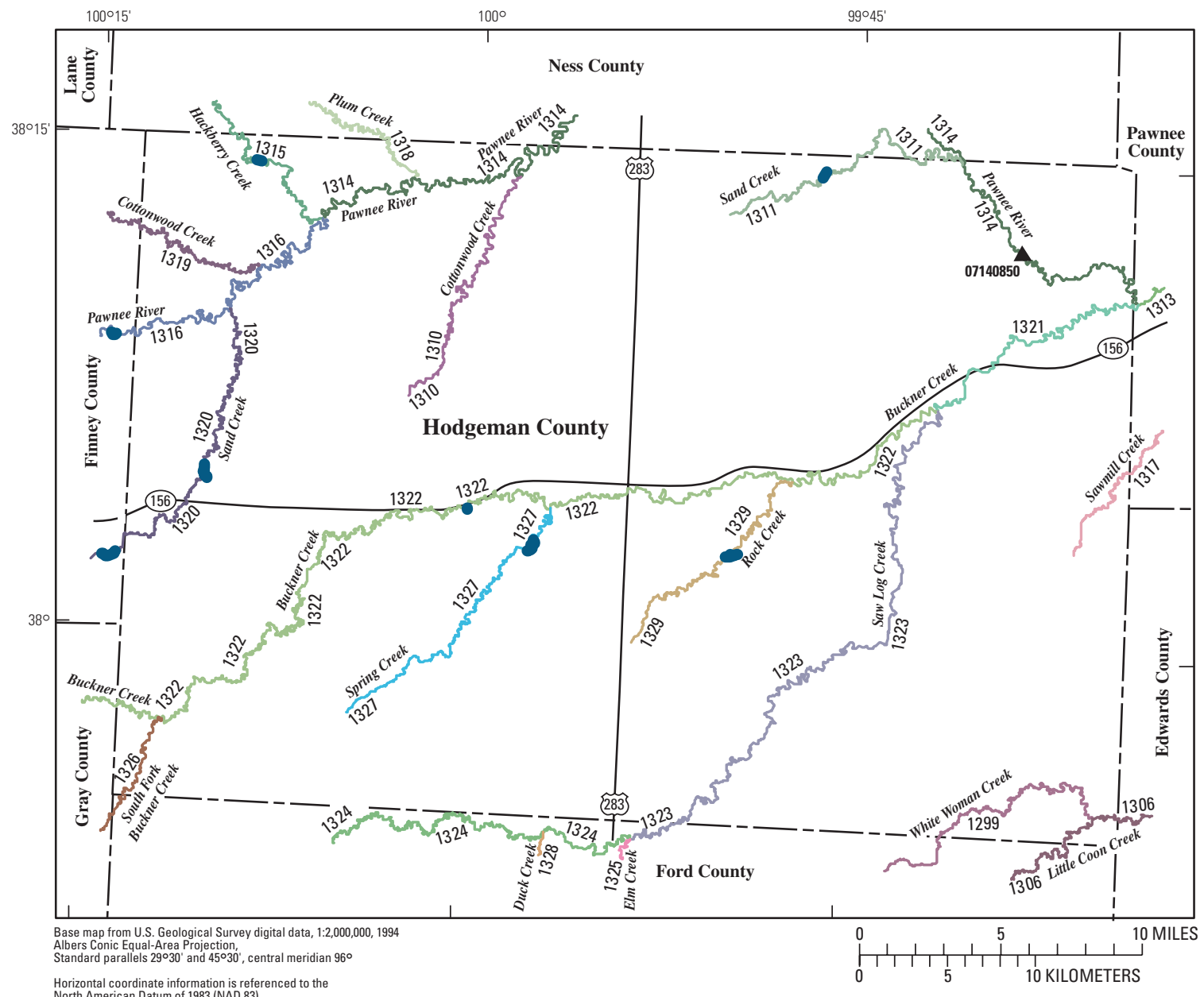

rdinate information is referenced to the

\section{EXPLANATION}

\begin{tabular}{|c|c|}
\hline 1649 & Kansas Surface Water Register stream segment and number- \\
\hline 205 & Stream-segment color is only intended to differentiate stream \\
\hline 2030 & segments (entire segment one color). Stream-segment and \\
\hline & corresponding CUSEGA numbers are listed in table 6 \\
\hline & Tribal stream segment (unclassified) \\
\hline $1,1,1,1,1,0$ & Irrigation ditch segment (unclassified) \\
\hline $\mathbf{0}$ & Lake segment (unclassified) \\
\hline & Stream segment controlled by large reservoir \\
\hline${ }^{07183000} \Delta$ & $\begin{array}{l}\text { U.S. Geological Survey streamflow-gaging station and number } \\
\text { used for estimates of median flow }\end{array}$ \\
\hline
\end{tabular}

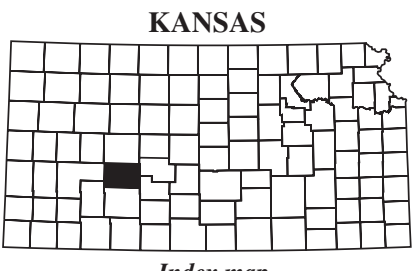

Index map

Figure 50. Location of U.S. Geological Survey streamflow-gaging stations and stream segments on the 1999 Kansas Surface Water Register for Hodgeman County. 


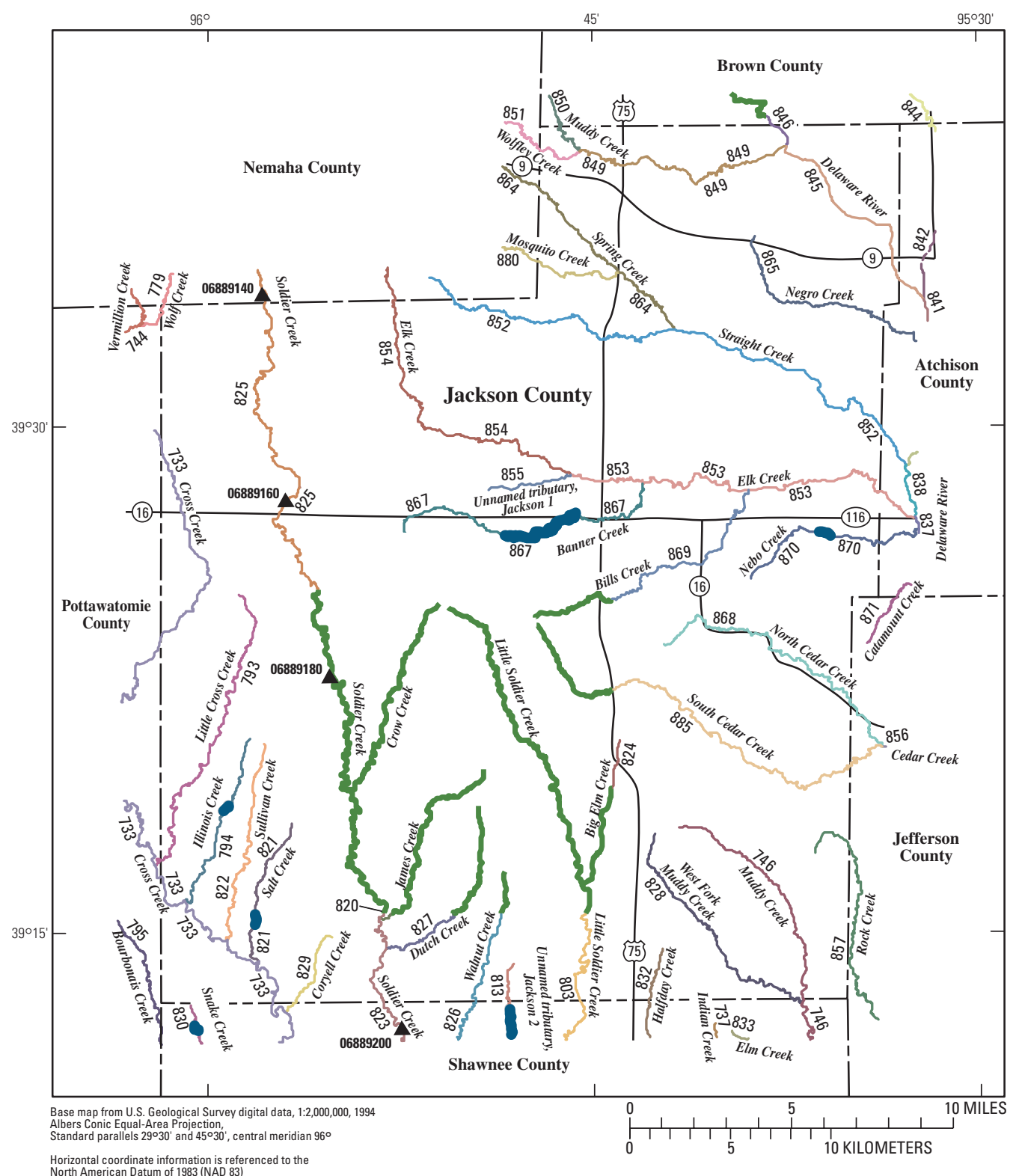

EXPLANATION

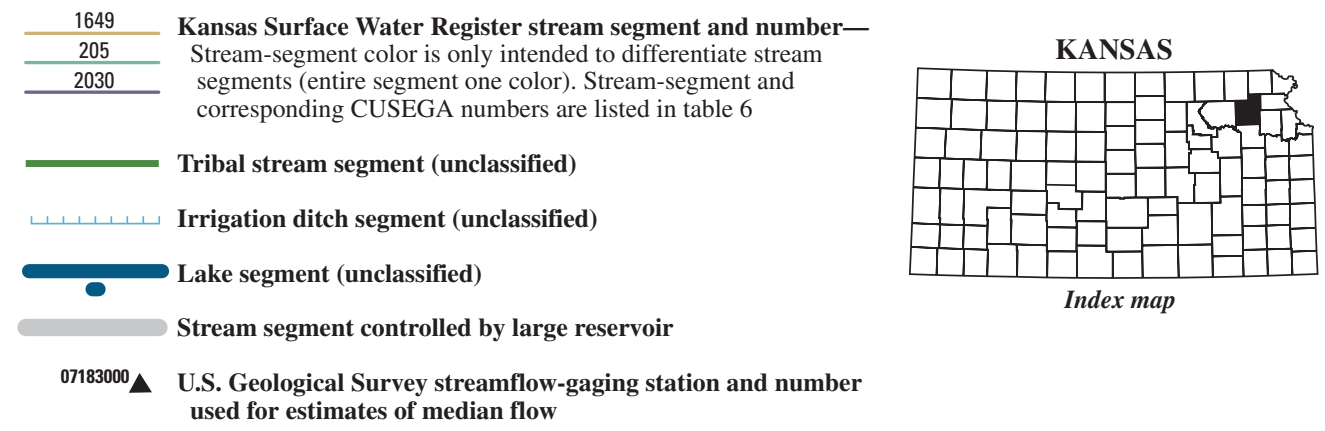

Figure 51. Location of U.S. Geological Survey streamflow-gaging stations and stream segments on the 1999 Kansas Surface Water Register for Jackson County. 


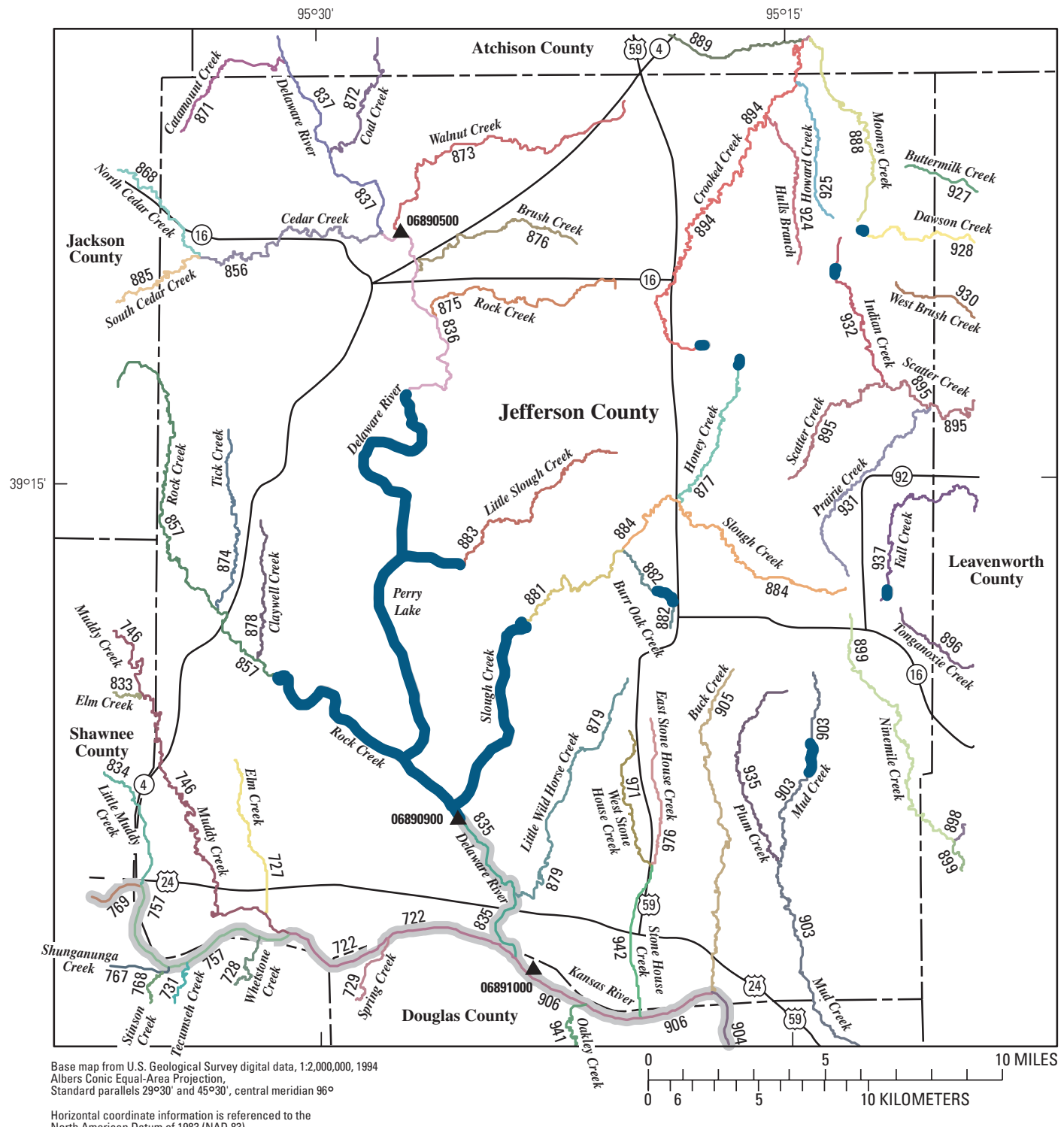

EXPLANATION
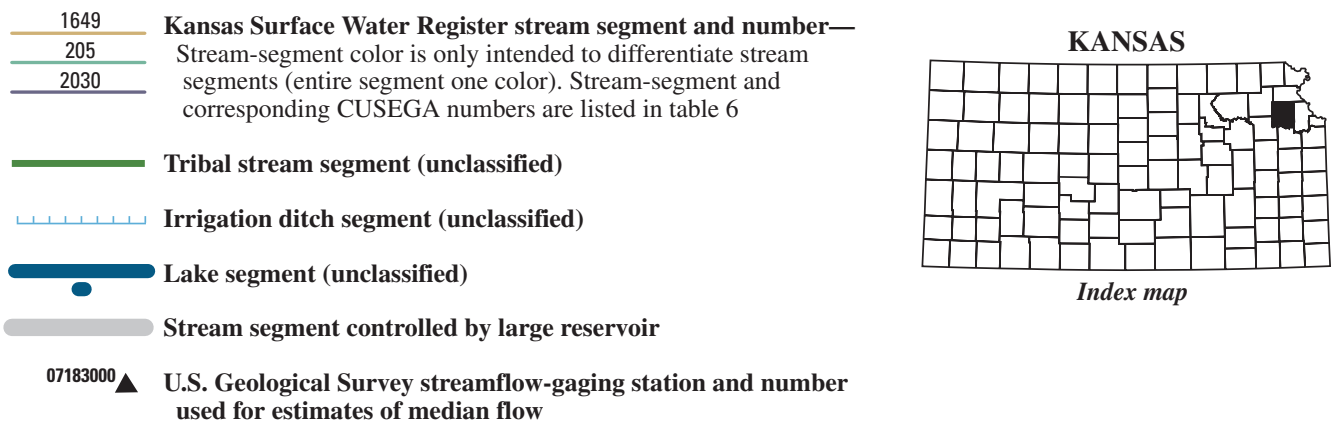

Index map

Figure 52. Location of U.S. Geological Survey streamflow-gaging stations and stream segments on the 1999 Kansas Surface Water Register for Jefferson County. 


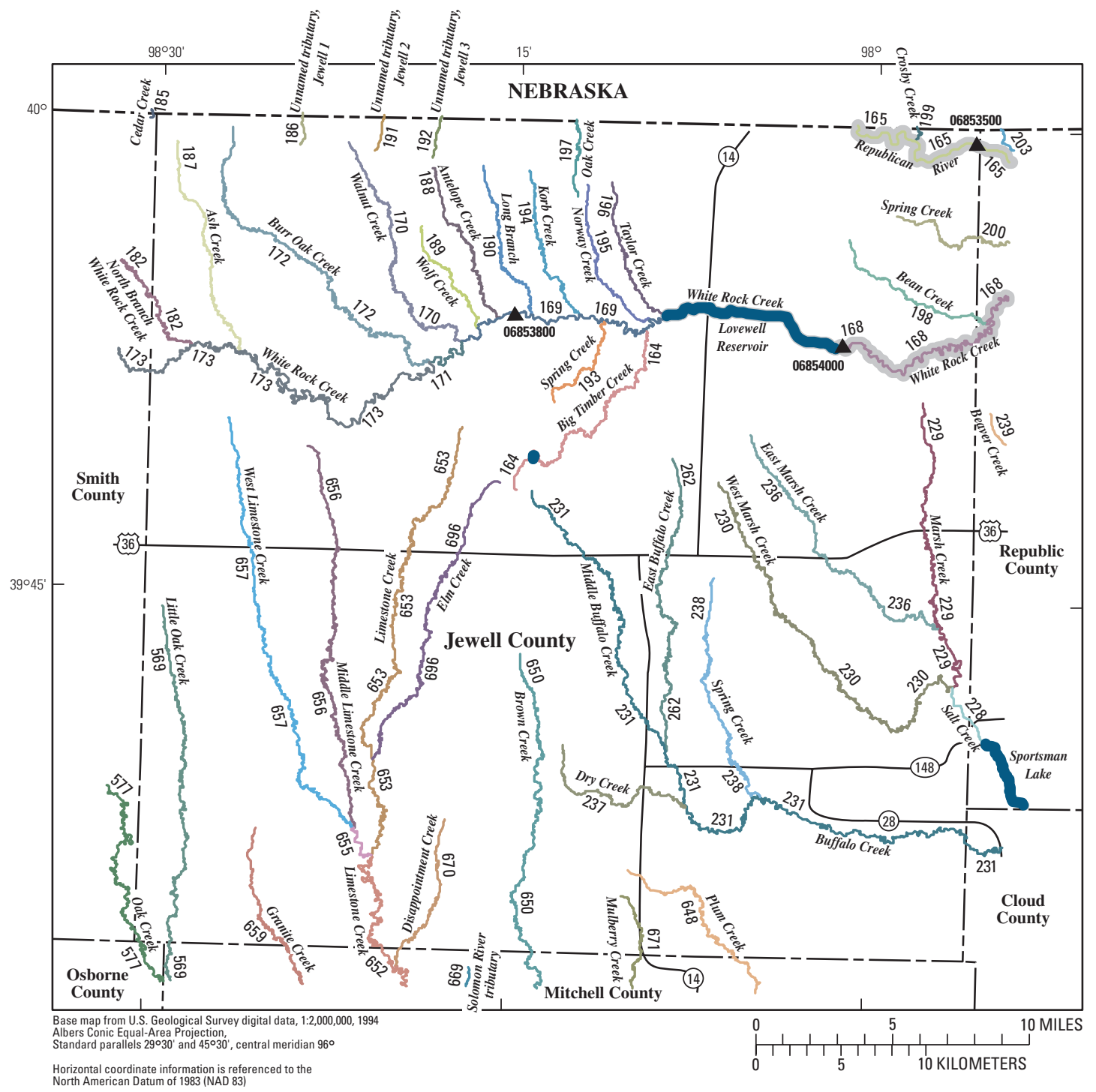

\section{EXPLANATION}

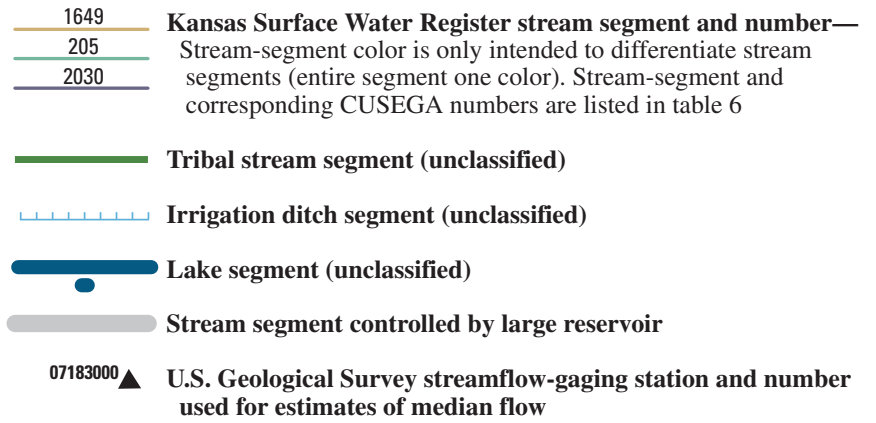

Figure 53. Location of U.S. Geological Survey streamflow-gaging stations and stream segments on the 1999 Kansas Surface Water Register for Jewell County. 


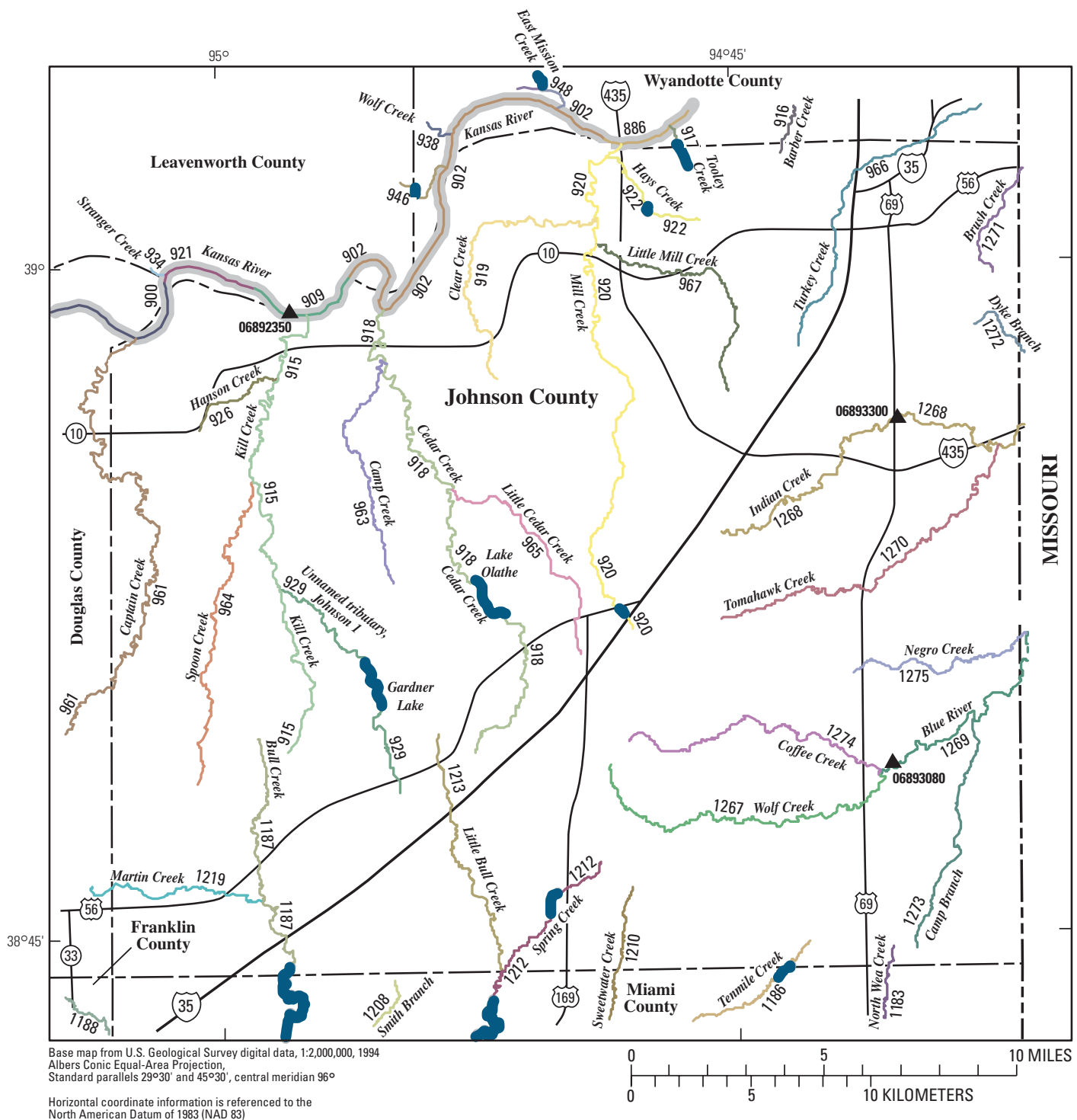

EXPLANATION
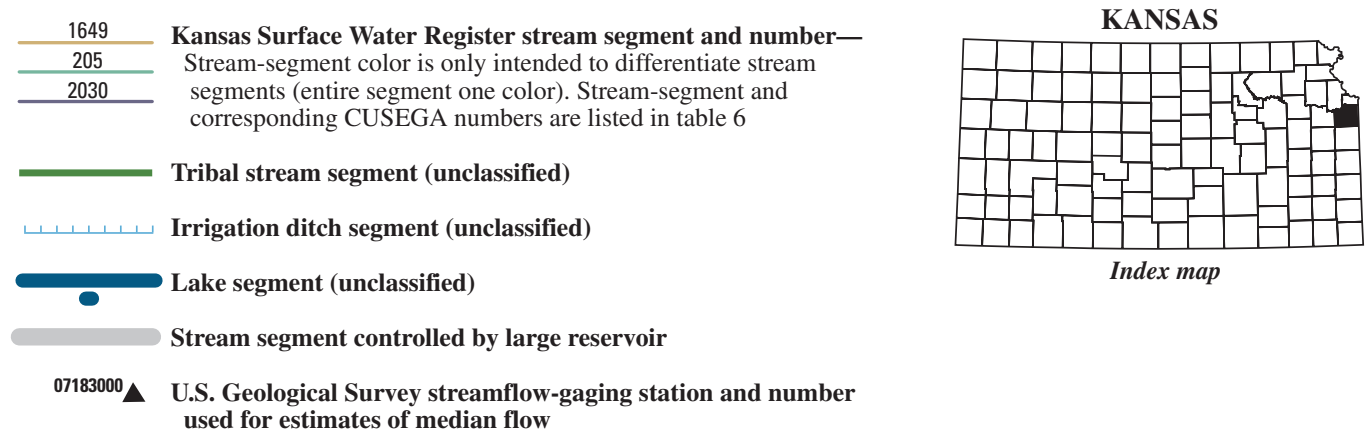

Index map

Figure 54. Location of U.S. Geological Survey streamflow-gaging stations and stream segments on the 1999 Kansas Surface Water Register for Johnson County. 


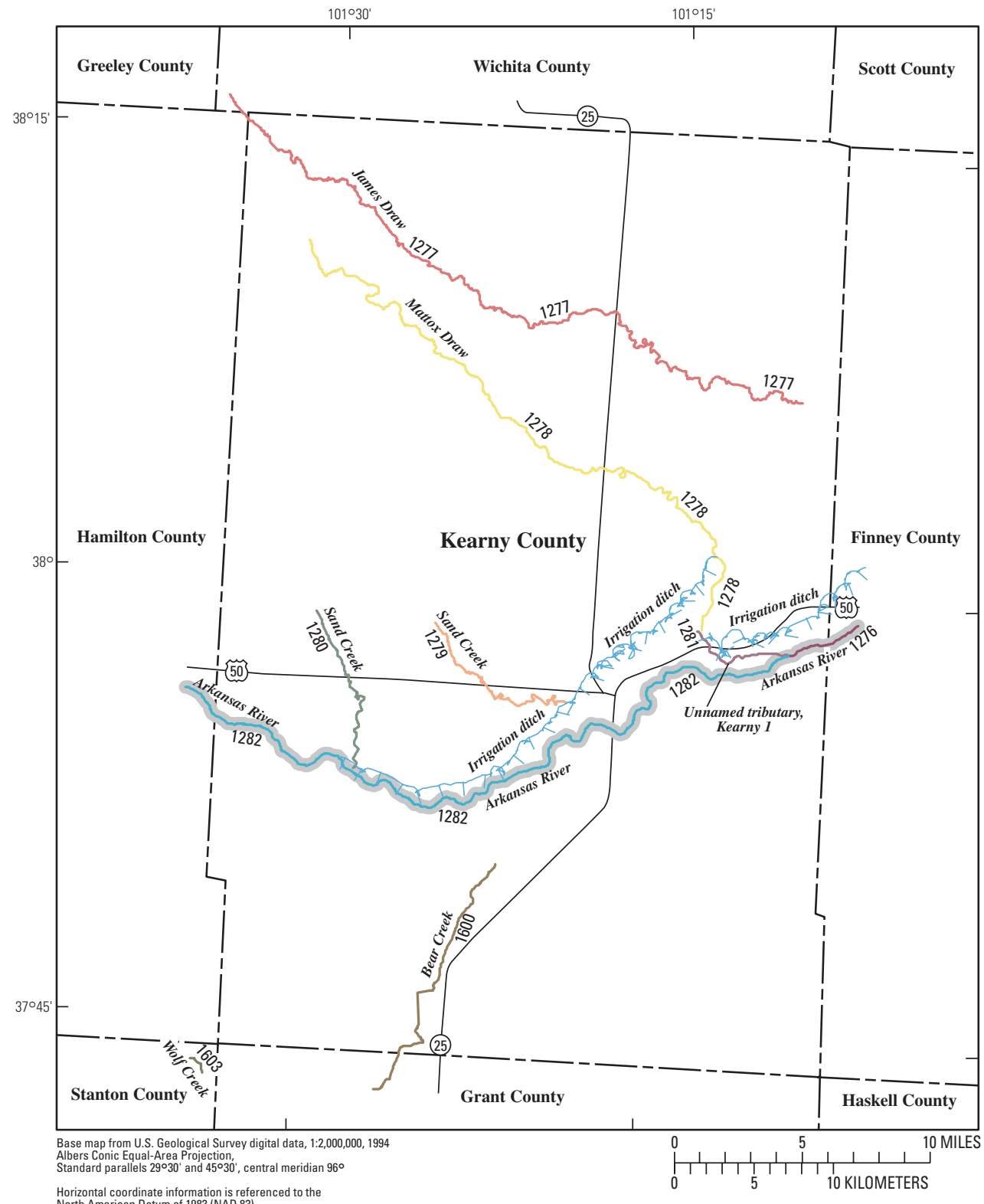

EXPLANATION

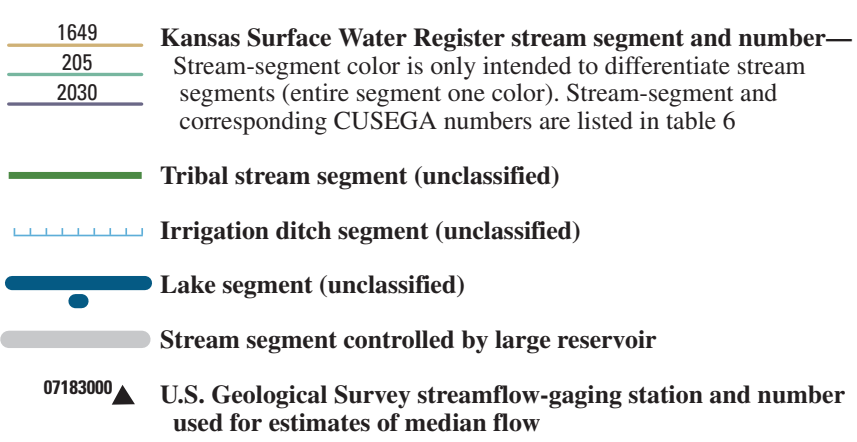

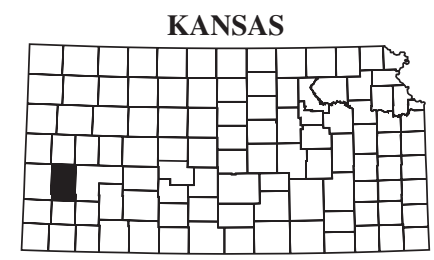

Index map

Figure 55. Location of U.S. Geological Survey streamflow-gaging stations and stream segments on the 1999 Kansas Surface Water Register for Kearny County. 


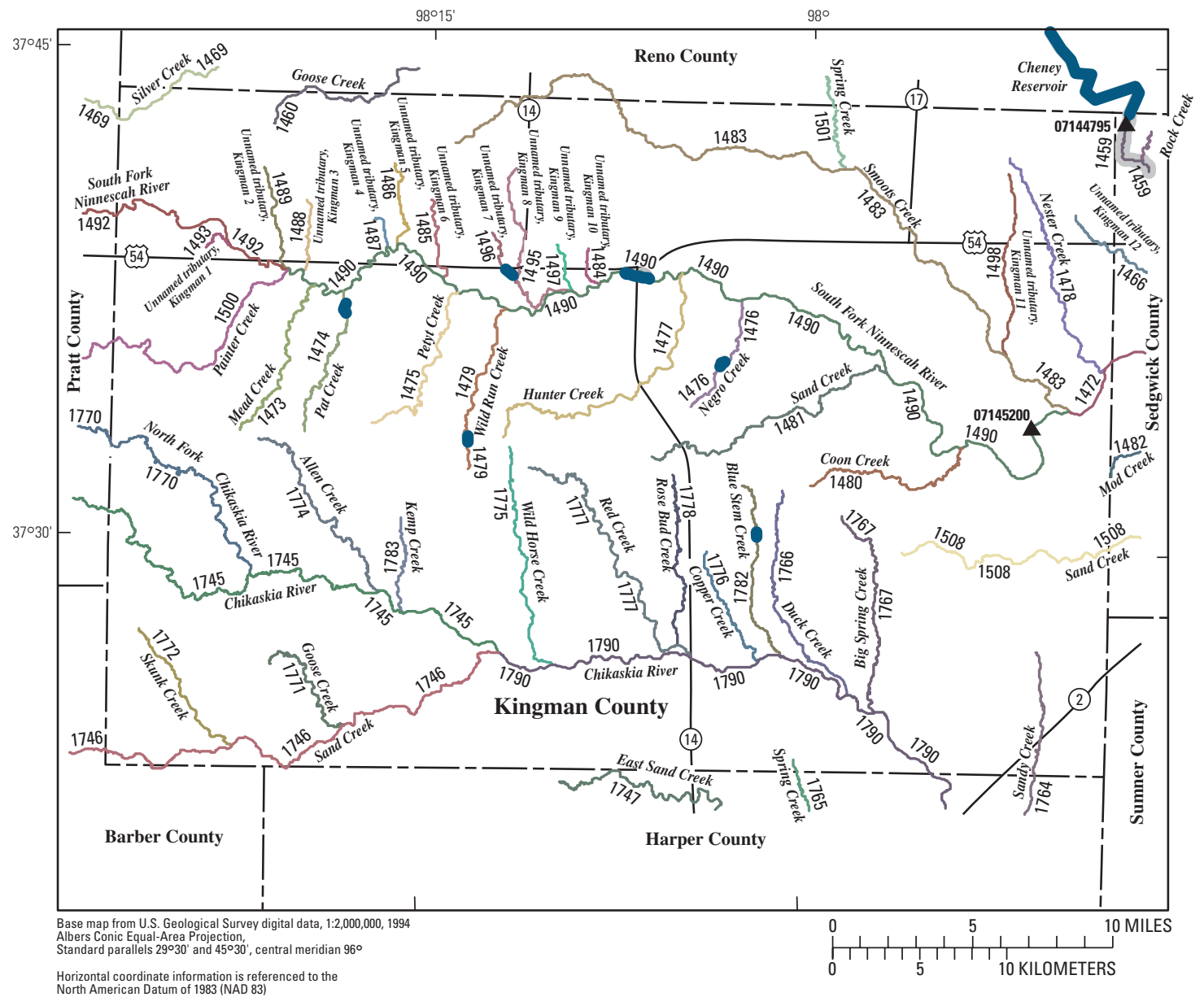

EXPLANATION

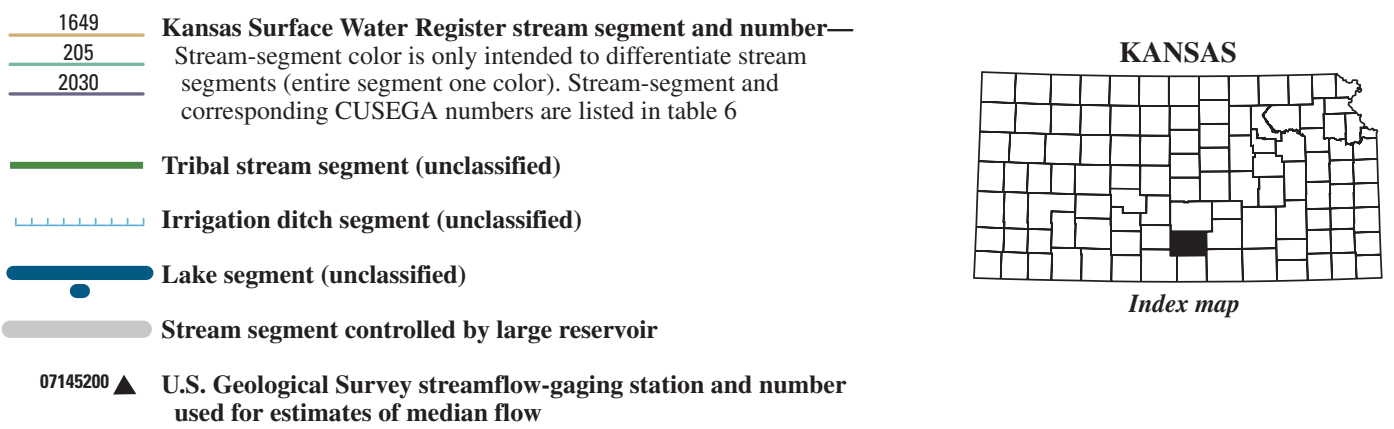

Figure 56. Location of U.S. Geological Survey streamflow-gaging stations and stream segments on the 1999 Kansas Surface Water Register for Kingman County. 


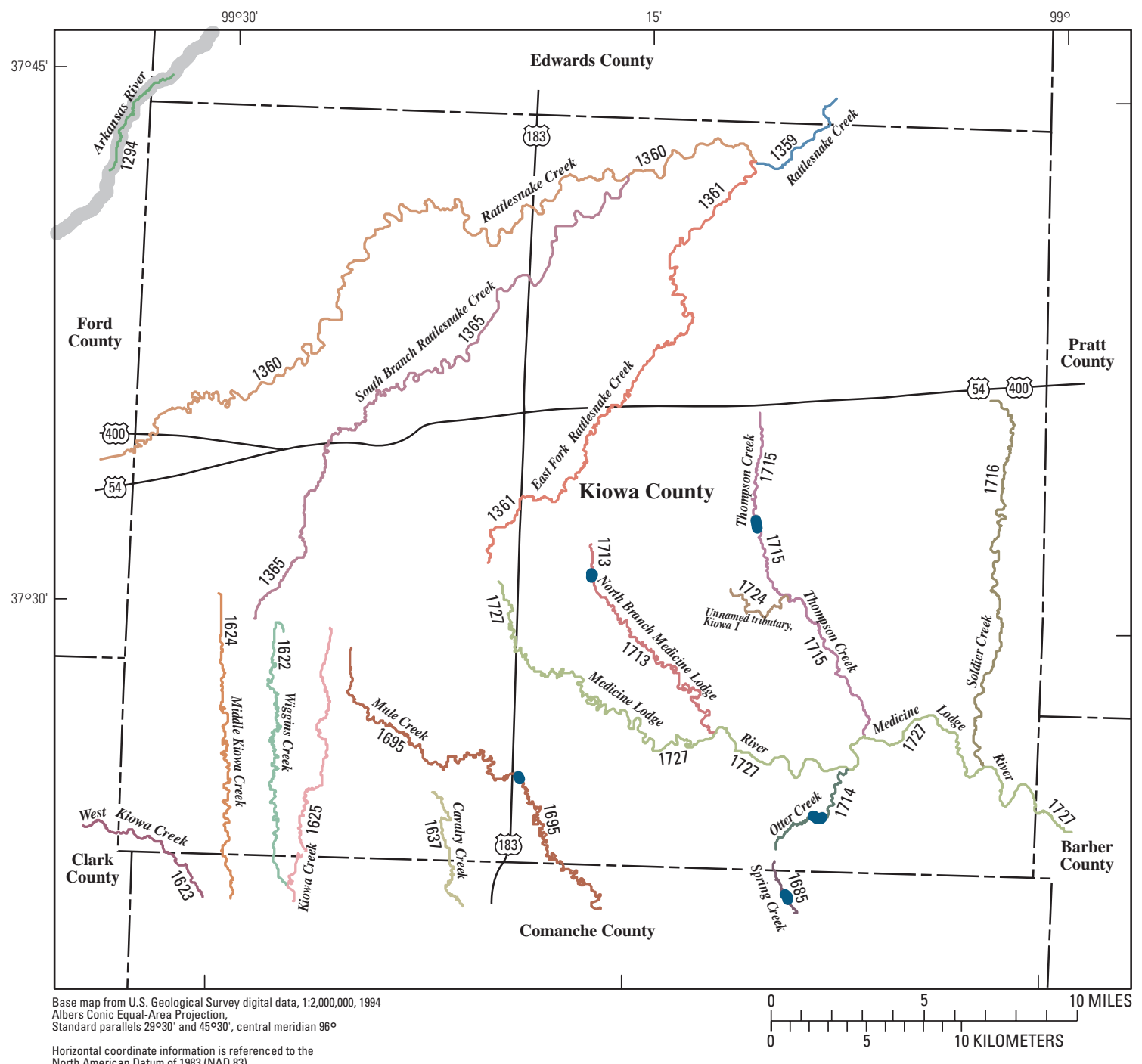

EXPLANATION
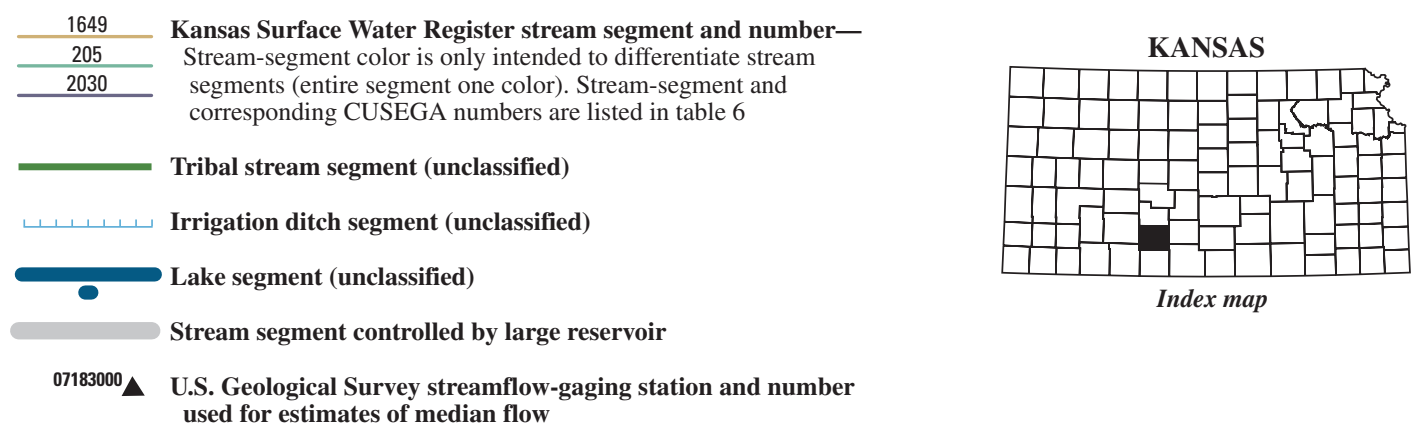

Figure 57. Location of U.S. Geological Survey streamflow-gaging stations and stream segments on the 1999 Kansas Surface Water Register for Kiowa County. 


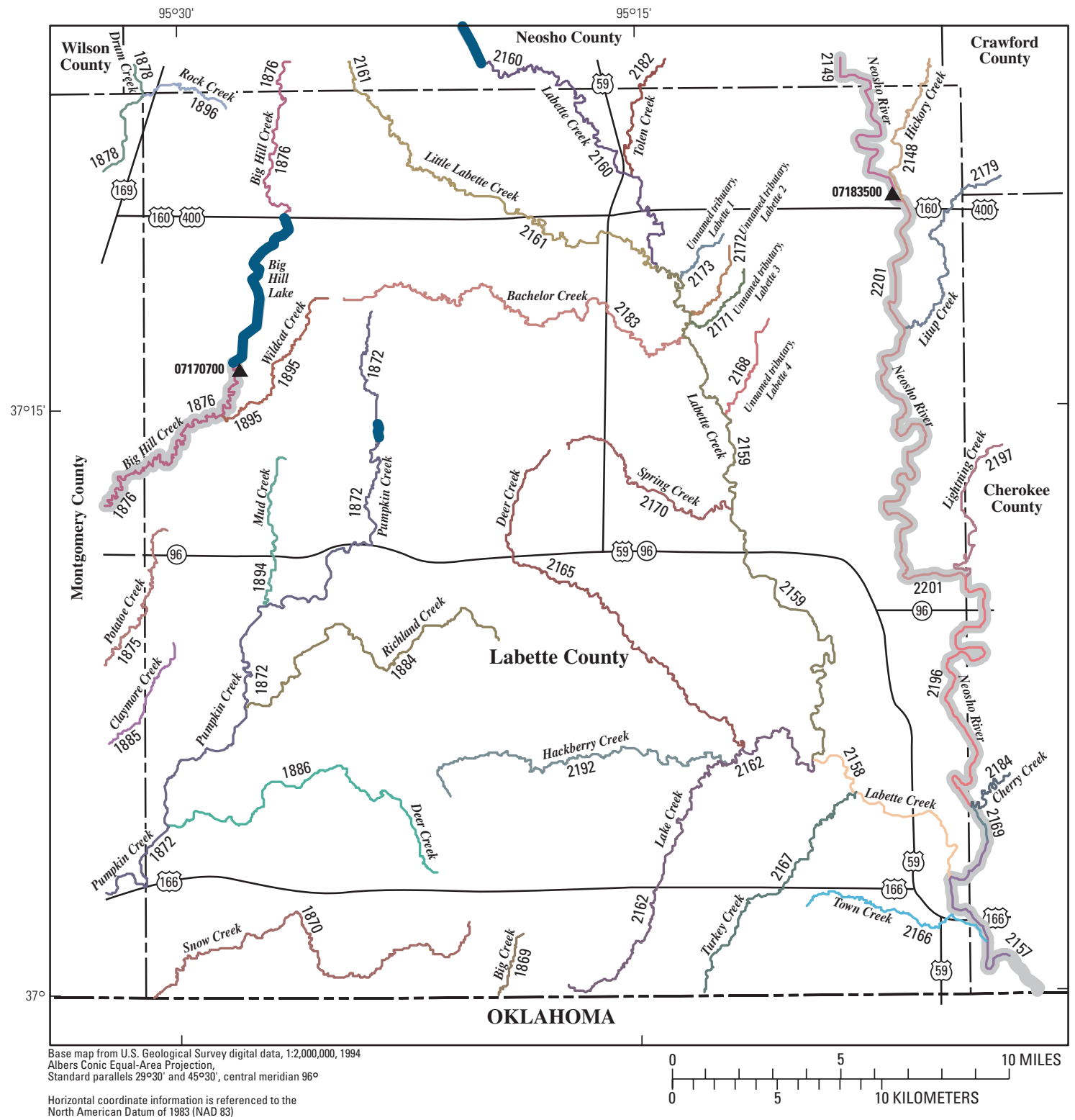

EXPLANATION
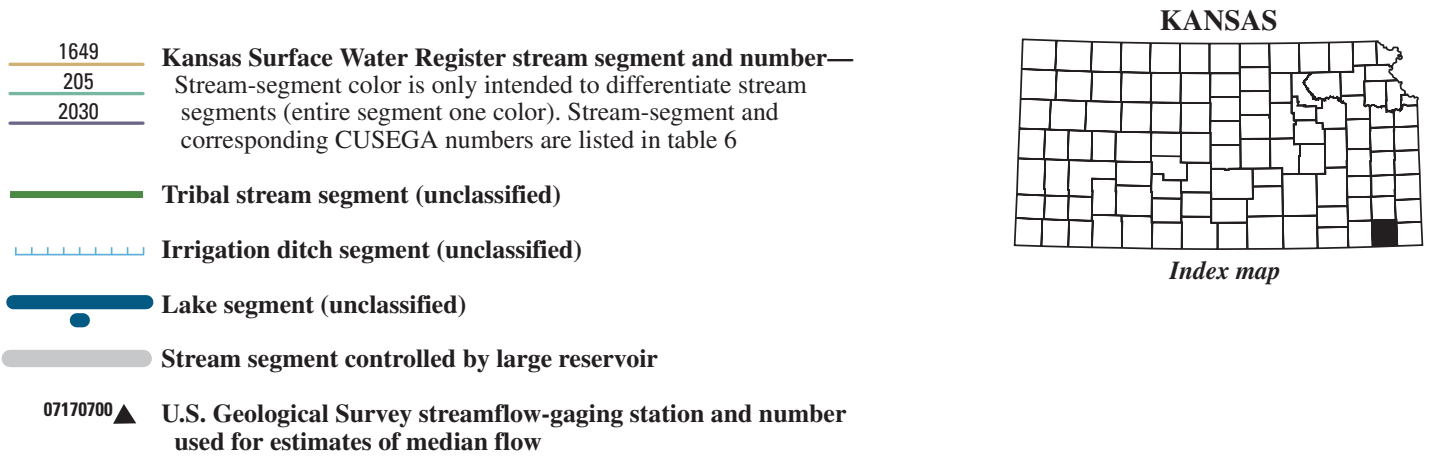

Index map

Figure 58. Location of U.S. Geological Survey streamflow-gaging stations and stream segments on the 1999 Kansas Surface Water Register for Labette County. 


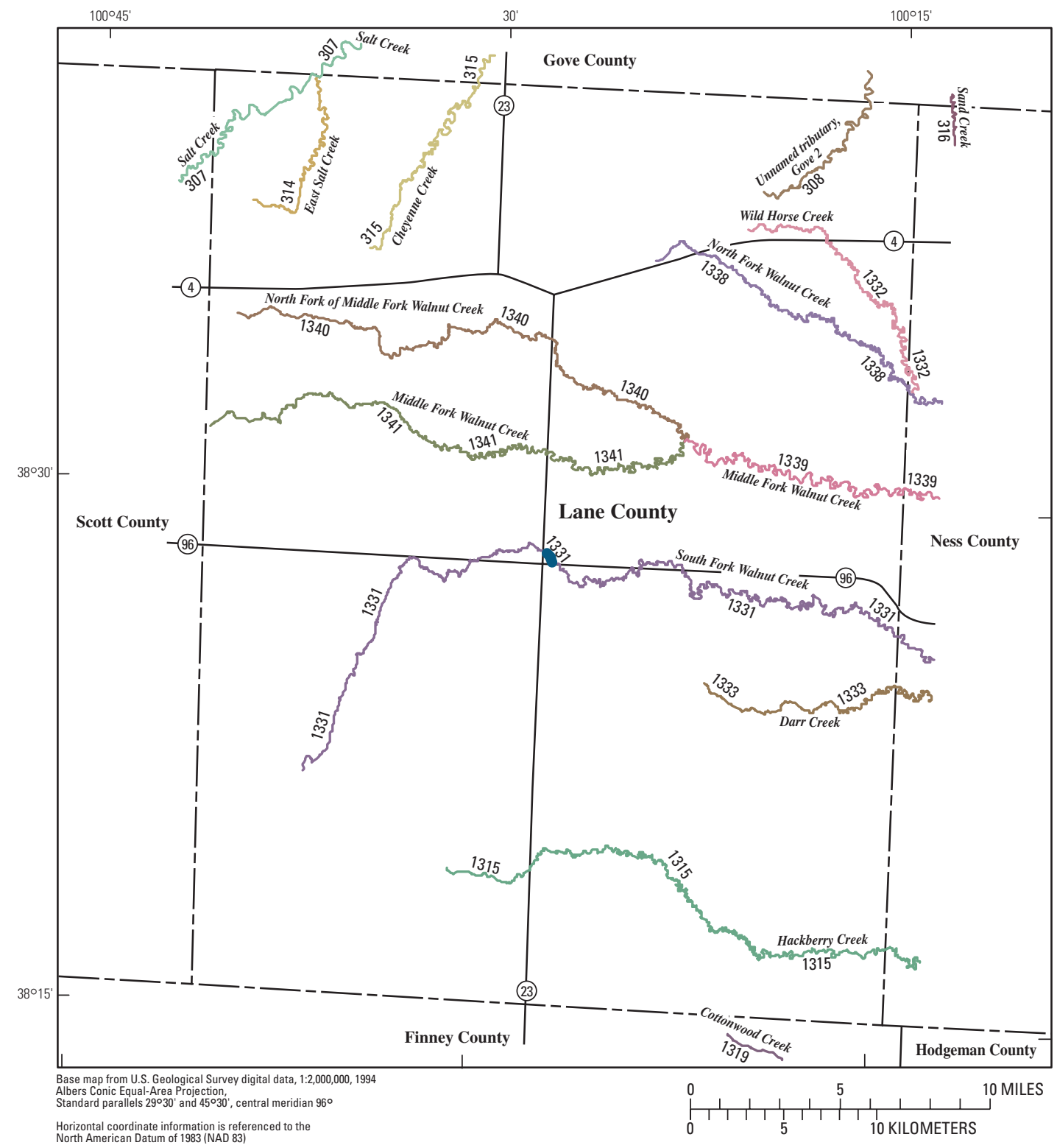

EXPLANATION

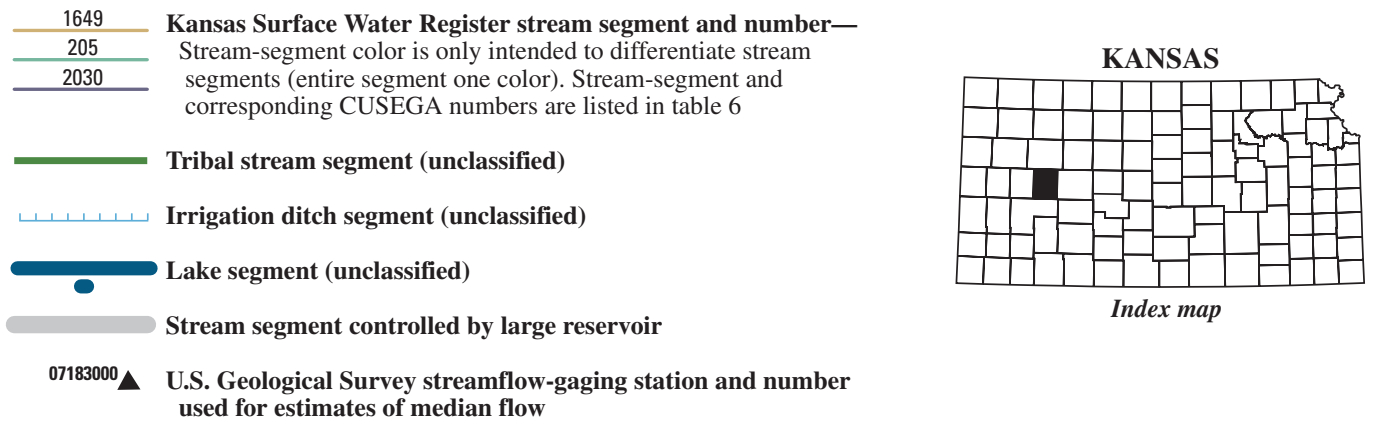

Figure 59. Location of U.S. Geological Survey streamflow-gaging stations and stream segments on the 1999 Kansas Surface Water Register for Lane County. 


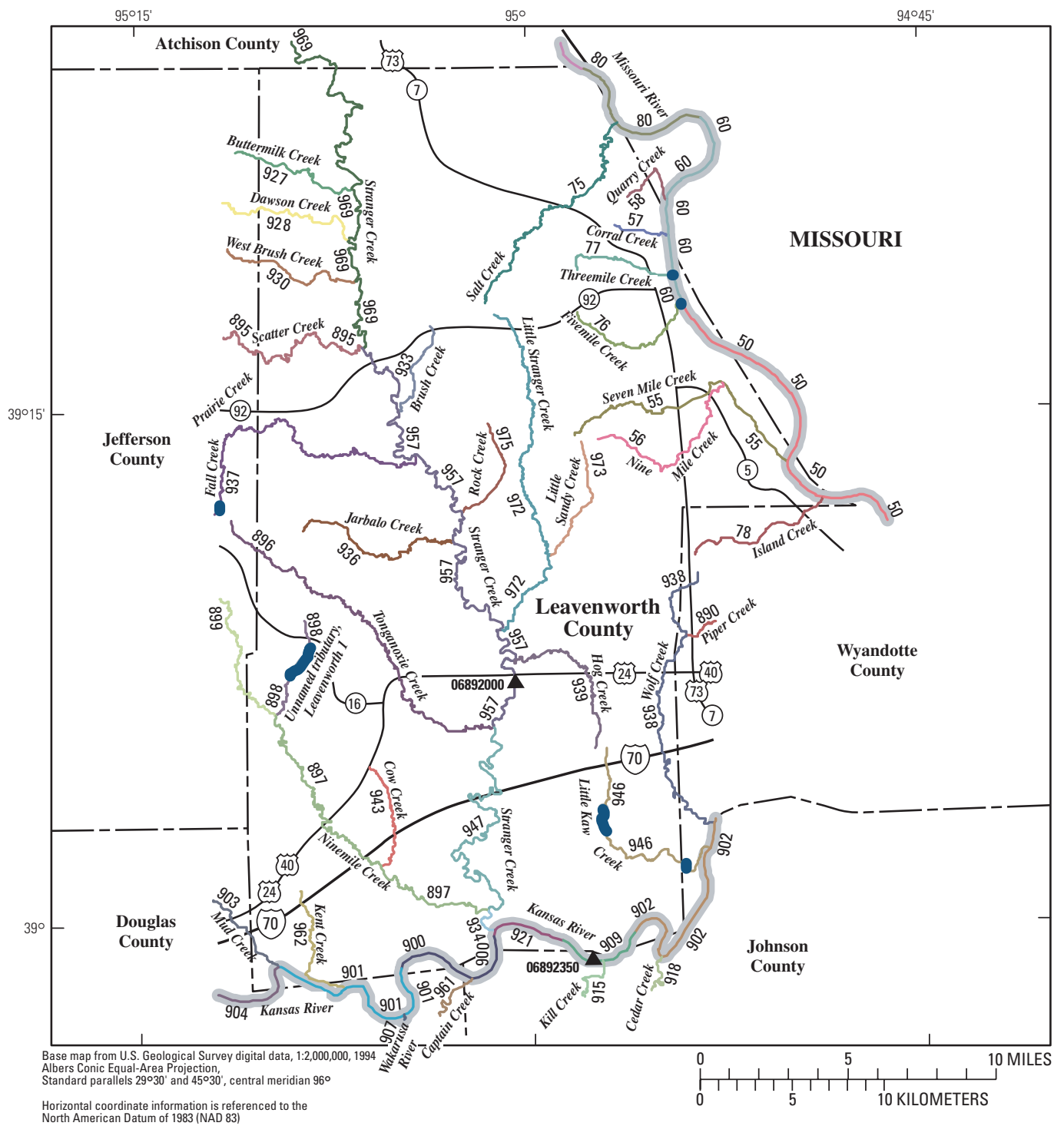

EXPLANATION
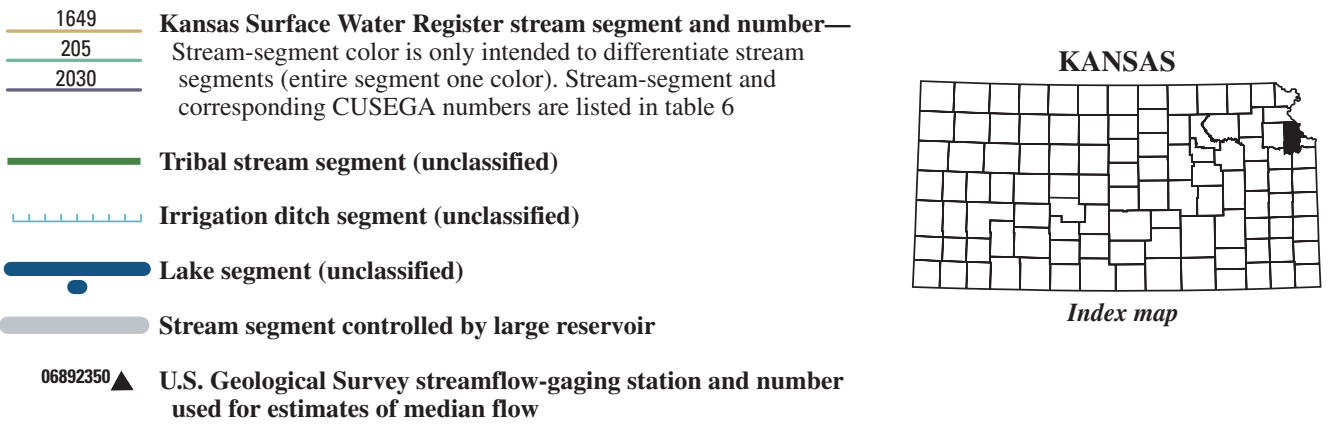

Figure 60. Location of U.S. Geological Survey streamflow-gaging stations and stream segments on the 1999 Kansas Surface Water Register for Leavenworth County. 


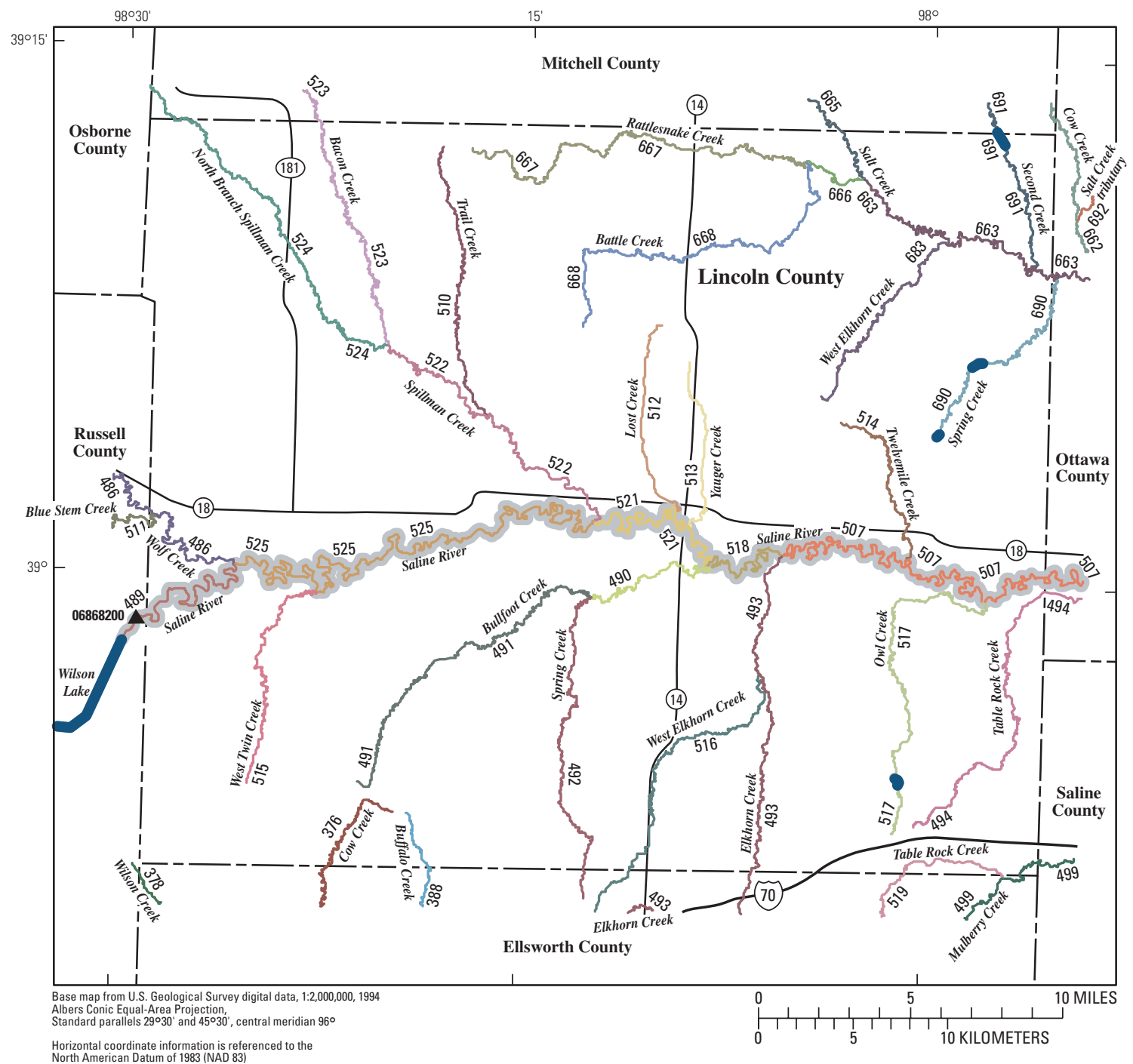

EXPLANATION

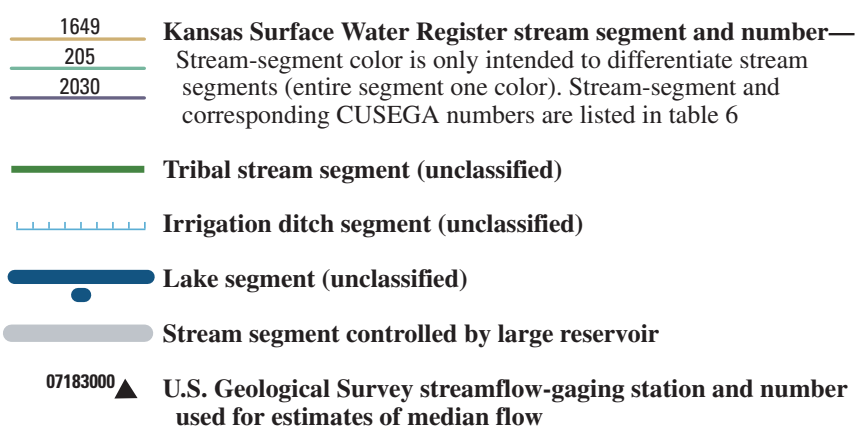

KANSAS

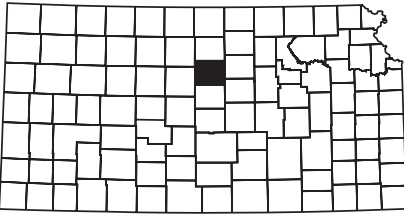

Index map

Figure 61. Location of U.S. Geological Survey streamflow-gaging stations and stream segments on the 1999 Kansas Surface Water Register for Lincoln County. 


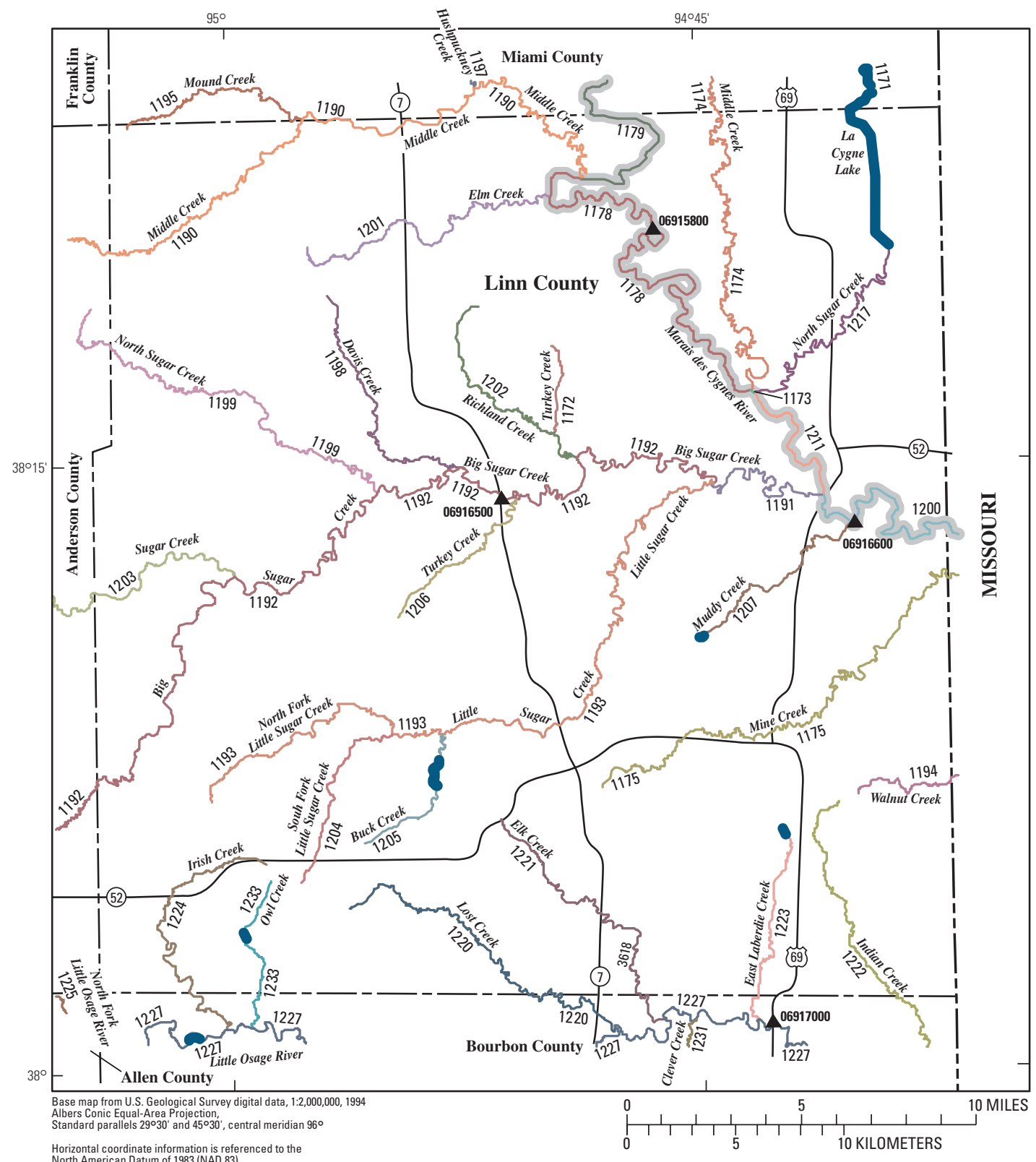

EXPLANATION
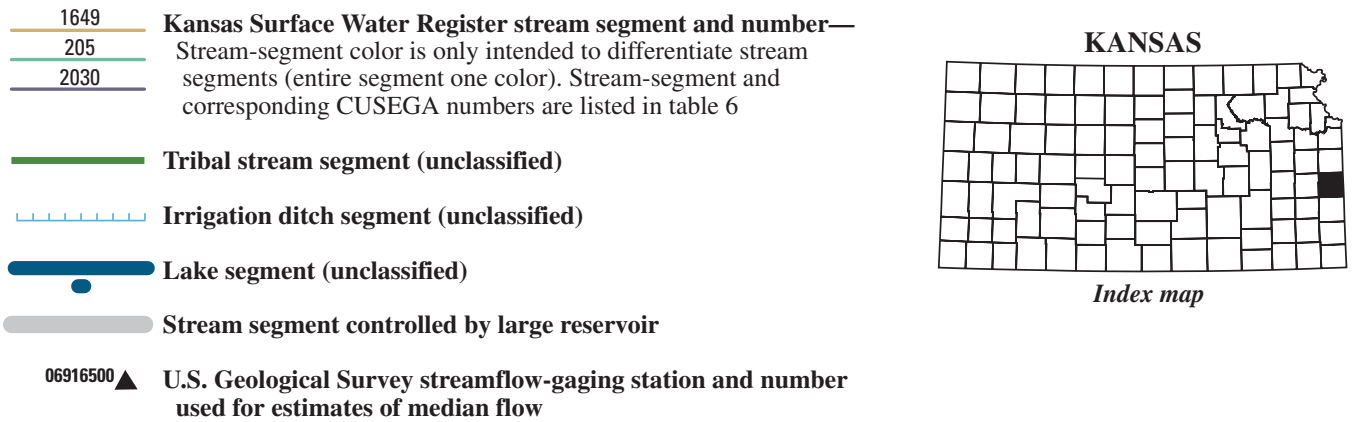

Figure 62. Location of U.S. Geological Survey streamflow-gaging stations and stream segments on the 1999 Kansas Surface Water Register for Linn County. 


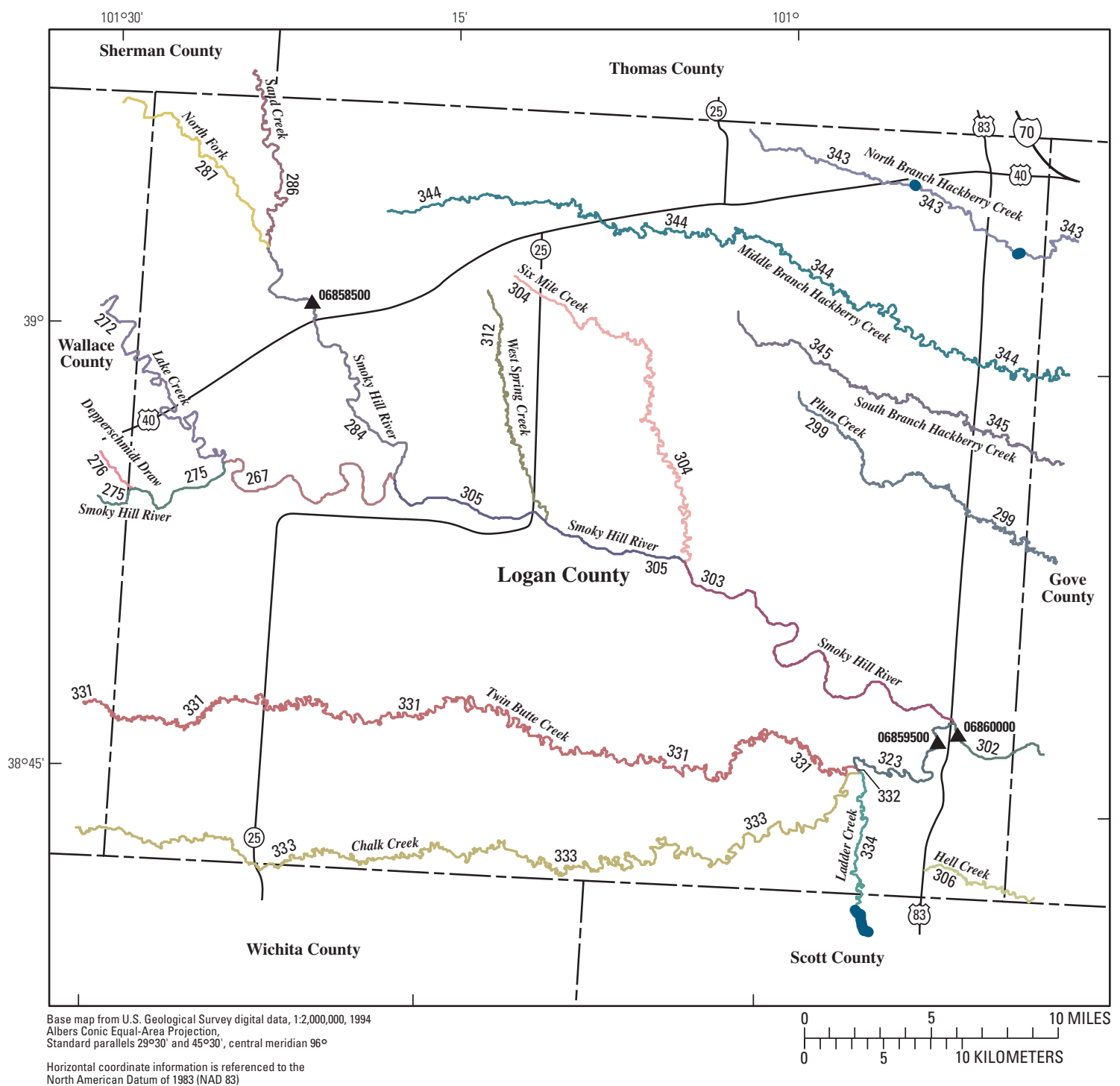

EXPLANATION

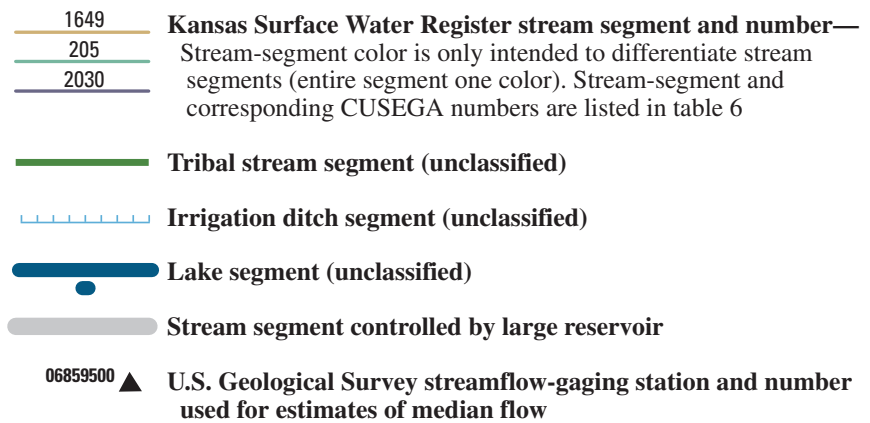

Figure 63. Location of U.S. Geological Survey streamflow-gaging stations and stream segments on the 1999 Kansas Surface Water Register for Logan County. 


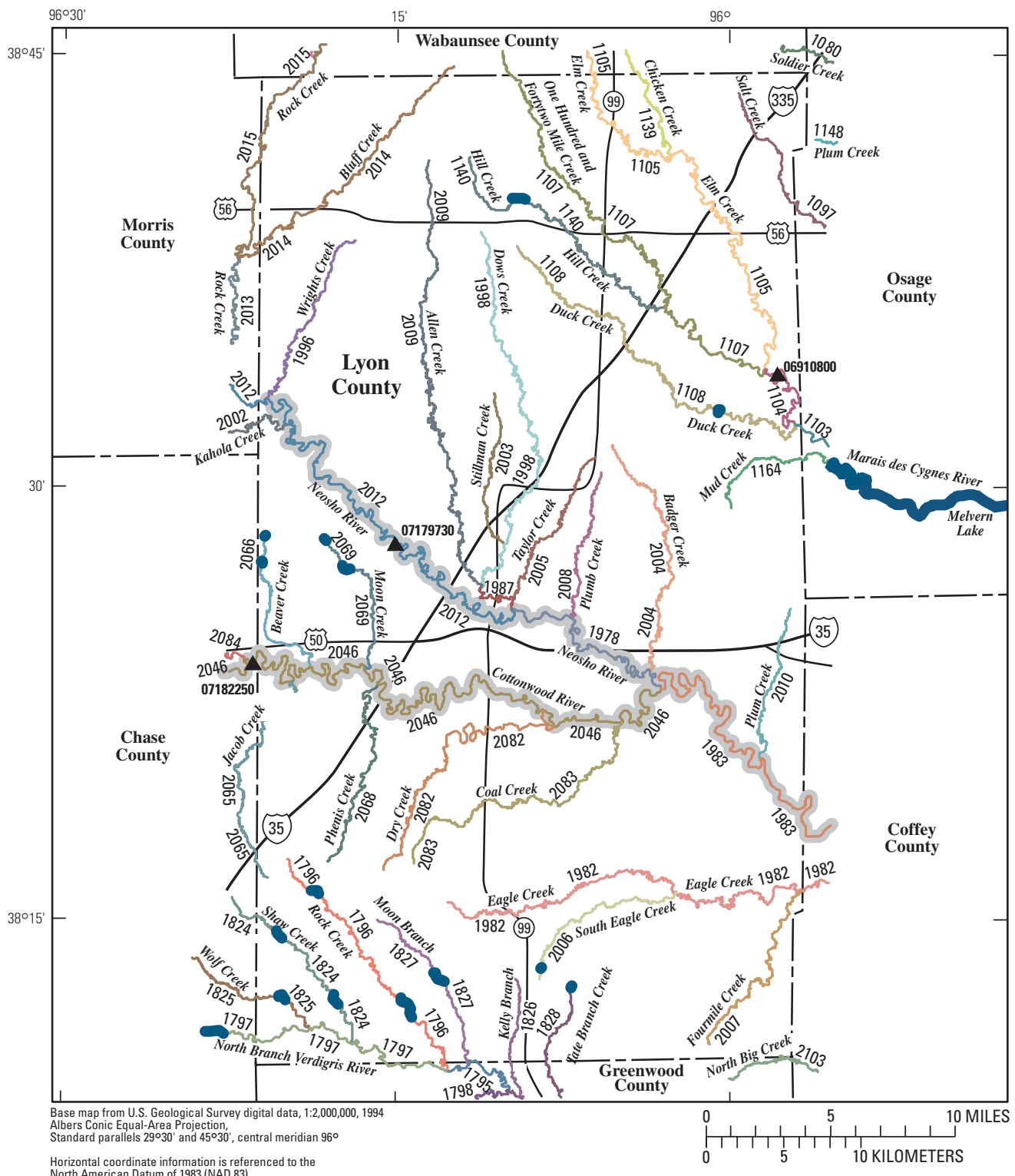

EXPLANATION
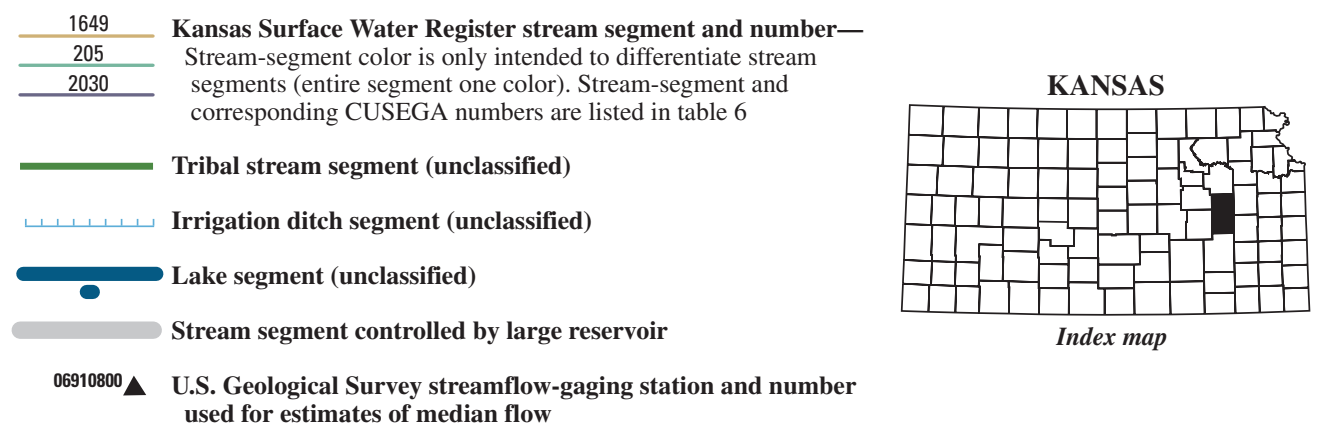

Index map used for estimates of median flow

Figure 64. Location of U.S. Geological Survey streamflow-gaging stations and stream segments on the 1999 Kansas Surface Water Register for Lyon County. 


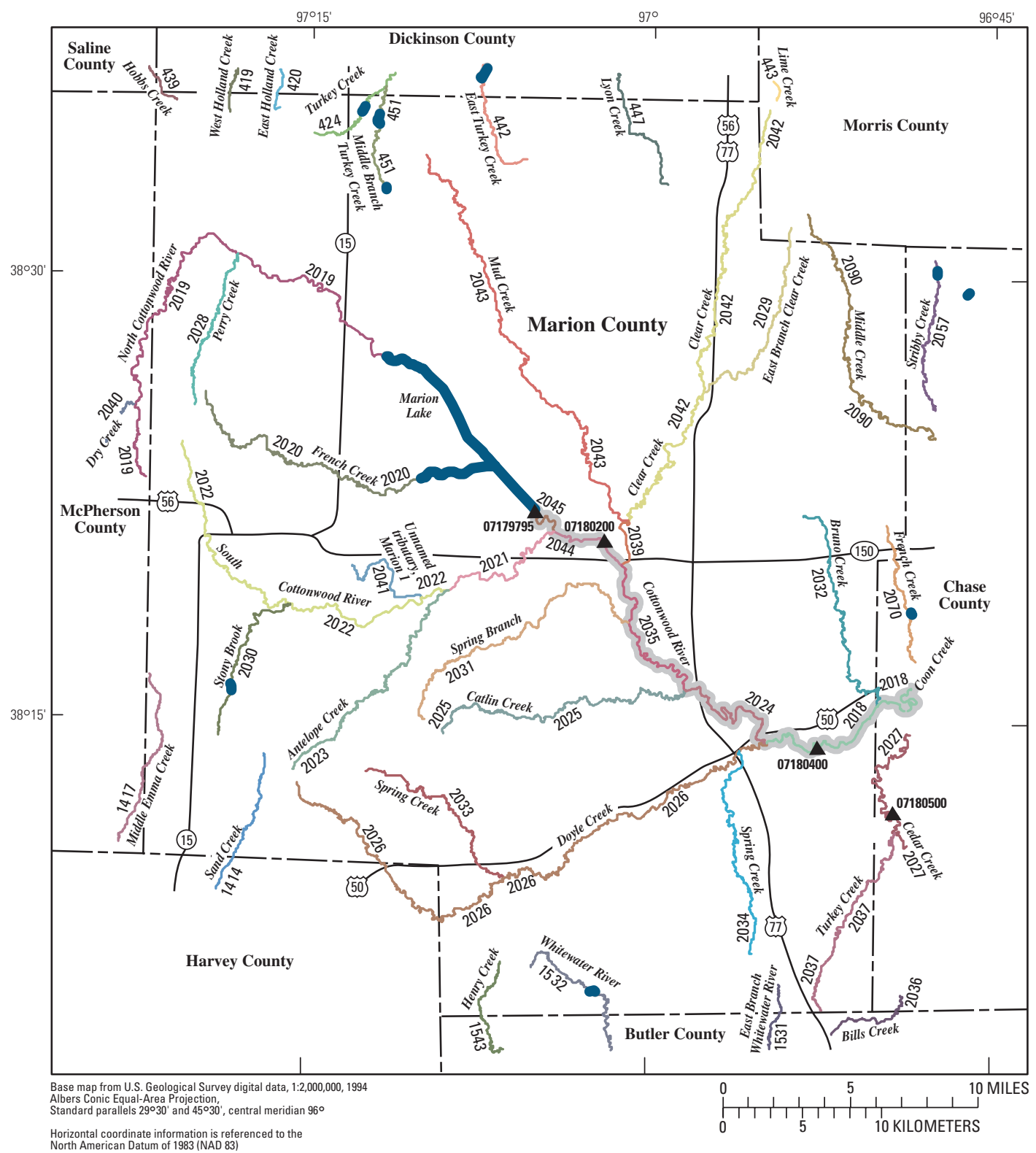

EXPLANATION
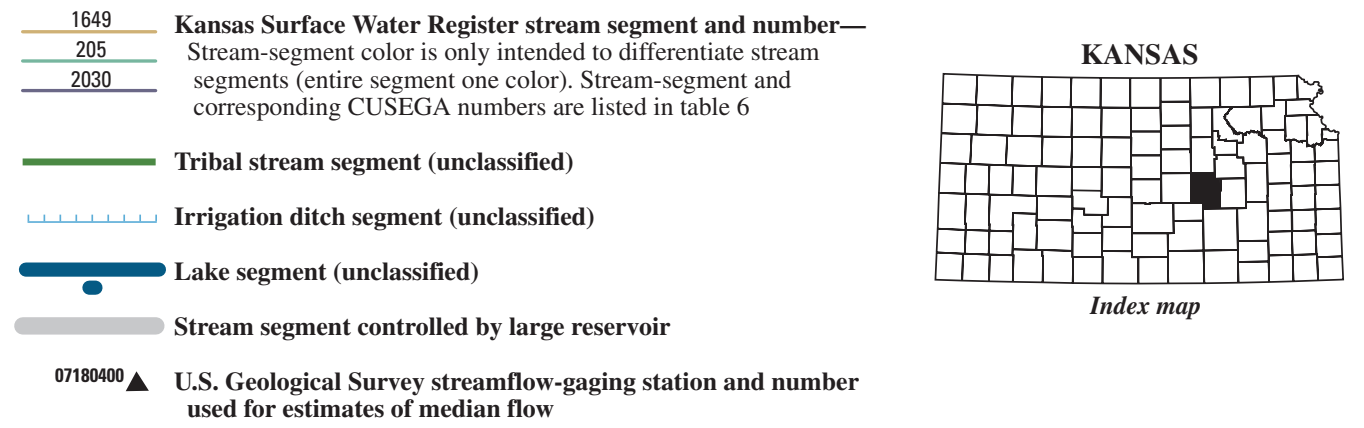

Figure 65. Location of U.S. Geological Survey streamflow-gaging stations and stream segments on the 1999 Kansas Surface Water Register for Marion County. 


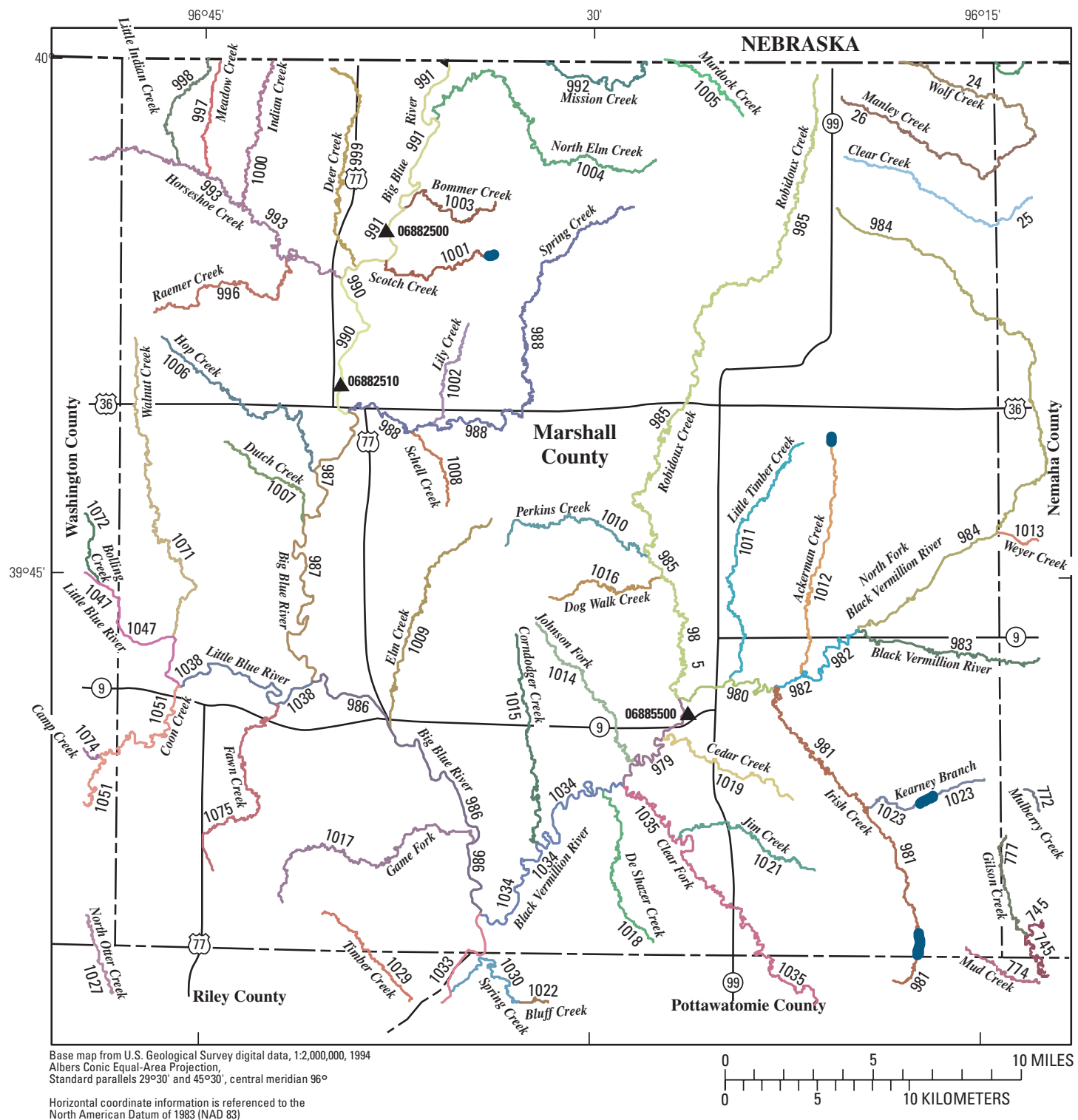

EXPLANATION
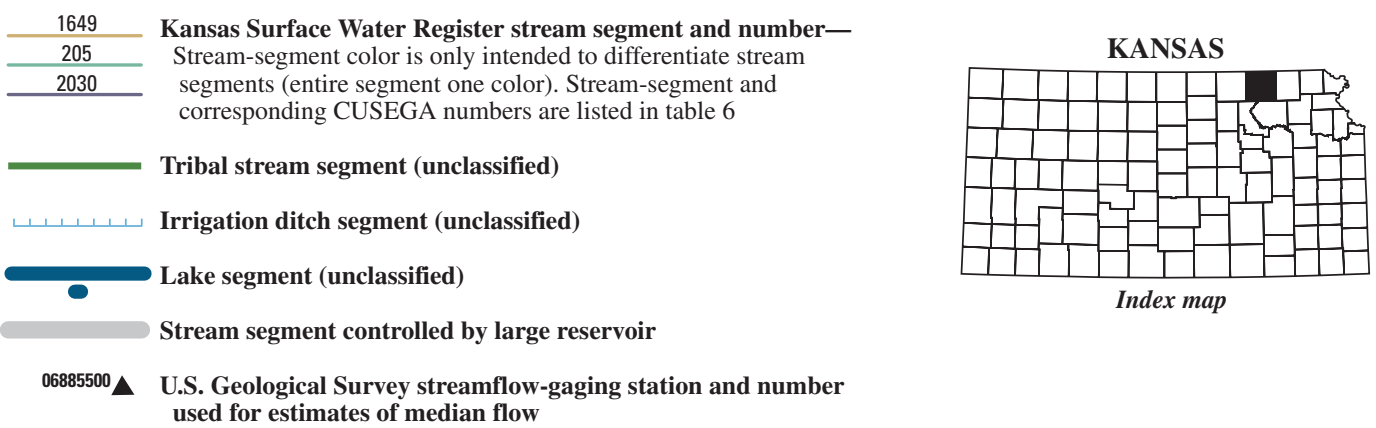

Figure 66. Location of U.S. Geological Survey streamflow-gaging stations and stream segments on the 1999 Kansas Surface Water Register for Marshall County. 


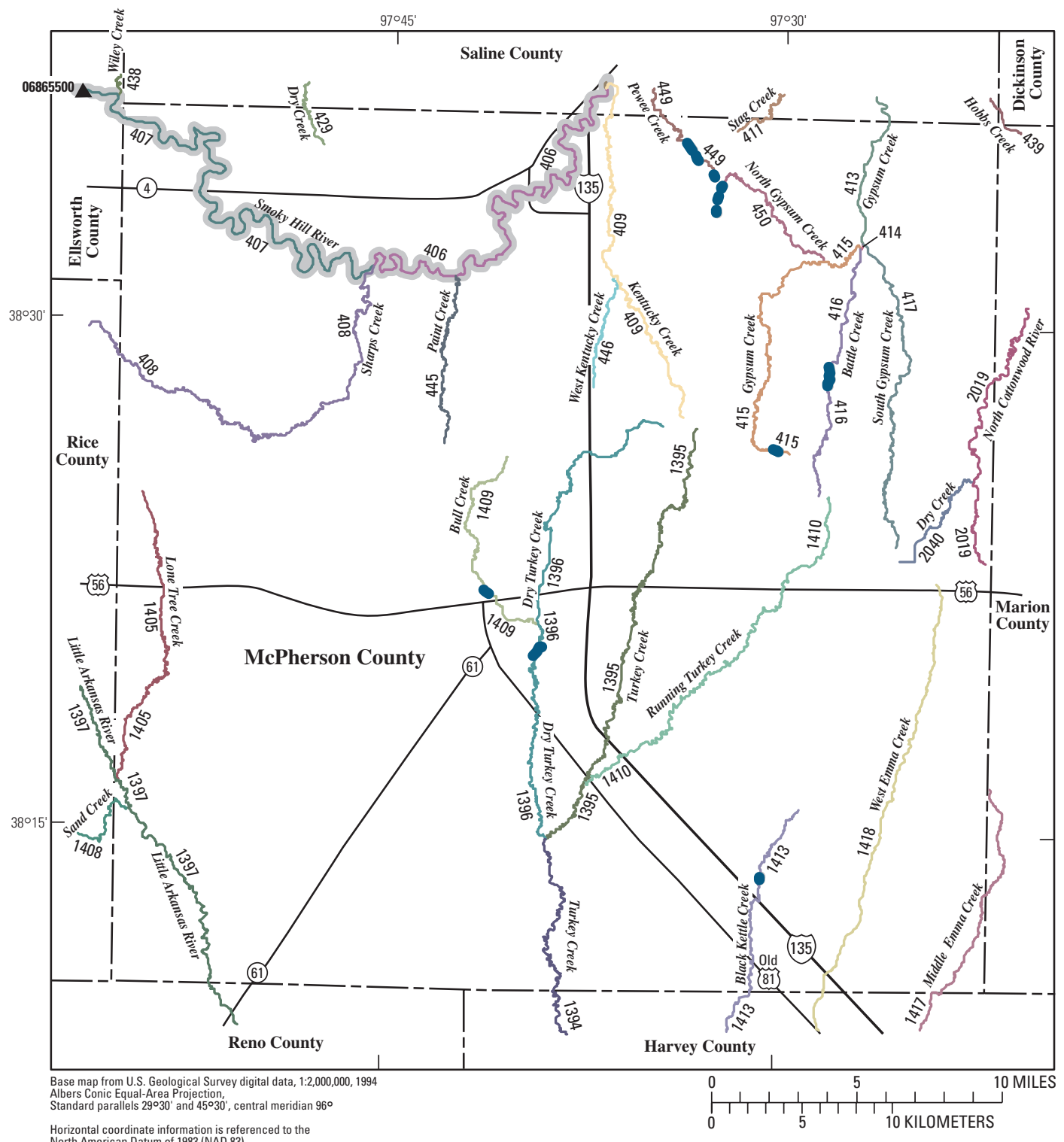

\section{EXPLANATION}

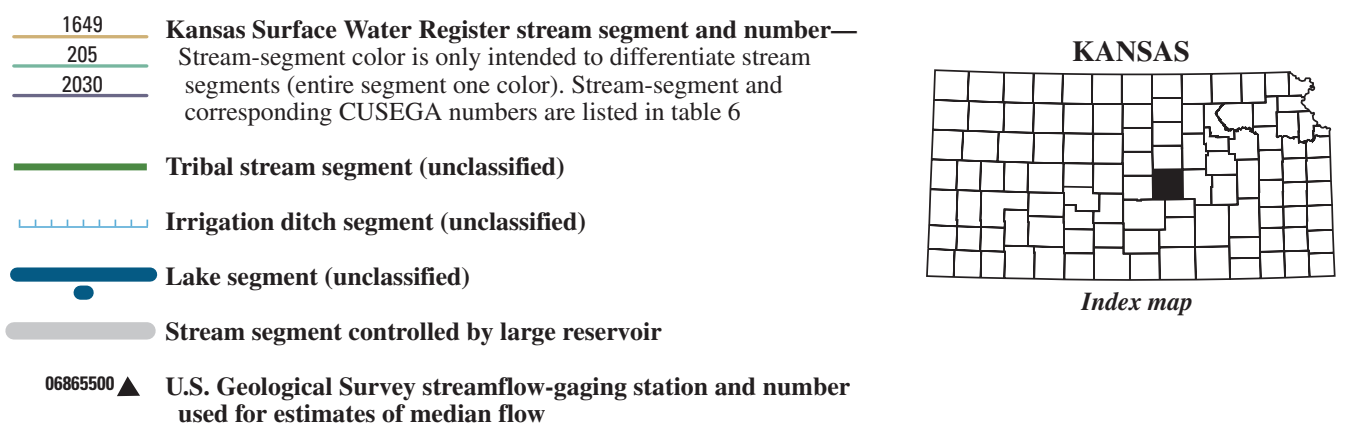

Figure 67. Location of U.S. Geological Survey streamflow-gaging stations and stream segments on the 1999 Kansas Surface Water Register for McPherson County. 


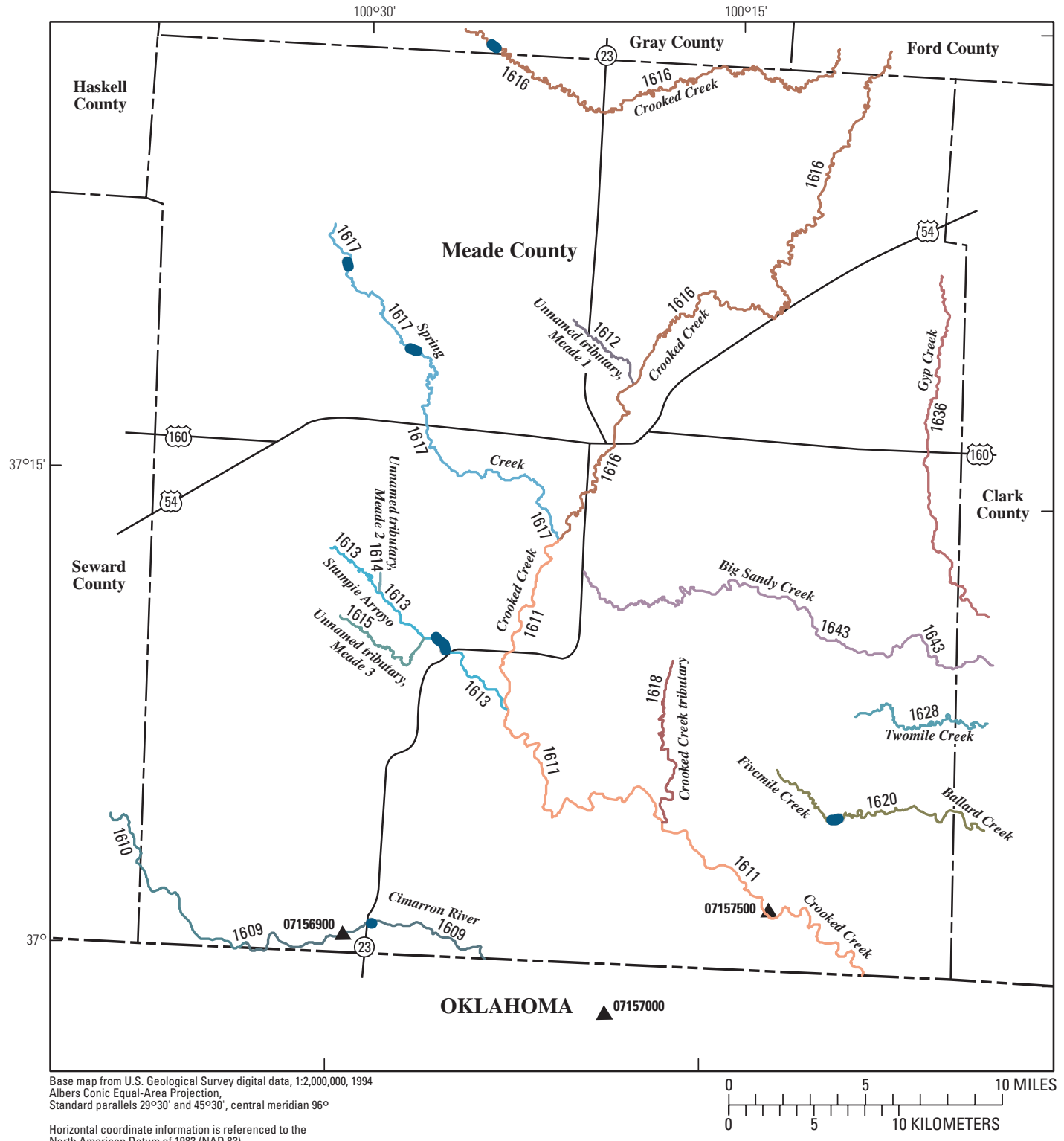

EXPLANATION
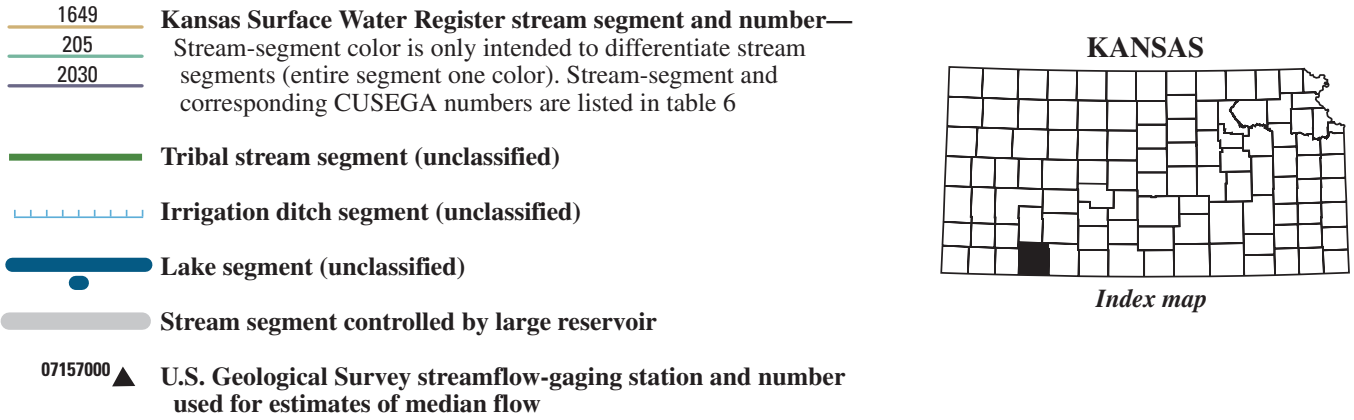

Figure 68. Location of U.S. Geological Survey streamflow-gaging stations and stream segments on the 1999 Kansas Surface Water Register for Meade County. 


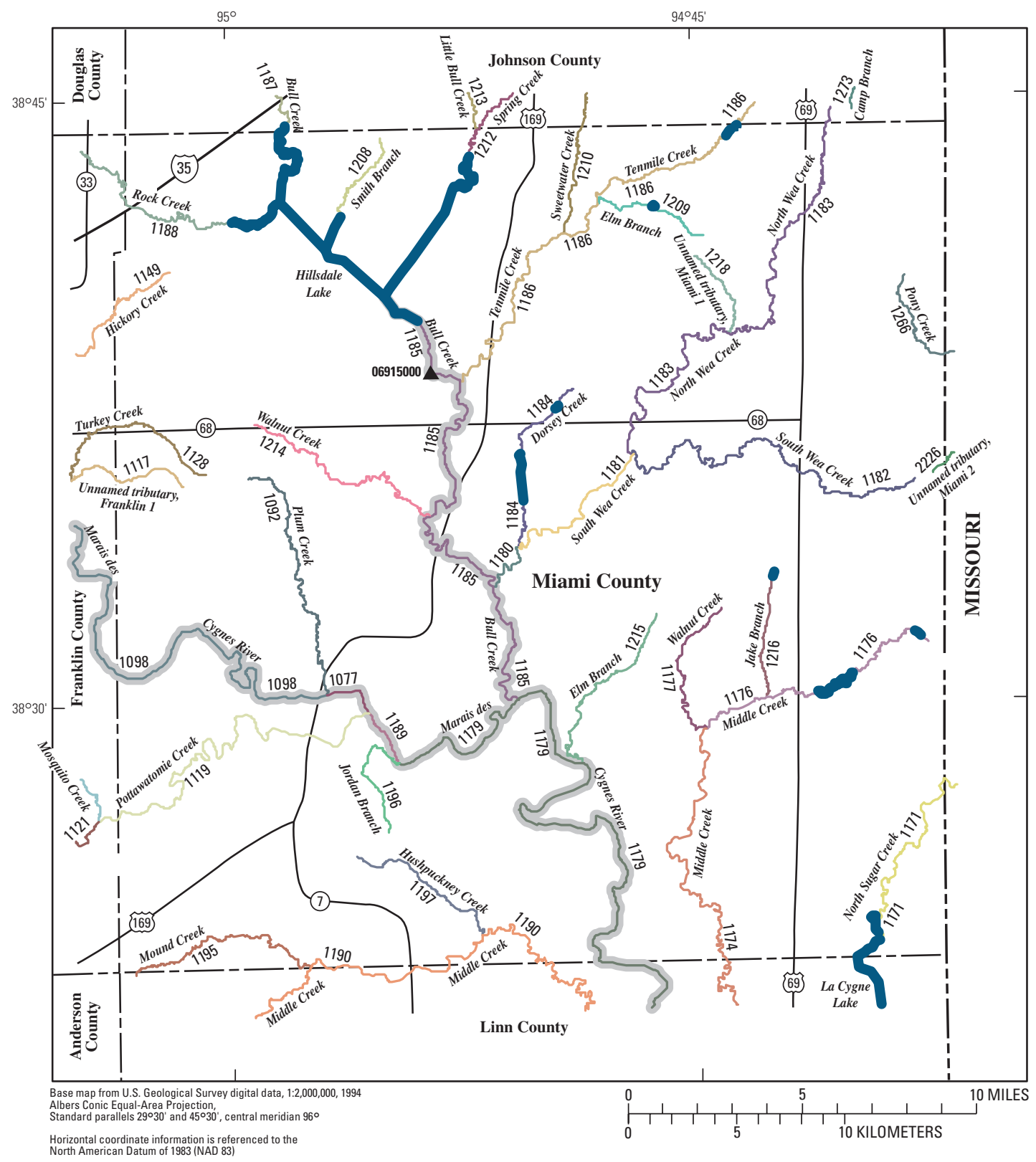

\section{EXPLANATION}
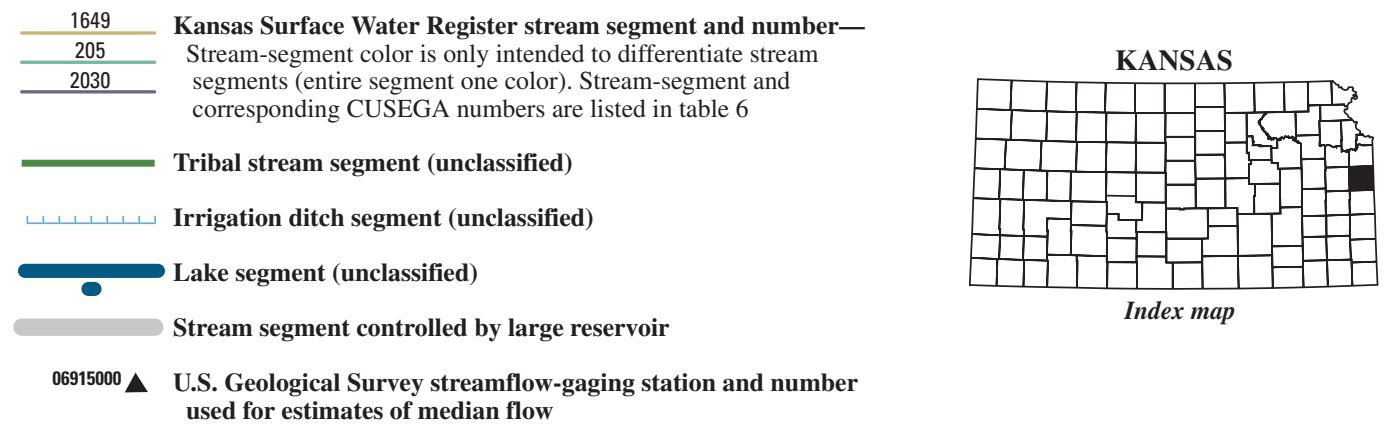

Figure 69. Location of U.S. Geological Survey streamflow-gaging stations and stream segments on the 1999 Kansas Surface Water Register for Miami County. 


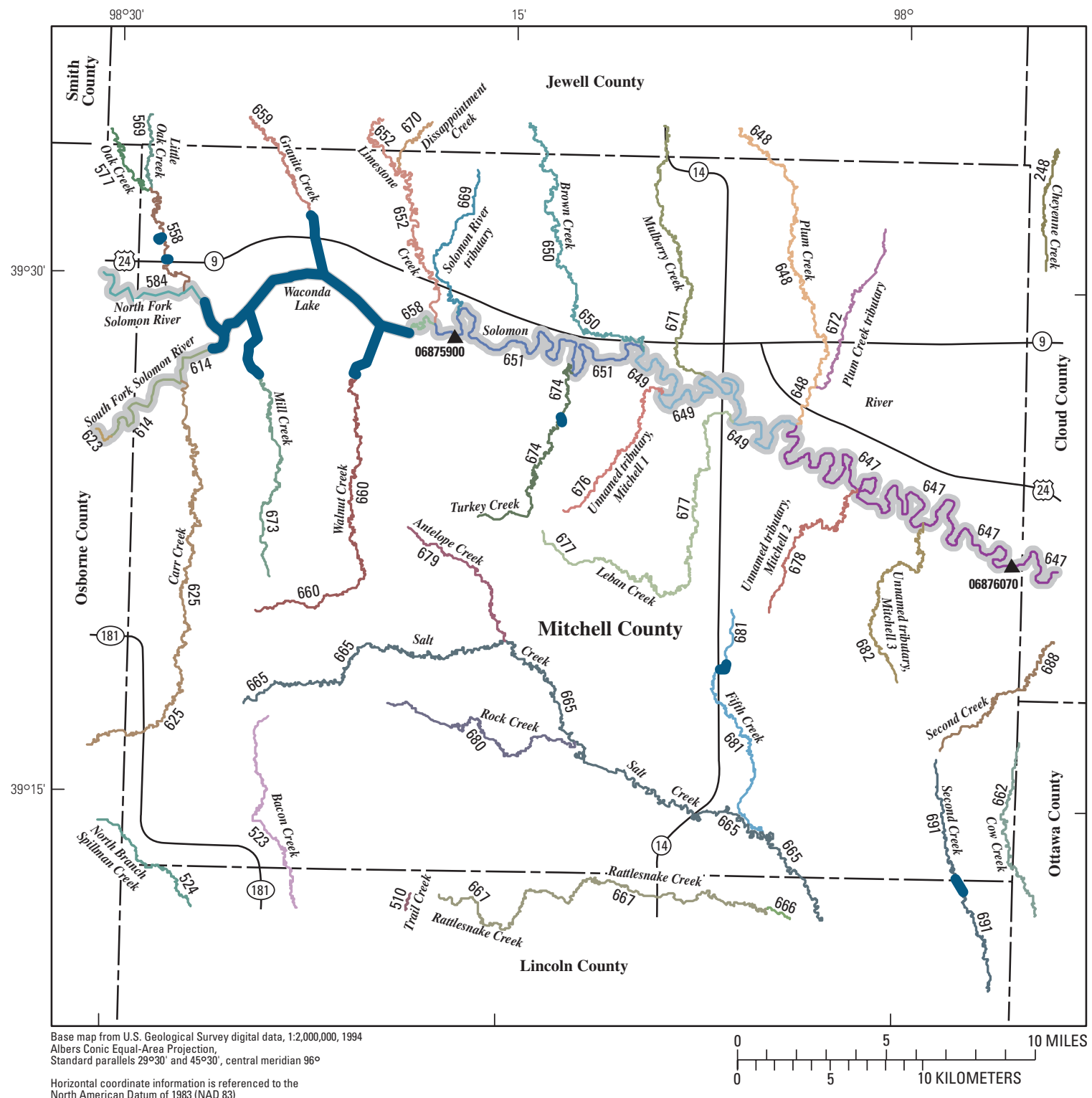

EXPLANATION

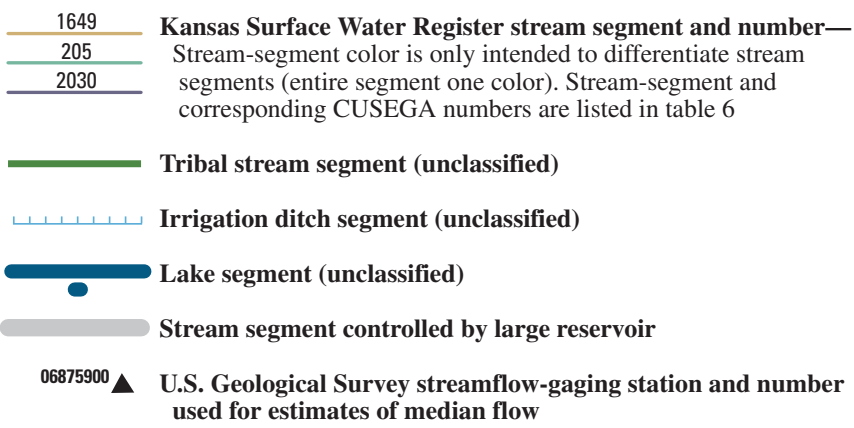

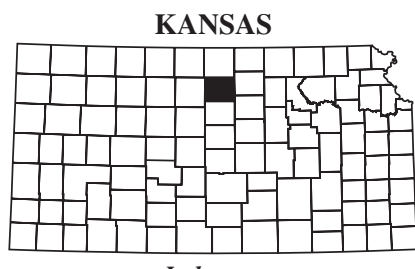

Index map

Figure 70. Location of U.S. Geological Survey streamflow-gaging stations and stream segments on the 1999 Kansas Surface Water Register for Mitchell County. 


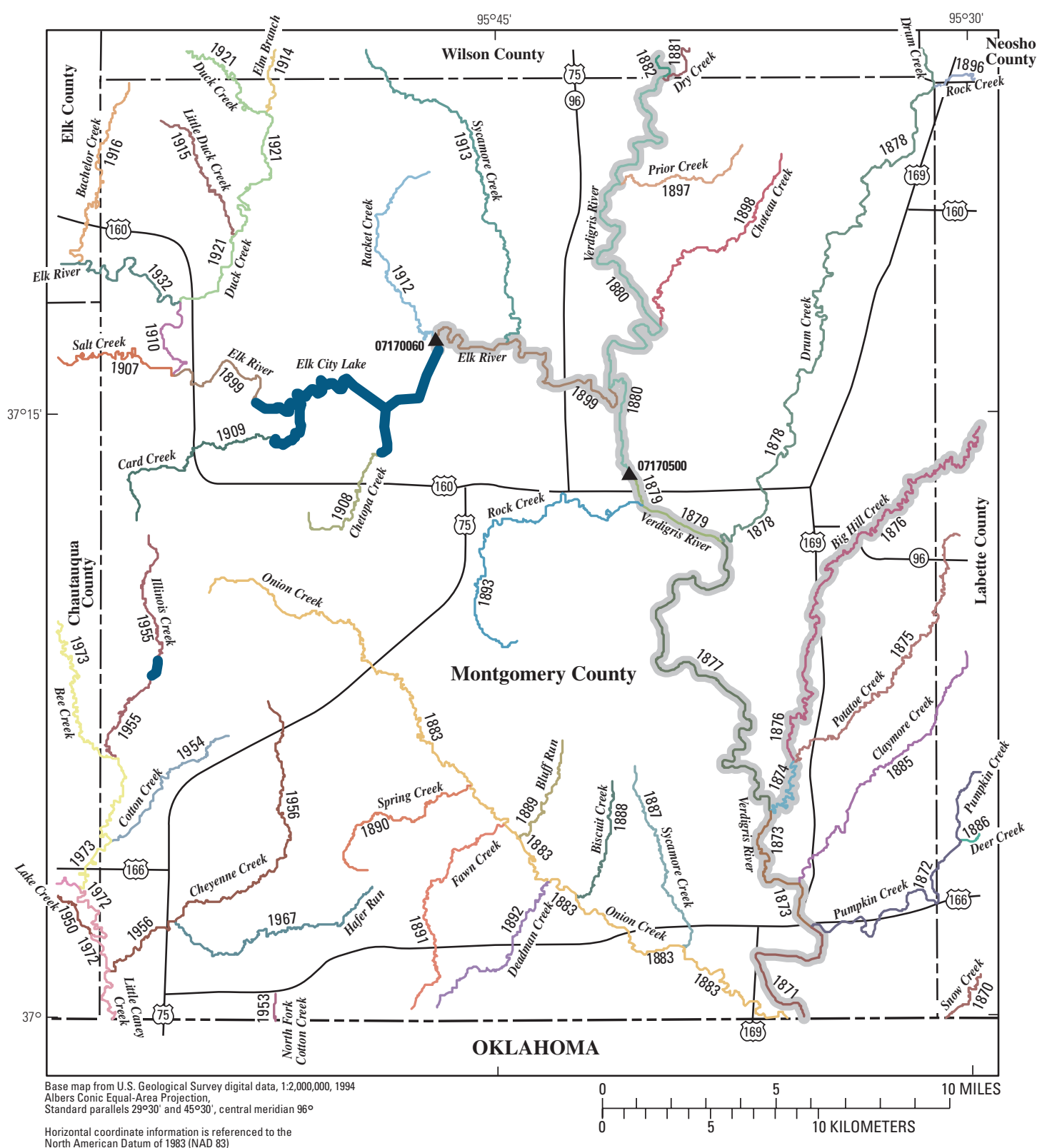

EXPLANATION
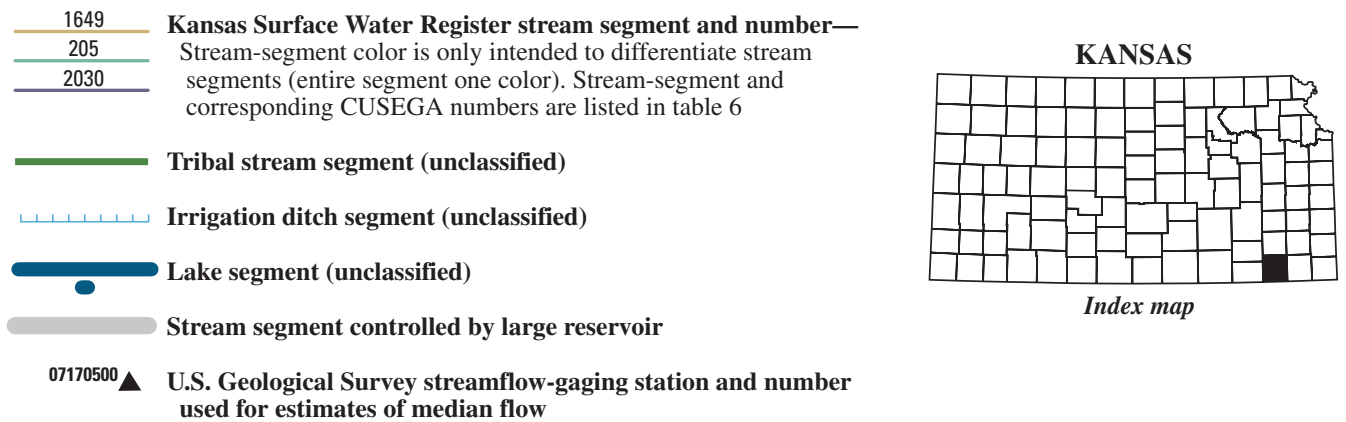

Index map

Figure 71. Location of U.S. Geological Survey streamflow-gaging stations and stream segments on the 1999 Kansas Surface Water Register for Montgomery County. 


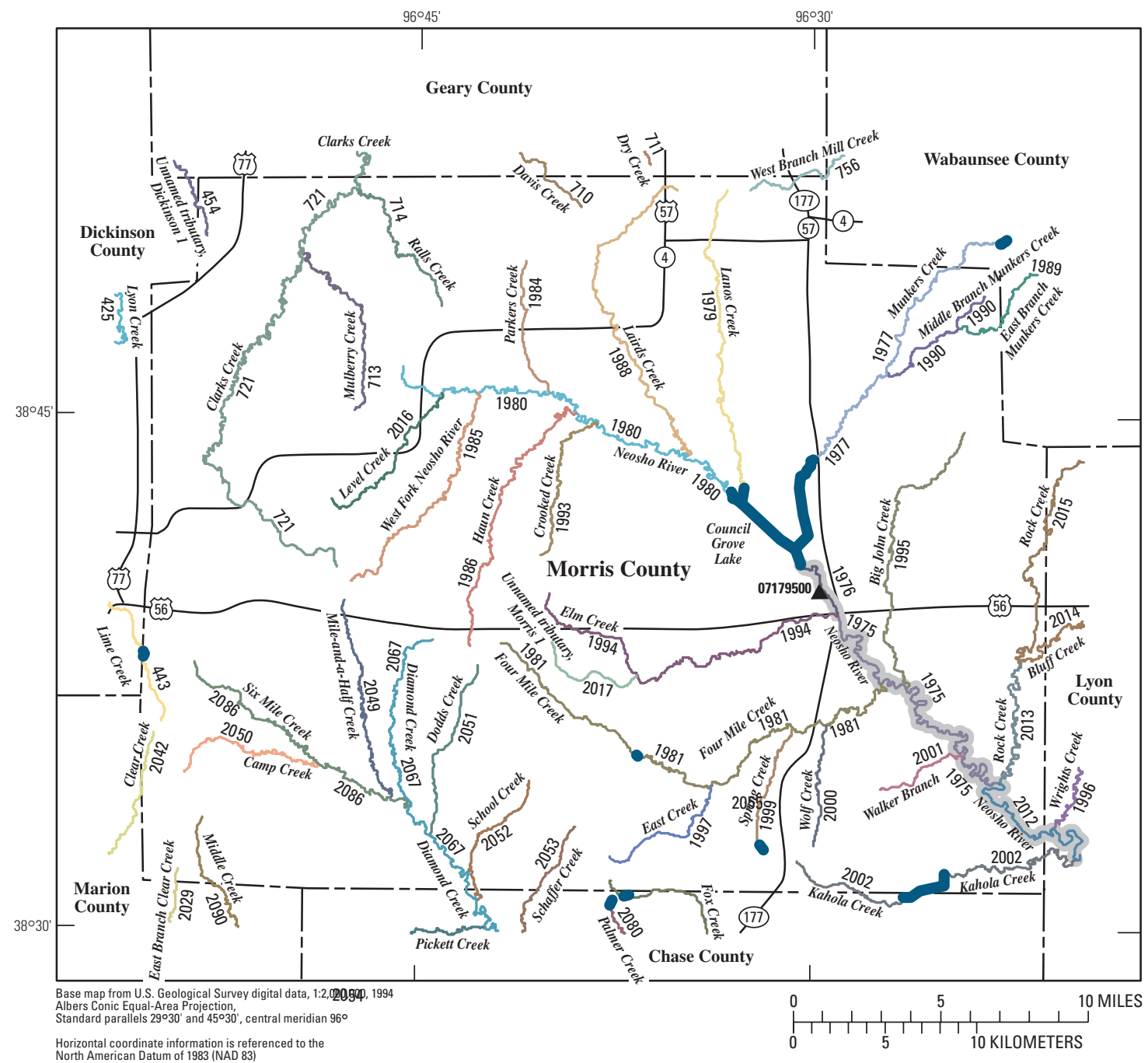

EXPLANATION

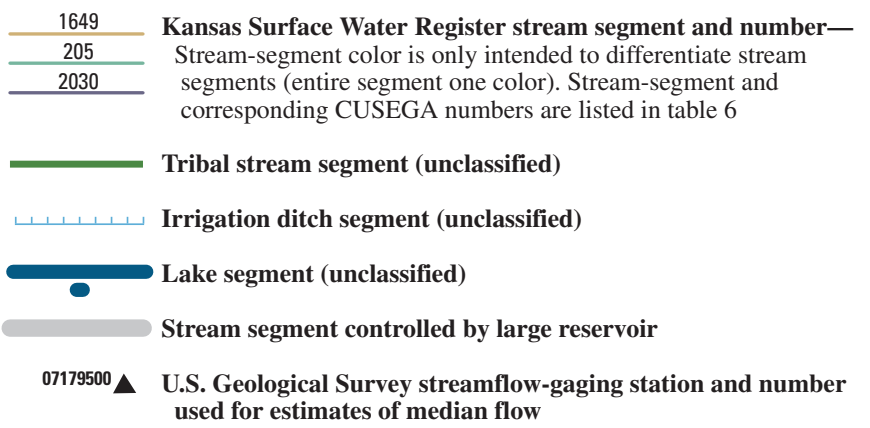

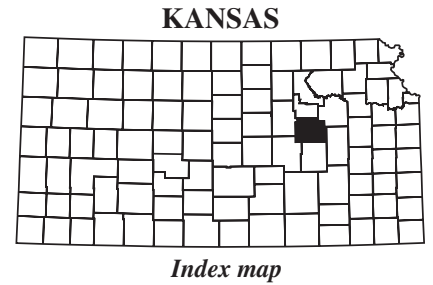

Figure 72. Location of U.S. Geological Survey streamflow-gaging stations and stream segments on the 1999 Kansas Surface Water Register for Morris County. 


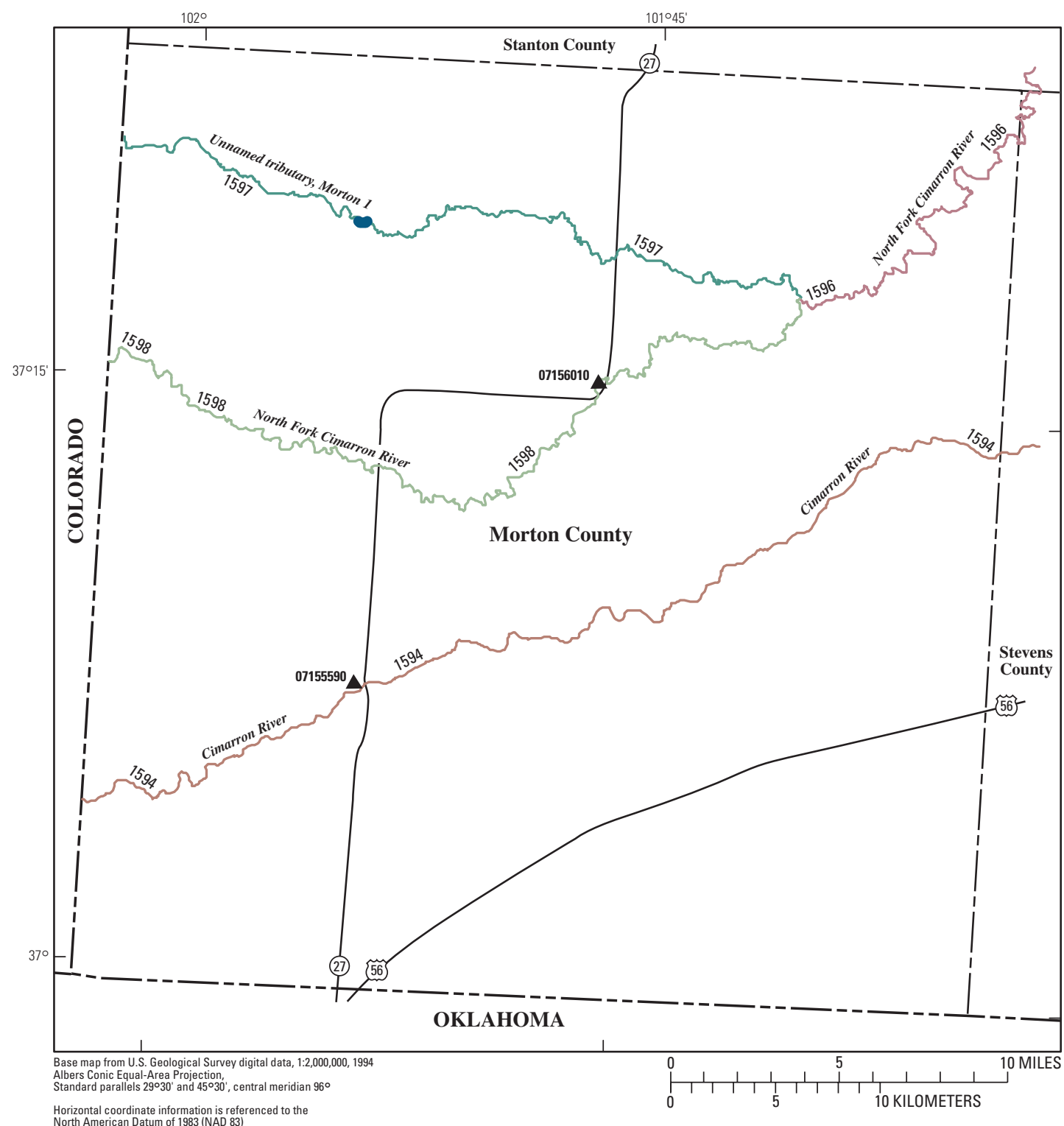

EXPLANATION
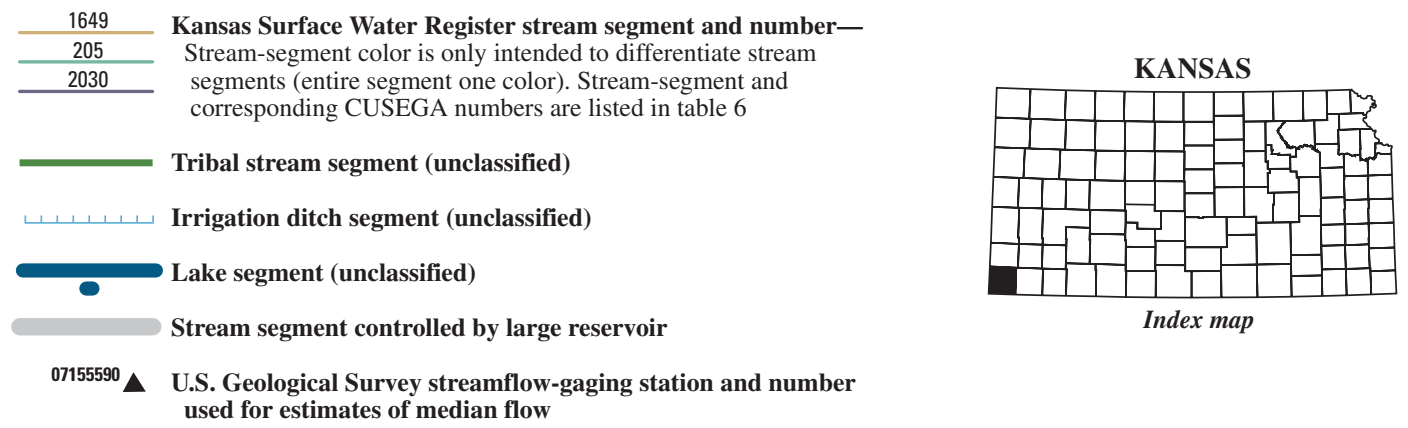

Index map

Figure 73. Location of U.S. Geological Survey streamflow-gaging stations and stream segments on the 1999 Kansas Surface Water Register for Morton County. 


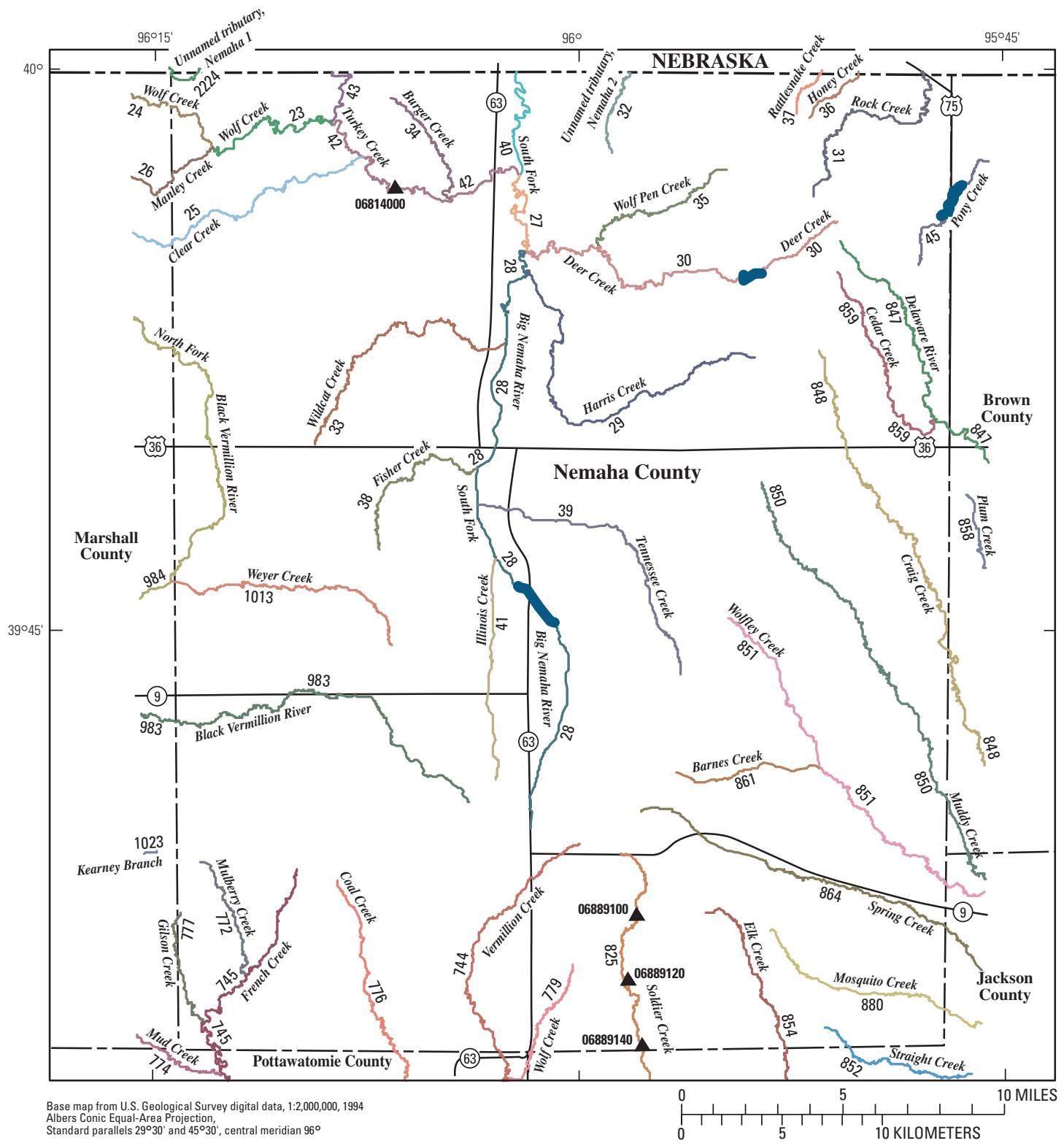

Horizontal coordinate information is referenced to the
North American Datum of 1983 (NAD 83)

\section{EXPLANATION}
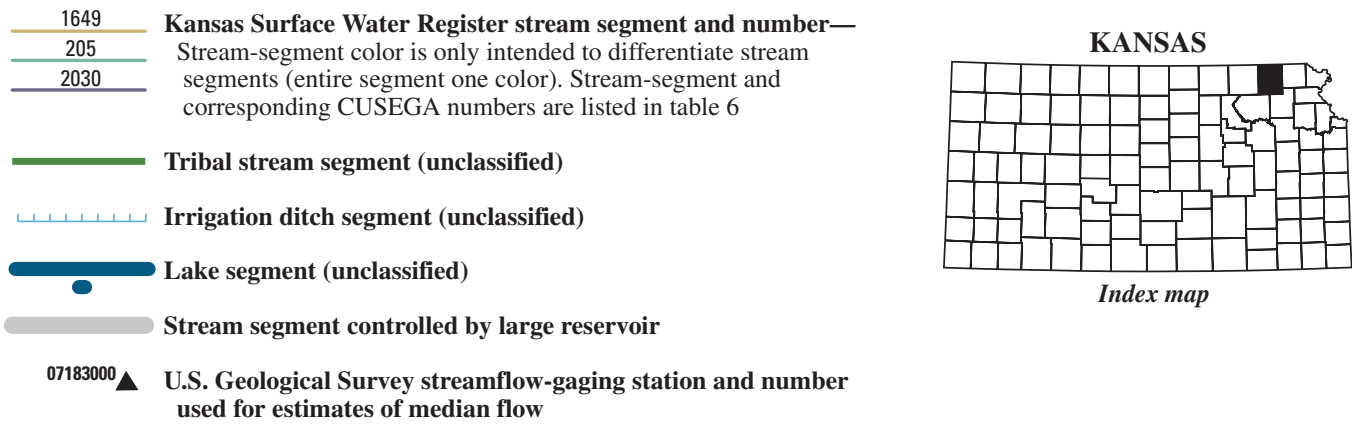
used for estimates of median flow

Figure 74. Location of U.S. Geological Survey streamflow-gaging stations and stream segments on the 1999 Kansas Surface Water Register for Nemaha County. 


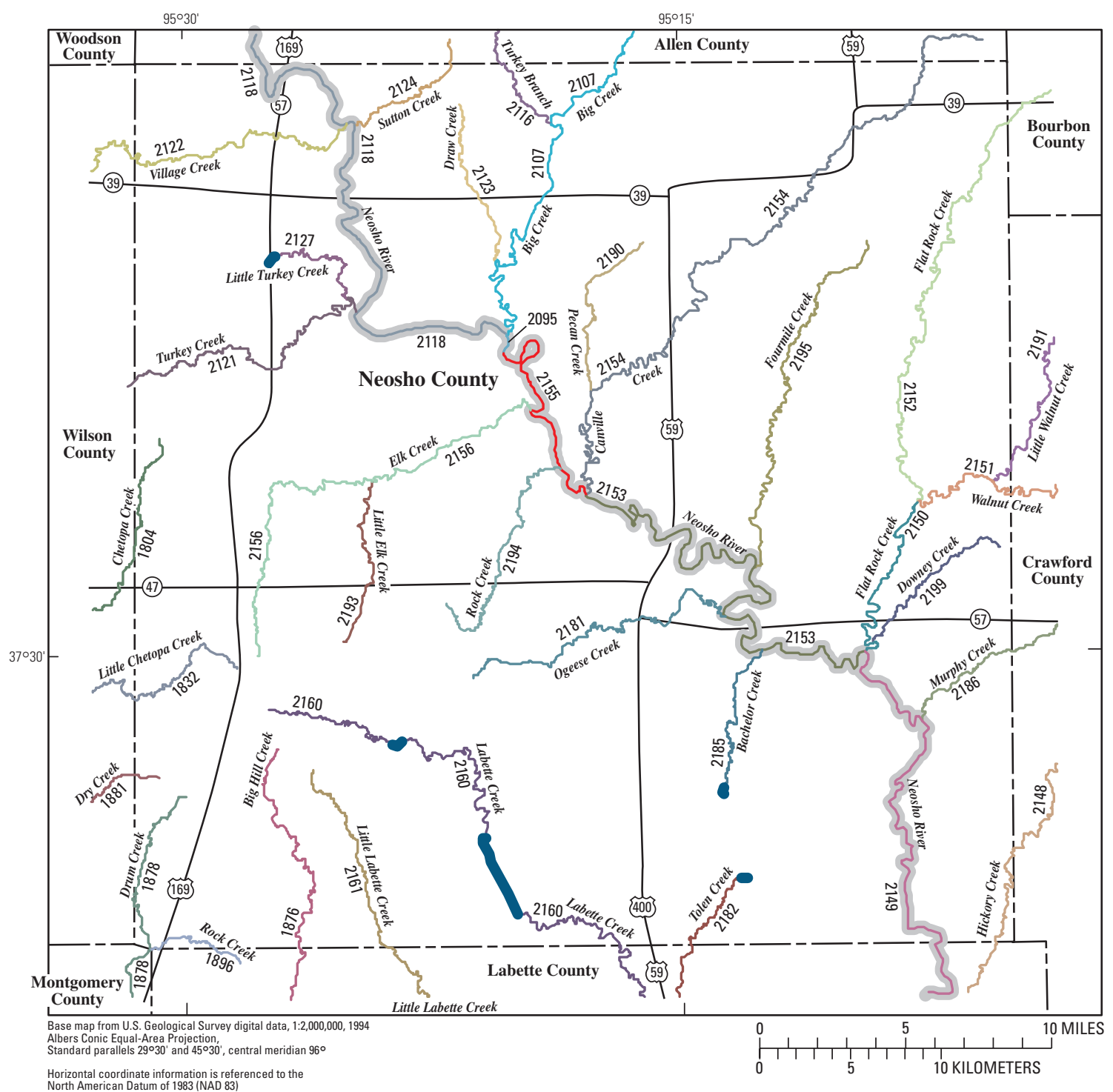

EXPLANATION
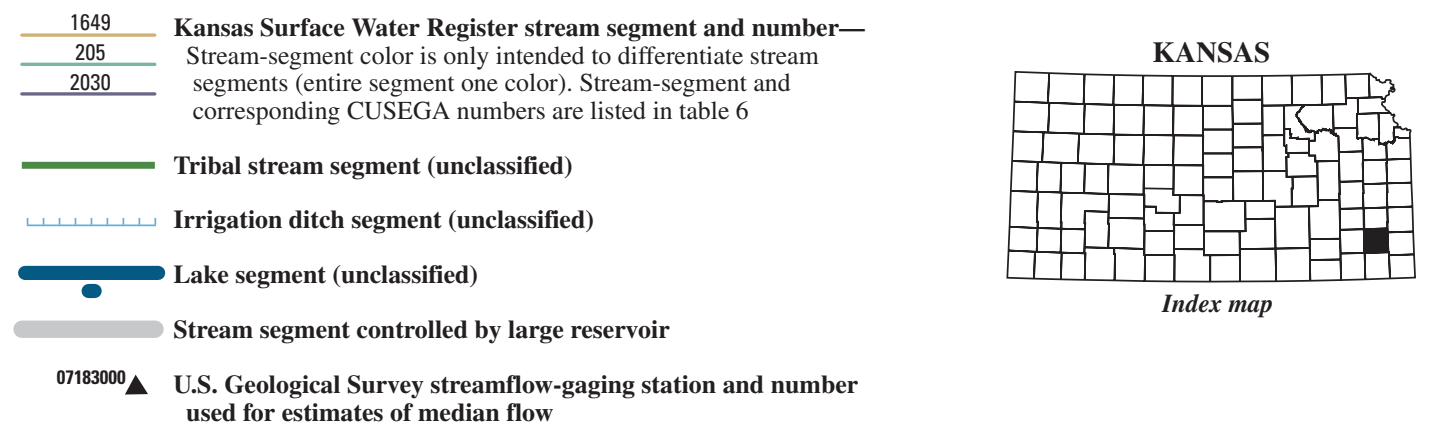

Figure 75. Location of U.S. Geological Survey streamflow-gaging stations and stream segments on the 1999 Kansas Surface Water Register for Neosho County. 


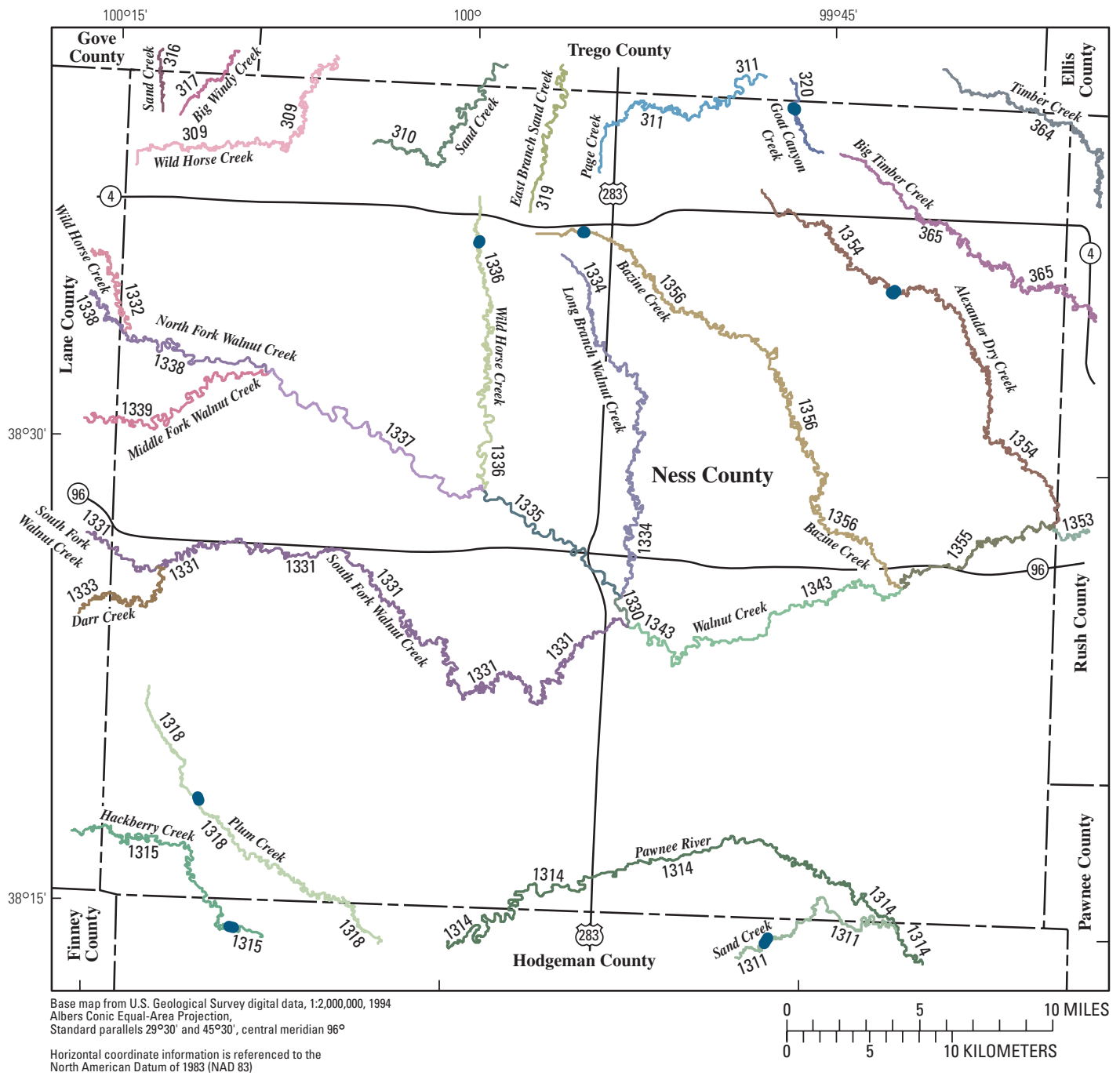

EXPLANATION
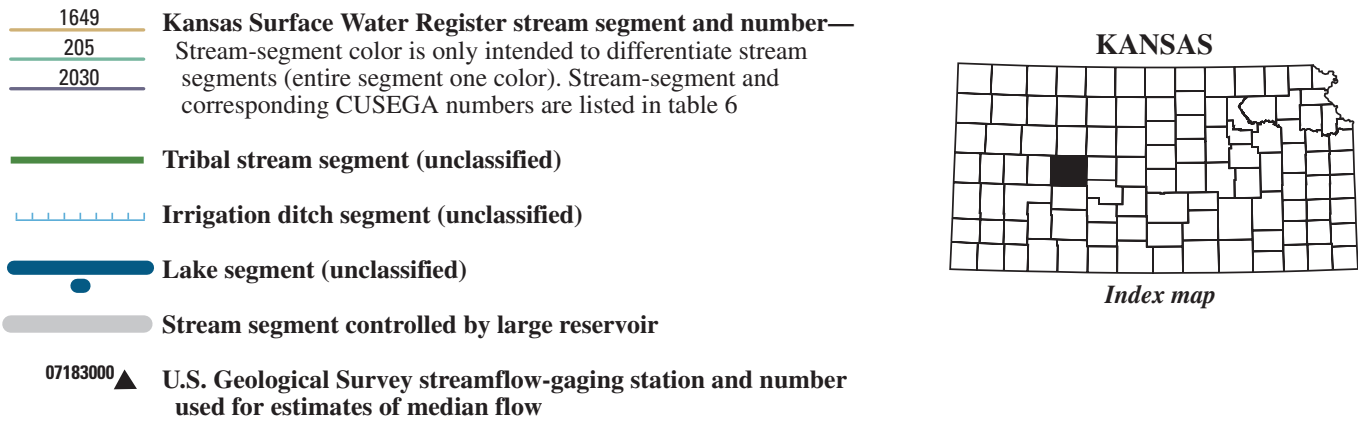

Figure 76. Location of U.S. Geological Survey streamflow-gaging stations and stream segments on the 1999 Kansas Surface Water Register for Ness County. 


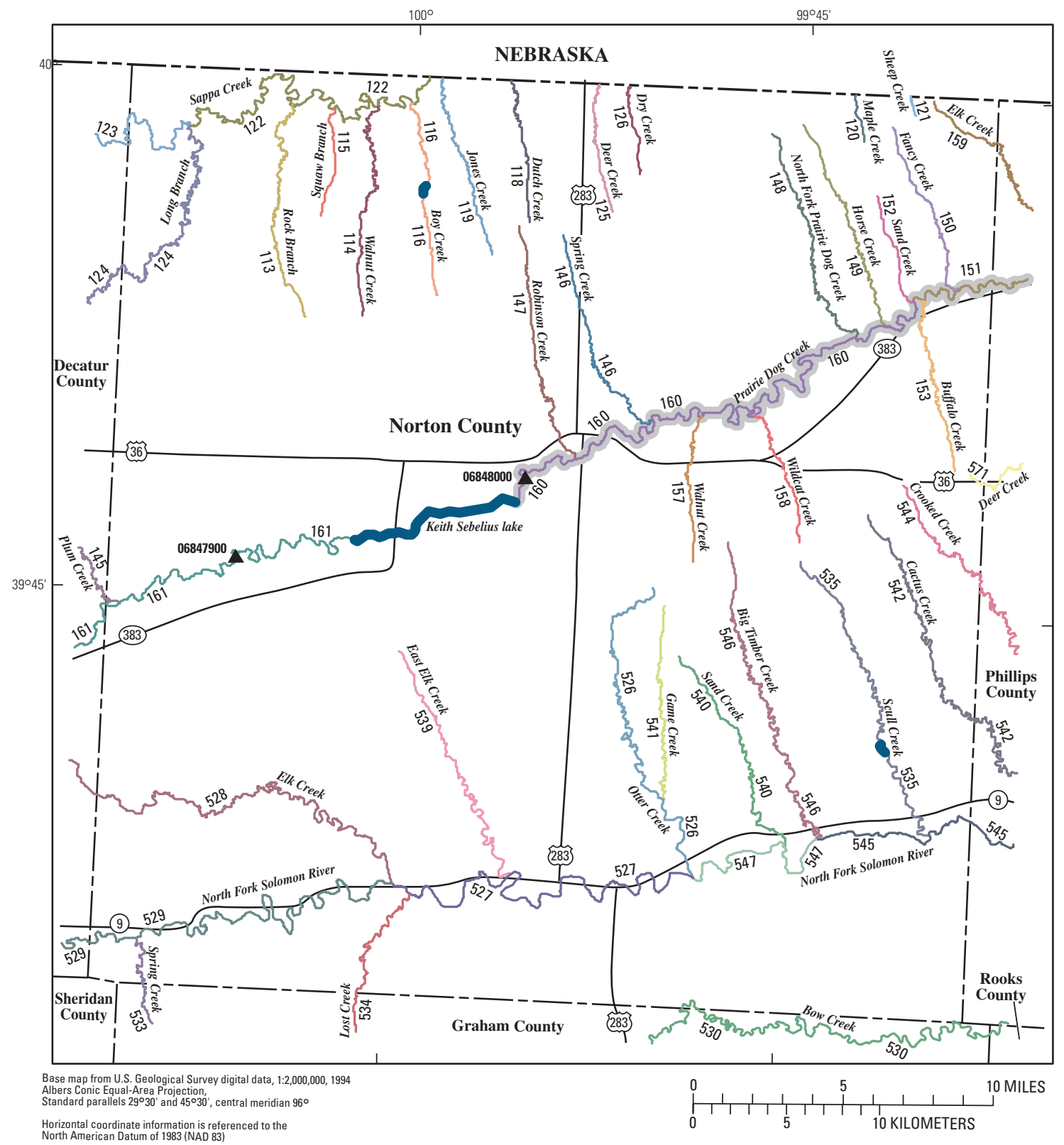

\section{EXPLANATION}
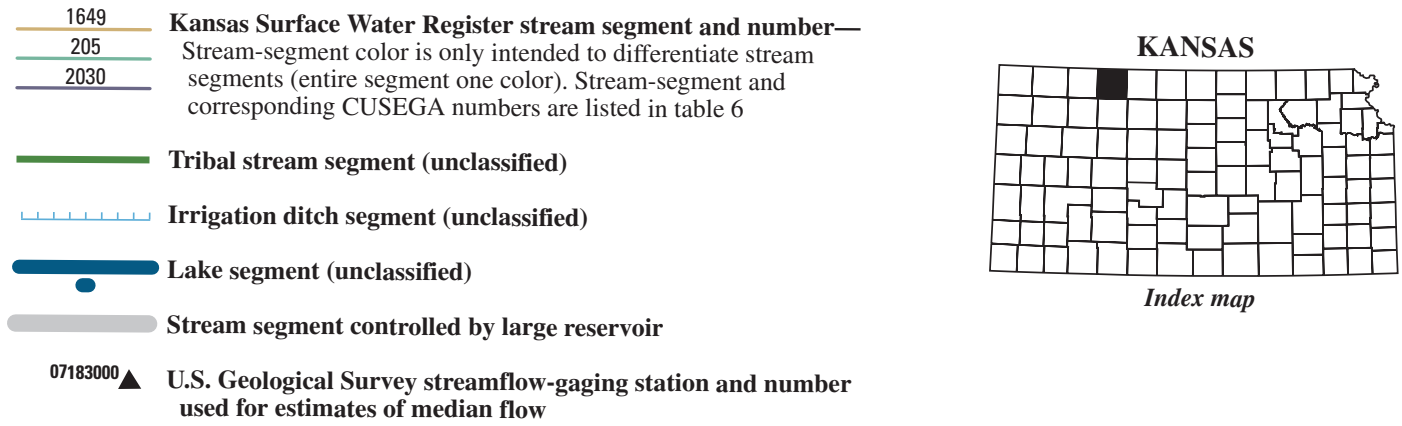

Index map used for estimates of median flow

Figure 77. Location of U.S. Geological Survey streamflow-gaging stations and stream segments on the 1999 Kansas Surface Water Register for Norton County. 


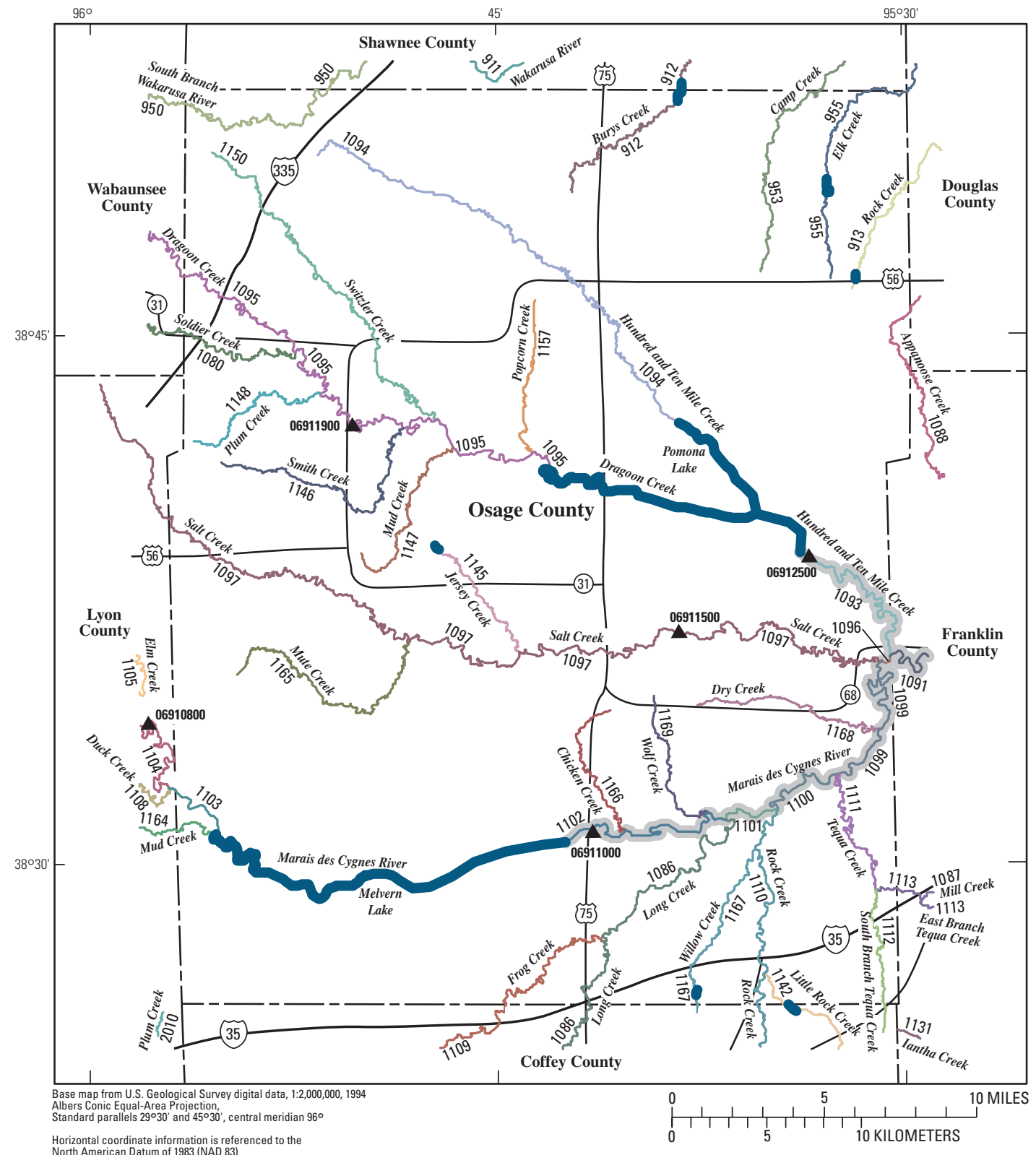

EXPLANATION

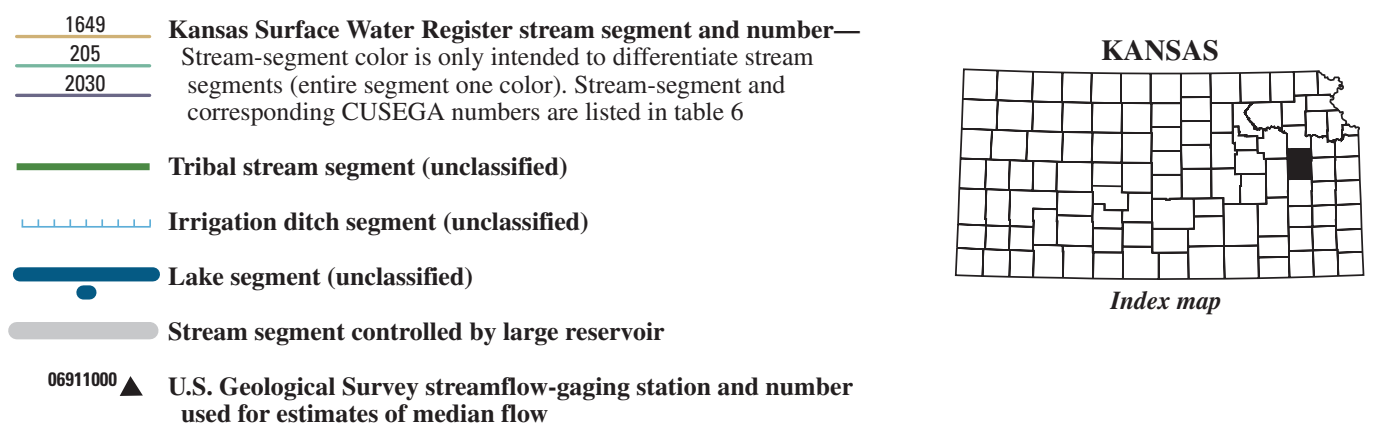

Figure 78. Location of U.S. Geological Survey streamflow-gaging stations and stream segments on the 1999 Kansas Surface Water Register for Osage County. 


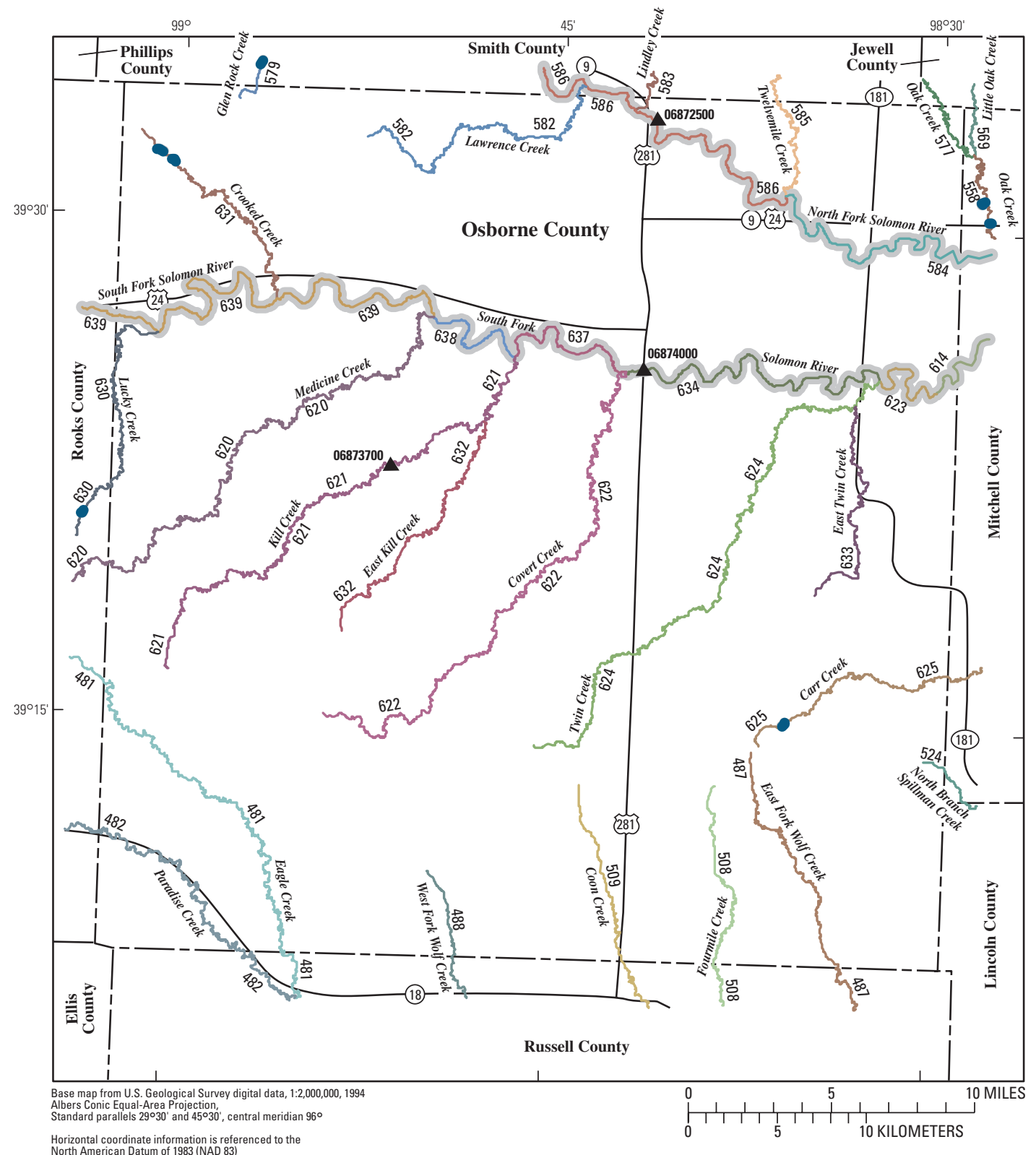

EXPLANATION
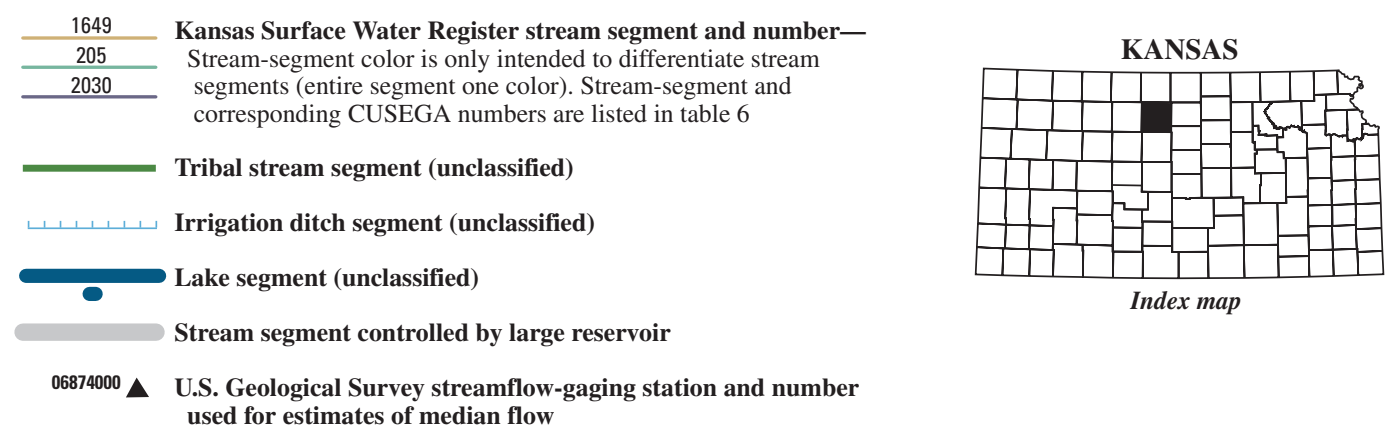

Figure 79. Location of U.S. Geological Survey streamflow-gaging stations and stream segments on the 1999 Kansas Surface Water Register for Osborne County. 


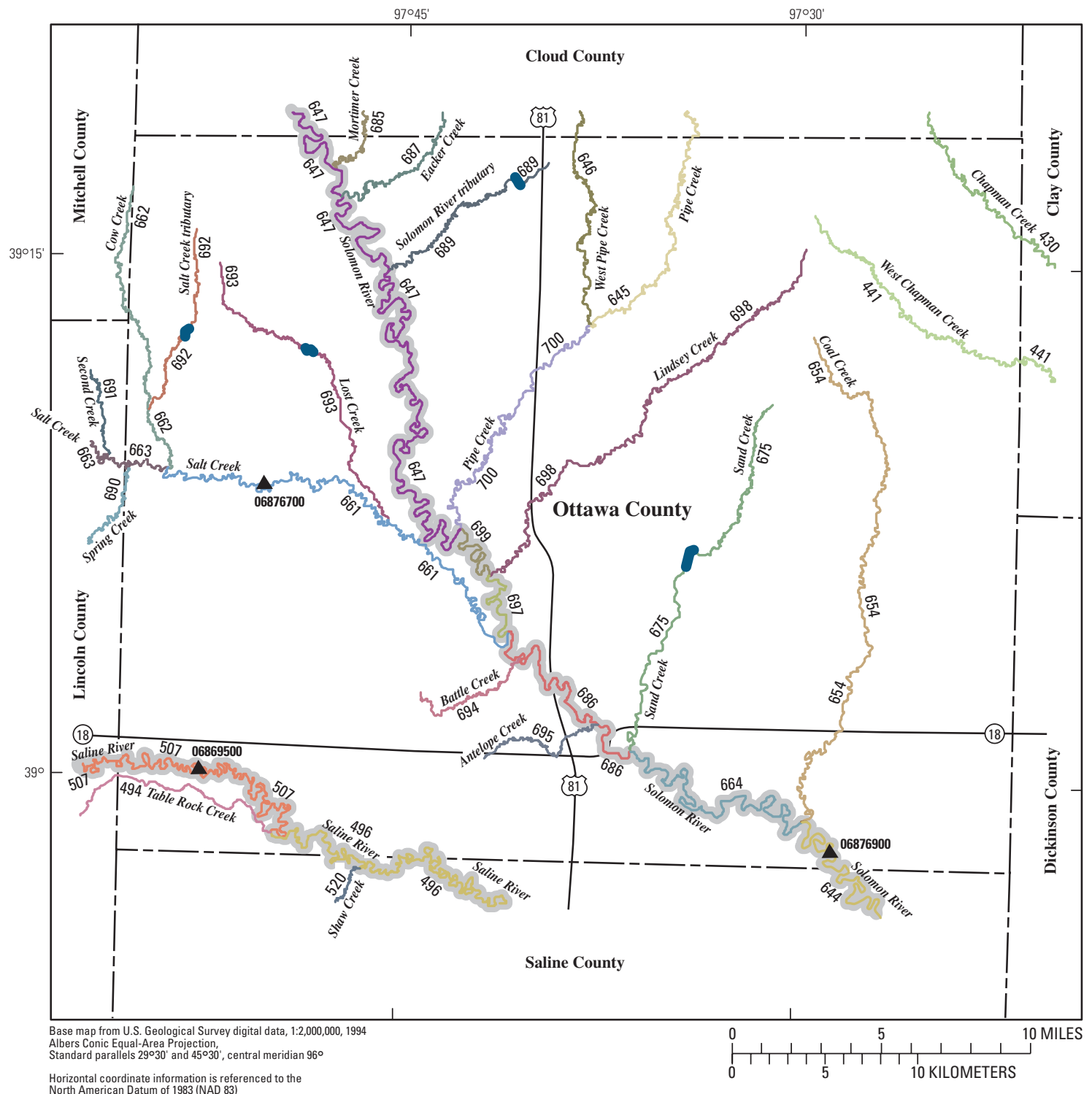

EXPLANATION
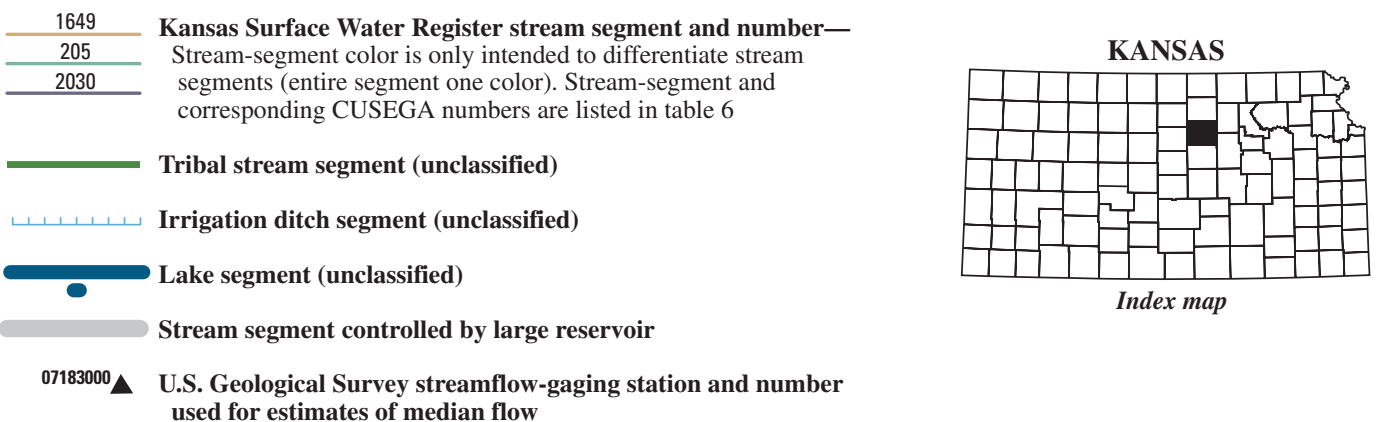

Figure 80. Location of U.S. Geological Survey streamflow-gaging stations and stream segments on the 1999 Kansas Surface Water Register for Ottawa County. 


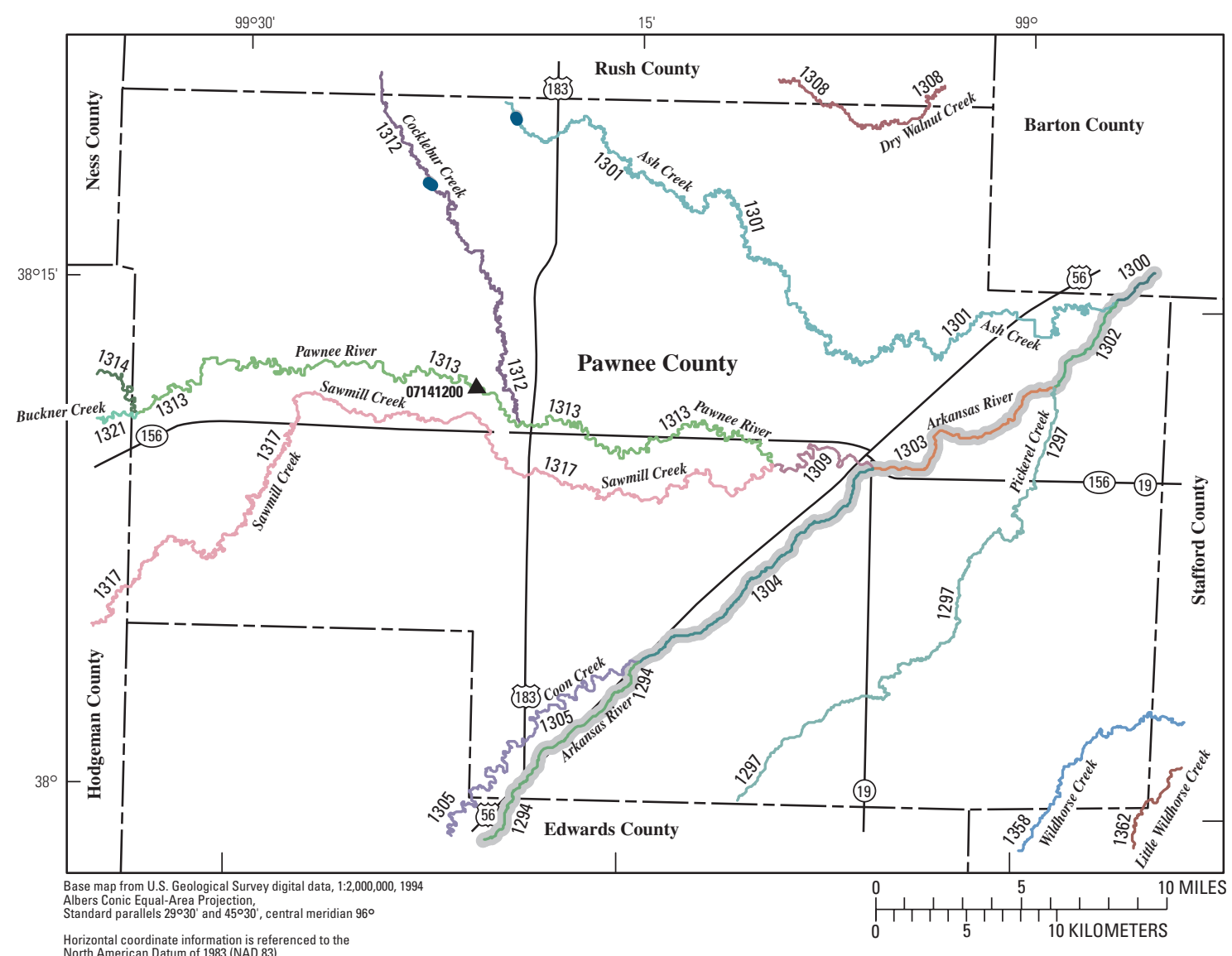

\section{EXPLANATION}

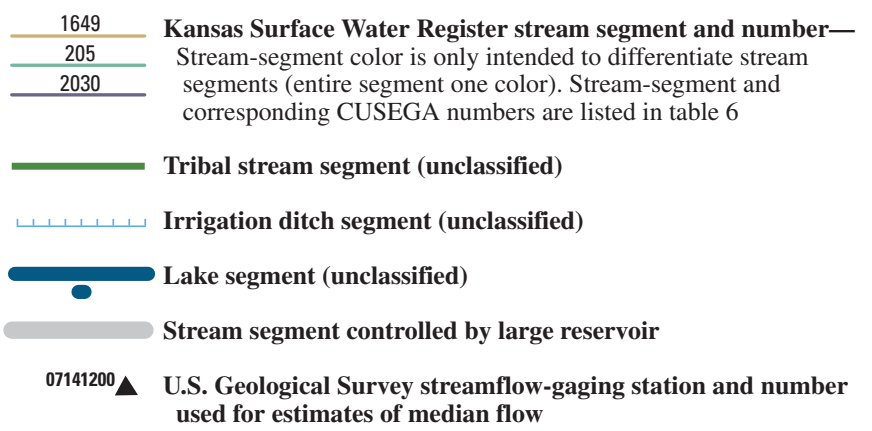

Figure 81. Location of U.S. Geological Survey streamflow-gaging stations and stream segments on the 1999 Kansas Surface Water Register for Pawnee County. 


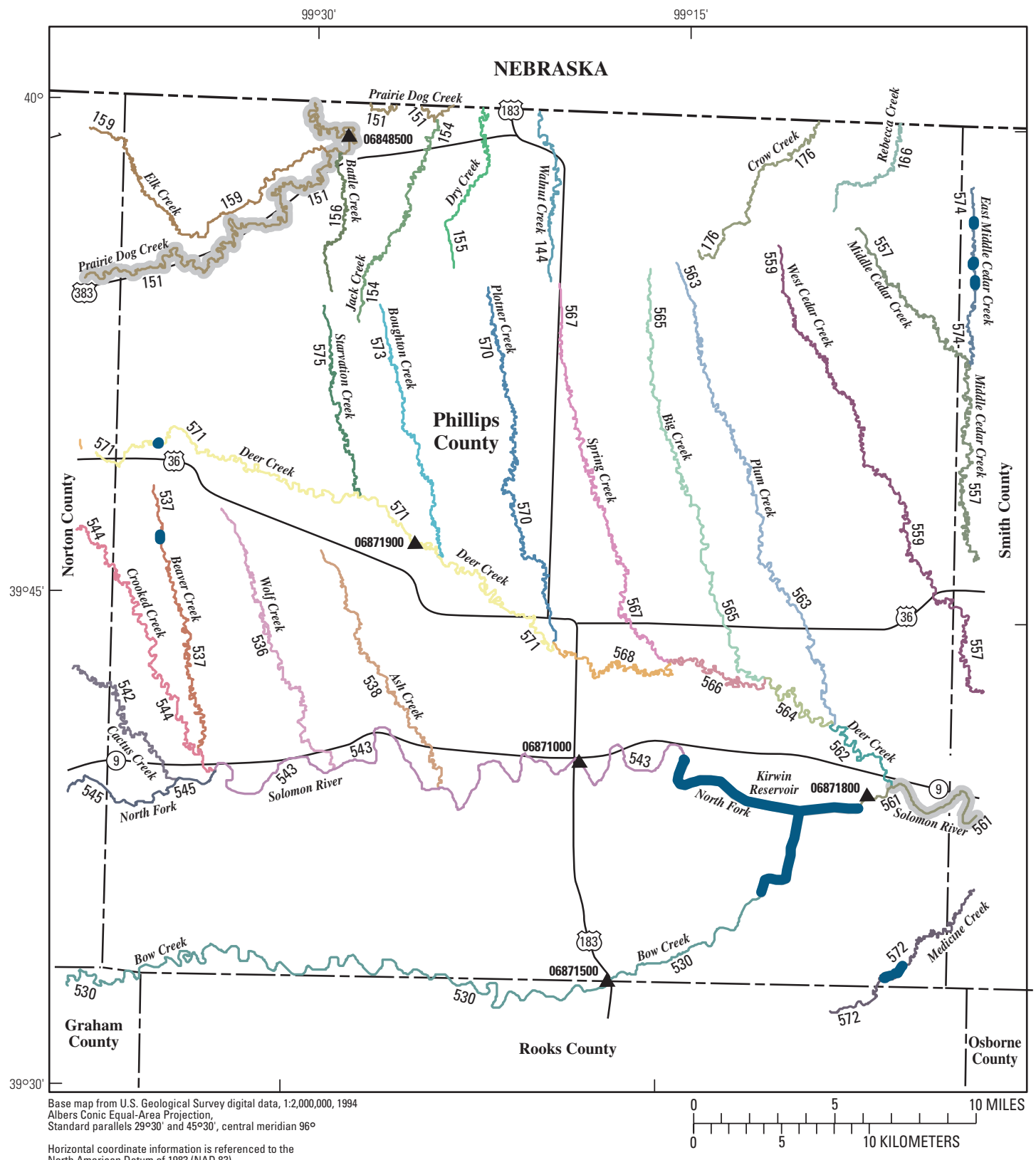

EXPLANATION

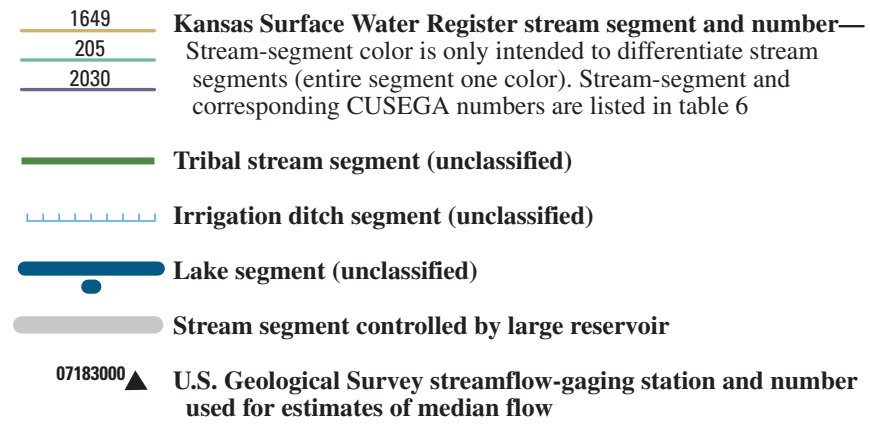

KANSAS

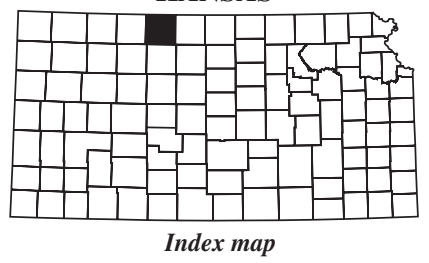

Figure 82. Location of U.S. Geological Survey streamflow-gaging stations and stream segments on the 1999 Kansas Surface Water Register for Phillips County. 


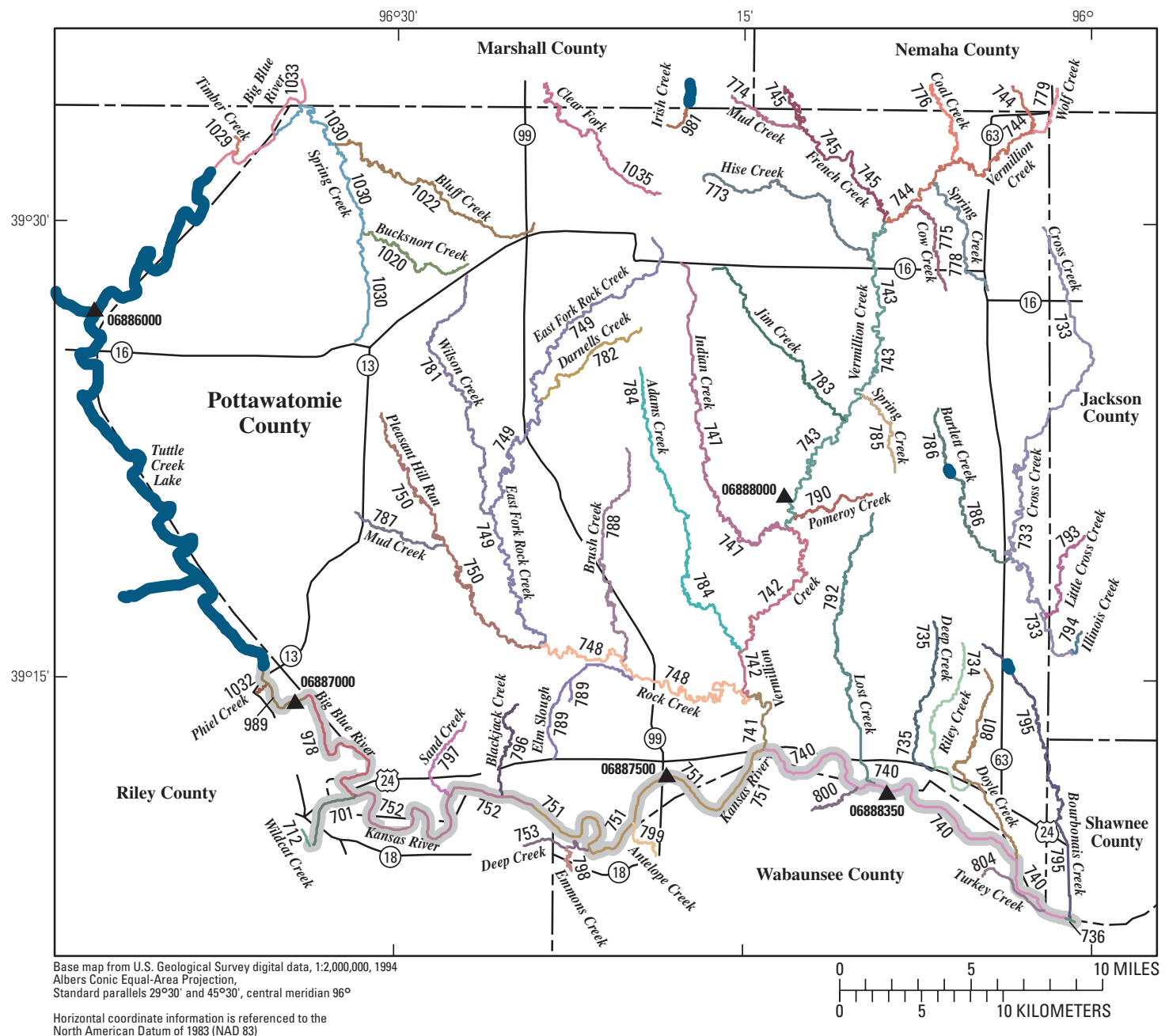

EXPLANATION
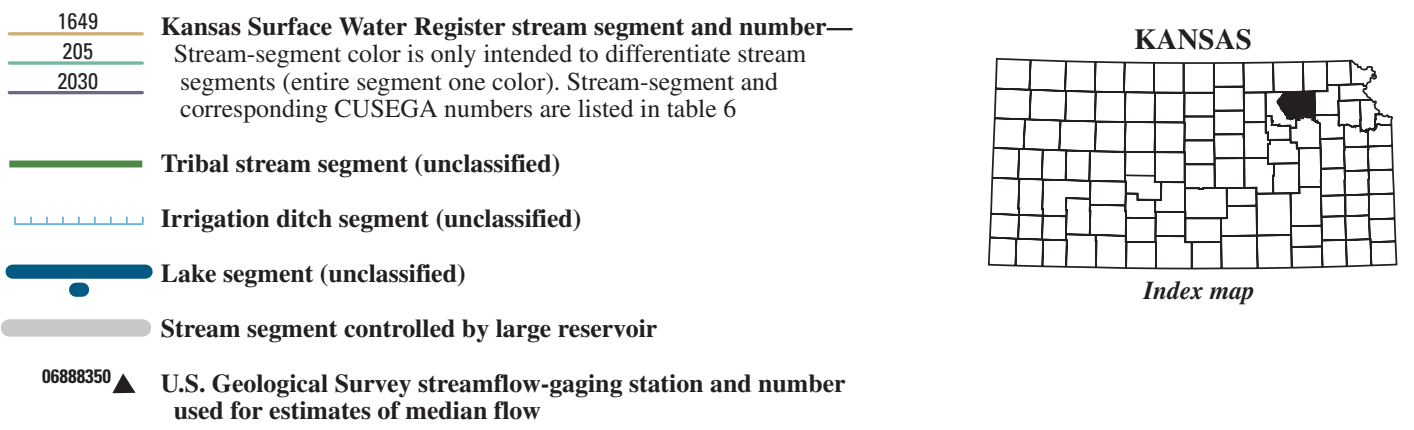

Index map

Figure 83. Location of U.S. Geological Survey streamflow-gaging stations and stream segments on the 1999 Kansas Surface Water Register for Pottawatomie County. 


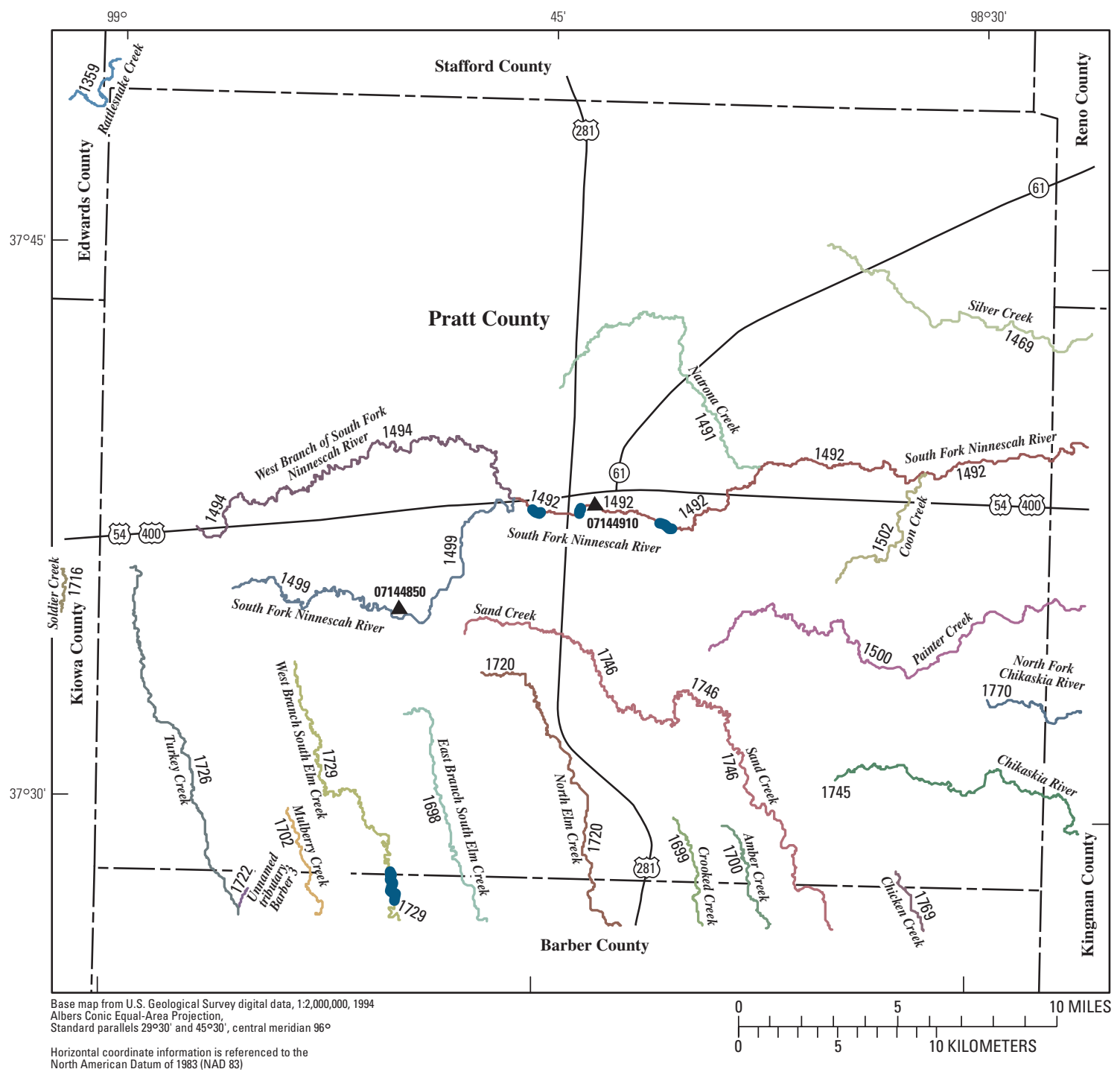

EXPLANATION
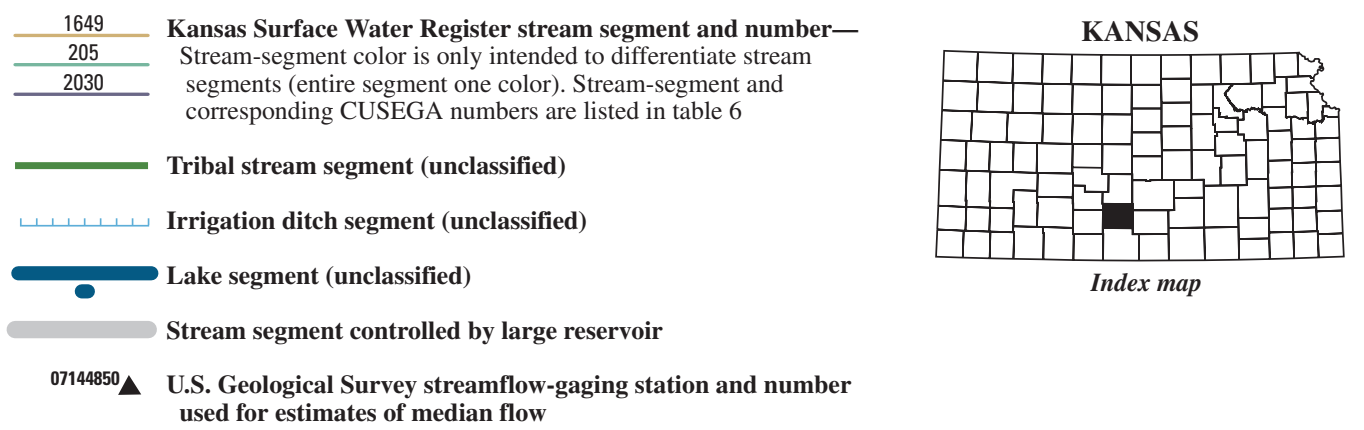

Figure 84. Location of U.S. Geological Survey streamflow-gaging stations and stream segments on the 1999 Kansas Surface Water Register for Pratt County. 


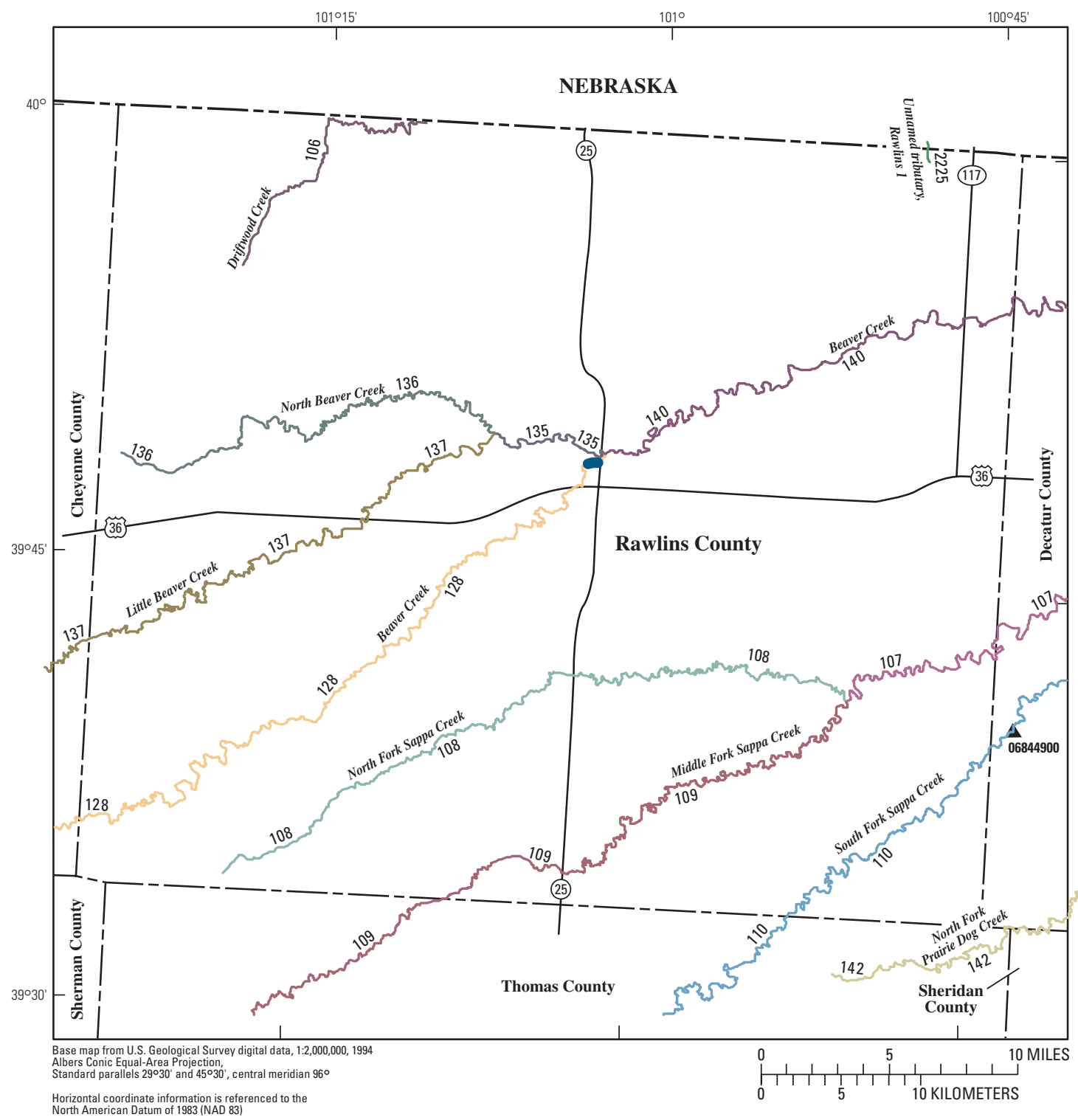

EXPLANATION
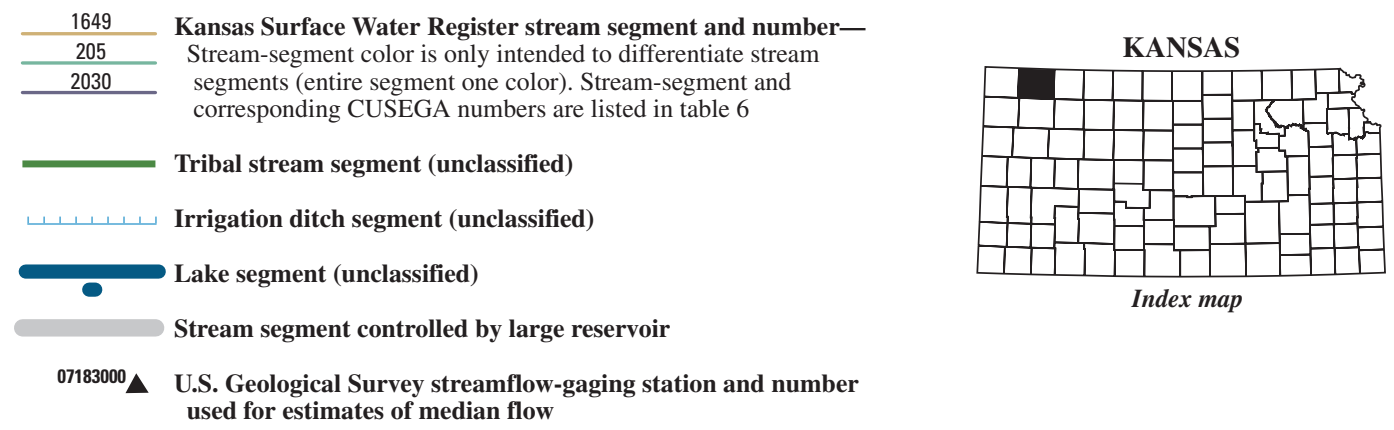

Figure 85. Location of U.S. Geological Survey streamflow-gaging stations and stream segments on the 1999 Kansas Surface Water Register for Rawlins County. 


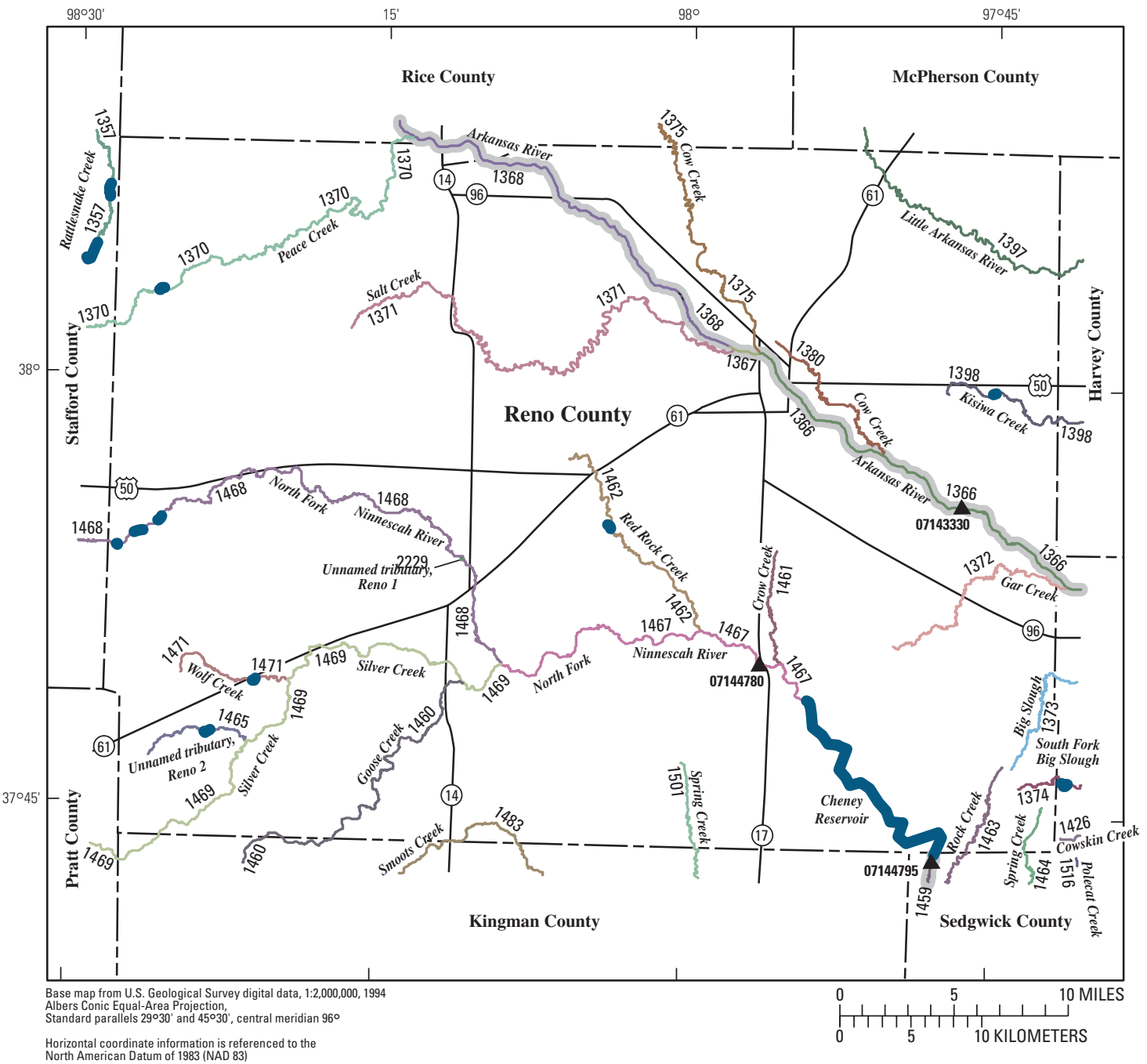

EXPLANATION

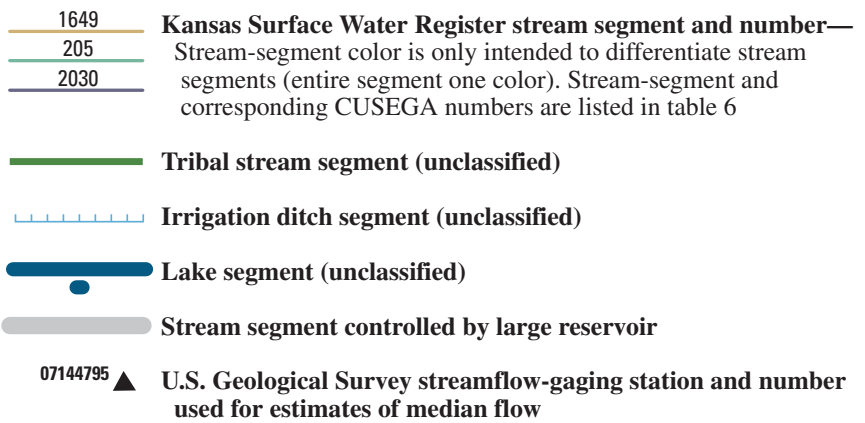

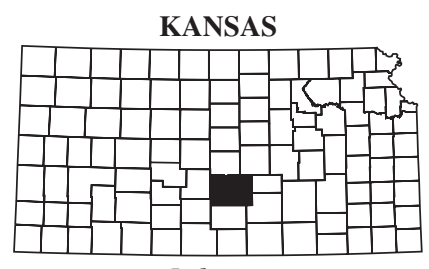

Index map used for estimates of median flow

Figure 86. Location of U.S. Geological Survey streamflow-gaging stations and stream segments on the 1999 Kansas Surface Water Register for Reno County. 


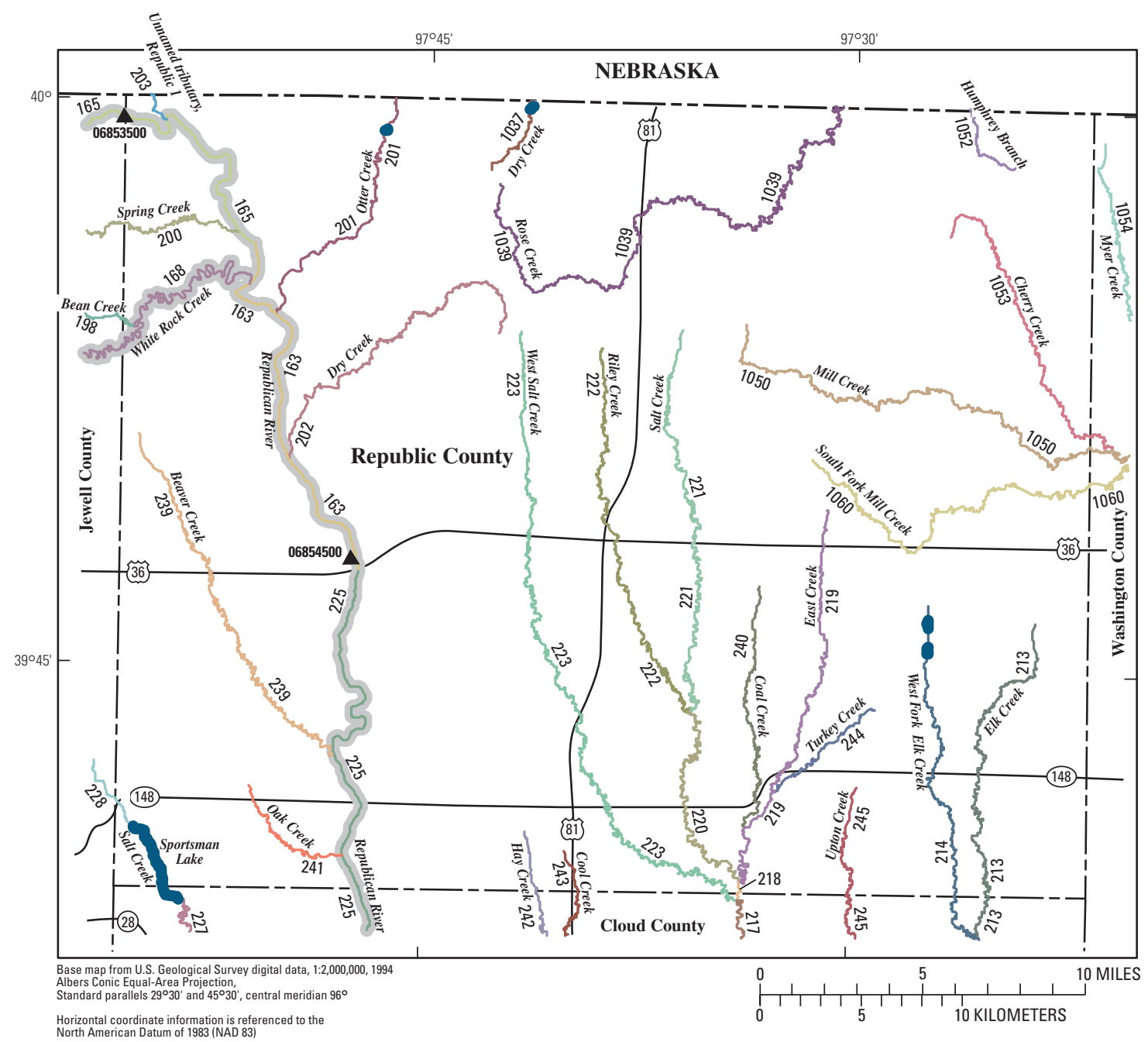

EXPLANATION

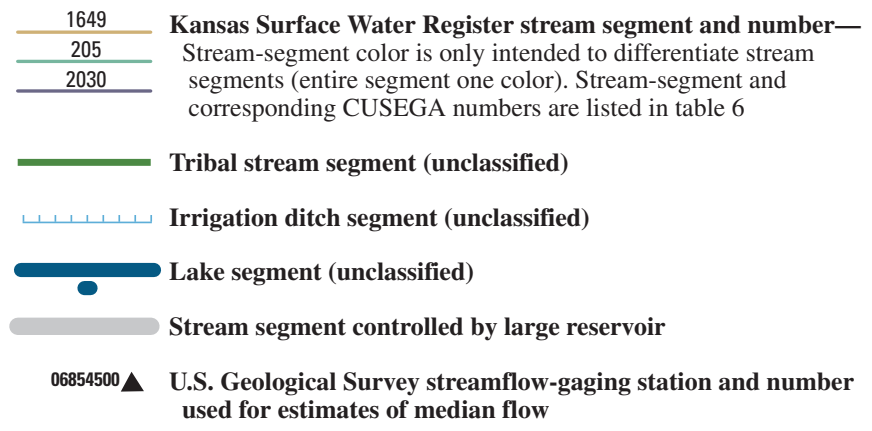

Figure 87. Location of U.S. Geological Survey streamflow-gaging stations and stream segments on the 1999 Kansas Surface Water Register for Republic County. 


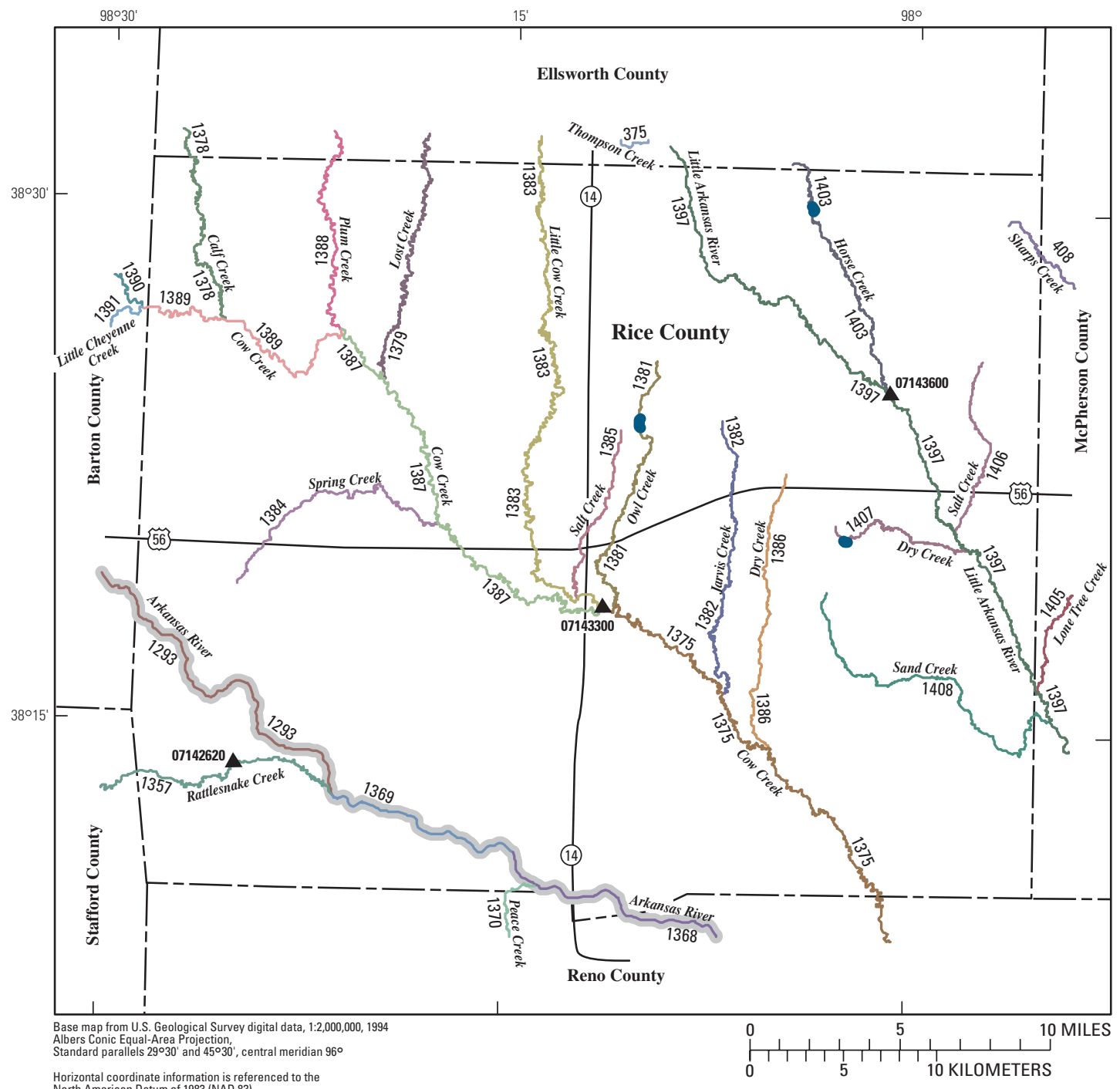

EXPLANATION
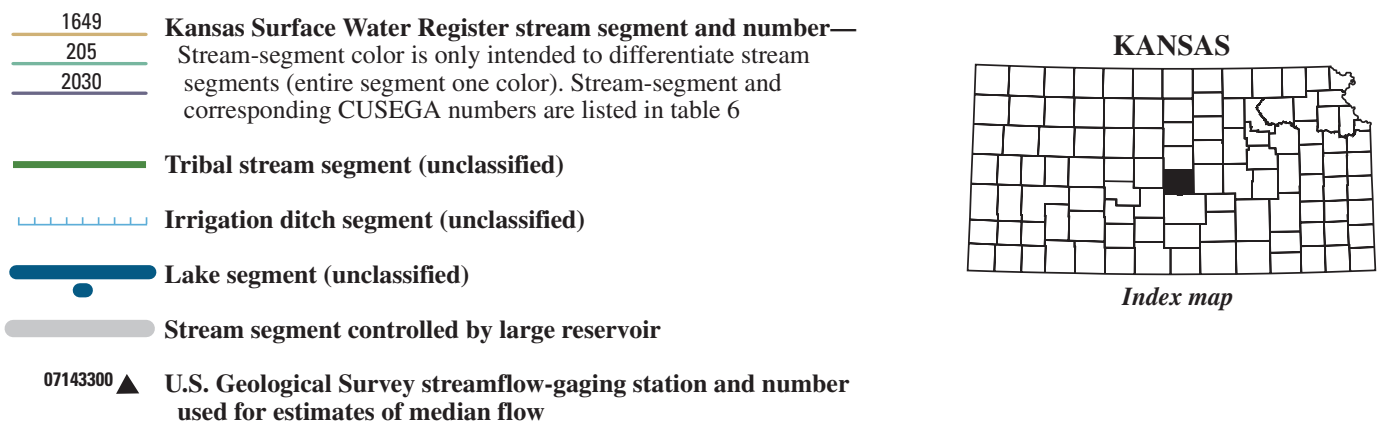

Figure 88. Location of U.S. Geological Survey streamflow-gaging stations and stream segments on the 1999 Kansas Surface Water Register for Rice County. 


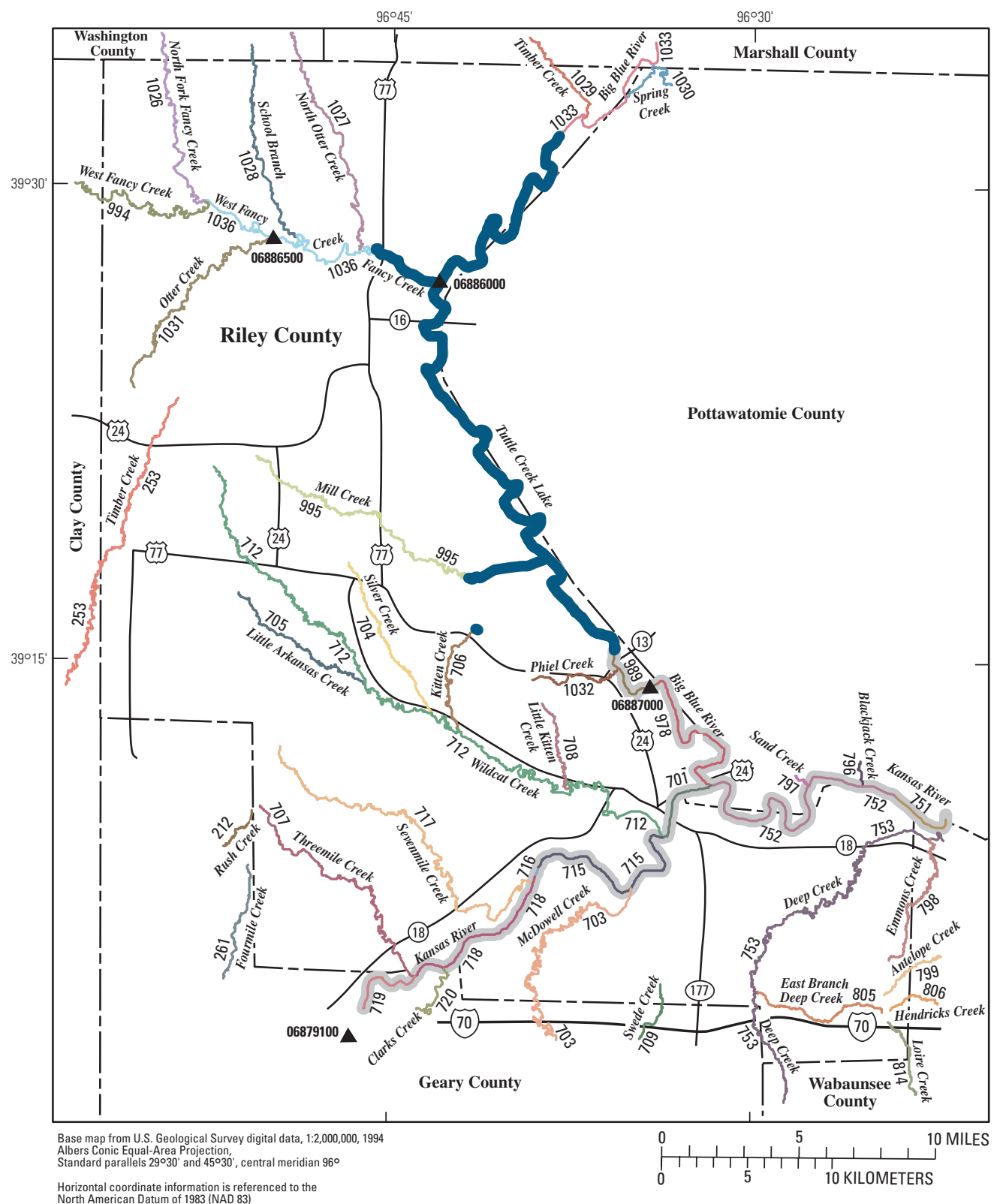

EXPLANATION

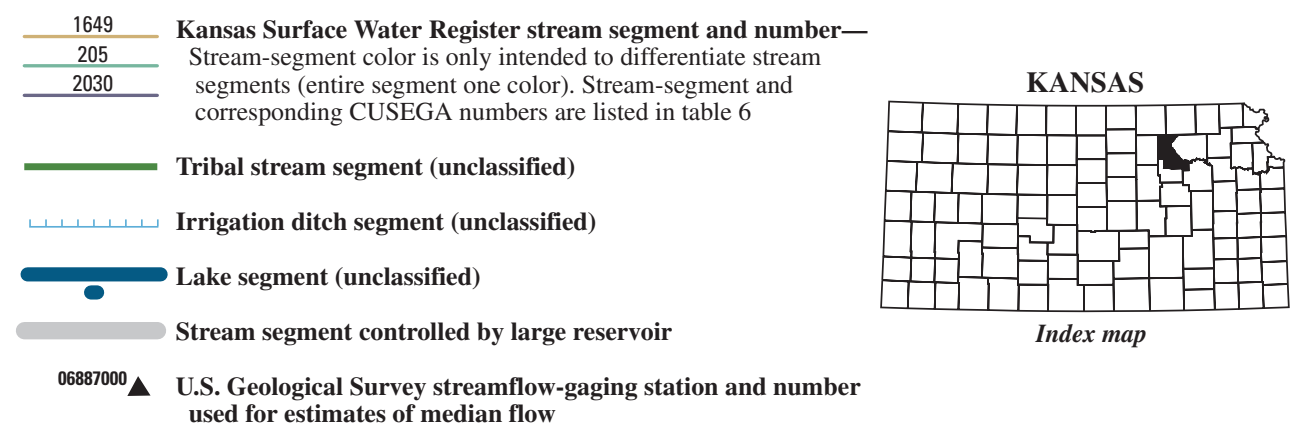

Figure 89. Location of U.S. Geological Survey streamflow-gaging stations and stream segments on the 1999 Kansas Surface Water Register for Riley County. 


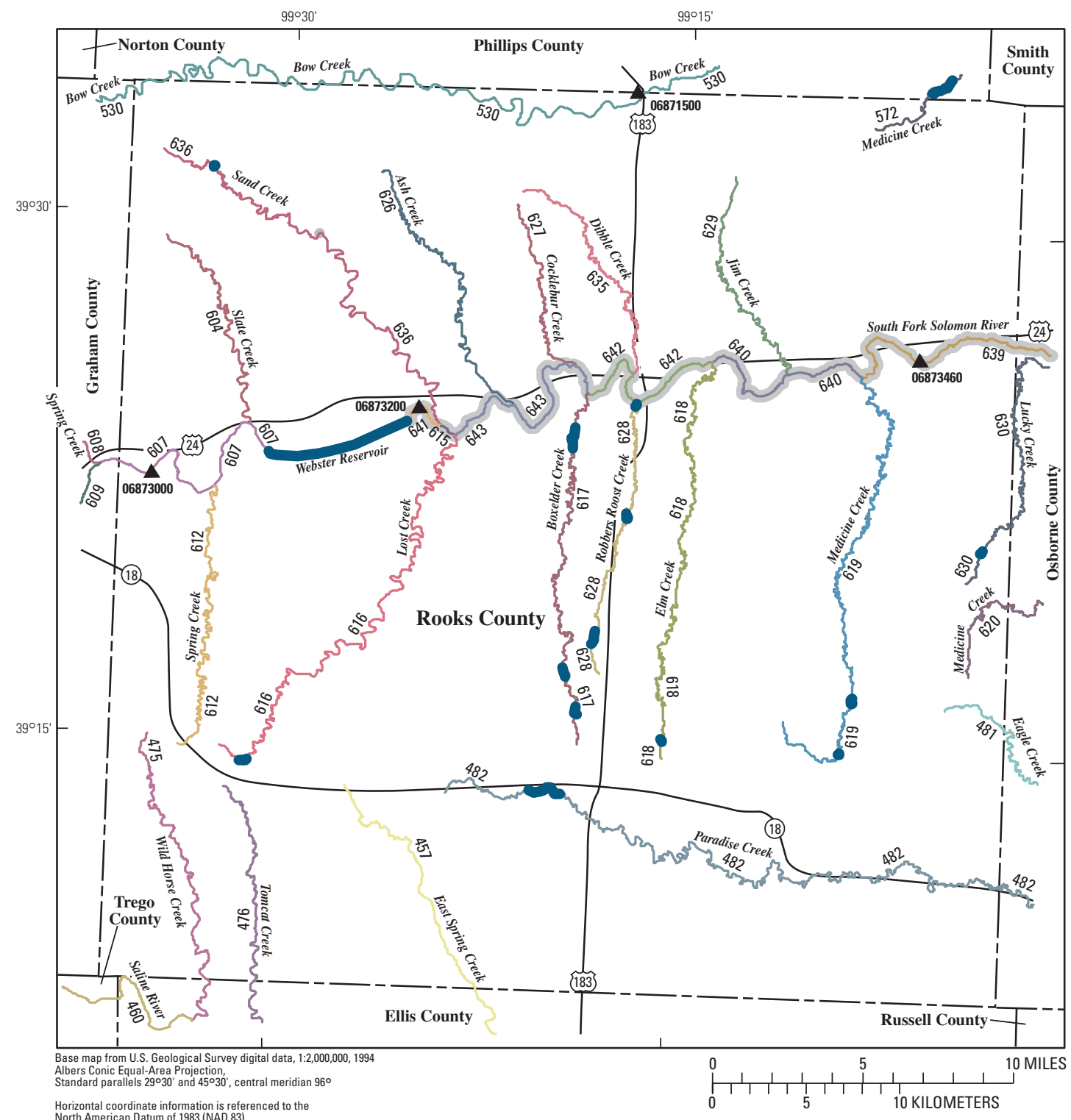

EXPLANATION
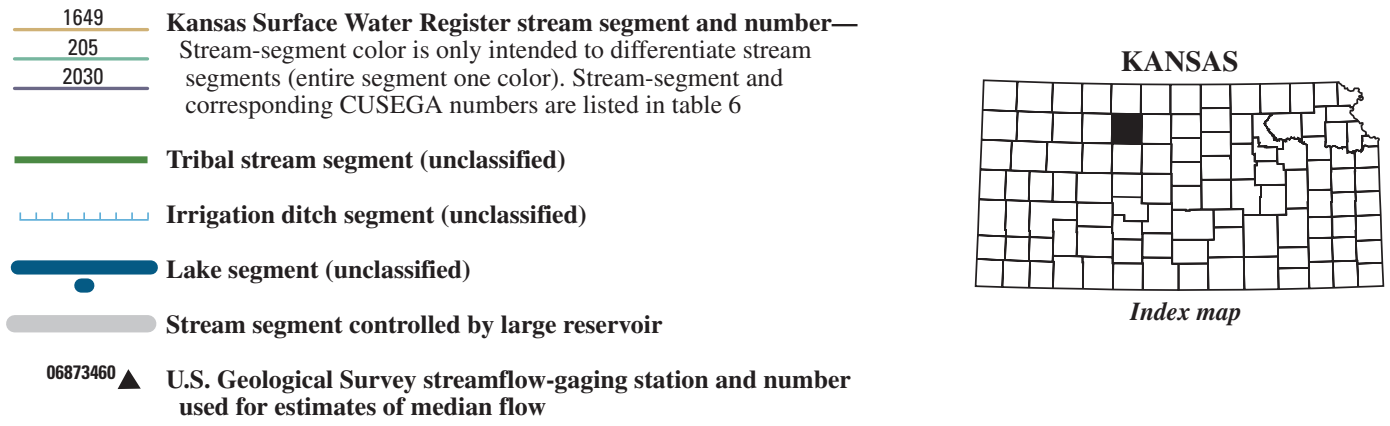

Figure 90. Location of U.S. Geological Survey streamflow-gaging stations and stream segments on the 1999 Kansas Surface Water Register for Rooks County. 


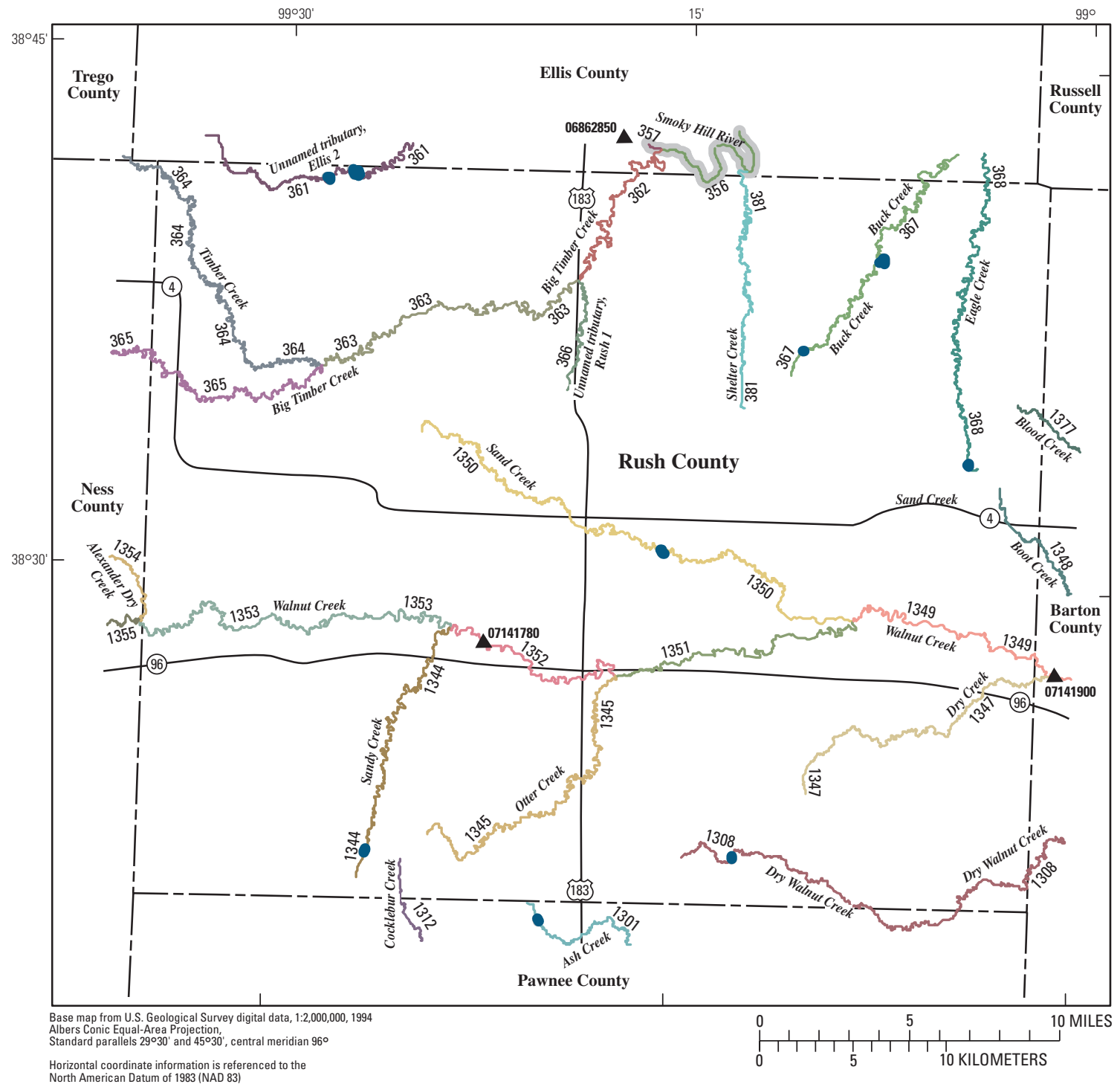

EXPLANATION
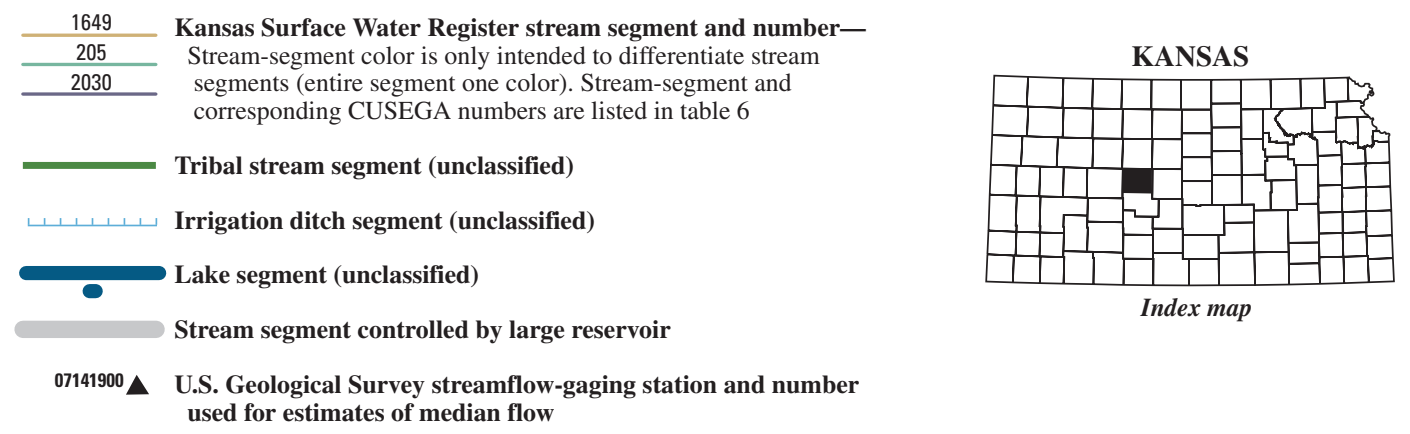

Figure 91. Location of U.S. Geological Survey streamflow-gaging stations and stream segments on the 1999 Kansas Surface Water Register for Rush County. 


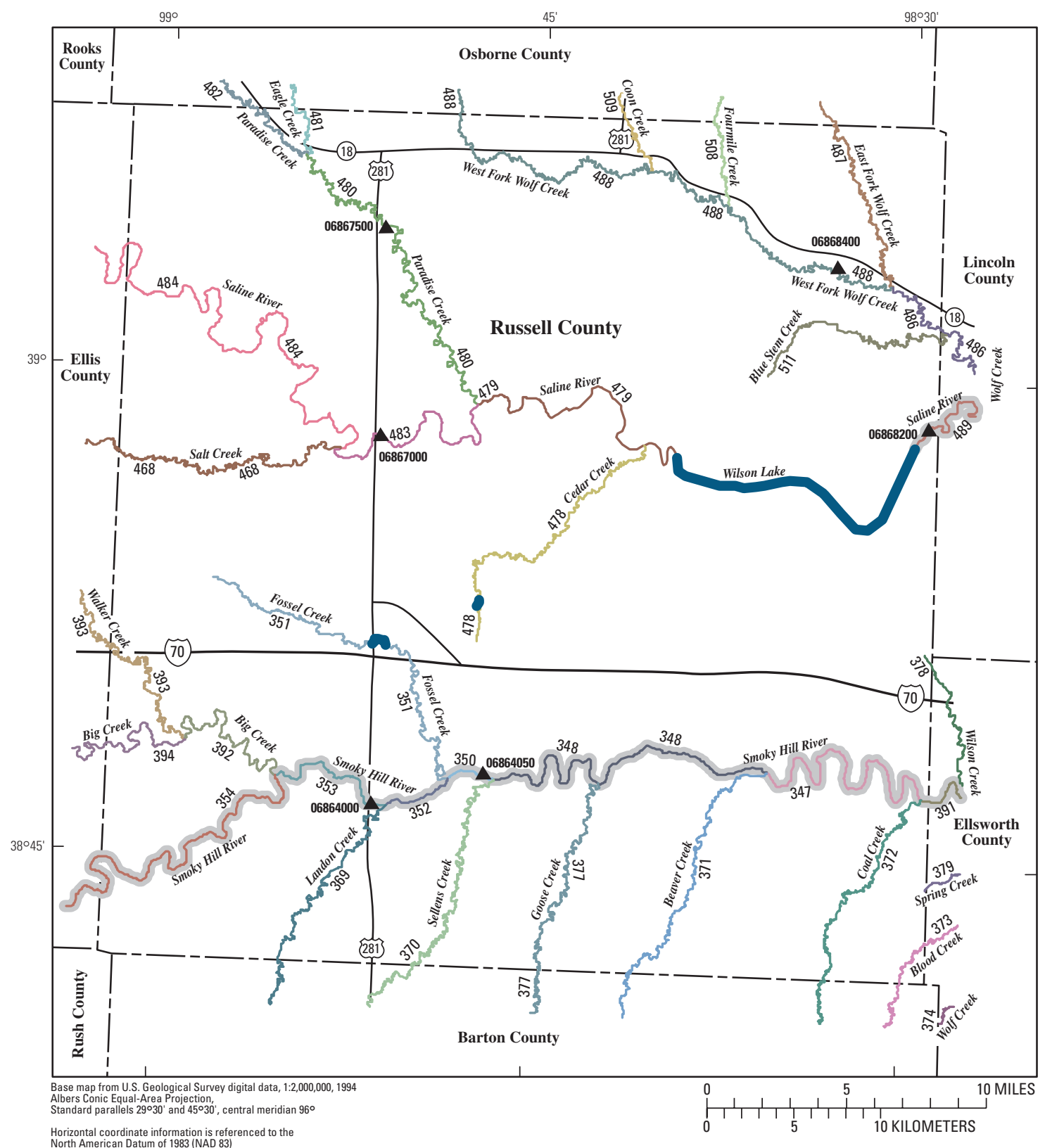

EXPLANATION

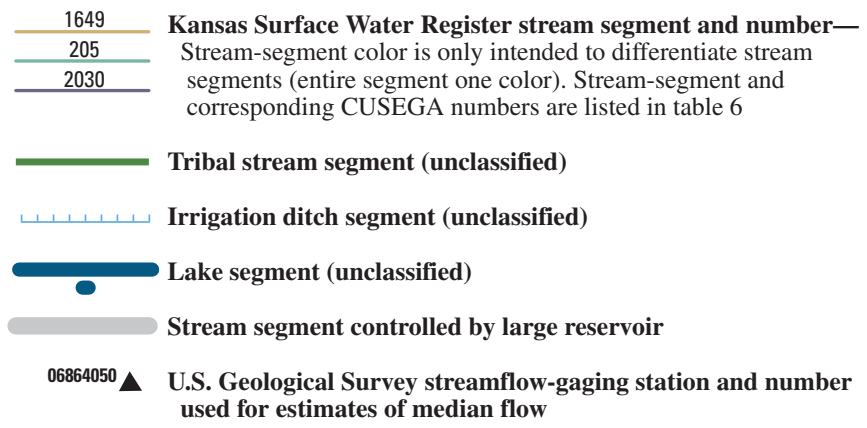

Figure 92. Location of U.S. Geological Survey streamflow-gaging stations and stream segments on the 1999 Kansas Surface Water Register for Russell County. 


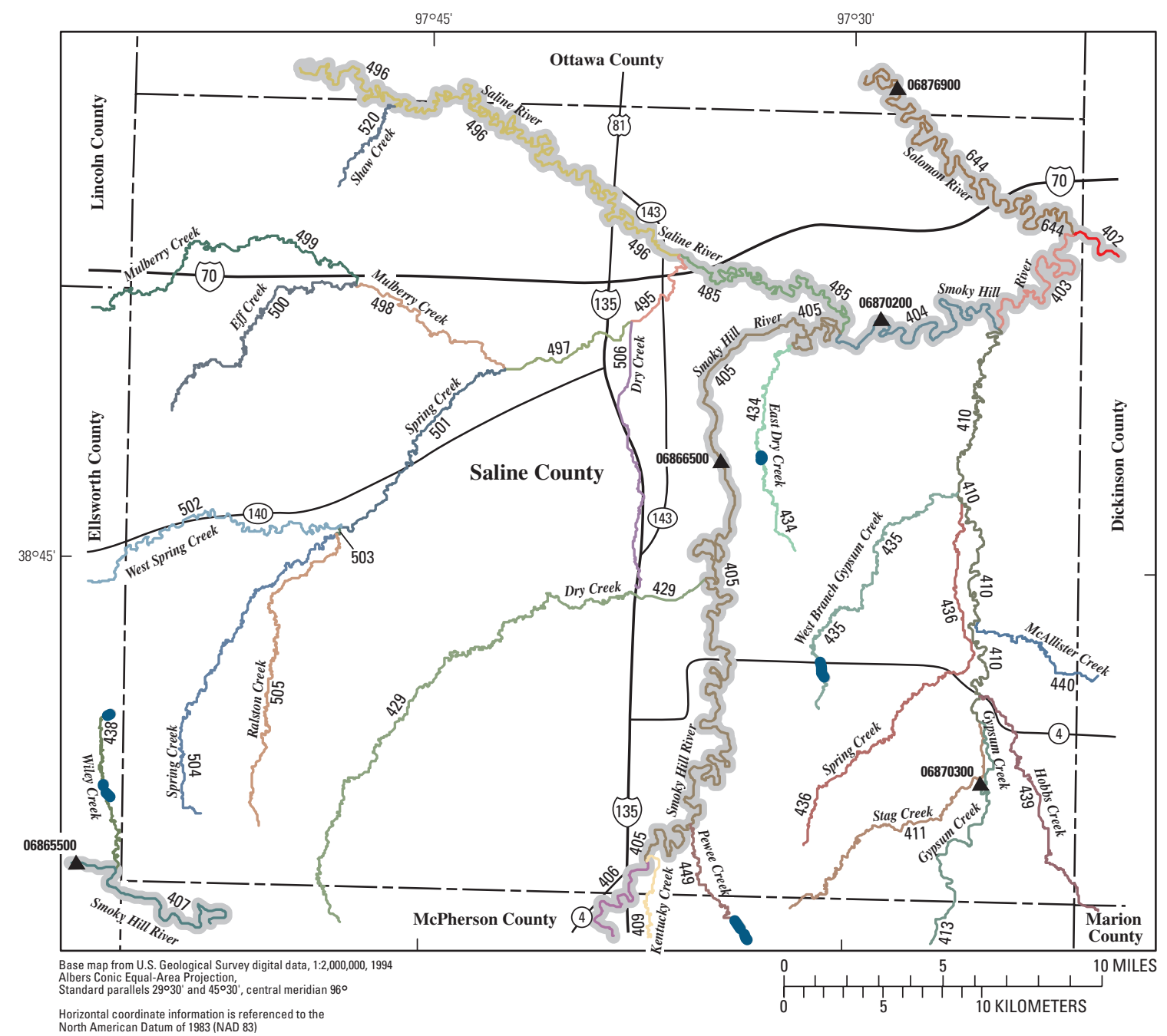

EXPLANATION

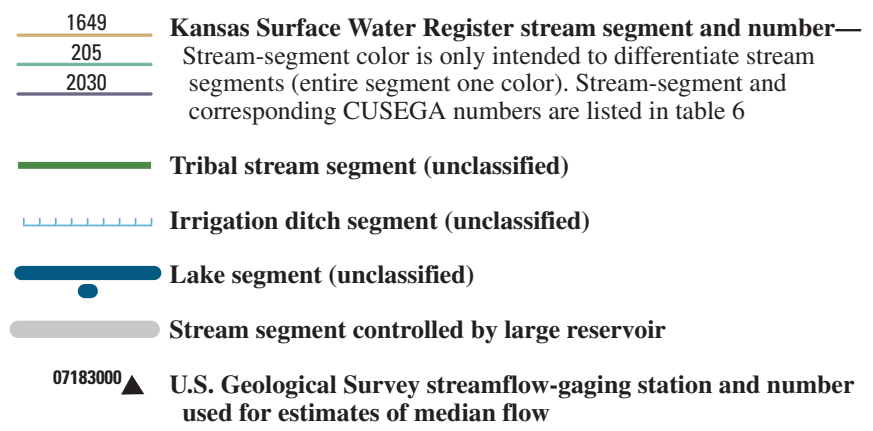

Figure 93. Location of U.S. Geological Survey streamflow-gaging stations and stream segments on the 1999 Kansas Surface Water Register for Saline County. 


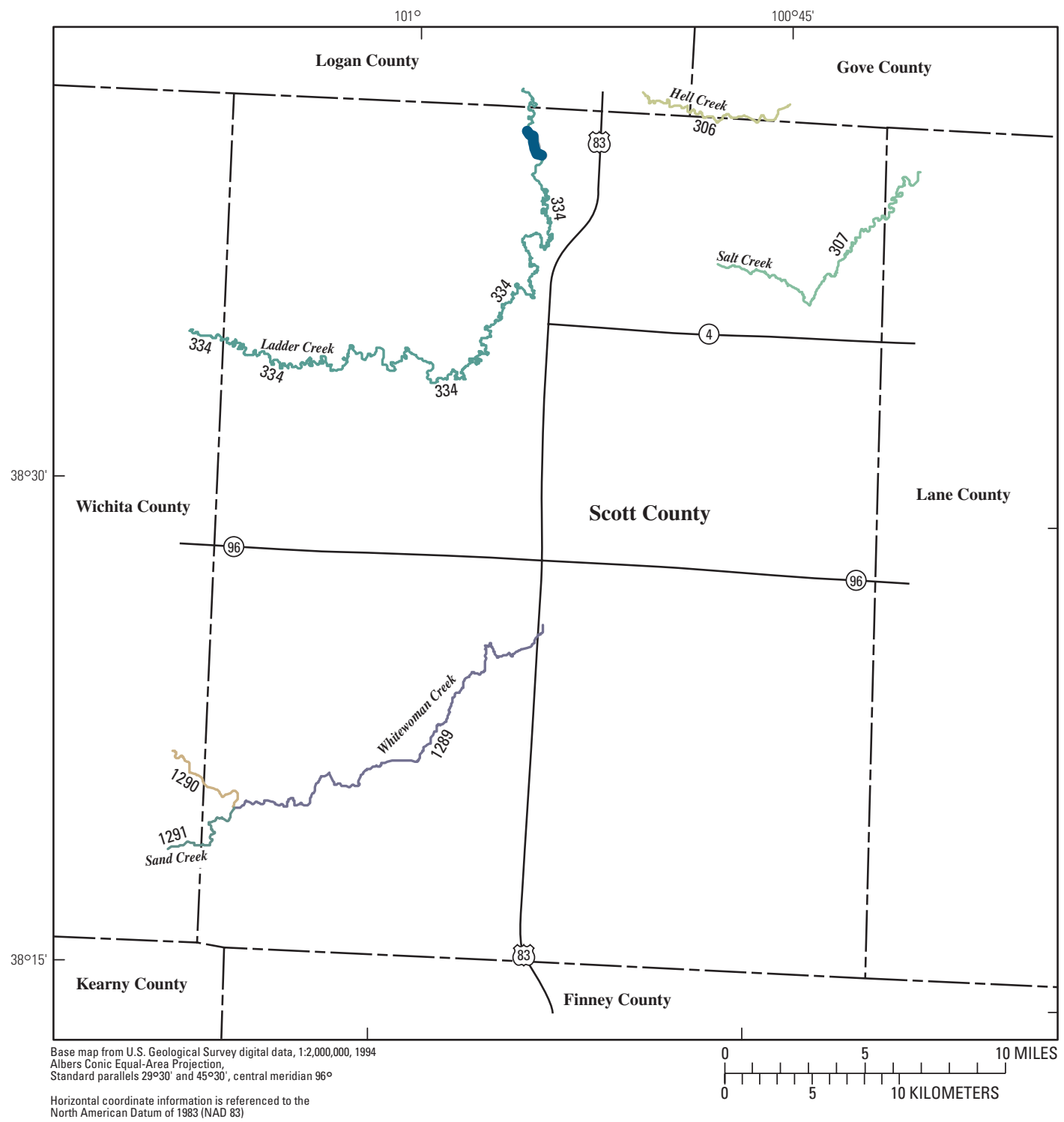

EXPLANATION

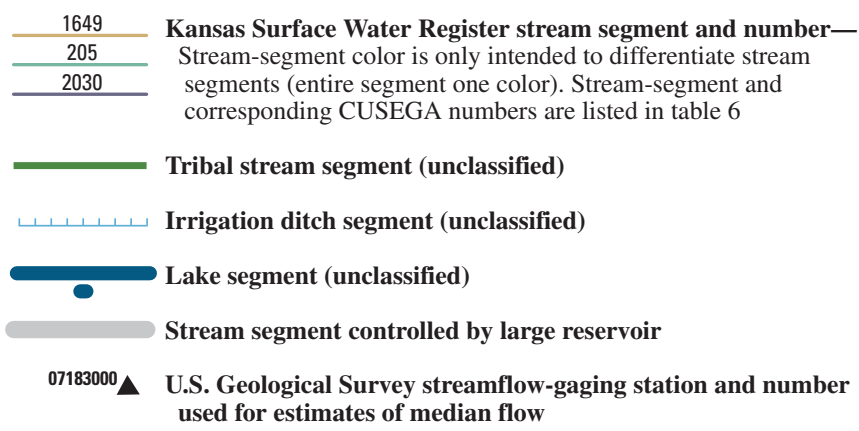

Figure 94. Location of U.S. Geological Survey streamflow-gaging stations and stream segments on the 1999 Kansas Surface Water Register for Scott County. 


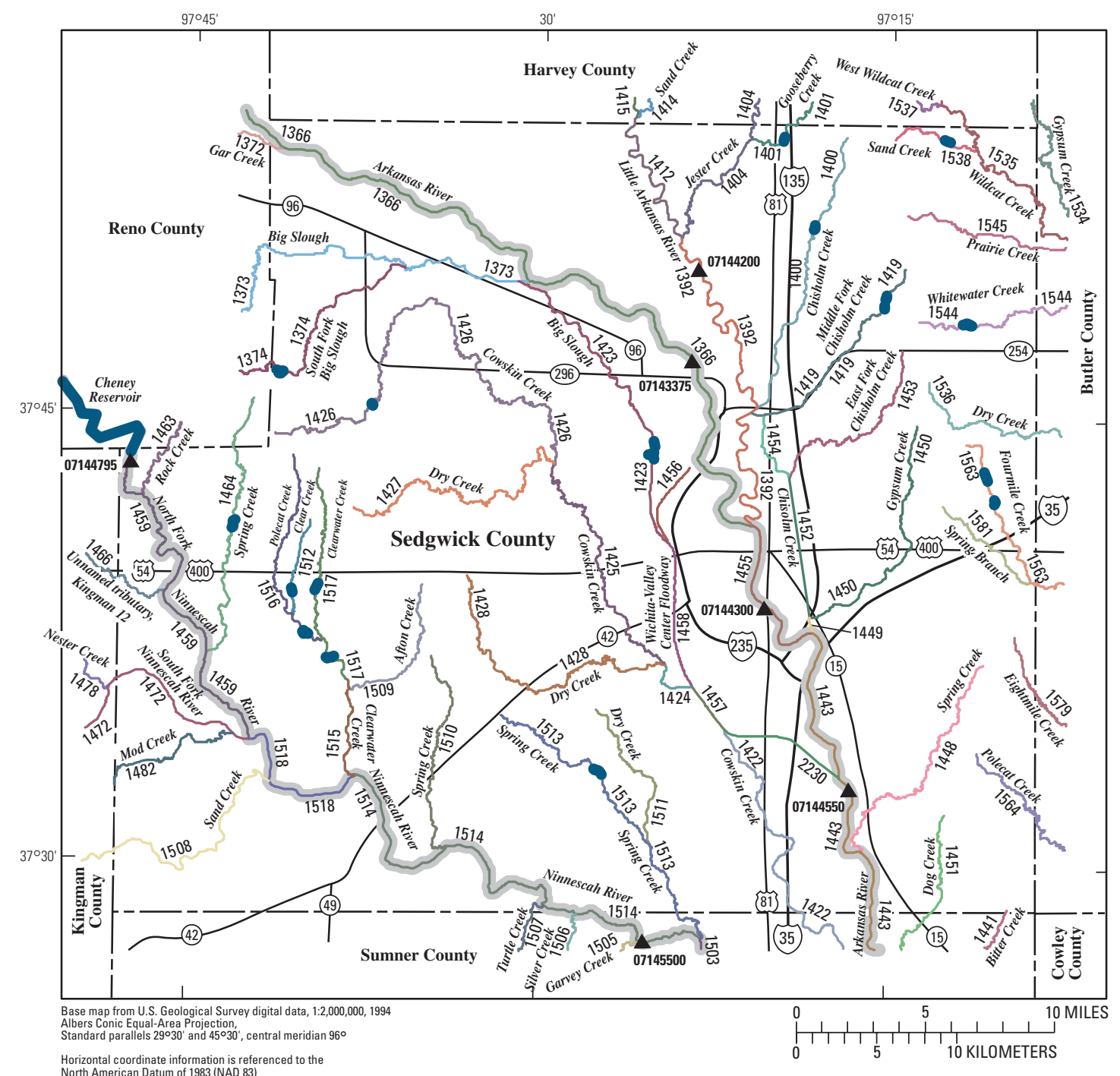

\section{EXPLANATION}
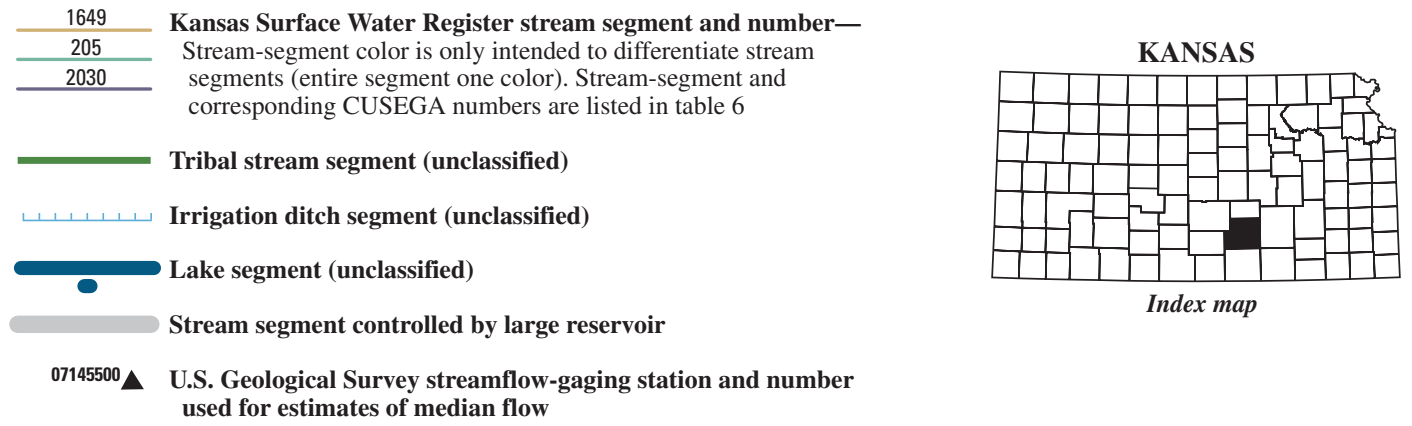

Figure 95. Location of U.S. Geological Survey streamflow-gaging stations and stream segments on the 1999 Kansas Surface Water Register for Sedgwick County. 


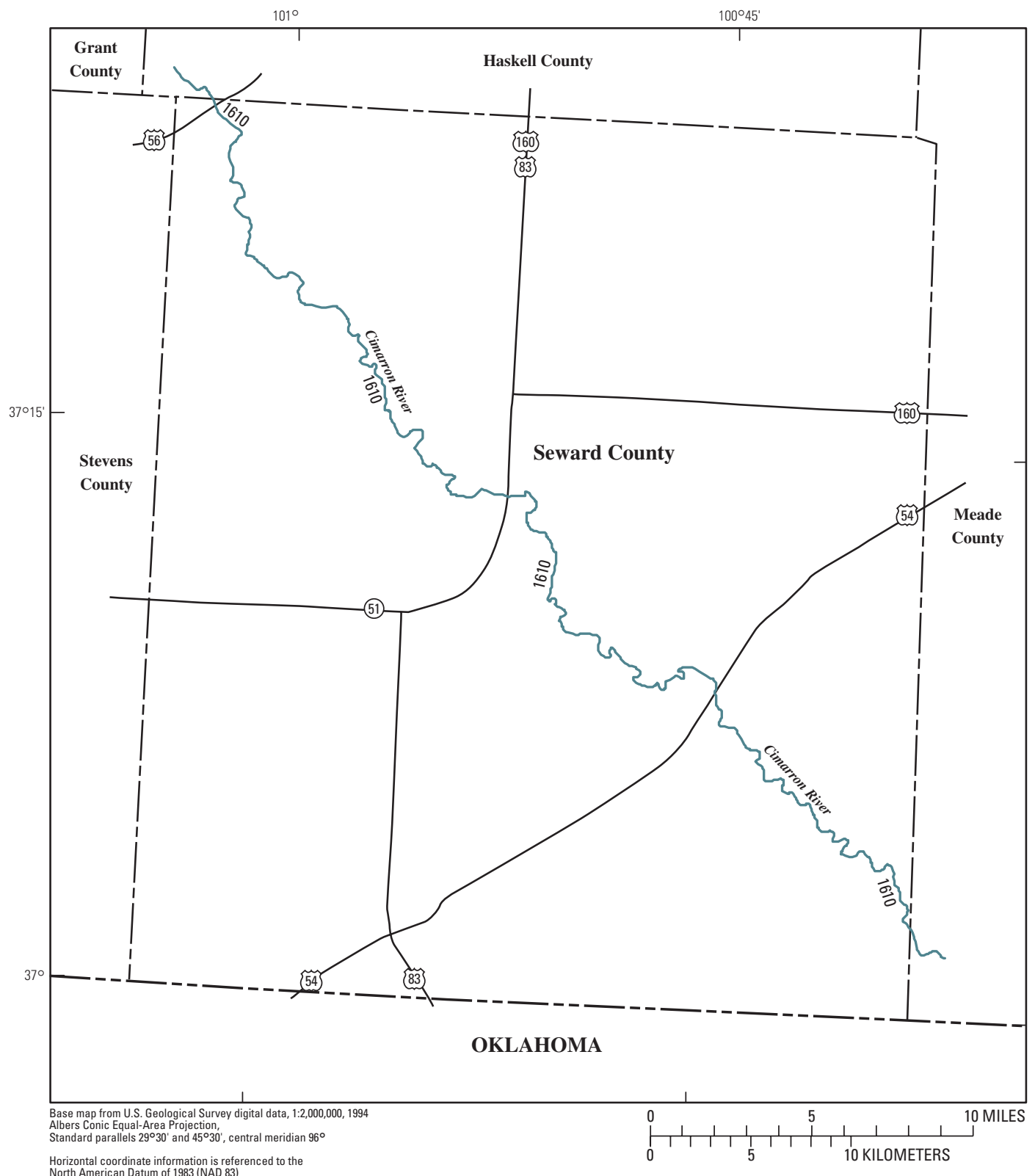

\section{EXPLANATION}

\begin{tabular}{|c|c|}
\hline 1649 & \multirow{4}{*}{$\begin{array}{l}\text { Kansas Surface Water Register stream segment and number- } \\
\text { Stream-segment color is only intended to differentiate stream } \\
\text { segments (entire segment one color). Stream-segment and } \\
\text { corresponding CUSEGA numbers are listed in table } 6\end{array}$} \\
\hline 205 & \\
\hline \multirow[t]{3}{*}{2030} & \\
\hline & \\
\hline & Tribal stream segment (unclassified) \\
\hline $1,1,1,1,1$, & Irrigation ditch segment (unclassified) \\
\hline \multirow[t]{2}{*}{0} & Lake segment (unclassified) \\
\hline & Stream segment controlled by large reservoir \\
\hline $07183000 \Delta$ & $\begin{array}{l}\text { U.S. Geological Survey streamflow-gaging station and number } \\
\text { used for estimates of median flow }\end{array}$ \\
\hline
\end{tabular}

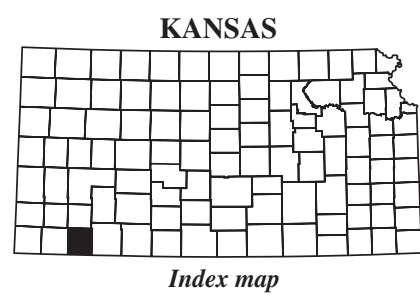

Figure 96. Location of U.S. Geological Survey streamflow-gaging stations and stream segments on the 1999 Kansas Surface Water Register for Seward County. 


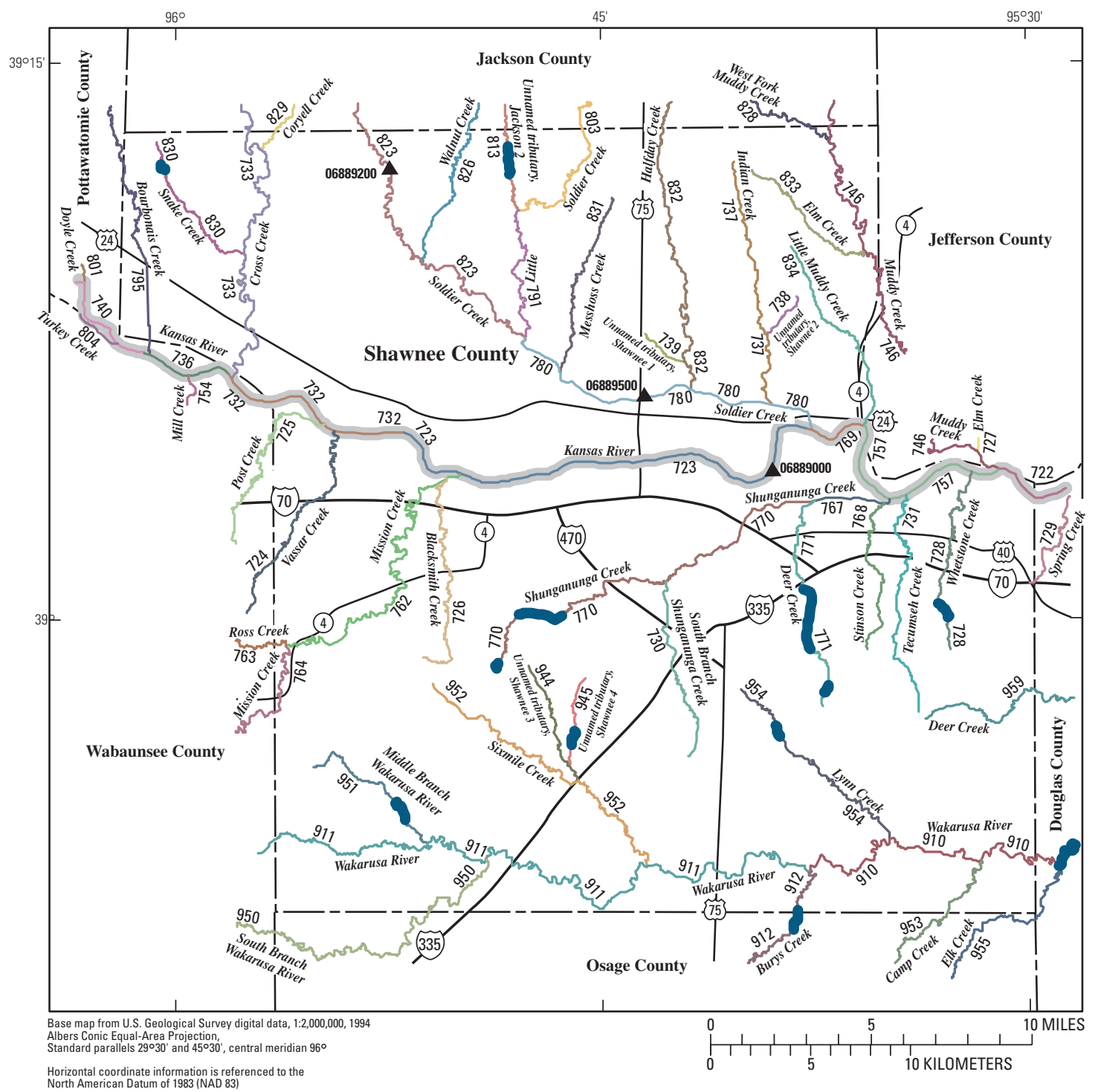

EXPLANATION

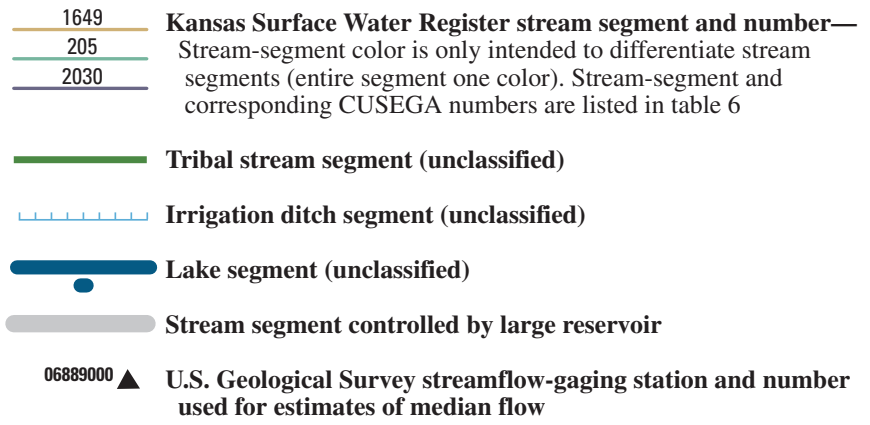

KANSAS

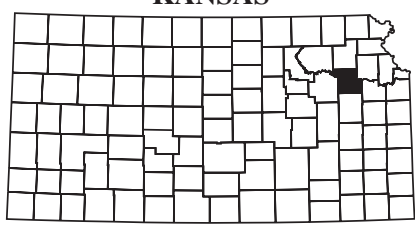

Index map used for estimates of median flow

Figure 97. Location of U.S. Geological Survey streamflow-gaging stations and stream segments on the 1999 Kansas Surface Water Register for Shawnee County. 


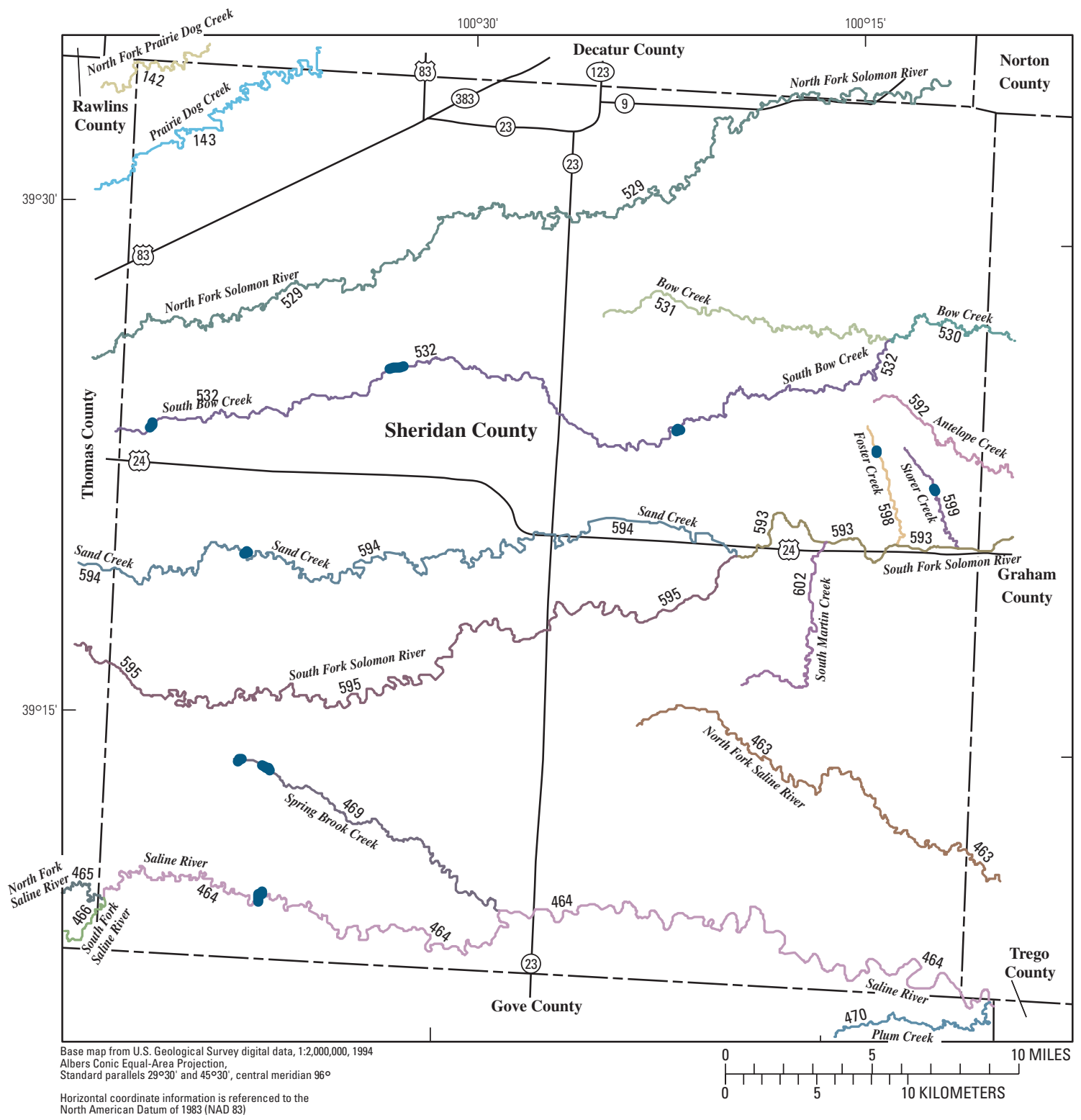

EXPLANATION
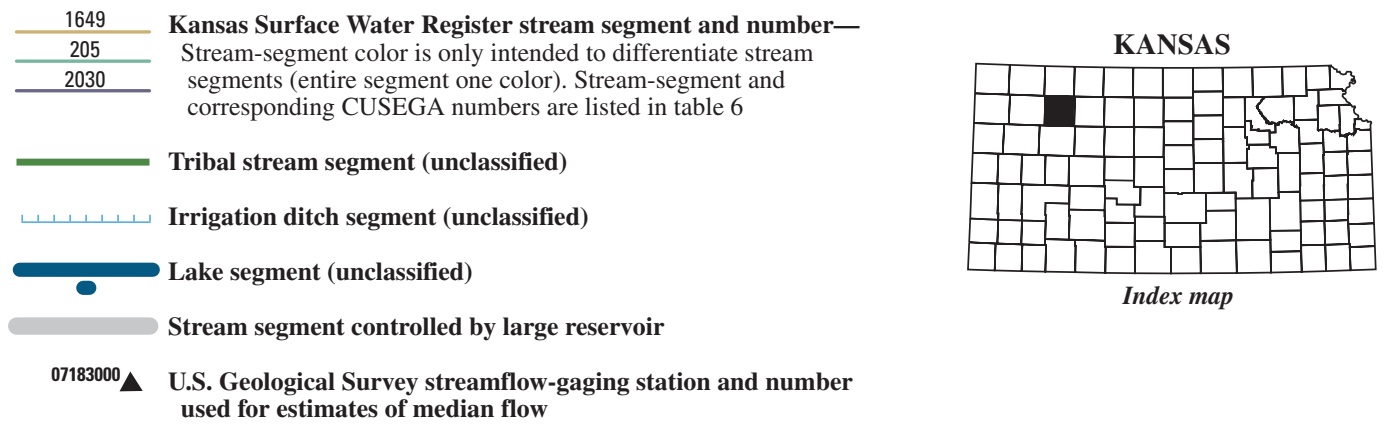

Figure 98. Location of U.S. Geological Survey streamflow-gaging stations and stream segments on the 1999 Kansas Surface Water Register for Sheridan County. 


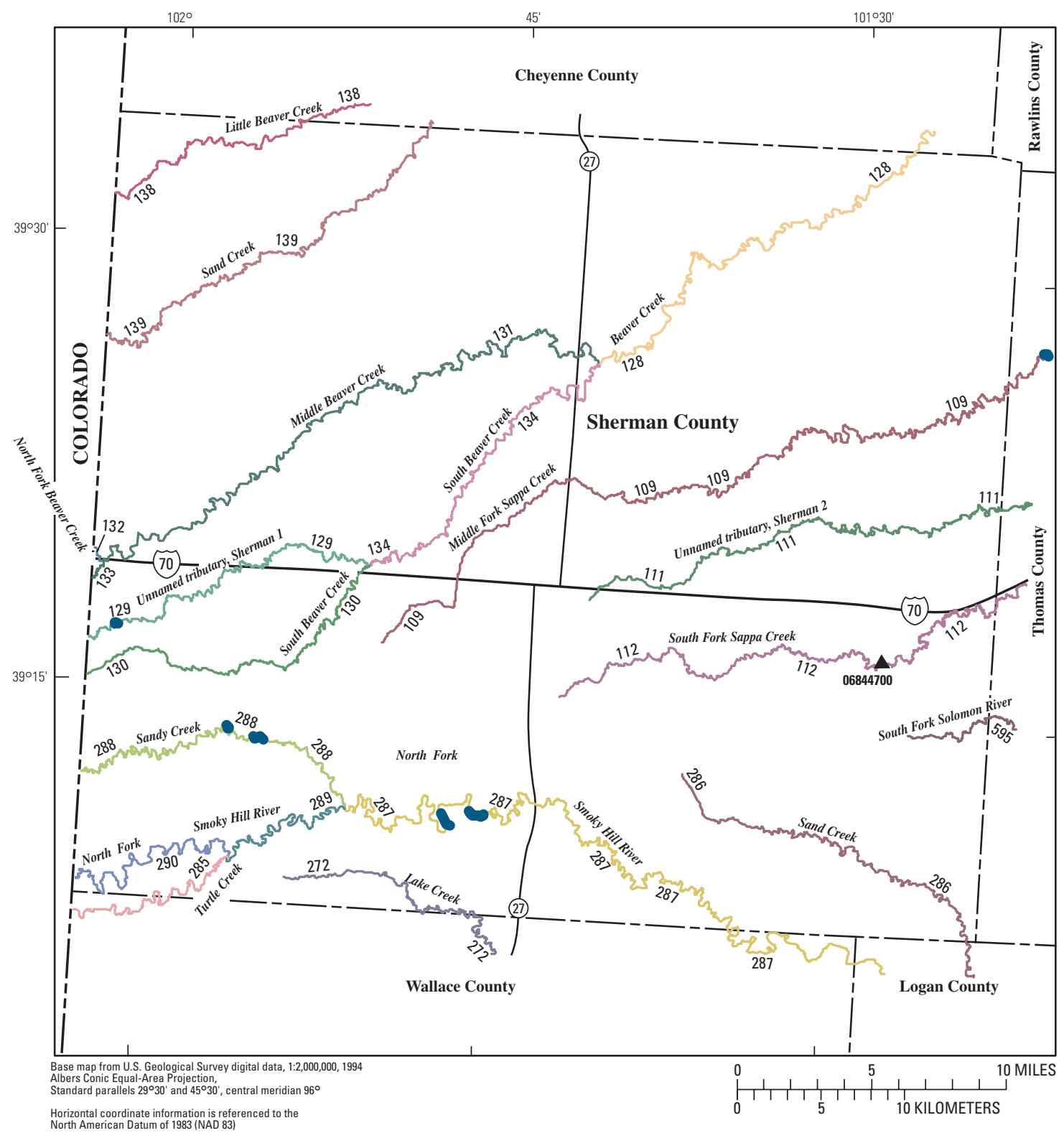

EXPLANATION
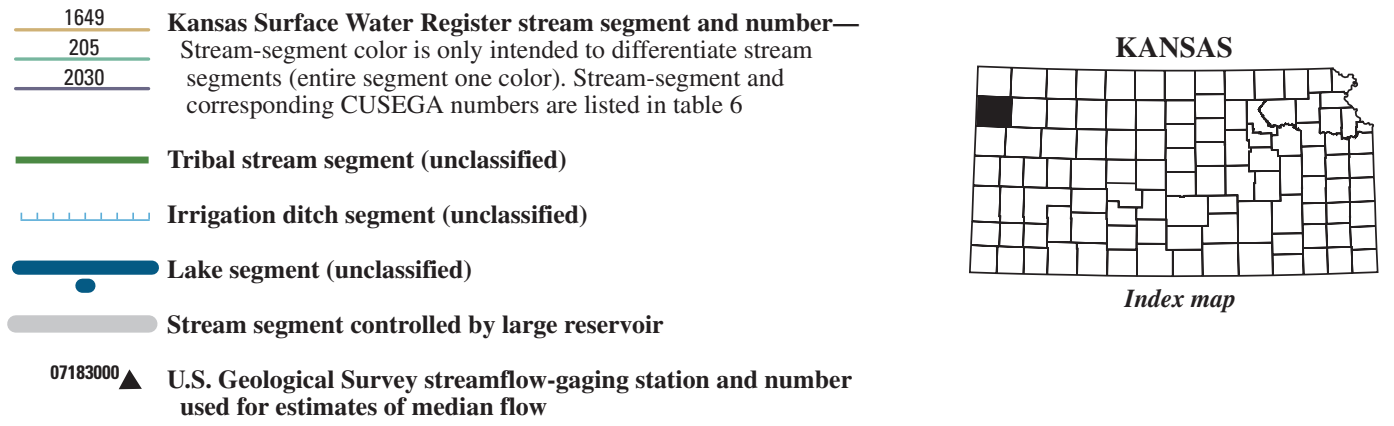

Index map used for estimates of median flow

Figure 99. Location of U.S. Geological Survey streamflow-gaging stations and stream segments on the 1999 Kansas Surface Water Register for Sherman County. 


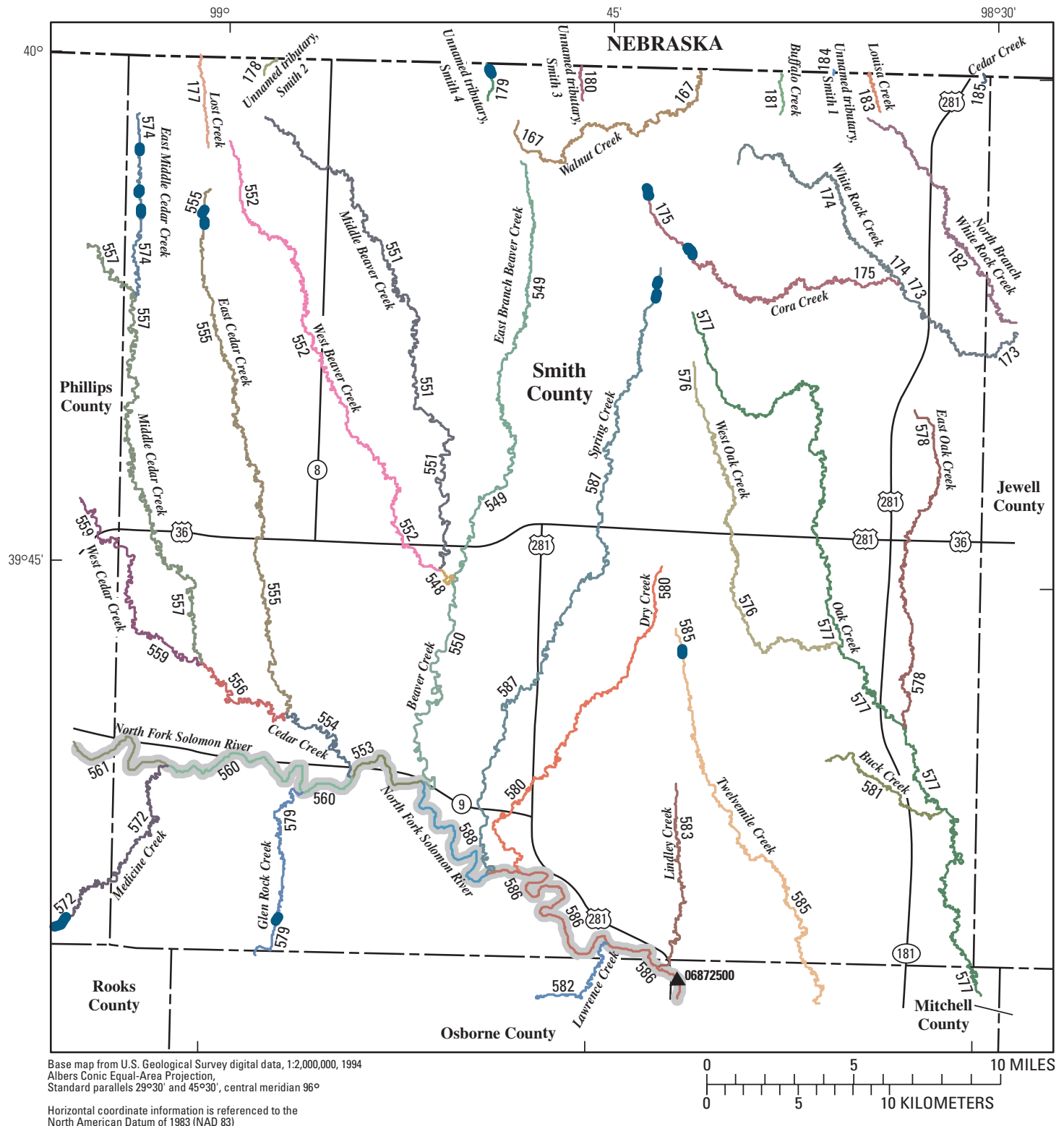

EXPLANATION

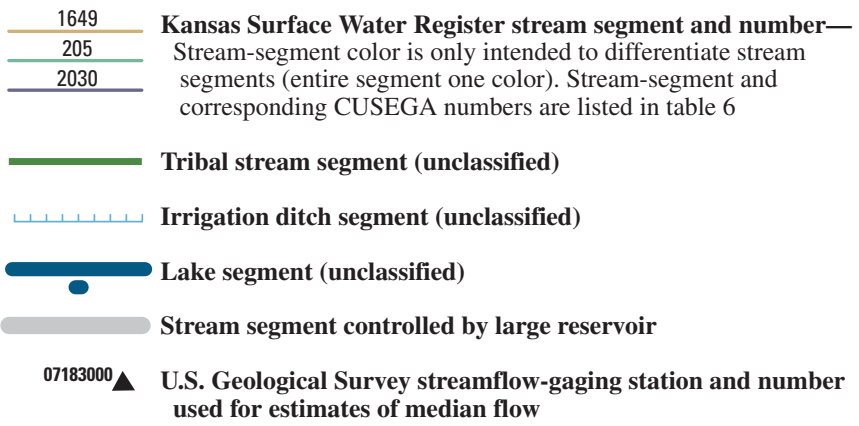

KANSAS

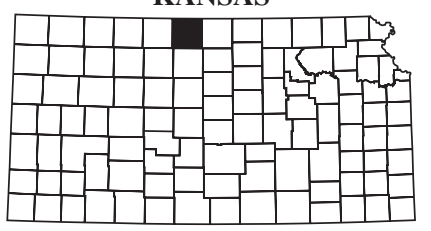

Index map used for estimates of median flow

Figure 100. Location of U.S. Geological Survey streamflow-gaging stations and stream segments on the 1999 Kansas Surface Water Register for Smith County. 


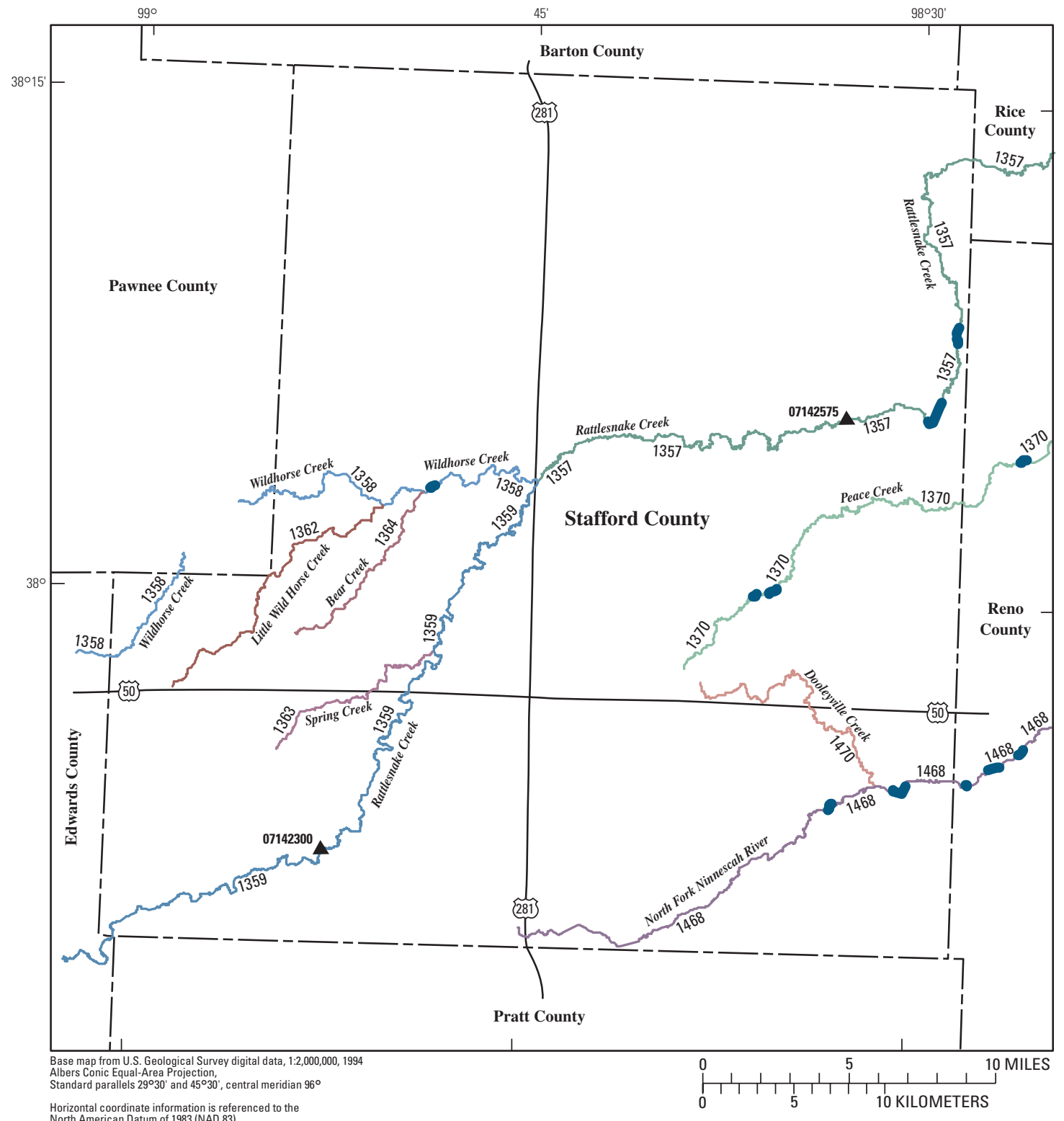

EXPLANATION

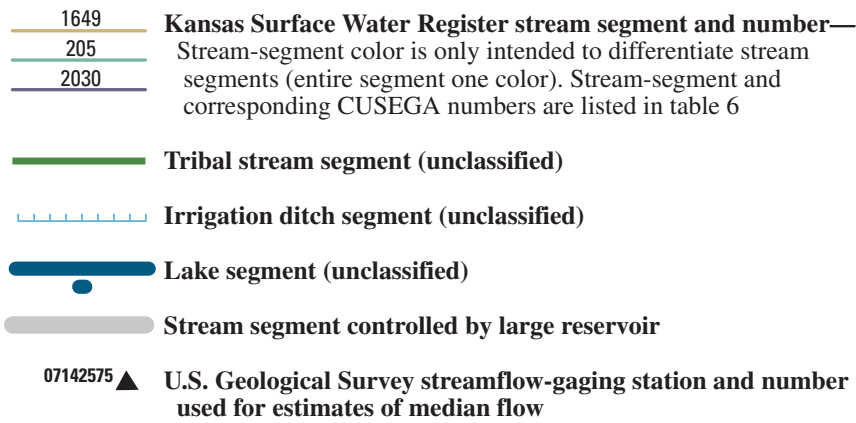

Figure 101. Location of U.S. Geological Survey streamflow-gaging stations and stream segments on the 1999 Kansas Surface Water Register for Stafford County. 


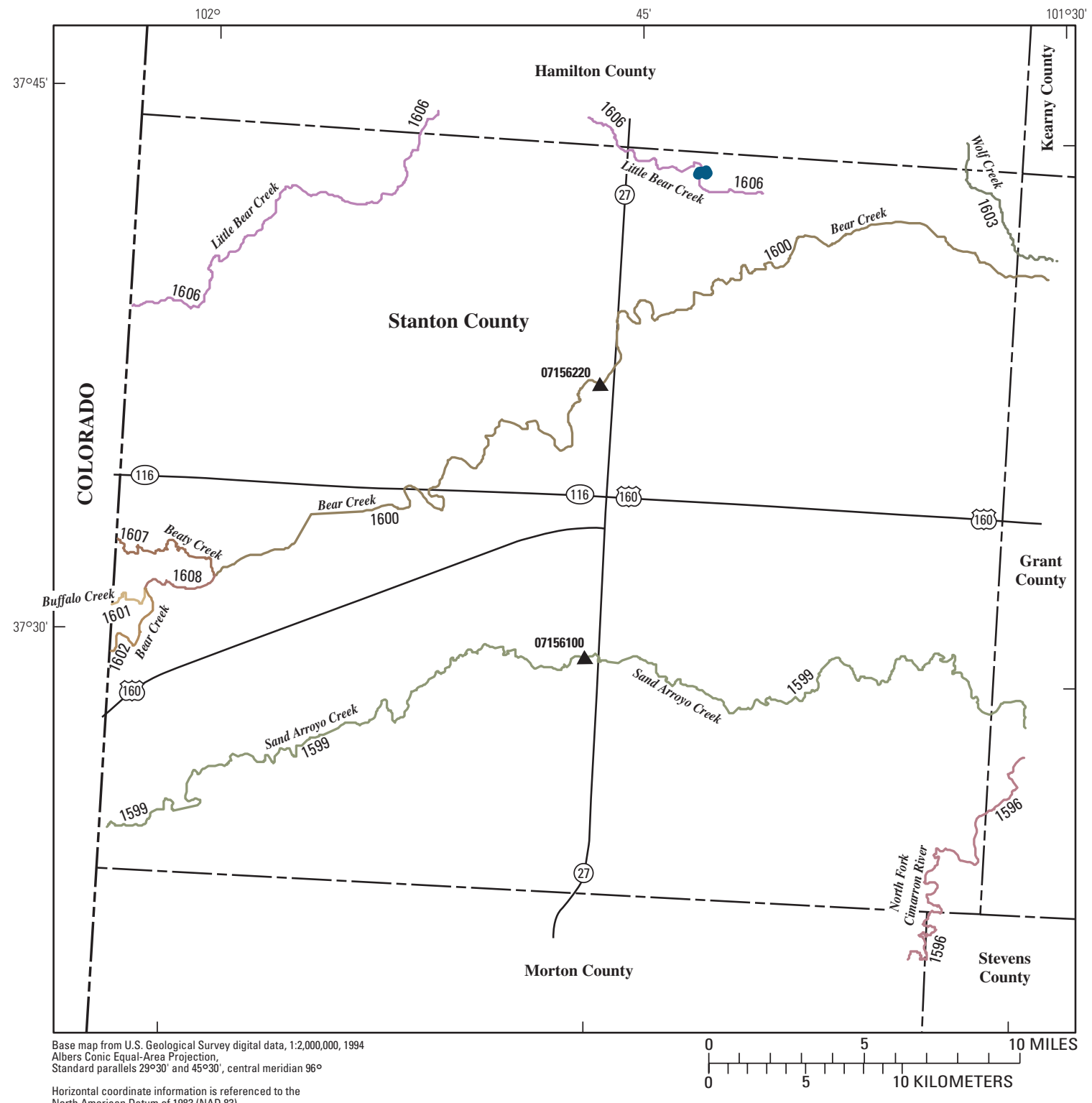

Horizontal coordinate information is referenced to the

\section{EXPLANATION}

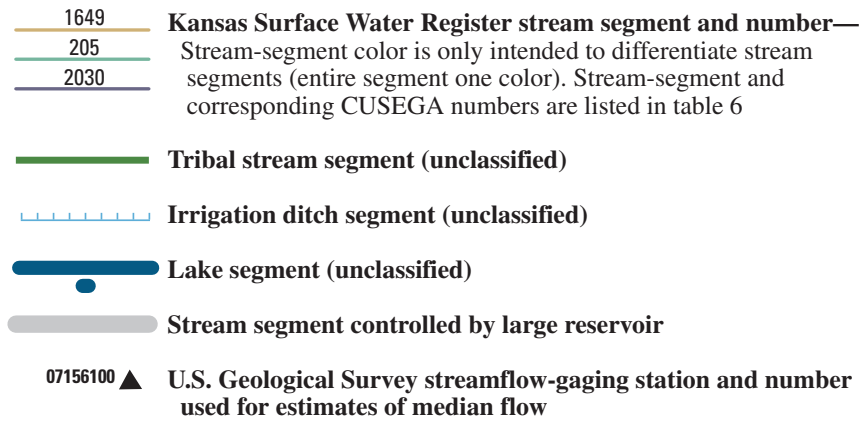

Figure 102. Location of U.S. Geological Survey streamflow-gaging stations and stream segments on the 1999 Kansas Surface Water Register for Stanton County. 


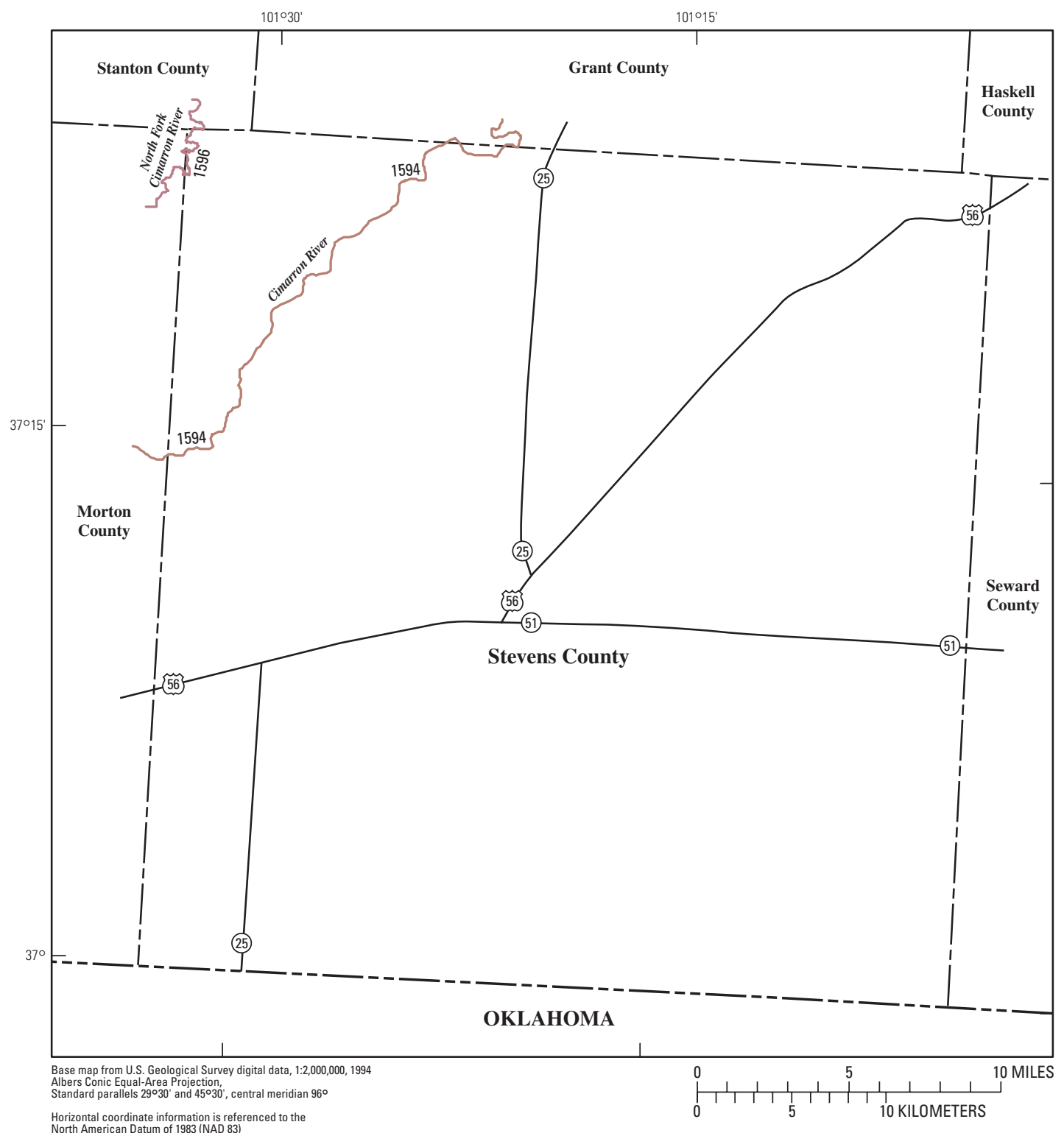

EXPLANATION

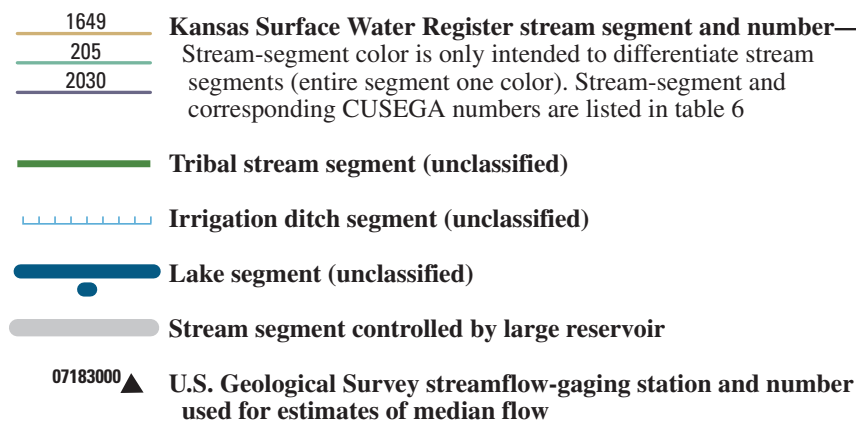

Figure 103. Location of U.S. Geological Survey streamflow-gaging stations and stream segments on the 1999 Kansas Surface Water Register for Stevens County. 


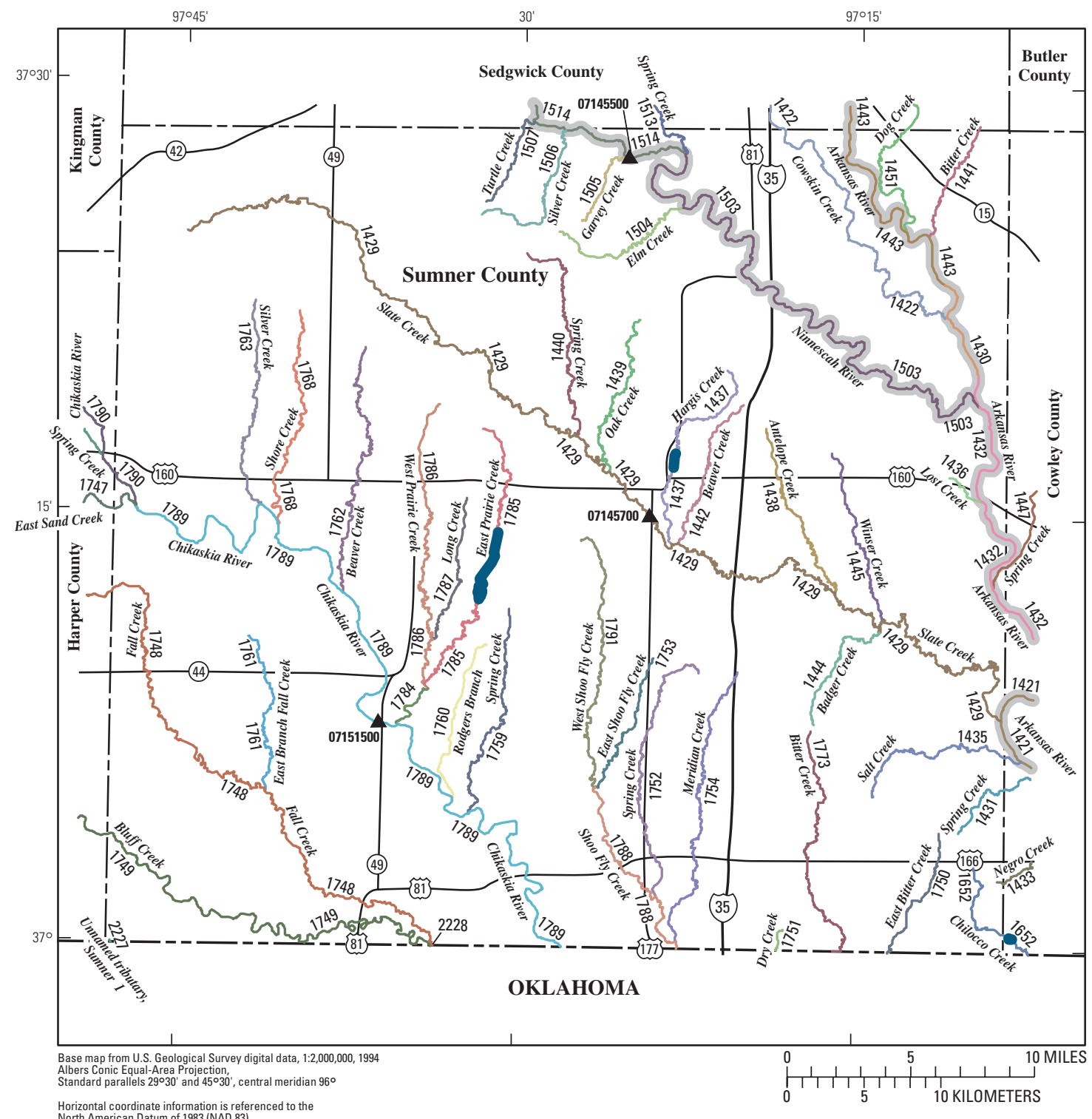

\section{EXPLANATION}
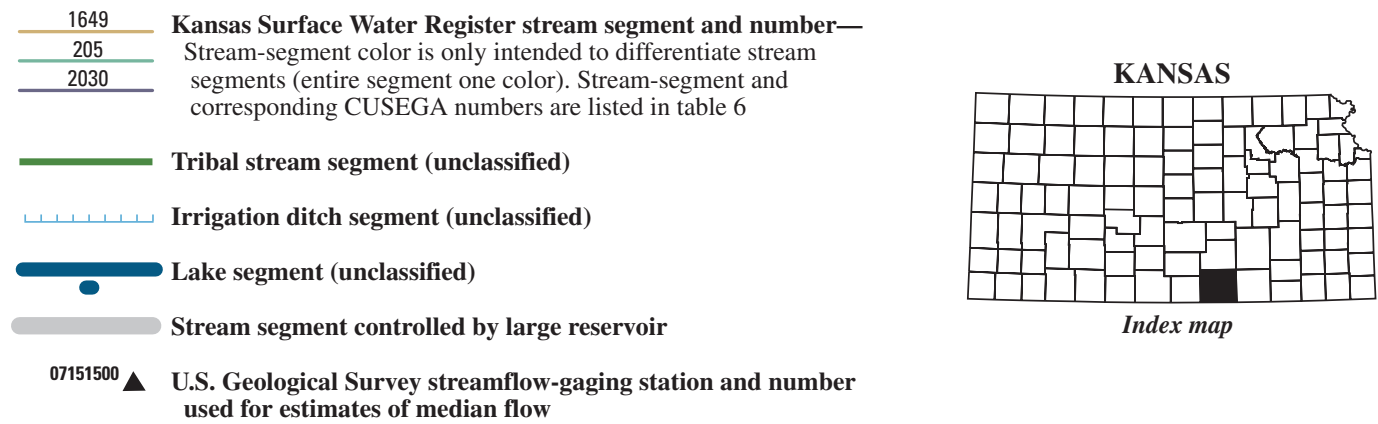

Figure 104. Location of U.S. Geological Survey streamflow-gaging stations and stream segments on the 1999 Kansas Surface Water Register for Sumner County. 


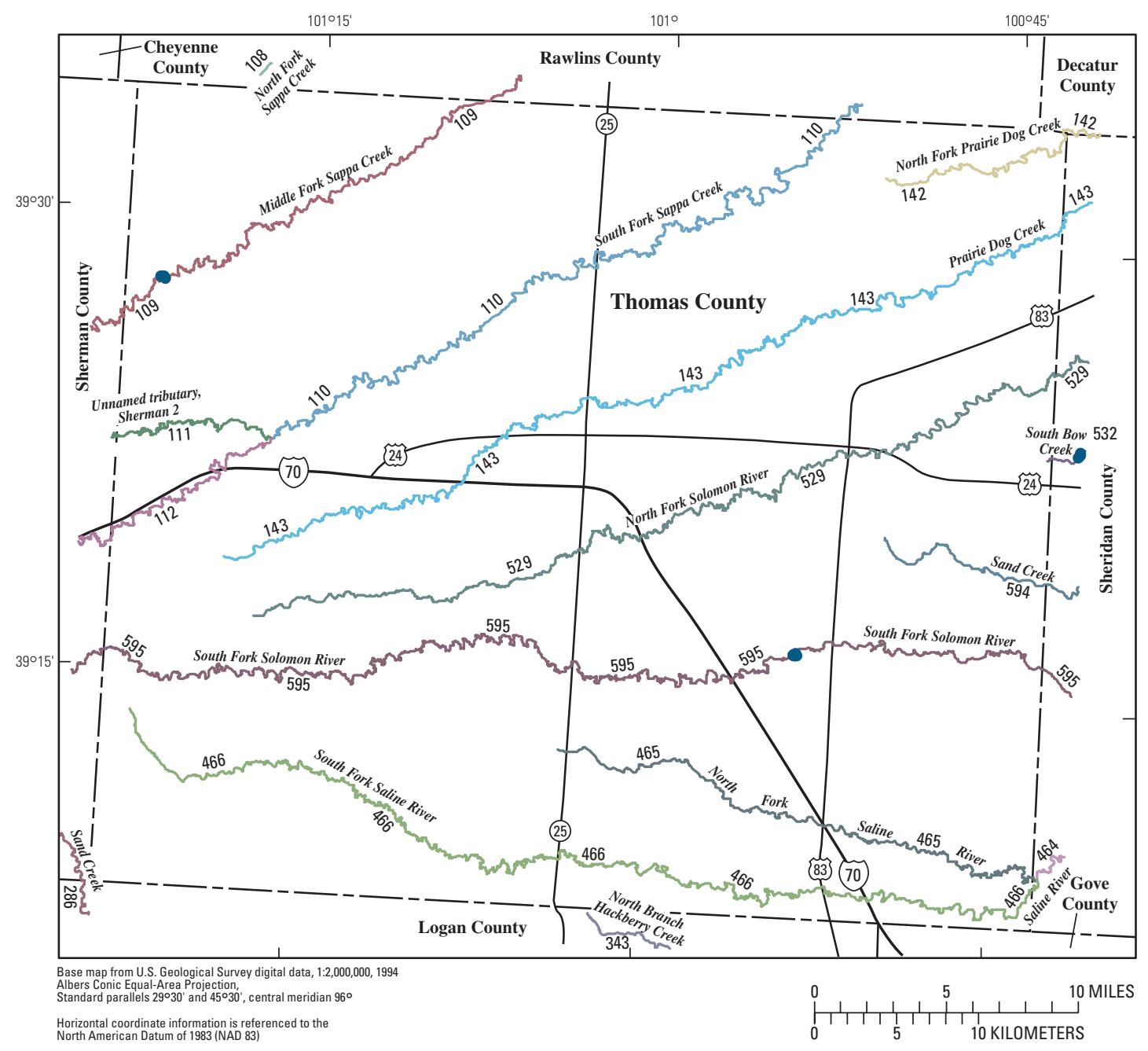

EXPLANATION

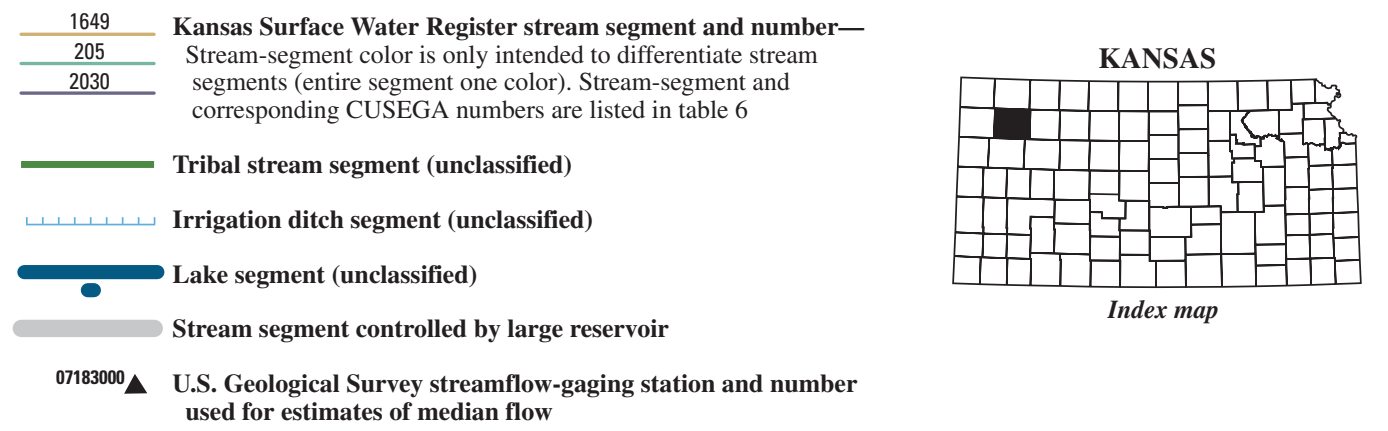

Figure 105. Location of U.S. Geological Survey streamflow-gaging stations and stream segments on the 1999 Kansas Surface Water Register for Thomas County. 


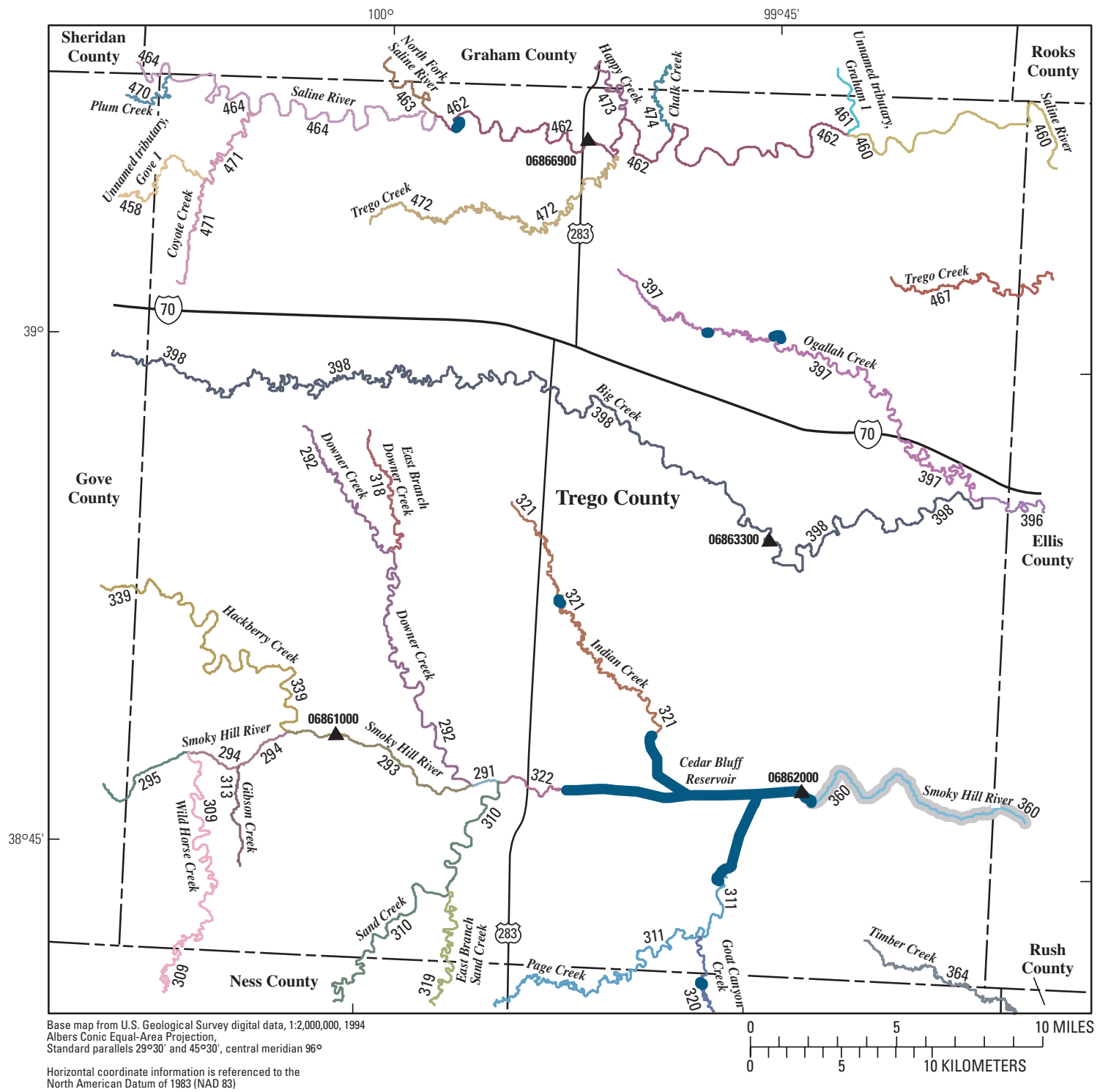

EXPLANATION
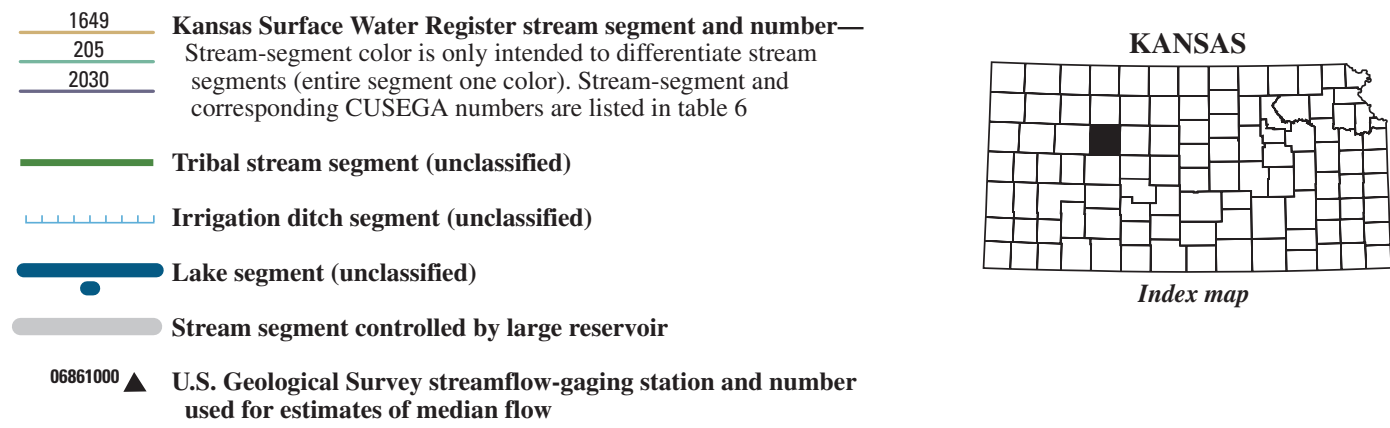

Index map

Figure 106. Location of U.S. Geological Survey streamflow-gaging stations and stream segments on the 1999 Kansas Surface Water Register for Trego County. 


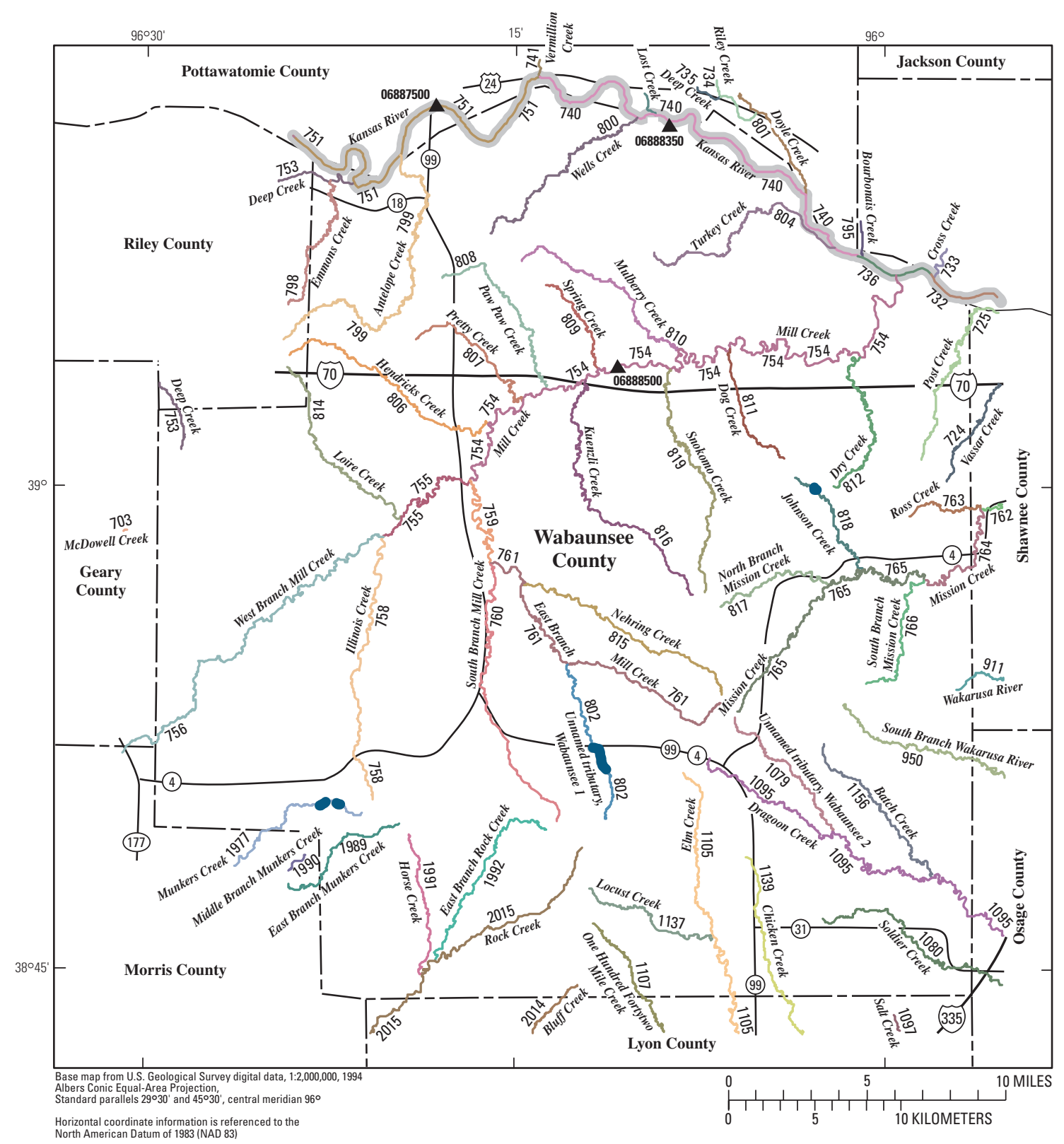

EXPLANATION
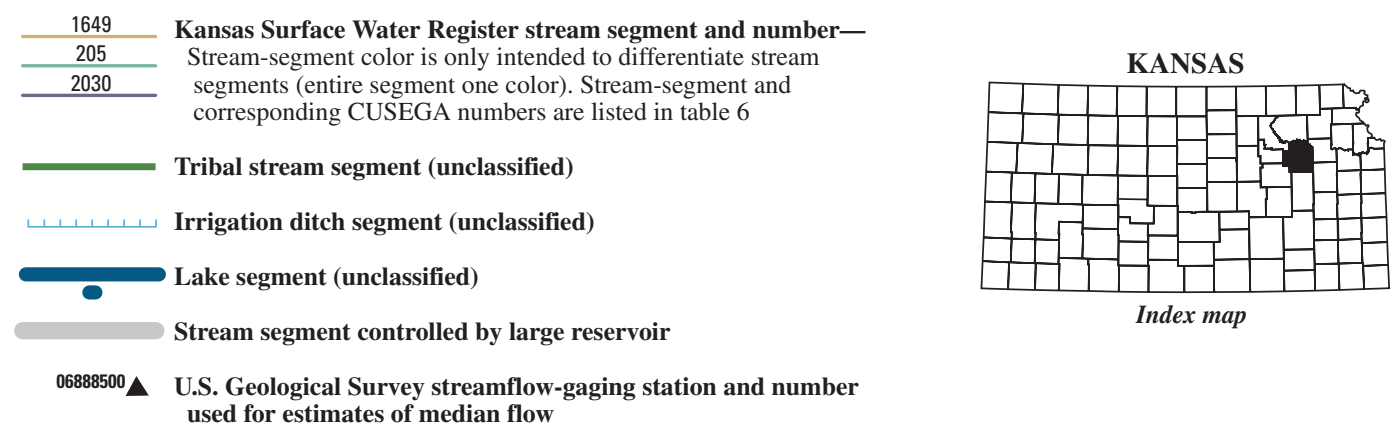

Index map

Figure 107. Location of U.S. Geological Survey streamflow-gaging stations and stream segments on the 1999 Kansas Surface Water Register for Wabaunsee County. 


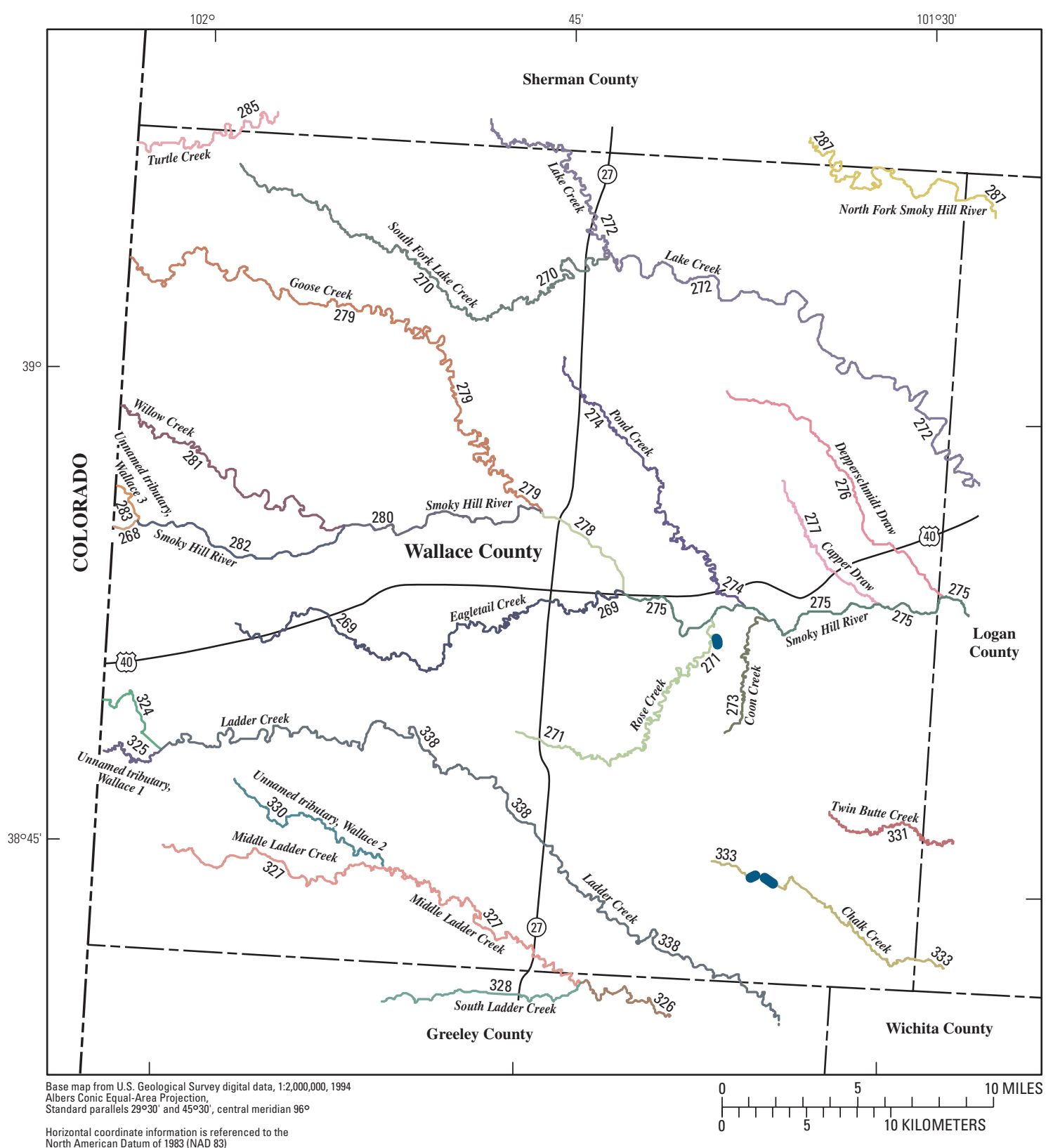

EXPLANATION

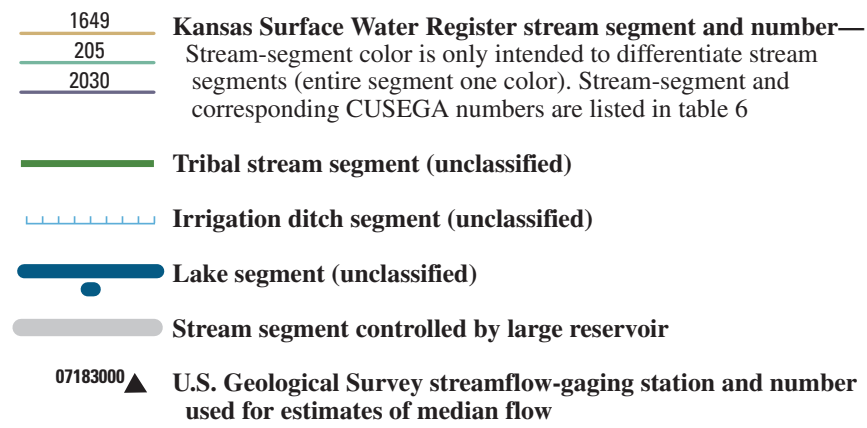

Figure 108. Location of U.S. Geological Survey streamflow-gaging stations and stream segments on the 1999 Kansas Surface Water Register for Wallace County. 


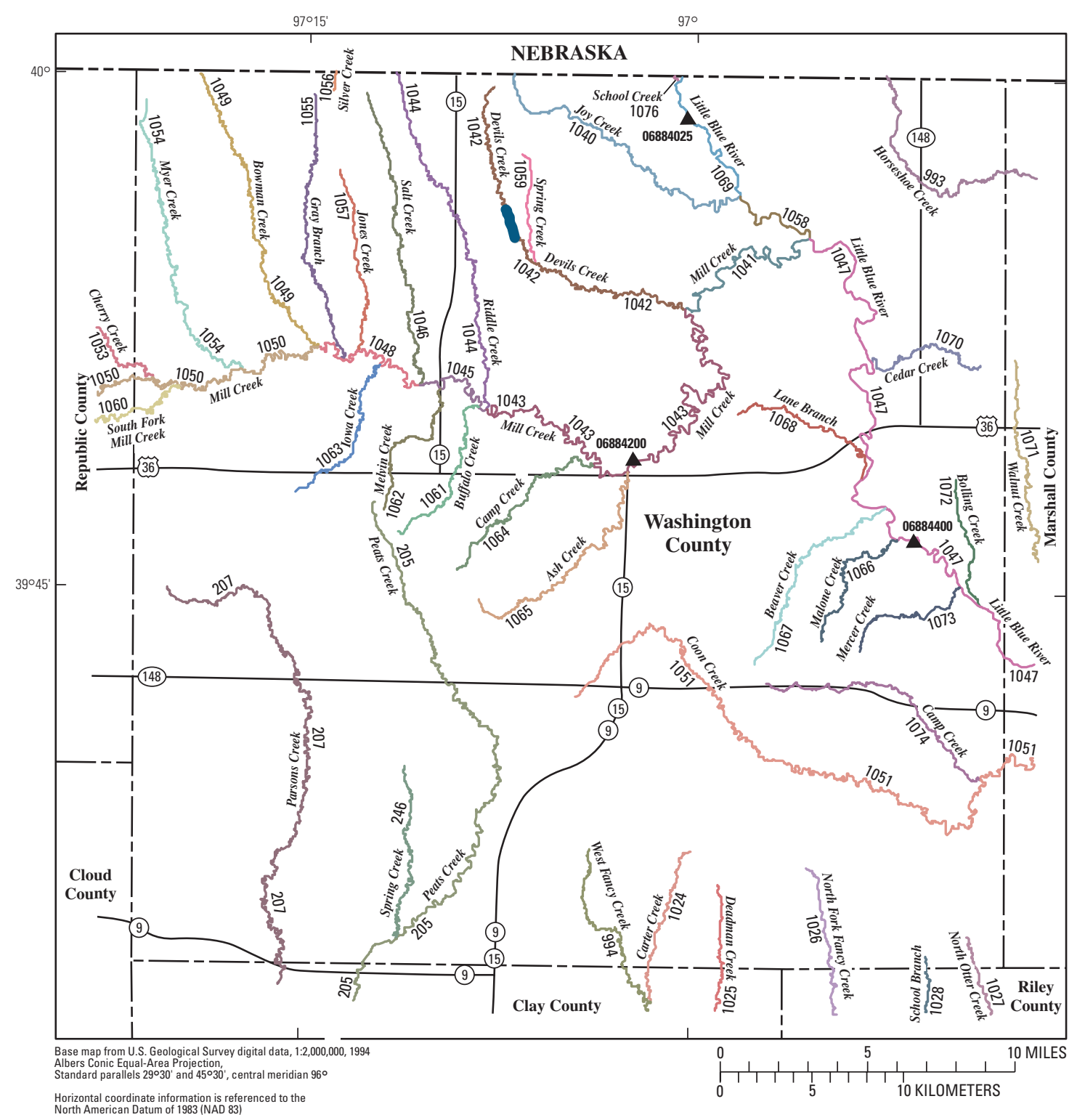

EXPLANATION
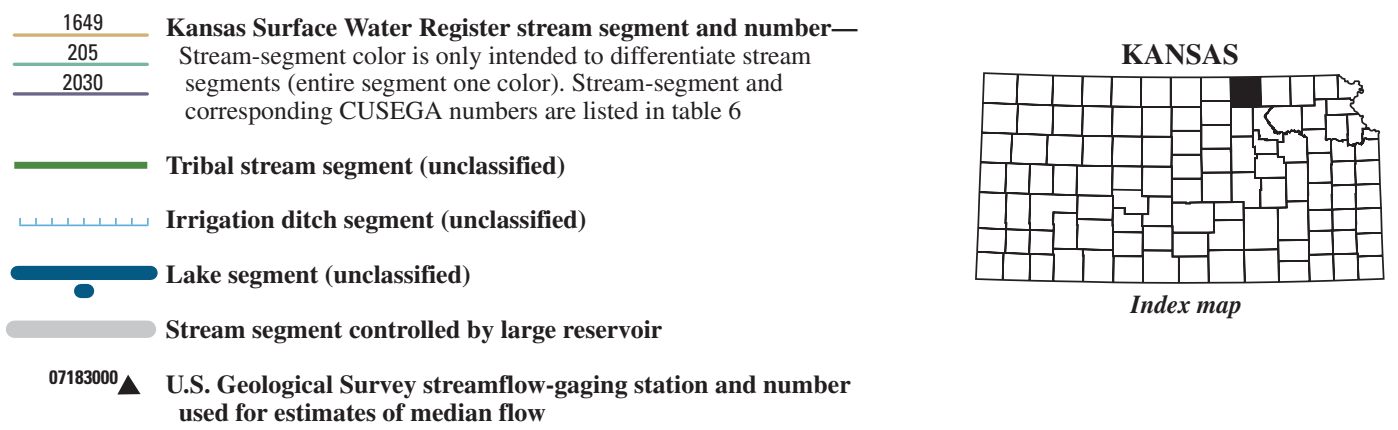

Figure 109. Location of U.S. Geological Survey streamflow-gaging stations and stream segments on the 1999 Kansas Surface Water Register for Washington County. 


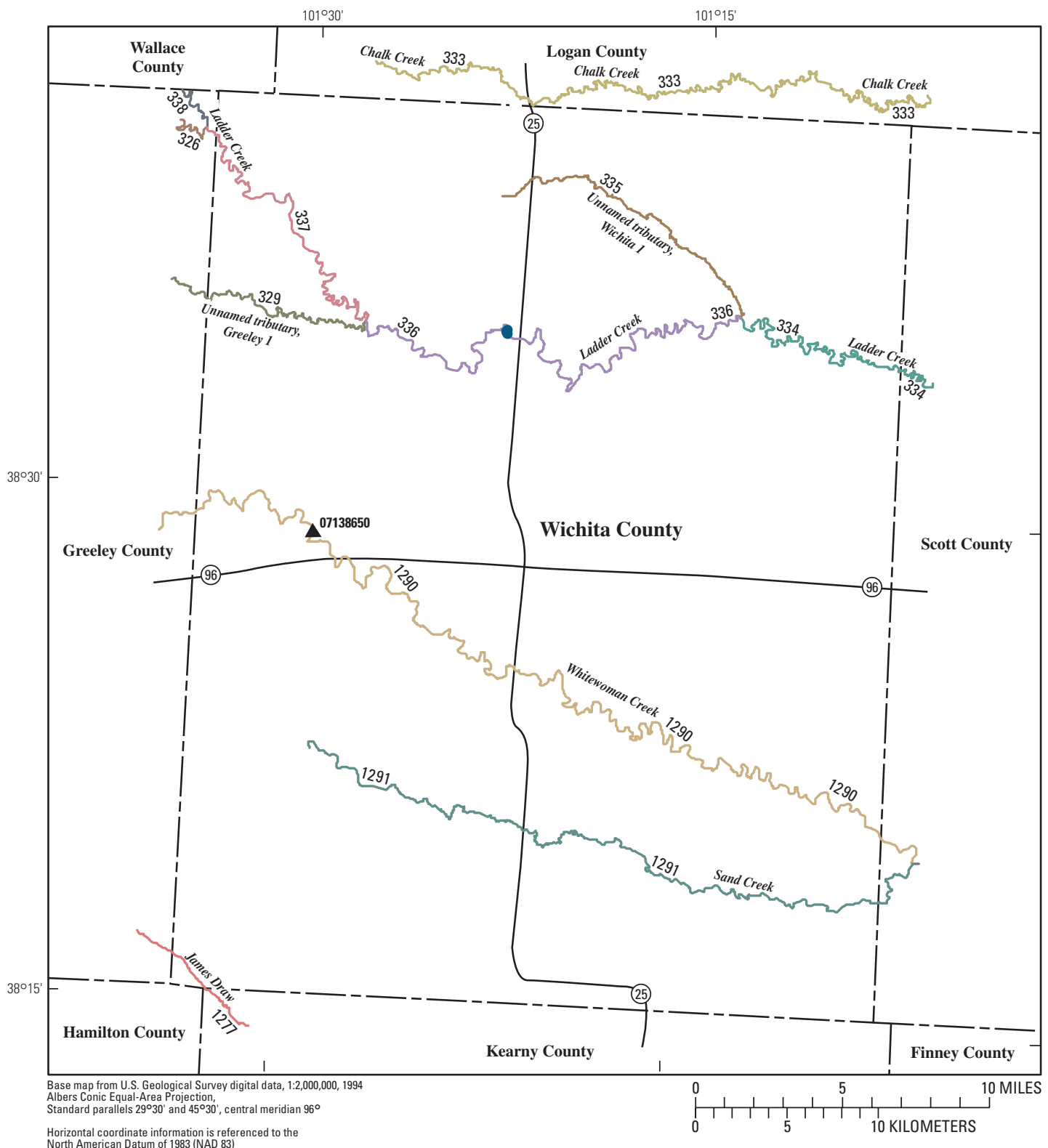

EXPLANATION

\begin{tabular}{|c|c|}
\hline 1649 & Kansas Surface Water Register stream segment and number- \\
\hline 205 & Stream-segment color is only intended to differentiate stream \\
\hline 2030 & segments (entire segment one color). Stream-segment and \\
\hline & corresponding CUSEGA numbers are listed in table 6 \\
\hline & Tribal stream segment (unclassified) \\
\hline $5,1,1,1,1,1,1$, & Irrigation ditch segment (unclassified) \\
\hline 0 & Lake segment (unclassified) \\
\hline & Stream segment controlled by large reservoir \\
\hline $07138650 \Delta$ & $\begin{array}{l}\text { U.S. Geological Survey streamflow-gaging station and number } \\
\text { used for estimates of median flow }\end{array}$ \\
\hline
\end{tabular}

Figure 110. Location of U.S. Geological Survey streamflow-gaging stations and stream segments on the 1999 Kansas Surface Water Register for Wichita County. 


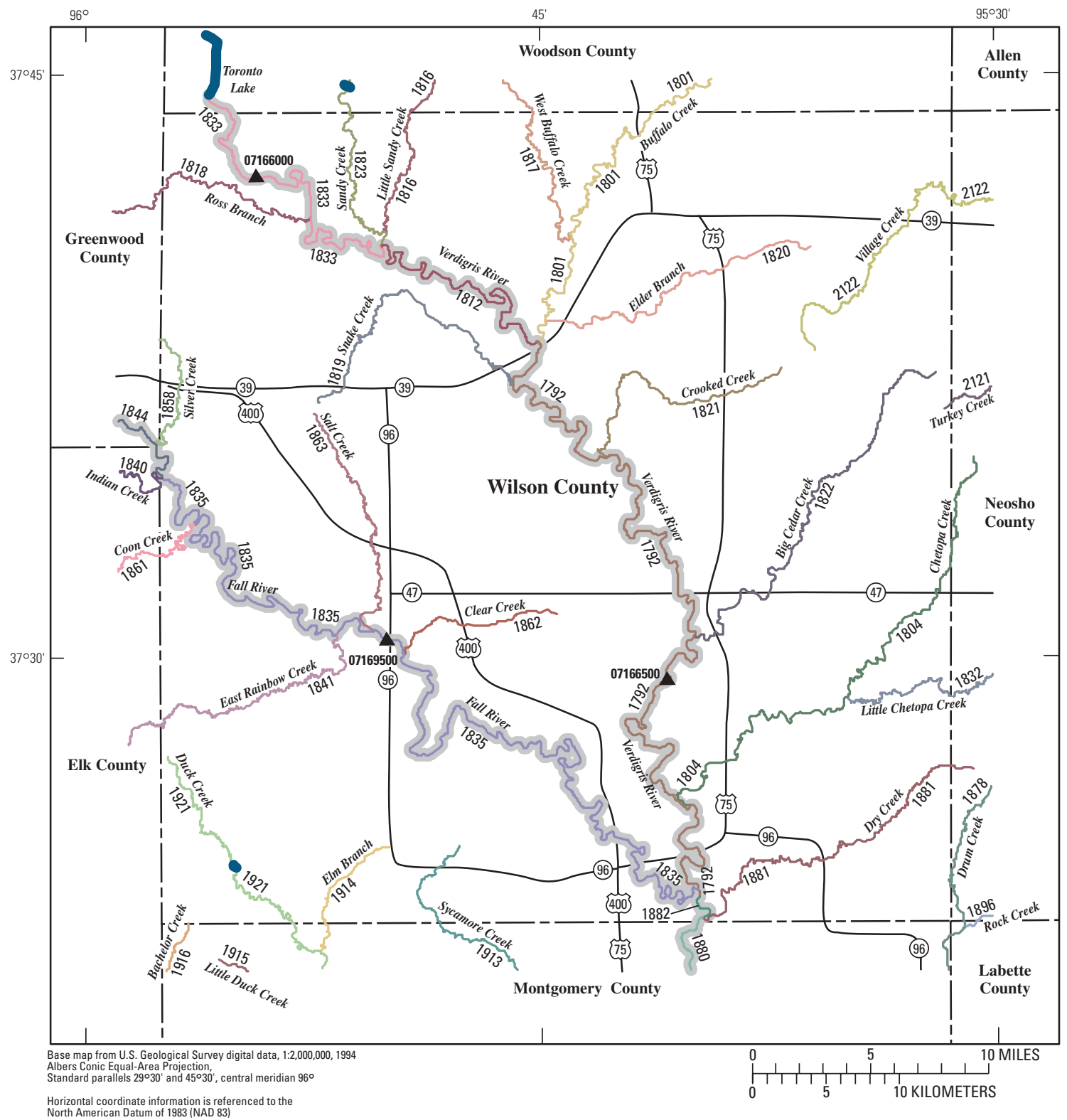

EXPLANATION
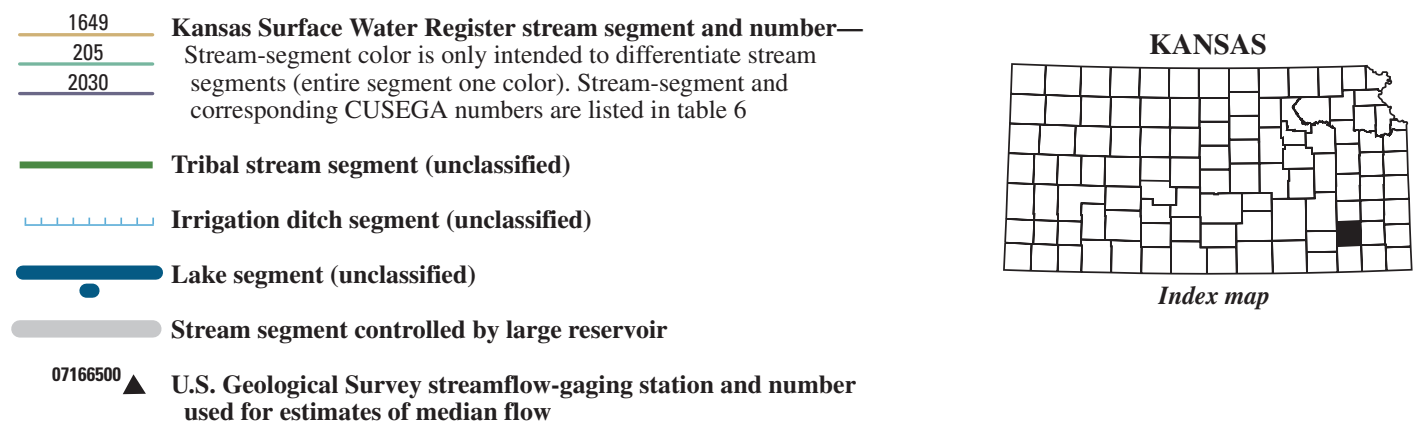

Index map

Figure 111. Location of U.S. Geological Survey streamflow-gaging stations and stream segments on the 1999 Kansas Surface Water Register for Wilson County. 


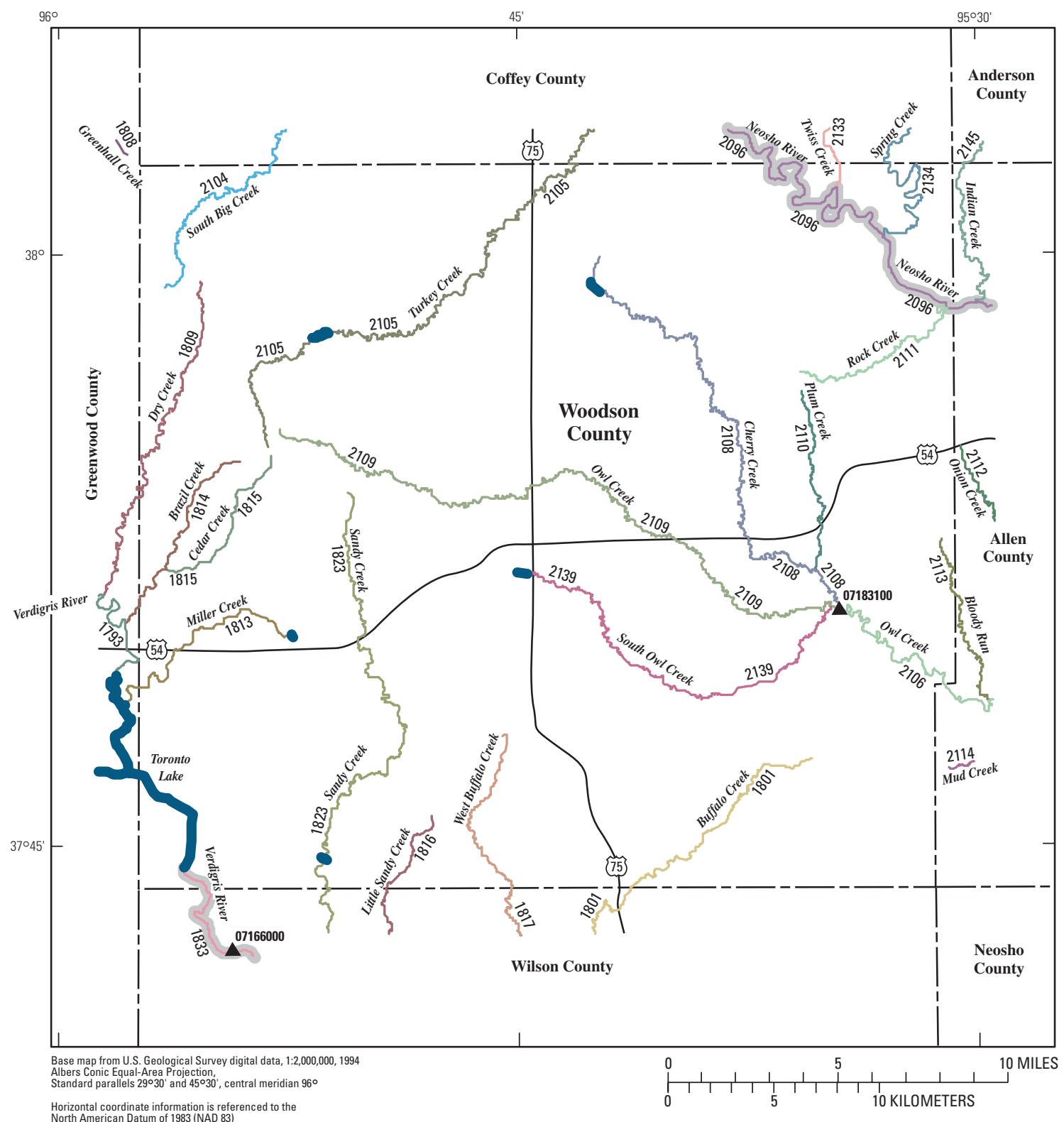

EXPLANATION

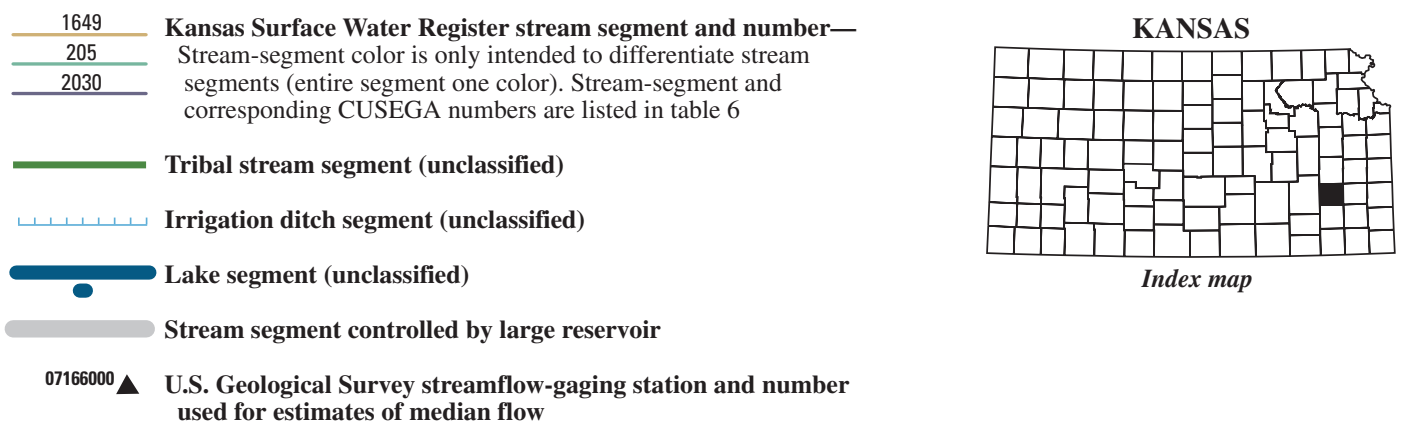

Figure 112. Location of U.S. Geological Survey streamflow-gaging stations and stream segments on the 1999 Kansas Surface Water Register for Woodson County. 


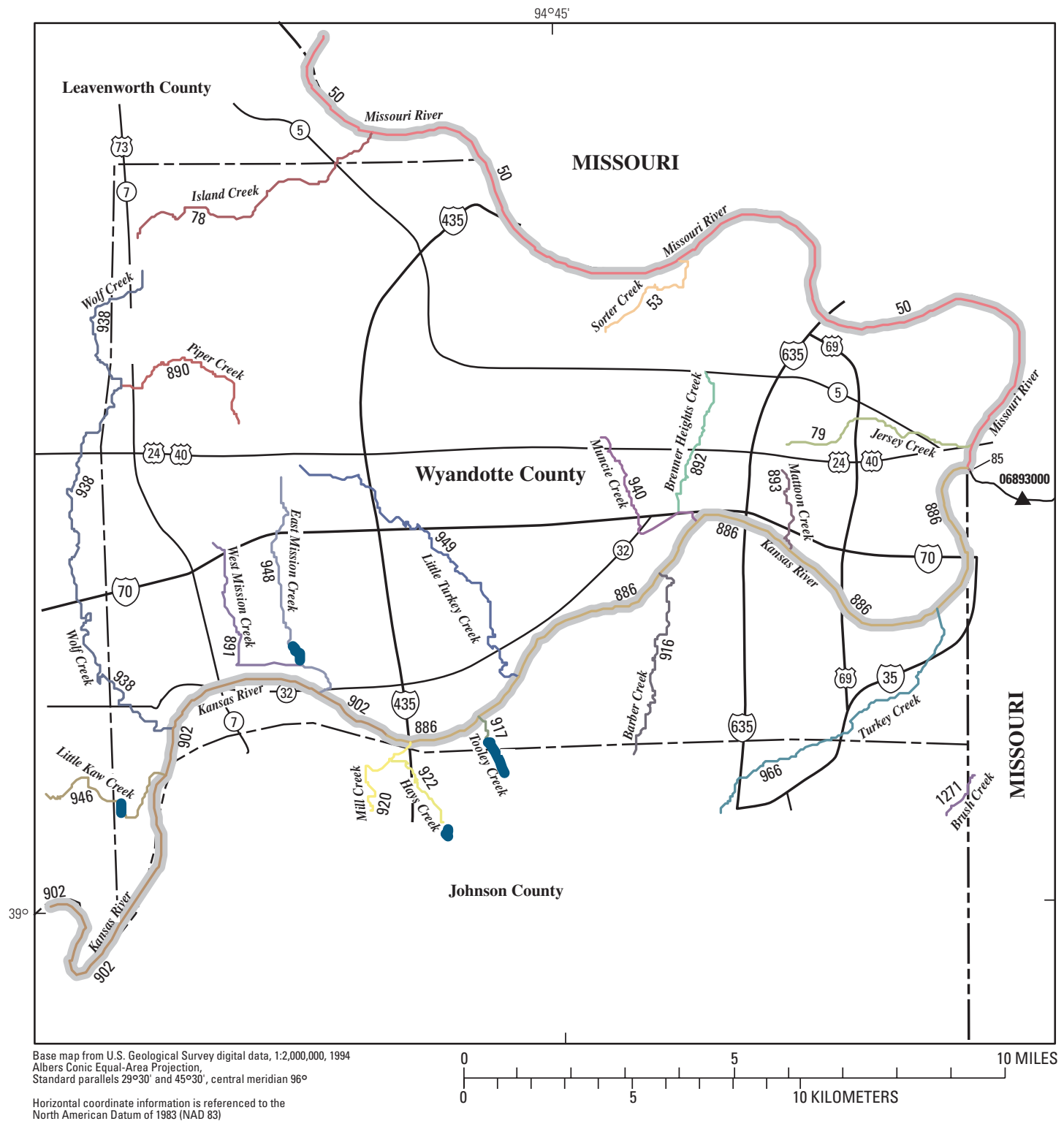

EXPLANATION
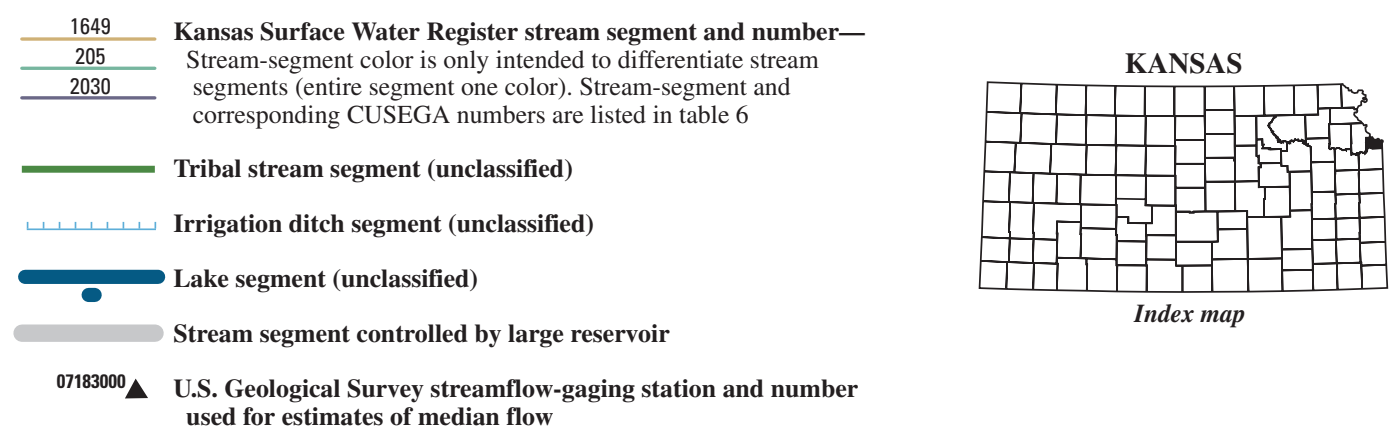

Index map

Figure 113. Location of U.S. Geological Survey streamflow-gaging stations and stream segments on the 1999 Kansas Surface Water Register for Wyandotte County. 